\title{
CIÊNCIAS HUMANAS: 0 \\ INDIVÍDUO COMO PONTO \\ DE PARTIDA E CHEGADA
}

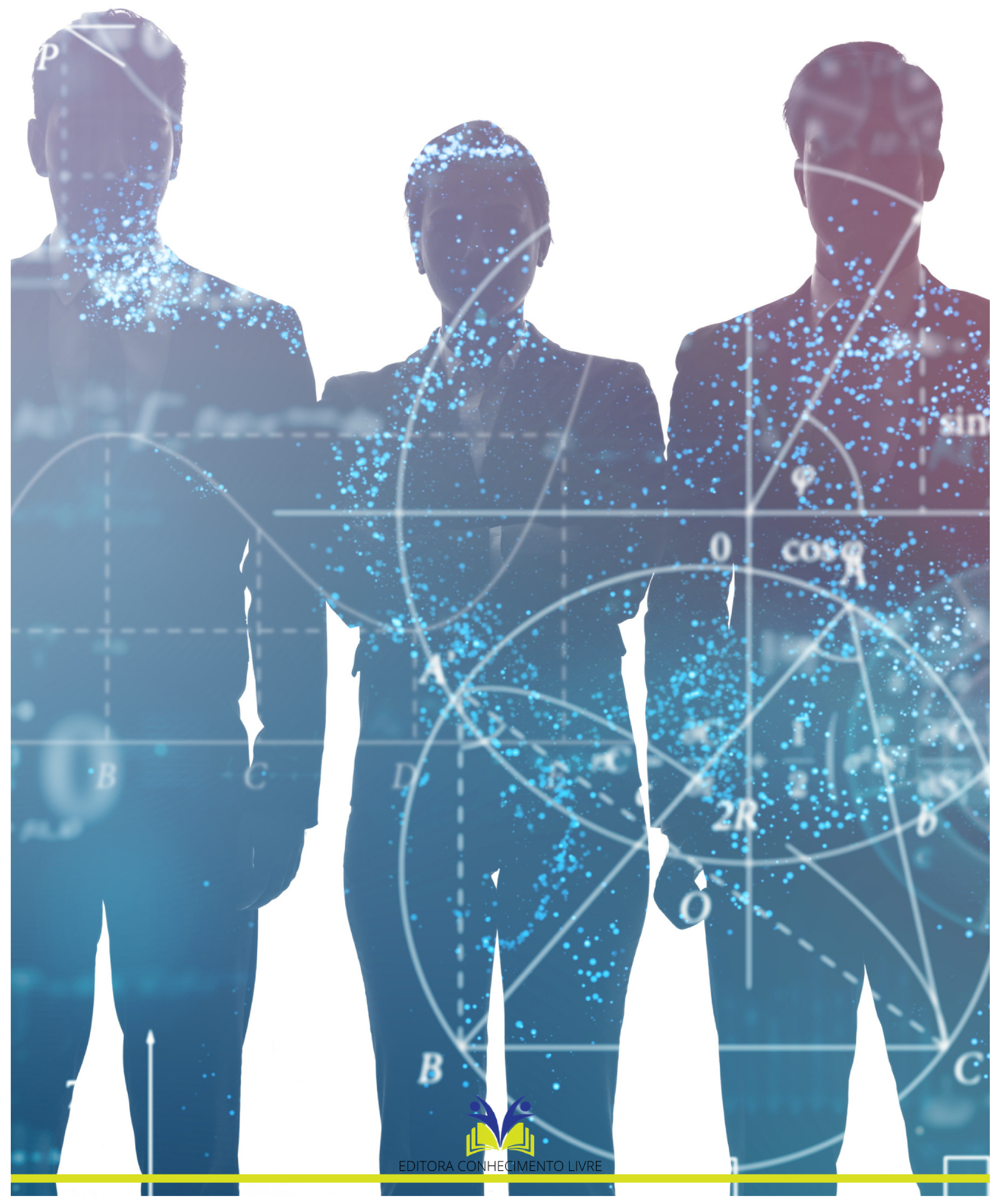


Frederico Celestino Barbosa

Ciências humanas: o indivíduo como ponto de partida e chegada

$1^{\text {a }}$ ed.

Piracanjuba-GO

Editora Conhecimento Livre

Piracanjuba-GO 
$1^{\mathrm{a}} \mathrm{ed}$

\section{Dados Internacionais de Catalogação na Publicação (CIP)}

Barbosa, Frederico Celestino
B238C Ciências humanas: o indivíduo como ponto de partida e chegada
/ Frederico Celestino Barbosa. - Piracanjuba-GO
Editora Conhecimento Livre, 2021
423 f.: il
DOI: 10.37423/2021.edcl274
ISBN: 978-65-89955-30-6
Modo de acesso: World Wide Web
Incluir Bibliografia
1. humano 2. integralidade 3. características I. Barbosa, Frederico Celestino II. Título

https://doi.org/10.37423/2021.edc1274

O conteúdo dos artigos e sua correção ortográfica são de responsabilidade exclusiva dos seus respectivos autores. 


\title{
EDITORA CONHECIMENTO LIVRE
}

\section{Corpo Editorial}

\author{
Dr. João Luís Ribeiro Ulhôa \\ Dra. Eyde Cristianne Saraiva-Bonatto \\ Dr. Anderson Reis de Sousa \\ MSc. Frederico Celestino Barbosa \\ MSc. Carlos Eduardo de Oliveira Gontijo
}

$\underline{\text { MSc. Plínio Ferreira Pires }}$

Editora Conhecimento Livre

Piracanjuba-GO 


\section{SUMÁRIO}

CAPÍTULO 1

RESENHA: MEMÓRIA E IDENTIDADE LOCAL EM ICAPUÍ - CEARÁ

ANGELA ESTER MALLMANN CENTENARO

ANDRÉIA BORGES

DOI 10.37423/210604309

CAPÍTULO 2

A IMPORTÂNCIA DA AFETIVIDADE EM PROFESSORES DO ENSINOSUPERIOR NOS

PROCESSOS DE ENSINO-APRENDIZAGEM

Patrícia dos Santos Pessoa

Elida Pereira Macedo

DOI 10.37423/210604271

CAPÍTULO 3

JOVENS [IN] VISÍVEIS: TRABALHO E TERRITORIALIDADE DOSCATADORES DA

COOPERATIVA SANTA MARIA DA CIDADE DEITAPEVA-SP

Tiago da Silva Souza

DOI 10.37423/210604274

CAPÍTULO 4

A INTERAÇÃO E ENVOLVIMENTO ENTRE ALUNOS NEGROS E NÃO NEGROS NAS AULAS

DE QUÍMICA DA ESCOLA ESTADUAL TANCREDO ALMEIDA NEVES

UEUDISON ALVES GUIMARÃES

DOI 10.37423/210604285

CAPÍTULO 5

A PARTICIPAÇÃO SOCIAL NA SEGURANÇA PÚBLICA EM TEMPOS DE PANDEMIA E AS

TEORIAS CONTRATUALISTAS DE HOBBES, LOCKE E ROUSSEAU

RAIMUNDO CÉZAR MAGALHÃES DANTAS

DOI 10.37423/210604303

CAPÍTULO 6

A VISÃO TRADICIONAL DA AVALIAÇÃO DA APRENDIZAGEM NO ENSINO SUPERIOR

Carla Priscilla Barbosa Santos Cordeiro

Lana Lisiêr de Lima Palmeira

DOI 10.37423/210604305

CAPÍTULO 7 81

EXTENSÃO UNIVERSITÁRIA E SEUS IMPACTOS SOCIAIS: ANÁLISE DO PROJETO APAE E TECNOLOGIA - INCLUIR É EXCEPCIONAL

LUIZ CARLOS GARCIA

LEONARDO SALGADO REZENDE

NAYARA MARIA DE LIMA

DOI 10.37423/210604307 
RELAÇÕES DO TEATRO DO OPRIMIDO COM A EDUCAÇÃO: HISTÓRIAS E REFLEXÕES.

MARCEL CAVALCANTE DE SOUZA

ROSSANA DE VASCONCELOS PUGLIESE VITO

DOI 10.37423/210604326

CAPÍTULO 9

EDUCAÇÃO PATRIMONIAL COMO FERRAMENTA DE PRESERVAÇÃO DE TÉCNICAS

CONSTRUTIVAS COM TERRA CRUA

Mateus de Carvalho Martins

João Vítor Januário

Guilherme Peixoto dos Santos

DOI 10.37423/210604327

CAPÍTULO 10

BREGAFUNK: A COLONIZAÇÃO PRESENTE NO FAZER MIDIÁTICO EM DISSONÂNCIA COM A MANUTENÇÃO DE PRÁTICAS DE RESISTÊNCIAS POR JOVENS PERIFÉRICOS

Alice Oliveira Ferreira

Jonhson Douglas Alves de Souza

Laís Catarine Umbelino dos Santos

DOI 10.37423/210604333

CAPÍTULO 11

OS PRINCIPAIS DESAFIOS E POTENCIALIDADES DAS COMUNIDADES TERAPÊUTICAS NO

BRASIL

Felipe Hruschka do Amaral

DOI 10.37423/210604338

CAPÍTULO 12

UMA ABORDAGEM AO USO DOS RECURSOS TECNOLÓGICOS NA PRÁTICA DO DOCENTE

DE MATEMÁTICA.

GLEIDSON JOSÉ DUMONT OLIVEIRA

ANDREIA GENÍ DE BARROS GUEDES

MOISÉS DOS SANTOS

DOI 10.37423/210604339

CAPÍTULO 13

CONTRIBUIÇÕES DO TEATRO DO OPRIMIDO NA EDUCAÇÃO DE JOVENS E ADULTOS -

EJA: ABANDONO, RETOMADA E PERMANÊNCIA

Edina Honorato Gonçalves

Robson Rosseto

DOI 10.37423/210604340 
ADAPTAÇÃO ESCOLAR NA PERSPECTIVA DAS CRIANÇAS DO PRE I

Edlaine Rodrigues Pereira

Elenir Araújo Silva

Wandela Jheny Diniz Sinézio

Rafaela Correia dos Santos

Livânia Beltrão

DOI 10.37423/210604345

CAPÍTULO 15

REDES SOCIAIS COMO MEIOS DE SOCIABILIDADE DE PORTADORES DE ESCLEROSE

LATERAL AMIOTRÓFICA - ELA

Jassenildes Ditzel de Azevedo

Maria Rafaella Bech

Maria Marce Moliani

DOI 10.37423/210604348

CAPÍTULO 16

230

A ANTROPOLOGIA BRASILEIRA E O MITO DA BRASILIDADE

MARCOS SILVA DA SILVEIRA

DOI 10.37423/210604353

CAPÍTULO 17

NEOLIBERALISMO E POLÍTICAS EDUCACIONAIS NO BRASIL: INFLUÊNCIAS SOBRE A BASE NACIONAL COMUM CURRICULAR

Francisco Dened Lima Alves

Deusemar Cardoso do Nascimento

Rosana Siqueira Alves

Elton Amaral de Araújo

DOI 10.37423/210604355

CAPÍTULO 18

ANÁLISE DA PSICOPATIA SOB A ÓTICA DA PSICOLOGIA FORENSE

ALLYNE EVELLYN FREITAS GOMES

Arthur Delmiro da Silva

Luiza Gabriela Martins Pinto Mendes

Márcia Adalgisa de Assis de Morais Barbosa

DOI 10.37423/210604357 
A PSICOLOGIA ORGANIZACIONAL E DO TRABALHO COMO FERRAMENTA DE APOIO À GESTÃO DO CONHECIMENTO: UM ESTUDO NA MARINHA DO BRASIL

Lucilio Fontes Moura

Diego Lopes Pontes Duarte

DOI 10.37423/210604369

CAPÍTULO 20

ONDE SE INTEGRA AS(OS) PRETAS (OS) NA ORDEM COMPETITIVA DA REGIÃO

METROPOLITANA DE SÃO PAULO?

DANIEL VITOR NUNES DE MELO

DOI 10.37423/210604371

CAPÍTULO 21

A MORALIDADE SECULAR: ACESSO E DISTRIBUIÇÃO DE RECURSOS NA ASSISTÊNCIA À

SAÚDE POR H. T. ENGELHARDT JR.

Isabel Cristina Correia

Monique de Alencar Lucena

DOI 10.37423/210604372

CAPÍTULO 22

QUANDO ADOLESCENTES SE MATAM: O COMPORTAMENTO SUICIDA EM ADOLESCENTES

NO CONTEXTO DAS IGREJAS EVANGÉLICAS

Isabel Cristina Correia

Nilton Eliseu Herbes

DOI 10.37423/210604373

CAPÍTULO 23

A AUTONOMIA, O CONSENTIMENTO E OS INDIVÍDUOS SEM A CAPACIDADE PARA

CONSENTIR: UMA REFLEXÃO.

Isabel Cristina Correia

Débora R. O. Eleutério de Azevedo

DOI 10.37423/210604374

CAPÍTULO 24

BIODIVERSIDADE E SEGURANÇA ALIMENTAR

Isabel Cristina Correia

Bárbara Braga Cavalcante

DOI 10.37423/210604375 
A CLASSE ESPECIAL NA CONJUNTURA DA EDUCAÇÃO ESPECIALINCLUSIVA: UMA

POSSIBILIDADE DE ESCOLARIZAÇÃO?

Maria José Calado Souza

Glória Maria Alves Machado

Maria José de Souza Marcelino

DOI 10.37423/210604397

CAPÍTULO 26

MEMÓRIA E PATRIMÔNIO:O PRIMEIRO RESGATE DO COMPLEXO INDUSTRIAL TÊXTIL

ALAGOANO, FERNÃO VELHO

Mônica Peixoto Vianna

Débora do Nascimento Oliveira

Joyce Caroline Cavalcante Pantaleão

DOI 10.37423/210604404

CAPÍTULO 27

REFLEXÕES SOBRE A TRAJETÓRIA DA MULHER NO CAMPO ESPORTIVO

Ester Gomes Bernabé

Raquel Quirino

DOI 10.37423/210604406

CAPÍTULO 28

MINERAÇÃO DE DADOS: UM ESTUDO PARA IDENTIFICAÇÃO DO PERFIL DOCENTE DAS IES

COM CONCEITO 3 OU SUPERIOR NO IGC AVALIADO EM 2016 NO ESTADO DO ES

Denilton Macário de Paula

André Bessa da Silva

Geórgia Regina Rodrigues Gomes

DOI 10.37423/210704435 


\section{Capítulo 1}

\section{doi $10.37423 / 210604309$}

\section{RESENHA: MEMÓRIA E IDENTIDADE LOCAL EM ICAPUÍ - CEARÁ}

ANGELA ESTER MALLMANN CENTENARO

ANDRÉIA BORGES

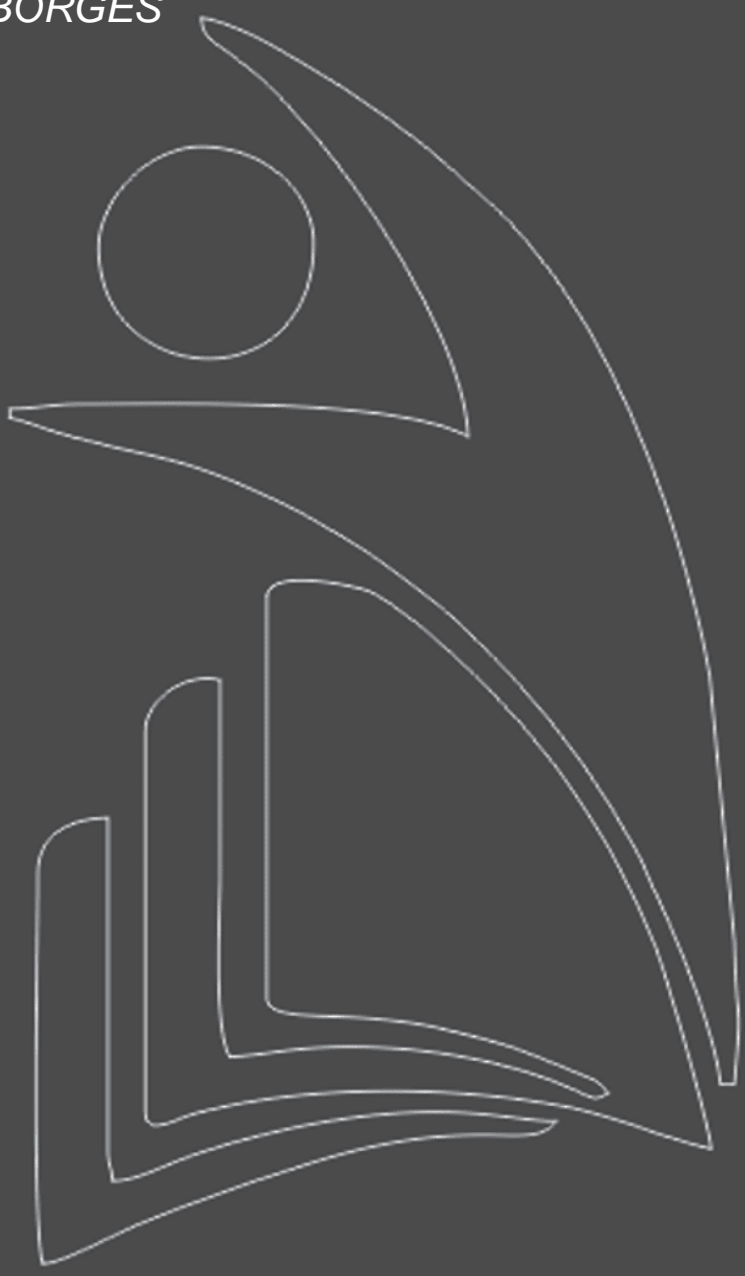

Universidade do Estado de Mato Grosso UNEMAT

Universidade do Estado de Mato Grosso UNEMAT

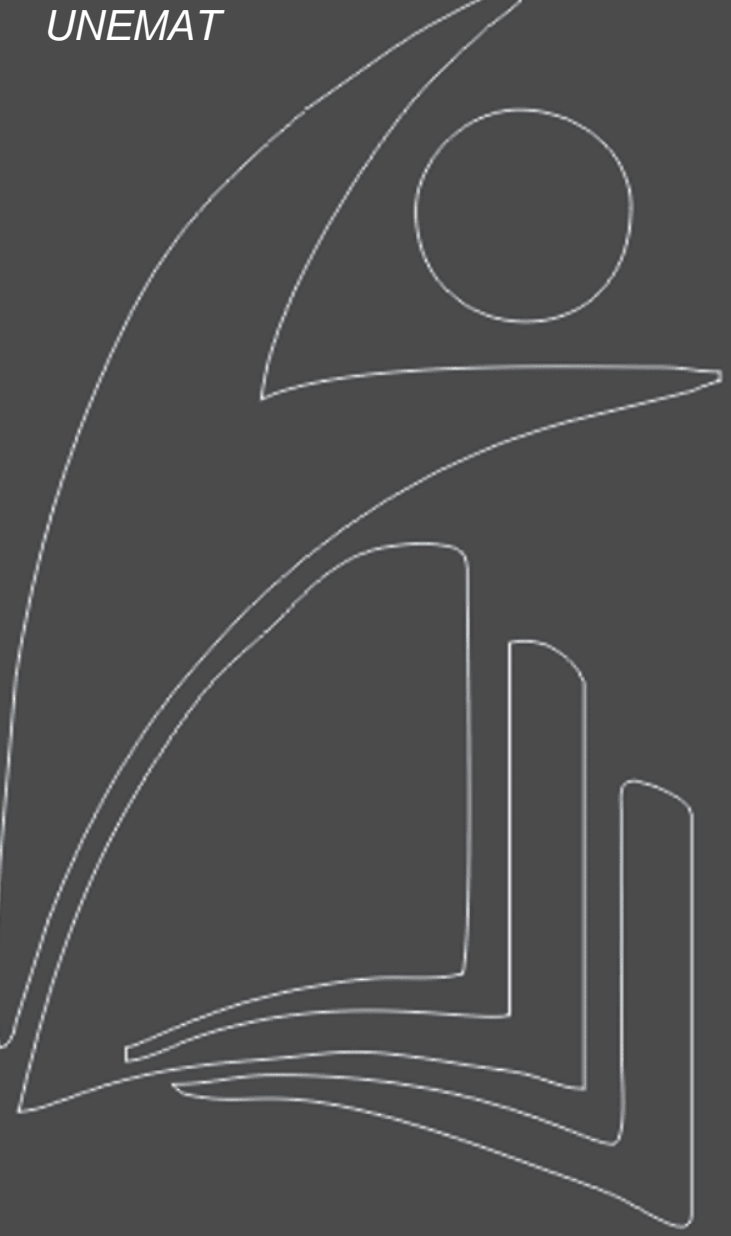




\section{Resenha: Memória E Identidade Local Em Icapuí, Ceará}

Esta tese de Ana Maria Goulart Bustamante mostra a luta de uma pequena população determinada a conquistar sua autonomia e construir sua cidadania em conjunto com todos os munícipes. O tema gira em torno da análise do discurso de alguns moradores do município de Icapuí acerca, principalmente, da questão da construção de uma identidade de lugar e da sua memória sobre a passagem de Icapuí de distrito a município, entre outros aspectos, tendo em vista, que o objetivo da tese é melhor entender os processos de construção da identidade local, no caso, de identidade icapuiense (p. 17-8). Uma característica marcante da tese é a boa escrita, que envolve os leitores desde o princípio, não deixando de ser crítica e elucidativa.

A pesquisa se divide em cinco partes. Na introdução (p. 13-24) apresenta o objetivo do trabalho que é explorar os modos como se expressa alguns processos de construção de identidade em relação ao lugar no município de Icapuí, Ceará (p. 13). Além do objetivo geral pudemos identificar alguns objetivos específicos: a) Procurar conhecer melhor as instituições capazes de desvelar as vozes e os silêncios que as envolvem, e que fazem chegar à cidadania concreta a cada cidadão, em cada localização (p. 15); b) Analisar os efeitos da ação social e das diferentes práticas junto aos grupos interessados no âmbito local (p. 18); c) Identificar questões ligadas à propriedade intelectual de bens culturais em razão do valor econômico (p. 19). A hipótese apresentada pela autora versa sobre a afirmação que todo o efeito da existência das instituições dirige-se à criação ou à manutenção da comunidade do segundo tipo, psicossocial, de que podem ser exemplos as nações, as "comunidades de imaginação", descritas por vários autores, mas também tudo aquilo que se tornou instituído e tem existência material reconhecida na vida social (p. 15). Também justifica o tema e a utilização de alguns conceitos no decorrer do trabalho, como o pertencimento, a importância das instituições na organização da vida social, cidadania, nação, paisagem, tradição, espaço, entre outros. O problema que Ana Maria se propôs a responder é envolvente, atual e interessante, a saber: Como as narrativas sobre a nação, as memórias que conectam seu presente com seu passado e as imagens que dela são construídas produzem sentido, mas se transformam sob a influência da globalização econômica ( $p$. 17).

Na segunda parte (p. 25-65), a autora se aproxima de autores, estudiosos das questões dos processos de globalização e revaloração da cultura frente às forças globais, noção de cidadania e construção da identidade local a partir da participação comunitária. A revisão bibliográfica apresenta uma abordagem psicossocial dos processos de construção da identidade local para entender a construção da identidade dos cidadãos icapuienses. 


\section{Resenha: Memória E Identidade Local Em Icapuí, Ceará}

Para iniciar esta abordagem no subtítulo "Reparação e Renomeação" (p. 25-41) a autora se serviu de Milton Santos para entender a questão de territórios e topônimos relacionados com a identidade do lugar, este último também assunto de Freitas Filho; Cascudo (1972) e Teodoro Sampaio (1928) se estendem sobre a origem indígena dos nomes de locais também relacionados com a identidade, o mesmo ocorrendo com Myriam Mesquita (1963), Berta Ribeiro (1985) e Diegues (1984) com o significado da palavra caiçara (indígena), sendo que a autora indica que o nome Icapuí, atual nome da cidade pesquisada significa "canoa veloz" (indígena); Waldemar de Almeida Barbosa (1968) e outros (Augusto de Lima Júnior, Salomão de Vasconcelos, Joaquim Ribeiro da Costa, Nélson de Sena) registram a preocupação com que vêem a mudança de topônimos sem a consulta popular, Almeida Barbosa inclusive afirma que o nome de uma localidade é tão importante quanto a bandeira e que ambos estão ligados à construção da identidade de um grupo; Burke (2005) comenta as diferentes maneiras das pessoas ao redor do mundo recordar o passado e explica que a tradição de nomear e renomear lugares vem da antiguidade; Hobsbawm \& Ranger (1984) e Carvalho (1990) tratam da questão da construção das tradições pelos estados nacionais. Além destes utiliza-se de Antonio Houaiss (Dicionário histórico das palavras tupis) e de vários Decretos.

No subtítulo "Território e Identidade" (p. 41-50) a pesquisadora utilizou-se do geógrafo Milton Santos (2000 e 2001) para conhecer o conceito de lugar e espaço. Para Santos, na página 50 da tese explica que o papel do lugar em que se vive é determinante porque, além de um quadro de vida, ele é um espaço de experiência renovada, o que permite reavaliar as heranças e indagar sobre o presente e o futuro: "A experiência naquele espaço exerce um papel revelador sobre o mundo". Santos ainda coloca que "não serve falar de território em si mesmo, mas de território usado"; Para falar sobre a identidade construída no social utilizou-se de Barus-Michel (2004) que também escreve sobre o sentimento de pertencimento "é como algo do nível afetivo que faz com que os membros de um grupo possam dizer 'nós'” (p. 45); Já Fustel de Coulanges (2002) mostra o significado de território na Antiguidade; De Giddens (2002) retira o conceito de Estado-Nação e reflexividade; Em Stuart Hall (2000) discute a mudança estrutural ocorrida no final do século XX que desencadeou, segundo o autor, uma "crise de identidade" (p. 42); Otávio lanni (1996) complementa Hall inserindo a questão da globalização econômica como outro fator de "crise" como mudança de significados, deixando a identidade nacional de ser mais forte dando lugar a outras identidades sociais ou culturais ou reforçando as identidades locais (p. 43); Ao discutir a identidade cultural e o pertencimento, a autora vale-se de autores como Morin (2001) e Halbwachs (1999) "quanto maior é a participação do sujeito, tanto em duração como em intensidade, mais a identidade cultural se fortalece e retroalimenta o processo" (p. 45); Orlandi 


\section{Resenha: Memória E Identidade Local Em Icapuí, Ceará}

(1984) discute a idéia de que somos o "outro" da Europa, porém a Europa não é nosso "outro", portanto somos o "outro excluído", porém também não queremos ser o brasileiro nativo. A mesma autora também escreve sobre a significação silenciosa e a linguagem; Todorov (1990) destaca que a identidade brasileira, como de toda a América, nasce da descoberta do "eu" que faz o "outro". Para ele, após a vinda de Colombo na América, os homens descobrem a totalidade de que fazem parte, pois, até então, "formavam uma parte sem todo" (p. 47).

O terceiro subtítulo da segunda parte da tese se intitula "Tradição e Nomeação" (p. 51-61) a autora se serviu das contribuições de Hobsbawm e Ranger (1984: 12) que dizem que a nomeação é uma prática social e uma prática discursiva, podendo ser também uma tradição inventada. Utilizam o termo "tradição inventada" que inclui tanto o termo "tradições" realmente inventadas, construídas e formalmente institucionalizadas, quanto as que surgiram de uma maneira mais difícil de localizar no tempo. Seu objetivo primordial não é estudar as chances de sobrevivência de uma "tradição inventada", mas sim o modo como elas surgem e se estabelecem (p. 51). Carvalho (1990) assume a posição de que o contraste entre as constantes mudanças e inovações do mundo moderno e a tentativa de estruturar de maneira imutável e invariável, ao menos alguns aspectos da vida social, que torna a invenção da tradição importante numa discussão sobre identidade de lugar (p. 52). Em Putnam (apud Gohn, 2004: 17) a autora encontrou a definição de comunidade cívica caracterizada por cidadãos atuantes e imbuídos de espírito público, por relações políticas igualitárias, por uma estrutura social firmada na confiança e na colaboração. De Braczko (apud Carvalho, 1990:13) retirou o termo "comunidade de imaginação". Na página 54 a autora cita Carvalho (1990): é no imaginário que as sociedades definem sua identidade e objetivos, determinam inimizades, organizam o tempo - o passado, o presente e o futuro da comunidade. Por isso a elaboração de um imaginário é parte integrante da legitimação de qualquer regime político (p. 54). Para a pesquisadora, o imaginário é transmitido através da linguagem que serve de transmissor de um conhecimento necessário a outros, neste momento do texto Ana Maria, novamente volta para a questão dos topônimos (p. 57). Sampaio (1928) escreve sobre as palavras tupis e não-tupis demonstrando a influência do diferente. Quer dizer, na página 58, o tupi deixa marcas nos topônimos do litoral e das margens dos rios navegáveis e os não-tupis estão no interior, nos terrenos mais áridos e nas baixadas interiores. Utilizou-se igualmente de decretos, resoluções, leis, e o dicionário Houaiss.

No último subtítulo desta seção “Memória e Identidade" (p. 62-65) cita Herrera (1986) que afirma que os topônimos, além de servir para identificar uma locação e endereço de comunicação, os nomes de 


\section{Resenha: Memória E Identidade Local Em Icapuí, Ceará}

lugares também expressam tangivelmente a atividade humana de investir uma paisagem de significado e memória (p. 62). A pesquisadora citando Gohn (2004) afirma que a identidade de um grupo se constrói a partir de um conjunto de percepções e de visões de mundo que transparece no próprio processo de experiência histórica do grupo, ao atuar coletivamente, aliado às representações simbólicas que também constroem ou adotam (p. 62). De Carvalho (1990) retira o conceito de símbolo que estabelece uma relação de significado entre dois objetos, duas idéias, entre objetos e idéias, ou duas imagens, porém esta relação depende de um ato de vontade e de aceitação, pois o símbolo só será eficaz em termos políticos se existir um terreno comum, com raízes no imaginário preexistente ou nas aspirações coletivas por um novo imaginário (p. 62-3). Neste subcapítulo, a autora aponta para a importância da memória e dos discursos nos processos de construção da identidade do lugar. Isto também se verifica quando aponta no decorrer do texto, quando se muda o nome do lugar, pois a renomeação pode servir para construir/desconstruir tradições tanto quanto é capaz de destruí-las.

A parte três (p. 67 - 92) se apóia nos estudos de Maurice Halbwachs sobre a memória individual e coletiva; a memória coletiva, o tempo e o espaço. Este autor ajuda a situar a aventura pessoal da memória, a sucessão dos acontecimentos individuais, que resulta de mudanças que ocorrem nas relações com os grupos a que estão misturados e nas relações que se estabelecem nestes grupos. Religiões, atitudes políticas, organizações administrativas carregam consigo dimensões temporais que são outras tantas projeções voltadas para o passado ou para o futuro e correspondem aos dinamismos mais ou menos intensos e acentuados dos conjuntos humanos como as paredes das cidades, as casas, as ruas das cidades ou as paisagens rurais. Este capítulo é dividido em sete subitens para melhor entendimento. No primeiro subcapítulo "Memória individual, memória coletiva e discurso" (p. 67- 69) a autora expõe que os pontos de divisão do tempo coletivo, embora tenham origem nos pensamentos individuais, se impões de fora a todos nós. As lembranças históricas evocam certos acontecimentos que deixaram um traço profundo no pensamento da coletividade, principalmente quando suas instituições são alteradas. Por estarmos então engajados no grupo, nada do que ocorreu enquanto dele fizemos parte nos é completamente estranho. Ela de remete a Halbwachs (1999) para concluir que a memória individual se apóia na história vivida e não na história aprendida (p. 69). No segundo subcapítulo "Nunca estamos sós: grupo, memória e discurso" (p. 69 - 73) a pesquisadora expõe que é comum evocarmos testemunhas para confirmar ou evocar uma lembrança, porém este ato é ilusório e complementar, pois é necessário que as lembranças tenham se conservado em meu próprio espírito. É importante frisar, segundo a autora, que a lembrança, ou uma de suas partes, deva subsistir em cada pessoa, mas sim que, ao permanecer em contato com o grupo, a pessoa continua a ser capaz de se 


\section{Resenha: Memória E Identidade Local Em Icapuí, Ceará}

identificar com ele e de confundir o passado dele com o do grupo (p. 72). No próximo subtítulo "Identificação com os grupos" (p. 74 - 76) a pesquisadora afirma que é possível que a memória coletiva tire sua força e sua duração do fato de ter por suporte um conjunto de homens. Essa massa de lembranças comuns, em que umas se apóiam sobre as outras, vai aparecer para cada um dos membros do grupo em lembranças de intensidade variável. Uma forma de dizer isso, é admitir que cada memória individual é um ponto de vista sobre a memória coletiva, mas este ponto de vista varia conforme o lugar ocupado pela pessoa no grupo, e o próprio lugar ocupado no grupo muda de acordo com as relações que o indivíduo mantém com os meios (p. 75). O quarto subitem "Memória pessoal e memória social" (p. 76 - 79) A autora inicia citando Halbwachs (1999) que reconhece que pode parecer estranho falar, mesmo como metáfora, da memória de um grupo, pois tendemos pensar na memória como uma faculdade ligada a um corpo ou a um cérebro individual. E continua conceituando as memórias. A memória individual (ou interna) por apoiar-se na memória coletiva para confirmar algumas lembranças ou mesmo preencher lacunas, deslocando-se nela e se confundindo momentaneamente com ela. Já a memória coletiva (externa ou social) envolve as memórias individuais, sem se confundir com elas, e evoluindo segundo as suas leis (coletivas) (p. 77). Porém, segundo Halbwachs elas só podem tornar-se lembranças coletivas ao preço de perder sua individualidade (p. 78). Na página 79 a 84 encontramos o subcapítulo "Tempo e memória" onde a autora expõe que o tempo só é perceptível pela memória e que a consciência individual é apenas o ponto de encontro dos tempos coletivos. Somos obrigados a regular nossas atividades pelos ponteiros de um relógio e a ser avaros com nosso tempo para não perdermos oportunidades e vantagens oferecidas pela vida em sociedade (p. 80). Podemos dizer que os grupos, de uma maneira em geral, dividem o tempo do jeito que herdaram pela tradição. No sexto subcapítulo "Tempo e a transformação social” (p. 84 - 89) cita novamente Halbwachs que define que cada indivíduo é membro de vários grupos e tem seu olhar mergulhado sucessivamente em vários tempos coletivos. Assim, a duração interior se decompõe em várias correntes de pensamento que têm sua origem nos próprios grupos sendo a consciência individual apenas o ponto de encontro dos tempos coletivos. No último subcapítulo "Espaço e memória coletiva" (p. 89 - 92) a pesquisadora citando Halbwachs apresenta que as imagens espaciais desempenham um papel fundamental na memória coletiva. O lugar recebe a marca do grupo e vice-versa, de tal modo que todas as ações do grupo se podem traduzir em termos espaciais. O lugar ocupado pelo grupo é simplesmente a reunião de todos os termos. E cada detalhe, cada aspecto do lugar, tem um sentido inteligível para os membros do grupo porque cada um deles corresponde a aspectos da estrutura e da vida da sociedade em que o grupo está inserido, pelo menos 


\section{Resenha: Memória E Identidade Local Em Icapuí, Ceará}

no que nela há de mais estável, principalmente os objetos, diz, nos fazem recordar de memórias "esquecidas ou adormecidas". Segundo a teoria da memória coletiva de Halbwachs (1999), cada sociedade recorta o espaço a seu modo, e há tantas maneiras de representar o espaço quantos sejam os grupos (p. 91). Para lembrar de pessoas ou fatos do passado é necessário sair do espaço. Segundo Halbwachs é a imagem do espaço que consegue nos dar a ilusão de não mudar através do tempo. Portanto é o território, espaço coletivo, que vai permitir guardar e relembrar.

No quarto capítulo "Icapuí - cidade e identidade" (p. 94-136), dividido em cinco subtítulos, Ana Maria versa sobre o município de Icapuí criado em 1985 e durante vinte anos administrado com métodos participativos, priorizando a educação e a saúde. Situada no extremo leste do litoral do estado do Ceará, na divisa com o Rio Grande do Norte, os quase dezesseis mil habitantes de Icapuí transformaram por completo a realidade local depois que o município se desmembrou de Aracati, um dos mais antigos e importantes centros econômicos regionais. Esta população foi vítima de arbitrariedades dos governos federais autoritários quando teve o nome alterado na década de 1940 e teve cancelada a primeira emancipação legalmente conquistada na década de 1960, porém a luta pela cidadania não terminou por aí. A autora traça um retrato do município de Icapuí e de suas tentativas de construir e manter uma tradição e identidades próprias, principalmente através da manutenção de seu patrimônio natural e cultural.

A quinta parte "Pesquisa de Campo" (p. 137 - 209) apresenta a metodologia de análise e a própria análise da pesquisa de campo realizada com vinte (sete mulheres e treze homens) habitantes do município de Icapuí, residentes em 2002 e nascidas antes de 1984, data da realização do plebiscito que decidiu pela emancipação do município. Três dos entrevistados nunca moraram fora do município. O desenvolvimento das entrevistas foi tranqüilo, apesar de alguns entrevistados mostrarem preocupações quanto a declarações. A autora utilizou códigos para proteger a identidade de seus entrevistados. Em relação aos procedimentos, a autora coloca que foi importante a atenção que teve de uma equipe de pessoas do próprio município, o que facilitou o trabalho de apresentação e "confiança" na pesquisadora, bem como apoio de logística e planejamento. A pesquisadora descreve todo o entorno em que se deu a pesquisa, o espaço em que ela chegou a morar, as comidas que lhe chamaram a atenção, os amigos. Demonstrando, assim que não só as entrevistas são importantes, mas a observação do espaço também o é. As entrevistas foram semi-dirigidas e incluíram basicamente três blocos: a) identificação pessoal; b) bloco sobre história, memória e identificação com o lugar; c) bloco sobre o nome do município (p. 142-143); e todas foram totalmente transcritas com fidelidade 


\section{Resenha: Memória E Identidade Local Em Icapuí, Ceará}

até em relação às ações dos entrevistados. Sendo as entrevistas analisadas em três categorias: a) identificações locais em processo; identificação com as tradições; $c$ ) identidade e mudança social (p. 143). Também é apresentado o resultado da análise dos discursos colhidos pela pesquisadora utilizando várias citações ou, partes de transcrições das entrevistas.

No capítulo seis "Considerações Finais" (p. 210 - 219) a autora apresenta que da identidade do lugar, podemos dizer, como se disse da cidadania, que existirá somente enquanto for reclamada. Portanto o pertencimento a um lugar, ou identificação com um lugar (identidade local) existe à medida que existe o espaço do cidadão, seja como partícipe na construção das instituições, seja como beneficiário da eficiência das instituições. A importância das instituições se deve ao fato de que só por meio delas se poderia prover igual acesso ao usufruto do território e das riquezas, serviços e produtos, de um lugar ou de uma determinada localização. A pesquisadora igualmente remete o leitor a novas pesquisas a partir deste trabalho. Porém, não se observou a volta aos objetivos propostos e consequentemente, as explicações se foram atingidos ou não. Na mesma idéia, o problema também não foi retomado de maneira clara, sendo simplesmente feito um resumo do que foi descoberto com a pesquisa com a utilização de citações de autores citados na bibliografia.

Em suma, esta tese apresenta questões como memória, reconhecimento, identidade, topônimos e espaço para destacar os mais importantes, sobre a complexidade de interação destas na relação de pertencimento e construção de identidades a partir do lugar. Entretanto, o resultado deste estudo estimula a leitura e prende a atenção dos leitores. 


\section{Resenha: Memória E Identidade Local Em Icapuí, Ceará}

\section{REFERÊNCIAS}

BUSTAMANTE, Ana Maria Goulart. Memória e identidade local em Icapuí, Ceará. Orientadora: Maria Lúcia Rocha-Coutinho. Rio de Janeiro: UFRJ/EICOS, 2005. Tese (Doutorado em Psicossociologia de Comunidades e Ecologia Social). 


\section{Capítulo 2}

doi $10.37423 / 210604271$

\section{A IMPORTÂNCIA DA AFETIVIDADE EM PROFESSORES DO ENSINOSUPERIOR NOS PROCESSOS DE ENSINO-APRENDIZAGEM}

Patrícia dos Santos Pessoa

Elida Pereira Macedo

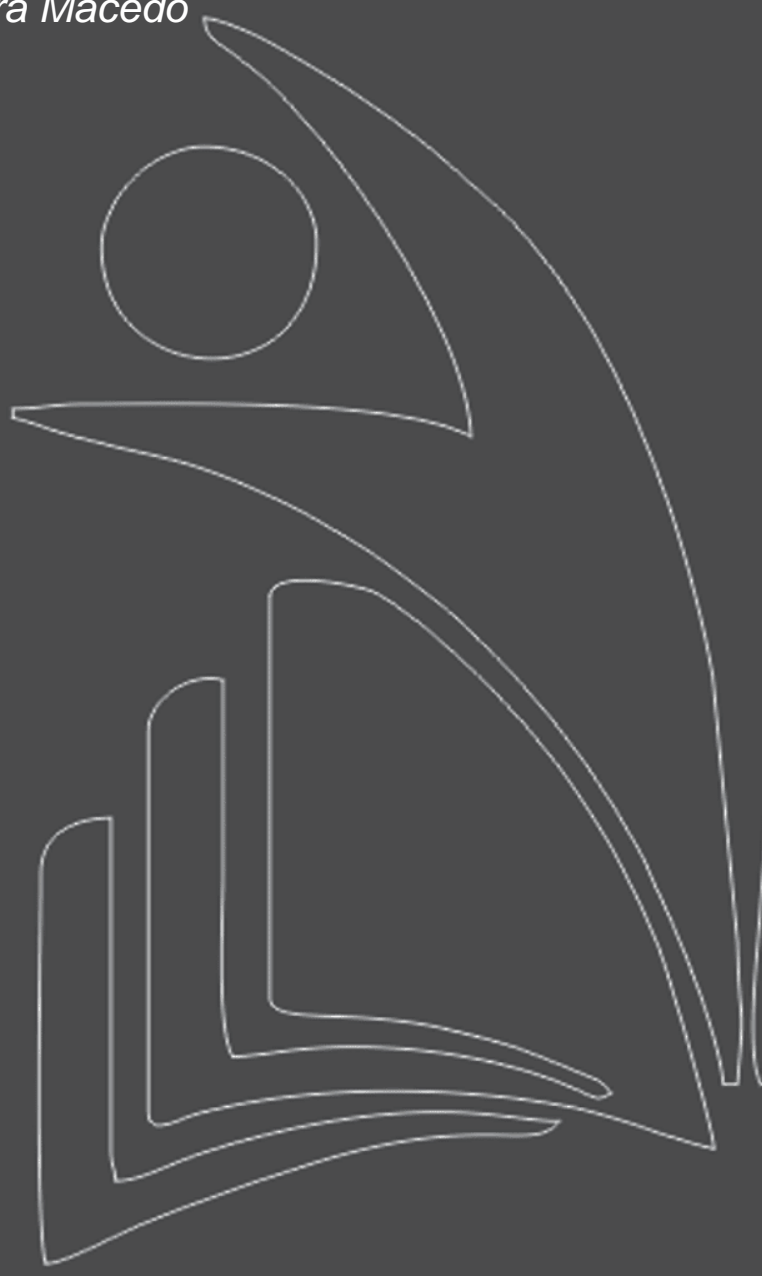

Centro Universitário Fieo

Faculdade Flamingo

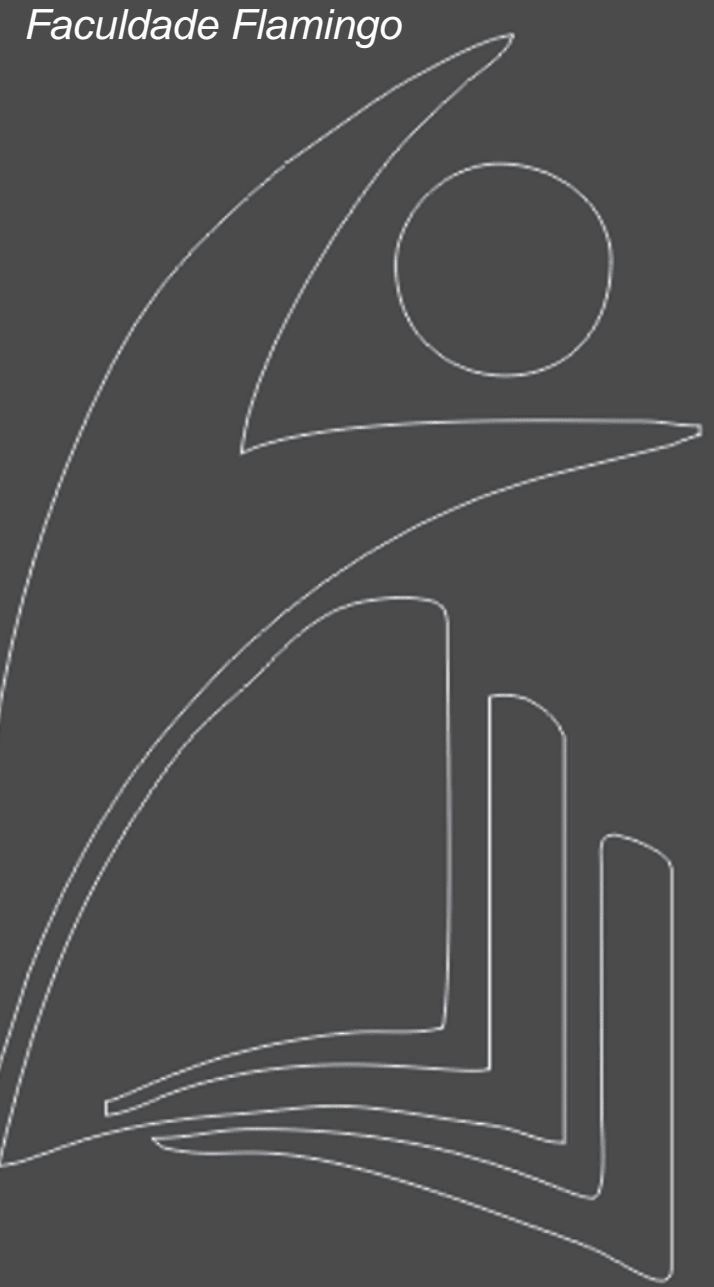


Resumo: O presente artigo apresenta uma revisão de literatura sobre "A importância da Afetividade em Professores do Ensino Superior nos processos de Ensino- Aprendizagem". Afetividade neste artigo refere-se aos conceitos direcionados a Educação e a Psicologia. Estes conceitos referentes à afetividade e as emoções podem remeter a uma mesma definição; mas ao nos aprofundarmos em seus significados é possível esclarecer que a afetividade é um conjunto de fenômeno psíquico sobre as formas de emoção. A afetividade cumpre uma função decisiva na vida do sujeito e forma uma união na relação professor-aluno no campo da qual educar é colaborar com o aluno para tomar consciência de si mesmo, dos outros e da sociedade em que vive. Foi realizado o levantamento bibliográfico na base de dados da Scielo entre 2000 e 2016 e livros de base a partir de 2003 . Foram selecionados diversos artigos e textos relevantes para contribuir com a pesquisa. Os resultados indicam que para que o professor possa ter resultados satisfatórios no processo de ensino-aprendizagem, a relação afetiva com seus alunos deve estar presente em sua atuação, e para isso é necessário que ele tenha facilidade de relacionamento e gostar da sua profissão. Neste sentido, torna-se relevante repensar sobre a afetividade no Ensino Superior.

Palavras-chave: Afetividade; Ensino Superior; Aprendizagem; Professores. 


\section{INTRODUÇÃO}

O Ensino Superior no Brasil tem sido objeto de estudo de diversos teóricos. De acordo com Silva (2013), este é um tema relevante, que remete a interrogações para promover a evolução do nível de ensino e suas abrangentes dimensões tanto históricas, políticas, sociais e econômicas. Esse contexto histórico permite $\mathrm{o}$ avanço de novos questionamentos que possivelmente contribua nesta temática. $O$ professor para atuar como docente do Ensino Superior precisa ter características diferenciadas, para Vasconcellos (2003), o professor necessita colaborar com a formação do aluno na sua totalidade, consciência, caráter e cidadania, tendo como mediação fundamental o conhecimento, visando à emancipação do aluno.

No processo de ensino e aprendizagem, tanto o aluno quanto o professor, são ambos afetados; cada professor, cada aluno será afetado de uma forma singular no seu processo de aprendizagem; esta educação se constrói nas relações afetivas estabelecidas e dá sustentação ao papel de socialização (França, Silva, Santos, Vasconcelos, 2015). A afetividade se origina do latim "affectus", que significa um conjunto de ações ou atitudes como, por exemplo, o acolhimento. $O$ afeto pode ser caracterizado por circunstâncias em que há uma preocupação com o outro (PORTO, SANTOS, CRUZ, 2016).

Os conceitos de afetividade e emoções podem remeter a uma mesma definição; mas ao nos aprofundarmos em seus significados é possível esclarecer que a afetividade é um conjunto de fenômeno psíquico sobre as formas de emoção. A afetividade cumpre uma função decisiva na vida do sujeito e forma uma união na relação professor-aluno no campo da qual educar é colaborar com o aluno para tomar consciência de si mesmo, dos outros e da sociedade em que vive. A afetividade é relevante para a construção das relações que se estabelecem entre o alunado e os diversos objetos de conhecimento: conteúdos disciplinares e atividades acadêmicas (PORTO, SANTOS, CRUZ, 2016).

A educação do século XXI tem como objetivo estabelecer-se em torno dos quatro pilares da educação, aprendizagens fundamentais apontadas pela Organização das Nações Unidas para a Educação, Ciência e Cultura (UNESCO), que, serão para o ser humano, os pilares do conhecimento: a) aprender a conhecer (adquirir as ferramentas da compreensão praticando a atenção, a memória e o pensamento), b) aprender a fazer (para poder atuar sobre o meio inserido, este aprendizado está ligado à questão da formação profissional), c) aprender a viver (aprender a viver juntos, com o objetivo de participação e colaboração com os outros em todas as atividades humanas) d) aprender a ser (a educação deve contribuir para o completo desenvolvimento da pessoa, para melhor progresso de sua 
personalidade e atuar com autonomia, discernimento e de responsabilidade pessoal) (DELORS et al., 2010).

Para que o professor possa ter um êxito em seus objetivos, a relação afetiva com seus alunos deve estar presente em sua atuação, e para isso é necessário que ele tenha uma personalidade equilibrada, facilidade de relacionamento e gostar dasua profissão. Dessa forma, ele será capaz de desenvolver vínculos afetivos com seus alunos, devendo propiciar bons resultados na aquisição de conhecimento dos discentes (MACÊDO, MACEDO, MACÊDO, 2007).

O objetivo deste artigo foi fazer uma revisão de literatura sobre "A importância da Afetividade em Professores do Ensino Superior nos processos de Ensino- Aprendizagem".

\section{METODOLOGIA}

Para o levantamento bibliográfico, buscaram-se artigos na Scielo entre 2000 e 2016 e livros de base a partir de 2003. Foram selecionados diversos artigos e textos relevantes para contribuir com a pesquisa.

\section{DESENVOLVIMENTO, FUNDAMENTAÇÃO TEÓRICA, RESULTADOS E DISCUSSÕES.}

A afetividade atua como função psicológica do ser humano, sendo de grande progresso no comportamento e no aprendizado do sujeito juntamente com o desenvolvimento cognitivo Sarnoki (2014). A afetividade e suas decorrências com o ensino tem sido um tema frequente na Instituição de Ensino Superior (IES), nas duas últimas décadas. Sarnoski (2014) afirma que a afetividade é a forma mais intensa e complexa de que o sujeito possa integrar. É possível inferir que para que possa haver uma compreensão adequada referente ao pensamento humano, é necessário compreender inicialmente a sua base afetiva.

Aquele que separa o pensamento do afeto tende a negar a probabilidade de estudar a influência oposta no plano afetivo (Santos, Junqueira, Silva, 2016). Por conseguinte, a construção do conhecimento humano não ocorre de maneira isolada.

Ele é a consequência das relações coletivas assinaladas pelos encontros e desencontros sociais e culturais. Sendo assim, a afetividade não pode ser vista separada do processo de ensinoaprendizagem, pois ela pode contribuir para a obtenção do conhecimento de forma prazerosa e segura (SANTOS, JUNQUEIRA, SILVA, 2016).

Wallon (2007) enfatiza que o desenvolvimento está ligado a três aspectos: afetivo, cognitivo e motor. Neste contexto, a teoria destaca três momentos marcantes referenciando a afetividade como um 
conjunto funcional que abrange emoções (Manifestação da afetividade, expressão corporal motora) sentimentos (corresponde à demonstração da afetividade, não sendo direta como a emoção) e paixão (mostra se através do autocontrole para dominar uma situação, tentando calar a emoção.

Sendo caracterizada por ciúmes, cobranças e exclusividade). Wallon (2007) menciona que a relação com o outro nos acompanha, "como parceiro do eu na vida psíquica", pois, o sujeito constrói-se nas suas interações com o meio. O sujeito ao se sentir inserido ao meio transforma não só a sua realidade como também transforma o outro, ou seja, isso acontece quando o sujeito valoriza o outro ao percebêlo (AZEVEDO, 2017).

Piaget relata que a importância da afetividade além de estar ligada a relação professor- aluno, também é um mecanismo de estratégia pedagógica. Ele menciona que ela deve se fazer presente nas decisões de ensino em que o docente tende a assumir. Desta forma, haverá qualidade dos vínculos entre aprendizagem e o objeto de conhecimento (PORTO, SANTOS, CRUZ, 2016).

Para Piaget (2014), a afetividade é fundamental na socialização. Ele enfatiza que ela compreende sentimentos tais como: prazer, desprazer, simpatia, vontade e emoções; bem como os elementos energéticos, que são os interesses, os afetos das relações interindividuais, sentimentos morais. Neste sentido, o afeto promove um papel essencial no funcionamento da inteligência.

Nessa interação, o sujeito apreende as informações do meio, internalizando-as e transformando-as, de maneira ativa, integrando os conhecimentos que já adquiriu.

Dessa forma, quando o sujeito aprende, seu pensamento se modifica e se transforma em novos conhecimentos para que ele possa agir no meio e transformá-lo novamente (FRANÇA et al., 2015).

Quando há a aprendizagem, o pensamento se modifica e transforma-se em novos conhecimentos para que o sujeito possa retornar ao meio transformando-o novamente. $O$ espaço para a aprendizagem, segundo França et al., (2015), é preenchido por meio das emoções, dos sentimentos e pensamentos que são externados, proporcionando a oportunidade de reflexão e interação entre os sujeitos, instigando-os e motivando-os. Dessa forma, a aprendizagem exerce um papel fundamental no processo de desenvolvimento. O conhecimento ocorre mediante as relações entre o sujeito e o objeto (LEITE, 2012).

$\mathrm{O}$ ato de lecionar é consequência de um método pedagógico relacional, por isso envolve a afetividade dos discentes e dos docentes que estão envolvidos no processo de ensino e aprendizagem. A afetividade é fundamental nas relações interpessoais. Por meio dela a tarefa escolar pode ser mais 
bem direcionada. Servindo ainda de elo para a construção do conhecimento discente e para o processo da aprendizagem (SANTOS, JUNQUEIRA, SILVA, 2016).

A afetividade cumpre uma função decisiva na vida das pessoas e forma uma união na relação professor-aluno no campo da qual educar é colaborar com o discente para tomar consciência de si mesmo, dos outros e da sociedade em que vive. Desta forma a afetividade é relevante para a construção das relações que se estabelecem entre o alunado e os diversos objetos de conhecimento: conteúdos disciplinares e atividades acadêmicas (PORTO, SANTOS, CRUZ, 2016).

Ser professor vai além, se incide em despertar no discente, valores e sentimentos como o amor e o respeito ao próximo; tornando o aprendizado mais atraente, o aluno se sente competente e motivado em sala de aula Sarnoski (2014).

Vygotsky descreveu a Zona de Desenvolvimento Proximal (ZDP) como a área onde se contém os conhecimentos e habilidades que o sujeito é capaz de realizar.

Vygotsky classifica esses conhecimentos em dois conceitos: o primeiro trata sobre a zona de desenvolvimento real (aquilo que o sujeito pode realizar sozinho, habilidades internas), o segundo, denomina-se a zona de desenvolvimento potencial (são habilidades potenciais que permitem ao sujeito a realização de práticas em colaboração de outras pessoas mais experientes). A partir do momento em que estes conceitos são internalizados, há a transição da zona de desenvolvimento potencial para a zona de desenvolvimento real, que permanece durante todo o desenvolvimento do sujeito (GODOI, 2012).

Nesse sentido, Vygotsky (2007) afirma que "a Zona de Desenvolvimento Proximal é a distância entre o nível de desenvolvimento real, que se costuma determinar através da solução independente de problemas" (Vygotsky, 2007, p. 97).

O autor elucida a relevância da mediação para a aprendizagem, deixando grande contribuição para a compreensão dos processos de desenvolvimento humano, pois para o autor, este conceito se evidencia ao longo da vida.

\section{CONSIDERAÇÕES FINAIS}

Os resultados indicam que para que o professor possa ter um êxito em seus objetivos, a relação afetiva com seus alunos deve estar presente em sua atuação, e para isso é necessário que ele tenha uma facilidade de relacionamento e gostar da sua profissão. Dessa forma, ele será capaz de desenvolver 
vínculos afetivos com seus alunos, devendo propiciar bons resultados na aquisição de conhecimento do seu alunado.

A forma com que o professor apresenta o conteúdo de sua disciplina pode ser mediada por afetos. Neste sentido, diante da pesquisa levantada, entende-se que nessa relação ambos são afetados. Ressalta-se que este estudo possibilita a ampliação de novos artigos para que possa auxiliar no progresso e desenvolvimento da afetividade em professores do Ensino Superior no Processo de Ensino- Aprendizagem. 


\section{REFERÊNCIAS BIBLIOGRÁFICAS}

AZEVEDO, Cleomar. A mediação das emoções em professores alfabetizadores. Curitiba: Appris Editora e Livraria Eireli-ME, 2017.

DELORS, Jacques et al.Educação: um tesouro a descobrir. Relatório para a UNESCO da Comissão Internacional sobre Educação para o século XXI. T. Guilherme João de Freitas. (Trads.). Brasília: 96/WS/9, 2010

FRANÇA, George; Silva, Liliam Maria da; Santos, Luciana Aparecida; Vasconcelos, Paulo A. C. de. Design Instrucional: metodologias, comunicação, afetividade e aprendizagem. InterSciencePlace, v.1, n.2, 2015.

GODOI, Lídia Silva Guimarães. Zona de desenvolvimento proximal, aprendizagem cooperativa e tutoria entre pares: implicações para a qualificação da prática pedagógica nos centros de educação infantile. Revista da Faculdade Eça de Queirós, v.2, n.8, p.1-22, 2012.

LEITE, Sérgio Antônio da Silva. Afetividade nas práticas pedagógicas. Temas em psicologia, v.20, n.2, p.355-368, 2012.

MACÊDO, Paula Maria; Macedo, Maria Leomar; Macêdo, Barbara Maria. Inteligência emocional entre professores do ensino superior. Revista de Psicologia, v.1, n.3, p.33-41, 2007.

PIAGET, Jean. Relações entre a afetividade e a inteligência no desenvolvimento mental da criança. Cláudio J. P. Saltini \& Doralice B. Cavenaghi (Trads. \& Org.). Rio de Janeiro: Wak, 2014.

SANTOS, Anderson Oramisio; Junqueira, Adriana Mariano Rodrigues; Silva, Graciela Nunes da. A afetividade no processo de ensino e aprendizagem: Diálogos em Wallon e Vygotsky. Perspectivas em Psicologia, v.20, n.1, p.86-101, 2016.

SARNOSKI, Eliamara Aparecida. Afetividade no processo ensino-aprendizagem. Revista de Educação do IDEAU, v.9, n.20, p.1-13, 2014.

SILVA, Maria Vitória. (RE)lendo a trajetória do ensino superior no Brasil: implicações na formação de professores para a educação básica. Revista multidisciplinar em ciências humanas, Saberes em perspectiva, v.3, n.7, p.29-50, 2013

SIMÕES, Bruno dos Santos; Quadros, Ana Luiza de; Gehlen, Simoni Tormöhlen; Corrêa, Hamilton Perez Soares; Langhi, Rodolfo. A afinidade com a física: uma análise feita com estudantes da universidade federal do Mato Grosso do Sul (UFMS). Revista Ensaio Belo Horizonte, v.15, n.1, p.67-80, 2013.

SOUSA, Priscila Batista; Santos, Fernanda Cavalcante; Valverde, Clodoaldo. A influência da afetividade no processo de aprendizagem. Pedagogia em Foco, v.11, n.6, p.168-179, 2016.

PORTO, Cristiane de Magalhães; Santos, Fábio Maurício Fonseca; Cruz, Marisete Augusta da. Uma revisão bibliográfica da relação entre professores e aluno no ensino superior sob a ótica da afetividade. 9o enfope 10fopie, v.9, n.1, p.1-16, 2016.

VASCONCELLOS, Celso dos Santos. Para onde vai o professor? Resgate do professor como sujeito e transformação. 13. ed. São Paulo: Libertad, 2003. 
VYGOTSKY, Lev Semyonovitch. A Formação Social da Mente. 7ạ ed. São Paulo: Martins Fontes, 2007. WALLON, Henri. A evolução psicológica da criança. São Paulo: Martins Fontes, 2007. 


\section{Capítulo 3}

doi $10.37423 / 210604274$

\section{JOVENS [IN] VISÍVEIS: TRABALHO E TERRITORIALIDADE DOSCATADORES DA COOPERATIVA SANTA MARIA DA CIDADE DEITAPEVA-SP}

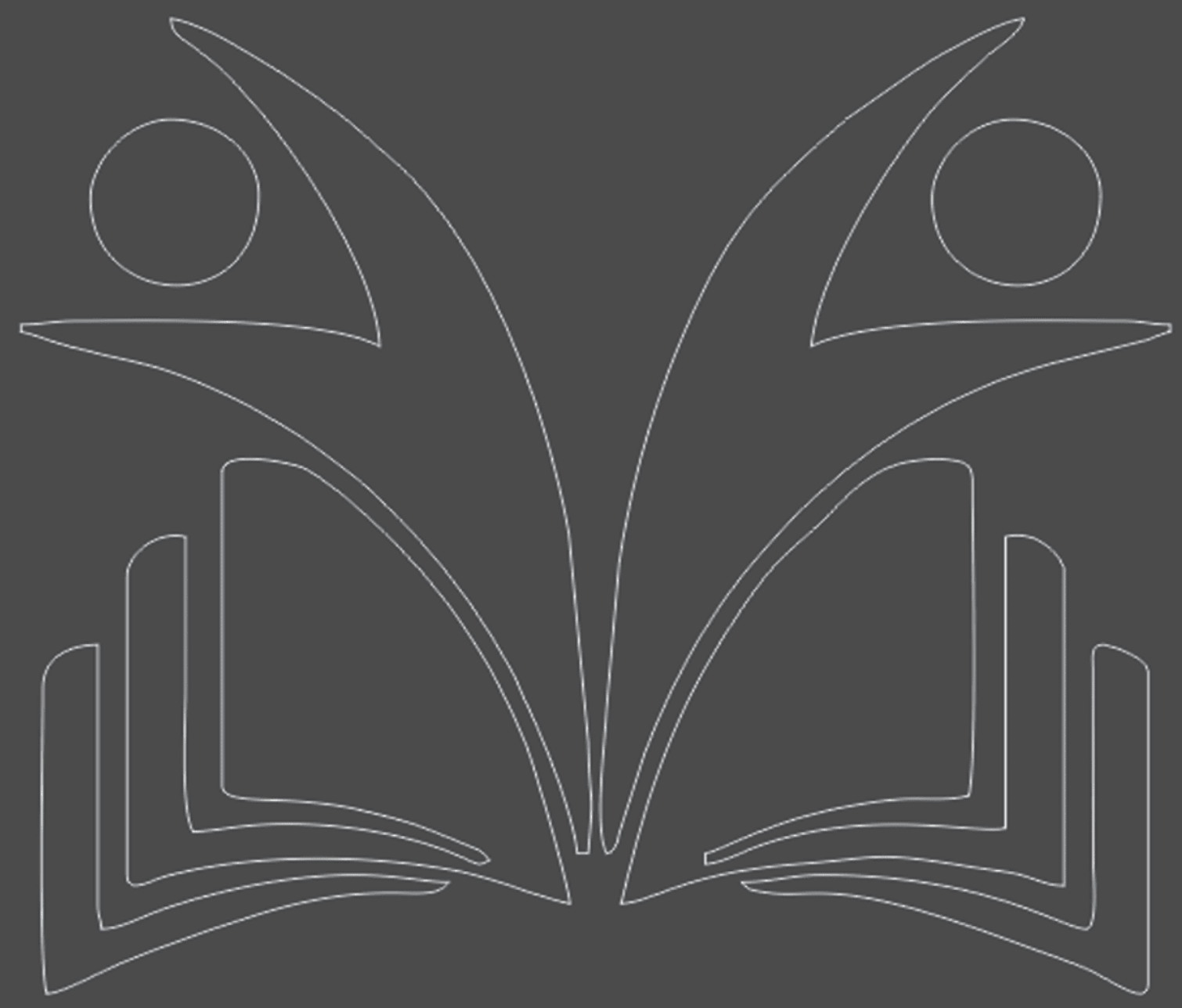


Resumo: Esse artigo traz como principal problemática as significações do trabalho para os jovens da Cooperativa de Recicláveis Santa Maria, da cidade de Itapeva, estado de São Paulo. A investigação parte também dos estigmas que esses jovens enfrentam por residir e trabalhar na Vila Santa Maria, periferia da cidade, e o quanto essa territorialidade influenciou nos caminhos que eles seguiram, no que diz respeito ao trabalho, pois a vila está situada nos arredores do lixão municipal, ambiente de trabalho para muitos deles em um passado próximo. Entender as significações dessa territorialidade para esses jovens também é objetivo da pesquisa, trazendo à tona as trajetórias desses jovens pobres que se tornaram trabalhadores sobrantes do sistema capitalista. O caminho de uma pesquisa só é possível ser trilhado quando esse caminho é feito de forma flexível, dessa forma a metodologia escolhida foi a qualitativa e o referencial teórico está atrelado a pesquisa de juventude. Quando se pensa analiticamente nos jovens como sujeitos de uma pesquisa, percebe-se que não há como rotulálos ou defini-los, por estarem em constante metamorfose. Os primeiros resultados da pesquisa estão ainda sendo analisados, tendo em vista que foram aplicados formulários iniciais com os sujeitos, após uma observação participante, tendo em vista que as entrevistas semiestruturadas estão programadas para o segundo semestre de 2020. Neste contexto já surgiram questões importantes ligadas aos suportes que esses jovens não têm, para que tenham acesso a direitos básicos, o cerceamento do sonho da educação formal é um grande exemplo disso.

Palavras-chave: Juventude; Trabalho; e Periferia. 


\section{INTRODUÇÃO}

A pesquisa que está em curso no Programa de Pós Graduação em Educação da UFSCar, campus de Sorocaba tem como objetivo central investigar, entender e trazer à tona a relação dos jovens catadores da Cooperativa de Recicláveis Santa Maria com o trabalho e com as significações da territorialidade, tanto nos duros anos que passaram trabalhando no lixão municipal da cidade de Itapeva-SP, na Vila Santa Maria, periferia da cidade, quanto nos significados que o trabalho e a territorialidade tem para eles hoje na cooperativa que nasceu no seio desse grupo. Essa relação com o trabalho no lixão cerceou muitos dos seus sonhos, tais como o sonho de estudar, mas trouxe muitas transformações que hoje tanto os alegram, como a formação da Cooperativa Santa Maria, que nasceu após anos de trabalho no lixão municipal, sendo esse trabalho potência para as suas vidas nos dias atuais.

A ideia desse artigo é apresentar um breve contexto da cidade e da Vila Santa Maria (periferia da cidade) e o quanto esse contexto influenciou na vida desses jovens, denunciando todo esse processo desumano que esses sujeitos foram inseridos, se tornando assim invisíveis, por muitas vezes, para a sociedade itapevense. $O$ debate teórico se dará em torno do quanto a realidade do território em que vivem trouxe outros problemas ligados a precarização do trabalho e a negação de direitos básicos de um cidadão. Ao final pretende-se apresentar os primeiros resultados, ligados aos questionários aplicados.

A cidade de Itapeva, no estado de São Paulo, segundo o Censo $2010^{1}$ tem 87.753 mil habitantes, possuindo Índice de Desenvolvimento Humano de 0,732, ocupando assim a 965a posição entre os 5.565 munícipios brasileiros. Dentre as dez primeiras cidades do Estado de São Paulo com menores $\mathrm{IDH}^{\prime} \mathrm{s}^{2}$, sete delas são do Vale do Ribeira e Sudoeste Paulista, região em que Itapeva está situada, e que são consideradas, portanto, por esse sistema de classificação, como as regiões mais pobres do Estado.

Como em outras regiões do Brasil, no Sudoeste Paulista existe uma exagerada distância social, que é observada como resultado do sistema capitalista, gerador de desigualdade por ser baseado em uma lógica produtivista. Neste contexto, o lixo que era produzido pela sociedade de Itapeva tinha destino certo, que era não apenas o território chamado de lixão municipal, mas cada um dos jovens catadores, que têm nome, sentimentos e vontades próprias, e que eram os principais destinatários do lixo. 
Itapeva é uma cidade com características rurais, o que era mais evidente na década de 1990, quando era ainda conhecida como "ramal da fome". A região onde hoje se localiza a Vila Santa Maria foi ocupada em um momento de êxodo rural na cidade. A maioria das famílias que lá se instalou foi extremamente afetada pela realidade precária da região, o que os distanciou ainda mais de um trabalho formal. Sem opção para a sobrevivência, essas famílias passaram a catar lixo, o que explica a formação da referida vila em torno do lixão municipal.

\section{PROCEDIMENTOS METODOLÓGICOS}

Na pesquisa que está em curso, há a necessidade de um extremo cuidado, principalmente porque os sujeitos são jovens que vivem na periferia e na precariedade, como catadores de lixo, e que na verdade foram pouco estudados até agora pela academia. O caminho de uma pesquisa só é possível ser feito quando esse caminho é trilhado de forma flexível, de forma que a forma da pesquisa escolhida foi a qualitativa, sendo possível, assim, voltar muitas vezes nas primeiras hipóteses e corrigi-las, dependendo dos resultados obtidos após o contato direto com os sujeitos. Novas questões surgem no decorrer do caminho, sendo elas de grande interesse para a pesquisa, que tem um compromisso de não apenas fazer emergir indagações, mas que tais questionamentos estejam atrelados a um compromisso social, principalmente neste caso (FERREIRA, 2017, p.19).

O autor Vitor Sérgio Ferreira (2017, p. 16) faz uma análise importante sobre a pesquisa em juventude, inclusive inspiradora para seguir com a investigação,

Dada a natureza aparentemente caótica da sociedade contemporânea, existem efetivamente sérios riscos de seguir à risca os caminhos sugeridos por manuais de metodologia, nomeadamente quando temos pela frente pesquisas com e sobre realidades juvenis (Allaste e Tiidenberg 2016; Heath e Walker 2012). Ir armado de certeza teóricas e regras metodológicas para enfrentar as aventuras que os mundos juvenis hoje convocam, refugiando-se no seguidismo de métodos mais padronizados, é meio caminho andado para se andar em círculo e se chegar onde já se conhece.

Diante de tantas experiências com esses jovens da periferia de Itapeva, sejam elas ruins ou boas, no ano de 2019 passei a olhar todo o contexto como um pesquisador, o que no início foi muito difícil e ainda está sendo, pelo meu envolvimento com os sujeitos. Porém, foi possível fazer um planejamento através de um minucioso olhar pelo campo da pesquisa. As primeiras impressões, que foram anotadas no que se pode chamar de um "diário de bordo", que foi concebido através de uma observação participante, e que já foi analisado de forma minuciosa para algumas decisões de tomada de direção. Inicialmente, foram aplicados questionários com oito jovens no mês de julho de 2019, e no segundo 
semestre desse ano estão programadas as primeiras entrevistas semiestruturadas, que apontarão direções a serem seguidas.

O tema e os sujeitos da pesquisa apresentam larga relevância para a academia, tendo em vista as especificidades que enfrentaram e enfrentam em suas vidas, por isso a importância de trazer à tona a realidade desses jovens que trabalhavam no lixão e a influência em suas vidas desse "chão" que pisaram.

\section{VILA SANTA MARIA E CONTEXTUALIZAÇÃO DE PERIFERIA}

Na formação inicial da Vila Santa Maria a precarização foi a principal dificuldade do povo, que se alojou por lá sem o mínimo de estrutura, sem saneamento básico, sem água potável. As pessoas que fixaram suas moradias na localidade logo se depararam com dificuldades para encontrar empregos na cidade ou na área rural, o que propiciou aos poucos a invasão do lixão municipal para que pudessem tirar o sustento. O lixão que foi projetado para ser aterro sanitário ${ }^{3}$, se tornou fonte e ambiente de trabalho para muitos da Vila Santa Maria.

Nos dias atuais, a Vila Santa Maria é periferia do munícipio de Itapeva, exibindo ainda muitos problemas relacionados à falta de saneamento básico e outros serviços que são mínimos para a sobrevivência dos cidadãos, o que pode ser atribuído à negligência do poder público em seus mais variados estágios.

A urbanização sem planejamento trouxe muitos problemas para a cidade de Itapeva, relacionados à miséria e ao trabalho desumano. No lixão municipal, tantos catadores lutaram por anos para conseguir ao menos sobreviver. É necessário compreender, ainda que previamente neste subcapítulo, o conceito de "periferia" e as significações do trabalho de "catador de material reciclável" ${ }^{4}$ ou o que se pode intitular de "trabalhadores sobrantes" desse sistema desigual que o capitalismo proporciona (BURGOS, 2013, p. 25 e 30).

Para que se entenda o que é periferia é valioso voltar às raízes dessa definição. 0 dicionário Aurélio $(2020)^{5}$ define periferia como "o que fica nos arredores, nas circunjacências de algum lugar". Segundo Guimarães (2016, p. 109-110):

Na literatura construída nas décadas de 1970 e 1980 sobre o urbano no Brasil, as periferias urbanas situadas nas metrópoles eram geralmente descritas como "o urbano possível" para as classes trabalhadoras. A periferia seria então o resultado de um processo dual de construção do espaço: a chamada relação "centro-periferia" é a expressão mais acabada desse movimento. [...] As metrópoles seriam espaços estanquizados, marco da segregação sócio- 
espacial; a centralidade concentraria o emprego, os equipamentos urbanísticos mais modernos e as funções centrais de direção da vida urbana. A periferia seria resultado do crescimento do espaço metropolitano, gerado pela ação localizada de um amplo leque de agentes privados e pela ação deficitária do Estado. Esses espaços nasceram desse duplo movimento e caracterizam-se geralmente por um decréscimo nas condições de vida das classes ditas populares. [...] A periferia, então, é o produto de uma lógica cruel e segregadora, uma lógica baseada na exclusão da urbe, criada e recriada a partir dos mecanismos especulativos sobre o solo, sobre a propriedade fundiária, que exclui e (re) inclui os indivíduos dentro de uma urbe estanquizada e precária.

Há, contudo, a necessidade, nesses novos tempos, de definir essa periferia como algo que tem muito de social, não sendo ela apenas um resultado do crescimento das metrópoles, muitas vezes imposta pelo capitalismo, pois a pobreza que está inserida nesse contexto deixa esses trabalhadores ao redor de um outro mundo concebido pelas classes sociais mais abastadas, bloqueando a relação entre os periféricos com a própria cidade. Sorj e Martuccelli (2008, p.60) analisam a interferência do capitalismo na cidade,

As novas modalidades do capitalismo vivem afetando, e em geral debilitando, os atributos das cidades como núcleos centrais da vida cidadã. Essas transformações reestruturam não apenas os modos de produzir, mas também os de consumo e de reprodução social, com enormes impactos nas interações sociais nas grandes cidades.

\section{JOVENS TRABALHADORES SOBRANTES}

Os jovens catadores, sujeitos dessa pesquisa, estiveram por muito tempo no cerne do descarte da sociedade, ou seja, no lixão, trabalho tão diferenciado de outros, e que é gerador de tantos sofrimentos. Léa Pinheiro Paixão, da Universidade Fluminense, em uma pesquisa feita junto às catadoras da cidade do Rio de Janeiro, debate esse tipo de trabalho:

O trabalho que as catadoras do lixão realizam, no entanto, não é um trabalho qualquer. Além de não ser reconhecido, "desqualifica" socialmente quem o realiza. Entende-se, então, a ambigüidade que marca as relações das entrevistadas com suas atividades no lixão. Suas vidas são reguladas pela luta cotidiana e pela sobrevivência e pela tentativa de provar aos outros e a si mesmas que são dignas trabalhadoras. (PAIXÃO, 2005, p. 143)

A exclusão de um trabalho formal, como ocorre no caso das catadoras do lixão do Rio de Janeiro e também com os catadores do lixão de Itapeva, conduz esses jovens a serem trabalhadores que não estão inseridos no mundo do trabalho decente ${ }^{6}$, o que os torna "trabalhadores sobrantes" do sistema, sendo esses os "trabalhadores pobres urbanos" que não têm carteira assinada e nem os direitos trabalhistas básicos assegurados pela lei ${ }^{7}$. Segundo José de Souza Martins (1997, p.33) “a sociedade moderna está criando uma grande massa de população sobrante, que tem pouca chance de ser de 
fato reincluída nos padrões atuais do desenvolvimento econômico". Esses trabalhadores sobrantes vêm de diversos setores do trabalho, que em um dado momento não conseguem mais se adequar e se inserir no mercado formal, passando a catar lixo para que possam sobreviver. Segundo Burgos (2013, p.68),

A denominação de trabalhadores sobrantes se refere aos trabalhadores pobres urbanos que, à margem do mercado de trabalho, são (re)inseridos produtivamente, sem contudo se emanciparem da condição de sobrantes. São trabalhadores que perderam seu emprego no setor formal (no contexto da reestruturação produtiva) ou que nunca conseguiram nele ingressar. Mais do que isso, são trabalhadores que sequer participam da denominada classe-quevive-do-trabalho, noção ampliada de classe trabalhadora, formulada por Antunes (1999).

Essa falta de um trabalho formal e decente pode ser inerente ao que chamamos hoje de exclusão social, que é caracterizada por um "estado carente ou de privação material, de segregação, de discriminação, de vulnerabilidade em alguma esfera" (FEIJÓ, 2004, p. 158). O termo exclusão social, tão utilizado por pesquisadores, é até compreensível, mas é necessário fazer uma análise mais aprofundada dos contextos que são denominados com esse termo. Por muitas vezes usar essa expressão de forma definitiva é um erro por um simples motivo: o capitalismo que hoje usa o caminho neoliberal acaba por incluir, de alguma maneira, todas as pessoas, dependendo da realidade. Quando se compreende de uma forma mais reflexiva, como ensina José de Souza Martins, "não existe exclusão: existe contradição, existem vítimas de processos sociais, políticos e econômicos excludentes", sendo que as pessoas são excluídas de partes desse processo, mas não de todas as partes (MARTINS, 1997, p.14). A pobreza, que é raiz de muitas dessas exclusões, é parte fundamental para o entendimento dessa questão, pois priva muitas pessoas, inclusive, por muitas vezes de alcançar seus próprios direitos, conforme expõe Martins (1997, p.18), estudioso desse tema,

Portanto, quer dizer que a exclusão é apenas um momento de percepção que cada um e todos podem ter daquilo que concretamente se traduz em privação: privação de emprego, privação de meios para participar no mercado de consumo, privação de bem-estar, privação de direitos, privação de liberdade, privação de esperança. É isso, em termos concretos, o que vulgarmente chamamos de pobreza. É preciso, pois estar atento ao fato de que, mudando o nome de pobreza para exclusão, podemos estar escamoteando o fato de que a pobreza hoje, mais do que mudar de nome, mudou de forma, de âmbito e de consequências. Estamos longe do tempo em que pobre era quem não tinha apenas o que comer. Sem contar que a realidade da pobreza inclui hoje mais do que a comida, além de incluir a negação subjetiva da pobreza por parte dos pobres: na medida do possível eles preferem não se reconhecer como tais. Isso se deve, em grande parte, ao fato de que a pobreza, no mundo moderno, é relativa. A linha que separa ricos e pobres é uma linha móvel, constantemente 
redefinida por uma cultura que também muda, e que define de modos sucessivamente diferentes e até contrastantes do que é pobreza.

As privações que o sistema impõe aos mais pobres e miseráveis do país está muito ligada ao acúmulo de capital, que se concentra nas mãos de muito poucos, o que torna a vida das pessoas sujeitas a tais privações muito precária. Por outro lado, os pobres acabam tendo outros tipos de privações, sendo impedidos até mesmo de ter acesso aos meios básicos para sua sobrevivência. Em que pese tenham acesso a direitos básicos, como saúde e educação, e sejam, portanto, incluídos de alguma forma, essa inclusão por muitas vezes tende a ser desumana, não se tratando, assim, de uma total "exclusão". Segundo Martins (1997, p. 21), "discutimos exclusão e, por isso, deixamos de discutir as formas pobres, insuficientes e, às vezes, até indecentes de inclusão".

Nesse contexto temos o que José de Souza Martins chama de "nova desigualdade", pois o sistema unifica as pessoas em variados âmbitos, ideologicamente falando, mas inclui precariamente em outros. Os anseios pelo consumismo passam a ser muitas vezes comuns entre ricos e pobres, pois a cultura massificadora prega e convence a isso. Martins (1997, p. 21) explica que

A nova desigualdade separa materialmente, mas unifica ideologicamente. No entanto, a nova desigualdade se caracteriza basicamente por criar uma sociedade dupla, como se fossem dois mundos que se excluem reciprocamente, embora parecidos na forma: em ambos podem ser encontradas as mesmas coisas, aparentemente as mesmas mercadorias, as mesmas ideias individualistas, a mesma competição. Mas, as oportunidades são completamente desiguais. A nova desigualdade resulta do encerramento de uma longa era de possibilidades de ascensão social, que foi característica do capitalismo até há poucos anos. Apesar disso, o imaginário que cimenta essa ruptura é um imaginário único, mercantilizado, enganador e manipulável.

Nesse sistema, todos estão incluídos de algum modo, pelo simples fato de que "todos têm o que vender e o que comprar". A diferença são as formas de inserção na sociedade, como foi apresentado e debatido. Existe uma "sub-humanidade", que advém, na maioria das vezes, de um trabalho indecente, uma precarização do trabalho, que para catadores é uma realidade tão gritante (MARTINS, 1997, p. 36).

\section{JUVENTUDE POBRE E DIFICULDADE DE INSERÇÃO SOCIAL}

A afirmação de Bourdieu, citado por Catani e Gilioli (2008, p. 16), de que "a juventude é apenas uma palavra" e tantos são os seus significados, leva a uma profunda reflexão sobre o que é a juventude realmente. Existe uma diversidade de juventudes, dependendo de seu contexto sócio-histórico, trazendo um sentido de heterogeneidade entre esses grupos, dependendo dos espaços que ocupam e das circunstâncias que vivem, onde os mais prejudicados são os jovens que estão abaixo da linha da 
pobreza $^{8}$, fortemente castigados por esse sistema desigual, que impõe uma visão desenvolvimentista nos jovens, demarcando suas transições (ABRAMO; LÉON, 2005, p.10). Segundo Coimbra (2005, p. 1), “majoritariamente, na sociedade capitalista, o jovem tem sido construído como um ser em formação, em crescimento, em desenvolvimento, em evolução", por ser uma ideia que a sociedade se apropriou, obrigando os mesmos a padronizar o termo juventude, pois a evolução tem que acontecer, custe o que custar, trazendo um espelho do capitalismo para suas vidas.

Para Carrano (2007, p.4), existem muitas maneiras de ser jovem hoje,

As passagens entre os tempos da infância, da adolescência, da juventude e vida adulta podem ser entendidas como "acordos societários". De certa forma, as sociedades estabelecem acordos intersubjetivos que definem o modo como o juvenil é conceituado ou representado (condição juvenil). Em algumas sociedades os rituais de passagem para a vida adulta são bem delimitados e se configuram em ritos sociais. Em nossas sociedades urbanas, principalmente, as fronteiras encontram-se cada vez mais borradas e as passagens de época não possuem marcadores precisos. Algumas dimensões marcavam o fim da juventude e a entrada no mundo adulto: terminar os estudos, conseguir trabalho, sair da casa dos pais, constituir moradia e família, casar e ter filhos. Estas são "estações" de uma trajetória societária linear que não pode mais servir para caracterizar a "transição da juventude para a vida adulta". A perda da linearidade neste processo pode ser apontada como uma das marcas da vivência da juventude na sociedade contemporânea. Assim, é preciso ter em conta as muitas maneiras de ser jovem hoje.

Na sociedade capitalista a juventude pobre carrega estigmas a ela impostos, e essa fase de transição se transforma por vezes em fases de transgressão, definindo esses sujeitos como problemáticos. $O$ jovem aparece como fundador dos problemas que ameaçam a "ordem social", sendo por muitas vezes condenado como o grande culpado do declínio ético da sociedade e, antes de efetivamente começar sua vida "independente", já perde o direito, inclusive, de iniciá-la com dignidade (ABRAMO; LEÓN, 2005, p.20).

A juventude pobre aparece nesse contexto com mais dificuldades ainda, pois a busca por um trabalho formal torna-se cada vez mais difícil, e essa busca aparece como uma forma de emancipação individual do jovem, o que para eles é mais difícil de acontecer. Nesse contexto concordo com a análise que segue de Carrano (2007, p. 5),

A trajetória de busca e inserção no mundo do trabalho dos jovens, especialmente os das famílias mais pobres, é incerta, ou seja, estes ocupam as ofertas de trabalho disponíveis que, precárias e desprotegidas em sua maioria, permitem pouca ou nenhuma possibilidade de iniciar ou progredir numa carreira profissional. A informalidade é crescente à medida que se desce nos estratos de renda e consumo do beneficiário do emprego. $\mathrm{O}$ aumento da escolaridade, em geral, coincide com maiores chances de conseguir empregos 
formais, algo decisivo para os jovens, considerando que o desemprego juvenil no Brasil é, em média, quase três vezes maior que o do conjunto da população.

Para ter acesso a questões como o prestígio social por exemplo, o indivíduo moderno precisa estar inserido em classes sociais que possam proporcionar esse quesito, considerando que os que não podem participar da sociedade com mais influência são os que não têm acesso aos chamados "suportes", sendo assim oprimidos pela sociedade. Segundo Carrano (2011, p. 15)

Os suportes podem ser definidos como a relação entre recursos subjetivos que os indivíduos conseguem articular para que se sustentem a si mesmos e o entorno social existente na forma de redes e apoios materiais e simbólicos. Um suporte não se define, então, apenas como um apoio material, pois ele pode ser mesmo uma relação afetiva ou uma representação que contribua para apoiar o indivíduo na tarefa de sustentar-se no mundo.

\section{ESCOLA: SONHOS CERCEADOS E SONHOS NASCENTES}

Para tentar entender um pouco da juventude "in loco" dessa pesquisa, foram aplicados questionários para uma pré-análise com oito jovens no mês de julho do ano de 2019. A idade deles naquele momento era entre dezoito e vinte e oito anos. Importante trazer essa primeira experiência com eles pois notou-se que o nível escolar era muito baixo. Dos oito, apenas um deles tinha o Ensino Médio completo. Alguns não chegaram nem a completar o Ensino Fundamental 1.

Partindo desta primeira experiência, abre-se um debate de quais as motivações que os levaram a desistir da escola, sendo que dentre as mais variadas razões, de alguma forma sempre aparece a palavra "trabalho" atrelada ao cerceamento do estudo formal. Mas as motivações para o abandono da escola podem ser inúmeras, tendo em vista que cada vida tem suas peculiaridades. Entretanto, é impossível não levar em conta a quase que completa inexistência de condições mínimas para o estudo, o que acontece muitas vezes nas comunidades da periferia. Carrano, Marinho e Oliveira (2015, p. 1443), em uma ampla pesquisa feita sobre abandono escolar nas comunidades menos favorecidas economicamente da cidade do Rio de Janeiro, ressalta que houve uma "significância na correlação entre alunos que moram em comunidade e abandono no ensino fundamental".

No formulário aplicado com os jovens da Cooperativa Santa Maria, em uma das questões, foi levantada a possibilidade de voltar ao estudo formal, sendo que seis dos oito jovens responderam que pretendiam voltar a estudar. Essa vontade de estudar já resultou em algumas ações, uma delas foi a inscrição de alguns deles para a prova do ENCCEJA (Exame Nacional para Certificação de Competências de Jovens e Adultos), no ano de 2019, depois de várias tentativas de estudar pela modalidade presencial do EJA (Educação de Jovens e Adultos), e que diante das dificuldades muitos deles acabaram 
desistindo, por terem que trabalhar muito para complementar a baixa renda. A busca pela escolarização é um processo que pode estar atrelado a muitos anseios e é preciso um olhar profundo para entender os percursos escolares desses jovens. A necessidade de trabalhar para auxiliar no sustento da família faz com que a escola perca a importância central e o abandono dessa torna-se realidade. (CORROCHANO, 2008, p. 171).

\section{CONSIDERAÇÕES FINAIS}

A pesquisa desenvolvida até aqui, nesse momento está muito próxima da análise da banca de qualificação, o que pode trazer horizontes ainda não pensados, sendo esses teóricos e metodológicos, tendo em vista as entrevistas programadas para o segundo semestre de 2020. As pressuposições levantadas, por muitas vezes podem mudar nessa trilha, mas os autores já estudados apresentam conformidade com a realidade dos sujeitos pesquisados, que tiveram trajetórias tão peculiares, por serem catadores de lixo reciclável e por estarem durante tanto tempo no meio do lixão municipal, trabalhando de forma tão difícil e desumana.

As vozes dos jovens mais pobres necessitam de espaço nas pesquisas de juventude, e a pesquisa tem uma obrigação ética de apresentar e porque não denunciar essa realidade da inclusão tão precária que é apresentada para eles, na sociedade moderna capitalista. É extremamente importante nessa última fase da pesquisa não perder de vista que esses jovens podem trazer exemplos de organização social para a sociedade local e para tantas realidades semelhantes no país. 


\section{REFERÊNCIAS}

ABRAMO, H. W.; LEÓN, O. D. Juventude e adolescência no Brasil: referências conceituais. 1a edição. São Paulo: Ação Educativa, 2005.

BURGOS, R. Periferias Urbanas: O chão dos catadores no urbano periférico. 1a Edição. São Paulo: Humanitas, 2013.

CARRANO, P. Educação de jovens e adultos e juventude: o desafio de compreender os sentidos da presença dos jovens na escola da "segunda chance". REVEJ@: Revista de Educação de Jovens e Adultos, Belo Horizonte, v. 1, n. 0, p. 55-67, 2007.

CARRANO, P. C. R.; MARINHO, A. C.; OLIVEIRA, V. N. M. Trajetórias truncadas, trabalho e futuro: jovens fora de série na escola pública de ensino médio. Educ. Pesqui. São Paulo, v. 41, n. spe, p. 1439-1454, Dec. 2015.

CARRANO, P. Jovens, escolas e cidades: desafios à autonomia e a convivência. Revista Teias, Rio de Janeiro, vol. 12, no 26, set/dez, 2011: $07-22$.

CATANI, A. M.; GILIOLI, R. S. P. Culturas juvenis: múltiplos olhares. São Paulo: UNESP, 2008.

COIMBRA, C. M. B.; NASCIMENTO, M. L. A produção de crianças e jovens perigosos: a quem interessa? Rio de Janeiro: UFF, 2005.

CORROCHANO, M. C. [et al.]. Jovens e trabalho no Brasil: desigualdades e desafios para as políticas públicas. São Paulo: Ação Educativa, Instituto ibi, 2008.

FEIJÓ, M. C. O contexto de exclusão social e de vulnerabilidades de jovens infratores e de suas famílias. Universidade do Contestado. 2004. Revista Estudos de Psicologia 2004, 9(1), 157-166

FERREIRA, V. Jovens e gerações em tempos de crise: entre Portugal e o contexto global. Fortaleza: Expressão Gráfica e Editora, 2019. p.34-69

FERREIRA, V. S. Pesquisar jovens. Caminhos e desafios metodológicos. 1a edição. Lisboa: Instituto de Ciências Sociais, 2017.

GUIMARÃES, L. S. Periferia e espaços periféricos: Notas Gerais. Revista Perspectiva Geográfica Marechal Cândido Rondon, v. 10, n. 13, p. 109-118, jul.-dez., 2015.

MARTINS, J. S. Exclusão Social e a nova desigualdade. 1a edição. São Paulo: Paulus, 1997.

PAIXÃO, L. P. Significado da escolarização para um grupo de catadoras de um lixão. Cad. Pesqui. [online]. 2005, vol.35, n.124, pp.141-170.

SORJ, B.; MARTUCCELLI, D. O desafio latino-americano: coesão social e democracia. Rio de Janeiro: Civilização Brasileira, 2008. 


\section{Capítulo 4}

doi $10.37423 / 210604285$

\section{A INTERAÇÃO E ENVOLVIMENTO ENTRE ALUNOS NEGROS E NÃO NEGROS NAS AULAS DE QUÍMICA DA ESCOLA ESTADUAL TANCREDO \\ ALMEIDA NEVES}

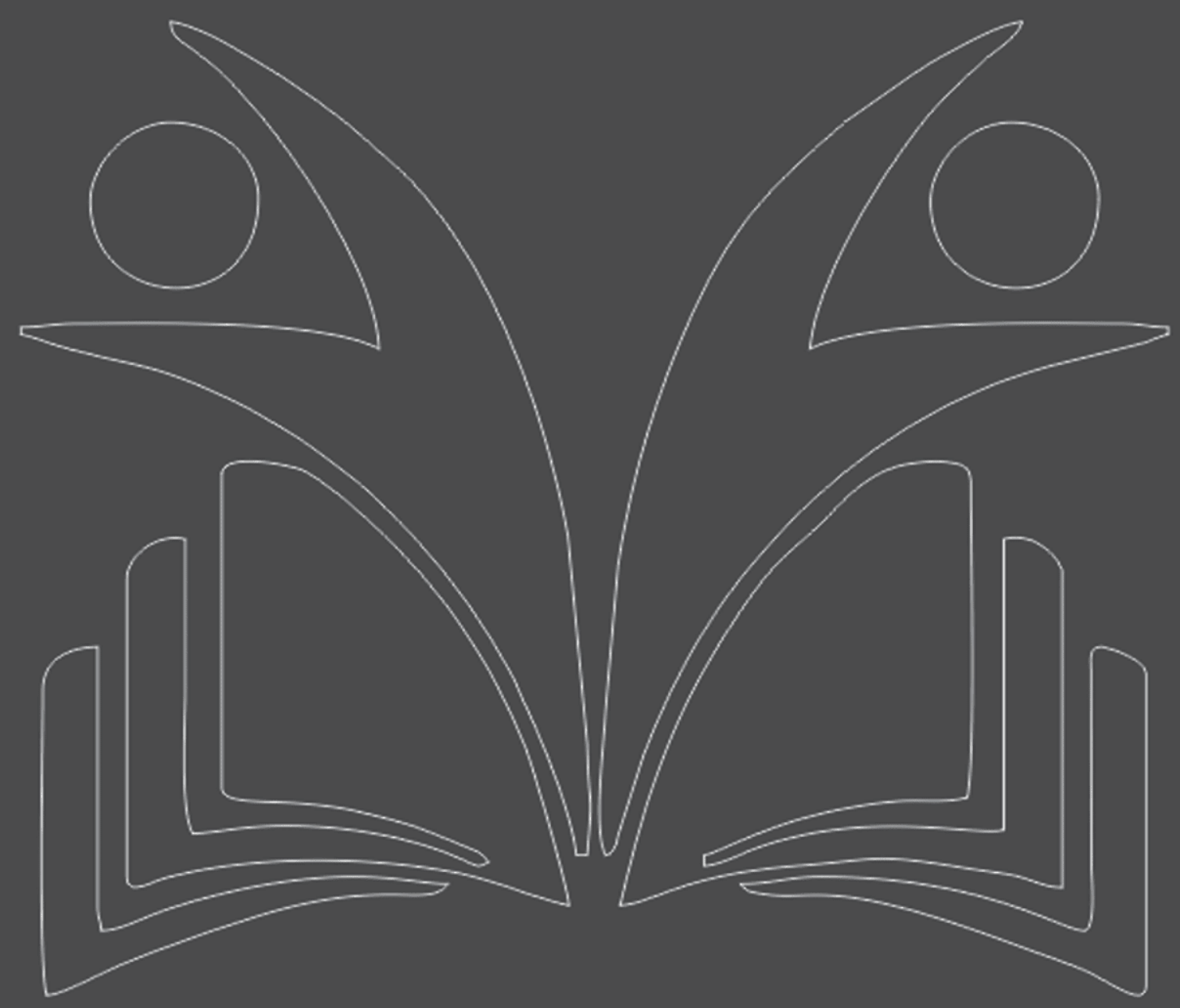


Resumo: Este trabalho discute a interação e envolvimento de estudantes negros e não negros em sala de aula, considerando as aulas de Química. Essas interações foram construídas mediante questionários sobre aspectos culturais dos alunos, observação de aulas e dos registros para analisar o desempenho desses alunos nas aulas. Esses contrastes consideraram as trajetórias escolares dos alunos, seus pertencimentos étnicos, de classe social e de relação étnico racial. Por meio da análise de eventos e das sequências discursivas pude evidenciar que os processos de inclusão/exclusão de alunos negros e não negros não estão dados, mas são construídos no dia-a-dia da sala de aula e estão articulados com os pertencimentos socioculturais dos estudantes e com suas trajetórias escolares. Além disso, a inclusão dos alunos negros e não negros na classe deve ser feita de forma continua para que todos tenham um excelente aprendizado, com isso, é necessário estabelecer uma relação com o saber que é sempre pessoal, singular e passa pela compreensão de uma linguagem específica e pela construção de oportunidades de ensino-aprendizagem para todos independentemente de cor e raça. Nessa construção identifiquei como fundamental o papel dos professores, como mediadores desse processo, seja orientando o trabalho em pequenos grupos, seja propiciando metodologias diversificadas de ensino-aprendizagem de química, interagindo todos em um só contexto.

Palavras chaves: inclusão, exclusão, estudantes, negros e química. 


\section{INTRODUÇÃO}

Não sou eu que vivo no passado/é o passado que vive em mim. (Paulinho da Viola).

Tenho um pressuposto de propor e compreender os métodos que uma escola pública reconhece, trabalha e lida com questões de relações étnicas raciais, que se fazem presentes no cotidiano escolar, identificando e caracterizando os diversos mecanismos de inclusão/exclusão

sob este tema relacionado.

O estudo direcionado as relações étnicos raciais na área educacional teve um grande desenvolvimento relevante e constante nos últimos anos, buscando trazer grandes contribuições para a área acadêmica, por meio de estudos e publicações, estudiosos brasileiros e estrangeiros buscam expandir e dar um maior reconhecimento e importância para o tema construindo assim uma sociedade plural, menos desigual e inclusiva. A relevância desta pesquisa insere na busca por novos dados que contribuam de forma significativa com o fim ao preconceito racial.

Busquei relacionar e analisar os fundamentos que as relações raciais trazem para a Escola Estadual Tancredo Almeida Neves, situada no município de Nova Nazaré - MT. Nosso município é bastante pequeno, mas infelizmente temos sinais de atos racistas na instituição e no município, trabalhamos no intuito de conscientizar nossos discentes sobre a importância de sermos cidadãos iguais, sem qualquer ato racista, incluindo todos os alunos negros e não negros em um mesmo contexto.

[...] o processo de inclusão se refere a quaisquer lutas, nos diferentes campos sociais, contra a exclusão de pessoas: tanto as que se percebem com facilidade, como aquelas mais sutis. Refere-se ainda, num nível mais preventivo, a todo e qualquer esforço para se evitar que grupos e sujeitos em risco de serem excluídos de dados contextos, por qualquer motivo que seja, acabem sendo excluidos de fato. (SANTOS, 2009 p. 12).

O tema é de fundamental importância para termos uma noção de relatos ou colocações de alunos que acabam sendo descriminados pela sociedade. O projeto instiga os discentes sobre a importância das relações étnicas raciais, esclarecer que todos somos iguais independentemente de cor e raça e que devemos aceitar e respeitar cada cidadão, sendo que a escola tem um papel fundamental neste processo, tendo como incumbência a inclusão total desses alunos e não estimular sua exclusão no meio social, pois o mesmo terá vários problemas na adaptação de convivência social, onde não terá seu devido respeito das demais pessoas que convive na sociedade.

É muito importante e recente, por parte das instituições de educação e pesquisa, a preocupação com a educação dos negros brasileiros. A falta desses estudos justifica-se, por um lado, pela carência de 
fontes que trabalham com este tema. Em tempos atuais, quando discutem a implementação da Lei 10.639/03 faz necessário a busca por respostas sobre como foi o processo de acesso do negro à escolarização.

A Lei 10.639/03 e suas respectivas diretrizes curriculares nacionais podem ser consideradas como parte do projeto educativo emancipatório do Movimento Negro em prol de uma educação anti-racista e que reconheça e respeite a diversidade. Por isso, essa legislação deve ser entendida como uma medida de ação afirmativa, pois introduz em uma política de caráter universal, a LDBEN 9394/96, uma ação específica voltada para um segmento da população brasileira com um comprovado histórico de exclusão, de desigualdades de oportunidades educacionais e que luta pelo respeito à sua diferença (GOMES, 2007b, p.106).

É dever do Estado garantir, por meio da educação, direitos iguais para o pleno desenvolvimento de todas as pessoas, oferecendo garantias de ingresso, permanência e sucesso na educação escolar, bem como da valorização do patrimônio histórico-cultural afro-brasileiro. Nesse contexto, segundo Gomes,

A construção de uma educação anti-racista e que respeite a diversidade, baseada na Lei 10.639/03, depara-se com alguns desafios. Dentre eles destacamos: o incremento dos intercâmbios intelectuais Brasil/África; a superação dos guetos acadêmicos que dominam o financiamento internacional dos projetos voltados para a temática racial e africana no Brasil; a superação da lógica conteudista no processo de formação de professores (as); a ausência da Lei 10.639/03 nas orientações do Programa Nacional do Livro Didático, a necessidade de maior sistematização e divulgação do pensamento negro brasileiro nos meios acadêmicos e para os profissionais da educação básica; a socialização dos saberes produzidos pela comunidade negra na formação inicial e continuada de professores(as); o diálogo com as questões trazidas pelo Movimento Negro, a articulação entre o conteúdo da lei 10.639/03 e a educação da juventude negra; a inclusão da discussão, estudo e trato ético das religiões de matriz africana na formação de professores(as) da educação básica e na prática das escolas e a implementação concreta nas escolas particulares (GOMES, 2007b, p.108).

A referida Lei visa o reconhecimento por iguais direitos sociais, civis, culturais e econômicos e valorização da diversidade através da mudança nos discursos, raciocínios, lógicas, gestos, posturas, modos de tratar as pessoas negras, respeitando-as em todos os aspectos, tantos físicos, quanto religiosos, evitando apelidos, brincadeiras, piadas em busca do conhecimento da sua história e, com isso, desconstruir o mito da democracia racial na sociedade brasileira.

Com objetivo de compreender e analisar os processos de escolarização dos negros, pesquisadores se dedica a analisar a trajetória institucional da educação dos descendentes de africanos no Brasil, buscando respostas para trabalhar este contexto. Os mesmos devem conter informações necessárias, 
inclusive, para a compreensão da necessidade da Lei 10.639/03 e dos estudos que apontam uma histórica desigualdade entre as diversas trajetórias escolares de negros e brancos no Brasil.

A lei cita ideias para trabalhar as questões raciais no contexto educacional, propondo estabelecer, pela escola, o negro, introduzindo seus valores e as relações raciais no contexto educacional e na sociedade brasileira. Contribuirá para isso conhecermos a história da educação do negro brasileiro, em seus aspectos de exclusão, resistência e inclusão, com o exercício de seus direitos perante a sociedade. A história da educação do negro é um conjunto de fenômenos.

Surya Aronovich Pombo de Barros, (2000) em “Discutindo a escolaridade da população negra em São Paulo entre o final do século XIX e o início do século", apresenta análises do que chama de ação negra e ação branca, isto é, a ação de grupos que protagonizavam um embate no que se refere ao acesso à escola. No âmbito da ação branca, o debate acerca da educação a ser direcionada aos negros estava no âmbito da construção da nação, da importância de um povo educado, escolarizado, e por isso era estimulada pelas elites dirigentes. Por outro lado, como naquela época, a escolarização era um elemento que passava a estruturar a sociedade, a autora destaca que barrar o acesso à cultura letrada significava manter a superioridade, a cidadania como atributo dos brancos, daí o surgimento da existência de mecanismos de discriminação em relação a alunos negros nas escolas oficiais. Ela discute ainda o posicionamento da população negra, que buscava a instrução formal, procurando se inserir no sistema oficial de ensino, mas não era vista como um bloco homogêneo, dado que parte de seus componentes não participaram desse movimento, muitas vezes não se interessava pela escola, ficando de fora da cultura escolar.

A escola era vista como um não lugar para os negros constituindo-se pela invisibilidade, pelo esquecimento. E também pelas políticas de negação do reconhecimento e direito às diferenças. A educação do negro traz para o nosso convívio determinações históricas de exclusão.

O trabalho de incluir os negros no âmbito escolar tem importância, em discutir as intervenções curriculares na escola, concentra-se em atividades que poderão subsidiar a prática pedagógica dos professores, elemento para o qual a atenção é especial, pois apesar de encontrarmos alternativas de trabalhos na perspectiva multicultural asseguradas pela política educacional vigente, percebemos que tudo depende muito mais de vontades coletivas (Gomes, 1999) dentro e fora das escolas. Acredito que adquirindo mais conhecimentos sobre as intervenções da militância negra no funcionamento de escolas sempre será útil quando se leva em conta as taxas de analfabetismo, repetência e evasão escolar da população afrodescendente. Santana, (2014) em “Gestão Escolar, Relações Raciais na 
Educação de Jovens e Adultos" conceitua que a proposta para educação das relações raciais deve oferecer às escolas um suporte didático-pedagógico, para que os profissionais da educação possam desenvolver uma ação educativa voltada para a formação de valores e posturas que contribuam para que cidadãos, valorizando seu pertencimento étnico-racial, tornem-se parceiros em uma nova cultura antirracista, do fortalecimento da dignidade e da promoção da igualdade real de direitos.

A escola precisa, para isso, construir e colocar em prática um currículo que contemple todos os grupos que fazem parte de seu contexto. (SANTANA, 2014, p.17).

Nesse sentido, seria importante e interessante tentar olhar um pouco mais para dentro da escola e do currículo e ver que histórias estão sendo produzidas aí e como se constroem os sentidos de pertencimento e exclusão, bem como as fronteiras raciais e étnicas entre os diferentes grupos sociais que ali interagem e estão representados.

Os estudos desenvolvidos por Nascimento (2014) e Marques (2014), revelaram que a educação é uma das formas de promover a mobilidade social das pessoas. Maiores níveis de escolaridade garantem melhores oportunidades de inserção em postos de trabalho de prestígio social e remuneração salarial elevada. A formação escolar ofertada na educação de jovens e adultos, nesse sentindo, pode contribuir para a melhoria de vida dos estudantes que a frequentam.

Promover a inclusão social e a inserção no mercado de trabalho de jovens $e$ adultos que não tiveram acesso à educação na idade própria, proporcionar condições para que essa parte da população construa cidadania e possa ter acesso à qualificação profissional, aumentar as taxas de escolarização. (NASCIMENTO; MARQUES, 2014, P.24).

As expectativas dos alunos que retornam à escola de educação de jovens e adultos são muitas. Seus projetos de vida estão bem formalizados e elaborados. Com isso, espera-se que as escolas realizem realmente um processo de formação escolar que contribua para que os jovens e adultos concluam sua trajetória de escolarização e possam se inserir no mercado de trabalho, possibilitando melhores condições de vida e a realização de seus projetos pessoais.

\section{DESENVOLVIMENTO}

\subsection{O PRECONCEITO E A DISCRIMINAÇÃO NO COTIDIANO ESCOLAR.}

A criança/jovem é um ser social cujo processo de desenvolvimento necessita ter um excelente referencial do contexto sócio histórico em que vive. A escola é um dos locais em que os discentes manifestam relações diversas, apresentando questões coerentes e recorrentes quanto à formação do 
sujeito e seu lugar na sociedade. Talvez uma das mais marcantes e relevantes, do ponto de vista das relações entre os indivíduos humanos seja a questão que envolve relações entre raças. Assim, a escola é um dos primeiros lugares em que a criança/jovens se depara com as diferenças, inclusive as de relações étnicos raciais. Meninos e meninas disputam/dividem espaços, reproduzem/superam valores, entram em conflitos.

O racismo e as práticas discriminatórias disseminadas no cotidiano brasileiro não representam simplesmente uma herança do passado. O racismo vem sendo recriado e realimentado ao longo de toda a nossa história. Seria impraticável desvincular as desigualdades observadas atualmente dos quase quatro séculos de escravismo que a geração atual herdou (BRASIL, 2001, p. 45).

A questão do racismo deve ser apresentada à comunidade escolar de forma que sejam permanentemente repensados os paradigmas, em especial os eurocêntricos, com que fomos educados. Não nascemos racistas, mas nos tornamos racistas devido a um histórico processo de negação da identidade humanista dos povos africanos. A luta contra o racismo, em nosso país, possibilita várias discussões e compreensão de todo esse processo, mostrando a resistência dos africanos e seus descendentes, que não se submeteram à escravidão, que se rebelaram e que conseguiram manter vivas as suas tradições culturais.

Crianças, adolescentes e jovens, negro-negras, têm vivenciado um ambiente escolar inibidor e desfavorável ao seu sucesso, ao desenvolvimento pleno de suas potencialidades. Lançar um novo olhar de contemporaneidade, para que se instalem na escola posicionamentos mais democráticos, garantindo o respeito às diferenças, é condição básica para a construção do sucesso escolar para os (as) estudantes.

O entendimento da simbologia do corpo negro e dos sentidos da manipulação de suas diferentes partes, entre elas, o cabelo, pode ser um dos caminhos para a compreensão da identidade negra em nossa sociedade. Pode ser, também, um importante aspecto do trabalho com a questão racial na escola que passa desapercebido pelos educadores e educadoras. (...) A discussão sobre a riqueza do trato com o corpo negro e sobre os processos de opressão que o mesmo tem recebido ao longo da história pode vir a ser uma rica atividade pedagógica a ser desenvolvida com os alunos e alunas em sala de aula, possibilitando debates e atividades sobre a história e cultura afro-brasileira. (GOMES, 2003, p. 174)

A escola que deseja pautar sua prática escolar no reconhecimento, aceitação e respeito à diversidade racial articula estratégias para o fortalecimento da autoestima e do orgulho ao pertencimento racial de seus alunos e alunas. Excluir de seu ambiente qualquer texto, referência, descrição, decoração, desenho que instiga o preconceito contra negro-negras, ou de qualquer outro segmento étnico-racial diferenciado. 
Os métodos como a escola/docente trabalham com as relações raciais, na maioria das vezes ocorre através da criação de espaços antigos que acabam aprisionando os valores e as identidades dos sujeitos, espaços estes que quando são relacionados e inseridos deixam os professores sem rumo para lidar com questões referentes às relações étnicas raciais.

A escola possui um papel fundamental na interação de todo público que busca conhecimento, sendo assim, deve incluir todas as crianças sem que haja qualquer ato que instiga o preconceito, trabalhando no sentindo de conscientizar os alunos que todos somos iguais, mesmo tendo raça e cor diferente.

Os educadores do Brasil, nos dias de hoje, ainda têm um pouco de restrição ou dificuldades em trabalhar com as crianças a questão étnico-racial. Para alguns educadores, as crianças não iriam entender ou diferenciar uma pessoa por sua cor. Outros ainda apresentam dificuldade diante de um ato de racismo em sua sala de aula. Diante disso, sabe-se que os livros didáticos ainda dão pouco suporte necessário para os educadores, mas não se pode colocar somente a culpa nos livros, ainda existem educadores que colocam barreiras quando é preciso falar sobre a História Afro brasileira em suas aulas.

\subsection{RELAÇÕES RACIAIS NA EDUCAÇÃO.}

O racismo está presente em todos os setores da sociedade, manifestando não só a nível individual, através de atos discriminatórios impetrados por indivíduos contra outros, mas também a nível institucional. O denominado Racismo Institucional vem a ser a forma mais perversa em que este se sustenta uma vez que atuam dentro das organizações, profissões, instituições educacionais e prisionais, meios de comunicação de massa, etc., de forma muitas vezes implícita, através de procedimentos que colocam pessoas de grupos raciais ou étnicos discriminados em situação de desvantagem no acesso a benefícios gerados pelo Estado e por demais instituições e organizações.

A aspiração de ser reconhecido como ser humano corresponde ao valor que chamamos de autoestima. Ela leva os negros a desejarem libertar-se do estado de inferioridade a que foram relegados e desembaraçar-se das imagens depreciativas de si mesmos. Particularmente, leva-os a lutar contra o racismo que representa, acima de tudo, uma reação de identidade configurada pela negação radical do valor das heranças histórica e cultural de onde advém a discriminação e a segregação. (D' ADESKY, 1997, p. 53).

A escola é considerada via de acesso ao conhecimento, como possibilidade de ascensão social para uma grande maioria que deseja ingressar no mercado de trabalho e sair da condição de pobreza. As expectativas dos pais com relação à escola levam-nos a crerem que esta terá uma ação transformadora na vida dos filhos garantindo-Ihes o exercício pleno da cidadania, bem como o aperfeiçoamento de 
suas aptidões pessoais, o que lhes garantirá o acesso à vida em sociedade. No entanto, essas expectativas, não raro, são frustradas, sobretudo quando se trata de crianças negras. O que se observa é que, em geral, a escola desconsidera a pluralidade cultural presente na sala de aula e acaba direcionando sua metodologia para satisfazer as necessidades do grupo dominante, o que via de regra leva a inculcação dos valores da classe dominante. Sendo assim, o que deveria ser espaço de promoção da equidade pode converter-se em espaço de exclusão, inclusive refletindo-se em outros espaços sociais.

As escolas brasileiras vêm sendo convocadas para contribuir de maneira mais clara e eficaz no enfrentamento daquilo que impede ou dificulta a participação social e política e que, ao mesmo tempo, contribui para a reprodução de lógicas perversas de opressão e de incremento das desigualdades sociais. Inúmeras colocações têm objetivado o combate à violência nas escolas e nas comunidades que a mesma compõe. Verifica-se, no entanto, a ausência de esforços mais abrangentes e sistemáticos, frutos de políticas públicas melhor articuladas e com efeitos de compromisso no enfrentamento da violência, do preconceito e da discriminação racial.

No espaço escolar são reproduzidos constantemente valores e conceitos propagados socialmente, talvez de maneira mais reveladora e objetiva, que dependendo do posicionamento e método pedagógico fundamentado e adotado pela escola, podem ganhar ou não mais força, o que tem acontecido de um modo geral nas escolas públicas brasileiras, revelando a incapacidade e o atraso presente predominantemente nas práticas pedagógicas diante das situações discriminatórias. Tudo depende do tipo de informação que os alunos têm acesso, que em geral, são distorcidas da realidade dentro e fora do espaço escolar, pois se nas escolas prevalece a presença de materiais didáticos que excluem e inferiorizam acultura afro-brasileira, fora dela a situação é praticamente a mesma, afinal, existem hoje uma série e infinidade de meios de socialização diferentes da escola que influenciam diretamente na mentalidade desses sujeitos que estão em processo de desenvolvimento (AZEVEDO, 1990).

As práticas de discriminação sofridas por muitos estudantes negros em nossas escolas não devem ser nunca camufladas, naturalizadas, mas sim explicitadas com atitudes firmes e comprometidas e com ações que venham a combater tais práticas.

Importante salientar que essa problemática de educação antirracista, que no caso do Brasil, passa pela valorização das africanidades e dos valores civilizatórios afro- brasileiros no processo educacional escolar, é uma questão da sociedade e para a sociedade e não especificamente da escola, ou da 
população negra/afro brasileira. Valorizar a diversidade é uma tarefa de todas as pessoas que fazem a educação e a sociedade. Mesmo que a escola não seja um foco de diversidade étnico-racial é seu papel trabalhar essa diversidade, que compõe a sociedade brasileira. (LIMA \& TRINDADE, 2009, p. 37-38).

Quando falamos em educação o que logo vem em mente é, um espaço de formação e desenvolvimento contínuo de indivíduos. Falar em educação é acreditar que o pleno desenvolvimento de uma criança só é efetivo quando ela passa por um processo de escolarização institucional. Isso não significa dizer que, o sujeito só aprende na escola e que os outros ambientes sociais não sejam importantes, mas que para nossa sociedade a educação oferecida no espaço educativo é fundamental para o pleno desenvolvimento do indivíduo, principalmente nos anos iniciais de sua vida, para que saiba interagir plenamente como um indivíduo social, que tenha direitos e deveres a serem compridos na sociedade.

A sociedade brasileira caracteriza-se por uma pluralidade étnica, sendo este produto de um processo histórico que inseriu num mesmo cenário três grupos distintos: portugueses, índios e negros de origem africana. A escola que é considerada como um espaço onde ocorre a construção da identidade do indivíduo também pode desvalorizá-la, negando-a principalmente as crianças de cor negra, pois é nesse ambiente que muitos professores têm manifestado seu tratamento diferenciado entre as crianças negras e brancas.

A escola sempre foi considerada uma instituição de seleção e diferenciação social. Com isso, estamos sempre em situações de fragilidades, de "está pisando em ovos" na pratica escolar, sem podermos romper com isso. É fato que não se pode negar a seletividade que está presente na pratica institucional da escola $e$, por vezes, de caráter elitista. A vivência do preconceito pode ser notada pela prática da diferença, que é muito presente no cotidiano Brasileiro (ITANI, p.120121 apud. AQUINO, 1988).

A escola pode contribuir na diminuição do preconceito existente nas diversas formas de tratamentos que a sociedade tem exposto, machucando e prejudicando na formação e construção de sujeitos. Neste ambiente os alunos devem aprender virtudes sociais, para que todos tenham olhares de humanismo sobre os demais indivíduos de sua sociedade e mundo.

A escola, como parte integrante dessa sociedade que se sabe preconceituosa e discriminadora, mas que reconhece que é hora de mudar, e está comprometida com essa necessidade de mudança e precisa ser um espaço de aprendizagem onde as transformações devem começar a ocorrer de modo planejado $e$ realizado coletivamente por todos os envolvidos, de modo consciente. [...] a educação escolar deve ajudar professor e alunos a compreenderem que a diferença entre pessoas, povos e nações é saudável e enriquecedora; que é preciso valorizá-las para garantir a democracia que, entre outros, significa respeito pelas pessoas e nações tais como são com suas características próprias 
e individualizadoras; que buscar soluções e fazê-las vigorar é uma questão de direitos humanos e cidadania. (CAVALLEIRO, 2005, p. 28-30).

A ação do professor em sala de aula tem sido nos últimos tempos tema de investigação e discussões constantes por parte dos pesquisadores da área educacional, pois a interação entre aluno e professor contribui, portanto, para o rendimento escolar, a aprendizagem e proporciona, ainda, comportamentos necessários à vida adulta, ou seja, a ação educativa exerce influência sobre os indivíduos em sua postura, valores, agressões, atitudes, crenças e modos de agir.

O preconceito racial na sala de aula é algo muito frequente se pararmos para observar e, na maioria das vezes, aqueles que deveriam interferir, como professores e pedagogos, não sabem como fazê-lo ou, outras vezes é propagador deste tipo de atitude, o que reforça e estimula o preconceito ao invés de intervir e combatê-lo. Para trabalhar com os alunos utilizei de um questionário, onde os discentes tinham que responder algumas perguntas relacionadas ao tema do projeto.

\section{DESCRIÇÃO DOS SUJEITOS DA PESQUISA}

A trajetória percorrida, com base no referencial metodológico escolhido foi a descrita a seguir. Primeiramente analisei juntamente com a direção a realidade da instituição (escola), analisando o envolvimento dos alunos negros e não negros presentes na instituição. A presente investigação foi desenvolvida na Escola Estadual Tancredo Almeida Neves - MT, com alunos do 2으 e 3을. A escola funciona atendendo ao Ensino Fundamental EJA: 10 e 20 segmentos (sexto ao nono ano); o Ensino Médio REGULAR: 1으, 2으 e 3으 ano e Ensino Médio EJA: 1을 e 2 o segmentos (primeiro ao terceiro ano). Há 3 (três) turmas de Sala de Recursos e Apoio Pedagógico. Possui 5(cinco) turmas, contidas em um único turno: Noturno: das 18h às 22:30h. O prédio escolar possui as seguintes dependências: Quinze salas de aula, Sala de professores, Sala da direção, Secretaria, Refeitório, Banheiro dos funcionários, Quatro banheiros de alunos (masculino e feminino), Cozinha, Dispensa e Pátio interno.

A instituição tem como proposta pedagógica de trabalho assentada nos seguintes pilares: pensar, sentir, trocar e fazer de modo crítico, reflexivo, criativo, significativo, solidário e prazeroso. Visamos à construção de uma escola em que a ação pedagógica seja baseada na pratica libertadora, orientada a construir o conhecimento de forma crítica, reflexiva e sustentada com a realidade, buscando uma relação teoria-prática de aprender as diferentes faces do saber.

Com o intuito de superar a educação fracionada, buscaremos transcender os limites disciplinares e conceituais do conhecimento. Valorizando as práticas educativas interdisciplinares, visando o diálogo entre as várias disciplinas, como forma de estabelecer a unidade na diversidade. Enfim, trabalharemos 
para desenvolver uma pedagogia em que se valoriza o afeto e a elevação da autoestima do aluno, resgatando a sua alegria de aprender por meio de atividades significativas, criando e promovendo brincadeiras e jogos, contribuindo para o desenvolvimento da expressão artística e corporal, além de garantir um ambiente acolhedor na sala de aula, onde os alunos possam se expressar sem receio de serem discriminados, promovendo a reflexão sobre os valores humanos, comportamentos éticos, formação do caráter. Iniciei o trabalho junto à escola para analisar as diversas relações étnicas raciais, presentes em seu contexto. Importante lembrar que, conforme o referencial teórico adotado, o que se pretende é uma análise compreensiva dos dados obtidos, considerando dispensável o controle de variáveis dependentes e independentes (raça, cor e entre outros), para se atingir os objetivos da pesquisa.

A eles era explicado o objetivo do trabalho, justificando a importância de sua participação para a compreensão da problemática vivenciada por eles; e a sua contribuição para a reorientação oferecida a esta unidade escolar. Esclareci que o estudo cuidaria do sigilo necessário e não identificação dos participantes bem como a liberdade de decisão em participarem ou não do projeto

As justificativas dadas pelos discentes que não participaram das atividades de pesquisa foram: outros compromissos ou ocupações ou por não se sentirem com disposição para colaborar, medo, receio da sociedade, vergonha entre outros. Com os que aceitaram participar, foi realizado um questionário com perguntas informais estabelecendo-se assim um relacionamento interpessoal após, o qual se realizava as perguntas, orientadas pelo roteiro flexível, previamente elaborado e avaliado através de plano piloto, com vistas à obtenção dos dados significativos para a compreensão da temática em questão.

Trabalhei com quinze alunos propondo a eles um questionário, pedindo que eles me respondessem sobre atos com relação ao envolvimento e interação dos alunos negros e não negros nas aulas de Química. Sendo assim, todos foram bem participativos com o questionário, tendo uma interação e apontamentos bastante positivos em relação à participação dos alunos nas aulas e no seu aprendizado. As tabelas seguintes mostram a quantidade de alunos que participaram do questionário: 
Tabela 1 - Alunos que participaram do questionário.

\begin{tabular}{|l|l|}
\hline HOMENS & 8 \\
\hline MULHERES & 7 \\
\hline SÉRIE/ ANO & 2 e $3^{\circ}$ ano EJA \\
\hline TOTAL & 15 \\
\hline
\end{tabular}

Fonte: Dados coletados pelo pesquisador.

Tabela 2 - Sobre o pertencimento racial dos alunos.

\begin{tabular}{|c|c|c|c|c|c|}
\hline$\underbrace{\text { Sua }}_{\text {Etnia }}$ & & Feminino & Masculino & Feminino & Masculino \\
\hline \multirow{2}{*}{$\begin{array}{c}\text { Negro(a)e } \\
\text { afro- } \\
\text { descenden } \\
\text { te }\end{array}$} & $\mathrm{M}$ & - & 04 & - & - \\
\hline & $\mathrm{F}$ & 01 & - & 02 & - \\
\hline \multirow{2}{*}{$\begin{array}{c}\text { Brancos(as } \\
))\end{array}$} & $\mathrm{M}$ & - & & - & 04 \\
\hline & $F$ & 04 & - & - & - \\
\hline Total & & 05 & 04 & 02 & 04 \\
\hline
\end{tabular}

Fonte: Dados coletados pelo pesquisador

\section{APRESENTAÇÃO, DISCUSSÃO E ANÁLISE DE DADOS}

A análise de práticas pedagógicas realizada nessa pesquisa tem o objetivo de trazer para um primeiro plano, mudanças que estão ocorrendo nas instituições de Educação a partir de proposições de políticas curriculares voltadas para questões relacionadas às relações étnicas raciais. Políticas educacionais em geral e políticas curriculares em específico têm um impacto que nunca é direto nas escolas, pois os processos de mediação são muitos e as formas de resistência são diversas. As Diretrizes Curriculares Nacionais para Educação das Relações Étnico-Raciais trazem proposições que tencionam as redes e as 
escolas, e o intuito foi discutir práticas pedagógicas que expressam tais tensões e que revelam movimentos e mudanças na escola Estadual Tancredo Almeida Neves. Buscando incluir alunos negros e brancos em um só contexto para que haja melhorias no ensino - aprendizagem dos alunos na aula de Química.

Neste capítulo são apresentados os resultados obtidos com a pesquisa, desde a elaboração da proposta curricular, seu desenvolvimento e os dados coletados por meio de um questionário. $\mathrm{Na}$ sequência dos resultados apresentados, segue a discussão dos mesmos, ou seja, o confronto entre estes dados com o conhecimento teórico acumulado a respeito do assunto.

As expectativas se referem às possíveis mudanças no quadro de alunos que sofrem com preconceito racial em sala de aula, a partir das atividades educacionais implementadas no projeto por meio de um questionário. Além disto, pretende-se tratar e orientar os alunos dos casos positivos que podemos ter, quando respeitamos um ao outro sem termos diferença entre cor ou raça. Espero contribuir em muito para a melhoria da qualidade de vida dos estudantes, passando pontos relevantes que mudem suas atitudes e pensamentos, sobre as relações raciais na escola, para que todos possam conviver bem, relacionando - se de forma que melhore o convívio em sala.

Para analisar as opiniões dos alunos, com relação ao tema trabalhado em sala, realizei um trabalho com perguntas condizentes ao contexto do assunto proposto, para que os mesmos respondessem com sua própria opinião expressando de forma crítica seus conceitos e pensamentos sobre as relações étnicos raciais e seu envolvimento na aula de Química.

Após realizar o questionário com os alunos, tive pontos relevantes com relação à pesquisa realizada com os discentes, respostas bastante coerentes, sendo que ambos expressaram suas opiniões de forma positiva, sempre sendo realistas sobre seus pensamentos, respondendo às perguntas com muita sinceridade e clareza.

Os alunos que aceitaram participar ganharam um novo conhecimento sobre as questões raciais na escola, família e sociedade. Sendo, que todos mudaram suas opiniões sobre o tema trabalhado e disseram satisfeitos com o trabalho, pois ajudou bastante no ensino-aprendizagem e na socialização entre si na sala.

\section{RESULTADOS DO QUESTIONÁRIO APLICADO AOS ALUNOS}

Percebi por meio das respostas que existe uma boa relação entre os alunos negros e não negros, sendo assim, no termo voltado para o desempenho escolar à relação é positiva, mas mesmo assim precisa 
melhorar este conceito para inibir o preconceito na escola. Enquanto pesquisador pode notar a existência de uma pequena diferença entre as porcentagens, visto que precisa ser melhorado o ensino aprendizagem desses alunos e que precisamos trabalhar buscando incluir todos em um só contexto independentemente de cor e raça.

Analisando os resultados presentes no estudo notei divergências com relação às opiniões dos alunos devida à pequena diferença entre as porcentagens, sendo assim, eles ficaram indecisos com relação ao desempenho escolar entre negros e não negros, tendo receio talvez de falar realmente a verdade por sentir medo, vergonha ou até mesmo sofrerem perseguição ou qualquer tipo de preconceito e discriminação.

Através do estudo notei que existe uma grande diferenciação entre os alunos negros e não negros durante a realização das aulas práticas, sendo assim, cabe ao professor trabalhar a inclusão desses discentes buscando sanar essas diferenças presente nas aulas. Enquanto pesquisador pode visualizar que o preconceito é visível e existente entre os alunos negros e brancos, e como educadores devemos buscar métodos que ajude a melhorar esta situação, trabalhando de maneira que inclua todos esses alunos em um só contexto.

Todos os alunos foram convictos com relação à resposta, desta maneira, todos perceberam que existe uma grande diferenciação entre os alunos negros e não negros, sendo assim, todos foram sinceros sobre sua afirmação. Por meio desses relatos devemos ter ciência que existe de fato preconceito na escola, e que os alunos negros se sentem isolados, sozinhos sem ter uma convivência social com os demais colegas e que isso influencia diretamente em sua vida pessoal e social.

Na turma existe grupos definidos, principalmente na formação de grupos para estudos e realização de trabalhos, tendo um isolamento de alunos negros e brancos. Desta forma precisa trabalhar a inclusão de alunos negros e não negros buscando trazer uma socialização de culturas e raças para sanar aos poucos esses grupos definidos na realização das atividades.

Notei enquanto pesquisador que a escola juntamente com os educadores precisa conscientizar os alunos sobre o preconceito existente entre os alunos. Analisando o resultado das respostas nota-se que os alunos percebem concretamente na existência dos grupos definidos entre eles, e que na formação desses grupos leva a ocorrência do preconceito. 


\section{CONCLUSÃO}

No decorrer do curso Educação das Relações Étnico-Raciais no Contexto da Educação de Jovens Adultos, foram discutidos assuntos relevantes para a convivência em sociedade, priorizando a igualdade de direitos a todos, bem como o direito à liberdade de escolhas do ser humano. Este foi bastante enriquecedor tanto para a vida profissional, mas também pessoal, pois os assuntos tratados no mesmo estão presentes no cotidiano escolar e fora dele.

Durante a construção deste trabalho foi possível perceber o olhar dos alunos perante as práticas de racismo existentes no contexto escolar e social da escola, bem como estas relações se permeiam no cotidiano escolar. Ao final do questionário desenvolvido no texto, é possível sinalizar que um dos aspectos que mais prejudicam os trabalhos de combate ao racismo é o fato de não existirem um projeto institucional fixo que possibilite ações referentes a temáticas que possibilite um trabalho multidisciplinar sobre relações raciais.

Sabemos que a trajetória das relações raciais entre negros e brancos na sociedade brasileira, sempre foram marcadas por situações desagradáveis de preconceitos e discriminações, onde a população negra sempre foi atingida por uma densa desigualdade social, fruto de ideias racistas que enraizaram na mente das pessoas. Ao observar os resultados das pesquisas e concebendo a escola enquanto espaço de sociabilização e de construção de conceitos, o universo dos alunos negros se torna extremamente preocupante.

Infelizmente ainda temos que conviver em nossa sociedade com posturas preconceituosas, que denigrem e desvaloriza o negro, e principalmente interfere na sua vida escolar. Com tudo isso, tive uma grande conscientização sobre os alunos, para que os mesmos repassem esta aprendizagem para nossa sociedade, para sermos unidos como pessoas que tem os mesmos direitos e deveres independentemente de cor e raça.

O silêncio da escola em relação aos conflitos raciais existente em seu cotidiano fortalece o preconceito e a discriminação que vai além de seus muros. Essas situações somadas a um conjunto de condições escolares como a falta de formação de professores sobre a temática, ausência do negro nos livros didáticos, a descontextualização do currículo, a preferência pelos alunos brancos, o não reconhecimento pelas potencialidades dos alunos negros podem influenciar no processo de ensino e aprendizagem dos alunos, comprometendo seu desempenho educacional, apontando-Ihes de forma consciente ou inconsciente seus lugares na sociedade. 
A partir deste estudo percebi a importância dos estudos e pesquisas do NEPRE na Universidade Federal de Mato Grosso, visto que as pesquisas realizadas até o presente momento vêm contribuindo para que os profissionais da educação revejam suas práticas pedagógicas, possibilitando a escola repensar sobre sua verdadeira função sociais frente a essa problemática, e a necessidade de um trabalho conjunto. Cabe aqui destacar a importância dessa equipe de pesquisadores em estar desenvolvendo esse trabalho, esclarecendo e encorajando muitos outros profissionais a debater e a perceber que precisamos de um novo projeto de nação com vistas à igualdade racial.

Percebi que as discussões trazidas nesses estudos só vêm acrescentar na sensibilização dos educadores para a adoção de estratégias que visem um ensino de qualidade, possibilitando a inclusão de todos, com fins no respeito à diversidade que há no interior da escola, como também estar concebendo a lei 10.639/03 como instrumento valioso no combate as atitudes preconceituosas e discriminatórias contribuindo na superação das desigualdades raciais na educação brasileira. 


\section{REFERÊNCIAS}

BRASIL. Ministério da Educação. Secretaria de Educação Fundamental. Parâmetros Curriculares Nacionais: Ciências Naturais/Secretaria de Educação Fundamental. Brasília: MEC/SEF, 1998.

CARVALHO, Marília - Quem é negro, quem é branco: Desempenho Escolar e classificação racial de alunos. Universidade de São Paulo, Faculdade de Educação. Acessado em 05/05/2015.

CAVALLEIRO, Eliane. Racismo e antirracismo na educação- repensando nossa Escola. - org, São Paulo: Summus, 2003.

CAVALLEIRO, Eliane. Racismo e antirracismo na educação- repensando nossa Escola. -org, São Paulo: Summus, 2003.

COSTA, J.F. A ética e o espelho da cultura. Rio de Janeiro: Rocco, 1994.

GIL, Antonio Carlos. Métodos e técnicas de pesquisa social. 5ed. São Paulo: Atlas, 1999. 202 p. ISBN: 8522422702.

GONÇALVES, Vanda Lúcia - O racismo e o desempenho escolar de crianças - UFMT, GT: Afro-Brasileiro e Educação / no.21.

GUIMARÃES, Antonio Sérgio - Preconceito de cor e racismo no Brasil. Acessado em 28/04/2015.

MINISTÉRIO DA EDUCAÇÃO. Diretrizes Curriculares Nacionais para a Educação das Relações ÉtnicoRaciais e para o Ensino de História e Acultura Afro-Brasileira e Africana. Brasília, DF. Out. 2015.

NASCIMENTO, Cleonice Ferreira, MARQUES, Zilma Maria silva. Relações Raciais e a História da Educação de Jovens e Adultos. Cuiabá - MT. UAB/NEPRE/ UFMT. Vol. 05, 2014. p. 24.

PASSOS, Joana Célia - As desigualdades educacionais, a população negra de Jovens e Adultos. Acessado em 02/05/2015.

RIBEIRO, Álvaro. SOUZA, Barbara. Souza Edleuza. RIBEIRO, Eglê. (Org). História e Cultura Afro-Brasileira e Africana na Escola. Brasília: Agare. 2008.

ROSA, Maria Virgínia de Figueiredo Pereira do Couto; ARNOLDI, Marlene Aparecida Gonzalez Colombo. A entrevista na pesquisa qualitativa: mecanismos para a validação dos resultados. Belo Horizonte: Autêntica Editora, 2006. 112 p.

SANTANA, MalseteArestides - Gestão Escolar, Relações Raciais na Educação de Jovens e Adultos. Cuiabá - MT. UAB/NEPRE/ UFMT. Vol. 13, 2014. p. 17.

SANTOS, Cleito Pereira (Org); VIANA, Nildo (Org.). Raça e Etnia. Capitalismo e Questão racial. 1. ed. Rio de Janeiro: Corifeu, 2009. p. $08-22$.

Sexualidade e afetividade na escola. Revista Presença Pedagógica, julho/agosto/ 2013, págs. 49 a 55, Aratangy, Claudia, Claudia Aratangy; Altmann Helena, Helena Altmann; Vilela, Helena Maria, Maria Helena Vilela.

SILVA, Tomaz Tadeu. Documentos de Identidade: uma introdução a teorias do currículo. 2a edição. Belo Horizonte: Autentica. 2004. 


\section{Capítulo 5}

\section{doi $10.37423 / 210604303$}

\section{A PARTICIPAÇÃO SOCIAL NA SEGURANÇA PÚBLICA EM TEMPOS DE PANDEMIA E AS TEORIAS CONTRATUALISTAS DE HOBBES, LOCKE E ROUSSEAU}

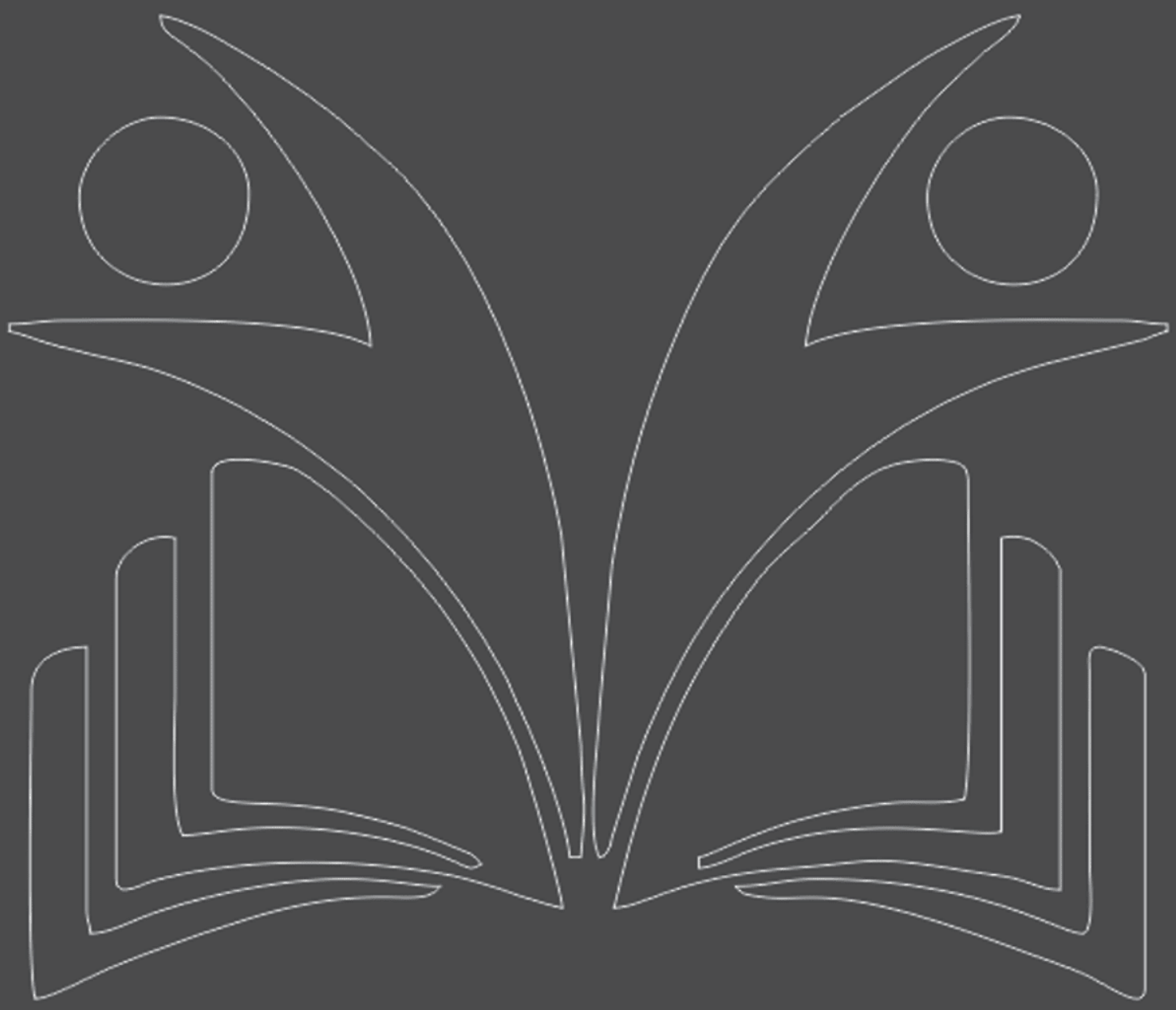


Resumo: Trata este capítulo, no cenário brasileiro, da participação social no âmbito da segurança pública em tempos de pandemia no país, em confronto com o modelo de Estado, com base nas abordagens e referenciais de Hobbes (1588-1679), Locke (1632-1704) e Rousseau (1712-1778), filósofos iluministas que produziram os paradigmas jusfilosóficos utilizados até os dias atuais. Até que ponto a principiologia contratualista do Estado abrigaria os contornos de atuação da segurança pública no âmbito dos entes estatais, em tempos de pandemia, sem contemplar a participação das pessoas, esta é a questão que se busca esclarecer. Objetiva, pois, apresentar as ideias de Hobbes, Locke e Rousseau, em face desta questão que estava no surgimento do Estado e da própria sociedade. Mediante o estabelecimento de correlações entre os ideais dos filósofos citados e a configuração do Estado contemporâneo, buscou-se o liame entre o viver como indivíduos separados e a vida em sociedade, que traz como supedâneo o benefício coletivo, sem abrir mão da participação. Portanto, o contrato social surge como uma ideia que explica a atitude racional dos seres humanos para criar um comum acordo. Assim, o papel do Estado visa assegurar garantias de sobrevivência aos seres humanos, como a liberdade e a igualdade, ou mesmo a propriedade, evitando a guerra de todos contra todos. No Brasil, a Constituição de 1988, no corolário contratualista, erigiu na agenda das políticas públicas a participação social e esta se tornou, nos anos 1990, um dos princípios organizativos, aclamado por agências nacionais e internacionais, nos processos de formulação de políticas públicas, inclusive, nas de segurança pública, que não pode afastar a participação e/ou representatividade, mesmo no estado de emergência e calamidade hoje vivenciado pela pandemia da Covid 19. Concluise que nesses tempos pandêmicos de decretos em todos os âmbitos, cometendo aos cidadãos o ônus de ver suas liberdades e direitos civis relativizados por decisões monocráticas no judiciário e executivo, há distorção aos princípios contratualistas apresentados.

Palavras-chave: segurança pública. Contrato social. Teorias do Estado. 


\section{INTRODUÇÃO}

No campo da segurança pública, a participação social em tempos de pandemia vive um dilema que merece uma reflexão crítica. 0 problema atual que atravessa a sociedade brasileira se constitui nas manifestações coletivas que são coibidas pelo Estado por intermédio do seu braço armado. Objetivase, pois, perquirir sobre como a pandemia impôs aos estados o controle da população com medidas repressivas ou restritivas que ferem o direito de ir e vir e, portanto, o princípio da participação. Neste cenário, a proteção à coletividade se impõe face aos direitos individuais. Essa situação suscita a reflexão dos filósofos contratualistas Hobbes, Rousseau e Locke, na medida em que defendem, cada qual ao seu modo, a primazia da coletividade sobre o indivíduo.

A participação social suscita discussões acaloradas nos dias de hoje, em vários âmbitos dos poderes do Estado brasileiro, em face da crise sanitária instalada pela pandemia de Covid-19, que coloca em xeque a legitimidade de medidas de restrição que atingem direitos constitucionais consagrados. É bem verdade que, em nome da coletividade, os direitos individuais devem se submeter ao bem comum, 0 que nos leva a revisitar os cânones contratualistas no Estado Moderno.

SILVA (2021) adverte que os serviços de saúde estão todos voltados para evitar a proliferação da doença ou cuidar daquelas pessoas que estão infectadas pelo coronavírus. Assevera que

A polícia passou a ser responsável por cuidar não apenas da prevenção ao crime, mas também garantir o cumprimento das medidas de fechamento do comércio, uso de máscaras e proibição de aglomeração. (SILVA, 2021, pag. 16)

Há de levar em conta, até que ponto o Estado deve auscultar os interesses individuais, pelo princípio constitucional participativo, no exercício de seu poder soberano.

Na seção seguinte, as fundamentações contratualistas são apresentadas; na terceira seção, apresentase a leitura atual da participação no campo estatal da segurança; na quarta seção, faz-se digressão sobre as relações entre o indivíduo e a sociedade em tempos de pandemia; e, ao final, a título de conclusão, faz-se análise desse cenário comparado da contemporaneidade pandêmica com o problema das manifestações à luz dos princípios dos teóricos clássicos.

\section{FUNDAMENTAÇÕES CONTRATUALISTAS}

Hobbes (1588-1679), Locke (1632-1704) e Rousseau (1712-1778), produziram os paradigmas jusfilosóficos sobre as relações entre estado e sociedade e que são referências até os dias atuais no direito. Para esses filósofos, estava em questão o surgimento do Estado e da própria sociedade. Ao 
invés de viver como indivíduos separados, a vida em sociedade devia trazer algum benefício. Portanto, o contrato social surge como uma ideia que explica uma atitude racional das pessoas para criar o consenso. Assim, o papel do Estado visa assegurar algumas garantias de sobrevivência aos indivíduos, a exemplo da liberdade e da igualdade, ou mesmo da propriedade, evitando a guerra de todos contra todos.

Locke, em sua obra Dois tratados sobre o governo (2005), declara, diferente de Hobbes, que a índole social é a harmonia, e que o desequilíbrio e violência social surgem em razão da ausência de um terceiro para julgar os conflitos que emergem da convivência social. Assim as lides originárias da vida social eram resolvidas com violência pela ausência desse terceiro. Adverte, Locke, que a função precípua do Estado é a proteção da propriedade. Valor que informa sistemas jurídicos até os dias atuais. Ele também entende que um juiz, ao decidir de forma contrária aos direitos naturais, abre espaço para a resistência legitima do cidadão que pode se opor a submeter-se à decisão. Pode-se notar assim, as sementes da ideia de desobediência civil (Locke, 2005).

Hobbes instrumentaliza a ideia de contratos sociais em seu Leviatã, que seria a representação do Estado como uma entidade mítica. A imagem iconográfica atrelada a esse "monstro" é formada de diversos indivíduos e suas "liberdades concedidas" em troca da segurança que este poderoso ser pode garantir a todos os cidadãos. Hobbes acreditava que os direitos naturais tinham de se render a uma autoridade absoluta a fim de impedir a "guerra de todos contra todos" (Hobbes, 1979).

Rousseau explicita o rompimento de vez com a ideia de "deus e fé" no Estado e no direito. O jusnaturalismo antecede a Hobbes, Locke e Rousseau, embora os Locke e Hobbes estejam ligados a essa doutrina. John Locke, defende os direitos naturais, que não seriam inatos, mas de fácil apreensão pela razão e não poderiam ser desrespeitados pelo "estado civil" que é instituído, exatamente, com o intuito de assegurar sua proteção.

Rosseau (1979), em “Do contrato social”, expõe que o contrato social é resultado do exercício de vontade deliberada de criação da sociedade e do Estado, e traz em si um conceito de justiça próprio, isto é, "a justiça é o pacto". Assim, concluído o contrato social surgiriam os direitos civis, que sucedem os direitos naturais no tempo. Uma vez que os direitos naturais existem antes de qualquer tipo de convenção social, o acordo é útil e legítimo, devendo prevalecer no contrato a igualdade e os fins comuns. Não somente os súditos devem observar os termos do contrato, mas também o soberano.

Rousseau, diferente de Hobbes, entende que o Estado de natureza do homem é um estado de harmonia, e que a concessão de poder do indivíduo ao Estado, ou seja, o 
reconhecimento de que a violência e imposição do direito somente pode ser exercida pelo Estado, tem fundamento na necessidade de proteger o homem da índole inerente de corrompimento deste que a sociedade possui.

Hobbes e Rousseau concordam no estado de guerra, contudo, discordam das razões originais do conflito que ocorre. Enquanto um entende que tal conflito tem por razão de ser a natureza do ser humano o outro entende que o conflito surge em razão das interações humanas, que corrompem a natureza inerentemente gentil e pacífica do ser humano. Assim, o indivíduo abre mão de sua liberdade para que o Estado o proteja dos outros indivíduos também corrompidos pela vida em sociedade.

Hobbes, diferente de Rousseau, afirma a existência natural do estado de guerra de todos contra todos. O medo generalizado é o que leva o indivíduo a conceber o Estado, O Leviatã, como algo necessário, abrindo mão de suas liberdades e concedendo-as ao Estado que se torna o único legítimo a exercer a violência (Hobbes, 1979).

A título de resumo, tem-se pois que para Hobbes, os indivíduos abdicam de seus desejos e liberdade individuais em benefício de uma vontade única, assegurando a paz por meio de leis e a segurança da coletividade. Já para Locke, os indivíduos não devem renunciar à sua liberdade, mas sim, submetê-la a uma nova forma de liberdade que ocorre com a instauração de leis centralizadas nas mãos do estado. Os direitos naturais estão preservados, pois foram positivados legalmente. Nos postulados de Locke, o Estado não é um mal necessário, mas sim a realização dos direitos por meio do arbítrio do direito de propriedade. Inobstante, para Rousseau, o pacto social considera todos os indivíduos, ninguém é excluído, pois caso isso ocorresse a desigualdade se estabeleceria e a sociedade correria o risco de se desintegrar. $O$ indivíduo não abre mão de sua liberdade individual em benefício de uma única pessoa, mas entrega o controle da sua liberdade individual a um individuo coletivo por intermédio de um pacto social. E esse indivíduo coletivo vem a ser o estado.

\section{PARTICIPAÇÃO SOCIAL E O ESTADO}

No Brasil, a retomada do modelo do Estado centralizador tradicional a partir do golpe de 2016 não mais se sustenta, sendo mesmo um retrocesso, considerando que o cidadão vive num contexto local, onde a noção de desenvolvimento que se associa crescimento econômico sofreu violento ataque. No campo da segurança, as práticas participativas, de ações compartilhadas e efetivas de controle da violência, se confundem com a necessidade de controle das ações sanitárias nas cidades. 
As organizações de segurança, enquanto instituições sociais, têm sido estudadas ao longo da história e, na contemporaneidade, assumem relevância incomum, por integrarem o conjunto de estratégias do Estado, através de políticas de segurança pública no contexto da violência, criminalidade e do próprio controle social (DANTAS, 2014).

A partir da redemocratização consagrada na Constituição da República Federativa do Brasil (CRFB) de 1988, o Estado brasileiro foi reestruturado e assumiu, dentre outros princípios, o da participação da sociedade civil na formulação e implementação de políticas públicas, inclusive no campo da segurança pública.

Nessa nova configuração do Estado, a segurança pública é prescrita como um "dever do estado" e "direito e responsabilidade de todos", conforme o artigo 144 da CFRB (BRASIL, 1988) sendo "exercida para a preservação da ordem pública e da incolumidade das pessoas e do patrimônio", taxativamente, pelas organizações policiais a nível federal e estadual responsáveis pela segurança pública. Esse modelo institucionalizado desde a implantação da República (século XIX) evidencia características inibidoras ou mesmo dificultadoras para o estabelecimento de processos participativos.

O sistema policial brasileiro é descentralizado em face do controle das polícias estaduais (militar e civil) ser independente em cada unidade federativa (herança do período colonial), conforme atribuições previstas nas constituições federal e estadual e nas leis orgânicas estaduais, enquanto o controle das polícias federais (judiciária, rodoviária e ferroviária) é da União. Por outro lado, esse sistema é multiplamente descoordenado em face de não haver a distribuição de competência pela delimitação geográfica, ou seja, mais de uma organização policial tem autoridade sobre o mesmo território. Persiste o modelo policial brasileiro na bipartição de sua atividade, ou seja, a prevenção e a repressão das infrações penais cabem a duas polícias distintas: aquela que atua ostensivamente na prevenção até a ocorrência do fato delituoso (polícias militares, polícia rodoviária federal e polícias ferroviária federal); e outra que atua após a ocorrência do fato delituoso, na apuração de sua materialidade e autoria (polícia federal e polícias civis), conforme Dantas (2014). Por fim, o fato de serem as polícias militares instituídas como "forças auxiliares e reservas do Exército" (BRASIL, 1988, art. 144, § 6ㅇ), a despeito de serem o uso de estratégias policiais (não militares), de natureza democrática.

Em face de tais considerações e do texto constitucional, sobressai-se a necessidade de compreender como se configura a participação no âmbito da "segurança pública", entendida como "o conjunto de processos políticos e jurídicos, destinados a garantir a disposição pacífica e harmoniosa da convivência pública, conforme os princípios éticos vigentes na sociedade", o que contrapõe o modelo policial 
instituído, já que se constitui atividade eminentemente em prol da civilidade e não militar (SILVA, 2014).

Assim, justifica-se a importância de determinar em que medida a participação social, no cenário democrático brasileiro, implica descentralização de poder e construção de interesse coletivo no campo da segurança pública, estando a discussão do modelo de Estado, no centro da discussão.

A participação social na segurança tem se consubstanciado na prática da polícia comunitária no âmbito da polícia ostensiva, no caso, a polícia militar, de função administrativa. Essa prática tem como princípio se afastar do uso exclusivo da força, em razão das falhas existentes no modelo tradicional de atuação da polícia, não deixando alternativa senão a de estreitar o relacionamento entre policiais e a comunidade, entendida, segundo Cohen (1985 apud MARCINEIRO, 2009, p. 15), como "a arena onde as pessoas adquirem suas experiências mais fundamentais e substanciais da vida social, fora dos limites do lar".

Como já dito, a partir de 1988, o Estado brasileiro erigiu na agenda das políticas públicas a participação social e está se tornou, nos anos 1990, um dos princípios organizativos, aclamado por agências nacionais e internacionais, nos processos de formulação de políticas públicas e de deliberação democrática em escala local. O texto constitucional estimula a participação popular na tomada de decisões sobre políticas públicas, como no caso do princípio de cooperação com associações e movimentos sociais no planejamento municipal, no artigo 29, ou de participação direta da população na gestão administrativa da saúde, previdência, assistência social, educação e criança e adolescente, nos artigos 194, 198, 204, 206 e 227 (BRASIL, 1988).

A participação social passa a fazer parte da noção de governança e assume o caráter primário de direito do cidadão na definição das políticas públicas, programas e projetos de governo que afetam direta e/ou indiretamente suas vidas.

Ham e Hill (1993, p. 41) alertaram que não há dúvida de que, enquanto função de Estado, "o principal papel da polícia e das forças armadas é a manutenção da lei, da ordem e da paz". Não há como dizer que a influência do Estado no campo da segurança pública é relativa, podendo se afirmar que dentre as teorias que explicam o desenvolvimento de políticas públicas "centradas na sociedade", a pluralista, com viés democrático e conferindo maior importância à participação, consegue explicar que "as fontes de poder estão distribuídas de forma desigual, mas de forma ampla entre indivíduos e grupos" (1993, p. 47). 
Dahl (2012) entre outros autores, assevera que embora todos os grupos e interesse não tenham o mesmo grau de influência, mesmo os menos poderosos são capazes de fazer-se ouvir em algum estágio do processo de tomada de decisões e, conclui, "nenhum indivíduo ou grupo é completamente desprovido de poder". A participação, sobretudo dos segmentos sociais que não têm força econômica e política, deve ser efetiva, afastando-se de uma participação instrumental e pragmática.

Assim, a fundamentação da previsão das instâncias de controle social formal (polícias, poder judiciário, direito penal, prisões) encontra-se na concepção de construção do Estado, como ente que é formado a partir da cessão das liberdades individuais, e detêm sua força a partir desta redução de liberdades subjetivas o que implica na proibição do exercício de determinadas liberdades por parte dos indivíduos, inclusive a liberdade de "exigir" o que entende ser o seu direito legítimo por meio do uso da sua força, perfeitamente consonante com os paradigmas contratualistas antes analisados.

Há exclusividade do exercício da violência por parte do Estado. Somente o Estado pode aplicar penas, nenhum outro indivíduo pode. É uma das maiores expressões do poder do Estado e sujeição da redução de liberdades do indivíduo, violência por parte do Estado. Somente o Estado pode aplicar penas, nenhum outro indivíduo pode. É uma das maiores expressões do poder do Estado e sujeição da redução de liberdades do indivíduo, processual.

\section{AS RELAÇÕES ENTRE INDIVÍDUO E SOCIEDADE EM TEMPOS DE PANDEMIA}

Se o Estado não consegue manter a segurança, a exemplo da extrema insegurança que se experimenta nas grandes cidades, a partir da concepção contratualista sobre o pacto social que tem por objetivo a manutenção da ordem, o que pode a sociedade e o indivíduo fazer? A resposta dependeria de quem quebra o pacto. Se o outro indivíduo, que abriu mão de sua liberdade de exercer a violência em face de outro cidadão assim o faz, quebrando o pacto social, compete ao Estado, valendo-se do poder que possui, punir este violador das regras de convivência social. As penas são inúmeras e previstas conforme o valor do bem violado. Se o pacto social é quebrado pelo Estado, a exemplo da ineficiência do Estado em reprimir e eliminar condutas de violência entre sujeitos, tem-se diversas respostas possíveis, a exemplo das práticas de desobediência civil - Gandhi e Marthin Luther King, a formação de grupos paramilitares - milícias e seguranças privados (substituindo privadamente um dever do Estado), bem como em situação extrema a substituição do governo.

Em março de 2020, se instalou no Brasil a pandemia de COVID-19. A Organização Mundial de Saúde (OMS) reconheceu tal situação e diversos países decretaram medidas de isolamento para conter a 
disseminação da doença. SILVA (2021) avaliou as alterações vivenciadas na rotina doméstica das pessoas durante o período de isolamento social e demonstrou, a partir da coleta de questionários "on line" em todas as regiões do país, que as medidas de prevenção à Covid-19 afetam o estresse no ambiente doméstico, levando a uma maior chance de agressividade em casa. Ora, emerge hoje a discussão sobre a legitimidade dessa intervenção do Estado, considerando que este tem mostrado despreparado para enfrentar a pandemia, gerando equívocos na condução coordenada de ações pela União, Estados e Municípios. O pesquisador conclui que se torna mais preocupante quando a pandemia parece não ter data para acabar e assevera que "o poder público precisa agir de forma efetiva e eficiente, garantindo que medidas adotadas na saúde pública não impactem sobremaneira a saúde - física e mental - daqueles que estão em isolamento dentro do lar". Tem-se, nesse caso, nítida dimensão da necessária participação dos cidadãos, no acompanhamento das medidas restritivas que o poder público vem impondo, extrapolando os limites do Estado Democrático de Direito, quando não garante os direitos civis inerentes ao "contrato social", ou mesmo, quando deixa de ouvir e dar voz aos que são impactados indiscriminadamente pelas medidas verticais, quase sempre aplicadas pelo sistema de controle social formal (polícias, judiciário, autoridades sanitárias entre outras). A postura do Estado tem contribuído para que os índices de óbitos por Covid-19 sejam alarmantes, ou mesmo, o índice de mortes por desassistência e fome.

Sob tais óticas, evidente que a participação social no âmbito da segurança pública, como função intrínseca do soberano não se instala fácil nessas estruturas de poder do Estado, sendo busca incessante da sociedade e do próprio direito criar estruturas participativas que aquebrantem o agigantamento do Estado em detrimento dos direitos civis e do controle da violência. Nesses tempos de decretos em todos os âmbitos, cometendo aos cidadãos o ônus de ver suas liberdades e direitos civis enxovalhados por decisões monocráticas no judiciário e executivo, há distorção aos princípios contratualistas antes explanados, a partir de Hobbes, Locke e Rousseau.

\section{CONCLUSÃO}

Nessa digressão histórico-comparativa, fica claro que a preocupação dos contratualistas, que vivenciaram lapsos temporais distintos, entre os séculos XVI e XVIII, foi a teorização do Estado, nos contornos de privilégios medievais (Hobbes e Locke) e o surgimento do capitalismo (Rosseau), para entender sua função e limites (Conceição, 2016, p. 90). 
$\mathrm{Na}$ atualidade, se vivencia uma relação conflituosa entre direitos individuais e coletivos, entre Estado e sociedade. Se o pacto social é quebrado, exercendo o Estado poder além do que está legitimado, tem-se um colapso das instituições e direitos civis, oportunizando a coletividade assumir o direcionamento de seu destino. Em meio a verdades e fake News, negacionismo e mortes, nesse momento pandêmico, tem-se instalada uma crise em vários âmbitos das funções do Estado. Não há dúvida de que o indivíduo, quando acatou o pacto social, não autorizou o ensimesmamento do Estado, ao ponto de promover a morte de cidadãos, por inação ou ações equivocadas. Se efetiva bem nítido, o afastamento do Estado contemporâneo dos ideais contratualistas.

Até que ponto a principiologia contratualista do Estado abrigaria os contornos de atuação dos entes estatais, em tempos de pandemia, sem contemplar a participação das pessoas? seja na segurança ou na crise sanitária, o limite claro está na garantia da vida, dos direitos individuais e coletivos. Assim, a participação da sociedade está garantida constitucionalmente, legitimando afastar aqueles que em nome do Estado extrapole os poderes inscritos no pacto social originário. 


\section{REFERÊNCIAS}

BRASIL. Constituição da República Federativa do Brasil. Brasília: Senado Federal, 1988.

CONCEIÇÃO,Isis Aparecida. Filosofia do direito. Londrina : Editora e Distribuidora Educacional S.A.. 2016.260 p.

DAHL, Robert A. A democracia e seus críticos. Tradução Patrícia de Freitas Ribeiro; revisão da tradução Aníbal Mari. São Paulo: Editora WMF Martins Fornte, 2012.

DANTAS, Raimundo C. M. Gestão participativa e Polícia Comunitária: uma análise da participação social na gestão da polícia ostensiva da Base Comunitária de Segurança do Calabar (Dissertação) Mestrado em Desenvolvimento e Gestão Social da Universidade Federal da Bahia. 131 f. Salvador, BA, 2014

HAM, C.; HILL, M. O processo de elaboração de políticas no Estado capitalista moderno. Campinas, tradução: Renato Amorim e Renato Dagnino, adaptação e revisão: Renato Dagnino, Cap. 4 e 5, 1993.

HOBBES, Thomas. Leviatã ou matéria, forma e poder de um estado eclesiástico e civil. São Paulo: Abril Cultural, 1979. (Col. Os pensadores).

LOCKE, John. Dois tratados sobre o governo. São Paulo: Martins Fontes, 2005.

MARCINEIRO, Nazareno. Teoria de polícia comunitária. Palhoça (SC): UnisulVirtual, 2009.

ROUSSEAU, Jean-Jacques. Do contrato social. São Paulo: Abril Cultural, 1978. (Col. Os pensadores).

SILVA, André Ricardo Guimarães. A estratégia institucional de policiamento através das bases comunitárias de segurança: analisando o plano de impementação das BCS, com base nos critérios identificadores do Sistema Koban. (Dissertação) Mestrado Profissional em Segurança Pública, Justiça e Cidadania. Salvador: UFBA, 2014.

SILVA, Bráulio Figueiredo Alves da. Quem está seguro em casa? Riscos associados ao lar na pandemia de Covid. UFMG, BH. 2021. 


\section{Capítulo 6}

\section{doi $10.37423 / 210604305$}

\section{A VISÃO TRADICIONAL DA AVALIAÇÃO DA APRENDIZAGEM NO ENSINO SUPERIOR}

Carla Priscilla Barbosa Santos Cordeiro

Lana Lisiêr de Lima Palmeira

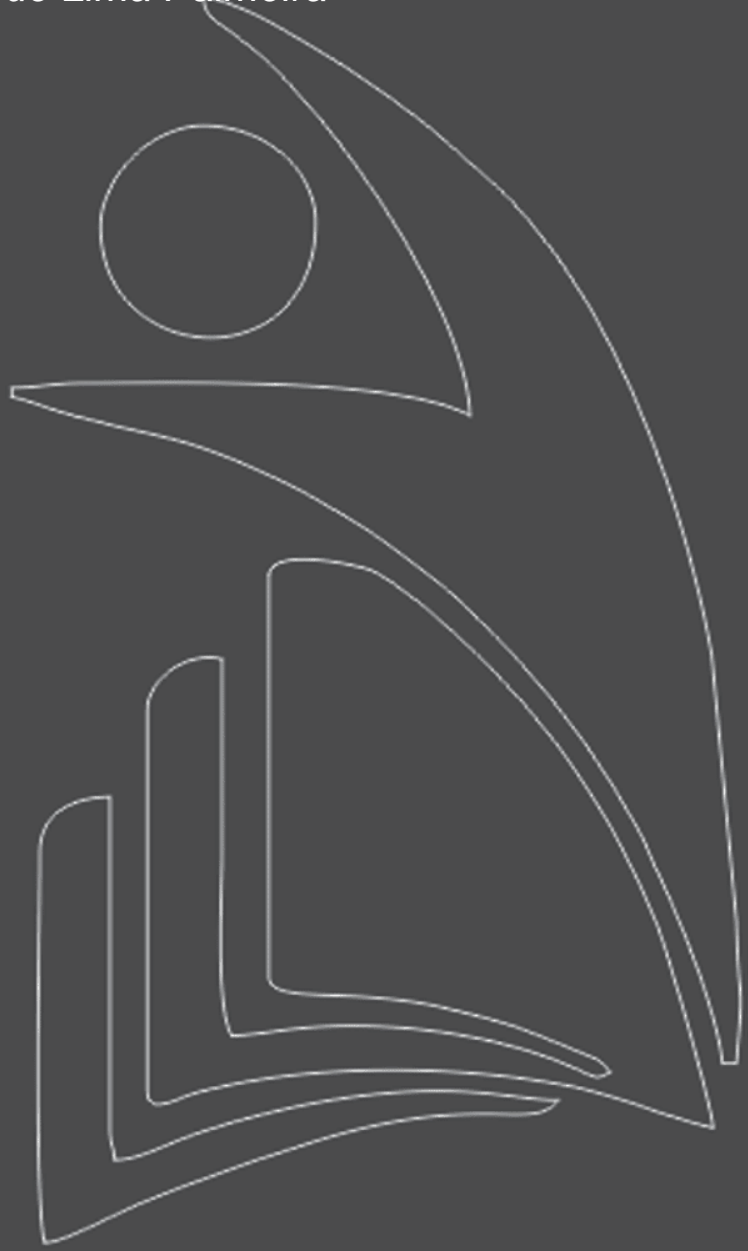

Faculdade Cesmac do Agreste

Universidade Federal de Alagoas

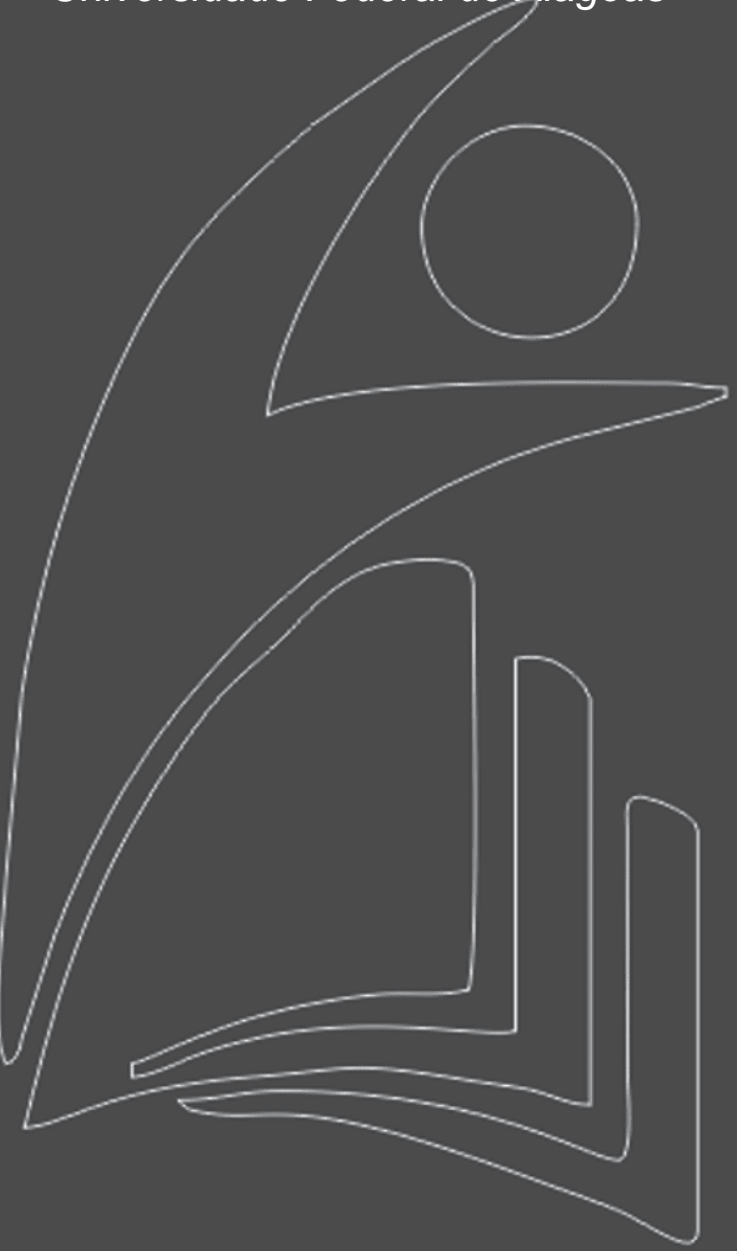


Resumo: Este trabalho tem como objetivo analisar a avaliação da aprendizagem no ensino superior, a partir da investigação sobre a visão tradicional sobre a avaliação da aprendizagem que ainda prevalece nesse nível de ensino. Para isto, partiu-se de uma metodologia qualitativa, em que foram analisados autores como Sobrinho (2003), Rodrigues (1999), Vianna (2000), Haydt (2004), Hoffmann (1995), Perrenoud (2010) Luckesi (2002), Abrecht (1994), dentre outros, que permitiram a análise da temática. Como resultados, percebe-se que a avaliação ainda assume um viés classificatório na educação superior, o que impõe uma necessária ressignificação da visão que prevalece sobre ela para que possa assumir uma feição dialética dentro do ensino superior.

Palavras-chave: Avaliação, Aprendizagem, Ensino Superior, Educação, Ressignificação. 


\section{INTRODUÇÃO}

Um dos maiores problemas da educação superior na contemporaneidade, é a qualidade das práticas de ensino que são realizadas em sala de aula. Professores que adentram esse espaço com feições sisudas, sem estabelecer qualquer diálogo com seus alunos; aulas que apenas reproduzem a visão de autores e o programa do curso; avaliações que se resumem à aplicação de provas, testes e a realização de seminários, dentre outros instrumentos, são exemplos de práticas bastante comuns nessa modalidade de ensino.

A avaliação do ensino e aprendizagem é um dos pontos mais frágeis dos problemas inerentes às práticas educativas dentro do ensino superior. Isto porque pouco se tem avançado no sentido de superar a visão tradicional da avaliação que a coloca no lugar comum de classificar os indivíduos a partir de sua capacidade de adequação ao sistema social prevalente.

Nesse viés, deve-se perceber que no modelo social capitalista, a educação acaba tendo uma função muito específica: preparar os indivíduos para o mercado de trabalho. Nesse quadro, a educação vai servir ao objetivo de formar quadros profissionais, reproduzindo os anseios do sistema em que se insere. Essa redução da educação à formação indivíduos aptos a meramente cumprir sua função dentro da lógica liberal capitalista ocorre de forma muito clara na avaliação que ocorre no ensino superior (SOBRINHO, 2003), que representa essa visão de mundo buscada dentro do sistema capitalista.

Deste modo, este artigo busca analisar a forma com que a avaliação tem acontecido no Ensino Superior, a fim de discutir possibilidades sobre sua ressignificação dentro desse contexto, para que assuma um caráter dialético e ocorra ao longo de todo processo educativo, não em dados momentos e de forma somativa.

\section{METODOLOGIA}

A metodologia adotada nesta pesquisa partiu de uma análise qualitativa da temática da avaliação no ensino superior. Realizou-se uma pesquisa do tipo bibliográfica, com a análise de autores que estudam a temática da avaliação, como Sobrinho (2003), Rodrigues (1999), Vianna (2000), Haydt (2004), Hoffmann (1995), Perrenoud (2010) Luckesi (2002), Abrecht (1994), dentre outros.

Com isto, tornou-se possível analisar as questões apresentadas e refletir sobre a necessária mudança de paradigma da avaliação no ensino superior. 


\section{A AVALIAÇÃO DO ENSINO E APRENDIZAGEM NO ENSINO SUPERIOR}

A palavra "avaliação" remete a vários tipos diferentes de compreensão ou medida de algo. Realiza-se a avaliação dos fatos do dia a dia a todo tempo, o que ocorre de maneira muito espontânea, com pouco ou nenhum planejamento, como é o caso dos julgamentos morais realizados pelos indivíduos em diversas instâncias sociais. De outro lado, existem os procedimentos em que a avaliação é vista como instrumento formal, institucionalizada em diversos ambientes públicos e privados com o objetivo de se realizar a aferição de algum dado, resultado, opinião etc. Ainda há que se falar da avaliação como um instrumento que pertence, por excelência, ao cotidiano escolar, gerando, por vezes, a ideia errônea de ser mesmo o objetivo final da aprendizagem, que deveria ser medida em testes e provas no geral.

Rodrigues (1999) explica que a avaliação pode ser vista de diferentes ângulos: dos alunos; dos sistemas educativos e de inovação; dos professores, dos currículos. Desta maneira, ao mencionar a avaliação dos alunos, refere-se à observação de como ocorre o processo de aprendizagem e a produção de conhecimentos.

Trata-se de um dos momentos mais importantes do processo educacional, pois, a partir dela, é possível perceber como a ação educativa ocorreu na prática, a partir da identificação dos conteúdos, conceitos e visões que foram apreendidos pelos discentes em sala de aula. Ela pode e deve, para além disso, ser utilizada como um potente instrumento de geração de novos conhecimentos pelo aluno, com um propósito emancipador e não com o mero intuito de classificar, rotular ou selecionar indivíduos. Por isso, seu estudo se tornou uma importante pauta para o ensino superior brasileiro, que passa, hoje, por uma evidente necessidade de reformas que melhorem a qualidade neste nível de educação.

Ao longo de sua história, o ensino superior brasileiro foi desenvolvido sem trabalhar, de fato, a questão da avaliação do ensino e aprendizagem. Embora de algumas maneiras o tema tenha sido discutido em instâncias legislativas, principalmente dentro da discussão da melhoria da qualidade do ensino, não foi levada a cabo, até o presente, nenhuma mudança significativa na forma como a avaliação do ensino e aprendizagem se realiza. Por isso, dentro do contexto histórico da educação brasileira, trata-se de uma das necessidades mais urgentes.

A avaliação deve ser encarada como um momento de grande reflexão, pois permite, de um lado, que docentes observem como a construção do conhecimento aconteceu para cada aluno, aproveitando a 
oportunidade para melhorar sua atuação e corrigir eventuais falhas ou dificuldades que os alunos possam ter tido. Não pode ser realizada de qualquer maneira, sem o adequado planejamento, pois precisa seguir procedimentos e etapas específicas a depender do tipo de conhecimento que se deseja produzir dentro da escola ou universidade. Por isso, compreender seu conceito, as teorias que lhe fundamentam, tipos, formas de realização, dentre outras coisas, torna-se essencial a quem deseja atuar no magistério de qualquer área. Neste sentido, pontua Vianna (2000, p. 29-30):

A atividade do avaliador torna-se bastante complexa, exigindo o emprego de técnicas sofisticadas, quando se considera que um construto precisa ser comparado a outros para que se possa determinar se o novo construto representa, efetivamente, algum avanço em relação ao anterior; por outro lado, é preciso testar a aplicabilidade de suas conclusões na explicação dos fenômenos e comparar o constructo a outros anteriormente comprovados confirmando sua veracidade ou positivando sua falsidade. O problema implícito, no campo da avaliação, estaria na comprovação da validade ou dos instrumentos que supostamente estariam medindo ou características definidas nos constructos.

Percebe-se, desta maneira, que a realização da avaliação passa pela compreensão de procedimentos específicos, que irão variar a cada tipo de ensino que se pretende. Por isso, a formação de quem pretende utilizar a avaliação para realizar qualquer tipo de análise, em um contexto educacional, de nível escolar ou universitário, passa pela esfera pedagógica.

É preciso reconhecer que existem vários conceitos para a avaliação, como pode ser visto a partir de alguns dos importantes teóricos contemporâneos que estudam a temática:

A avaliação é entendida aqui como uma etapa do processo educacional que tem por fim comprovar, de modo sistemático, em que medida se alcançam os resultados pelos objetivos especificados com antecedência (LAFOUCADE, 2010, p. 18).

Avaliar consiste, essencialmente, em determinar em que medida os objetivos previstos estão sendo realmente alcançados. Portanto, a avaliação é funcional, pois se realiza em função dos objetivos estabelecidos (HAYDT, 2004, p. 29).

A avaliação do ensino e aprendizagem é o procedimento docente que atribui símbolos a fenômenos cujas dimensões foram medidas, a fim de thes caracterizar o valor, por comparação com padrões prefixados (ROMÃO, 2011, p. 83-84).

São inúmeras as visões que norteiam o conceito. Neste sentido, após Haydt (2004, p. 13-14) analisar os estudos de teóricos como Scriven, Stufflebeam, Bloom, Hastings e Madaus, afirma que a avaliação segue alguns princípios básicos, a partir de uma dimensão orientadora: 
* É um processo contínuo e sistemático. Portanto, ela não pode ser esporádica nem improvisada, mas, ao contrário, deve ser constante e planejada. Nessa perspectiva, a avaliação faz parte de um sistema mais amplo que é o processo de ensino-aprendizagem, nele se integrando. Como tal, ela deve ser planejada para ocorrer normalmente ao longo de todo esse processo, fornecendo feedback e permitindo a recuperação imediata quando for necessário.

* A avaliação é funcional, porque se realiza em função de objetivos. Avaliar o processo ensino-aprendizagem consiste em verificar em que medida os alunos estão atingindo os objetivos previstos. Por isso, os objetivos constituem o elemento norteador da avaliação.

* A avaliação é orientadora, pois "não visa eliminar alunos, mas orientar seu processo de aprendizagem para que possam atingir os objetivos previstos". Nesse sentido, a avaliação permite ao aluno conhecer seus erros e acertos, auxiliando-o a fixar as respostas corretas e a corrigir as falhas.

* A avaliação é integral, pois analisa e julga todas as dimensões do comportamento, considerando o aluno como um todo. Desse modo, ela incide não apenas sobre os elementos cognitivos, mas também sobre o aspecto afetivo e o domínio psicomotor.

Percebe-se, com isso, que não se trata de um processo que, a priori, se esgota em um único momento. Ao contrário, exige reflexão, planejamento, procedimentos adequados para sua realização, escolha de instrumentos avaliativos, análise de dados, análise de resultados, ação transformadora, dentre outras etapas. Não pode ser realizada de qualquer modo, uma vez que uma ação descoordenada de objetivos pedagógicos perde toda a essência do processo educativo. Torna-se urgente, deste modo, no atual contexto em que se encontram os cursos superiores brasileiros, superar grandes dicotomias que ainda permeiam a realização da avaliação do ensino e aprendizagem, como a utilização do viés positivista em detrimento de uma abordagem construtivista. É preciso compreender que toda avaliação deve ser processual, deve estar envolta no processo de ensino e aprendizagem, uma vez que faz parte desse processo de maneira inseparável.

Ainda prevalece uma cultura, no ensino superior, de aferição de conhecimentos por meio de notas, pura e simplesmente. Nas palavras de Souza et al (2018): “O que se percebe atualmente é que o corpo docente do ensino superior revela-se muito impermeável à discussão da prática tradicional de avaliação". Essa forma de pensar a avaliação precisa ser superada, pois representa uma prática educativa classificatória, transposta pelas ideologias liberais de educação.

É neste sentido que Sobrinho (2003) afirma que a avaliação, no ensino superior, acaba sendo submetida aos interesses políticos das instituições, dos programas e docentes, sendo a representação de uma determinada forma de ver o mundo. 
As instituições de ensino superior, neste sentido, devem ser vistas como aparelhos ideológicos do Estado, moldando os indivíduos com sanções, exclusões, seleções, hierarquizações etc., (ALTHUSSER, 1985) como é o caso do modelo tradicional de avaliação que se realiza em grande parte desses ambientes.

\section{ENTRE MEDIR E AVALIAR}

De um lado, os estudiosos da esfera da avaliação chegam a um consenso de que estabelecer a medida de alguma coisa faz parte do conceito de avaliação. Mas não é só isso. Falar em avaliação vai além da identificação de um objetivo sendo atingido ou não, pois toda avaliação realiza um juízo de valor sobre o que está sendo examinado, de forma quantitativa e/ou qualitativa. E toda a ação de preparação, inclusive a forma como são estudados conteúdos e práticas, em termos educativos, faz parte do processo avaliativo, que não se resume a um exame, em termos genéricos. Neste sentido, Haydt (2004, p. 9-10) aponta que testar, medir e avaliar são três ações diferentes nesta área:

Testar significa submeter a um teste ou experiência, isto é, consiste em verificar o desempenho de alguém ou alguma coisa (um material, uma máquina, etc.), através de situações previamente organizadas, chamadas de testes.

Medir significa determinar a quantidade, a extensão ou o grau de alguma coisa, tendo por base um sistema de unidades convencionais.

Avaliar é julgar ou fazer a apreciação de alguém ou alguma coisa, tendo como base uma escala de valores (grifos meus).

A medida de um padrão ou conhecimento não pode, pura e simplesmente, ser o único subsídio do professor para aprovar ou reprovar um aluno. Por isso que se fala, aqui, em interpretação de uma medida, o que vai muito além de levantar dados quantitativos sobre erros e acertos dos alunos em um teste. Este, por seu turno, é apenas um "[...] instrumento de constatação e mensuração e não investigação" (HOFFMANN, 1995, p. 47), devendo ser usado com prudência e planejamento adequado dentro de um amplo contexto avaliativo.

Nas palavras da autora, para muitos docentes quanto maior é o nível de dificuldade de uma prova, maior o nível de excelência obtido dos alunos. A aprovação de todos seria, assim, sinônimo de incompetência (HOFFMANN, 2014a).

Neste sentido, o teste é tido muitas vezes como o resultado final do processo avaliativo, o que corrobora a criação de um sistema de medição e comparação de alunos e até mesmo professores por desempenho. Isto tem o que tem como base o que Perrenoud (2010) chama de "norma de excelência", geralmente a máxima capacidade de reprodução do sistema, sustentada por professores e inclusive 
alunos. Assim, muito do processo avaliativo acaba sendo resumido na aplicação de testes e na aferição de conhecimento adquirido objetivamente neles, mas a avaliação vai além, interpretando esses resultados em âmbito quantitativo e qualitativo, visão bastante usual no ensino superior.

Por isso, diferenciar o ato de mensuração da avaliação é essencial para que o professor possa atuar de maneira democrática, permitindo aos alunos que possam participar diretamente do processo de produção do conhecimento. Veja-se, neste sentido, o exemplo dado por Haydt (2004, p. 10-11):

Um professor quer verificar se os alunos estão atingindo os objetivos propostos para determinado componente curricular. Para isso, ele aplica em sua classe um teste de aproveitamento. Após a correção, atribui a cada aluno uma nota, de acordo com o número de respostas certas. Esse é um processo de mensuração; mas o professor sabe que as notas isoladas pouco significam. Por isso, ele compara as várias notas notas entre si, e também a nota atual do aluno com aquelas que ele obteve anteriormente, e faz um julgamento sobre o seu rendimento, considerando-o bom, regular ou insuficiente. Neste caso, o professor está avaliando.

O exemplo dado pela autora, embora sirva ao propósito da diferenciação entre medir e avaliar, precisa ser observado de forma atenta. Além de realizar um julgamento sobre o rendimento, a partir de uma análise comparativa, cabe ao professor observar o histórico do aluno na disciplina que ele leciona e em outras correlatas, assim como analisar fatores referentes ao ambiente, a personalidade do aluno etc. Não se deve esquecer que uma avaliação mais abrangente precisa levar em consideração a análise do próprio instrumento avaliativo e sua efetividade, pois embora o planejamento da avaliação deva levar em consideração as peculiaridades de cada grupo de alunos, muitas vezes o instrumento avaliativo se mostra inadequado, depois de aplicado, para a aferição de conhecimentos adquiridos.

Luckesi (2002, p. 56) afirma que ainda hoje, no ambiente escolar, realiza-se a simples verificação da aprendizagem, explicando a diferença entre o simples "verificar" e o "avaliar". Em suas palavras,

O processo de verificar configura-se pela observação, obtenção, análise e síntese dos dados ou informações que delimitam o objeto ou o ato com o qual se está trabalhando. A verificação encerra-se com a obtenção do dado ou informação que se busca (...).

$\mathrm{O}$ ato de avaliar implica coleta, análise e síntese dos dados que configuram o objeto da avaliação, acrescido de uma atribuição de valor ou qualidade, que se processa a partir da comparação da configuração do objeto avaliado com um determinado padrão de qualidade previamente estabelecido para aquele tipo de objeto. $O$ valor ou qualidade atribuídos conduzem a uma tomada de posição a seu favor ou contra ele. E o posicionamento a favor ou contra o objeto, ato ou curso de ação, a partir do valor ou qualidade atribuídos, conduz a uma decisão nova: manter o objeto como está ou atuar sobre ele. 
A avaliação é um momento sem igual no processo de ensino e aprendizagem, pois garante que os conhecimentos desenvolvidos pelos alunos possam ser identificados e, em seguida, interpretados a partir de um conjunto de objetivos esperados para a aprendizagem, garantindo que o professor possa orientar melhor seus alunos em um contínuo processo de construção do conhecimento. Mesmo tendo esse potencial transformador da aprendizagem, muito das tradicionais práticas educativas ainda permeiam o uso da avaliação, transformando-a em um fim em si mesma, como a própria razão de ser do processo educacional. Isso porque as tradicionais práticas avaliativas a concebem como um instrumento de medida do quanto o aluno conseguiu aprender daquilo que o professor lhe passou em sala de aula, dando a ela o papel de identificar os que melhor se adaptam e reproduzem o sistema. Como narra Perrenoud (1999, p. 9), “[...] a avaliação inflama necessariamente as paixões, já que estigmatiza a ignorância de alguns para melhor celebrar a excelência de outros". São práticas que ainda são sentidas em grande intensidade, mostrando o quão difícil pode ser mudar o viés hierarquizador que a avaliação tem tido ao longo de sua existência.

Esse é um dos aspectos que tradicionalmente faz parte não apenas da avaliação, mas do processo educativo como um todo. De um lado, formam-se as chamadas hierarquias globais, a partir do desenvolvimento da vida escolar dos indivíduos, passando pela formação em nível superior e adentrando na vida profissional. Assim, os sistemas educativos como um todo vão servindo para formar a posição de alunos dentro do próprio sistema social. Mas os sistemas educativos não atuam sozinhos nesse processo. Os próprios alunos trabalham dentro desse sistema, posicionando-se estrategicamente dentro dele, informando sua posição em relação aos demais (PERRENOUD, 1999). Trata-se de uma relação complexa, em que vários atores envolvidos corroboram a ampla massificação dos sistemas de ensino.

É preciso lembrar, também, que nem todo fenômeno pode ser medido ou mensurado, pois isto pressupõe a possibilidade de que os dados colhidos a partir dessa ação possam ser expressos em escalas de valores ou numéricas, como explica Hoffman (1995). O docente, portanto, ao incorporar ao processo avaliativo instrumentos de medida, deve, em um primeiro momento, pensar em como sua ação vai ocorrer, para que o instrumento não se torne um fim em si mesmo. Para além disso, deve estar atento para sua sala de aula, para cada contexto em que irá atuar, pois instrumentos de medida não são aplicáveis a todas as situações: 
Assim, nem todos os fenômenos podem ser medidos, por não haver instrumentos para tanto, ou por não admitirem tal precisão numérica. (Felizmente, os cientistas ainda não fabricaram instrumentos para medir o amor ou a tristeza e outros sentimentos humanos. Podemos medir, na escola, a frequência às aulas, por exemplo. (Elemento sempre presente nos regimentos escolares) Ou podemos medir (contar) o número de acertos em uma tarefa, o número de livros lidos ou de trabalhos entregues (HOFFMANN, 1995, p. 48-49).

Por isso, instrumentos de medida devem ser utilizados em um contexto maior, combinados outros instrumentos avaliativos e com uma ação pedagógica direcionada a cada tipo de turma. Não podem ser utilizados como sinônimo de avaliação, pois isto tornaria a mesma um fim em si mesmo, o que não é aceitável com uma prática educativa voltada ao desenvolvimento social, a construção de indivíduos reflexivos e críticos.

\section{O USO EXCLUSIVO DA AVALIAÇÃO SOMATIVA NO ENSINO SUPERIOR}

A avaliação somativa busca verificar se houve ou não a aprendizagem dos indivíduos, aplicando-se punições àqueles que não adquiriram os conhecimentos necessários para avançar às etapas seguintes da formação escolar ou universitária. Rejeita-se o erro, pois ele é visto como um defeito inerente ao processo de aprendizagem, que nasce de alguma incapacidade do aluno (ABRECHT, 1994). A partir dos valores e objetivos do programa, o professor realiza atividades e julga o resultado, o que pode ser realizado a partir de instrumentos como questionários, pesquisas, entrevistas, observações e testes, como as provas, por exemplo, com o objetivo de verificar se os alunos apreenderam o conteúdo.

No plano do ensino superior, algumas críticas podem ser realizadas ao uso exclusivo do modelo por docentes ao longo do processo avaliativo, como destaca Abrecht (1994). O que se percebe, das tradicionais práticas pedagógicas que ensejam o uso da avaliação somativa, é que as técnicas utilizadas para subsidiar a verificação da aprendizagem, como testes, podem não produzir resultados totalmente confiáveis, quer seja porque o professor pode não compreender o que está medindo, quer seja porque o instrumento de medida nem sempre é utilizado de maneira correta. Isso significa, em outras palavras, que mesmo uma avaliação que busque identificar o domínio de um dado conteúdo pelos alunos (de viés quantitativo) pode acabar não servindo ao seu propósito. Além disso, deve-se olhar com cautela para os padrões de aprovação/reprovação que são adotados nesse modelo.

Um aluno é considerado apto a avançar em seus estudos quando atinge uma determinada quantidade de pontos, geralmente obtida a partir de uma média aritmética ou do somatório de pontos dos testes e atividades realizados. Essa espécie de medida leva a decisões arbitrárias, que indicam o quão preparado está um aluno a partir de seus erros e acertos. A nota se torna, então, o elemento central 
desse tipo de avaliação, bastando que o aluno atinja uma quantidade mínima de pontuação em uma disciplina. Isso leva a inúmeras distorções no sistema: os alunos passam a estudar em função de uma nota, pois ela lhe classifica em uma hierarquia social superior dentro do espaço educacional. Deixa-se de lado a capacidade de produção de conhecimentos, de reflexão crítica, de correlação entre teoria e prática, o diálogo com a realidade, o olhar analítico do sistema, dentre outras coisas que levariam o aluno a romper com seu próprio status intelectual e cultural.

Outro ponto que levanta discussões é a análise (qualitativa) dos resultados. Poucos professores se debruçam sobre os seus resultados, para os interpretar de acordo com os seus objetivos. Nessa ótica, a avaliação perde totalmente seu sentido, pois ao invés de servir como um instrumento que serve ao processo de ensino e aprendizagem, se transforma em um momento estanque de uma disciplina, sendo um fim em si mesma. Consequentemente, o resultado será catastrófico: ao invés de o aluno focar suas energias no processo de aprendizagem, na construção real e efetiva do conhecimento, ele passa a se preocupar com a satisfação do critério "avaliação", para que assim possa avançar no curso e seguir rumo a sua formação profissional. A produção de conhecimento, assim, é substituída pelo processo de decorar ou memorizar o máximo de informações, que se tornam vazias sem uma correlata produção do seu sentido no contexto individual do aluno.

\section{CONSIDERAÇÕES FINAIS}

É preciso compreender a educação dentro do quadro conjuntural em ela se insere, pois só assim se torna possível identificar e entender as forças sociais que estão no poder. Sob esta ótica, a educação pode ser utilizada como um instrumento que sirva à dominação social, à manutenção da hegemonia das classes dominantes, mantendo o apartheid histórico que o país viveu ao longo de sua existência entre os ricos e pobres, ou como um "importante instrumento de construção e consolidação da hegemonia das classes populares" (FÁVERO, 1991, p. 11).

A avaliação não pode se resumir à medição de conhecimentos, pois isto implicaria em admitir que possui um caráter meramente classificatório dentro do ensino superior. Os instrumentos avaliativos devem ser utilizados a partir de um planejamento adequado, com a percepção de que o processo educativo acontece de forma contínua e permanente, não se esgotando como a aplicação de provas e exames.

Diante da constatação de que existe uma visão equivocada sobre a avaliação da aprendizagem no ensino superior, importante pensar em estratégias no campo das políticas públicas para esse nível de 
ensino que permitam ressignificar o conceito equivocado que a avaliação tem assumido para muitos docentes e discentes. Deste modo, Estado e IES devem estimular e propiciar a continua formação do corpo docente para realizar uma avaliação da aprendizagem que tenha caráter dialético, apropriandose dos seus resultados para melhorar as práticas docentes em sala de aula. 


\section{REFERÊNCIAS}

ABRECHT, R. Avaliação formativa. Tradução de José Carlos Tunas Eufrásio. Rio Tinto/Portugal: Edições Asa, 1994.

ALTHUSSER, L. Ideologia e aparelhos ideológicos do Estado. Rio de Janeiro: Graal, 1985.

FÁVERO, M. L. A. Da universidade "modernizada" à universidade disciplinada: Atcon e Meira Mattos. São Paulo: Cortez; Autores Associados, 1991.

HAYDT, R. C. Avaliação do Processo de Ensino-Aprendizagem. 6.ed. São Paulo: Ática, 2004.

HOFFMANN, J. Avaliação Mediadora: uma prática em construção da pré-escola à universidade. 33.ed. Porto Alegre: Mediação, 2014a.

HOFFMANN, J. Avaliação: Mito \& Desafio. 16.ed. Porto Alegre: Educação e Realidade, 1995.

HOFFMANN, J. O jogo do contrário em avaliação. 9d. Porto Alegre: Mediação, 2014b.

LUCKESI, C. C. Avaliação da aprendizagem escolar. São Paulo: Cortez, 2002.

LUCKESI, C. C. et al. Fazer universidade: uma proposta metodológica. São Paulo: Cortez, 2012.

LUCKESI, C. C. O que é mesmo o ato de avaliar a aprendizagem? Disponível em: <https://www.nescon.medicina.ufmg.br/biblioteca/imagem/2511.pdf>: Acesso em: 13/03/2017.

PERRENOUD, P. Não mexam na minha avaliação! Para uma abordagem sistêmica da mudança pedagógica. In ESTRELA, Albano; NÓVOA, Antonio (Orgs.). Avaliações em educação: novas perspectivas. Porto: Porto Editora, 1999.

RODRIGUES, P. A avaliação curricular. In ESTRELA, Albano; NÓvOA, Antonio (Orgs.). Avaliações em educação: novas perspectivas. Porto: Porto Editora, 1999.

SOBRINHO, J. D. Avaliação: políticas educacionais e reformas da educação superior. São Paulo: Cortez, 2003. 


\section{Capítulo 7}

\section{doi $10.37423 / 210604307$}

\section{EXTENSÃO UNIVERSITÁRIA E SEUS IMPACTOS SOCIAIS: ANÁLISE DO PROJETO APAE E TECNOLOGIA - INCLUIR É EXCEPCIONAL}

LUIZ CARLOS GARCIA

\section{LEONARDO SALGADO REZENDE}

NAYARA MARIA DELIMA

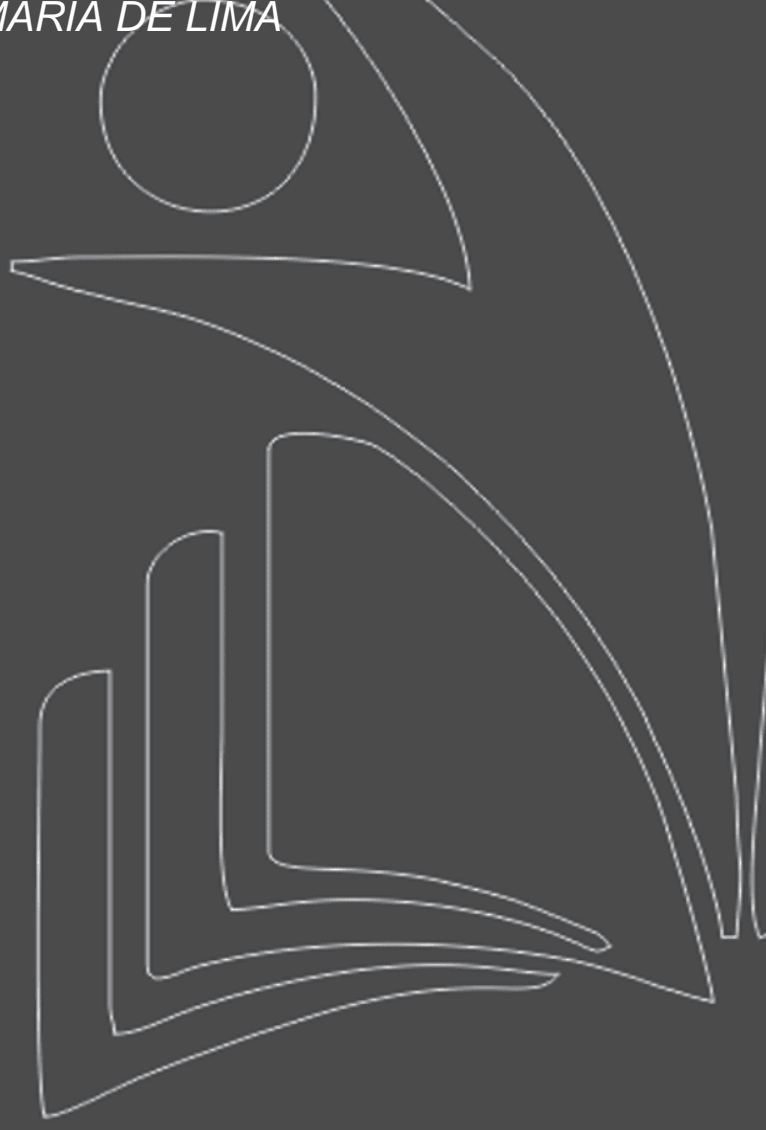

UNIVERSIDADE FEDERAL DE MINAS GERAIS

UNIVERSIDADE ISABELA HENDRIX

UNIVERSIDADE PRESIDENTE ANTONIO CARLOS

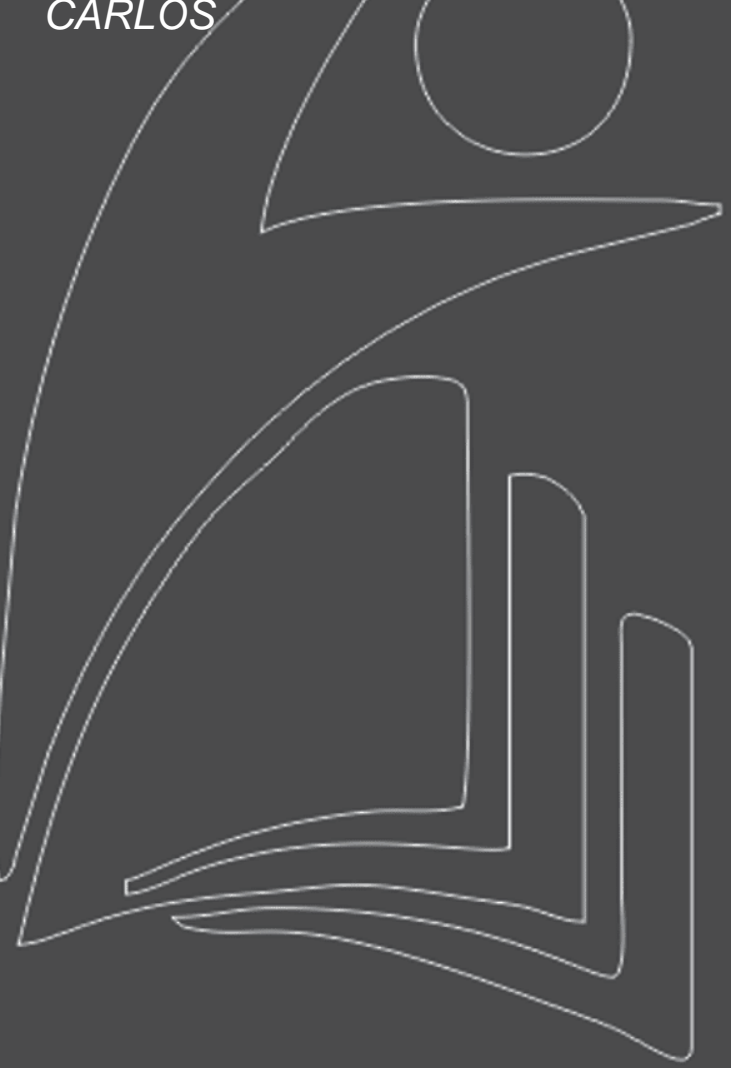




\section{INTRODUÇÃO}

A Associação de Pais e Amigos dos Excepcionais (APAE) de Ouro Preto foi fundada em 17 de novembro de 1982, resultando da necessidade da população ouro-pretana em auxiliar crianças, jovens e adultos excepcionais. Seu principal objetivo é integrar e orientar os processos educacionais e assistenciais de pessoas portadoras de deficiências, que são atendidas de segunda a sexta-feira em três turnos diferentes: manhã (7:00 às 11:20), tarde (12:15 à 16:35) e noite (16:45 à 19:45). Em relação à estrutura, a APAE conta com salas de fonoaudiologia e fisioterapia, além de salas que estimulam o aprendizado e desenvolvimento, uma cozinha, uma área externa, uma kombi e um carro. Cerca de 200 pessoas contam com o atendimento da APAE.

Trata-se de instituição que historicamente passa por grandes problemas. Suas atividades são basicamente mantidas por verbas que esta recebe de vinculação a programas do setor público. Temse ainda a ajuda e colaboração de pessoas que se dispõe a auxiliar. Assim, projeto APAE E TECNOLOGIA: INCLUIR É EXCEPCIONAL vem como mais uma atividade a agregar àquelas que já são desenvolvidas de modo a tornar do dia-a-dia dessas crianças e jovens mais dinâmico e mais produtivo. O projeto, que é um braço de extensão do Programa de Extensão Humanista que pertence à Escola de Minas da Universidade Federal de Ouro Preto (UFOP), objetiva, por meio do uso da tecnologia, dos modernos programas desenvolvidos para o trabalho com pessoas que possuem necessidades especiais, uma melhora no desenvolvimento psicomotor dos alunos/pacientes da APAE do bairro Bauxita, do município de Ouro Preto - MG.

Além da utilização dessa mesma ferramenta para incluir essas pessoas, que muitas vezes não podem sair diariamente e assim são privadas de um contato com o mundo globalizado e com muitas coisas que acontecem na dinâmica da vida social. Trata-se de trabalhar a acessibilidade não pelo viés físico de, por exemplo, conseguir entrar em um lugar, mas o acesso à informação e ao conhecimento. A uma formação atinente com as novas tecnologias e com a rede mundial. Assim, o objetivo principal da ação é exatamente promover um maior desenvolvimento tanto físico quando social aos alunos/pacientes da instituição.

A inclusão digital destes indivíduos representa um processo de acessibilidade e inclusão, de modo a propiciar não apenas benefícios sociais, mas ainda benefícios e ganhos físicos, com a utilização de softwares específicos que ajudam nas questões de aprendizagem e aspectos motores. 
Ante o exposto, o projeto se justifica diante da demanda latente e das muitas necessidades que a instituição possui. Nesse caso, trata-se de uma iniciativa que irá ao mesmo tempo atender a instituição, pois irá fortalecer um trabalho que ainda não é desenvolvido e que é manifestamente querido pela direção da instituição, haja vista que representa uma oportunidade dos alunos/pacientes em terem contato com a tecnologia e as muitas vantagens tanto físicas quanto psicológicas, no que diz respeito ao desenvolvimento e ao sentimento de pertencer a uma sociedade que cada vez mais se projeta no plano virtual, ao passo que, será uma oportunidade de grande enriquecimento pessoal e profissional para os pesquisadores- extensionistas para além do contato com as muitas limitações vividas por essas pessoas, que já por si só um enriquecimento, há um ganho acadêmico no que diz respeito ao aprendizado na utilização dos programas utilizados, especiais para atender as necessidades dos alunos, e dos próprios planos pedagógicos que serão desenvolvidos para o trabalho acontecer de forma satisfatória.

\section{DESENVOLVIMENTO}

O público diretamente atendido são os alunos atendidos na APAE, que possuem necessidades especiais variadas. Esse público compreende indivíduos com problemas motores, desenvolvimento mental comprometido e alguns com síndromes genéticas que podem afetar tanto a aprendizagem quando a capacidade de movimento de forma feral.

Na primeira fase do projeto foi realizada reunião para identificação da demanda exata existente na instituição, junto a funcionários e direção da mesma; planejou-se e construção do laboratório de informática que foi a base para todos os trabalhos desenvolvidos pelo projeto; pesquisou-se acerca de métodos de pesquisa e tabulação de dados para traçar o perfil do público atendido; pesquisou-se, em material específico, sobre as necessidades apresentadas pelos alunos atendidos pela APAE; e elaborou-se um questionário prévio - parcial - para ser aplicado junto aos alunos e funcionários da instituição e reuniões periódicas realizadas pela equipe do projeto para avaliar e discutir as ações desenvolvidas.

O trabalho foi desenvolvido da seguinte maneira: Os pesquisadores-extensionistas fizeram uma série de pesquisas acerca da utilização da tecnologia para trabalhos com alunos com necessidades especiais. Após essa etapa de formação do grupo, houve a fase de preparação não só dos alunos da APAE, mas também dos funcionários da instituição através de oficinas que debateram temas afins com a situação vivida por eles e de como a tecnologia pode auxiliar e melhorar esta situação. Além de esclarecer o 
papel de emancipação e inclusão que estas ferramentas podem representar especialmente para aqueles que possuem alguma espécie de limitação física/motora. Com a instalação do laboratório, começaram os trabalhos diretos com os programas selecionados com a ajuda de orientações didáticas acerca do assunto, além de orientações didáticas tanto de profissionais que atuam na instituição quanto de professores da área da saúde e pedagogia da UFOP. Com a utilização dos computadores, os alunos são levados a trabalhos que abarquem desde aspectos de desenvolvimento físico e psíquico, a acesso a informação e as atualidades buscando uma interlocução com a sociedade, e assim, atender a esta demanda de inclusão e acessibilidade.

Articulação Proposta Ensino: O trabalho será todo pautado por ações que demandam daqueles que o participam o contato direto com conceitos de pedagogia, psicopedagogia, além de técnicas de saúde coletiva e de trabalho com grupos. Deste modo, a articulação com o ensino se dará a medida que se fará necessário o contato com professores, técnicos e outros graduandos das respectivas áreas para atender as necessidades preexistentes e vindouras.

Conforme o que se espera de um projeto de extensão de qualidade, este se articula com outras áreas de atuação. No que tange à pesquisa, além das buscas realizadas para confecção das oficinas, nas mais diversas áreas - pedagogia, psicopedagogia, educação - há as anotações pessoais feitas por cada pesquisador-extensionista sobre o trabalho, o dia-a-dia do projeto e considerações sobre as atividades desenvolvidas, que serão debatidas pelo grupo, gerando dados, fontes de pesquisa para o grupo e para a comunidade acadêmica de modo geral. Gerando posteriormente trabalhos científicos em diversas áreas, desde a extensão puramente, como em vários sentidos da educação regular e superior. Em relação às demandas sociais, o projeto vem atender a uma demanda clara da comunidade, diante das muitas necessidades da instituição, que sobrevive de doações e repasses e atende crianças e jovens carentes e com muitas e variadas necessidades. $\mathrm{E}$ o que diz respeito às entidades externas, $\mathrm{O}$ mesmo irá se articular, principalmente, com a APAE, com a UFOP, a Prefeitura Municipal de Ouro Preto e a Fundação Gorceix.

\subsection{AÇÕES DESENVOLVIDAS}

O desenvolvimento do projeto deu-se por meio de oficinas que tiveram como escopo principal a utilização da tecnologia, através de um laboratório de informática instalado na instituição, como meio de inclusão dos alunos/pacientes da APAE na sociedade moderna. Os participantes foram convidados, através da utilização das ferramentas de softwares específicos, a aumentarem suas habilidades tanto 
psicomotoras como na utilização das ferramentas tecnológicas disponíveis como forma de inclusão e acessibilidade.

Além disso, foram realizados trabalhos como cunho artístico e de socialização dos mesmos entre si e com os demais integrantes da sociedade de modo geral. Além da capacitação diária e contínua dos trabalhadores da instituição através da participação nas atividades desenvolvidas, com o objetivo que possam perpetuar a ação na instituição a médio prazo independentemente das universidades, indo ao encontro de uma política emancipadora proposta pelo programa ao qual o projeto é vinculado.

A importância das atividades está exatamente em, por meio do trabalho desenvolvido se conseguir levar até a comunidade parte não só dos conhecimentos, mas dos valores sociais e humanos que são apreendidos dentro da universidade (SILVA, SOUZA, CHAVES, et all, 2019)

\subsection{PRODUTO}

O projeto visa, através do acesso à tecnologia, facilitar o dia-a-dia dos alunos/pacientes da APAE e promover, deste modo, uma maior inclusão e atender aos princípios de acessibilidade. O produto esperado é o desenvolvimento alcançado pelo projeto, através das ações propostas, que serão identificados à medida que estes desenvolverem as atividades e alcançarem os objetivos traçados.

Falar de diversidade é buscar constantemente a desconstrução de todo um sistema cultural que exclui e agride todos e todas que não se enquadram em determinado padrão. A maior dificuldade reside exatamente no fato de que somos criados numa cultura binária, onde a ideia de não estar dentro de um padrão comportamental esperado configura verdadeiro crime.

Cultura essa que simplesmente ignora as múltiplas possibilidades existentes em todas as esferas de compreensão e manifestação humana (SCOTT, 1998).

Visto que o projeto ainda está em andamento, os produtos finais ainda não ocorreram, tendo assim produtos intermediários que servem de base para a continuidade dos trabalhos. Quais são eles: planejamento e execução do laboratório de informática nas dependências da APAE; visitas junto a APAE para identificação das instalações bem como contato com a direção, funcionários e alunos da instituição; acesso as fichas de cadastro dos alunos para conhecimento e avaliação do público alvo atendido pelo projeto; dados relativos ao levantamento das atividades que já são desenvolvidas na instituição; levantamento de métodos e questionários - aspectos físicos da instituição e psicossomáticos dos alunos da mesma - além de dados sociais para se elaborar um questionário próprio para traçar o perfil da instituição, dos alunos - de saúde e social - para assim atender de forma 
melhor e de maneira mais específica a demanda. Além de formar um histórico palpável e acessível do projeto e, consequentemente, dos trabalhos de extensão da UFOP.

\subsubsection{QUESTIONÁRIO}

Utilizando como base as fichas de anamnese e de cadastro usadas pela própria instituição, elaborouse um questionário a fim de caracterizar a população atendida.

Segue abaixo a prévia do questionário:

Questionário do Perfil das crianças e adolescentes frequentadores da APAE

- Dados Gerais:

1. Nome:

2. Data de nascimento: /

3. Sexo: $M() F()$

4. Idade:

5. Grau escolar:

6. Quantos dias frequenta a APAE por semana? Quais dias? Quais horários?

7. Apresenta/apresentou alguma

8. Tem boa relação familiar?

9. Os pais/responsáveis são participativos?

- Dados Físicos

1. Utiliza cadeira de rodas para se locomover: ( )S ( )N

2. Apresenta alguma dificuldade visual: ( )S ( )N Qual?

3. Faz uso de óculos: ( )S ( )N

4. Apresenta alguma dificuldade auditiva: ( )S ( )N Qual?

5. Faz uso de aparelho auditivo: ( )S ( )N

6. Apresenta alguma dificuldade na fala: ( )S ( )N Qual?

7. Apresenta algum atraso/ déficit de aprendizado: ( )S ( )N Qual? 
8. Possui alguma alteração física que impede a realização de algum movimento: ( )S ( )N Qual parte do corpo?

9. Faz acompanhamento médico: ( )S ( )N Qual especialidade? Quantas vezes ao mês?

10. Faz uso de algum medicamento: ( )S ( )N Qual? Para que usa? Quantas vezes ao dia faz uso? Quais são as recomendações de uso?

11. Realiza alguma atividade física: ( )S ( )N Qual? Possui alguma restrição?

- Dado específico

1. Possui algum contato com a tecnologia virtual (computadores, laptops, tablets, celulares e outros) ? ( )S ( ) N

\subsection{AVALIAÇÃO}

O trabalho foi avaliado pelos próprios membros do projeto, pela coordenação do programa e pela direção da instituição e, principalmente, pelos alunos/pacientes atendidos.

O projeto foi avaliado no que diz respeito às atividades já desenvolvidas pela direção da APAE e seus funcionários. Além das avaliações feitas pelos alunos por meio de perguntas e situações propostas pelo grupo de trabalho do projeto. A avaliação externa foi feita por meio de reunião realizada junto à direção da APAE, que contou ainda com a participação de funcionários da instituição, além da equipe do projeto.

O projeto tem seguido as bases de uma boa extensão que inter-relaciona a solução de uma demanda social identificada, com a participação da comunidade inserida no trabalho e o ganho acadêmico dos alunos envolvidos. Assim sendo, a coordenação avalia de forma muito positiva o trabalho desenvolvido e acredita que o resultado final - após a execução de todas as etapas - será extremamente positivo e de grande valia para a comunidade e para os acadêmicos.

\section{CONSIDERAÇÕES FINAIS}

A inclusão digital destes indivíduos representa com certeza um processo de acessibilidade e inclusão. De modo a propiciar a eles não apenas benefícios sociais, mas ainda benefícios e ganhos físicos, com a utilização de programas específicos que ajudam nas questões de aprendizagem e aspectos motores. Trata-se, portanto, de importante contribuição dada pela universidade enquanto parte dos processos e fenômenos sociais na comunidade na qual está inserida. 
É importante ressaltar que a metodologia utilizada pelo projeto é a pesquisa-ação, que consiste na montagem do projeto ao longo do desenvolvimento do mesmo. Isso proporciona um intercâmbio de conhecimento entre os pesquisadores-extensionistas e os funcionários da APAE. Como resultado do projeto, pode ser percebido não só o ganho real para a instituição, para os membros que dela fazem parte, tanto como profissionais como alunos, mas para os estudantes que tiveram a oportunidade de vivenciar uma experiência real e efetiva de extensão universitária.

Entende-se assim que, a experiência do projeto em questão conseguiu atingir no momento de sua execução os objetivos aos quais se propôs, principalmente de propiciar aos estudantes da Universidade Federal de Ouro Preto - UFOP, de variados cursos uma extensão de qualidade enquanto parte de sua formação universitária e aos membros da comunidade do Município, um contato direto e proveitoso vindo de uma instituição que já está no local há muitos anos. 


\section{REFERÊNCIAS}

FREIRE, Paulo. Pedagogia do oprimido. Rio de Janeiro: Paz e Terra, 12a ed., 1983.

MELO NETO, José Francisco de. Pesquisa-Ação - Aspectos práticos da pesquisa-ação nos movimentos sociais populares e em extensão popular. Disponível em:

<http://www.prac.ufpb.br/copac/extelar/producao_academica/artigos/pa_a_pesquisa_acao.pdf> Acesso em 20 ago. 2011.

SANTOS, Boaventura de Souza. A crítica da razão indolente: contra o desperdício da experiência. São Paulo: Cortez, 4ae ed., 2005. THIOLLENT, Michel. Metodologia da pesquisa- ação. São Paulo: Cortez, 14ạ ed., 2005.

SCOTT, Joan. Tradução: Christine Rufino Dabat. Maria Betânia Ávila. Gênero: uma categoria útil para análise histórica. Revista Educação e Realidade. 1998.

Silva ALB, Sousa SC, Chaves ACF, Sousa SGC, Andrade TM, Filho DRR. A importância da Extensão Universitária na formação profissional: Projeto Canudos. Rev enferm UFPE on line. 2019;13:e242189 DOI: https://doi.org/10.5205/1981-8963.2019.242189. 


\section{Capítulo 8}

\section{doi $10.37423 / 210604326$}

\section{RELAÇÕES DO TEATRO DO OPRIMIDO COM A EDUCAÇÃO: HISTÓRIAS E REFLEXÕES.}

MARCEL CAVALCANTE DE SOUZA

ROSSANA DE VASCONCELOS PUGLIESE VITO

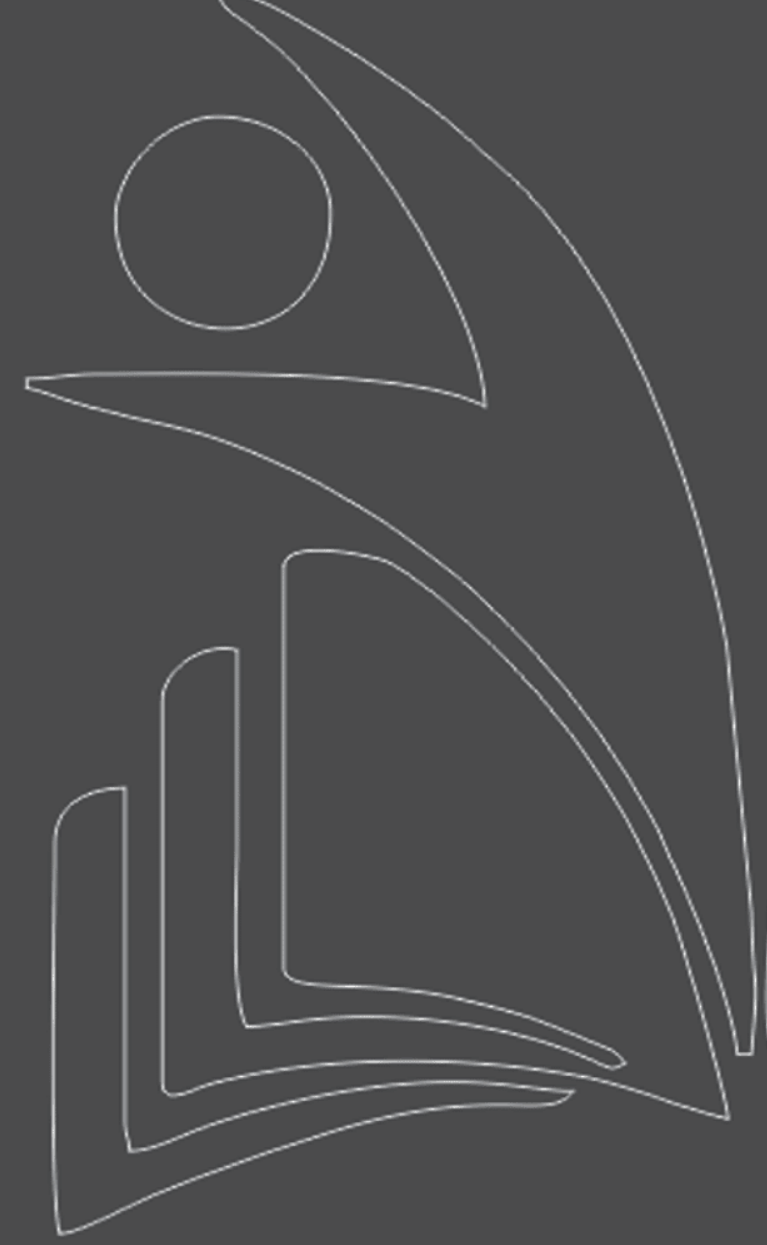

Secretaria Municipal de Educação do Rio de Janeiro.

Universidade Estácio de Sá

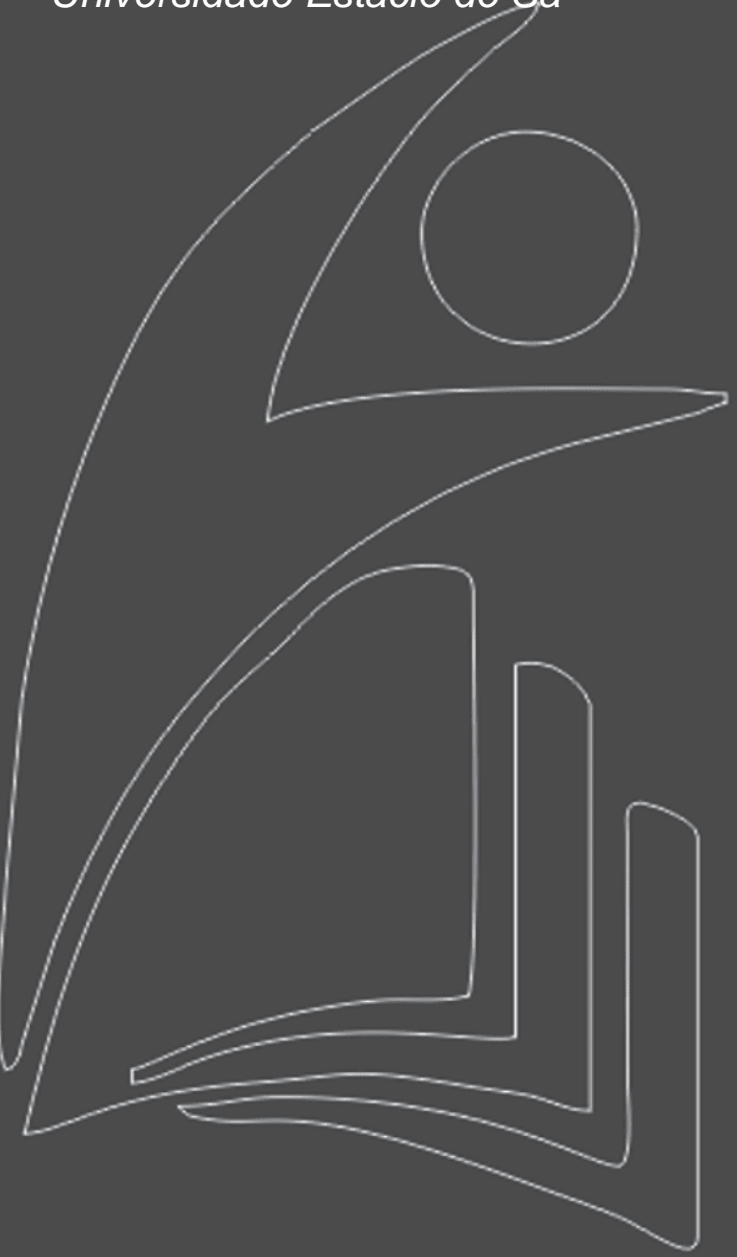


Resumo: Muito já foi escrito sobre Teatro do Oprimido (TO), tanto por Boal, quanto por seus Curingas. O objetivo dessa pesquisa é investigar as relações do TO com a Educação, em especial no Brasil e no Peru. Nossa pesquisa justifica-se tanto pela oportunidade de auxiliar a outros(as) pesquisadores(as), quanto como forma de resistência político-filosófica frente à barbárie que temos acompanhado e vivido em nossos dias atuais, dentro e fora do país. Ao contemplar a relação do TO com a Educação, acredita-se que a pesquisa ganha ainda mais importância, principalmente diante de todos os ataques que a educação pública vem sofrendo. Que este trabalho sirva como fonte de pesquisa, que possa contribuir com outras pesquisas. Em especial, sobre TO e Educação. E também, que sirva como provocação político-filosófico-pedagógica a todos os educadores e educadoras que possuam a inquietação de transformar para melhor a realidade à sua volta. A metodologia utilizada é a Revisão Integrativa da Literatura, de caráter qualitativo, que se sustenta epistemologicamente nas obras produzidas por Augusto Boal e alguns de seus Curingas. O objeto de pesquisa é a relação que o TO sempre nutriu, desde os primeiros dias de sua existência, com os educadores, com a Educação. O que se espera com este trabalho é que em cada etapa se possa aprofundar mais o conhecimento, ao mesmo tempo em que se dilata o olhar, tornando nossa visão mais ampla, menos preconceituosa e mais sensível, sobre as possíveis relações entre TO e Educação.

Palavras-Chave: Teatro do Oprimido; Educação; Pesquisa; Multiplicação; Mudança. 


\section{INTRODUÇÃO}

Muito já foi escrito sobre Teatro do Oprimido (TO), tanto por Boal, quanto por seus Curingas (Licko Turle, Bárbara Santos, Silvia Balestreli, Cachalote Mattos, Helen Sarapeck, Flávio da Conceição, Monique Rodrigues, Cláudia Simone, Alessandro Conceição, dentre tantos outros e outras). Em especial de 2009 em diante - ano em que o genial teatrólogo nos deixou. Muito também continua sendo produzido, mesmo doze anos após a sua morte.

As inferências que nasceram dos estudos com TO passam por Educação, Psicologia, Sociologia, Política, Ética e Estética, Filosofia, Artes, dentre diversas outras áreas que vem se interrelacionando no contexto brasileiro.

O objetivo dessa pesquisa é investigar possíveis relações do TO com a Educação, em especial no Brasil e no Peru. A escolha destes países está diretamente relacionada a situações em que o TO foi trabalhado de forma integrada a práticas pedagógicas, ou seja, à Educação.

Esta pesquisa justifica-se, tanto pela oportunidade de auxiliar a outros(as) pesquisadores(as), quanto como forma de resistência político-filosófica frente à barbárie que temos acompanhado e vivido em dias atuais, no Brasil e no mundo. Ao contemplar a relação do TO com a Educação, acredita-se que a pesquisa ganha ainda mais importância, principalmente diante de todos os ataques que a Educação pública vem sofrendo em nosso país. Uma das perspectivas é que este trabalho sirva como fonte de pesquisa, organizada de forma a contribuir com outras pesquisas. Em especial, sobre TO e Educação. E também, que sirva como provocação político-filosófico-pedagógica a todos os educadores e educadoras que possuam a inquietação de transformar para melhor a realidade à sua volta.

\section{METODOLOGIA}

Foi realizada uma Revisão Integrativa da Literatura, de caráter qualitativo, que se sustenta epistemologicamente nas obras produzidas por Augusto Boal e alguns de seus Curingas. O objeto de pesquisa é a relação que o TO sempre nutriu, desde os primeiros dias de sua existência, com os educadores, com a Educação.

Para melhor entendimento do que seja o Curinga do TO:

Augusto Boal batizou o facilitador do Teatro do Oprimido (TO) de "Curinga": artista com função pedagógica; praticante, estudioso e pesquisador do Método. Trata-se de um especialista em processo de aprendizagem. Deve ser um conhecedor rigoroso dos fundamentos teóricos, políticos, estéticos e filosóficos do TO, que ao mesmo tempo, é sensível às demandas da realidade, sendo capaz 
de reinventar o conhecimento das pessoas. (SANTOS, 2003, p. 75 apud ALTIERI, 2016, p. 123).

Em termos de tempo de publicação, foram consideradas tanto as obras clássicas dentro do TO (como, por exemplo, os primeiros livros de Augusto Boal), quanto os trabalhos mais recentes que ora ressignificam aspectos do método, ora descobrem ou encontram novos aspectos. Acontecimento que é possível pela própria característica do TO, de ser instrumento vivo de transformação do ser humano (SANTOS, 2016). Assim como Freire (2011) dizia que somos seres inacabados, Boal (1998) deixa bem claro que esse teatro não é de um oprimido, mas dos oprimidos e oprimidas de forma geral. Ou seja, de todos e todas que se sentirem oprimidos e quiserem usar o método a seu favor, no melhor dos sentidos (BOAL, 1998).

Em outras palavras: Teatro do Oprimido manter-se-á sempre fiel à sua essência e aos princípios básicos, mas enquanto método criado para atender necessidades humanas, estará, dialeticamente, sempre em transformação, uma vez que essa é também uma característica humana.

O que se espera com este trabalho (além do já citado anteriormente), é que em cada fase se possa aprofundar mais o conhecimento, ao mesmo tempo em que se dilata o olhar, tornando nossa visão mais ampla, menos preconceituosa e mais sensível, sobre as possíveis relações entre TO e Educação.

\section{REVISÃO DE LITERATURA}

\section{Pontos Fundamentais sobre o Teatro do Oprimido}

Antes de citar qualquer obra de outros autores, que não do próprio Augusto Boal, faz-se necessário lembrar um pouco da essência do TO, enquanto atividade assumidamente política, propondo a transformação da sociedade através da conscientização e atuação humanas. Atuação que modifica o espectador - ser passivo que só assiste - em Espect-Ator: aquele ou aquela que protagoniza uma ou mais mudanças necessárias em sua realidade, diante de uma opressão.

Tal ação parte de uma inquietação de Boal, sobre devolver ao povo os meios de produção teatral (BOAL, 1980). Segundo ele, em sua "Poética Política", no início o teatro era feito pelo povo, nas ruas. Aos poucos o teatro foi sendo apropriado pelos poderosos, dividindo o povo em espectadores - os que só poderiam assistir - e artistas: 'seres especiais' ${ }^{1}$ que sobem ao palco depois de meses de preparação. (BOAL, 1980) 
Sem nenhum demérito aos profissionais - seria um contrassenso, uma vez que o próprio Boal era teatrólogo, dramaturgo e diretor teatral - ele acreditava e difundia a ideia de que atores somos todos nós. Somos todos: teatro!

Todo mundo atua, age, interpreta. Somos todos atores. Até mesmo os atores! Teatro é algo que existe dentro de cada ser humano, e pode ser praticado na solidão de um elevador, em frente a um espelho, no Maracanã ou em praça pública para milhares de espectadores. Em qualquer lugar... até mesmo dentro dos teatros. (BOAL, 1998, p. 352).

Ainda que considerássemos tais afirmações somente do ponto de vista artístico, já seria maravilhoso. Mais ainda quando encaramos a ideia no aspecto político, de vida em sociedade. É ele também que ressalta que toda atividade humana é por si só atividade política. E o teatro é uma delas (BOAL, 1980).

Outra premissa fundamental para nosso conhecimento básico do método é o entendimento de que o TO não pode se limitar apenas a um conjunto de atividades voltadas para o entretenimento. Embora seja lúdico e emancipador, ele se propõe a entrar, de preferência, nos locais em que se detecta alguma opressão acontecendo.

Quanto à estrutura do Arsenal²desenvolvido por Boal (1998), podemos dizer que os jogos trazem o que há de melhor do ser humano. Resgatam nossa criança: aquela que nos permite dançar, brincar, criar, pintar e até errar, sem muito medo das críticas ou julgamentos adultos.

Os exercícios proporcionam a preparação fundamental, pois que segundo o próprio Boal (1998), não basta tomarmos consciência de que somos atores: é preciso trabalhar a voz, desenvolver nossa expressão e nos reconhecermos como sujeitos/protagonistas da situação.

As técnicas trazem o refinamento do método. É onde conseguimos organizar nosso pensamento, fortalecendo a atuação coletiva, direcionando nosso fazer político.

Há que se falar ainda da Estética do Oprimido (BOAL, 2009; SANCTUM, 2012; MATTOS, 2016) e das Ações Sociais Concretas e Continuadas (SANTOS, 2016) - partes fundamentais da Árvore do TO ${ }^{3}$ (SARAPECK, 2016). Voltaremos a elas mais a frente.

Para tomarmos exemplos concretos sobre o que está sendo dito, de como as pessoas vem se organizando para lutar contra as opressões, podemos citar: TO na Saúde Mental (em diferentes épocas e instituições, com Augusto Boal, Cláudia Simone, Alessandro Conceição, Monique Rodrigues, dentre outros e outras), tendo como forte representante o GTO 4 Pirei na Cenna: que completou 22 anos e permanece ativo até hoje em Niterói. Grupo Marias do Brasil: composto por trabalhadoras domésticas que acaba de completar 20 anos em atividade, inclusive colecionando prêmios no Brasil e no exterior, 
neste momento sendo curingado por Maria Isabel Lourenço. Grupo Cor do Brasil: com Alessandro Conceição, Cachalote Mattos, Carolina Netto, dentre outras e outros: trata das questões do racismo, tanto o velado quanto o descarado, em nosso país. Grupo Pantera: criado e dirigido por Gabriel Horsth, atua diretamente nas opressões sofridas pelo público LGBTQIA+, principalmente moradores/as em comunidades em situação de conflito. Coletivos Madalena e Madalena-Anastácia: ambos iniciados através de laboratórios, propostos por Alessandra Vannucci e Bárbara Santos ${ }^{5}$. O primeiro, tratando das opressões sofridas pelas mulheres, de modo geral. O segundo, sobre mulheres negras (pois que, segundo as participantes espect-atrizes, traz opressões a mais, quando comparadas com mulheres brancas $^{6}$ ). GESTO: Grupo de Estudos em Teatro do Oprimido - composto por pesquisadores/as que hoje estão espalhados/as em diferentes universidades pelo país (UNIRIO, UFMG, UFBA, UFAC ${ }^{7}$, dentre outras), e já tem dois livros (lançado em 2016 e $2021^{8}$ ), além de toda contribuição com a pesquisa em $\mathrm{TO}^{9}$. É deles também a organização de um dos mais importantes eventos, as JITOU: Jornadas Internacionais do Teatro do Oprimido e Universidade, que teve as cinco primeiras edições na UNIRIO e as duas mais recentes na UFBA ${ }^{10}$. Além de diversos outros coletivos e do próprio trabalho desenvolvido no CTO (Centro de Teatro do Oprimido $^{11}$ ), no Rio de Janeiro, que hoje abriga também a Escola de Teatro Popular: uma escola de teatro criada especialmente para militantes e simpatizantes dos diversos movimentos sociais pertencentes ao nosso país, que enfatiza além do TO, outros tipos de teatro considerados políticos em suas épocas (Teatro Épico, Teatro Jornal, dentre outros). Esta escola existe também em outros estados e foi idealizada por Julian Boal, junto a outros colaboradores, partindo de uma experiência semelhante bem sucedida, observada na Argentina.

Outra experiência muito digna de ser lembrada são os grupos criados no Complexo da Maré (de onde saíram lideranças importantes que hoje atuam também no CTO, como Maiara Carvalho e Gabriel Horsth), e onde foram criados pelo menos cinco grupos atuantes, que tratam dos mais diversos assuntos relacionados com seu dia a dia numa comunidade em situação de confronto.

Para fechar por enquanto os exemplos de atuação concreta, cito o próprio Educadores/as In Cena: grupo de estudo e experimentação em Teatro do Oprimido e Educação, que começou como uma oficina direcionada a professores/as que queriam refletir sobre a educação em nosso país, problematizando-a através do método. Transformado em 2017 em grupo, já conseguimos participar de diversos eventos, tanto como ouvintes, quanto apresentando trabalhos, trocando com outros/as praticantes de TO e também propondo oficinas, palestras e minicursos. Esta pesquisa é também, a meu ver, uma extensão desse trabalho que junto a tantos outros, vem tentando fazer a diferença na 
vida das pessoas. Destacamos, também relacionando TO e Educação, o trabalho feito no Rio de Janeiro, pela professora-curinga Claudete Félix, adaptando e criando jogos em formato remoto, com professores da rede pública do ensino fundamental.

\section{DISCUSSÃO}

\section{Alguns momentos da história do TO e seus entrelaçamentos com a Educação:}

Segundo Boal, em entrevista concedida a Dina $S f a t^{12}$, não há uma data precisa ou um acontecimento que marque sozinho o nascimento do TO. Sabemos que o Teatro Jornal (TJ), considerada primeira técnica do TO, era praticado no Teatro de Arena (TA) antes de Boal ser exilado, portanto, muito antes de se pensar no nome Teatro do Oprimido (BOAL, 1980; 2014).

Em Hamlet ou Filho do Padeiro (2014), ele relata sobre a experiência vivida junto ao elenco do TA, quando em excursão com um espetáculo que falava em "pegar em armas, dar o sangue pela causa". Neste episódio ele cita Virgílio: liderança camponesa que fica tão empolgado com a apresentação, que propõe que os atores se juntem a eles para pegar em armas (neste caso, armas de verdade). Diante da situação os atores se negam muito envergonhados, alegando que não tinham armas de verdade. $O$ camponês explica que isso não seria problema, pois eles possuíam uma quantidade de armas que daria para todos. Assustados, os atores explicam que não saberiam como manusear uma arma, pois na verdade eram só atores, não se viam na vida real fazendo aquilo. O que gerou uma indignação em Virgílio e nos camponeses em geral. Segundo Boal, o camponês indagou ao grupo de atores, que quando falam na peça em derramar o sangue pela causa, na verdade estariam se referindo ao sangue deles, camponeses? O que obviamente gerou um desconforto no grupo todo e levou Boal a pensar muito sobre o assunto ${ }^{13}$. (BOAL, 2014). Tal experiência o marcou profundamente e ele atribui a este acontecimento, parte da inquietude que o levou a sistematizar o TO.

Cita também a já mundialmente conhecida história do nascimento do Teatro do Fórum (TF), em que pela primeira vez uma pessoa é provocada a entrar em cena no lugar dos atores. E uma terceira experiência ocorrida em Santo André, estado de São Paulo, durante um trabalho em um sindicato. Tais situações são muito bem contadas em diversas obras sobre TO, além da autobiografia já citada acima: Hamlet ou o Filho do Padeiro (2014). Portanto, não há porque repeti-las aqui. Sigamos.

Além destas três lembranças de Boal, Licko Turle (2016), pesquisador e Curinga da primeira geração de TO no Brasil (de 1986, das Fábricas de Teatro Popular), nos chama atenção para outro acontecimento que ele acredita que tenha sido fundamental para o fortalecimento político- 
pedagógico do método. Trata-se do Projeto ALFIN (Alfabetização Integral), no Peru. Neste projeto havia profissionais de diferentes linguagens artísticas e Boal, foi convidado para ficar a frente das aulas de teatro.

Em 1973, o Governo Revolucionário Peruano iniciou um plano nacional de alfabetização integral, com objetivo de erradicar o analfabetismo em um prazo aproximado de 4 anos. Supõe-se que haja no Peru entre 3 a 4 milhões de analfabetos ou semianalfabetos, em uma população de 14 milhões de pessoas. (BOAL, 1980, p. 124).

Boal, em sua Poética do Oprimido (1980), explica mais detalhadamente sobre este projeto, nas atividades que foram utilizadas e ainda, na inovação para a época, de tal concepção de alfabetização. Normalmente só pensamos na escrita e nos aspectos cognitivos envolvidos na aprendizagem. Mas alfabetizar ou mesmo educar alguém, integralmente, passa por diversos outros modos de estar no mundo. O ser humano é um ser complexo, que precisa se expressar por diferentes meios e linguagens. Boal enxergou neste projeto, uma oportunidade para aplicar e desenvolver ainda mais o TO. Embora ainda não tivesse publicado o livro, já havia começado experimentações com o método em outros países. Válido lembrar que ele foi exilado em 1968 e durante todo este período, entre o exílio e o projeto ALFIN, Boal jamais esteve parado, sem criar ou pensar novas possibilidades ${ }^{14}$. Quando ele chega ao Peru para participar dessa alfabetização integral, ele leva em sua bagagem pedagógica e artística o TO, como proposta que poderia compor aquele currículo, junto às outras formas artísticas ali presentes.

Talvez este seja o período na história de Boal, em que primeiro tenha se aproximado de forma mais veemente de um projeto nacional de educação (é difícil dizer, considerando-se o tamanho da história deste homem, não só em termos de quantidade de anos; sobretudo em qualidade, intensidade e impetuosidade). Independente de ter sido a primeira, é inegável que tal experiência viria a influenciar no fortalecimento e no desenvolvimento do TO (TURLE, 2016).

Dando um salto no tempo, indo para 1986, ano em que Darcy Ribeiro convida Boal para atuar nas Fábricas de Teatro do Popular, nos recém-inaugurados CIEPs, no Rio de Janeiro, vemos mais uma vez a estreita relação do TO com a força da Educação, em especial, a pública (TURLE, 2013).

Embora tenha durado pouco tempo, é neste período que se constroem as bases para o que depois viria a ser o Centro de Teatro do Oprimido (CTO), bem como a confirmação de que aqueles animadores culturais do início do projeto tornar-se-iam os Curingas: pessoas responsáveis pela multiplicação do método, por apoiar epistemologicamente e filosoficamente muito do que viria a ser produzido, anos depois. Cabem aqui, enquanto exercício de reflexão, algumas questões (considerando ainda que a 
Maiêutica $^{15}$, sempre foi uma das formas que Boal gostava de usar para nos fazer pensar). Pergunto: 0 TO seria o mesmo (pensando nos debates com Boal, nas ideias propostas pelo grupo, em todo convívio, confecção de projetos e ações em geral) se neste início os profissionais fossem outros, que não professores e professoras do ensino básico?

É uma resposta que não tem importância enquanto exaltação sobre a relevância de uma profissão ou do impacto que esta tem sobre a sociedade em que está inserida, mas enquanto reflexão políticopedagógica se coloca bem propícia. Será que no caso deste trabalho ter se desenvolvido no meio artístico, ou ainda acadêmico universitário - que embora também tenha relação com a Educação, traz outro discurso e modo de agir no dia a dia - ou na área da saúde... Teria o mesmo desenvolvimento? Provavelmente não: uma vez que a forma de pensar e agir no mundo de alguém que é professor do ensino básico na rede pública - ou ainda que não seja professor (a), mas que atue como animador cultural neste contexto educacional, portanto, também um(a) educador(a) - traz toda uma especificidade e modo de estar no mundo.

Gosto de pensar que Boal, junto a Darcy Ribeiro, enxergaram nas Fábricas de Teatro Popular - ainda que no primeiro momento, pensando mais nos alunos que nos professores - um espaço de formação humana e uma oportunidade educativa para pensarmos uma sociedade mais justa, menos desigual. Instrumentalizar estes jovens que viriam a se tornar os Curingas foi um passo essencial para o fortalecimento não só do método, mas das lideranças que hoje continuam em luta por um mundo melhor.

Dando outro salto "à frente", lembremos o início da pesquisa sobre a Estética do Oprimido: algo que passou a ser essencial no desenvolvimento e na multiplicação do método. Partindo da ideia de que todo ser humano tem sua Estética e que esta é composta por palavra, som e imagem, Boal junto aos Curingas, desvela todo um novo Arsenal artístico, bebendo um pouco nas fontes das Artes Plásticas, das experiências com tinta, pincel, materiais alternativos e recicláveis, dentre outros. Aproxima-se um pouco da Neurociência, aprofundando o que há de mais bonito da alma humana: o contato com nossa Criança: não no mesmo sentido da aplicação dos jogos, mas indo mais a fundo - em termos de percepção, afetividade e busca pela própria Estética (BOAL, 2009).

Em 2001, aproximadamente, iniciam este processo (MATTOS, 2016) realizando laboratórios internos no CTO e posteriormente levando para escolas em municípios circunvizinhos ao Rio de Janeiro. Em 2009 é lançado o livro A Estética do Oprimido: obra assinada por Boal, mas com certeza trazendo junto todos e todas que construíram este processo com ele. Bárbara Santos, curinga do CTO nesta época, 
coloca em sua obra Raízes e Asas (2016) alguns dos trechos das conversas por e-mail entre ela e Boal: o quanto ele era inquieto e provocava diariamente os/as Curingas para que juntos/as desenvolvessem cada vez mais a Pedagogia que levariam consigo ao multiplicar suas vivências, discussões e laboratórios sobre a Estética do Oprimido.

Outro pilar importante neste processo é a ideia de que o ser humano possui duas formas de pensamento. Segundo Boal:

Ser humano é ser artista. Nenhuma percepção da sociedade e da natureza estará completa sem as duas formas humanas de pensar: o Pensamento Sensível, criador de arte e cultura, e o Pensamento Simbólico das palavras. 0 TO procura desenvolver esses dois pensamentos que, entre os oprimidos, foram atrofiados pela prevalência do pensamento único. Nossa filosofia e nossa política são claras: a luta contra todas as formas de opressão, em todos os segmentos sociais. (2009, p. 184. Grifos do Autor).

Mais uma vez, de forma extraordinária, o TO estreita laços com a Educação, não só por ter multiplicado e experimentado a Estética do Oprimido no interior das escolas, mas, sobretudo, por trazer de forma pedagógica as ideias que queria compartilhar com os educandos. Não se quer dizer que o TO só poderia ter se desenvolvido assim ou que a Educação, seja o único meio em se trabalhar o método. Uma das belezas do TO é justamente sua capacidade multidisciplinar, de servir aos oprimidos em variadas frentes de trabalho. O foco é combater a opressão, sempre. Mas é inegável o quanto TO e Educação caminham entrelaçados desde sempre. Seja no projeto ALFIN, nas Fábricas de Teatro Popular, na Estética do Oprimido ou ainda, mais recentemente, na Escola de Teatro Popular, as duas formas de intervenção humana (TO e Educação), potencializam-se mutuamente.

Válido lembrar também neste contexto, quando Flávio Sanctum (2016) diz que Curinga é o pedagogo do Teatro do Oprimido.

\section{CONSIDERAÇÕES FINAIS}

\section{Cenário Atual: perspectivas e desafios para quem continua na luta.}

Tempos de tensão. Sendo perseguidos, de forma velada ou não: profissionais da Saúde, da Arte e da Educação. Pensar e expressar qualquer opinião, ainda que calcada em pesquisas ou conhecimentos científicos, tornou-se algo de pouca importância para o governo vigente. É fácil imaginar (e se perguntar): o que estaria articulando Boal se aqui ainda estivesse?

É preciso lutar com as armas que temos, ou lembrando nosso mestre: com nosso Arsenal! Ou ainda para lembrar outro mestre, Bertold Brecht: é chegado o momento em que precisamos explicar o óbvio 


\section{Relações Do Teatro Do Oprimido Com A Educação: Histórias E Reflexões}

(WILLET, 1967). Que escrever, jogar, atuar, sejam também formas de resistência e transformação em nossa sociedade.

Debruçarmos sobre a obra de Boal e sobre tudo que vem sendo escrito sobre o TO, além de importância política, é fundamental também como formação cultural, educacional, em termos de ganho de conhecimento. Já nos ensinavam nossos avós que este sim - o conhecimento - é o único bem que não podem nos tirar. E é justamente por isso, que estão tentando apagar da nossa memória nomes como Paulo Freire, Augusto Boal, Darcy Ribeiro, dentre outros.

Estudar e estar atento ao que vem sendo feito no dia a dia dos grupos, trupes, coletivos e cias de Teatro (não só de TO) é um exercício de desalienação (BOAL, 1980), pois que mesmo na "era da informação", seguimos sendo direcionados somente para o que interessa aos grupos hegemônicos. Forças político-econômicas que ditam como se deve pensar, agir e seguir trabalhando sem questionar nada.

Que resgatemos, nós, oprimidos e oprimidas, nossa Ética, Estética, nossa criança interior e os valores mais próximos da humanização, do sensível e da Arte. Enfim: do que pode modificar para melhor nossas vidas: individual e coletivamente.

Viva Augusto Boal! Viva Paulo Freire!

Viva o Teatro do Oprimido!

E viva a Educação Brasileira! 


\section{REFERÊNCIAS BIBLIOGRÁFICAS}

ALTIERI, Antonio Luis de Quadros. Cultura de Augusto Boal: Processos Constitutivos de Teatro e Educação. Jundiaí: Paco Editorial, 2016.

ANDRADE, Clara de. O exílio de Augusto Boal: Reflexões sobre um teatro sem fronteiras. Rio de Janeiro: 7 letras, 2014.

BERTHOLD, Margot. História Mundial do Teatro. São Paulo, Ed. Perspectiva, 2000.

BOAL, Augusto. Hamlet e o Filho do Padeiro: memórias imaginadas. São Paulo: Cosac Naify, 2014. . A Estética do Oprimido. Rio de Janeiro: Garamond, 2009. . Jogos Para Atores e Não-Atores. Rio de Janeiro: Civilização Brasileira, 1998.

Brasileira, 1980. - Teatro do Oprimido e Outras Poéticas Políticas. Rio de Janeiro, RJ: Civilização

BEZERRA, Antonia Pereira, et al (org). Teatro do Oprimido e Universidade (Volume II): Experiências Pedagógico-Artivistas e(m) Redes Para Esperançar. Rio de Janeiro: Mundo Contemporâneo, 2021.

CHAUI, Marilena. Convite à Filosofia. São Paulo: Editora Ática, 2005.

CHIARI, Gabriela. Laboratório Madalenas: Teatro das Oprimidas. In: MATTOS, Cachalote, et al (orgs). Teatro do Oprimido e Universidade: Experimentos, Ensaios e Investigações. Rio de Janeiro: Metanoia, 2016.

CORTELLA, Mário Sérgio. A Escola e o Conhecimento: fundamentos epistemológicos e políticos. Cortez Editora: São Paulo, 2011.

FREIRE, Paulo. Pedagogia da Esperança: um reencontro com a pedagogia do oprimido. São Paulo, SP: Paz e Terra, 2011.

MATTOS, Cachalote, et al (orgs). Teatro do Oprimido e Universidade: Experimentos, Ensaios e Investigações. Rio de Janeiro: Metanoia, 2016.

SANCTUM, Flavio. Os Curingas de Boal. In: MATTOS, Cachalote et al. (Org.). Teatro do Oprimido e Universidade: experimentos, ensaios e investigações. Rio de Janeiro: Metanoia, 2016.

. A Estética de Boal: odisseia pelos sentidos. Rio de Janeiro, RJ: Multifoco, 2012.

SANTOS, Bárbara. Teatro do Oprimido, Raízes e Asas: uma teoria da práxis. Rio de Janeiro: Ibis Líbris, 2016.

SARAPECK, Helen. Minha Casa na Árvore: um memorial de experiências com o Teatro do Oprimido. In: MATTOS, Cachalote et al. (Org.). Teatro do Oprimido e Universidade: experimentos, ensaios e investigações. Rio de Janeiro: Metanoia, 2016. 
TURLE, Licko. Alfabetização Teatral: o encontro do Teatro Popular com a Pedagogia do Oprimido. In: MATTOS, Cachalote et al. (Org.). Teatro do Oprimido e Universidade: experimentos, ensaios e investigações. Rio de Janeiro: Metanoia, 2016.

. O Centro do Teatro do Oprimido no Brasil: Primeiros Passos. In: LIGIÉRO, Zeca; TURLE, Licko e ANDRADE, Clara de (org). Augusto Boal: Arte, Pedagogia e Política. Rio de Janeiro: Mauad X, 2013. p.69-93.

WILLET, John. O Teatro de Brecht. Rio de Janeiro, RJ: Zahar Editores, 1967.

Vídeo:

Augusto Boal: https://www.youtube.com/watch?v=c-LE9kXutRw. Compilação do acervo audiovisual do Instituto Augusto Boal; Publicado em 30 de abril de 2012. Acesso em 31/07/19.

Link:

ANAIS VIII JITOU - Jornadas Internacionais do Teatro do Oprimido e Universidade (2020): https://www.even3.com.br/anais/jitou2020/

GONZALEZ, Mariana. Movimento LGBTQIA+: entenda o que significa cada uma das letras da sigla. Universa Uol (site): https://www.uol.com.br/universa/noticias/redacao/2021/06/03/movimentoIgbtqia-entenda-o-que-significa-cada-uma-das-letras-da-sigla.htm?cmpid=copiaecola Publicado em 03/06/2021. Acesso em 18/06/2021. 


\section{NOTAS}

Nota 1

Aqui não se trata de ironia, que fique bem claro. É apenas a forma como o Artista é visto pelo senso comum, em especial quando falamos de Teatro Grego, considerado berço do teatro ocidental. (BOAL, 1980; BERTHOLD, 2000).

Nota 2

Termo escolhido por Boal (1998) para designar o conjunto de Jogos, Exercícios e Técnicas do TO. É interessante observar que para Augusto Boal, aparentemente, nenhuma nomenclatura pode ser escolhida a esmo. Quanto mais conhecemos o método mais significados enxergamos: em cada escolha, em cada nome.

Nota 3

Vide Anexo 1.

Nota 4

GTO: Grupo de Teatro do Oprimido.

Nota 5

A sigla LGBTQIA+ reúne orientações sexuais; cada uma dessas sete letras e o sinal de soma + representam: L: Lésbicas; G: gays; B: Bissexuais; T: transexuais ou Travestis; Q: Queer; I: Intersexo; A: Assexual; +: demais orientações sexuais e identidades de gênero. Fonte:

https://www.uol.com.br/universa/noticias/redacao/2021/06/03/movimento-lgbtqia-entenda-o-quesignifica-cada-uma-das-letras-da-sigla.htm?cmpid=copiaecola. Acesso em 18/06/2021.

Nota 6

Interessante ressaltar obra de Santos: TO Raízes e Asas: uma teoria da práxis (2016) em que ela relata mais detalhadamente todo o processo de criação dos laboratórios e o quanto tal ação cresceu mundo afora, com a criação de seminários e encontros internacionais com o nome Madalena. Um trabalho que vai muito além da criação de um coletivo. Vale a pena conhecer mais de perto. Recomenda-se a leitura atenciosa.

\section{Nota 7}

Importante a leitura de: CHIARI, Gabriela. Laboratório Madalenas: Teatro das Oprimidas. In: MATTOS, Cachalote, et al (orgs). Teatro do Oprimido e Universidade: Experimentos, Ensaios e Investigações. Rio de Janeiro: Metanoia, 2016.

Nota 8

UNIRIO: Universidade Federal do Estado do Rio de Janeiro; UFMG: Universidade Federal de Minas Gerais; UFBA: Universidade Federal da Bahia; UFAC: Universidade Federal do Acre. Importante ressaltar que embora a dispersão dos Curingas-pesquisadores no primeiro momento possa parecer 
um aspecto que dificulta o trabalho do GESTO, é possível observar que o TO acaba ocupando outros espaços importantes, tanto no meio acadêmico, quanto artístico de modo geral.

\section{Nota 9}

MATTOS, Cachalote, et al (org). Teatro do Oprimido e Universidade: Experimentos, Ensaios e Investigações. Rio de Janeiro: Metanoia, 2016. / BEZERRA, Antonia Pereira, et al (org). Teatro do Oprimido e Universidade (Volume II): Experiências Pedagógico-Artivistas e(m) Redes Para Esperançar. Rio de Janeiro: Mundo Contemporâneo, 2021.

Nota 10

Durante a pandemia, no período de março a julho de 2020, o Prof. Dr. Licko Turle conduziu um grupo de estudo com mais de 100 pessoas, de modo remoto (via Google Meet / Youtube) debruçando-se sobre algumas obras de Boal: TO e Outras Poéticas Políticas (1980), O Arco-Íris do Desejo (1996) e A Estética do Oprimido (2009). Em maio de 2021 inicia um curso de extensão (que vai até setembro), em que estudaremos o livro "Teatro Legislativo". Nome também de uma das técnicas do TO.

Nota 11

Em 2020, por causa da Pandemia de Covid-19, o evento foi totalmente em formato remoto. A de 2021 seguirá esse mesmo formato.

\section{Nota 12}

Não podemos deixar de ressaltar a importância deste centro na formação de Curingas e no desenvolvimento do próprio método. O CTO é referência para praticantes do mundo inteiro. Era a sede usada por Boal e pelos Curingas para criar os laboratórios, lapidar as técnicas, discutir todos os assuntos pertinentes às ações concretas que deveriam ser executadas pelo coletivo. Ainda hoje, abriga, além da Escola de Teatro Popular, diversos cursos de formação, inclusive para pessoas de outros países. Localiza-se na Rua Mem de Sá, no 31, Lapa - centro do Rio de Janeiro.

\section{Nota 13}

Augusto Boal: https://www.youtube.com/watch?v=c-LE9kXutRw. Compilação do acervo audiovisual do Instituto Augusto Boal; Publicado em 30 de abril de 2012. Aos 6'10". Acesso em 31/07/19.

Nota 14

Até que ponto se pode ou deve falar em nome dos oprimidos? Quais são suas reais necessidades de luta? Ninguém melhor que os próprios oprimidos para responder a estas e outras perguntas (BOAL, 1980; 2014).

Nota 15

Para entender melhor sobre este período em que Boal esteve exilado: Andrade (2014). 
Nota 16

Estratégia utilizada por Platão com seus discípulos, em que, ao invés de trazer o conhecimento pronto e apresenta-lo de forma expositiva, ele indagava aos educandos. Ele acreditava que desta forma, 0 discípulo chegaria verdadeiramente à essência do conhecimento (BOAL, 1980; CORTELLA, 2011; CHAUI, 2005). 


\section{Capítulo 9}

\section{doi $10.37423 / 210604327$}

\section{EDUCAÇÃO PATRIMONIAL COMO FERRAMENTA DE PRESERVAÇÃO DE TÉCNICAS CONSTRUTIVAS COM TERRA CRUA}

Mateus de Carvalho Martins

João Vítor Januário

Guilherme Peixoto dos Santos

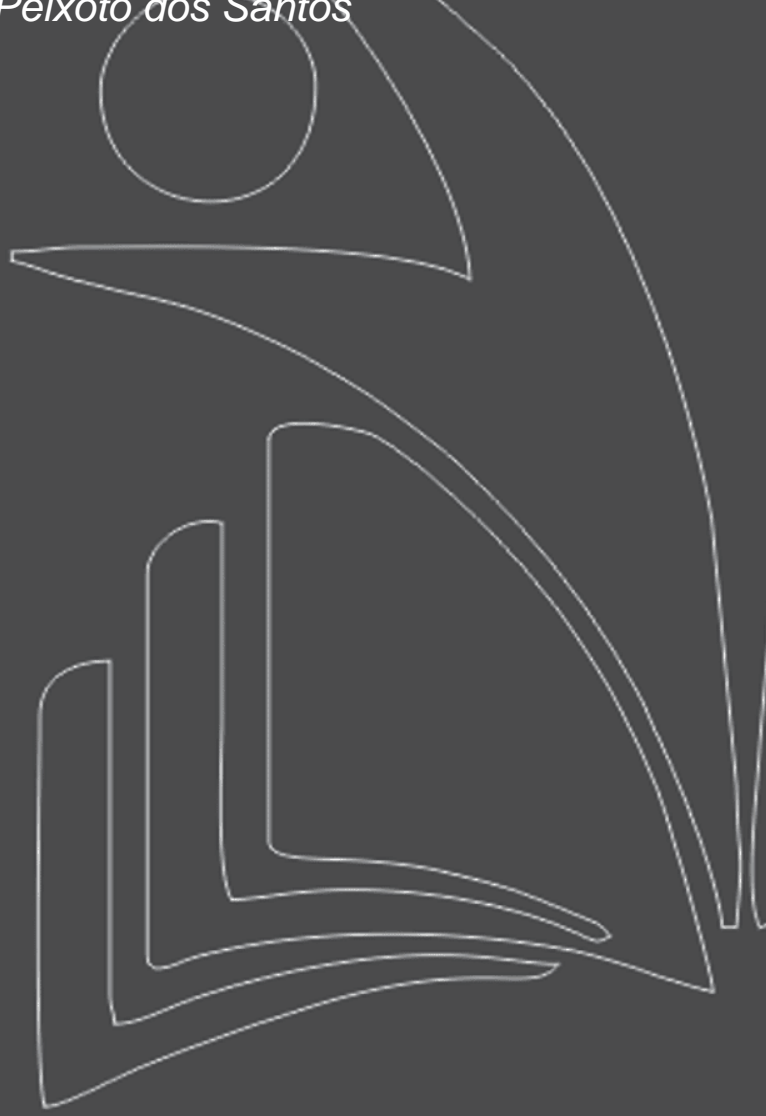

Universidade Federal de São João del-Rei

Universidade Federal de São João del-Rei

Universidade Federal de São João del-Rei 
Resumo: As construções feitas a partir de técnicas que utilizam a terra como matéria-prima são presentes em diversas culturas e localidades do mundo, sendo possível encontrar exemplares com milhares de anos. No Brasil, o uso da terra na arquitetura está presente desde o período colonial, tanto em construções cotidianas como em grandes monumentos. Atualmente, muitas dessas construções são parte integrante de centros históricos e de patrimônios construídos. Assim sendo, para realizar a conservação desses bens faz-se necessário o conhecimento das técnicas tradicionais empregadas neles. Desse modo, visando promover a valorização do uso da terra na arquitetura e, com isso, disseminar a relevância da preservação de construções que empregam essas técnicas, foi criado, em 2011, o Programa Saberes da Terra, Programa de extensão universitário, promovido pela Pró- Reitoria de Extensão e Assuntos Comunitários (PROEX) e pelo Departamento de Arquitetura, Urbanismo, e Artes Aplicadas (DAUAP), da Universidade Federal de São João del-Rei. O Programa atua por meio de oficinas teóricas a práticas acerca de técnicas construtivas com terra, buscando sensibilizar os participantes a respeito da importância da preservação desses saberes. Em suas atividades, o Saberes da Terra tem a educação patrimonial como uma ferramenta para instigar a valorização e preservação do patrimônio cultural relacionado ao uso da terra.

Palavras-chave: Patrimônio; Terra; Educação; Preservação. 


\section{INTRODUÇÃO}

A terra é um recurso natural que vem sendo utilizada há milhares de anos por diversas culturas, além de se apresentar como um dos materiais mais antigos utilizados na construção. Segundo Minke (2015, p.13) “As técnicas de construção com terra são conhecidas há mais de 9000 anos". É possível encontrar hoje construções milenares que utilizaram a terra como matéria-prima, como é o caso das casas encontradas no Turquistão - cidade da região do Cazaquistão - que são datadas do período de 6000 a 8000 a.C. (PUMPELLY, 1908 apud MINKE, 2015, p.13). Para mais, de acordo com Santos (2015, p. 72) “Alguns exemplares centenários ainda estão em uso, como a mesquita de Djénne, em Mali (1280 d.C.), atualmente a maior construção em terra do mundo (em adobe) [...] o Castelo de Baños de laEncina, na Espanha (968 d.C.)", dentre outras construções.

Nos estudos de Santos (2015, p.73), a autora retrata sobre registros que evidenciam que o uso da terra na construção e na arquitetura surge no continente Asiático e no continente Africano, onde posteriormente foram sendo disseminados por todo o mundo, tendo registros do uso da terra nas construções em todos os continentes do globo.

Desta forma, a terra na construção e na arquitetura se estende ao longo de milhares de anos, devido a diversos fatores como o fato de ser um recurso natural que se encontra em profusão pelo mundo, sendo acessível por diversos povos. "Em quase todos os climas quentes, áridos ou temperados, a terra sempre prevaleceu como material de construção.

Mesmo hoje, um terço da população habita em casas de terra" (MINKE, 2015, p.13).

Atribuindo a diversas escalas e fazendo um recorte para o Brasil, Santos (2015, p.80) retrata que o uso da terra nas construções brasileiras foi abrangentemente sendo atribuída durante o período colonial, tendo as construções mais antigas datadas das primeiras décadas seguintes ao descobrimento do país por Portugal à chegada dos portugueses e demais europeus. Essas edificações não correspondiam apenas às residências, mas também a terra estava presente em construções com usos religiosos e institucionais. Essas, por sua vez, eram construídas principalmente por sistemas construtivos, como a taipa de pilão e taipa de mão. "As casas grandes e casas bandeiristas [...] tinham frequentemente estrutura em taipa de pilão e divisórias em taipa de mão" (SANTOS, 2015, p.81).

Como exemplo dessa cultura histórica presente no país, a cidade de São João del-Rei, localizada no Estado de Minas Gerais, compreende uma grande representatividade na arquitetura colonial - dentre outros estilos arquitetônicos - que utilizam a terra crua como principal matéria prima, como é 
destacado por Andrade, no trecho: "A arquitetura civil, assim como a religiosa, adotou as estruturas em pedra, adobe e taipa" (ANDRADE, 2013, p.61).

Com mais de 300 anos de sua formação, em decorrência do processo do ciclo do ouro, o município se destaca por suas obras arquitetônicas, bem como o grande acervo que retratam o patrimônio histórico-cultural do uso da terra crua.

Associado a este contexto, notou-se a necessidade de debater sobre o assunto retratado até então, visto que a cidade de São João del-Rei agrupa um grande acervo arquitetônico que compreende técnicas e saberes construtivos que fazem parte do patrimônio cultural.

Ademais, em decorrência das novas tecnologias e da demanda de outros segmentos da construção civil, os saberes populares e suas respectivas técnicas de se trabalhar a terra estão sendo desvalorizadas e se perdendo ao longo do tempo.

Portanto, o Programa Saberes da Terra, vinculado ao Departamento de Arquitetura, Urbanismo e Artes Aplicadas (DAUAP), da Universidade Federal de São João del-Rei (UFSJ), se apresenta com o intuito de resgatar técnicas construtivas vernáculas, bem como contribuir promover na educação patrimonial sobre a cultura e seus saberes, promovendo a valorização do uso da terra na arquitetura, juntamente com a preservação e conservação dos bens históricos, além da troca de saberes sobre bioconstrução e sustentabilidade. A troca de conhecimentos entre o programa e a comunidade são realizadas por meio de oficinas teóricas-práticas que envolvem a terra como principal matéria-prima. Atualmente, o Programa Saberes da Terra está em vigência há 9 anos e na sua primeira edição - abril de 2011 a março de 2012 - foi feito um estudo que analisava o perfil da população do município de São João del-Rei, o que foi constatado a falta de conhecimento dos moradores a respeito do uso da terra na arquitetura, bem como sobre as questões patrimoniais (MENDES; MARTINS; 2012). Sendo assim, por meio dessa demanda, o Programa destinou seus estudos para a difusão e o resgate de técnicas construtivas vernáculas que utilizam a terra crua com matéria-prima.

\section{A TERRA NA ARQUITETURA E NO PATRIMÔNIO}

Como já citado anteriormente, a terra é um recurso utilizado a milhares de anos nas construções em todo o mundo. Essas edificações milenares espalhadas em todos os continentes representam um acervo de diversas técnicas construtivas que foram sendo desenvolvidas e aprimoradas ao longo do tempo. 
Por ser um recurso natural de abundância em grande parte das regiões do mundo, a terra foi amplamente utilizada para pequenas e grandes construções devido ao seu fácil e farto acesso. Como consequência a este fator, atualmente é possível encontrar diversos exemplares de técnicas construtivas empregadas nas edificações. Esses processos agregam em si valores patrimoniais que se materializam por meio da arquitetura, dos conhecimentos e dos valores empregados pelas civilizações, fazendo da terra um elemento fundamental para entender e se discutir sobre patrimônio arquitetônico.

De modo a exemplificar, a cidade de São João del-Rei possui um grande acervo do período a partir da terra, dentre essas obras destaca-se o Solar da Baronesa - atualmente utilizado como o Centro Cultural da Universidade Federal de São João del-Rei - construção datada por volta do início do século XIX que possui paredes autoportantes feitas de tijolos de adobe, além de paredes de fechamentos feitas em pau a pique. Ademais, o edifício carrega consigo um patrimônio histórico-cultural de saberes populares, bem como a estrutura por trás das características de uma arquitetura colonial que marca a história da cidade, do estado e também do país. Além de inúmeros outros exemplares, a Rua Santo Antônio, em

São João del-Rei, destaca-se pelo fato de que há diversas edificações com técnicas de adobe, de pau a pique e de taipa de pilão Por ser um recurso natural de fácil acesso, encontrando muitas das vezes no próprio local da construção, e como explica Santos (2015, p.37) a técnica da utilização da terra foi sendo aperfeiçoada e moldada de acordo com as culturas que as adotavam. Desta forma, a presença da terra estava integrada a cultura, ou seja, a sua aplicação não se estendia apenas por um elemento construtivo, mas sim abarcava conhecimentos e valores culturais daquela população.

Todavia, em decorrência do surgimento de novas tecnologias, a aplicação da técnica da terra crua padeceu frente aos novos modelos de elementos construtivos, como é descrito no trecho:

[...] a terra crua, [...] sofreu praticamente uma interrupção em sua evolução com o aparecimento de novas tecnologias construtivas e novos materiais, especialmente o cimento e o aço. Com a industrialização dos processos construtivos, construir com terra passou a ser relacionado à falta de recursos e de acesso à tecnologia (SANTOS, 2015, p.37).

Como apresentado pela autora, e complementado por Minke $(2015$, p.13), tornou-se inalcançável seguir as demandas construtivas que determinavam o tijolo, o concreto e o aço como os materiais industriais que ditavam a construção civil. Grande parte da população não está dotada de recursos financeiros para empregar tais técnicas industrializadas. 
Portanto, essas populações aproveitavam dos recursos que se apresentavam próximos e que não demandam grande renda, o que levou a associação do uso da terra à falta de tecnologia. "Como ocorre em comunidades tradicionais em diversos países, no Brasil a terra ainda é usada como material de construção também por populações de baixo poder aquisitivo" (SANTOS, 2015, p. 82).

Todavia, destaca-se que "[...] a exploração descuidada de recursos e capital, combinados com a produção intensiva de energia, não é apenas desperdício, acaba por poluir o ambiente [...]" (MINKE, 2015, p.13). Para mais é importante destacar os benefícios que a terra traz para a construção, e dentro desse contexto, pode-se listar inúmeras vantagens como, por exemplo, a eficiência térmica e energética, menor custo de produção, dentre outros. No que diz respeito a saúde, a edificação que atribui a terra no processo construtivo, obtém uma regulação da umidade do espaço, podendo controlar a temperatura interna, poupando energia e poluindo menos o meio ambiente.

Por conta destes e outros fatores, está havendo um processo crescente da retomada do uso de técnicas construtivas que possuem a terra como matéria-prima, como é descrito no trecho: “Estão começando a perceber que a terra, como material de construção natural, é superior aos materiais de construção industriais como o concreto, tijolo e cal-arenito.

(MINKE, 2015, p.13). Sendo assim, implicitamente estão surgindo a necessidade de aprender e reaprender o manuseio e os conhecimentos de se utilizar a terra na construção.

Além disso, Minke (2015, p.13) complementa apontando para o surgimento de novas soluções e técnicas do emprego da terra, não somente na autoconstrução, mas também nos processos em grande escala.

Por fim, em virtude destes aspectos mencionados, é importante conscientizar a população sobre a valorização dessas técnicas construtivas que fazem parte dos saberes populares que atravessam gerações e percorrem a linha do tempo. Assim sendo, o Programa Saberes da Terra se apresenta como uma ferramenta no processo de desenvolver uma educação patrimonial para preservar e conservar os valores da cultura, no qual o programa está inserido, mostrando os benefícios e as possibilidades e as belezas dessas técnicas construtivas vernáculas e do patrimônio arquitetônico.

\section{EDUCAÇÃO PATRIMONIAL}

O Programa Saberes da Terra atua com a educação patrimonial por meio de oficinas teóricas e práticas acerca do uso da terra crua como matéria-prima na arquitetura. Para chegar às propostas de 
atividades, o Programa leva em consideração conceitos importantes sobre o tema, entendendo a educação patrimonial como:

[...] um processo permanente e sistemático de trabalho educacional centrado no Patrimônio Cultural como fonte primária de conhecimento e enriquecimento individual e coletivo. A partir da experiência e do contato direto com as evidências e manifestações da cultura, em todos os seus múltiplos aspectos, sentidos e significados, o trabalho da Educação Patrimonial busca levar as crianças e adultos a um processo ativo de conhecimento, apropriação e valorização de sua herança cultural, capacitando-os para um melhor usufruto destes bens, e propiciando a geração e a produção de novos conhecimentos, num processo contínuo de criação cultural (Horta et all, 1999, p.6).

Esse processo permanente e sistemático se dá à medida que há uma ação contínua, promovida por diversos agentes e por diversas áreas do conhecimento. Muitas vezes, apenas uma ação pontual não é suficiente para abordar a extensa temática do patrimônio, mas pode despertar nas pessoas a importância da preservação do patrimônio cultural.

Nesse sentido, ações como as promovidas pelo Saberes da Terra pode ser o princípio de uma educação patrimonial e um ponto de partida pelo qual é possível gerar um entendimento e um sentimento de pertencimento em relação aos bens patrimoniais.

Um ponto importante para o Saberes da Terra levantado no conceito de educação patrimonial acima, é o processo ativo. Para o Programa, estabelecer apenas um contato distante e sem interação não gera muito efeito quando se trata da educação patrimonial.

Pelo contrário, é necessário incluir as pessoas no processo, utilizando exemplos locais e estabelecendo uma troca de saberes e experiências. Essa troca e o contato direto com os bens patrimoniais estudados fazem com que o entendimento seja mais efetivo.

Além de gerar um entendimento mais efetivo, um processo ativo que parte de referenciais locais e que gera uma discussão coletiva acerca do objeto estudado, capacita as pessoas a aplicar os novos conhecimentos a outras realidades e culturas. Uma vez, que a partir de referências culturais locais, é possível "[...] acessar processos sociais e culturais mais amplos e abrangentes, em um registro no qual cada sujeito, a partir de seu repertório de referências, possa compreender e refletir, tanto sobre contextos inclusivos quanto sobre a diversidade cultural que o cerca" (IPHAN, 2014, p. 27).

Desse modo, a educação patrimonial pode proporcionar tanto uma compreensão local do patrimônio cultural, quanto abrir a possibilidade das pessoas realizarem uma leitura do mundo que as rodeia e, com isso, compreender e valorizar a cultura brasileira como sendo múltipla e plural (Horta et all, 1999). 


\section{EDUCAÇÃO PATRIMONIAL APLICADA NO PROGRAMA SABERES DA TERRA}

Atualmente, o Programa Saberes da Terra aplica a educação patrimonial por meio de oficinas. Elas são realizadas em diversas localidades, instituições e com um público variado, que inclui desde crianças até idosos. Nos seus nove anos de duração, o Programa já realizou oficinas acerca de diversas técnicas construtivas com terra, como adobe, tinta de terra e pau-a-pique. Mas no momento atual, a principal técnica desenvolvida nas oficinas é a tinta de terra.

O foco das oficinas é a técnica construtiva com terra, desde a sua história até o modo de preparo. Todavia, as atividades realizadas pelo programa não se reduzem às técnicas, pois a terra na arquitetura é apenas um ponto de partida pelo qual é introduzida a discussão sobre questões voltadas ao patrimônio cultural. Ou seja, o Saberes da Terra faz uso de um material construtivo tradicional para, por meio dele, abordar a temática do patrimônio. Dessa maneira, é possível criar uma comunicação acessível sobre um tema complexo, uma vez que, ao explicar com algo palpável e cotidiano, o entendimento se torna mais fácil.

Com isso, ao traduzir o conhecimento acadêmico e levá-lo ao restante da comunidade, é possível incluí-lo na construção e disseminação desse conhecimento. Quando se trata de um conhecimento relacionado ao patrimônio cultural, além de colaborar nessa construção, as pessoas podem ajudar na salvaguarda do patrimônio. Isto é, ao incluir as pessoas nas discussões e nos processos que envolvem a questão patrimonial, elas podem se sentir mais pertencentes e apitas a proteger os bens. Desse modo, ao longo dos anos de experiência, o Programa foi se aprimorando e testando várias metodologias em busca de transmitir e trocar os conhecimentos da maneira mais clara possível. Atualmente, as oficinas são compostas por um momento teórico, outro prático e, por uma questão metodológica, esses momentos são realizados em cinco etapas: Observação, Sensibilização, Memorização, Apropriação e Disseminação.

Na etapa de Observação, as pessoas participantes da oficina se apresentam e, em seguida, os membros do Programa apresentam sobre o Saberes da Terras. Para dar inicio às atividades, é exposto sobre o histórico do uso da terra na arquitetura - exemplificando com construções mundialmente conhecidas e com edificações locais - e as principais técnicas utilizadas ao longo da história. Essa primeira explicação é feita com o intuito de munir as pessoas que não tenham experiência com tema com um repertório básico e com o intuito de despertar a lembrança das pessoas que tenham alguma experiência com o que foi exposto. 
Em seguida, na etapa de Sensibilização, é instigada uma discussão entre os participantes para que eles possam expor suas vivências, tanto em relação ao uso de alguma técnica construtiva com terra, quanto em relação às edificações que utilizam essas técnicas e em relação o patrimônio. Após essa conversa entre os participantes, os membros do Programa apresentam questões básicas de patrimônio e a importância de preservar e conservar as técnicas e edificações que foram faladas. Essa troca de saberes entre participantes e membros do Saberes da Terra enriquece a discussão e potencializa os resultados das oficinas.

Posteriormente a parte teórica, e dado início à parte prática com a etapa de Memorização.

Nela, é executada uma das técnicas construtivas com terra. Primeiramente é explicado o processo de produção, os materiais utilizados e, em seguida, os participantes realizam a técnica. Com isso, a associação dos conhecimentos compartilhados nas discussões e a experiência prática potencializam a assimilação do conteúdo.

A etapa de Apropriação está relacionada aos efeitos que as etapas anteriores podem causar nos participantes. Isto é, ao munir os participantes de conhecimento teóricos e práticos acerca do uso da terra na arquitetura e a sua relação com o patrimônio, espera-se incitar o reconhecimento do coletivo, o envolvimento afetivo, o sentimento de pertencimento às tradições, a valorização do bem cultural e sua preservação. Ao incluir as pessoas na construção do conhecimento, é possível ampliar a capacidade de apropriação em relação aos locais da cidade que os participantes passam a identificar.

Além da possibilidade de apropriação, as oficinas buscam incentivar o compartilhamento dos conhecimentos adquiridos, com a etapa de Disseminação. Esse último estágio das atividades do Programa vai para além das oficinas, está relacionado com a repercussão que a atividade pode gerar. Ou seja, após a apreensão das discussões e entendimento na prática, o participante se torna um agente disseminador apto a repassar para outras pessoas os conhecimentos adquiridos na oficina, potencializando o alcance das discussões e incluindo mais pessoas na salvaguarda do patrimônio cultural e a utilização da terra como material de fácil acesso.

Todas essas etapas foram desenvolvidas para estruturar as atividades realizadas pelo Saberes da Terra, de modo a gerar um melhor entendimento e um maior alcance do conhecimento. Apesar da descrição das etapas separadamente, durante as oficinas elas ocorrem de maneira fluída, para deixar a atividade mais didática e dinâmica. Além disso, cada etapa é adaptada de acordo com o público que irá participar da oficina, uma vez que a atuação do Programa abrange pessoas de diversas faixa etárias e de diversas realidades sociais. 


\section{OFICINAS}

O Programa Saberes da Terra realiza suas oficinas de técnicas construtivas com terra em diversos tipos de instituições, desde escolas, comunidades e museus, até projetos sociais e APAES. A atuação principal do Programa se localiza em São João del-Rei - cidade de origem do Saberes da Terra - mas constantemente surgem oportunidades de atuação em cidades da região, como: Tiradentes/MG, Lagoa Dourada/MG, São Tiago/MG, Jeceaba/MG, Ritápolis/MG, Nazareno/MG, entre outras. Dessa maneira, as atividades do Programa não se limitam apenas a uma localidade.

Para exemplificar o modo como o Saberes da Terra aplica a educação patrimonial e para expor alguns resultados, serão detalhadas o processo realizado em três oficinas distintas:

\section{OFICINA DE TINTA DE TERRA NO MUSEU CASA PADRE TOLEDO}

A convite da organização do evento 13a Primavera de Museus, realizada na cidade de Tiradentes/MG, o Saberes da Terra ministrou uma oficina de tinta de terra, no Museu Casa Padre Toledo, para uma turma de alunos da Escola Municipal Basílio da Gama, de Tiradentes. Essa atividade foi desenvolvida de modo que os alunos entendessem principalmente sobre a sustentabilidade da tinta de terra, bem como a sua preservação.

Quando as oficinas são realizadas com crianças, os conceitos teóricos são simplificados e, muitas vezes, explicados por meio de alguma dinâmica ou jogo, para captar o interesse dos participantes e deixar o conteúdo mais claro.

Nesse caso, o local onde foi realizada a oficina potencializa as discussões e torna mais fácil a assimilação do conhecimento, uma vez que os participantes estavam vivenciando os conceitos discutidos. O Museu se localiza em um casarão do século XVIII e tem diversas técnicas construtivas com terra empregas na sua construção, desse modo, ele pôde ser utilizado para exemplificar as explicações durante a oficina, tanto em relação às técnicas quanto em relação ao patrimônio.

Após as discussões entre os membros do programa e os alunos, cada um pôde produzir uma pequena quantidade de tinta de terra e fazer pintura em papel. Desse modo, os participantes puderam facilmente compreender as questões levantadas por meio da exemplificação com o próprio Museu e puderam também assimilar a técnica de tinta de terra ao aplicar ela nos seus desenhos. 


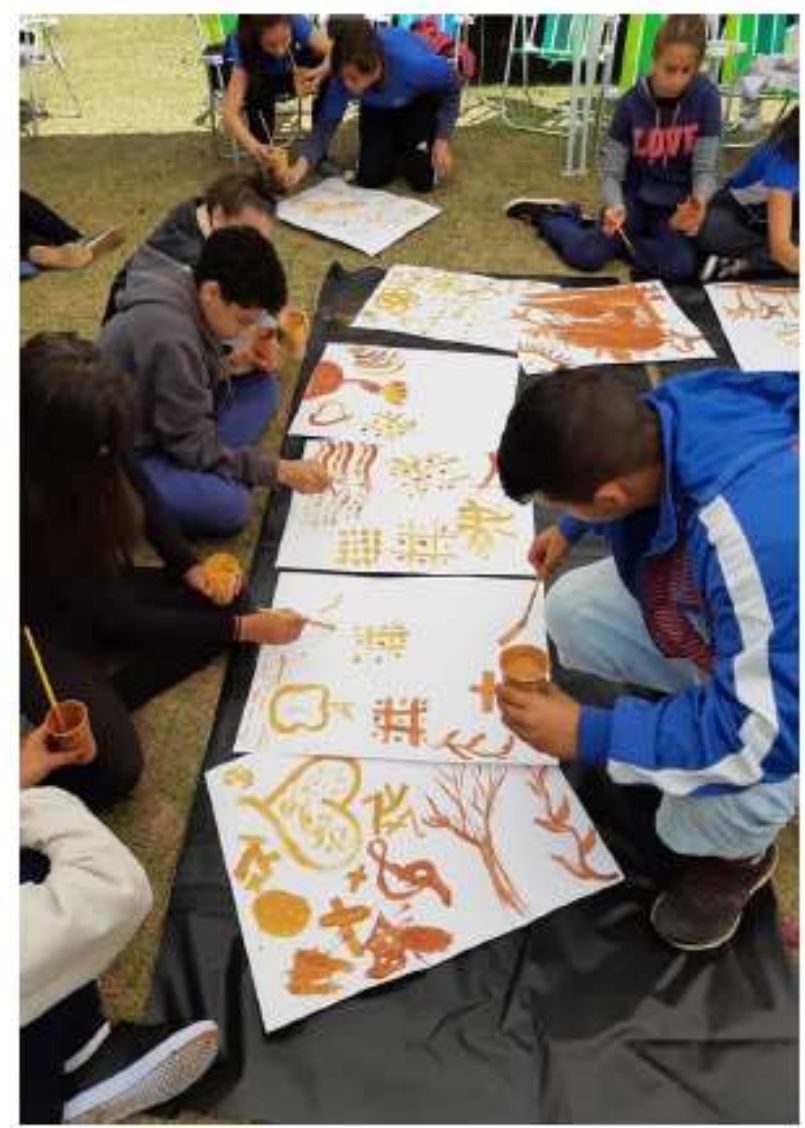

Figura 1 - Oficina de tinta de terra no Museu Casa Padre Toledo, 2019.

Fonte: acervo do Programa Saberes da Terra

\section{OFICINA DE TINTA DE TERRA NO ALBERGUE SANTO ANTÔNIO}

A oficina foi realizada no Albergue Santo Antônio, em São João del-Rei, com um pequeno grupo de idosos e com o apoio do Projeto de Extensão PROASA, da Universidade Federal de São João del-Rei. Devido às dificuldades apresentadas pelos participantes, a parte teórica da oficina foi reduzida a uma conversa, na qual os idosos puderam expor suas vivências em relação às construções e técnicas com terra. A parte prática da oficina foi dividida em dois grupos, enquanto uma parte dos membros do Programa produziu tinta de terra com os idosos para eles pintarem em papel. A outra parte, produziu tinta de terra com os membros do PROASA, para fazer pinturas em uma parede do refeitório do albergue.

Essa oficina é um exemplo da necessidade de adaptação do conteúdo de acordo com o público. Apesar de não ter sido possível abordar conceitos teóricos na oficina em questão, foi possível relembrar aos participantes os locais e as técnicas com terra aplicadas. Além disso, também foi possível realizar a técnica de tinta de terra com eles e ainda revitalizar uma parte do espaço que eles vivem. 


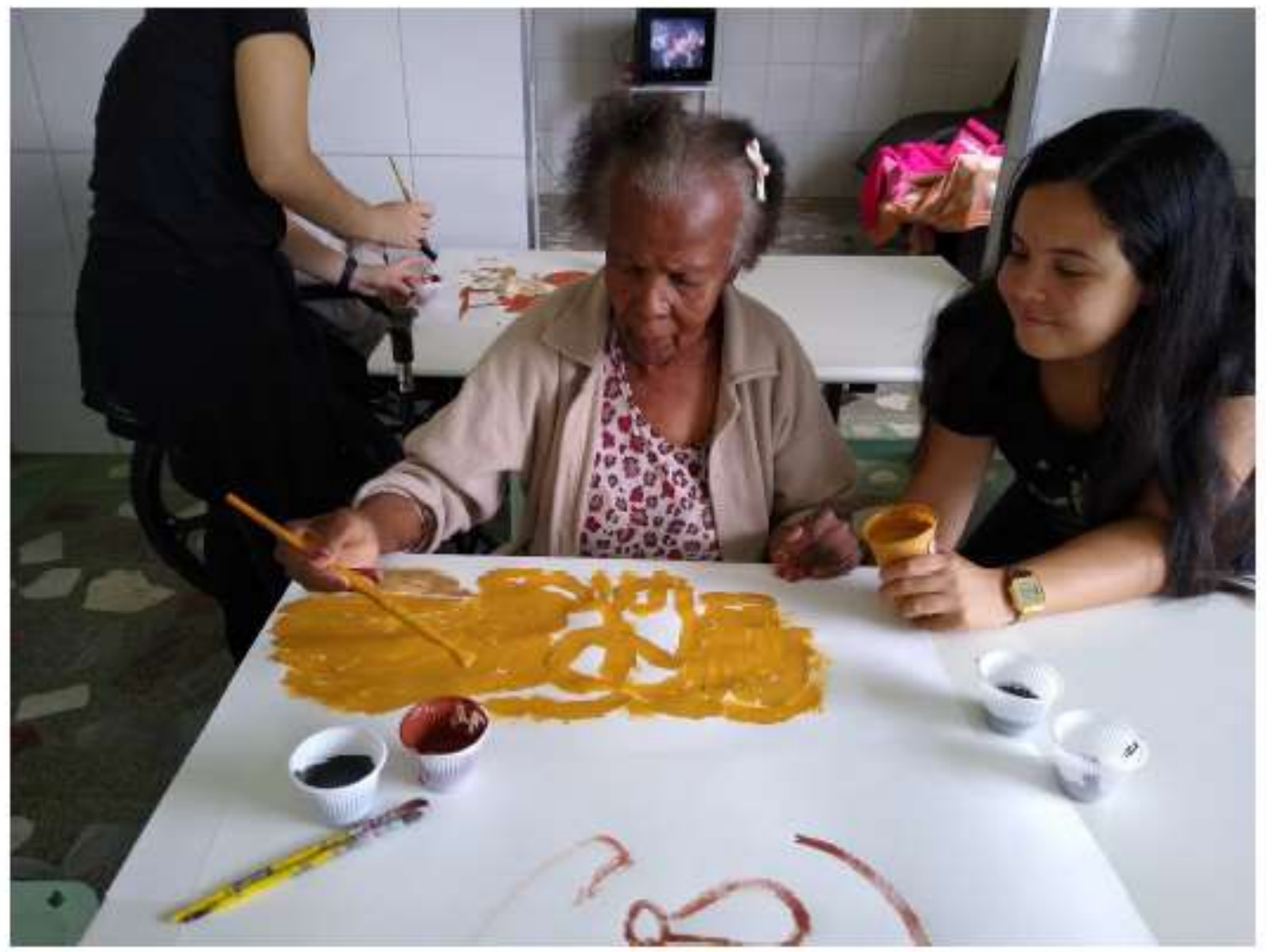

Figura 2 - Oficina de tinta de terra no Albergue Santo Antônio, 2019.

Fonte: Acervo do Programa Saberes da Terra

\section{OFICINAS NO EVENTO "VIVA JECEABA"}

A convite da prefeitura de Jeceaba/MG, o Programa participou do evento "Viva Jeceaba". O Saberes da Terra atuou em dois dias do evento. No primeiro deles, realizando oficinas de tinta de terra na Escola Municipal Zuleika Halfeld de Albuquerque, com a participação de alunos e de moradores da cidade. No segundo dia, em parceria com um artista plástico que estava participando do evento, foram pintados vários murais nas paredes da escola, utilizando a tinta de terra produzida nas oficinas. 0 evento foi uma oportunidade de levar os conhecimentos do Programa para outra cidade, para trabalhar em parceria com pessoas de outras áreas e para colocar em prática - com a pintura dos murais - as técnicas estudadas pelo Programa. Além das parcerias externas, essa foi oficina também foi realizada em parceria com a pesquisa de iniciação científica intitulada "Saberes da Terra - Tons dos Solos: aprofundamento dos estudos das cores das tintas de terras produzidas em São João del-Rei e região. Aplicação na arquitetura e urbanismo, nas artes e na sustentabilidade do patrimônio histórico, da bioconstrução e da cultura popular". 
Nas oficinas do primeiro dia, foi possível abordar todas as etapas já descritas nesse trabalho Observação, Sensibilização, Memorização, Apropriação e Disseminação, por se tratar de um público composto por adolescentes e adultos. Nelas, a tinta de terra foi produzida e, em seguida, os participantes puderam fazer pintura em papel. Já na oficina do segundo dia, os alunos que estavam participando do evento tiveram a oportunidade de pintar murais nas paredes da Escola Municipal Zuleika Halfeld de Albuquerque, onde estudam. Essa transformação no espaço por parte dos alunos aumenta o pertencimento deles em relação à escola e potencializa a fixação dos conhecimentos compartilhados durantes as oficinas.

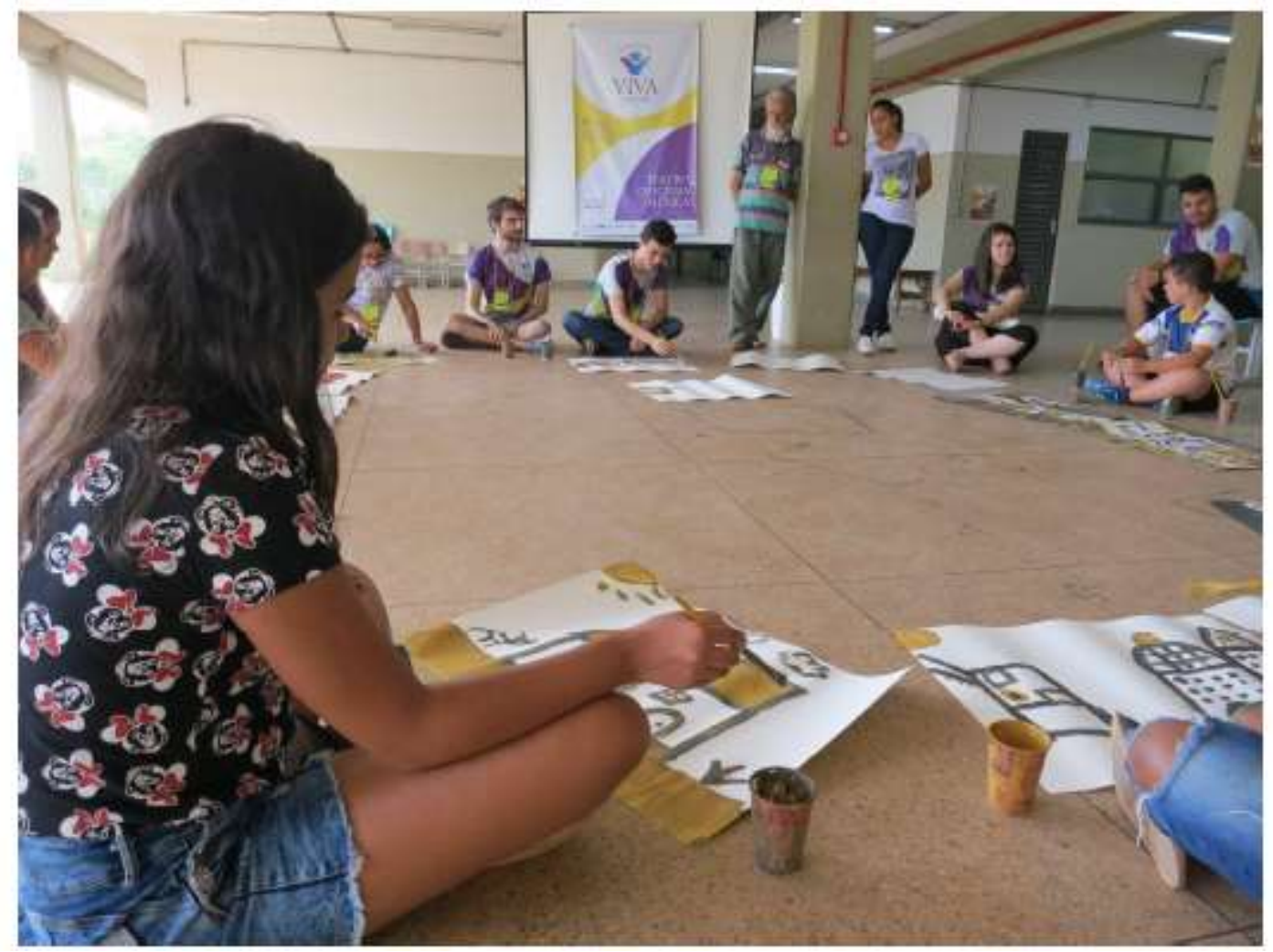

Figura 3 - Oficina de tinta de terra no evento "Viva Jeceaba", 2019.

Fonte: acervo do Programa Saberes da Terra 


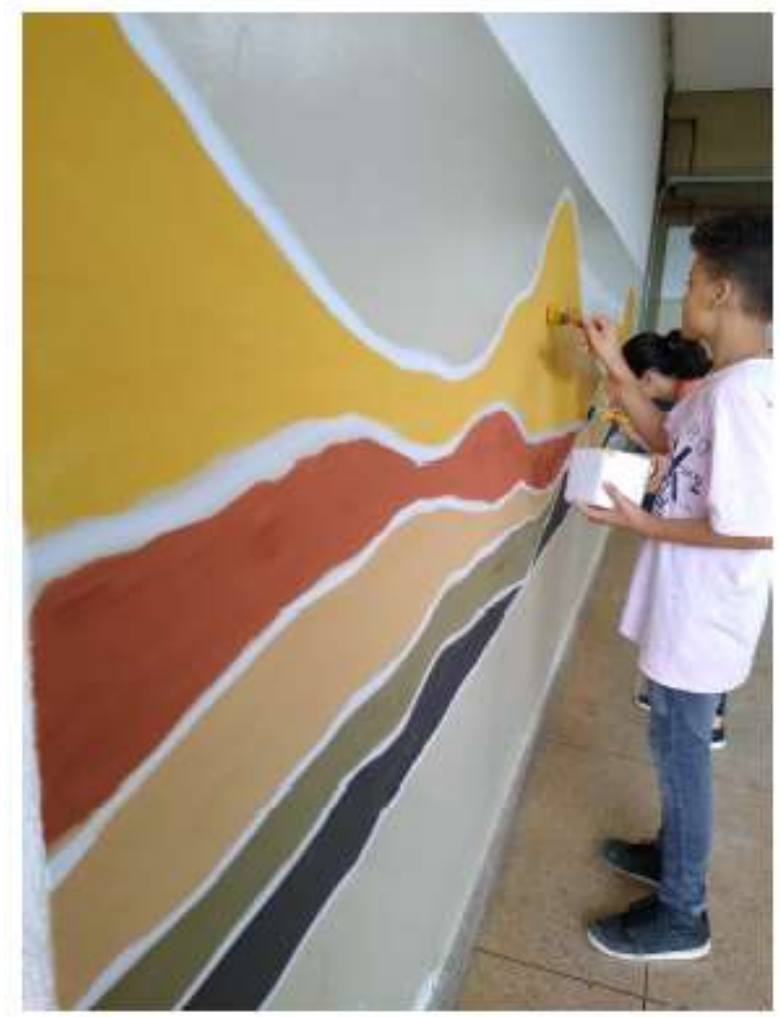

Figura 3 - Pintura com tinta de terra no evento "Viva Jeceaba", 2019. Fonte: Acervo do Programa Saberes da Terra

\section{CONSIDERAÇÕES FINAIS}

A atuação do Programa Saberes da Terra visa resgatar e valorizar o uso da terra como material na arquitetura, promover a importância da preservação e conservação desses saberes e dos locais onde é possível encontrar as técnicas aplicadas. Isso é feito por meio de oficinas teóricas e práticas que possuem como base a educação patrimonial, que é vista pelo Programa como uma ferramenta para gerar troca de saberes entre a comunidade acadêmica e a comunidade em geral. Essa troca de saberes enriquece as discussões e pode sensibilizar os participantes e contribuir na preservação do patrimônio cultural, uma vez que "O conhecimento crítico e a apropriação consciente pelas comunidades do seu Patrimônio são fatores indispensáveis no processo de preservação sustentável desses bens, assim como no fortalecimento dos sentimentos de identidade e cidadania" (Horta et all, 1999, p. 6).

Conforme os participantes vão desenvolvendo as etapas propostas pelas oficinas, automaticamente fazem parte de uma junção de informações, que compreendem aos mesmos, o pertencimento com o espaço no qual estão inseridos. Com isso, como citado anteriormente, a atuação do Programa não se aplica apenas nas técnicas, mas sim abre um leque de possibilidades para novas discussões sobre o patrimônio cultural. 
Sendo assim, por meio dessa sensibilização os partícipes tornam-se ferramentas difusoras dos saberes até então discutidos, propiciando a transmissão dos conhecimentos e das memórias para a comunidade e para o espaço no qual habita, agregando em diversas escalas o ciclo social, conforme é exposto por Choey:

[...] construir uma multiplicidade de histórias - história política, dos costumes, da arte, das técnicas - ao mesmo tempo que auxiliam na pesquisa intelectual [...]. Além disso, eles [monumentos históricos] funcionam como introdução geral do civismo: os cidadãos são dotados de uma memória histórica que terá o papel efetivo de memória viva, uma vez que mobilizará o sentimento de orgulho [...] (CHOEY, 2001, p.117).

Essa identificação e pertencimento da comunidade em relação às técnicas e aos locais podem gerar inúmeros benefícios ao patrimônio, desde a própria preservação dos bens, até a difusão e compartilhamento de um sentimento de responsabilidade em continuar com os saberes. Por esses motivos, destaca-se a importância de projetos de educação patrimonial, estimulando o reconhecimento e sobrevivência dos saberes populares e dos bens patrimoniais, além do resgate de materiais de baixo custo e de fácil acesso. 


\section{REFERÊNCIAS}

ANDRADE, M. F. O tombamento dos bens arquitetônicos e urbanísticos de São João del Rei: embates em torno da preservação e do progresso. Dissertação (Programa de Pós Graduação em Arquitetura e Urbanismo), Universidade Presbiteriana Mackenzie, São Paulo,2013.

CHOEY, Françoise. Alegoria do Patrimônio. São Paulo: UNESP, 2001. p. 282. Tradução de Luciano Vieira Machado.

HORTA et all. Guia Básico da Educação Patrimonial. Museu Imperial / DEPROM - IPHAN -MINC. 1999

IPHAN. Educação Patrimonial: Histórico, Conceitos e Processos. 2014

MENDES, Gabriela; MARTINS, Mateus de C. Estudo de caso município de São João del-Rei. Relatório do Programa de Extensão Saberes da Terra, Universidade Federal de São João del-Rei. 2012.

MINKE, Gernot. Manual de Construção com Terra: uma arquitetura sustentável. Tradução de Jorge Simões. 1a edição. São Paulo: B4 Editoras, 2015. PONTE, Maria C. C. Arquitetura de Terra: o desenho para a durabilidade das construções. Dissertação (Departamento de Arquitetura), Faculdade de Ciências e Tecnologia da Universidade de Coimbra, Coimbra, Portugal, 2012.

SANTOS, Clarissa A. Construção com terra no Brasil: panorama, normatização e prototipagem com terra ensacada. Dissertação (Programa de Pós-graduação em Arquitetura e Urbanismo), Universidade Federal de Santa Catarina, Florianópolis, 2015. 


\section{Capítulo 10}

\section{doi $10.37423 / 210604333$}

BREGAFUNK: A COLONIZAÇÃO PRESENTE NO FAZER MIDIÁTICO EM DISSONÂNCIA COM A MANUTENÇÃO DE PRÁTICAS DE RESISTÊNCIAS POR JOVENS PERIFÉRICOS

Alice Oliveira Ferreira

Jonhson Douglas Alves de Souza

Laís Catarine Umbelino dos Santos

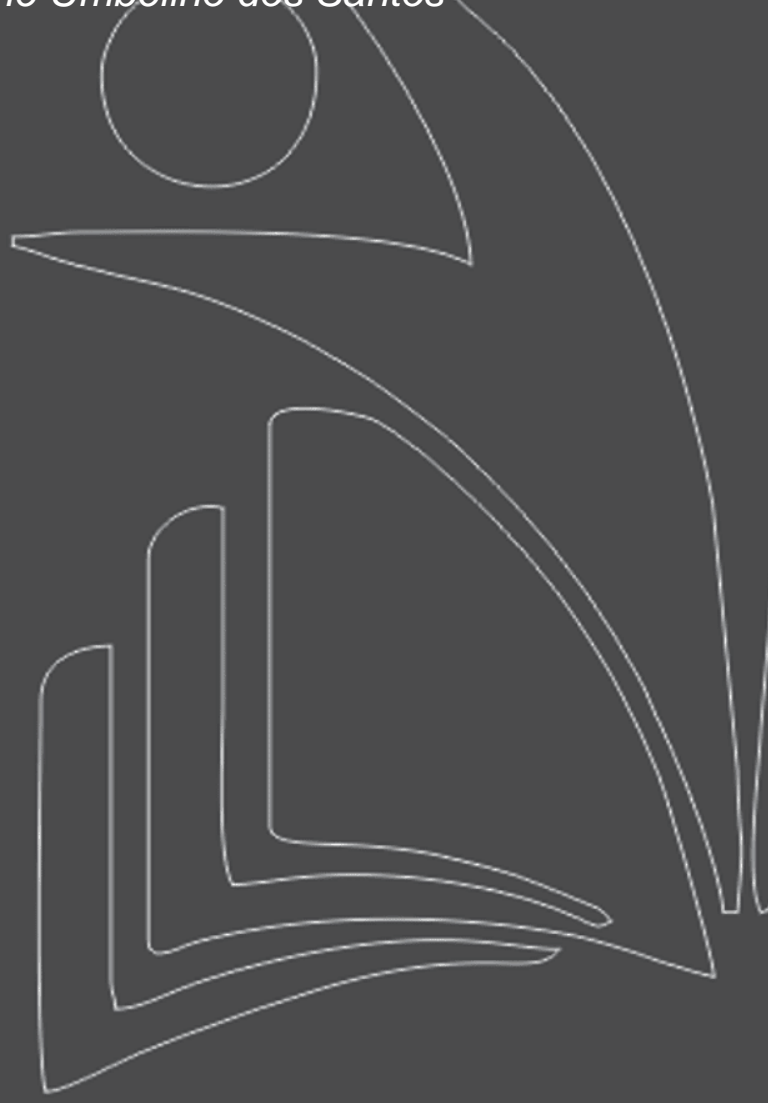

Universida Federal de Pernambuco

Universidade Federal de Pernambuco

Universidade Federal de Pernambuco

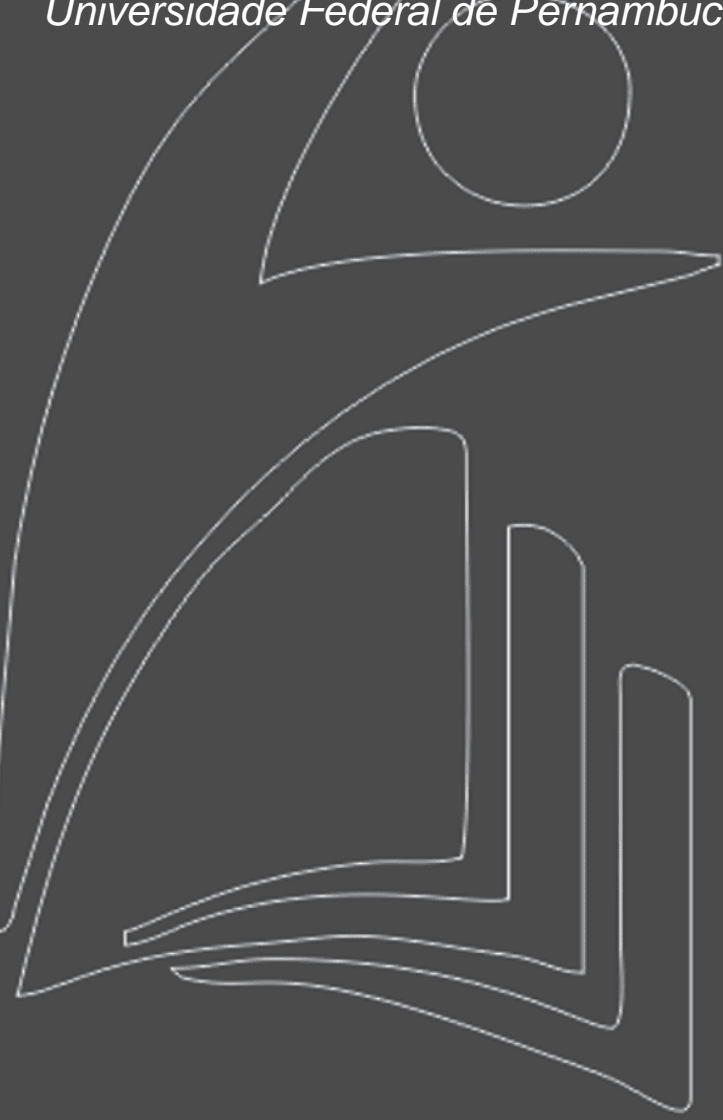


Resumo: O presente estudo propõe uma reflexão acerca da importância dos movimentos culturais periféricos como instrumento de resistência e ocupação de espaços sociais, utilizando o ritmo bregafunk e a dança proveniente desse movimento - o passinho -, para discutir envolta de tais questões. Mesmo com o fim da colonização, a construção narrativa da identidade nacional brasileira continuou pautada em ideais eurocêntricos, sofrendo de maneira concreta e simbólica, um embranquecimento responsável pelo silenciamento dos corpos negros e suas expressões. Para isso, nosso objetivo visa analisar de forma crítica a veiculação midiática em torno do bregafunk recifense a partir da perspectiva dos jovens que experienciam e constroem o movimento, de forma a proporcionar a identificação das possíveis limitações e potencializações relacionadas à ocupação simbólica e material dessa manifestação cultural periférica. No intuito de desconstruir esse imaginário colonizado que ainda reflete nas ações sociais da atualidade, partimos dos pensamentos de Grada Kilomba e Martín-Baró para pautar a discussão acerca dos limites impostos pelo pensamento colonial aos movimentos culturais periféricos - marcados pela negritude - e o lugar da Psicologia frente a essa problemática. Para a construção do estudo, entrevistamos 3 jovens praticantes do passinho na cidade do Recife, utilizando de 3 questões disparadoras em torno da expansão do bregafunk, seu impacto, importância e possíveis dificuldades encontradas na ocupação de espaços periféricos e nãoperiféricos.

Palavras-chave: bregafunk. decolonialidade. movimento cultural periférico. mídia. 


\section{INTRODUÇÃO}

A construção narrativa da nacionalidade brasileira foi pautada a partir de uma noção colonial que reflete nas relações até os dias atuais, bem como nas produções de sentido e significação dos papéis socioculturais. Dentro do processo de embranquecimento territorial, existe uma tentativa de estabelecer pressupostos teóricos e filosóficos de caráter universalizantes em relação a povos que têm o seu processo narrativo-discursivo silenciado, atendendo a um ideal de homogeneização baseado na racionalidade eurocêntrica, atuando assim nas vivências do corpo negro a partir de uma ótica branca. A colonialidade enquanto lócus de produção e manutenção de relações de poder - determinante dos modos de fazer, saber e ser dos corpos inseridos nessa dinâmica -, pode ser compreendida como um processo que se instaura não só na materialidade por meio de subordinação cultural, mas também em um processo que atinge o campo imaginário dos sujeitos. Apesar do fim da colonização, as relações de dominação continuaram a se perpetuar no imperialismo, e posteriormente, no capitalismo, de forma a sustentar uma ordem social na qual as formas de acesso às produções de conhecimento e consumo são estabelecidas de forma parcial (QUIJANO, 1992).

Diante dessa construção narrativa, a cultura negra se insere como corpos e símbolos disruptivos que divergem à formação de uma identidade nacional pautada numa lógica hegemônica, a qual atua através de estratégias de silenciamento e invisibilização de práticas e noções constitutivas de conhecimento e saberes populares (CRUZ \& MARTINS, 2017). Em meio ao processo de embranquecimento e epistemicídio da população negra no território nacional, foi-se construindo ambientes categorizados enquanto marginalidades sociais, sendo estes lugares entendidos como espaços apropriados para esses corpos não viáveis dentro de uma noção de ordenamento social e criação identitária nacional.

Falar de âmbitos marginalizados, implica em refletir a conceitos que constroem as representações acerca desses espaços, a exemplo disso, o termo periferia é trazido por Frederico (2013):

Os bairros populares, situados às margens da cidade, não eram chamados de periferia. O batismo ocorreu inicialmente na sociologia urbana para designar um espaço de carência, marginalidade, violência e segregação. Daí o termo foi adotado pelos movimentos culturais para, em seguida, ser incorporado pelas políticas públicas que visam à inclusão social - inclusão, diga-se, restrita à participação no mercado de bens de consumo. Ultimamente, a eterna sanguessuga, a indústria de entretenimento, passou a enfocar a periferia em filmes, novelas, anúncios publicitários etc. 
Dessa forma, falar em cultura periférica dizia para além de um espaço físico em relação ao urbano, mas também um distanciamento dos meios de consumo. Nesse contexto, o brega surge como uma manifestação cultural popularesca carregada das vivências periféricas - ocupadas principalmente por corpos negros marginalizados -, sendo atribuída de um olhar social estigmatizado (FONTANELLA, 2015). Posteriormente, nas tentativas de adaptação para a ocupação dos meios de consumo cultural, o brega recifense se associa ao funk como estratégia de sobrevivência e ascensão, demarcando também seu caráter identitário da cultura periférica pernambucana.

Atualmente é possível acompanhar uma crescente veiculação midiática do movimento bregafunk, na medida em que, como dito por Finco (2019), o mercado passa a enxergar o público negro como um novo nicho a ser explorado. Essa apropriação pela mídia se dá através da popularização e rentabilidade, trazendo à tona a lógica capitalista de restrição a forma de acesso mercadológico concedido à esses corpos, dentro de um caráter ilusório de transitoriedade e liberdade de produção, uma forma de mecanismo político de controle que promove silenciamento e impossibilitam as estratégias de subversão a estruturas de coerção.

A escolha de fazer o recorte olhando para o movimento bregafunk, se deu através do acompanhamento do fenômeno de expansão do ritmo do passinho - como é popularmente conhecido - onde Albuquerque (2018) narra o surgimento a partir de uma tentativa de sobrevivência dos MC's do Recife para continuar uma produção local representativa da figura de uma população marginalizada, trazendo à tona uma desvinculação com a violência e repressão do Estado, na tentativa de expandir e direcionar olhares para o que até então é invisibilizado.

Dentre as construções de narrativas dos movimentos populares, se faz presente uma perspectiva anticapitalista, na qual a crítica social se dá de forma latente. Como pontuado por Frederico (2013), a expressão artística se vê "acompanhada de uma crítica à sociedade que os condenava à segregação", sendo possível notar a aproximação do RAP e do bregafunk enquanto produções populares que buscam a ocupação de espaços anteriormente negados, atuando de forma simbólica - através da construção narrativa e crítica social - ou materializada, como percebido no bregafunk através da busca por ascensão social e ocupações de espaços, não só por quem produz, mas também para o público que consome, trazendo um caráter potencializante de identificação e pertencimento.

A proposta de trabalhar com um movimento cultural periférico - carregado de atravessamentos sociais que demarcam historicamente os corpos que constroem e participam ativamente do mesmo -, surge o intuito de compreender como essa cultura tem se expandido para além da periferia, levando em 
consideração essa expansão através de veiculações midiáticas. Tendo em vista que as práticas de coerção e controle se adaptam às transformações sociais por meio de novos mecanismos, atentamos para a importância de analisar criticamente como a ocupação de espaços físicos e virtuais têm se dado, de forma a proporcionar a identificação das possíveis limitações e potencializações relacionadas à expansão simbólica e material dessa manifestação.

A relevância de pensar essas questões se dá ao reconhecer que a colonialidade ainda se perpetua por meio de estratégias do distanciamento identidade e do pertencimento em relação aos grupos dominados, o que dificulta a articulação e elaboração de estratégias de subversão dos grupos atingidos como pontuado por Kilomba (2019). Dessa forma, construímos esse trabalho no intuito de potencializar o reconhecimento identitário e a identificação dos limites que podem agir nessa ocupação de novos espaços, destacando também o papel da Psicologia em trabalhar a afetação desses sujeitos, a promoção de equidade e do direito à cidade.

Diante disso, a nossa proposta visa analisar de forma crítica a veiculação midiática em torno do bregafunk recifense a partir da perspectiva dos jovens que experienciam e constroem o movimento, de forma a proporcionar a identificação das possíveis limitações e potencializações relacionadas à ocupação simbólica e material dessa manifestação cultural periférica, a partir de identificações de possíveis tensionamentos sociais vivenciados na experiência do movimento, da análise de como as pessoas percebem a veiculação do movimento do bregafunk nas mídias e de como o bregafunk potencializa a participação social dos participantes da pesquisa.

\section{DE ONDE PARTIMOS}

Partindo de uma perspectiva decolonial para construir um processo de descolonização dos saberes psicológicos e sociais, nos pautamos nas contribuições de Grada Kilomba e Martín-Baró, autores responsáveis por tecer discussões críticas acerca de como o pensamento etnocêntrico ainda domina nossas formas de conhecimento e relações. Na sua obra "Memórias da Plantação: Episódios de racismo cotidiano", Kilomba atenta para a importância de reconhecer que a colonialidade ainda se perpetua por meio de estratégias do distanciamento identidade e do pertencimento em relação aos grupos dominados, o que dificulta a articulação e elaboração de estratégias de subversão dos grupos atingidos.

Através dessa ótica, se faz necessário rever o que pauta os nossos fazeres e saberes, a partir da compreensão dos sujeitos enquanto indissociáveis dos discursos sociais presentes no contexto sócio- 
histórico-cultural nacional. Nesse sentido, o autor Martín-Baró, em sua obra Psicología de la Liberación (1988) tece reflexões acerca da desconstrução do aspecto colonizador e homogeneizante que por muito tempo influenciou a Psicologia de forma a negligenciar o caráter idiossincrático do sujeito em prol dessas diretrizes que direcionam práticas e construção de saberes sociais. A partir disso, o autor propõe a construção de uma Psicologia política crítica que leve em conta as estruturas de poder social na configuração do psiquismo dos sujeitos.

Ao considerar os pensamentos de Kilomba e Baró, propomos uma construção reflexiva a partir do nosso lugar de atores sociais e de futuros profissionais da Psicologia, no intuito de promover novos saberes e estratégias que possam abarcar grupos e sujeitos historicamente negligenciados pelas instituições sociais e áreas de conhecimento científico, entendendo e reivindicando através desse espaço o reconhecimento da potência da construção de saber produzido para além das barreiras academicistas, reiterando a necessidade de expandir e pautar realidades múltiplas. Nessa perspectiva, nossa proposta visa analisar de forma crítica a veiculação midiática em torno do bregafunk recifense, a partir da perspectiva dos jovens que experienciam o movimento, de forma a proporcionar a identificação das possíveis limitações e potencializações relacionadas à ocupação simbólica e material dessa manifestação cultural, destacando também o papel da Psicologia em trabalhar a afetação desses sujeitos, a promoção da equidade e do direito à cidade.

\section{METODOLOGIA}

Para o desenvolvimento do presente estudo, optamos por uma pesquisa participativa de cunho qualitativo, entendendo este posicionamento metodológico como fundamental na construção e busca de estratégias de superação das problemáticas sociais que podem vir a surgir em campo, a partir de uma tomada de consciência da realidade (OLIVEIRA \& OLIVEIRA, 1985).

Levando em consideração o recorte do movimento cultural do bregafunk de Recife, a pesquisa teve enquanto participantes, os jovens com idades entre os 14 a 19 anos, moradores do Engenho do Meio, que participam dos encontros do passinho nas praças do bairro, entendendo esses jovens enquanto principais atores das suas próprias histórias e produtores das narrativas sociais que dão sentido ao contexto em que estão inseridos.

O processo foi construído em dois momentos, no qual o primeiro se configurou a partir de uma metodologia netnográfica - etnografia virtual - possibilitando uma compreensão da dinâmica social no âmbito virtual, que também são constituídos de relações de grupos e populações, entendendo esse 
espaço, demarcado por traços culturais, estando em convergência com o discurso de Amaral, Recuero e Montardo (2008). Visto a ascensão do movimento nos meios midiáticos, optamos por trabalhar com essa veiculação compreendendo que a virtualidade atua tanto como instrumento para construção cultural, como também elemento dotado de experiências e vivências capaz de transpor os discursos construídos na sociedade (CRUZ \& MARTINS, 2017).

Já o segundo momento, se caracterizou por visitas aos espaços onde acontecem os encontros de passinho, visando uma maior aproximação com os jovens. Após os primeiros contatos, ao dispormos como um dos nossos objetivos fazer a análise de como os sujeitos, com suas subjetividades permeadas pelo pertencimento ao movimento cultural bregafunk, percebem a veiculação midiática deste movimento, utilizamos dos recursos de entrevistas não-diretivas e conversa informal, tendo como materiais disparadores conteúdo da mídia hegemônica.

Para tal, nos baseamos na conceituação de experiência proposta por Joan W. Scott propõe, diante da qual conceituar uma experiência, nessa fundamentação, vai para além de tornar visível uma identidade constituída em processos sociais diferentes. Scott (1999) indaga que é preciso debruçarnos sobre os processos históricos que atravessam a diferença operante, como ela constitui sujeitos através de uma experiência. Com isso, ao fazermos entrevistas não-diretivas e conversa informal, com jovens inseridos em um contexto sócio-econômico demarcado por uma vivência cultural e usarmos como material para análise conteúdos da mídia hegemônica, devemos dispor como alicerce para a escuta, olhar e escrita a atenção as estruturações que permeiam tais processos sociais.

A partir disso, a nossa produção de conhecimento se deu vinculada ao que surgiu nos discursos dos jovens entrevistados, dentro de uma perspectiva da Análise Crítica do Discurso (ADC), partimos da compreensão trazida por Fairclough, ao entender que a historicidade se faz presente e compõe o discurso, trazendo à tona os contextos e vivências que o permeiam, uma vez que o discurso atua como uma ferramenta que opera tanto como um mecanismo de dominação, como também de transformação da realidade (MAGALHÃES, 2001). É importante ressaltar que, a construção do trabalho em campo, foi respaldado mediante apresentação do TCLE (Termo de Consentimento Livre e Esclarecido) respeitando assim, as diretrizes estabelecidas na Resolução 466/12 do Conselho Nacional de Saúde (CNS), que visa a integridade do sujeito participante da pesquisa, principalmente no que diz respeito ao sigilo e privacidade informacional, quando necessária. 


\section{RESULTADOS E DISCUSSÕES}

Através da pesquisa realizada por meio da plataforma virtual "Google" com as palavras "passinho do Recife" e "passinho dos maloka", foram selecionadas três reportagens com os seguintes títulos: "Passinho do Recife conquista o Brasil: Conheça Shevchenko e Elloco", "O 'passinho dos maloka' de Recife: Um grito de identidade e visibilidade" e "Passinho: racismo policial reprime encontros e já fez a primeira vítima". As reportagens foram acompanhadas com os seguintes questionamentos: "Como conheceu o passinho e o que ele significa para você?", "Qual é a importância do passinho?" e "Como o passinho tem ocupado os espaços? Consegue enxergar limites nisso?", respectivamente.

Os instrumentos supracitados foram utilizados como questões disparadoras para auxiliar o delineamento do conteúdo que poderia ser desencadeado a partir da entrevista, de forma a seguir de acordo com os nossos objetivos de compreensão. Vale ressaltar que no uso desse artifício houve a abertura para que os participantes da pesquisa respondessem às questões de acordo com as próprias experiências, nos trazendo um contato mais próximo com a realidade e os atravessamentos históricos vivenciados dentro do movimento pelos seus participantes nas periferias recifenses - incluindo artistas, dançarinos e consumidores -.

No que tange ao contato com o movimento, os participantes da pesquisa trouxeram em suas falas a dança como uma atividade que sempre esteve presente durante a infância e juventude, passando por ritmos como brega, swingueira, funk, e agora o bregafunk, que veio a se expandir como uma inovação do brega pernambucano em conjunto com o funk carioca. Diante da viralização do ritmo, ele foi sendo incorporado por muitos jovens dentro das favelas - onde surge a maioria dos artistas que criaram o bregafunk -, e assim, veio a se tornar algo que é demarcado nas falas como não só uma atividade de descontração, mas também uma oportunidade de expressão, na medida em que se torna um movimento cultural amplamente compartilhado para além do seu local de origem.

Em relação à importância que o movimento tem adquirido, os relatos refletem o passinho como uma abertura de possibilidades para a juventude periférica no meio artístico junto aos MCs, levando a dança proveniente do ritmo - o passinho-, para diversos espaços físicos e virtuais. Além disso, o passinho também surge como instrumento que potencializa a retirada de jovens de práticas ilícitas, sendo utilizado como uma ferramenta que incorpora esses indivíduos em atividades artísticas e grupos, o que pode promover locais de identificação e inclusão. 
Quanto à forma que o bregafunk tem ocupado não só as periferias de Recife, mas também se expandido pelo Brasil, pela mídia e outros espaços que se sustentam de maneira elitizada, as falas trouxeram uma satisfação com o destaque que o movimento tem alcançado, no entanto, atentando para como ainda existem limites impostos por um preconceito envolta dos seus corpos e formas de expressão. Dentre essas limitações, a chegada da polícia militar em locais onde acontecem os encontros de passinho se faz algo recorrente e que se dá de maneira ostensiva e violenta, tratando os jovens presentes de maneira marginalizada.

Além disso, a crescente veiculação midiática e consumo do bregafunk por pessoas e espaços sociais que historicamente silenciaram a cultura produzida dentro das favelas e afastaram os corpos favelados de maneira simbólica e concreta, nos faz atentar para como o conteúdo tem sido incorporado. Nessa perspectiva, fica evidenciado que quando um produto das periferias gera lucro e entretenimento, ele pode chegar em espaços hegemônicos, entretanto, não há abertura para que os seus produtores acessem livremente. Essa questão retrata um mecanismo colonial atualizado pela realidade capitalista que cria uma aceitação de caráter ilusório, ao mesmo tempo em que inviabiliza as vozes sobre a realidade periférica e a construção de uma demarcação identitária cultural para além das margens sociais.

\section{CONSIDERAÇÕES FINAIS}

Diante da aproximação com as experiências dos jovens entrevistados, obtivemos demarcações trazidas em suas falas que convergiam com as problemáticas já enunciadas no presente trabalho. Entretanto, ressaltamos que essas narrativas não esgotam os questionamentos envolta da cultura popular periférica e os limites impostos pela colonialidade à sua disseminação ainda na atualidade. Diante do que foi construído, se faz necessário enunciar a importância de abrir espaços para a voz popular dentro da academia e nos aproximar das narrativas vivenciais do povo que carrega os reflexos históricos de um longo processo de colonização do imaginário nacional.

É importante também reafirmar que essa discussão é de suma importância dentro da Psicologia, sendo necessário se pensar cada vez mais em uma descentralização do sujeito padronizado nos moldes do pensamento eurocêntrico, responsável pelos instrumentos que silenciam o povo negro. Pensamos em uma perspectiva decolonial para a Psicologia que possa através de discussões, estudos e teorias, abarcar um sujeito contextualizado, atravessado por processos históricos e demarcações sociais, possibilitando também se pensar em estratégias de resistências aos mecanismos de opressão 


\section{Periféricos}

sustentados pelo sistema capitalista e potencializar o reconhecimento identitário dos grupos atingidos. O passinho, como um movimento cultural de expressão, traz à tona o deslocamento de pensar a margem como local de resistência aos diversos tipos de repressão e silenciamento, transformando essas negações em novos discursos através da sua própria arte e identidade. 


\section{REFERÊNCIAS}

ALBUQUERQUE, GG. O nascimento do brega funk é a história de sobrevivência dos MCs do Recife. Vice. 26 de Abril de 2018. Disponível em: https://www.vice.com/pt_br/article/vbxkk3/historiabregafunk-parte-1. Acesso em: 28 set. 2019.

AMARAL, A.; RECUERO, R.; MONTARDO, S. P. Blogs: mapeando um objeto. In: VI Congresso Nacional de História da Mídia. 2008. Rio de Janeiro. Resumos [...]. Rio de Janeiro: pp.4.

CRUZ, J. T.; MARTINS, P. Colorismo e embranquecimento na rede: o racismo e a tentativa histórica de apagar a ancestralidade africana. Paraná. 2017.

FINCO, M. D. As vantagens da apropriação da causa negra pela indústria cultural: Um estudo em torno do crescimento da abordagem do racismo na produção musical, 2019. Trabalho de conclusão de curso parcial (Pós-graduação em Mídia, Informação e Cultura) Universidade de São Paulo, São Paulo, 2019.

FONTANELLA, F. I. A Estética do Brega: Cultura de Consumo e o Corpo nas Periferias do Recife. 2005. Dissertação (Mestrado). Programa de Pós-Graduação em Comunicação, Universidade Federal de Pernambuco, Recife, 2005.

FREDERICO, C. Da periferia ao centro: cultura e política em tempos pós-modernos. Estudos Avançados, v. 27, n. 79, p. 239-255, 1 jan. 2013.

KILOMBA, Grada. Memórias da Plantação: episódios de racismo quotidiano. Lisboa: Orfeu Negro, 2019.

MAGALHÃES, Célia M. Reflexões sobre a análise crítica do discurso. Belo Horizonte: Faculdade de Letras, UFMG. Cap 1, p.15-30. 2001

MARTíN-BARÓ, I. Psicología de la liberación. Madrid: Trotta, 1998.

OLIVEIRA, M. D. \& OLIVEIRA, R. D. Pesquisa social e ação educativa: conhecendo a realidade para poder transformá-la. In: C. R. BRANDÃO (Org.). Pesquisa participante. São Paulo: Brasiliense, 1983. p. 17-33.

SCOTT, J. W. Experiência. Falas de Gênero. Org. de SILVA, A. L.; LAGO, M. C. S.; RAMOS, T. R. O. Editora Mulheres: Santa Catarina, 1999. pp. 21-55.

QUIJANO, Aníbal. "Colonialidad y Modernidad-racionalidad". In: BONILLO, Heraclio (comp.). Los conquistados. Bogotá: Tercer Mundo Ediciones; FLACSO, 1992, pp. 437-449. Tradução de wanderson flor do nascimento. 


\section{Capítulo 11}

doi $10.37423 / 210604338$

\section{OS PRINCIPAIS DESAFIOS E POTENCIALIDADES DAS COMUNIDADES TERAPÊUTICAS NO BRASIL}

Felipe Hruschka do Amaral

Faculdade Unyleya

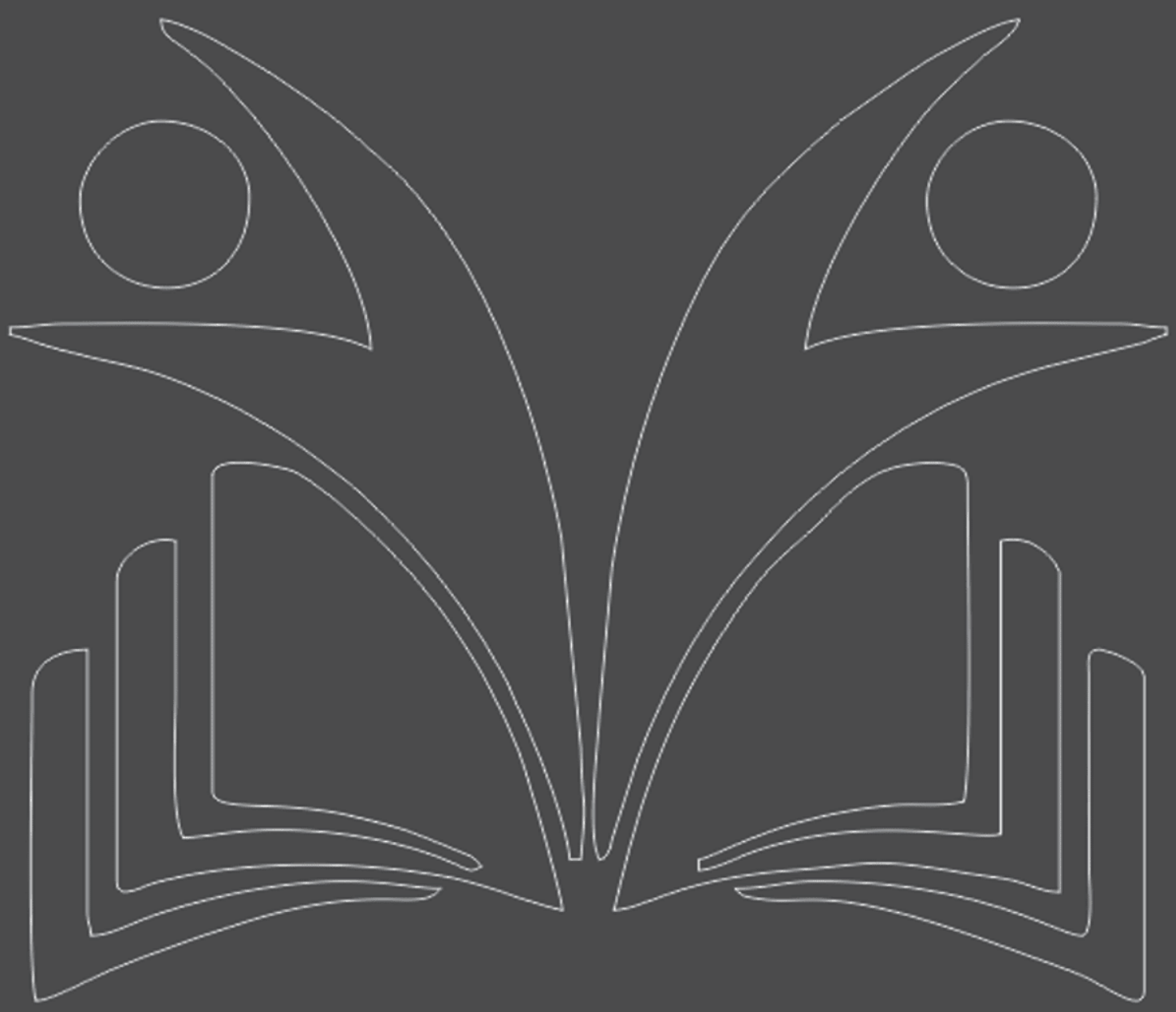


Resumo: O presente artigo destina-se a abordar diversas temáticas que cercam o movimento das Comunidades Terapêuticas no Brasil, tais como, histórico das CT's, modelo real de CT e suas distorções, legislações sobre o tema, organização do serviço em âmbito nacional, bem como, as mais recentes pesquisas sobre a eficácia dos métodos utilizados no modelo real de CT no País. Para a realização do estudo, os métodos de pesquisa utilizados orientaram-se a partir da pesquisa qualitativa com enfoque/recorte sobre a pesquisa documental, para tanto, utilizaram-se materiais bibliográficos, tais como, livros, revistas, artigos, legislações, além de, materiais disponíveis em plataformas digitais, como por exemplo, Scielo, Google Acadêmico entre outros, além disso, levaram-se em consideração para a elaboração do estudo, mídias digitais, tais como, áudios e vídeos sobre a temática abordada, e os conhecimentos adquiridos a partir das vivências, como membro do Corpo Técnico da Federação Brasileira de Comunidades Terapêuticas (FEBRACT-RS), e dos trabalhos desenvolvidos como psicólogo analista institucional nas Comunidades Terapêuticas, Fazenda do Senhor Jesus de São Borja, Associação Vida Plena Amor Exigente e Eu com Cristo (2018-2021), além da participação em Fóruns, Cursos e Palestras sobre o tema. Por fim o artigo busca discutir as principais dificuldades enfrentadas e potencialidades vivenciadas pelas CTs no Brasil, oferecendo assim, algumas diretrizes básicas para que possam ser refletidas e discutidas as propostas destes serviços de acolhimento e tratamento de dependentes químicos no País.

Palavras Chaves: Comunidades Terapêuticas, Dependência Química, Psicologia Social-Institucional. 


\section{INTRODUÇÃO}

O presente estudo busca refletir acerca do tema das Comunidades Terapêuticas (CT's) no Brasil, bem como, se apresentam os atravessamentos éticos, estéticos e políticos em seus ambientes institucionais. Para isso buscamos entender o que realmente são Comunidades Terapêuticas, assim como estes espaços de tratamento/acolhimento se apresentam em âmbito nacional e quais as relações existentes entre o serviço de tratamento para a dependência química conhecido como Comunidade Terapêutica (CT) e as atuais mudanças nas diretrizes da Política Nacional sobre Drogas.

O estudo foca-se inicialmente em delimitar, entender e apresentar o funcionamento/organização do serviço de acolhimento e tratamento voltado à Dependência Química (DQ), conhecido como CT (em nível histórico e institucional), isto em âmbito nacional e internacional, uma vez que é possível percebermos a necessidade de entendimento e desmistificação acerca deste serviço na atualidade, sendo que é possível percebermos e acompanharmos a crescente expansão no país, dos locais de acolhimento/tratamento que assim se denominam Comunidades Terapêuticas, mas que, por muitas vezes acabam fugindo/distanciando-se do modelo real de $\mathrm{CT}$, o que dificulta a organização deste serviço, tanto no que envolvem questões legais quanto terapêuticas. Em um segundo momento a pesquisa busca apresentar as relações existentes entre a comemoração dos 50 anos do movimento das CT's no país, as atuais mudanças nas diretrizes da Política Nacional sobre Drogas e as discussões éticas, estéticas e políticos-ideológicas que cercam este serviço no Brasil. Em um terceiro momento apresentaremos alguns dados atualizados da Federação Brasileira de Comunidades Terapêuticas (FEBRACT) sobre o serviço das CT's em âmbito nacional, bem como dados de eficácia do modelo de CT baseados nas mais recentes pesquisas realizadas no país. Por fim a presente pesquisa busca analisar e apresentar os atuais desafios enfrentados pelas CT's, assim como as principais potencialidades a serem exploradas.

\section{METODOLOGIA}

O estudo foi desenvolvido a partir da abordagem oferecida pela pesquisa qualitativa, de maneira que, a escolha deste modelo de pesquisa justificou-se através do fato de percebermos que a pesquisa qualitativa apresenta-se como ferramenta de particular relevância ao estudo das relações sociais na atualidade, visto a pluralização e singularização das esferas que constituem a vida no mundo contemporâneo (FLICK, 2009), assim a abordagem qualitativa demonstra-se de forma não enrijecida estruturalmente abrindo-se a possibilidade para a experimentação, criação critico reflexiva e exercício 
da imaginação do pesquisador, de modo que foi possível a proposição de um trabalho que explore novos enfoques sobre as situações já pesquisadas.

A delimitação metodológica da pesquisa organizou-se através do enfoque na pesquisa documental, assim, para realização do estudo, foram pesquisados/revisados materiais bibliográficos, presentes em livros e artigos, impressos e/ou disponíveis em plataformas digitais, também foram levados em consideração mídias digitais, como, áudios e vídeos sobre o tema das CT's em âmbito nacional e/ou internacional, além das experiências subjetivas advindas da participação em fóruns, cursos e palestras que envolvessem a temática pesquisada, por fim, outra importante fonte que contribuiu para a pesquisa foi a coleta de dados diretamente junto ao setor administrativo da Federação Brasileira de Comunidades Terapêuticas (FEBRACT). Nesse sentido, acreditasse que a pesquisa qualitativa/documental representa uma forma/estética metodológica que reveste-se de um caráter inovador, trazendo contribuições importantes no estudo do tema.

\section{I - COMUNIDADES TERAPÊUTICAS: CONSERVAR A ESSÊNCIA DE PORTAS ABERTAS PARA A INOVAÇÃO}

\section{I-1. BASE HISTÓRICA}

O que são Comunidades Terapêuticas? Qual a história destas instituições? Como se estruturam e se apresentam os serviços baseados no modelo de CT no Brasil?

Estes são alguns dos questionamentos iniciais que podem nos oferecer as diretrizes e delineamentos básicos sobre o tema em questão. Portanto começaremos por refletir a respeito da construção histórica destas instituições, para isso nos focaremos principalmente nas contribuições feitas por George De Leon, pesquisador norte americano que apresentou seu estudo realizado ao longo de quarenta anos sobre o tema das CT's (em nível mundial) e que encontra-se presente em seu livro "A comunidade Terapêutica: Teoria, Modelo e Método", assim poderemos entender a evolução deste serviço, que em seu princípio foi pensado para a atuação junto a hospitais psiquiátricos e que serviu como alternativa da reforma psiquiátrica inglesa na década de 1940, de acordo com o modelo inicial proposto por Maxwell Jones, a CT psiquiátrica tinha como alicerce fundamental a democratização entre os agentes envolvidos no dia a dia da instituição e encontrava seu potencial terapêutico na convivência entre os pares (DE LEON, 2014). 
A evolução/transmutação do serviço de CT psiquiátrica para a CT de tratamento/acolhimento voltada à dependência química se deu por influência de três grupos e ocorreu ao longo das décadas de 1920 a 1960 nos Estados Unidos, essa transmutação teve grande influência do grupo Oxford (1921) que contribuiu com as raízes da religiosidade presentes nas atuais CT's, o grupo Alcoólicos Anônimos (1935) que trouxe a contribuição de um programa espiritual para o tratamento da dependência, proposto em 12 passos, e organizado na modalidade de auto e mutuo ajuda, e o grupo Synanon (1958) que inaugurou o tratamento em caráter residencial transitório e intensivo, pautado sobre a influência dos outros dois grupos já citados e do modelo que alicerçava o potencial terapêutico na convivência entre os pares, além de apresentar ferramentas terapêuticas oriundas da psicologia individual e grupal da época, tais como a psicanálise (DE LEON, 2014). Contudo este último grupo (Synanon, 1958) mesmo tendo oferecido as bases para o modelo reproduzido nas atuais CT's, jamais assim se denominou.

Foi somente a partir da experiência vivenciada em Synanon que vimos eclodir e aumentar mundo afora serviços destinados ao tratamento de dependentes químicos que se denominaram Comunidades Terapêuticas, no Brasil o movimento das Comunidades Terapêuticas começou a se apresentar somente em 1968 com a inauguração da CT Movimento Jovens Livres em Goiânia/GO e a partir deste momento foi possível percebermos o rápido crescimento no número de locais destinados ao tratamento/acolhimento e reinserção social de dependentes químicos no país (BRASIL 2017). Sendo que atualmente, segundo o estudo realizado pelo Instituto de Pesquisa Econômica Aplicada (IPEA), existem 1.963 serviços denominados como Comunidades Terapêuticas no país, sendo que, estas instituições estão concentradas principalmente nos estados das regiões Sul com 25,53\% e Sudeste com $41,77 \%$, e os demais $32,7 \%$ destas instituições encontram-se espalhadas, sem concentrações significativas pelas demais regiões do país (IPEA, 2017).

\section{I-2. MAS AFINAL O QUE SÃO COMUNIDADES TERAPÊUTICAS?}

As CT's estão atualmente presentes em mais de 60 países e apresentam-se como ambientes de acolhimento voltadas ao tratamento de sujeitos que apresentam transtornos decorrentes do uso e/ou abuso de substâncias psicoativas (SPA's), as CT's classificam-se como ambientes especializados para o tratamento da Dependência Química (DQ), devido aos quadros multiprofissionais que compõem as instituições e também por oferecerem programas de tratamento altamente organizados através de Projetos Terapêuticos Institucionais (PTI), o tratamento nas CT's organizam-se de forma intensiva uma vez que o modelo de acolhimento/tratamento é vivenciado em caráter residencial transitório o qual visa o alcance e manutenção da abstinência de SPA's, além de ganhos nos processos de qualidade de 
vida dos acolhidos, as CT's configuram-se como um serviço que se inserem em uma rede de cuidados, trabalhando assim através de referênciamento e contra-referênciamento com outros serviços, por vezes também especializados e por vezes não especializados no tratamento da $D Q$, estes encaminhamentos dependem muito das necessidades especificas (singulares) dos sujeitos, o modelo de Comunidade Terapêutica funciona somente através da voluntariedade da adesão do tratamento por parte do acolhido.

O Modelo de Comunidade Terapêutica apresenta desde seu princípio ${ }^{2}$ a utilização de abordagens de auto e mutuo ajuda, realizadas e organizadas através da convivência democrática e transversal entre os pares, isso não mudou muito ao longo do tempo, uma vez que é possível percebermos que os ambientes das atuais CT's mantiveram esta característica básica, seja em maior ou em menor grau, contudo é possível percebermos a evolução e diversificação que o modelo de CT voltada ao tratamento/acolhimento de dependentes químicos apresentou, uma vez que incluiu e vem incluindo gradativamente outras abordagens psicossociais voltadas à $\mathrm{DQ}$, tais como, treinamento de habilidades sociais, prevenção a recaída, técnicas de entrevista motivacional, psicoterapia individual e/ou grupal oriundas de diferentes correntes teóricas, tanto para os acolhidos quanto para os familiares (diversas abordagens são utilizadas: TCC, Psicanalise, Psicologia Sistêmica, Psicologia Social...), além da utilização de técnicas de análise institucional. Também é possível percebermos que as atuais CT's utilizam-se de vários serviços complementares que são voltados às questões educacionais, de trabalho, de fármacoterapia e de saúde física e mental.

Assim as Comunidades Terapêuticas atualmente apresentam o objetivo geral de tratar o transtorno decorrente do uso de SPA's nos acolhidos, contudo, não focam-se somente na busca pela interrupção do consumo (manutenção da abstinência), mas sim, buscam tratar o acolhido de forma global, incentivando uma mudança mais profunda no estilo de vida e na forma como este se relaciona com o mundo (FIGLIE; BORDIN; LARANJEIRA, 2015), além de, oferecer alternativas terapêuticas para que o mesmo possa experiênciar ganhos no que se refere aos indicadores de qualidade de vida.

As CT's oferecem tratamentos que variam de 6 a 12 meses de duração (no Brasil), estas se apresentam como ambientes de tratamento que estão a pronta disposição dos sujeitos que delas necessitam, buscam tratar as diversas necessidades dos acolhidos não focando-se somente nas questões que envolvem o uso e/ou abuso de SPA's, as CT's em seus projetos terapêuticos institucionais buscam oferecer suporte de aconselhamento individual e/ou grupal além de técnicas de terapias variadas, oferecem também suporte de fármacoterapia e tratamento para comorbidades associadas à DQ, 
estruturando-se assim como ambientes de tratamento que estão constantemente se auto-avaliando, no que se refere a eficácia do modelo e dos métodos utilizados, buscando sempre a maximização dos resultados, estas características presentes no modelo de Comunidade Terapêutica vai de encontro ao proposto pelo National Institute on Drug Abuse (NIDA) em seu estudo que apresenta 13 princípios básicos que caracterizam um tratamento eficaz para a DQ (NIDA, 1998).

De modo geral as Comunidades Terapêuticas variam quanto ao público especifico que destinam seus tratamentos/acolhimentos, podendo desta forma apresentarem-se nas modalidades de CT's masculinas, femininas, mistas, para adultos, para adolescentes ou para idosos, aceitando ou não acolhidos com comorbidades psiquiátricas, portadores de doenças infecto contagiosas ou egressos do sistema prisional, as CT's também variam de acordo com suas orientações religiosas, frente a esta questão, podemos ver a divisão por percentual das CT's em âmbito nacional no gráfico 1, proposto pela nota técnica sobre o perfil das Comunidades Terapêuticas Brasileiras (IPEA, 2017):

Comunidades terapćuticas e vagas, segundo macrorregiào geografica e orientaçào religiosa (Em s)

\begin{tabular}{|c|c|c|c|c|c|c|c|}
\hline \multirow[b]{2}{*}{ MACRORREGLAßO } & \multicolumn{7}{|c|}{$\approx$ VAGAS } \\
\hline & PENTECOSTAL & Missio & $\begin{array}{l}\text { OUTRAS } \\
\text { CRISTAS }\end{array}$ & católuca & $\begin{array}{c}\text { SEM } \\
\text { ORIENTAÇAO }\end{array}$ & OUTRA & TOTAL \\
\hline VACAS BRASIL. & 34.27 & 4.386 & 2.130 & 21.461 & 15.918 & 5327 & 83530 \\
\hline No & 3,5 & 0,1 & 0,1 & 1,6 & 0,0 & 1,0 & 6,4 \\
\hline $\mathrm{NE}$ & 9,8 & 2,7 & 0,2 & 6,4 & 1,1 & 0,1 & 20,2 \\
\hline$\infty$ & 4,0 & 0,3 & 0,0 & 1,4 & 1,9 & 0,3 & 7,8 \\
\hline SE & 15,3 & 1,4 & 1,6 & 9,8 & 12,4 & 2,7 & 43,2 \\
\hline su & 8,4 & 0,8 & 0,6 & 6,5 & 3,7 & 2,3 & 22,4 \\
\hline 5 VAGAS & 41,0 & 5,3 & 25 & 25,7 & 19,1 & 6,4 & 100 \\
\hline $5 \mathrm{CTs}$ & 39,7 & 6,9 & 2,6 & 27,1 & 17,8 & 5,8 & 100 \\
\hline $\begin{array}{l}\text { MÉDLA VAGAS/ } \\
\text { RELLGLÅO }\end{array}$ & 4,2 & 32,7 & 41,8 & 40,6 & 45,7 & 47,1 & 42,8 \\
\hline
\end{tabular}

Fonte: Pesquisa Pofil das comunidades teraphatices (Diest/pea, 2016).

Gráfico 1: Relação entre percentual de vagas e orientação religiosa das CT’s no Brasil.

Como pode ser observado, $41 \%$ de todas as vagas existentes nas Comunidades Terapêuticas Brasileiras estão em CT's de orientação pentecostal, já as CT's católicas ofertam $26 \%$ das vagas, as CT's que se 
declaram sem orientação religiosa específica oferecem $19 \%$ de todas as vagas, e vem seguidas das CT's que mencionaram vincular-se a outras religiões a quais oferecem $9 \%$ das vagas brasileiras, por fim vemos as $\mathrm{CT}^{\prime}$ 's de orientação evangélica de missão ofertarem $5 \%$ das vagas.

Contudo todas as variações nas modalidades de CT levam em consideração que o acolhido apresente transtornos decorrentes do uso e/ou abuso de substancias psicoativas (Dependência Química instalada), demonstrando assim graves problemas decorrentes do uso/abuso, o que entre outras questões, Ihes causam dificuldades e/ou incapacidade nas relações interpessoais e sociais (externas a $\mathrm{CT}$ ), outra característica comum e essencial de todas as CT's que seguem o modelo real é o quesito voluntariedade, ou seja, o acolhido deve ser voluntário para aderir ao tratamento/acolhimento.

\section{I-3. CARACTERÍSTICAS GERAIS DO ATUAL MODELO DE CT NO BRASIL}

O espaço físico: as CT's podem se apresentar corporificadas em ambientes rurais ou urbanos, no Brasil grande percentual destas instituições encontram-se em ambientes rurais, uma vez que, historicamente foi construída a visão, de que fazia-se necessário isolar, retirar do convívio social mais amplo o sujeito, que em decorrência da Dependência Química apresentasse comprometimento nas relações interpessoais e sociais, assim as CT's por muitos anos apresentaram-se como ambientes de tratamento/acolhimento altamente artificiais (visão de redoma) o que não favorecia o objetivo de reinserir socialmente os acolhidos, contudo esta visão vem sistematicamente sendo questionada e desconstruída pelo atual modelo de $\mathrm{CT}$, o qual, apresenta como um dos focos centrais a rápida reinserção social dos acolhidos ao meio social mais amplo, abrindo desta maneira as fronteiras invisíveis pré-estabelecidas nestes ambientes. Outra característica essencial do atual modelo de CT, é que estes espaços apresentam-se por ambientes livre de trancas e grades. As CT's que seguem o modelo real apresentam ambientes físicos adequados a legislação proposta pela RDC ANIVSA № 29/2011, a qual dispõe sobre os requisitos de segurança sanitária para o funcionamento de instituições que prestem serviços de atenção a pessoas com transtornos decorrentes do uso, abuso ou dependência de substâncias psicoativas, assim as disposições especificas de seus ambientes físicos (tamanho, terreno, cozinha, refeitório, sala de atendimentos individuais e grupais, quartos/dormitórios, sala administrativa, pátio, lavoura, capril, chiqueiro, pomar, galinheiro, horta, lavanderia, banheiros, etc) estruturam-se de acordo com as necessidades singulares de cada CT.

A equipe: as equipes nas atuais CT's apresentam-se de maneira multiprofissional transdisciplinar constituídas com quadro de profissionais de diversas áreas do conhecimento e atuação, frente as 
especificações as equipes mínimas exigidas nas CT's para que estas sejam financiadas em programas do governo federal, são as de que, cada CT deve manter uma equipe multidisciplinar com ao menos dois profissionais de diferentes graduações podendo ser elas em ciências humanas ou em saúde, estes profissionais devem apresentar experiência profissional comprovada na área de dependência química. As instituições também devem contar com equipe multidisciplinar nas áreas da medicina, psicologia e assistência social. Além disso as CT's dispões de colaboradores que desempenham os papeis de conselheiros terapêuticos, educadores, e supervisores, estes são em sua grande maioria dependentes químicos recuperados e devidamente capacitados para desempenharem tais funções. Assim a equipe multiprofissional dentro da CT pode contar com profissionais graduados da Psicologia, Terapia Ocupacional, Assistência Social, Enfermagem, Filosofia, Sociologia, Antropologia, Medicina, Administração, Direito e Contabilidade, além de técnicos nas áreas de dependência química (conselheiros, coordenadores, educadores e supervisores) e em enfermagem, desta maneira a equipe multidisciplinar/transdisciplinar é constituída de acordo com as necessidades e foco terapêutico de cada CT, as equipes multidisciplinares apresentam-se assim, meramente como apoio/suporte ao processo terapêutico desenvolvido na $\mathrm{CT}$, uma vez que a convivência entre os pares é visto e entendido como o foco central do potencial terapêutico nestas instituições.

A organização social: a CT é organizada e pensada para que a convivência entre os pares seja o fator decisivo na construção de Clima Terapêutico adequado/saudável, para isso as relações estabelecidas no ambiente da CT estruturam-se e apresentam-se de forma democrática e transversal entre todos os envolvidos, negando assim o direito ao poder absoluto para um membro ou um grupo presente na instituição. De acordo com a organização social proposta, vemos diferentes atores sociais (acolhidos recém chegados, acolhidos intermediários, acolhidos concluintes, conselheiros em dependência química, supervisores terapêuticos, coordenadores, psicólogos, médicos, assistentes sociais, motoristas, entre outros), todos eles detém parcelas diferentes de poder dentro da instituição, uma vez que apresentam níveis de conhecimento (Saber) também diferenciados, estas relações estabelecidas entre saber-poder foram expostas e discutidas a fundo por Michel Foucault ao longo de várias de suas obras publicadas ${ }^{3}$, frente a estas questões Foucault nos mostra que é possível reconhecer que estas relações permeiam todo o tecido social, e apresentam-se na grande maioria das vezes de maneira explicita/desnudas nas instituições que corporificam a sociedade, assim as relações que se estabelecem acabam por instituir modos de ser e existir aos sujeitos que delas fazem parte, pois geram processos de subjetivação que podem ser voltados a saúde como também podem estar voltados ao adoecimento, frente a esta afirmação percebemos que a organização social da CT busca 
constantemente aumentar os níveis de democratização transversal no ambiente institucional uma vez que reconhece a convivência entre os pares e os demais agentes envolvidos como o ponto chave para a criação e manutenção de clima terapêutico que crie/construa/ofereça saúde aos envolvidos. Assim todos os envolvidos participam da construção das regras e normas de moradia, como também, tem espaços para exporem seus pensamentos, sugestões e questionamentos, sem que sofram punições e/ou represálias por isso, os acolhidos por sua vez também apresentam-se como atores de destaque em seus processos de tratamento, tendo espaço para construírem de maneira co-participativa seus planos de acompanhamento terapêutico durante o tratamento (Plano de Atendimento Singular -PAS).

A organização do Programa Terapêutico: as atuais CT's apresentam programas terapêuticoseducativos (FRACASSO, 2011), organizados e estruturados através de fases distintas, como por exemplo, 1ㅁ Fase - acolhimento, 2a Fase - avaliação diagnostica, 3a Fase - ressocialização inicial, 4aㅡ Fase - ressocialização intermediaria, 5a Fase - ressocialização avançada e 6a Fase - acompanhamento de manutenção, as fases do tratamento não revelam a mudança efetiva do acolhido, mas demonstram ganhos nos processos de aprendizagem em diversas áreas (social, emocional, comportamental, psicológica), assim as distintas fases do programa terapêutico se organizam a partir de objetivos terapêuticos bem definidos, os quais de formas gradativas devem ser alcançados pelos acolhidos. $O$ programa terapêutico da CT encontra-se presente no Projeto Terapêutico Institucional (PTI), o qual é organizado e pensado levando em consideração que a dependência química se apresenta como uma doença multifacetada, que tem em sua constituição influências de fatores biológicos, psicológicos, sociais e espirituais, assim os PTI's das atuais CT's oferecem métodos que buscam contemplar todas as áreas que envolvem a constituição da doença, como por exemplo, suporte fármaco-terapêutico, práticas de esporte (suporte ao fator biológico), técnicas de entrevista motivacional, treinamento de habilidades sociais, técnicas terapêuticas individuais variadas (TCC, Psicanálise, Gestalt, Humanista, Esquizoanálise), técnicas de prevenção a recaída, práticas de autoconhecimento presentes nos programas de 12 passos de Alcoólicos Anônimos e/ou Narcóticos Anônimos, práticas de lazer (suporte ao fator psicológico), técnicas terapêuticas grupais variadas (TCC, Psicanálise, Humanista, Esquizoanálise), intervenções familiares a partir do viés sistêmico, práticas de ensino e qualificação educacional e/ou profissional, práticas de trabalho alicerçadas sobre contribuições da terapia ocupacional, técnicas de analise institucional, práticas de espiritualidade através de técnicas de meditação (loga, Mindfulness, Reiki, etc), práticas de espiritualidade através da religiosidade (católica, espirita, evangélica, etc), práticas confessionais e espirituais propostas nos programas de 12 passos de Alcoólicos Anônimos e/ou Narcóticos Anônimos (suporte ao fator espiritual), assim, é possível 
percebermos que, estes recursos apresentam-se como alguns do métodos propostos nos PTI's de CT's que se propõe a tratar globalmente seus acolhidos. Os métodos e ferramentas terapêuticas existentes nos PTI's são dispostos em um cronograma semanal bem balanceado, o qual oferece organização e rotina ao dia a dia dos acolhidos das $\mathrm{CT}^{\prime}$ s.

As medidas socioeducativas: de maneira geral os programas terapêuticos das atuais CT's são baseados em métodos educativos e psicoeducativos que utilizam-se de técnicas de reforço positivo e reforço negativo (Terapia Cognitivo Comportamental), pressões positivas do grupo, além do fator espelhamento (entre os pares), de maneira que o modelo básico das CT's, que é constituído pela convivência entre os pares, possa ser respeitado e apresente o potencial de desempenhar seu papel terapêutico saudável, para que este modelo de tratamento psicoeducativo seja posto em prática e alcance seus objetivos de mudanças psicológicas, emocionais e comportamentais, atribui-se alto valor à comunicação não violenta e democrática/transversal entre todos os envolvidos no processo, uma vez que, está modalidade de comunicação oferece a possibilidade de estimular encontros e trocas de pontos de vista distintos, os quais ajudam a desconstruir verdades absolutas pré-estabelecidas, opiniões enrijecidas além de quebrar paradigmas que os acolhidos trazem enraizados devido ao antigo estilo de vida em que encontravam-se inseridos (Dependência Química Ativa).

A singularização do tratamento: visto que dentro de um micro ambiente terapêutico como é a CT por exemplo, existem muitas diferenças entre os sujeitos que ali encontram-se acolhidos, uma vez que, nem todos apresentam a mesma substância psicoativa (SPA) de preferência, ou então, não demonstram o mesmo nível de dependência, ou ainda, apresentam dificuldades singulares em áreas especificas (psicológicas, emocionais, habilidades sociais, motivação, relações sociais, ect), assim fazse necessário que os programas terapêuticos das CT's levem em consideração a máxima "Cada caso é um Caso", desta maneira são propostos Planos de Atendimento Singular (PAS) nos ambientes terapêuticos das atuais CT's, que visam singularizar/individualizar o tratamento dos acolhidos, visto as necessidades especificas apresentadas por estes. O PAS constrói-se de forma co-participativa envolvendo membros das equipes multidisciplinares (conselheiros, psicólogos, médicos, assistentes sociais, etc) e acolhidos, contudo os acolhidos tem o papel de protagonismo na construção do Programa de Acompanhamento Singular (PAS), pois são os principais responsáveis pelo tratamento, assim as equipes apresentam-se como meros suportes técnicos e administrativos do processo (FRACASSO, 2011), o PAS é organizado inicialmente até os primeiros vinte dias de acolhimento e é reavaliado e reelaborado mensalmente ou a qualquer momento que solicitado pelo acolhido ou pela 
equipe que acompanha o caso (CONAD № 1/2015) ${ }^{4}$. O PAS é construído levando em consideração trabalhar as dificuldades evidenciadas pelo/no acolhido, assim como incentivar o desenvolvimento de suas potencialidades, o PAS também apresenta foco na construção de Projeto de Vida, proposta esta que sugere a criação de metas a curto, médio e longo prazo para a vida em recuperação do acolhido, além disso, no PAS também buscam-se entender de formas singulares os principais fatores de risco e de proteção associados ao uso de substâncias psicoativas pelos acolhidos.

\section{I-4. AS PRINCIPAIS CARACTERÍSTICAS X AS PRINCIPAIS DISTORÇÕES DO MODELO DE CT}

O título geral do capítulo I é a reprodução de uma frase estampada em um modelo de camiseta oferecida pela Federação Brasileira de comunidades Terapêuticas (FEBRACT) e foi escolhido por oferecer-nos a reflexão a qual sugere que as Comunidades Terapêuticas devem conservar a essência de seu modelo, contudo, também devem estar abertas para novas práticas, ou seja, voltadas às evoluções dos serviços. Frente a esta afirmação devemos nos perguntar, qual essência é esta, que o título nos sugere, para que assim possamos pensar acerca de quais evoluções são possíveis e imagináveis de serem criadas/construídas nos ambientes terapêuticos das atuais CT's, na busca por elaborarmos esta reflexão já apresentamos um breve histórico destas instituições, tanto em nível mundial quanto nacional, assim como as principais características do atual modelo (Modelo de excelência), bem como, algumas das práticas que se apresentam nas CT's no Brasil, desta forma, o que buscaremos agora é demonstrarmos de maneira comparativa como este modelo que por sua essência central apresenta o fator democrático de convivência entre os pares é distorcido e aplicado em muitos ambientes de tratamento/acolhimento que levam o nome de Comunidade Terapêutica, mas que em sua constituição nada tem a ver com o modelo real, apresentando-se assim como ambientes que oferecem modelos de tratamento "iatrogênicos" (KURLANDER, 2014), ou seja, que devido as distorções do modelo original acabam por contribuir com os processos de doença-alienação dos sujeitos que encontram-se acolhidos.

Algumas das distorções existentes no modelo de CT, já foram evidenciadas e apresentadas por De Leon $^{5}$, o qual demonstrou que um dos principais fatores que contribuem para a existência destas distorções devem-se a falta de produção científica acerca do modelo, dos métodos utilizados e da averiguação de eficácia das CT's ao longo dos anos, além de que o fato de grande parte do que se sabe e se reproduz nesses ambientes de tratamento transmitiram-se de forma oral através das gerações que por ali passam, dificultando assim a criação e manutenção de protocolos organizados e estruturados para os serviços, essa constatação justifica-se uma vez que, a transmissão oral de 
conhecimentos apresenta-se carregada de "achismo subjetivo", amadorismo profissional e reprodução estereotipada de verdades absolutas por parte de membros específicos das equipes administrativas e técnicas que passam por estes ambientes de tratamento ao longo de suas constituições.

Frente a esta questão dicotômica (CT real X CT distorcida) vemos surgir e crescer a confusão que atualmente cerca o movimento das $\mathrm{CT}^{\prime}$ s no país ${ }^{6}$, a qual não busca(ou) entendimento, nem critérios de delimitação entre o que são e o que não são Comunidades Terapêuticas, tratando assim todos os ambientes que oferecem tratamento em caráter residencial transitório (acolhimento/internação) de forma igualitária, esta confusão pode encontrar justificativa e suporte se nos focarmos nas contribuições feitas por Goffmam ${ }^{7}$ acerca das instituições totais, uma vez que este vê estas instituições se caracterizarem através de estabelecimentos fechados que funcionam em regime de internação/acolhimento, onde um grupo majoritário de internos/acolhidos vive em tempo integral e é organizado/coordenado por um grupo minoritário que compõe a equipe dirigente/técnica/administrativa da instituição (MELO; RENATA; 2008), desta maneira é possível vermos que as CT's tanto em seu modelo real quanto em suas distorções enquadram-se nesta delimitação geral de instituição total, contudo ao examinarmos mais a fundo cada um dos casos é possível percebermos distanciamentos/diferenças gritantes entre os modelos (CT real X CT distorcida). Uma das principais diferenças apresenta-se frente a um dos objetivos terapêuticos centrais do serviço prestado pelas CT's, o de reinserção social do acolhido, uma vez que, no modelo real de CT o foco terapêutico em última análise é a reinserção social do acolhido de maneira que este possa exercer com autonomia, cidadania e autogestão seu(s) papel(is) social(is), em contrapartida vemos que as distorções do modelo de CT oferecem diversas dificuldades no processo de reinserção social dos acolhidos, uma vez que os ambientes terapêuticos distorcidos apresentam-se de maneira iatrogênica, assim os acolhidos acabam por não experiênciarem processos de empoderamento durante o tratamento, o que dificultam os ganhos de autonomia e autogestão dos mesmos, contribuindo assim, para o processo de alienação e institucionalização destes, como nos mostra Benelli, 2014, em instituições totais (CT distorcida) se e quando o interno/acolhido é enviado/liberado de volta à sociedade mais ampla, ele acaba por experimentar algumas dificuldades, tais como angústia, estigmatização e desaculturação, o que em muitos casos impossibilita o processo de ressocialização social. 
Como tentativa de desconstruirmos pré-conceitos e visões estereotipadas acerca do serviço oferecido pelas Comunidades Terapêuticas no Brasil, apresentaremos agora uma tabela comparativa (Tabela a.) entre as principais características do real modelo de CT e suas distorções.

\section{I.5. CARACTERÍSTICAS DO MODELO REAL DE CTX DISTORÇÕES NO MODELO DE CT}

\begin{tabular}{|c|c|}
\hline CARACTERÍSTICAS & DISTORÇÕES \\
\hline $\begin{array}{l}\text { A CT só aceita acolhidos que buscam tratamento de } \\
\text { forma voluntária. }\end{array}$ & $\begin{array}{l}\text { Aceita acolhidos de forma involuntária e/ou } \\
\text { compulsória. }\end{array}$ \\
\hline $\begin{array}{l}\text { Oferece ambiente institucional e terapêutico } \\
\text { voltado a democratização, incentivando maiores } \\
\text { níveis de transversalização das questões envolvidas } \\
\text { (poder, saber). }\end{array}$ & $\begin{array}{l}\text { Ambiente extremamente rígido, onde as relações se } \\
\text { estruturam hierarquicamente, beirando o } \\
\text { autoritarismo. }\end{array}$ \\
\hline $\begin{array}{l}\text { Oferece tratamento baseado em dados científicos, } \\
\text { técnicas estruturadas/protocolares e métodos } \\
\text { adequados as necessidades que se apresentam. }\end{array}$ & $\begin{array}{l}\text { A instituição oferece tratamento em modelo que } \\
\text { aproxima-se do assistencialismo, beirando o } \\
\text { amadorismo total. }\end{array}$ \\
\hline $\begin{array}{l}\text { Reconhece e trata a Dependência Química como } \\
\text { doença que envolve fatores biopsicossociais. }\end{array}$ & $\begin{array}{l}\text { A instituição reconhece e trata a Dependência } \\
\text { Química sobre um olhar moral. }\end{array}$ \\
\hline $\begin{array}{l}\text { NÃO oferece práticas de contenção física e/ou } \\
\text { medicamentosas. }\end{array}$ & $\begin{array}{l}\text { Oferece práticas de contenção física e/ou } \\
\text { medicamentosas. }\end{array}$ \\
\hline $\begin{array}{l}\text { O princípio básico do modelo de tratamento é } \\
\text { voltado à convivência entre os pares, (proposta de } \\
\text { auto e mútua ajuda + existência de clima } \\
\text { terapêutico saudável) Assim o principal } \\
\text { responsável pelo tratamento é o próprio acolhido. }\end{array}$ & $\begin{array}{l}\text { Apresenta a crença de que existem agentes } \\
\text { detentores do saber e agentes receptáculos do } \\
\text { saber (a equipe apresenta-se de forma superior aos } \\
\text { demais agentes que corporificam a instituição). }\end{array}$ \\
\hline $\begin{array}{l}\text { A CT apresenta Projeto Terapêutico Institucional } \\
\text { (PTI) organizado e estruturado a partir de objetivos } \\
\text { terapêuticos bem delimitados e propostos de } \\
\text { forma gradativa a serem alcançados/desenvolvidos } \\
\text { pelos acolhidos. }\end{array}$ & $\begin{array}{l}\text { Apresenta Projeto Terapêutico Institucional (PTI) } \\
\text { estruturado e organizado a partir do tempo de } \\
\text { acolhimento (ex: programa de } 9 \text { meses, "pois é o } \\
\text { tempo de uma gestação", 0-3 meses desintoxicação, } \\
\text { 3-6 meses interiorização, 6-9 meses ressocialização, } \\
\text { assim quando o acolhido chega ao fim dos } 9 \text { meses } \\
\text { acredita-se que o mesmo está "pronto" pois } \\
\text { concluiu o tempo proposto). }\end{array}$ \\
\hline $\begin{array}{l}\text { Oferece tratamento singularizado, a partir de Plano } \\
\text { de Acompanhamento Singular (PAS) (leva em } \\
\text { consideração a individualidade do acolhido, } \\
\text { propondo assim a adaptação singular do programa } \\
\text { frente as necessidades apresentadas pelos } \\
\text { sujeitos). }\end{array}$ & $\begin{array}{l}\text { Oferece tratamento hegemônico, não levando em } \\
\text { consideração as singularidades dos acolhidos, } \\
\text { justifica essa postura através das máximas: "Aqui } \\
\text { todo mundo é igual, o que serve pra um, serve pra } \\
\text { todos" "Comunidade é sinônimo de comum, o que é } \\
\text { para um, é para todos". }\end{array}$ \\
\hline $\begin{array}{l}\text { A CT oferece tratamento-(re)educativo voltado à } \\
\text { técnicas de psicoeducação, reforço positivo e } \\
\text { reforço negativo (TCC). }\end{array}$ & $\begin{array}{l}\text { A instituição oferece tratamento voltado à técnicas } \\
\text { de punição, humilhação e julgamento moral. }\end{array}$ \\
\hline $\begin{array}{l}\text { Busca-se o objetivo de reinserção social do acolhido } \\
\text { (A CT oferece ambiente terapêutico que busca a } \\
\text { aproximação da realidade exterior, o que facilita o } \\
\text { processo de reinserção social). }\end{array}$ & $\begin{array}{l}\text { Pratica-se a institucionalização dos acolhidos (a } \\
\text { instituição oferece ambiente terapêutico } \\
\text { extremante artificial, voltado ao protecionismo e a } \\
\text { evitação da realidade) ex: não é permitido que } \\
\text { informações exteriores adentrem a instituição, } \\
\text { protegendo assim o acolhido de frustrar-se, pois isso } \\
\text { poderia levar a desistência do tratamento. }\end{array}$ \\
\hline
\end{tabular}




\begin{tabular}{l} 
Apresenta ambiente terapêutico altamente \\
organizado/estruturado, oferecendo cronograma \\
semanal de atividades de forma balanceada entre \\
atividades de práticas inclusivas, de capacitação e \\
promoção da aprendizagem, atividades \\
recreativas, atividades de desenvolvimento da \\
espiritualidade e práticas de autocuidado (todas \\
atividades apresentam objetivo terapêutico \\
definido). \\
\hline A CT dispões de equipe multiprofissional, treinada \\
e em constante aperfeiçoamento/capacitação \\
profissional.
\end{tabular}

Oferece tratamento baseado em métodos voltados ao trabalho das questões biológicas, psicológicas, sociais e espirituais dos acolhidos.

A CT está aberta a evolução e inovação do processo de tratamento, buscando sempre auto avaliar-se (utilização de técnicas de analise institucional).

Busca oferecer suporte durante o tratamento para que o acolhido mude seus pensamentos (os gerencie de formas mais adaptativas) e (re)elabore seus sentimentos, para que assim possa alterar seus comportamentos.

$\underline{\text { NÃO }}$ se destina ao acolhimento/tratamento de todo tipo de dependente, ou seja, a partir de processo de triagem identificam-se necessidades singulares nos acolhidos que podem ou não incluirse nos critérios de admissão da CT.

Propõe ambiente/clima terapêutico que ofereça alternativas de maiores ganhos nos níveis de empoderamento dos acolhidos, o que automaticamente gera maior autonomia e aprimoramento dos processos de autogestão dos mesmos.

A CT busca trabalhar as questões dos acolhidos de forma dinâmica, levando em consideração resolver fatores internos que se presentam dentro da entidade (psicológicos e comportamentais) e fatores externos que se apresentam fora da entidade (sistêmico familiar, laborais, amizades da ativa, questões judiciais, etc).

O tratamento é construído e vivenciado nos três tempos da imanência: passado, presente, futuro.
Apresenta ambiente terapêutico altamente organizado/estruturado, NÃO oferecendo cronograma semanal de atividades de forma balanceado, focando-se em alguns casos somente em atividades religiosas, em outros em atividades laborais, ou ainda em atividades recreativas (as atividades do cronograma não apresentam fundamentação nem objetivos terapêuticos).

A instituição dispões de equipe despreparada, sem aperfeiçoamento técnico, que baseia-se somente na vivência pessoal de seus membros.

Oferece tratamento baseado em métodos voltados ao trabalho das questões espirituais/religiosas, laborais e morais dos acolhidos.

A instituição acredita que deve reproduzir métodos e o modelo já conhecido de tratamento, pois justifica que foi sempre assim que as coisas funcionaram, então existe a necessidade de manter tudo como foi/é (justificativas pessoais de membros das equipes sugerem que: "se algo funcionou para mim, vai funcionar para os outros").

Oferece tratamento voltado unicamente a mudança dos comportamentos apresentados pelos acolhidos (muitas vezes utiliza-se do modelo Behaviorista de condicionamento clássico).

Não apresenta critérios de admissão bem definidos, acolhendo assim qualquer tipo de usuário de SPA (ex: desde o experimentador, recreacional até o dependente químico com a doença já instalada).

Propõe ambiente/clima terapêutico voltado à alienação dos acolhidos, retirando destes o direito de escolha/decisão (nestas instituições utilizam-se as máximas: "aqui você só tem um direito, o de aceitar tudo que lhe for proposto", "aceita que dói menos", "você só está aqui para aceitar, quer decidir algo? Aqui não é o lugar", "Você já tentou do seu jeito e deu errado, agora chega de decidir, só aceite").

A instituição busca focar o trabalho nas questões apresentadas pelos acolhidos somente na resolução de fatores que se apresentam no interior da entidade (as vezes psicológicos, na maioria dos casos somente comportamentais) excluindo a possibilidade de resolução de questões que se apresentam de maneiras externas a instituição (sistema familiar, trabalho, amigos, dividas, problemas judiciais).

O tratamento é construído e vivenciado exclusivamente no presente. (Utilização da máxima: "não pense no que já foi, não sofra pelo que virá, foque-se somente no aqui e agora"). 


\begin{tabular}{|l|l|}
\hline Os acolhidos tem espaço para decidir e construir \\
em conjunto com a equipe multidisciplinar e \\
$\begin{array}{l}\text { administrativa o ambiente de tratamento na CT } \\
\text { (espaço físico, plano de atendimento singular (PAS), } \\
\text { normas e regras de moradia). }\end{array}$
\end{tabular} $\begin{aligned} & \begin{array}{l}\text { qua cria um ambiente de autoritarismo, } \\
\text { acolhidos, impondo regras rígidas e sem } \\
\text { fundamentações claras, utiliza-se do mecanismos } \\
\text { punitivos (medo) para moldar o comportamento } \\
\text { dos acolhidos. }\end{array} \\
& \begin{array}{l}\text { Métodos: utilização de caixa de sugestões, reuniões } \\
\text { matinais e assembleias gerais. }\end{array}\end{aligned}$

Tabela a: Adaptado a partir de JONES (1972), FRACASSO (2011), DE LEON (2014), KURLANDER (2014), FIGLIE; BORDIN; LARANJEIRA (2015), IPEA (2017).

\section{II - AS COMUNIDADES TERAPÊUTICAS NO BRASIL: SEUS ATRAVESSAMENTO LEGAIS E POLÍTICOS- IDEOLÓGICOS}

O movimento das CT's no Brasil no ano de 2019 completou seus 50 anos de existência, em meio a muitas dificuldades enfrentadas, barreiras ultrapassadas e vitorias alcançadas, frente a estas questões buscaremos apresentar neste capítulo alguns dos principais momentos das CT's no que se referem a construção de ferramentas legais que visam sua organização, acompanhamento e melhoramento do serviço em âmbito nacional, além de apresentarmos os ganhos que as CT's vem demonstrando junto as políticas públicas nacionais voltadas ao tratamento/acompanhamento e reinserção social de sujeitos com transtornos decorrentes do uso, abuso e/ou dependência química de substancias psicoativas.

É possível percebermos que ao longo destes 50 anos de história, as CT's por grande parte do tempo, mais especificadamente 32 anos, estiveram desamparadas de legislações que as organizassem, bem como, que as servissem de suporte técnico e legal para a regulamentação de seus serviços, assim foi a partir da constante e crescente oferta de entidades da sociedade civil voltadas ao cuidado/acolhimento de usuários e/ou dependentes químicos no país, que vinham apresentando-se como resposta à ausência de tradição mais forte da saúde pública Brasileira em lidar com o tema da drogadição, que no ano de 2001 vimos surgir a proposta pioneira voltada a questão de organização destes serviços, a resolução RDC/ANVISA № 101, de 30 de maio de 2001, buscou estabelecer regulamento técnico disciplinando as exigências mínimas para o funcionamento de serviços de atenção a pessoas com transtornos decorrentes do uso ou abuso de substâncias psicoativas, segundo modelo psicossocial de acolhimento, esta resolução serviu como o primeiro documento de suporte legal para os serviços oferecidos pelas Comunidades Terapêuticas no Brasil, que até então vinham apresentando-se como espaços privados de acolhimento/tratamento de dependentes químicos, 
contudo sem organização formal, e com propostas que em muitos casos beiravam o assistencialismo e/ou dispunham de visões higienistas de saúde pública.

Desta maneira iniciou-se a tentativa de organização técnica e legal das Comunidades Terapêuticas em âmbito nacional, neste momento as crescentes complicações sociais e de saúde pública que envolviam o uso, abuso e/ou DQ de substancias psicoativas no país, principalmente aquelas voltadas aos usuários de $\mathrm{Crack}^{8}$, assim no ano de 2006 as CT's começaram a ganhar gradativamente espaço também nas Políticas Públicas sobre Drogas, visto que apresentavam-se como serviços de caráter privado necessários ao Estado, pois ocupavam as mazelas deixadas pelo mesmo, no que se refere a atenção e reinserção social de usuários e/ou DQ de SPA's, sendo assim, no ano de 2006 a partir da publicação da LEI № 11.343, a qual instituiu o Sistema Nacional de Políticas Públicas sobre Drogas SISNAD, prescreveu-se medidas para prevenção do uso indevido de SPA's, atenção e reinserção social de usuários e dependentes de substâncias, propuseram-se também normas para repressão à produção não autorizada e ao tráfico ilícito de drogas e definiu crimes, nesta lei as CT's foram incluídas como instituições/entidades da sociedade civil, sem fins lucrativos, com atuações reconhecidas nas áreas de atenção à saúde e da assistência social que passam a oferecer atendimento a usuários e/ou dependentes químicos e que assim podem receber recursos do Fundo Nacional Antidrogas (Funad), fundo este vinculado à Secretaria Nacional Antidrogas (SENAD). É com esta legislação que vemos uma mudança significativa, um realinhamento no rumo das Políticas Públicas sobre Drogas no país, pois de acordo com esta legislação começaram-se a focar e fortalecer esforços em questões que envolvessem a prevenção ao uso de SPA's, atenção e reinserção social de usuários e/ou $D Q$, visto que, até este momento cultivava-se um histórico nas Políticas Públicas sobre Drogas no Brasil muito pautadas sobre o prisma do combate/repressão, visto como "questão/caso de polícia" "crime", visão esta que segue a lógica da política de guerra as drogas (COSTA, 2009).

Assim, de 2006 a 2011 foi possível percebermos que as parcerias estabelecidas entre o governo federal, os governos estaduais e municipais, e as instituições/entidades da sociedade civil conhecidas como Comunidades Terapêuticas foram ganhando força, desta maneira, como nos mostra Santos, 2011, isso ocorreu principalmente através da decisão do governo federal de apoiar financeiramente as CT's, a partir do Plano Integrado de Enfrentamento ao Crack e outras Drogas ${ }^{9}$, assim percebemos que, de acordo com a pesquisa realizada pela Diretoria de Estudos e Políticas do Estado, das Instituições e da Democracia (DIEST) e do Instituto de Pesquisa Econômica Aplicada (IPEA), em 2016, $24,1 \%$ das fontes que financiavam as CT's eram originarias de verbas advindas do governo federal, 
$27,8 \%$ oriundas dos governos estaduais e $41,1 \%$ dos governos municipais, como nos mostra o gráfico 1.1: Fontes de financiamento das CT's Brasileiras em \% (IPEA, 2017).

\begin{tabular}{|c|c|}
\hline FONTES DE FINANCLAMENTO & 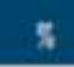 \\
\hline Doaçoes de pessoas que apoiam a causa & 75,4 \\
\hline Contribuiçoes voluntarias dos/as acolhidos/as ou suas familias & 66.6 \\
\hline Doaçòes de igrejas e demais instituiçōes religiosas & 63.5 \\
\hline Pagamento dos acolhidos & 46 \\
\hline Recursos próprios dos dirigentes da CT & 44,7 \\
\hline Levantamento de fundos, através de festas, bingos ou sorteios & 42 \\
\hline Financiamento do gowerno municipal & 41,1 \\
\hline Daap̧oes de entidades privadas nacionais & 33,9 \\
\hline Produçào e venda de produtos feitos na CT & 32,4 \\
\hline Financiamento do governo estadual & 27,8 \\
\hline Financiamento do governo federal & 24,1 \\
\hline Doaçoes de entidades privadas internacionais & 6,1 \\
\hline
\end{tabular}

\section{Fonte: Pesquisa Porfil das comunidades teraptuticas (Diestlipea, 2016).}

Gráfico 1.1: Fontes de financiamento das CT's Brasileiras em \%.

Então a partir de 2011, com o crescente incentivo financeiro dado pelo governo às CT's, o qual aumentou significativamente as parcerias entre o Estado e as instituições/entidades da sociedade civil que prestam serviços à comunidade na área da $D Q$, se fez necessário mudanças, revisão/melhoramentos nas regulações sanitária sobre o tema, a fim de melhor organizar os serviços e alcançar melhores resultados do mesmo, desta maneira, esta revisão da regulação sanitária, foi realizada em consonância com as ações do governo, especialmente do Ministério da Saúde (MS), o processo de revisão da normativa contemplou, ainda sugestões propostas pelas Federações de Comunidades Terapêuticas, além das considerações de órgãos do governo diretamente envolvidos com o tema, como, por exemplo, a Secretaria Nacional de Políticas sobre Drogas (SENAD) do Ministério da Justiça, assim, a partir desta revisão originou-se a resolução RDC-ANVISA № 29/2011, que dispõe sobre os requisitos de segurança sanitária para o funcionamento de instituições que prestem serviços de atenção a pessoas com transtornos decorrentes do uso, abuso ou dependência de substâncias psicoativas, a qual trouxe como principais mudanças, questões referentes ao plano terapêutico, não exigindo mais que as CT's apresentem rotina de atendimento à saúde, passando assim a funcionarem através de referênciamento e contrareferênciamento com serviços de atenção à saúde da rede pública 
ou privada, também instituiu referente as questões terapêuticas que "O principal instrumento terapêutico a ser utilizado para o tratamento das pessoas com transtornos decorrentes de uso, abuso ou dependência de substâncias psicoativas deverá ser a convivência entre os pares" (CAPÍTULO I, Seção I, Parágrafo único, RDC 29/2011). Outra modificação importante presente na RDC 29 referiu-se as questões que envolvem a organização da infraestrutura da CT, uma vez que dispensa a aprovação de projeto junto a vigilância sanitária, passando somente a exigir infraestrutura compatível com o número de residentes da instituição, determina também os ambientes que as instituições devem possuir, contudo não estabelece proporções entre os ambientes e o número de residentes. Estes são somente dois pontos principais modificados pela nova legislação se comparados a resolução RDCANVISA № 101/2001, que até então organizava estes espaços de tratamento/acolhimento (NOTA TÉCNICA № 1/2011).

Foi também no ano de 2011, que institui-se a Rede de Atenção Psicossocial (RAPS), para pessoas com sofrimento ou transtornos mentais e com necessidades decorrentes do uso de crack, álcool e outras drogas, no âmbito do Sistema Único de Saúde (SUS), através da Portaria № 3.088/2011, nesta legislação as CT's foram reconhecidas como um dos pontos efetivos na rede de cuidados/tratamento voltados à sujeitos que apresentam transtornos decorrentes do uso, abuso ou dependência de substancias psicoativas, neste documento as CT's foram classificadas como serviços de atenção em regime residencial transitório (Art. 5ㅇ, IV, b), mais especificadamente foram definidas como:

“...Comunidades Terapêuticas: serviço de saúde destinado a oferecer cuidados contínuos de saúde, de caráter residencial transitório por até nove meses para adultos com necessidades clínicas estáveis decorrentes do uso de crack, álcool e outras drogas" (Art. 9, II, PORTARIA № 3.088/2011).

Desta maneira é possível percebermos que, esta definição colocou as CT's no patamar de um "serviço de saúde", o que por sua vez encontra-se em desacordo com a resolução RDC № 29/2011, a qual reconhece as CT's como um "serviço assistencial à saúde", entretanto as CT's foram incluídas na construção/organização da RAPS, a partir do funcionamento articulado com o nível da atenção primaria à saúde que lhe reforça e apoia no cuidado clínico geral de seus usuários, bem como os Centros de Atenção Psicossociais Álcool e Drogas (CAPSAD), que de acordo com a portaria em questão (PORTARIA № 3.088/2011) é o responsável pela indicação do acolhimento, pelo acompanhamento especializado, pelo planejamento da saída e pelo seguimento dos cuidados aos usuários (Art. 9ㅇ, 53으, I, II), assim, vemos que as CT's acabaram sendo incluídas como um serviço efetivo da RAPS, mas ao mesmo tempo tiveram sua autonomia limitada por outro serviço (CAPSAD), o qual é responsável desde a indicação, até o acompanhamento especializado durante o acolhimento bem como depois dele, isso 
gerou e ainda gera muitas dificuldades/entraves e embarreiramentos ao serviço prestado pelas Comunidades Terapêuticas no Brasil, visto que enfrentamos uma batalha no cenário políticoideológico referente a supremacia do modelo de atenção/cuidado à usuários e/ou DQ de substancias psicoativas a ser utilizado e principalmente incentivado pelas políticas públicas no país, assim temos de um lado o CAPSAD, que traz a representação da lógico do cuidado voltada à redução de danos ${ }^{10} \mathrm{e}$ de outro lado as CT's, que focam seus serviços sobre o cuidado pautado na lógica da abstinência. Estes embarreiramentos impostos/construídos, acabam por desviar o foco real e central de qualquer que seja o serviço de atenção/cuidado destinado a usuários, abusadores ou DQ de substancias psicoativas, pois na verdade todos os serviços tem de estar, ou ao menos, deveriam estar orientados diretamente sobre os próprios usuários, respeitando assim suas decisões singulares de escolha de modelo de tratamento e não como vemos acontecer atualmente, onde o foco gira em torno de discussões político-ideológicas ${ }^{11}$ que somente satisfazem os egos inflados daqueles que detém provisoriamente certas parcelas do poder.

Assim, devido a disputa instaurada no campo político-ideológico e as constantes críticas ${ }^{12}$ voltadas as CT's e seu foco de tratamento/cuidado pautado sobre o modelo acolhimento residencial terapêutico transitório de caráter voluntário voltado à abstinência, foi em agosto de 2015 que o Conselho Nacional de Políticas sobre Drogas lançou a resolução CONAD № 1/2015, a qual buscou regulamentar, no âmbito do Sistema Nacional de Políticas Públicas sobre Drogas (SISNAD), as entidades que realizam o acolhimento de pessoas, em caráter voluntário, com problemas associados ao uso nocivo ou dependência de substâncias psicoativas, caracterizadas como Comunidades Terapêuticas, nesta resolução algumas mudanças foram propostas para os serviços, principalmente no que diz respeito ao seu enquadre, que passou a ser o de instituição de apoio à recuperação de usuários de drogas e não mais de serviço de saúde, passando assim a ser definido como um serviço de acolhimento e não mais de internação, neste documento também foram organizadas as principais diretrizes para que uma instituição caracterize-se como Comunidade Terapêutica (Modelo Real), assim, como também foram propostas as bases gerais da organização para o funcionamento terapêutico destas instituições, principalmente no que tange a organização do Plano Terapêutico Institucional (programa de acolhimento), o Plano de Atendimento Singular (PAS), além de organizar como devem se dar as articulações com os serviços da rede, tais como os do Sistema Único de Saúde, do Sistema Único de Assistência Social e da Rede de Atenção Psicossocial (RESOLUÇÃO CONAD № 1/2015). 
Esta tentativa foi realizada por parte de instâncias do legislativo envolvidas com o tema e instituições associativas/representativas das CT's, como forma de buscar maior organização e padronização dos serviços prestados por parte destas entidades/instituições em âmbito nacional, tentativa esta que foi questionada pelo Ministério Público Federal de São Paulo (MPF-SP), uma vez que, para o MPF-SP as Comunidades Terapêuticas se enquadrariam como equipamentos de saúde e não como serviço de apoio à saúde, tendo assim que apresentarem estruturas condizentes com um serviço de saúde cumprindo as exigências do Ministério da Saúde (MS), esta questão jurídica fez com que o Marco Regulatório das CT's ficasse suspenso por cerca de dois anos, contudo as Comunidades Terapêuticas voltaram a ser reconhecidas como instituições de apoio à recuperação de usuários de drogas em 2018, a decisão foi proferida pelo Tribunal Regional Federal da 3a Região (TRF3) e devolveu a validade da Resolução CONAD № 1/2015, indicando que os serviços prestados pelas CT's devem ser definidos como acolhimento e não como internação (prática própria do serviço de saúde) ${ }^{13}$. A questão envolvendo a tentativa de embargo da Resolução do CONAD № 1/2015 apresentou-se como uma nítida e clara posição político-ideológica por parte de parcelas contrarias ao modelo de atenção/cuidado oferecido pelas CT's, entretanto acreditamos que a decisão tomada de revalidar a presente resolução ofereceu e oferece ganhos no que diz respeito a construção/estruturação de um serviço de maior e melhor qualidade por parte das CT's enquadradas no Marco Regulatório.

Vemos que, frente aos principais desafios enfrentados pelas CT's na contemporaneidade, a desassistência no que se refere ao acompanhamento da organização/fiscalização e consultoria dos serviços prestados em âmbito nacional, são fatores que acabam por comprometer os resultados de eficácia do modelo atualmente oferecido ${ }^{14}$, assim como, as dificuldades enfrentadas em relação as pressões políticas-ideológicas que envolvem o tema, que ajudam em muito para a criação das más interpretações (reproduções estereotipadas) sobre o modelo de tratamento oferecido pelas CT's, foi somente a partir de 2018 que estas instituições tão mal vistas e em grande parte mal entendidas, passaram a incluir as propostas de produção e consolidação das Políticas Públicas no que se refere aos modelos de cuidado/atenção e tratamento à DQ validados e reconhecidos pelo Estado. Desta maneira a partir do realinhamento e fortalecimento da Política Nacional sobre Drogas (PNAD), ocorrido em março de $2018^{15}$, onde governo federal buscou repensar o favorecimento até então dado ao modelo de cuidado/tratamento pautado sobre a lógica da RD, abrindo o leque de possibilidades para o incentivo e construção de Políticas Públicas reais junto a outros modelos de cuidado/tratamento voltados à DQ no país, assim, foi possível percebermos que a atual mudança nas diretrizes da Política Nacional sobre Drogas foca-se em gerar maiores níveis de igualdade entre todos os serviços já 
existentes, desconstruindo desta maneira a dicotomia criada a partir de visões estereotipadas acerca do modelo de Redução de Danos $X$ modelo de Abstinência, podemos perceber esta afirmação no recorte realizado a partir da Nota Técnica № 11/2019 publicada pelo Ministério da Saúde, a qual busca apresentar as atuais mudanças na Política Nacional de saúde Mental e nas Diretrizes da Política Nacional sobre Drogas:

\begin{abstract}
"Todos os Serviços, que compõem a RAPS, são igualmente importantes e devem ser incentivados, ampliados e fortalecidos. O Ministério da Saúde não considera mais Serviços como sendo substitutos de outros, não fomentando mais fechamento de unidades de qualquer natureza. A Rede deve ser harmônica e complementar. Assim, não há mais porque se falar em "rede substitutiva", já que nenhum Serviço substitui outro. O país necessita de mais e diversificados tipos de Serviços para a oferta de tratamento adequado aos pacientes e seus familiares" (Grifos nossos. NOTA TÉCNICA № 11/2019).
\end{abstract}

As principais mudanças realizadas (realinhamento) nas diretrizes da Política Nacional sobre Drogas, basearam-se na priorização e incentivo de estudos técnicos e outros elementos produzidos pela comunidade científica, capazes de avaliar as práticas dos atuais serviços e apontar os caminhos que busquem uma eficaz utilização dos recursos disponíveis para estruturação de futuros programas e projetos nas áreas de prevenção, abstinência e redução dos danos. Outra mudança realizada direcionou-se para que os futuros programas, projetos e ações no contexto da atual Política Nacional sobre Drogas devem considerar, em sua estruturação, iniciativas de ampliação e reorganização da rede de cuidados, acolhimento e suporte social, e devem ser conceitualmente orientados(as) para a prevenção e mobilização social, promoção da saúde, promoção da abstinência, suporte social e redução dos riscos sociais e à saúde e danos decorrentes do uso, abuso ou DQ de SPA's. Desta maneira foi possível percebermos que o realinhamento das diretrizes da Política Nacional sobre Drogas focouse em incentivar todas as alternativas que existem à disposição atualmente, não oferecendo assim favorecimento a modelo especifico de serviço, seja qual for, sendo assim as CT's ganham espaço no cenário político e das Políticas Públicas voltadas ao cuidado/atenção à sujeitos que apresentam transtornos decorrentes do abuso e/ou dependência química de substancias psicoativas no Brasil.

Para que todos os serviços já existentes possam ser incentivados/financiados e organizados/expandidos foram propostas uma série de medidas visando a melhor organização, fiscalização e fortalecimento dos mesmos, deste maneira, referente aos serviços oferecidos pelas CT's:

"Foi criado um grupo de trabalho interministerial, com membros dos Ministérios da Saúde, Justiça, Trabalho e Desenvolvimento Social, para estabelecer critérios para o funcionamento, expansão e financiamento desses serviços (Portaria Interministerial n.o 2, de 21 de dezembro de 2017). O objetivo é garantir o acompanhamento do poder público, promovendo a oferta de 
cuidado de qualidade aos pacientes com dependência química acolhidos nessas entidades. Vale lembrar que há regramento federal sobre o funcionamento destas entidades, a resolução CONAD №01/2015 (disponível em http://www.justica.gov.br/sua-protecao/politicas-sobre drogas/comunidadesterapeuticas/anexos/conad_01_2015.pdf).Assim, entidades que contratualizam com o poder público devem satisfazer esta normativa" (NOTA TÉCNICA № 11/2019).

Portanto, percebemos que a constante evolução nas propostas de organização e incentivo dos serviços oferecidos pelas CT's no Brasil, alcançaram um novo nível a partir das mudanças nas ocorridas nas diretrizes da Política Nacional sobre Drogas (2019), as quais coincidiram com a comemoração dos 50 anos do movimento das Comunidades Terapêuticas no Brasil, assim, frente as atuais conjunturas de fatores que envolvem o tema das CT's no país, foi possível acompanharmos a realização do evento denominado: "Ações para o fortalecimento das Comunidades Terapêuticas: tratamento e prevenção ao uso de drogas", ocorrido no dia 19 de março de 2019 em Brasília-DF, onde membros do atual Ministério da Cidadania e da recém criada Secretaria Nacional de Cuidados e Prevenção às Drogas $\left(\right.$ SENAPRED) ${ }^{16}$, lançaram um pacote de medidas voltadas ao fortalecimento e organização do serviço prestado pelas CT's em âmbito nacional, o qual incluiu a criação do cadastro nacional de Comunidades Terapêuticas (Portaria № 563/2019), que objetiva diagnosticar e avaliar o atual cenário das CT's no Brasil e contribuir para o fortalecimento do modelo de CT, também foi lançado o roteiro de fiscalização das CT’s (Portaria № 562/2019), o qual será posto em prática pela SENAPRED e que busca avaliar as entidades contratadas e assim ofertar um serviço efetivamente de qualidade para os acolhidos, esta fiscalização além de avaliar e diagnosticar, foca-se também na busca por ajudar no fortalecimento das CT's, outra medida proposta pelo Ministério da Cidadania/SENAPRED foi a assinatura da portaria № 564/2019 a qual fez o lançamento do curso CoMPaCTa, voltado à capacitação, treinamento e qualificação das equipes, que pretende atingir cerca de dois mil profissionais que atuam nas entidades financiadas pelo governo em todo o país. A iniciativa foi estabelecida em parceria com a Universidade Federal de Santa Catarina (UFSC) e a Universidade Federal de São Paulo (Unifesp), o curso atualmente é oferecido em modalidade EAD (a distância), apresentando-se estruturado em 6 módulos e tendo duração de 9 semanas, além destas medidas foram realizadas as assinaturas de 216 novos contratos, entre o Governo Federal e Comunidades Terapêuticas de diversos estados do país, disponibilizando 4.274 novas vagas de acolhimento nestas entidades, assim, a partir de 19/03/2019 o Governo Federal passou a disponibilizar um total de 10.883 vagas, contratadas junto a 496 Comunidades Terapêuticas no país, totalizando um gasto de 153,7R\$ milhões de reais por ano com estes serviços. Foi realizado também no evento do dia 19/03/2019 em Brasília-DF o lançamento da frente parlamentar em favor 
das Comunidades Terapêuticas, frente parlamentar composta por Deputados e Senadores que apoiam o modelo de tratamento/acolhimento para a dependência química proposto pelas CT's. Assim, frente a todas as questões expostas é possível vermos que o atual momento em que o movimento das Comunidades Terapêuticas se encontram no país é de crescimento/fortalecimento, constante incentivo e organização.

\section{III - A ORGANIZAÇÃO DO SERVIÇO PRESTADO PELAS COMUNIDADES TERAPÊUTICAS NO BRASIL: REPRESENTAÇÃO, SUPORTE E APRESENTAÇÃO DE EFICÁCIA DO MÉTODO}

Atualmente vemos evoluir o movimento que busca a organização e maximização dos resultados dos serviços presentes na Rede de Atenção Psicossocial (RAPS), destinado a reinserção social de dependentes químicos, e que corporificam-se através do modelo de acolhimento voluntário em caráter residência terapêutico transitório, serviços estes, conhecidos em âmbito nacional como Comunidades Terapêuticas. É possível percebermos que além de resoluções, normativas e legislações que organizam estes serviços, temos entidades associativas/representativas que buscam oferecer suporte, qualificação, materiais terapêuticos estruturados/protocolares, dados de eficácia sobre o modelo terapêutico proposto, além de exercer representação junto ao governo federal e governos estaduais no que diz respeito a participação na criação de Políticas Públicas referente as CT's e as questões que envolvem a Política Nacional sobre Drogas no país.

Frente a todas as entidades associativas/representativas que existem no país, temos a Federação Brasileira de Comunidades Terapêuticas (FEBRACT), que desde sua fundação em 16 de outubro de 1990, tem como finalidade institucional: congregar as Comunidades Terapêuticas do Brasil, oferecer capacitação aos profissionais de Comunidades Terapêuticas, promover encontros, congressos e eventos científicos, participar na construção de Políticas Públicas, desenvolver pesquisas, representar as CT's em âmbito nacional e internacional, além de assessorar as Comunidades Terapêuticas, oferecendo para as entidades filiadas, serviços de consultoria, através da disponibilização de consultores técnicos treinados e de materiais terapêuticos estruturados e protocolares, que buscam a evolução e (re)organização dos serviços das CT's.

Assim sendo, de acordo com os objetivos institucionais apresentados demonstraremos alguns dados sobre a Federação Brasileira de Comunidades Terapêuticas (FEBRACT) visto que, a mesma se apresenta como a entidade associativa/representativa de maior impacto e abrangência no Brasil, 
também discutiremos ao longo deste capitulo alguns dados levantados nas atuais pesquisas referentes a eficácia do modelo de CT desenvolvidas por pesquisadores ligados a FEBRACT.

Partindo das finalidades/objetivos institucionais apresentadas(os), podemos ver o impacto que a FEBRACT tem atualmente no país, contando com 239 instituições filiadas, é possível percebermos que a maior concentração de CT's filiadas encontram-se na região sudeste, seguida pela região sul, o restante das Comunidades Terapêuticas filiadas apresentam-se distribuídas sem número expressivo

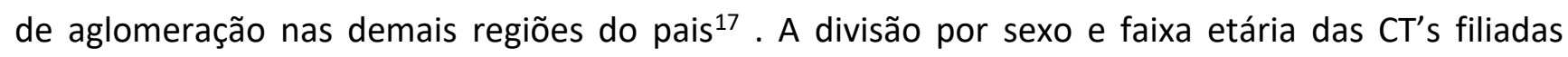
apresenta-se da seguinte maneira, 1 (uma) CT feminina para adolescentes, 8 (oito) CT's masculinas para adolescentes, 33 (trinta e três) CT's femininas para adultos, 196 (cento e noventa e seis) CT's masculinas para adultos e 1(uma) CT mista para adultos (FEBRACT, 2019).

A FEBRACT tem cede administrativa junto ao Instituto Padre Haroldo em Campinas-SP e conta com quatro delegações regionais, estando elas presentes nos estados do Rio Grande do Sul, Minas Gerais, Bahia e Rondônia. O total de CT's filiadas em entidade associativas/representativas no pais é de 1.171, o que corresponde a 59,7\% do total de 1.963 Comunidades Terapêuticas catalogadas pelo levantamento do IPEA, 2017, do número total de filiadas, 20,4\% são filiadas à FEBRACT ${ }^{18}$, o que demonstra que a Federação é a maior entidade associativa/representativa de CT's do Brasil, estando presente em 15 estados do país, além do Distrito Federal, podemos visualizar estes dados na Figura 1 que apresenta a presença da FEBRACT em território nacional e no Gráfico 1.2 que reproduz os dados percentuais das filiações de CT's em entidades associativas no Brasil. 


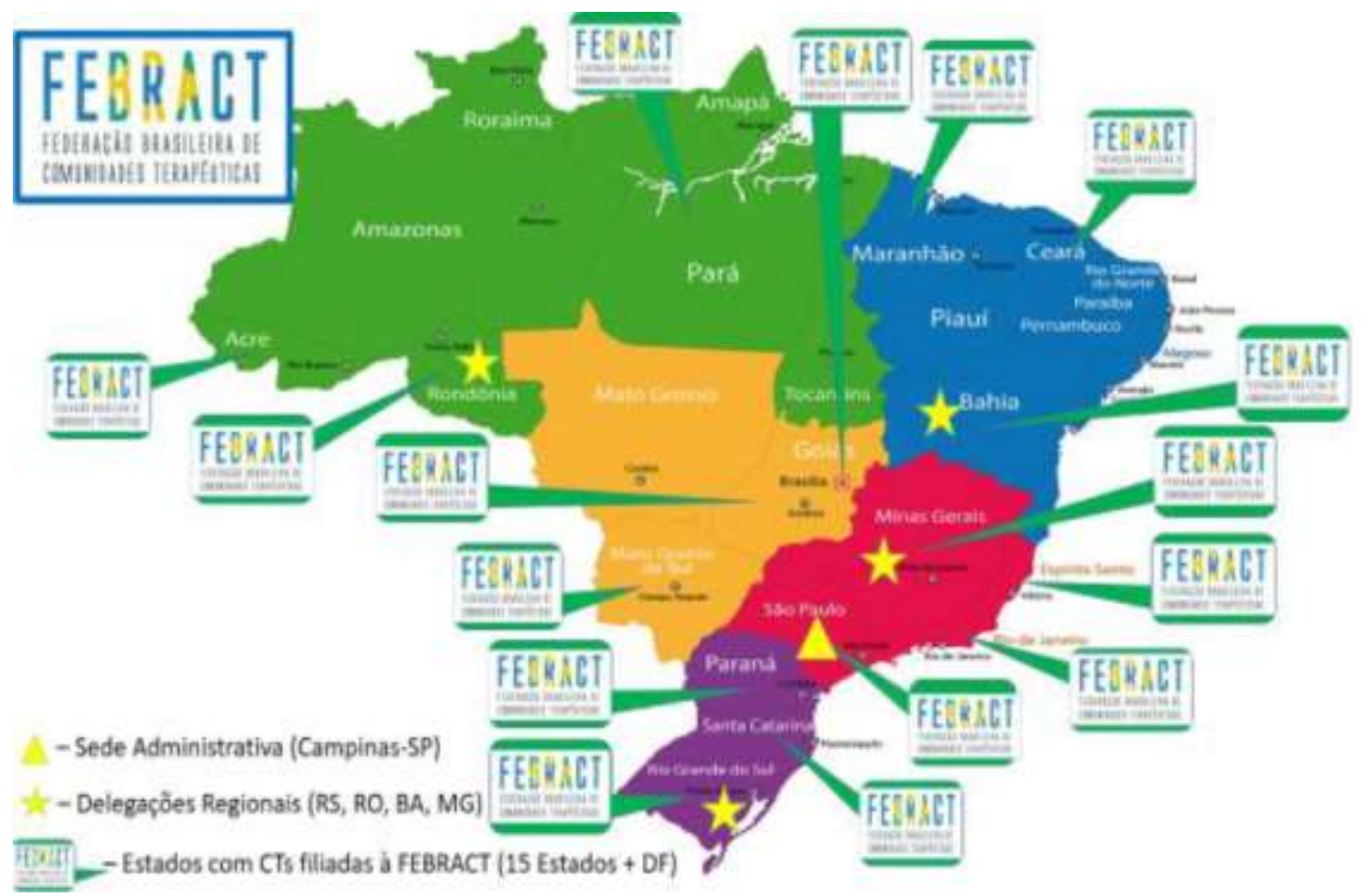

Figura 1: A presença da Federação Brasileira de Comunidades Terapêuticas (FEBRACT) no Brasil.

Filiaçào das entidades associativas/representativas das CTs - Brasil (Em \%)

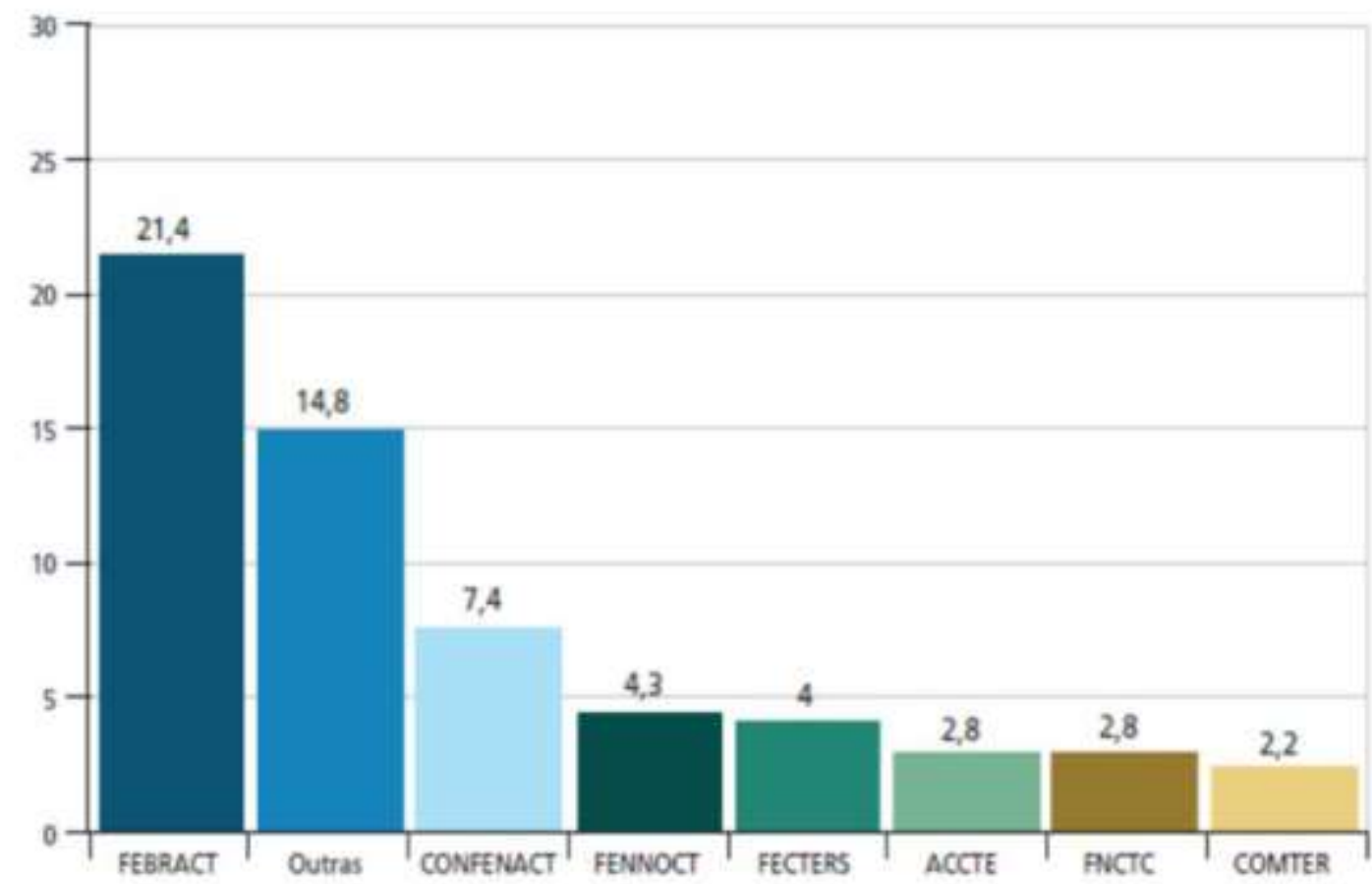

Fonte: Pesquisa Forfil das comunidades terapeiticas (Diest/pea, 2016).

Gráfico 1.2: \% da filiação em entidades associativas/representativas das CT’s no Brasil. 
É possível notarmos que os dados apresentados segundo o estudo realizado em 2016 pelo Ipea, estão desatualizados, uma vez que, atualmente a FEBRACT aparece com um percentual de 20,4\% do total de filiações das CT's no Brasil, isso se considerarmos o total de entidades filiadas sugeridos pelo estudo realizado em 2016, ainda assim a Federação Brasileira de Comunidades Terapêuticas apresenta-se como a entidade associativa/representativa de maior impacto no país.

\section{III.1. A EFICÁCIA DAS CT'S}

Em relação a eficácia do método das CT's no Brasil, temos alguns indicativos iniciais sobre o tema, o exemplo inicial, são os dados apresentados por Clarice Sandi Madruga, em sua pesquisa intitulada "A Pesquisa Científica na Avaliação da Eficácia do Método das CT's", estudo este, que foi realizado ao longo dos anos de 2013 a 2016, que contou com a participação de 58 Comunidades Terapêuticas filiadas a FEBRACT e cadastradas no Programa Recomeço, programa de Política Pública na área de tratamento à $D Q$ do governo de São Paulo, que objetiva proporcionar ações de prevenção, tratamento, reinserção social e recuperação, controle e requalificação das cenas de uso de SPA's e acesso à justiça e à cidadania, e que volta-se tanto para usuários e/ou abusadores de SPA's como também dependentes químicos e seus familiares (DECRETO № 61.674 / 2015).

De acordo com os números indicados, foram realizados 20.092 encaminhamentos para acolhimento voluntário em Comunidades Terapêuticas durante o período em que o estudo foi desenvolvido ${ }^{19}$.

Em relação ao apresentado acerca de eficácia do método das CT's, o estudo demonstrou que em 54,7\% dos acolhimentos, o desfecho final se deu através de alta terapêutica, totalizando 10.930 acolhidos que apresentaram processo positivo de reinserção social, sendo que deste total, $60,3 \%$ ou seja 6.590 acolhidos retornaram as famílias, contudo sem condições de auto-sustento, enquanto $38.9 \%$ o que representa 4.251 acolhidos, retornaram as famílias com condições de auto-sustento e ainda 0.8\% (87 acolhidos) não retornaram as família, mas apresentaram condições de auto-sustento. (MADRUGA, 2017)

É possível notarmos que, os indicativos de reinserção social levados em consideração neste estudo foram o retorno a família (de origem e/ou constituída) e o alcance de condições de auto-sustento pelos acolhidos que concluíram o período de acolhimento/tratamento através de alta terapêutica, o que significa, que os mesmos alcançaram os objetivos terapêuticos construídos em seus Planos de Atendimentos Singulares (PAS). 
O estudo também evidenciou que a cada dia a mais de permanência no processo de acolhimento/tratamento, aumenta-se em 1 ponto percentual as chances do acolhido de retornar a família com condições de auto-sustento, outro indicativo evidenciado foi, o de que, o acolhido que apresenta busca ativa da família durante o período de acolhimento aumenta em 5 vezes as chances de retornar a família com condições de auto-sustento, também foi possível perceber durante o estudo que quanto mais atividades foram realizadas durante o período de acolhimento, maiores as chances de retornar a família com condições de auto-sustento, por fim a pesquisa ainda apresentou o indicador de que os acolhidos que participaram de atividades de geração de renda na $\mathrm{CT}$, aumentaram em 2,3 vezes as chances de alcançarem condições de auto-sustento. (MADRUGA, 2017)

Frente a estes indicadores vemos que, a CT que apresenta um ambiente terapêutico favorável/positivo é aquela que conta com a disponibilização de Plano Terapêutico Institucional (PTI) diversificado/balanceado, ou seja que disponibilize diversas alternativas/ferramentas terapêuticas ao longo do processo de acolhimento e que por sua vez estimula o acolhido a participar do maior número de atividades. Este indicador demonstra de forma inicial, o que se faz necessário para o oferecimento de processos de acolhimento/tratamento com maior nível de qualidade, uma vez que estes indicadores aumentam os índices positivos dos acolhidos alcançarem processos saudáveis de reinserção social, contudo para que possamos caminhar na direção da evolução geral das CT's temos que abrir os espaços terapêuticos das Comunidades Terapêuticas no Brasil à disponibilização de alternativas terapêuticas múltiplas e diversas, estruturadas a partir de técnicas, protocolos organizados e embasamentos científicos que estejam para além do "mais do mesmo" que tem sido replicado em larga escala e de forma desorganizada e que beira o amadorismo ao longo dos últimos 50 anos no país.

Seguindo na busca por indicadores de eficácia vemos outro estudo que demonstra dados importantes de eficácia referentes ao atual método das CT's (modelo real), este é o apresentado por Pablo Andrés Kurlander Perrone, em seu estudo intitulado: “Fatores Associados a Recidiva e Abandono do Tratamento de Dependentes Químicos: um estudo longitudinal de eficácia em duas Comunidades Terapêuticas", o pesquisador demonstra através do acompanhamento durante o processo de tratamento/acolhimento alguns indicadores que contribuem para o abandono do tratamento (precoce ou geral ${ }^{20}$ ), bem como apresenta indicadores associados ao aumento das chances de conclusão através de alta terapêutica, além disso a pesquisa foca-se também no acompanhamento dos acolhidos ao longo de doze meses após o processo de alta terapêutica, e demonstra que aqueles 
que mantiveram o processo de abstinência da substância psicoativa (SPA) de preferência, melhoraram os indicadores positivos de qualidade de vida (KURLANDER, 2019).

Assim o pesquisador levanta o questionamento, será que ao manter o processo de abstinência aumentam-se as chances dos sujeitos acolhidos ou que realizaram tratamentos em CT's de apresentarem ganhos nos indicadores de qualidade de vida, ou, a partir do momento que o acolhido apresenta ganhos nos indicadores de qualidade de vida aumentam-se as chances do mesmo em manter-se no processo de abstinência?

Esta reflexão serve de ponto de partida para pensarmos a respeito do modelo de tratamento/acolhimento que são oferecidos pelas CT's em nosso país, pois vemos muitos destes espaços atualmente apresentarem modelos de tratamento/acolhimento iatrogênicos (KURLANDER, 2014), ou seja, são espaços que oferecem ambientes voltados à abstinência, contudo muitas vezes não criam condições para o oferecimento de ganhos nos indicadores de qualidade de vida, fator este, que por sua vez acaba criando clima terapêutico contrário a sua proposta inicial, de maneira que em muitos casos piora a saúde (física e/ou mental) do acolhido que busca tratamento nestes locais, assim sendo precisamos repensar, autoanalisar e buscar sempre a evolução do modelo de CT e desta forma desconstruir muitas das práticas enraizadas/enrijecidas nas atuais CT's do Brasil.

Frente a esta reflexão precisamos levar em consideração que ainda não temos o indicativo de qual fator tem maior influência sobre o outro, contudo o estudo nos sugere a hipótese inicial de que mesmo mantendo o processo de abstinência o sujeito acolhido que não consegue ter acesso e/ou alcançar ganhos nos indicadores de qualidade de vida, apresenta maiores dificuldades em manter a abstinência.

Também de acordo com o estudo, o pesquisador nos oferece alguns dados que demonstram maiores chances no que se refere as probabilidades de desistência do processo de tratamento/acolhimento, assim de acordo com os dados apresentados é possível percebermos que o acolhido que ingressa na CT com condições de auto-sustento, ou seja que esteja trabalhando antes de ingressar no processo de tratamento/acolhimento, obtém 9,4 vezes mais chances de abandono precoce do tratamento. Outro fator que contribui para o abandono encontra-se associado ao fato do acolhido estar casado/amasiado, uma vez que segundo o dado levantado isso significa 11 vezes mais chances de abandono precoce e quase 10 vezes mais chances de abandono geral. Ainda de acordo com o estudo também foi evidenciado através da aplicação do teste Cocaine Craving Questionnaire-Brief (CCQB), o qual buscou averiguar o nível de fissura do acolhido, que o acolhido que apresenta escore grave teve 
menos chances de abandono precoce, enquanto aquele que apresentou escore moderado no ingresso da CT teve 90 vezes mais chances de abandono precoce do tratamento (KURLANDER, 2019).

Estes indicadores nos trazem a reflexão acerca de questões interessantes, tais como, é possível percebermos e ligarmos o fato de que quanto maiores os problemas enfrentados pelos acolhidos ao ingressarem na CT (rompimento/inexistência familiar, falta/perca/inexistência de trabalho, nível grave de fissura) maiores as chances destes em darem seguimentos nos processos de tratamento/acolhimento, ao passo que quanto melhores forem os indicadores iniciais (ter emprego, estar casado/amasiado, nível moderado de fissura) maiores as chances de desistência do processo de tratamento/acolhimento, isto demonstra que os programas terapêuticos das atuais CT's necessitam buscar oferecer alternativas singularizadas e inovadoras para o melhor manejo destes casos, voltandose assim ao alcance da meta final de alta terapêutica para os sujeitos acolhidos, uma vez que outro dado apresentado pelo estudo, foi o de que quem teve alta terapêutica teve quase 2,5 vezes mais chances de desfecho bom (KURLANDER, 2019), ou seja, alcance de maiores ganhos nos indicadores de qualidade de vida.

Outro indicador importante que o estudo trouxe à tona, foi o de que acolhidos que estavam utilizando medicações psicoativas no momento do ingresso na CT tiveram quase 3 vezes mais chances de desfecho bom (KURLANDER, 2019), isso nos mostra que precisamos desmistificar visões estereotipadas de que os acolhidos não necessitam do uso de medicações psicoativas para trataremse nos ambientes das CT's, afinal, atualmente a dependência química é vista e entendida sobre a concepção de uma doença que leva em consideração fatores biológicos, psicológicos e sociais (Doença Biopsicossocial), assim o uso de medicações apresenta-se como um dos indicadores importantes para a maximização dos ganhos voltados à recuperação, outra questão significativa associada ao uso de medicações psicoativas, e que confirma os dados positivos apresentados no estudo, liga-se ao fato de que atualmente é possível percebermos que grande parte dos dependentes químicos, apresentam outra(as) patologia(s) associada(s) (Comorbidades Psiquiátricas) (FIGLIE; BORDIN; LARANJEIRA, 2015), este indicativo associativo, demonstra e justifica a necessidade da utilização de medicação psicoativa adequada para o tratamento de doenças comorbidas à dependência química, visto que muitas vezes estas doenças se apresentam ao longo do processo de tratamento/acolhimento, contudo para que tenhamos bom desfecho no que envolvem estas questões se fazem necessários bons/adequados processos de diagnóstico e/ou psicodiagnóstico dos acolhidos. 
Por fim, alguns indicadores gerais do estudo, sugerem que, para os acolhidos que tiveram alta terapêutica, estes apresentaram 95\% maiores chances de desfecho bom geral, índice de 2,52 vezes mais de participação em grupos de apoio, além de 2,27 maiores índices de participação em grupos religiosos, os acolhidos que concluíram com alta terapêutica, apresentaram ainda 83\% vezes mais participações em grupos de estudos, $19 \%$ vezes mais chances de conquistarem trabalhos remunerados, $27 \%$ vezes mais chances de reaproximações satisfatórias com as famílias de origem e $45 \%$ vezes mais chances de reaproximações satisfatórias com as famílias constituídas, esses dados são comparados aos dos acolhidos que não concluíram seus tratamentos com alta terapêutica, o que nos sugere que desligar-se da CT através de alta terapêutica oferece ganhos nestes aspectos (KURLANDER, 2019).

Desta maneira buscamos apresentar neste capítulo primeiramente um pouco sobre a entidade associativa/representativa de maior impacto e abrangência no pais, a Federação Brasileira de Comunidades Terapêuticas (FEBRACT), demonstrando um pouco sobre sua missão institucional e oferecendo dados atualizados sobre sua atuação em nível nacional, em um segundo momento apresentamos alguns dados científicos, baseados nas pesquisas mais recentes realizadas sobre os indicadores de eficácia dos tratamentos oferecidos a partir do modelo das atuais Comunidades Terapêuticas (modelo real), vale ressaltar que as CT's estudadas seguem o modelo de tratamento (terapêutico e institucional) proposto pela FEBRACT, o que sugere que nem todos os locais de tratamento que se denominam CT oferecem os mesmos indicativos de eficácia.

\section{CONSIDERAÇÕES FINAIS}

Frente as questões abordadas no artigo, foi possível percebermos que, as Comunidades Terapêuticas no Brasil, vivem atualmente um momento favorável, tanto no cenário das Políticas Públicas voltadas as questões de acolhimento, tratamento e reinserção social de usuários de drogas, como também, no cenário cientifico, uma vez que as CT's apresentam-se como ambientes de tratamento/acolhimento que estão vivenciando constantes transformações, (re)organizações e averiguações de eficácia, demonstrando assim, vasto potencial de exploração cientifica, para diversos campos do saber, que assim desejarem debruçar-se sobre estas instituições, bem como, seus atravessamentos.

Desta maneira, o presente artigo buscou explorar principalmente o cenário que diz respeito a produção/construção/estruturação cientifica do tema, visto que, fazem-se necessários estudos, que oferecem conhecimentos organizados/estruturados a respeito da área em questão, pois, ainda hoje 
enfrentamos graves dificuldades de entendimento do que realmente são CT's, isto ocorre em grande parte devido a muita desinformação reproduzida e pré-conceitos estereotipados (pensamento ideológico), que cercam os serviços oferecidos pelas Comunidades Terapêuticas no Brasil, a respeito desta dificuldade de entendimento e delimitação do que são realmente e o que não são Comunidades Terapêuticas, encontramos em raízes históricas algumas explicações, assim como nos mostra De Leon, 2014, quando sugere que, uma vez que grande parte do conhecimento produzido sobre o serviço prestado pelas CT's (em âmbito mundial) acabou sendo transmitido oralmente ao longo dos anos, carregando assim grandes cargas de subjetividade no decorrer do tempo, o que por sua vez acabou criando uma infinidade de distorções anti-terapêuticas vivenciadas por muitas instituições que levam o nome de Comunidade Terapêutica, mas que em suas práticas e dia-a-dia nada tem a ver com o modelo real de CT.

Assim, buscamos no capítulo I, demonstrarmos através do levantamento arqueológico/histórico, sociocultural e institucional destes serviços, o que realmente são Comunidades Terapêuticas, desta forma chegamos a um conjunto de práticas éticas e técnicas, que acabam por criar a caracterização básica desses ambientes de tratamento, sendo assim talvez os quatro principais pontos evidenciados como fatores de caracterização destes serviços girem em torno da existência de voluntariedade para aderência ao tratamento, acolhimento/tratamento intensivo vivenciado em caráter residencial transitório, constituição das relações institucionais experiênciadas de forma democrática/transversal, e clima terapêutico positivo construído através da convivência entre os pares, os demais pontos evidenciados que contribuem para a criação de identidade dos serviços prestados, ligam-se aos métodos atualmente utilizados, como por exemplo, os de, psicoeducação, (re)educação, ambiente livre de drogas e violências (físicas e/ou psicológicas-morais), ambientes de tratamento/acolhimento artificiais (em maior ou menor grau), e o oferecimento de práticas/métodos de tratamento que buscam o desenvolvimento global dos sujeitos acolhidos (voltados as áreas biopsicossociaisespirituais).

De acordo com o capítulo II, evidenciamos que o atual momento político vivenciado no País oferece favorecimento ao crescimento/incentivo, (re)organização, fiscalização/consultoria e ensino/pesquisa acerca do movimento das Comunidades Terapêuticas, uma vez que reconhece os serviços prestado por estas entidades particulares, sem fins lucrativos, como uma alternativa viável a demanda crescente de sujeitos que necessitam de tratamento/acolhimento para resolver problemas decorrentes do abuso ou dependência de SPA's e que acabam ficando muitas vezes desistidos pelos 
demais serviços públicos oferecidos atualmente, percebemos também ao longo do capítulo, que para que este desenvolvimento ocorra de forma satisfatória, as CT's necessitam por um lado comprometerem-se na busca da avaliação-reavaliação constante dos serviços oferecidos, focando-se assim na evolução e melhoramento (tanto em nível terapêutico quanto estrutural) permanente dos locais de tratamento/acolhimento. Entretanto vemos que, grandes passos já foram dados na direção da construção de Políticas Públicas voltadas as reais necessidades vivenciadas pela população brasileira no que se referem as questões envolvendo o abuso ou dependência de SPA's, assim, como também na desconstrução de favorecimentos à modelos de tratamento para a DQ que acabem por basearem-se em "politicagem ideológica" estereotipada, que são proferidas por parcelas detentoras do poder Estatal momentâneo, estas desconstruções de paradigmas dicotômicos (Abstinência $X$ Redução de Danos) contribui somente a quem realmente interessa a pluralidade de serviços oferecidos na área do tratamento/cuidado à $\mathrm{DQ}$, os dependentes químicos, pois são estes que realmente necessitam de amparo/cuidado/tratamento, independente de qual modelo possam se beneficiar.

A partir das discussões realizada no capítulo III, vimos que o serviço oferecido pelas CT's no Brasil carecem de organização/representação, uma vez que a grande maioria das instituições catalogadas em território nacional que prestam estes serviços (ou que pelo menos denominam-se CT's), não estão vinculadas a nenhuma entidade associativa/representativa, entretanto foi possível percebermos que, a Federação Brasileira de Comunidades Terapêuticas (FEBRACT), atualmente apresenta-se como a entidade associativa/representativa de maior abrangência no País, assim a partir dos dados oferecidos por esta entidade foi possível construirmos a noção de que as CT's caminham em direção da evolução do serviço oferecido, seja no que diz respeito as transformações/(re)organizações estruturais (questões físicas, terapêuticas e/ou legais), assim como no que diz respeito e averiguação/testagem cientifica da eficácia dos métodos oferecidos através do modelo real de CT (mesmo que de forma inicial os dados levantados, demonstram efetividade positiva do modelo, não somente em relação a manutenção da abstinência, mas principalmente nos ganhos relacionados aos indicadores de qualidade de vida). Assim, para que as CT's possam continuar a demonstrar ganhos de efetividade, como também maximiza-los, se faz necessário que estas instituições busquem construir organizações metodológicas e protocolares acerca dos serviços oferecidos em âmbito nacional, uma vez que desta maneira facilitam-se as aplicações de estudos científicos nestes ambientes, que tem o potencial de contribuir para o reconhecimento efetivo dos serviços como alternativas funcionais para o tratamento de $D Q$, além de que os acolhidos que utilizam-se destes serviços terão a possibilidade de apresentarem 
ganhos nos índices de efetividade e resultados positivos após seus períodos de acolhimento, pois sabemos que um serviço para ser eficaz de fato, necessita de organização e estruturação. Desta maneira não só o serviços oferecidos pela FEBRACT, mas, por todas as entidades associativas/representativas que direcionam-se à olhares éticos e comprometidos com o movimento das CT's, fazem-se de grande importância para o futuro destes serviços em âmbito nacional. Frente as questões que envolvem as necessidades de organização vemos que a FEBRACT vem sistematicamente caminhando para a construção de protocolos gerais de acolhimento e tratamento bem definidos e organizados, para as CT's filiadas, demonstrando que o modelo de tratamento em regime residencial transitório de caráter voluntário voltado a reinserção social de pessoas com transtornos decorrentes do abuso ou dependência de substâncias psicoativas, conhecido como Comunidades Terapêuticas, encontram entidades associativas/representativas preocupadas pela busca por inovação, aprimoramento, auto-avaliação e evolução dos serviços oferecidos.

Como foi possível percebermos ao longo deste estudo os métodos e práticas utilizados(as) nas atuais CT's (modelo real) em território nacional, encontram-se muito além das práticas assistencialistas/higienistas que comumente são/eram ligadas a estes serviços (imaginário cultural pautado no desconhecimento), assim vemos que um grande leque de possibilidades de atuações dentro destes ambientes de tratamento vem se abrindo, frente a esta constatação percebemos que práticas oriundas da análise institucional e do pensamento esquizoanálitico podem oferecer ganhos significativos para os ambientes institucionais das CT's, uma vez que é a partir das relações de podersaber que se estabelecem entre os agentes que corporificam estes espaços, que formam-se climas terapêuticos por vezes positivos-saudáveis-democráticos, por vezes negativos-iatrogênicosalienantes, assim tanto as contribuições da analise institucional quanto as da esquizoanálise oferecem suporte para pensarmos/repensarmos, avaliarmos/diagnosticarmos, desconstruirmos/micro revolucionarmos e transversalizarmos estas relações baseadas em saber-poder que se apresentam por vezes enrijecidas e extremamente hierarquizadas nas CT's Brasil afora, fazendo com que se percam uma das características básicas destes espaços de tratamento, a democratização. Estas práticas até então pouco comuns nestes ambientes institucionais, também podem oferecer alternativas para lidar com os altos índices de adoecimento enfrentados pelas equipe multidisciplinares/transdisciplinares que atuam nestes espaços, e que acabam muitas vezes sofrendo e adoecendo devido aos processos de subjetivação alienantes que os ambientes adoecidos oferecem. 
Por fim, a partir do estudo realizado foi possível vermos que, o processo de fazer/viver Comunidade Terapêutica é uma construção que se dá no coletivo, é uma experiência plural, multicultural, multiprofissional, diversificada, contudo não deixa de ser organizada, pensada, estudada, baseada em métodos e práticas com valor científico, desta forma as CT's que seguem o modelo real apresentamse atualmente como ambientes de produção e inovação, (re)significação da vida adoecida, além de fugirem de qualquer lógica de massificação, alienação ou institucionalização do sujeito, uma vez que estes ambientes de tratamento/acolhimento acreditam no potencial que somente o encontro das diferenças, das singularizações são capazes de produzir, mantendo a essência democrática, focadas no fazer-se coletivo, sem deixarem de estar abertas a inovação, este são alguns dos desafios das CT's nos dias atuais. 


\section{REFERÊNCIAS}

BENELLI, SJ. A lógica da internação: instituições totais e disciplinares (des)educativas [online]. São Paulo: Editora UNESP, 2014. Disponível em: http://books.scielo.org/id/74z7q/pdf/benelli9788568334447.pdf

BRASIL. Ministério da Justiça. Secretaria Nacional de Políticas sobre Drogas. Comunidades Terapêuticas: histórico e regulamentações. In: . Aberta: portal de formação a distância. Florianópolis: UFSC, 2017.

. Ministério da Cidadania/Gabinete do Ministro. PORTARIA № 562, DE 19 DE MARÇO DE 2019. Cria o Plano de Fiscalização e Monitoramento de Comunidade Terapêutica no âmbito da Secretaria Nacional de Cuidados e Prevenção às Drogas - SENAPRED. Edição: 54, Seção: 1, Página: 4. Publicado em: 20/03/2019.

. Ministério da Cidadania/Gabinete do Ministro. PORTARIA № 563, DE 19 DE MARÇO DE 2019. Cria o cadastro de credenciamento das comunidades terapêuticas e das entidades de prevenção, apoio, mútua ajuda, atendimento psicossocial e ressocialização de dependentes do álcool e outras drogas e seus familiares, e estabelece regras e procedimentos para o referido credenciamento no âmbito do Ministério da Cidadania. Edição: 54, Seção: 1, Página: 14. Publicado em: 20/03/2019.

. Ministério da Cidadania/Gabinete do Ministro. PORTARIA № 564, DE 19 DE MARÇO DE 2019. Institui a Certificação de Qualidade dos Cursos de Capacitação para Comunidades Terapêuticas. Edição: 54, Seção: 1, Página: 16. Publicado em: 20/03/2019.

. Decreto no 7.179, de 20 de maio de 2010. Institui o Plano Integrado de Enfrentamento ao Crack e outras Drogas, cria o seu comitê gestor, e dá outras providências. Diário Oficial da União, Brasília, p. 43, 21 maio 2010. Seção 1. Disponível em: https://goo.gl/OTfGDF Acessado em: 30/03/2019.

. Decreto no 7.637, de 8 de dezembro de 2011. Altera o Decreto no 7.179/2010, que institui o Plano Integrado de Enfrentamento ao Crack e outras Drogas. Diário Oficial da União Brasília, p. 29, 9 dez. 2011. Seção 1. Disponível em: https://goo.gl/IZAG7d Acessado em: 30/03/2019.

. Ministério da Saúde. Agência Nacional de Vigilância Sanitária. Resolução RDC-ANVISA № 101, de 30 de Maio de 2001. Estabelece Regulamento Técnico disciplinando as exigências mínimas para o funcionamento de serviços de atenção a pessoas com transtornos decorrentes do uso ou abuso de substâncias psicoativas, segundo modelo psicossocial, também conhecidos como Comunidades Terapêuticas. Disponível em:

http://www.saude.mg.gov.br/index.php?option=com_gmg\&controller=document\&id=556 Acessado em: 30/03/2019.

. Ministério da Saúde. Agência Nacional de Vigilância Sanitária. Resolução RDC_ANVISA № 29, de 30 de Junho de 2011. Dispõe sobre os requisitos de segurança sanitária para o funcionamento de instituições que prestem serviços de atenção a pessoas com transtornos decorrentes do uso, abuso ou dependência de substâncias psicoativas. Disponível em: 
http://bvsms.saude.gov.br/bvs/saudelegis/anvisa/2011/res0029_30_06_2011.html Acessado em: 30/03/2019.

Agência Nacional de Vigilância Sanitária. NOTA TÉCNICA № 1/2011. Esclarecimentos e orientações sobre o funcionamento de instituições que prestem serviços de atenção a pessoas com transtornos decorrentes do uso, abuso ou dependência de substâncias psicoativas - RDC $n^{\circ} 29$, de 30 de junho de 2011. Publicado em: 15 de julho de 2011. Disponível em: http://portal.anvisa.gov.br/documents/33852/271858/Nota+t\%C3\%A9cnica+n\%C2\%BA+01+de+201 1/fe65a47c-ae23-4cd6-a9be-bef63d0d30f9 Acessado em: 30/03/2019.

. Ministério da Saúde. Gabinete do Ministro. Portaria № 3.088, de 23 de Dezembro de 2011*. Institui a Rede de Atenção Psicossocial para pessoas com sofrimento ou transtorno mental e com necessidades decorrentes do uso de crack, álcool e outras drogas, no âmbito do Sistema Único de Saúde (SUS). *Republicada por ter saído, no DOU no 96, de 21.05.2013, Seção 1, págs. 37/38, com incorreção no original. Disponível em:

http://bvsms.saude.gov.br/bvs/saudelegis/gm/2011/prt3088_23_12_2011_rep.html Acessado em 01/01/2019.

- Ministério da Justiça. Conselho Nacional de Políticas sobre Drogas. Resolução do CONAD № 1, de 19 de Agosto de 2015. Regulamenta, no âmbito do Sistema Nacional de Políticas Públicas sobre Drogas Sisnad, as entidades que realizam o acolhimento de pessoas, em caráter voluntário, com problemas associados ao uso nocivo ou dependência de substância psicoativa, caracterizadas como Comunidades Terapêuticas. Diário Oficial da União Publicado em: 28/08/2015. Edição: 165. Seção: 1. Página: 51. Disponível em:

http://www.in.gov.br/materia/-/asset_publisher/Kujrw0TZC2Mb/content/id/32425953/do1-201508-28-resolucao-n-1-de-19-de-agosto-de-2015-32425806 Acessado em: 12/05/2018.

. Ministério da Justiça. Gabinete do Ministro. Resolução CONAD № 1, de 9 de Março de 2018. Aprova as diretrizes para o realinhamento e fortalecimento da Política Nacional sobre Drogas - PNAD, programas, projetos e ações dela decorrentes sob responsabilidade e gestão da União Federal. Diário Oficial da União. Publicado em: 13/03/2018. Edição: 49. Seção: 1. Página: 79. Disponível em: http://www.in.gov.br/materia/-/asset_publisher/Kujrw0TZC2Mb/content/id/6285975/do1-2018-0313-resolucao-n-1-de-9-de-marco-de-2018-6285971 Acessado em: 01/04/2019.

- Ministério da Saúde. Secretaria de Atenção à Saúde. Departamento de Ações Programáticas Estratégicas. Coordenação-Geral de Saúde Mental, Álcool e Outras Drogas. NOTA TÉCNICA № 11/2019-CGMAD/DAPES/SAS/MS. Assunto: Esclarecimentos sobre as mudanças na Política Nacional de Saúde Mental e nas Diretrizes da Política Nacional sobre Drogas. Disponível em: http://pbpd.org.br/wp-content/uploads/2019/02/0656ad6e.pdf Acessado em: 20/03/2019.

COED. Principais Números de Atendimento do Programa Recomeço: 2013 a 2016. Disponível em: http://www.desenvolvimentosocial.sp.gov.br/a2sitebox/arquivos/documentos/1493.pdf Acessado às 16:12, em 12/03/2019.

COSTA, Selma Frossard. As Políticas Públicas e as Comunidades Terapêuticas no Atendimento à Dependência Química. In: Serviço Social em Revista. ISSN 1679-4842. Vol. 11 - № 2, Jan/Jun 2009. 
DE LEON, G. A Comunidade Terapêutica: teoria, modelo e método. São Paulo: Loyola, 2014.

Evento do Ministério da Cidadania. Ações para o fortalecimento das Comunidades Terapêuticas: tratamento e prevenção ao uso de drogas. 19/03/2019. Disponível em: http://mds.gov.br/area-deimprensa/noticias/2019/marco/governo-amplia-vagas-e-regulamenta-o-tratamento-de-

dependentes-quimicos-em-comunidades-terapeuticas/view Acessado em: 19/03/2019.

FEBRACT. Dados disponibilizados pelo setor administrativo da Federação Brasileira de Comunidades Terapêuticas via e-mail, em: 11/03/2019.

FIGLIE, N. B; BORDIN, S; LARANJEIRA, R. Aconselhamento em dependência química. 3a ed. São Paulo: Roca, 2015.

FLICK, Uwe. Introdução à pesquisa qualitativa. 3a ed. Porto Alegre. Artmed, 2009.

FRACASSO, L. Características da Comunidade Terapêutica. In: . Drogas e Álcool Prevenção e Tratamento. Serrat, Saulo Monte (org.) Campinas: Ed. Komedi, 2011.

FRACASSO, L. Cap. 54. Comunidades Terapêuticas. In: . Dependência Química: Prevenção, Tratamento e Políticas Públicas. Alessandra Diehl ... [et. al.] Porto Alegre: Artmed, 2011.

IPEA. Nota técnica № 21: O perfil das Comunidades Terapêuticas Brasileiras. DIEST: Diretoria de Estudos e Políticas do Estado, das Instituições e da Democracia. Março, 2017.

JONES, M. A Comunidade Terapêutica. Petrópolis: Ed. Vozes, 1972.

KURLANDER, P. A. A comunidade terapêutica para recuperação da dependência do álcool e outras drogas no Brasil: mão ou contra mão da reforma psiquiátrica? Ciência \& Saúde Coletiva. ABRASCO Associação Brasileira de Saúde Coletiva, v. 19, n. 2, p. 569-580, 2014.

KURLANDER, P. A. Fatores associados a recidiva e abandono do tratamento de dependentes químicos: um estudo longitudinal de eficácia em duas Comunidades Terapêuticas. Tese de doutorado defendida no Programa de Pós-Graduação em Saúde Coletiva da Faculdade de Medicina de Botucatu. UNESP Botucatu, SP, 2019.

MADRUGA, Clarice Sandi. A Pesquisa Científica na Avaliação da Eficácia do Método das CTs. Painel apresentado durante a realização da XVI CONFERÊNCIA LATINO-AMERICANA DE COMUNIDADES TERAPÊUTICAS, ocorridos nos dias 07, 08 E 09 de dezembro em Campinas/SP, 2017. Disponível em: http://www.febract.org.br/palestras/CLACT-BRASIL-08-12-2017-11-00-Clarice-Madruga-A-PesquisaCient\%C3\%ADfica-na-Avaliacao-da-Eficacia-do-Metodo-da-CT.pdf Acessado em: 20/12/2017.

MELO, E. RENATA, R. Sobre as instituições totais: instituições totais, conceitos básicos. Disponível em: https://analiseinstitucional.wordpress.com/ Dezembro de 2008.

NIDA. National Institute on Drug Abuse. Princípios de tratamento da dependência química: um guia baseado em pesquisa. Conferência Nacional de Tratamento de Dependência em Drogas: da Pesquisa à prática. 1998. 
PAYÁ, R; PROENÇA, Patrícia França. Cap. 64. Cuidando de quem cuida: a equipe multidisciplinar também pode adoecer? In: - Dependência Química: Prevenção, Tratamento e Políticas Públicas. Alessandra Diehl ... [et. al.] Porto Alegre: Artmed, 2011.

SANTOS, Maria Paula Gomes. Políticas de cuidado a pessoas com transtornos decorrentes do uso de drogas: controvérsias em torno das Comunidades Terapêuticas. Apresentado no 41 으ctontro Anual da ANPOCS. SPG11 Drogas, atores e sociedade. Disponível em:

https://anpocs.com/index.php/encontros/papers/41-encontro-anual-da-anpocs/spg-4/spg114/10967-politicas-de-cuidado-a-pessoas-com-transtornos-decorrentes-do-uso-de-drogascontroversias-em-torno-das-comunidades-terapeuticas?format=html\&path=41-encontro-anual-daanpocs/spg-4/spg11-4 Publicado em 16/10/2017. Acessado em: 23/10/2018.

SÃO PAULO. Assembleia Legislativa do Estado de São Paulo. Secretaria Geral Parlamentar. Departamento de Documentação e Informação. Decreto № 61.674, de 02 de Dezembro de 2015. Reorganiza o "Programa Estadual de Enfrentamento ao Crack - Programa Recomeço", que passa a denominar-se "Programa Estadual de Políticas sobre Drogas - Programa Recomeço: uma vida sem drogas". Disponível em: https://www.al.sp.gov.br/repositorio/legislacao/decreto/2015/decreto61674-02.12.2015.html Acessado em: 23/03/2019. 


\section{NOTAS}

\section{Nota 1}

Título original: “OS PRINCIPAIS DESAFIOS E POTENCIALIDADES DAS COMUNIDADES TERAPÊUTICAS NO BRASIL: Reflexões à luz dos 50 anos do Movimento Nacional das CTs e das novas diretrizes da Política Nacional sobre Drogas"; Artigo apresentado à Faculdade UNYLEYA como exigência parcial à obtenção do título de Especialista em Psicopatologia e Dependência Química-2019.

Nota 2

Ocorrido a cerca de 75 anos atrás com as primeiras Comunidades Terapêuticas Psiquiátricas na GrãBretanha (De Leon, 2014).

Nota 3

Nascimento da Biopolítica (1978-1979), Microfísica do Poder (1979), Vigiar e Punir (1975), História da Loucura (1961), O Governo de Si e dos Outros (1983), O Governo de Si e dos Outros: a coragem da verdade (1984), Subjetividade e Verdade (1980-1981), entre outras obras.

Nota 4

Regulamenta, no âmbito do Sistema Nacional de Políticas Públicas sobre Drogas (SISNAD), as entidades que realizam o acolhimento de pessoas, em caráter voluntário, com problemas associados ao uso nocivo ou dependência de substância psicoativa, caracterizadas como Comunidades Terapêuticas.

Nota 5

A Comunidade Terapêutica: teoria, modelo e método. São Paulo: Loyola, 2014.

Nota 6

Referência ao Relatório da Inspeção Nacional em Comunidades Terapêuticas - 2017 / Conselho Federal de Psicologia; Mecanismo Nacional de Prevenção e Combate à Tortura; Procuradoria Federal dos Direitos do Cidadão / Ministério Público Federal; - Brasília DF: CFP, 2018.

\section{Nota 7}

Em seu livro Manicômios, prisões e conventos. 2a ed. São Paulo: Perspectiva. 1987.

Nota 8

Crack é uma substância psicoativa (SPA) ilícita, de ação estimulante do sistema nervoso central. 0 crack é um subproduto da pasta da cocaína, droga extraída por meio de processos químicos, das folhas da coca (Erythroxylum coca), uma planta originária da América do Sul.

Nota 9

Decreto no 7.179/2010 “Institui o Plano Integrado de Enfrentamento ao Crack e outras Drogas, cria o seu Comitê Gestor, e dá outras providências" (BRASIL, 2010). Decreto no 7.637/2011 “Altera o Decreto no 7.179/2010, que institui o Plano Integrado de Enfrentamento ao Crack e outras Drogas" (BRASIL, 2011). 
Nota 10

A Redução de Danos (RD) é uma alternativa de saúde pública para os modelos referentes ao uso, abuso e/ou DQ de SPA's que foge das visões e entendimentos pautados sobre prismas morais, criminais e de doença, a RD reconhece a abstinência como resultado ideal, mas aceita alternativas que reduzam os danos causados pelo uso e abuso de SPA'S (FIGLIE, N. B; BORDIN, S; LARANJEIRA, R, 2015), contudo, atualmente vivemos em nosso país grande nível de desinformação sobre este modelo de cuidado, sendo que na grade maioria das vezes a má interpretação deste modelo parte dos próprios agentes que corporificam as instituições que trabalham focadas sobre esta lógica.

Nota 11

Refere-se ao atual cenário da Política Nacional sobre Drogas do país, que criou o paradigmadicotômico de estereotipações, que relaciona o modelo de cuidado pautado sobre a RD com: liberdade - ideologia de esquerda - ao mesmo tempo que relaciona o modelo de cuidado pautado na Abstinência com: aprisionamento - ideologia de direita - assim ao invés do foco dos serviços estar voltado ao fortalecimento da rede de cuidados, este acaba se voltando para o congelamento/enrijecimento da mesma, priorizando vaidades tolas dos detentores do poder e dificultando os ganhos para aqueles que necessitam da rede (usuários).

\section{Nota 12}

Muitas destas críticas foram muito bem fundamentadas, visto a falta de organização e planejamento terapêutico que os ambientes de tratamento que se denominam CT's apresentam, isso justifica-se devido à falta de documentação legal e técnico cientifica que organiza/delimita seus serviços em âmbito nacional.

Nota 13

Fonte: Site do Ministério da Justiça e Segurança Pública. Disponível em: http://www.justica.gov.br/news/decisao-judicial-restabelece-status-de-comunidades-terapeuticas. Acessado em: 01/04/2019.

Nota 14

Esta afirmativa se fundamenta a partir da constatação de que a partir do ano de 2001 aconteceram constantes mudanças no que se refere a organização dos serviços oferecidos por instituições caracterizadas como Comunidades Terapêuticas (ANVISA-2001, SISNAD-2006, ANVISA-2011, RAPS2011 CONAD-2015), sendo assim, vimos e vemos as dificuldades que tais serviços tem em adequaremse as leis, normativas, decretos e resoluções propostos(as) ao longo dos anos, podemos constatar que até o ano de 2019, somente foram cobradas responsabilidades (enquadres jurídicos) destas instituições, contudo em contra partida não foram oferecidas alternativas de acompanhamento/consultoria/fiscalização que atingissem número significativo de instituições em âmbito nacional, o que, por sua vez dificultou o processo de adequação de tais entidades as atuais exigências, isso justifica-se devido ao favorecimento até então realizado pelo Estado ao incentivo da construção e consolidação de Políticas Públicas voltadas a RD e do esquecimento e desfavor da Abstinência. 
Nota 15

Resolução CONAD № 1/2018.

Nota 16

Órgão governamental responsável pelo realinhamento da Política Nacional sobre Drogas e pelo atual acompanhamento dos serviços de interesse desta política/temática. Substituiu a antiga Secretaria Nacional de Políticas sobre Drogas (SENAD) que respondia ao ministério da Justiça e Segurança Pública.

\section{Nota 17}

Dados obtidos através do site da Federação Brasileira de Comunidades Terapêuticas. Disponível em: https://febract.org.br/portal/filiadas/. Acessado em 01/04/2019.

\section{Nota 18}

Percentual atualizado comparando dados de 2016 e 2019 acerca do número de filiadas da FEBRACT, sendo que em 2016 a entidade contava com 250 filiadas e atualmente conta com 239 filiadas (FEBRACT, 2019).

\section{Nota 19}

Dados que seguem de acordo com os principais números de atendimentos do Programa Recomeço, levantados entre o período de 2013 a 2016 (COED).

Nota 20

Abandono precoce $=$ antes dos 90 primeiros dias de acolhimento/tratamento.

Abandono geral $=$ depois dos 90 dias de acolhimento/tratamento. 


\section{Capítulo 12}

\section{doi $10.37423 / 210604339$}

\section{UMA ABORDAGEM AO USO DOS RECURSOS TECNOLÓGICOS NA PRÁTICA DO DOCENTE DE MATEMÁTICA.}

GLEIDSON JOSÉ DUMONT OLIVEIRA

ANDREIA GENÍ DE BARROS GUEDES

MOISÉS DOS SANTOS

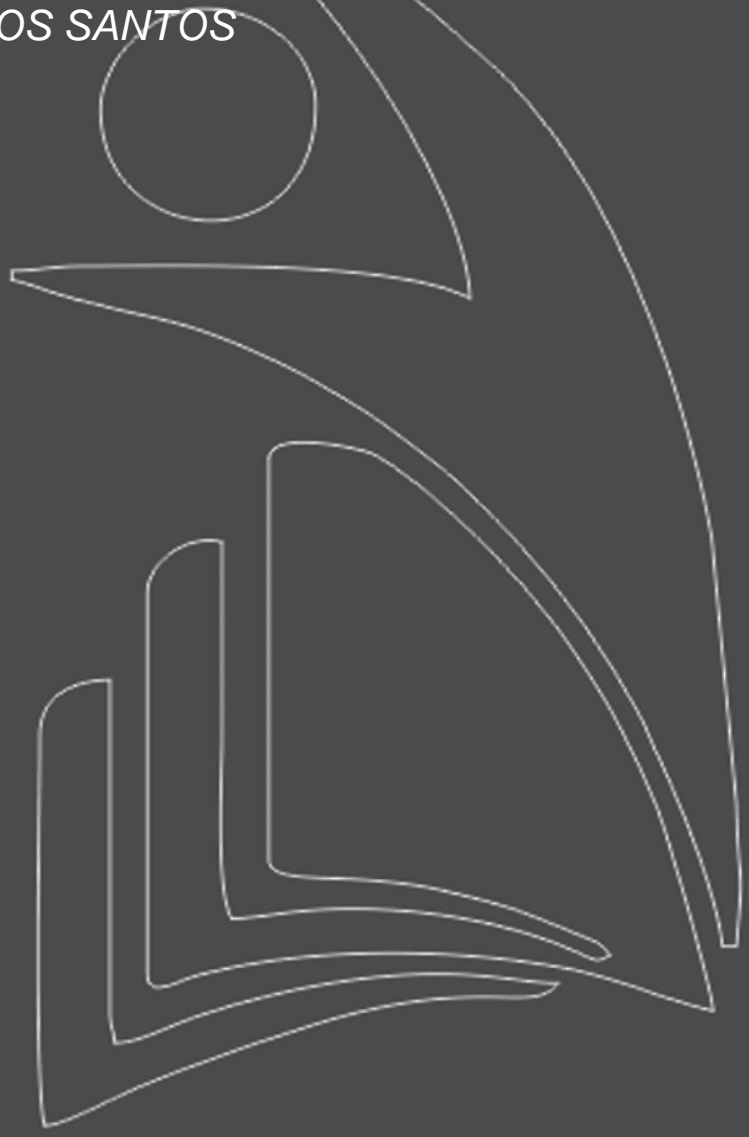

Instituto Federal de Pernambuco

Instituto Federal da Paraíba

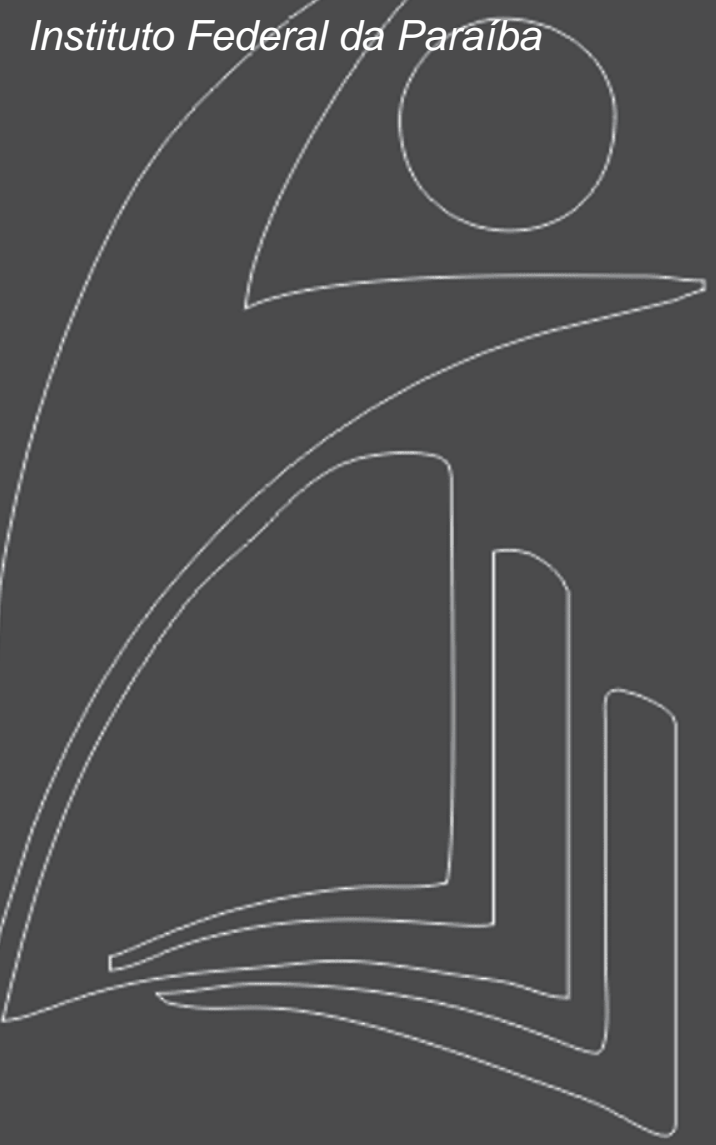


Resumo: Nos últimos anos os procedimentos metodológicos e as tendências educacionais foram modificando-se com o objetivo de facilitar o processo de ensino-aprendizagem, aproximando alunos, professores e recursos tecnológicos. Devido aos baixos índices de desempenho, e as mudanças no sistema educacional brasileiro, inúmeras discussões sobre como melhorar o desempenho dos alunos em sala de aula são tema de diversos encontros, congressos, e grupos que discutem sobre a educação matemática. Um tema bastante atual sobre métodos inovadores que facilitam a aprendizagem, independente das limitações sociais e cognitivas dos alunos, e que tornam as aulas de matemática mais dinâmicas é a utilização de recursos tecnológicos durante o processo de ensino. Neste trabalho buscou-se investigar como um grupo de professores, pensam a respeito de tais recursos, se os conhecem, com que frequência os utilizam, e qual a opinião deles sobre o uso de tais recursos em aulas de matemática, para facilitar o ensino, independente da dificuldade do aluno.

Palavras chave: Educação matemática, Novas tecnologias, Recursos didáticos, Educação Inclusiva. 


\section{INTRODUÇÃO}

Nos dias atuais, os recursos tecnológicos, tais como: televisão, rádio, calculadora, computadores, celulares e outros; estão cada vez mais presentes no cotidiano das pessoas, principalmente dos jovens, mas será que os professores utilizam esses ou outros recursos tecnológicos em suas aulas de matemática? Diante dessa indagação, buscou-se como problema de pesquisa verificar se docentes em matemática são a favor do uso dos recursos tecnológicos em suas aulas e também os utilizam como facilitador no processo de ensino-aprendizagem, independente de possíveis dificuldades apresentadas pelo aluno. Onde, como hipótese, acreditava-se que os professores conheciam os recursos tecnológicos, mas em sua maioria não utilizavam.

Os Parâmetros Curriculares Nacionais (Brasil, 1998), propõem que o trabalho para com o ensino de matemática em sala de aula, deverá ser realizado de forma a explorar objetos do mundo físico, e apontam ainda a necessidade de desenvolver diferentes linguagens como meio para produzir, comunicar e expressar ideias, assim como a utilização de recursos tecnológicos na construção de conhecimentos.

Uma nova fase em que a educação e o mundo estão passando, pode ser encarada como um momento de evolução tecnológica, evolução essa que poderá trazer vários benefícios para a inclusão digital, bem como facilidade na compreensão das aulas de matemática para alunos

com transtornos globais, dificuldades cognitivas; além de socialização com programas educacionais inovadores, contribuindo para o enriquecimento de estratégias de ensino na matemática, tornando-a menos "chata" e "cansativa", mesmo que a entrada da tecnologia na educação venha provocando inquietação aos professores, uma vez que estes, provavelmente, não foram devidamente preparados para lidar com esses recursos, e toda mudança traz consigo a insegurança e o "medo" do novo, requerendo uma adequação de postura frente aos novos equipamentos e desafios do processo educacional.

A pesquisa fundamentou-se nas ideias de Scheffer (2009), Miskulin (2009), D’Ambrósio (1993), Moran (2000), Brasil (1998) e outros que defendem o uso dos recursos tecnológicos como ferramenta metodológica e facilitadora no processo de ensino e aprendizagem para alunos com dificuldades em compreender conceitos matemáticos. O trabalho buscou como objetivo geral investigar a opinião de professores sobre a utilização de recursos tecnológicos e de forma mais específica procurou observar se os professores são a favor do uso dos recursos tecnológicos nas aulas de matemática, verificando 
quais ferramentas eles utilizam nas suas aulas, bem como com que frequência elas são exploradas, percebendo a opinião dos docentes a respeito do uso dos recursos.

A pesquisa foi realizada através de uma investigação qualitativa e quantitativa, exploratória de forma descritiva, apoiada nas ideias metodológicas de Oliveira (2008) e Cunha (2009). Tomaram-se como público alvo dez professores de matemática que responderam um questionário de análise a respeito do uso dos recursos tecnológicos nas aulas de matemática, o qual era composto por dez questões. Após a aplicação do instrumento de coleta de dados, questionário, os dados foram organizados através de gráficos e analisados.

Após análise dos questionários, percebemos que há uma grande aceitação do uso dos recursos tecnológicos na educação por grande parte dos educadores, e que os docentes percebem que os elementos tecnológicos estão cada vez mais presentes nas diferentes atividades humanas, além de serem exaustivamente atualizados e modificados; por meio dos avanços e inserção digital, novos equipamentos eletrônicos são lançados a todo momento, e com isso, observamos que é necessário ligarmos a tecnologia à didática. Porém não podemos esquecer que o uso de um recurso tecnológico, como o computador, Datashow, televisão, calculadora e celulares nas aulas de Matemática, requerem cuidados e reflexão a respeito de suas finalidades e funções.

\section{TECNOLOGIAS DA INFORMAÇÃO NA FORMAÇÃO DE PROFESSORES}

As mudanças na educação contemporânea sugerem um ensino-aprendizagem diferente do modelo tradicional. A matemática já foi, e ainda é por alguns, considerada como "bicho-papão" nas escolas, além de ser citada por estudiosos como filtro social, uma vez que os alunos bons em matemática são os que vão obter sucesso no mercado de trabalho. Tal dificuldade aumenta se inseríssemos, nesse contexto, alunos com dificuldade física, cognitiva e mental; visto que por muito tempo eles estudavam em escolas distintas das que alunos que não apresentam as dificuldades citadas estudavam, porém, hoje, o sistema de ensino foi reformulado e os alunos com necessidades especiais frequentam o ensino regular.

Procurando alternativas de recursos que facilitem o ensino de matemática, encontramos diversas ferramentas. Uma que despertou o interesse pela investigação foi às tecnologias da informação e comunicação (TICs), que segundo Miskulin (2009, p. 153) "pressupõem novas formas de gerar, dominar e disseminar o conhecimento", além de proporcionar uma nova dimensão ao processo educacional, a qual transcende os paradigmas ultrapassados de ensino tradicional. O ensino dinâmico 
proporciona uma melhor aprendizagem e promove o desenvolvimento do pensamento criativo dos alunos e cabe aos educadores estarem abertos as novas e diversas formas de ensinar matemática, proporcionando uma evolução nos índices de aprendizagem efetiva com relação à disciplina e também a não exclusão de alunos com dificuldades de passarem pelo mesmo processo de ensinoaprendizagem.

De forma geral percebemos o quanto as TICs estão presentes em nossas vidas, como exemplos simples têm-se: computadores, câmeras de vídeos, gravação domesticas de DVDs e CDs, celulares, e-mail, internet, entre outros; além de trazer um desenvolvimento que valoriza a experimentação, a exploração e o papel ativo dos discentes na aprendizagem.

Para D’Ambrósio (1993) é importante que os cursos de formação de professores de matemática preparem melhor os futuros docentes para estarem aptos a promoverem aulas diferenciadas, conhecendo os diversos softwares disponíveis e sabendo utilizá-los, pois grande parte dos professores do ensino superior tiveram uma formação tradicional e trazem para universidade aulas com esse tipo de influência, e não preparam bem futuros docentes para utilizar tais recursos.

Ainda com respeito ao preparo dos professores nos cursos de formação, também é importante dar atenção aos alunos com dificuldades, social os cognitiva, devido à inclusão destes no sistema regular de ensino, pois segundo Ceolin, Machado e Nehring (2009), "é necessário começarmos por uma discussão tanto no processo de formação inicial quanto continuada, no sentido de qualificação deste profissional da Matemática", onde os autores chamam atenção para que os cursos de formação de professores preparem os futuros docentes para atender a todos os alunos, independentemente de suas dificuldades cognitivas.

As novas tecnologias estão cada vez mais presentes no dia a dia das pessoas, e nas escolas não é diferente. Moran (2000) diz que o desafio da utilização pedagógica da internet está em transformar a informação em conhecimento e integrar as tecnologias em projetos pedagógicos para serem utilizados como recursos de ensino, além de fazer com que as aulas de matemática sejam mais atrativas e que não fiquem tão monótonas e cansativas.

A utilização de softwares em aulas de matemática é considerada um fator importante para professores que buscam práticas interdisciplinares. A tecnologia deve ser integrada à prática pedagógica dos docentes, e ao currículo que será desenvolvido, pois os recursos tecnológicos são ferramentas que facilitam a aprendizagem e suprem certas dificuldades, mas vale ressaltar as diferentes formas que cada aluno pode chegar ao conhecimento e os diferentes obstáculos que cada um pode enfrentar, 
pois, segundo Almeida (2016), dificuldades em matemática podem ocorrer não pelo nível de complexidade ou rejeição a disciplina, mas por fatores mentais, psicológicos e pedagógicos que envolvem uma série de conceitos e trabalhos que precisam ser desenvolvidos ao se tratar de dificuldades em qualquer âmbito, inclusive as necessidades especiais.

Os softwares são citados por Carreaher (1992 apud Scheffer, 2009) como "uma ferramenta intelectual que auxilia o estudante a raciocinar sobre certos fenômenos". Uma diversidade de softwares matemáticos gratuitos, está disponível para uso em diversos conteúdos, podendo ser usados no trabalho com certos conceitos matemáticos, dentre eles: Cabri-Geometry, Cinderella, Curve Expert, DR Geo, Euklid, Geometria Descritiva, Geoplan, Geospace, Great Stella, Poly, Régua e Compasso, Shapari, Sketchpad, Wingeom, Graphequation, Graphmatica, Mathgv, Modellus, Ratos, Vrum - Vrum, Winplot, Winmat; dentre outros que podem ser conseguidos pela internet, através de alguns links disponíveis e gratuitos.

Scheffer (2009) comenta sobre o uso de ambientes informatizados como ferramenta pedagógica, e que tal ambiente exige que o professor esteja sempre atualizado e bem preparado para pratica docente, apesar das dificuldades enfrentadas pelo exercício da sua profissão. Somando-se a isso, temos a política de inclusão nas escolas, onde o professor deve procurar meios diferenciados para facilitar a compreensão de conteúdo, não fugindo dessa responsabilidade, e buscando compreender a dificuldade cognitiva de cada aluno, pois, segundo Almeida et al (2014) "o aluno especial possui particularidades, relacionadas à suas limitações (sejam física, mentais ou cognitivas), e precisa ser tratado de tal maneira que não se sinta diferente dos demais e ao mesmo tempo tenha a possibilidade de aprender de maneira significativa".

\section{PROCEDIMENTOS METODOLÓGICOS}

Considerando os aspectos metodológicos da pesquisa cientifica, trabalhou-se com uma pesquisa de investigação qualitativa e quantitativa, exploratória de forma descritiva, na qual se procurou fazer um levantamento bibliográfico entre livros, dissertações e artigos que exploram o uso dos recursos tecnológicos na prática docente. Tendo como objetivo de pesquisa investigar a opinião de professores sobre a utilização de recursos tecnológicos.

Para Oliveira (2008), as abordagens qualitativas facilitam uma descrição mais complexa dos problemas, além de contribuir para a investigação das hipóteses iniciais, como também possibilita a análise e permitem classificar determinados processos sociais, oferecendo melhores contribuições ou 
intervenções. As pesquisas quantitativas são mais adequadas para apurar situações, pois utilizam instrumentos padronizados como questionários. Esse tipo de pesquisa testa de forma precisa as hipóteses levantadas, além de fornecer dados que podem ser comparados com outros.

Tem-se que a pesquisa quantitativa permite a mensuração de opiniões, reações, hábitos e atitudes em um universo, por meio de uma amostra que o represente estatisticamente. Além disso, colaborando com o pensamento de Oliveira (2008) a pesquisa foi exploratória por obter razões para o fenômeno que está sendo estudado, e descritiva por expor os dados estudados a parti da análise dos questionários.

Em seguida, através da aplicação de um questionário de análise composto por dez questões a respeito do uso dos recursos tecnológicos nas aulas de matemática, procurou-se identificar a formação dos professores de matemática, suas opiniões com relação ao uso das ferramentas tecnológicas e com que frequência eles a utilizam. O questionário foi aplicado com 10 professores de matemática de Campina Grande - PB, que lecionam em escolas públicas e/ou particulares, no ensino fundamental II e/ou no ensino médio.

A investigação também se apoiou nas ideias de Cunha (2009), na qual o objetivo da avaliação não é estabelecer uma perspectiva correta e sim, alcançar um "ideal" comum para o processo de investigação. Ideal esse que é fazer com que os docentes percebam que os recursos tecnológicos podem ser utilizados como ferramentas que facilitam o processo de ensino-aprendizagem, além de tornar as aulas de matemática mais interessantes, inclusiva e atrativas.

Em seguida, após análise dos resultados do instrumento de coleta de dados, as informações obtidas foram organizadas e analisadas, buscando-se tratar de forma estatística cada uma das questões. Para efeito de considerações finais, procurou-se expor, através de gráficos, as respostas dadas ao questionário de análise a respeito do uso dos recursos tecnológicos nas aulas de matemática e fazer um breve comentário com relação às respostas obtidas.

\section{ANÁLISE PRELIMINAR DO INSTRUMENTO APLICADO AOS DOCENTES}

Segue abaixo o que se buscou em cada item do instrumento aplicado.

1. No primeiro item, identificar o nível de instrução dos docentes.

2. No segundo item, verificar a quanto tempo o docente leciona. 
3. No terceiro item, investigar a opinião do professor a respeito do dos recursos tecnológicos nas aulas de matemática.

4. No quarto item, identificar quais recursos tecnológicos os docentes conhecem e que podem ser utilizados nas aulas de matemática.

5. No quinto item, verificar quais softwares matemáticos os professores conhecem e indicam para o uso nas aulas de matemática.

6. No sexto item, analisar se a escola que o docente trabalha possui recursos tecnológicos, e caso positivo identificar quais são.

7. No sétimo item, verificar se os professores utilizam recursos tecnológicos nas suas aulas de matemática.

8. No oitavo item, identificar com que frequência o professor utiliza os recursos nas suas aulas.

9. No nono item, verificar qual a opinião dos docentes a respeito do uso dos recursos tecnológicos nas aulas de matemática.

10. No décimo item, saber se o docente possui em alguma turma que leciona algum aluno com transtorno de aprendizagem, e se possuir, como o mesmo se comporta diante de uma aula com o uso de recursos tecnológicos.

\section{RESULTADOS E DISCUSSÕES}

Observamos que a metade dos professores entrevistados possui especialização, enquanto que apenas $20 \%$ deles possuem mestrado. Além disso, $20 \%$ dos entrevistados possuem apenas a graduação completa. Portanto mais da metade (70\%) dos docentes entrevistados possuem pós-graduação, além de apenas $10 \%$ dos entrevistados não concluíram a graduação, com isso percebe-se que a maioria dos professores entrevistados possui uma formação básica (mínima) para estarem lecionando a disciplina de matemática.

Com relação a quanto tempo o docente leciona, percebeu-se que a maioria dos professores entrevistados possuem mais de cinco anos de experiência na docência de matemática.

Todos os professores entrevistados aprovam o uso dos recursos tecnológicos nas aulas de matemática, com isso, conclui-se que os professores estão abertos a inserção das novas tecnologias nas aulas de matemática. 
Segue abaixo um gráfico para mostrar, em percentual, os recursos tecnológicos mais conhecidos pelos professores.

Gráfico 1: Percentual dos recursos tecnológicos mais conhecidos.

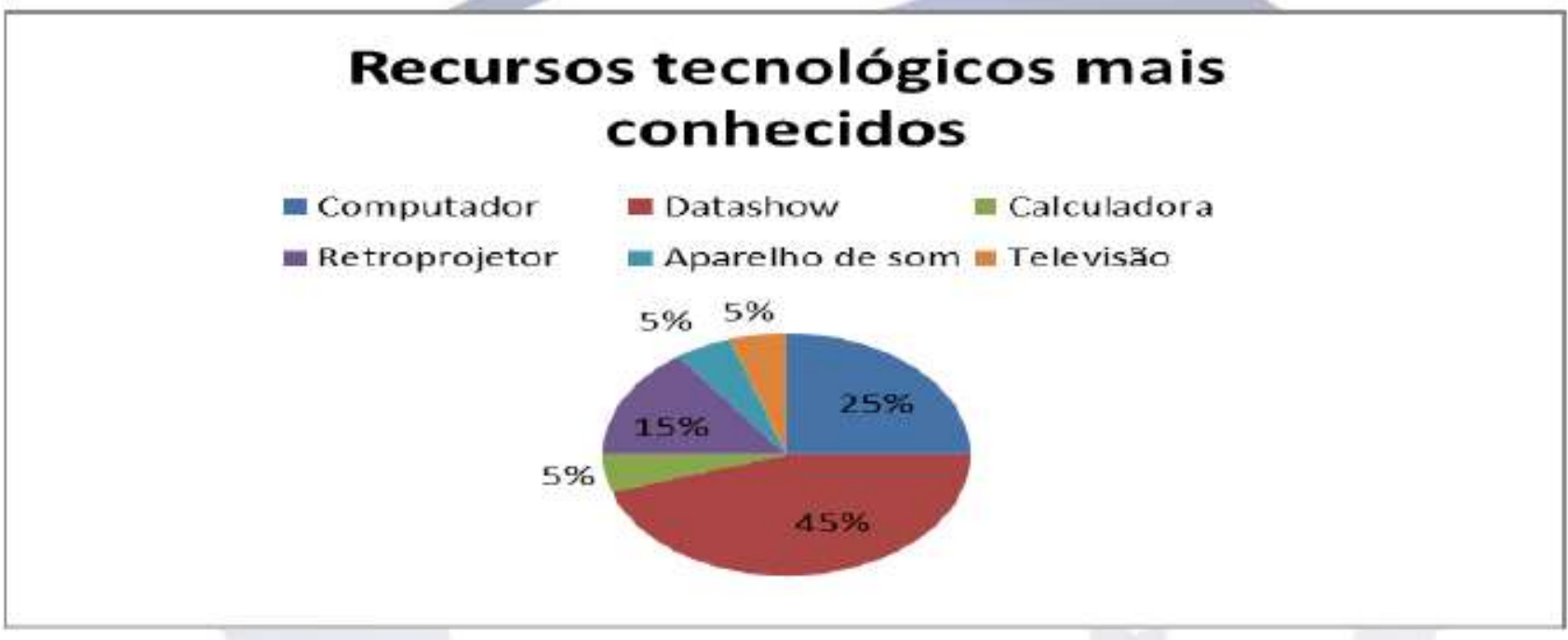

Fonte: Construído pelos autores.

Neste gráfico, verifica-se que dentre os recursos tecnológicos mais conhecidos e utilizados pelos professores de matemática o Datashow foi o mais citado, chegando ao percentual de $45 \%$ de conhecimento dentre os entrevistados, o segundo mais indicado foi o computador com $25 \%$, logo em terceiro vem o retroprojetor com o percentual de $15 \%$ e o aparelho de som com $5 \%$, assim como a televisão (5\%) e a calculadora (5\%). Sendo assim, percebe-se que os professores conhecem uma quantidade satisfatória de recursos tecnológicos disponíveis para utilização nas aulas de matemática.

Sobre o outro ponto discutido, que são os softwares matemáticos mais conhecidos tem-se o Geogebra liderando com 50\%, logo em seguida vem o Excel com 25\%. Tem-se também quatro softwares que obtiveram os percentuais entre 7\% e 6\%, foram eles: WinPlot (6\%), Cinderela (7\%), Maxima (6\%) e Régua e Compasso (6\%). Com isso percebe-se que os professores conhecem uma boa quantidade de softwares que podem ser utilizados nas aulas de matemática. 
Gráfico 2: Percentual dos recursos tecnológicos existentes na escola.

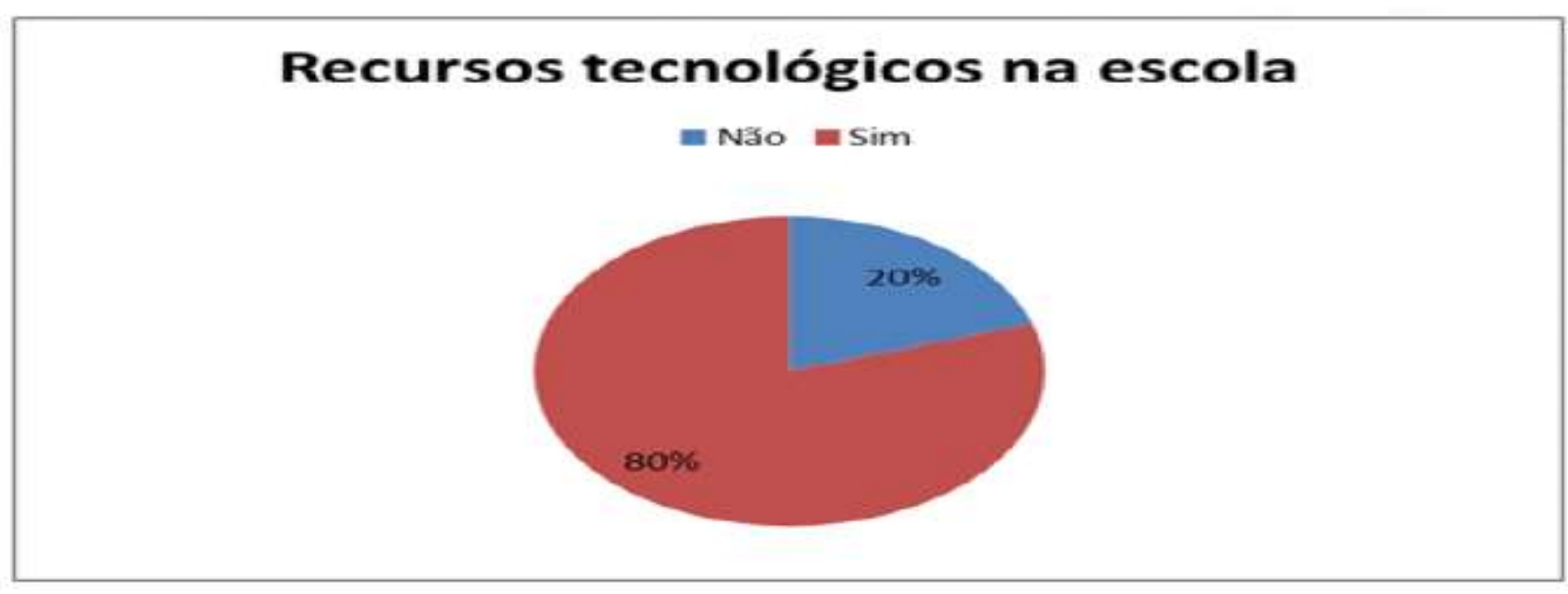

Fonte: Construído pelos autores.

Neste gráfico, verifica-se que a maioria dos entrevistados (80\%) relatam que há recursos tecnológicos em seu local de trabalho, enquanto que apenas $20 \%$ diz que não existem recursos tecnológicos nas escolas em que trabalham. Com isso é possível perceber que as escolas estão investindo em equipamentos tecnológicos e buscando se atualizar dentro da revolução digital que a educação, e o mundo, estão passando.

Verificou-se também que $70 \%$ dos professores entrevistados utilizam os recursos em suas aulas e que $30 \%$ não utilizam os mesmos. Com isso percebe-se que mesmo com tantos avanços e recurso ainda existem professores que resistem à inserção tecnológica que a educação vem vivendo.

Gráfico 3: Percentual da frequência da utilização dos recursos tecnológicos.

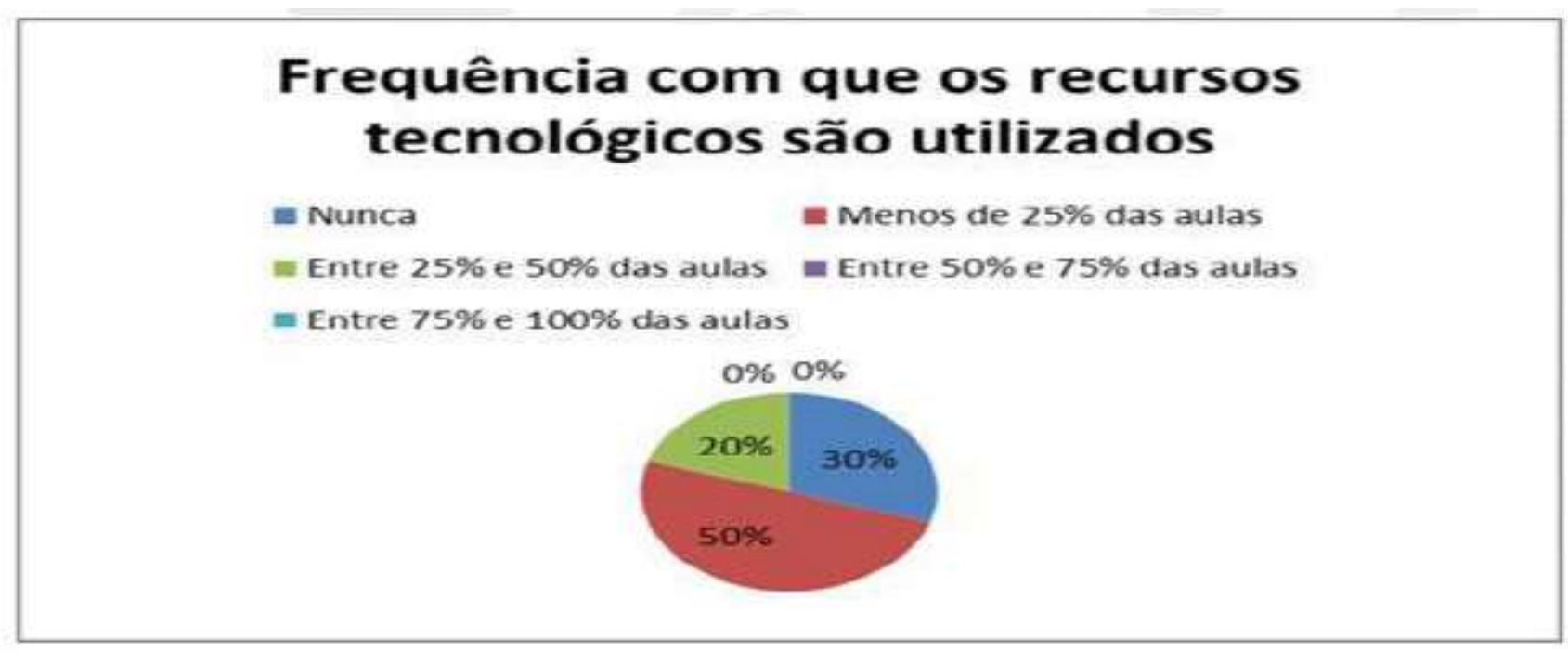

Fonte: Construído pelos autores. 
No gráfico 3, observa-se que a metade dos professores entrevistados utilizam os recursos, e em média de $25 \%$ das aulas ministradas, verificou-se também que $20 \%$ dos professores utilizam os recursos entre $25 \%$ e $50 \%$ de suas aulas, enquanto $30 \%$ dos professores nunca utilizam os recursos tecnológicos em sala de aula. Com isso, é possível verificar que mesmo com todos os recursos e softwares citados pelos docentes, ainda existem professores que resistem a utilização da tecnologia como ferramenta no processo de ensino-aprendizagem da matemática, desprezando o pressuposto de que o uso da tecnologia em suas aulas tornaria tal processo mais dinâmico e atrativo.

Na nona questão, que buscou saber a opinião dos professores a respeito do uso dos recursos tecnológicos nas aulas de matemática, foi verificado que apesar de $30 \%$ dos professores não utilizarem tais recursos em suas aulas, todos concordam com o seu uso, e que esses recursos também podem ser utilizados no processo de inclusão. Também foi verificado uma preocupação da parte dos professores em planejarem melhor suas aulas, para atrair a atenção dos alunos, bem como possuir os cuidados necessários para que eles não se dispersem durante o processo de uma aula com o uso de recursos tecnológicos, além de citarem que não podem ser o único caminho, pois, por mais interessante e útil que o recurso seja, se o professor não possuir o domínio do conteúdo e não souber adequá-lo ao recuso utilizado, e suas potencialidades, essa utilização não será tão proveitosa. Diante dos professores que foram entrevistados, nenhum deles relatou experiência em sala de aula usando, recursos tecnológicos, envolvendo alunos com transtorno de aprendizagem ou necessidades especiais.

\section{CONSIDERAÇÕES FINAIS}

Neste trabalho, que teve intuito de verificar se os professores de matemática conhecem os recursos tecnológicos e utilizam os mesmos durante suas aulas, observou-se, através das respostas dadas pelos entrevistados, que tais recursos representam inovação e esperança, pois são atrativos aos os alunos, chamando a atenção deles e despertando o interesse para com a disciplina, fazendo assim com que eles desenvolvam seu lado investigativo e crítico, contribuindo de forma positiva com ensino da matemática independente da dificuldade apresentada pelo aluno. Porém, mesmo eles demonstrando que acreditam na importância dos recursos tecnológicos para as aulas de matemática, percebeu-se que alguns não utilizam os recursos com frequência ou nunca usaram, mas isto em minoria, pois a maioria deles utilizam sim os recursos em suas aulas, reservando cerca de $25 \%$ da carga horária para esse fim, fato esse que foi uma surpresa, uma vez que se tinha como hipótese inicial que os professores apenas conheciam, mas não utilizavam esses recursos. 
Os docentes também relatam a preocupação de como utilizar os recursos tecnológicos em sala de aula sem que haja o sacrifício de "assuntos", pois eles precisam de mais tempo para planejar e desenvolver conteúdos durante as aulas de matemática onde os recursos tecnológicos estão envolvidos, assim os professores ficam apreensivos de que haja uma cobrança por parte da administração escolar e dos responsáveis pelos alunos, uma vez que os mesmos não teriam tempo suficiente para aplicar todas as atividades existentes no livro didático do aluno e utilizar os recursos tecnológicos em todas as aulas.

Após o desenvolvimento da pesquisa, percebemos que apesar de os professores de matemática gostarem da ideia de usar os recursos tecnológicos em suas aulas, eles também têm a opinião de que é preciso ministrar as aulas de forma expositiva (tradicional) para que haja assim uma combinação perfeita no ensino da matemática.

Por fim, foi possível perceber que as escolas e os professores estão procurando atualizar-se e seguir as novas tendências educacionais, inserindo no seu dia-a-dia os recursos tecnológicos, o que mostra que há uma grande preocupação em minimizar os resultados negativos que a matemática vem recebendo nos sistemas de avaliação dos alunos. Acredita-se que mesmo que os recursos tecnológicos não sejam os "salvadores" da educação inclusiva e do ensino da matemática, eles podem minimizar os resultados negativos e a "aversão" que os alunos possuem por essa disciplina, tornando o processo de ensino e aprendizagem mais prazeroso, significativo e inclusivo. 


\section{REFERÊNCIAS}

ALMEIDA, C. S. de. Dificuldades de aprendizagem em matemática e a percepção dos professores em relação a fatores associados ao insucesso nesta área. 2006. 13 f. Monografia (Graduação) Universidade Católica de Brasília, Brasília, 2006.

ALMEIDA, M. F. A. et al. O Ensino De Matemática Para Alunos Portadores De Necessidades Especiais: A Inclusão A Partir Da Ludicidade. In Ponta Grossa/PR: IV Simpósio Nacional de Ensino de Ciências e Tecnologia, 2014.

BRASIL. Ministério Da Educação. Parâmetros Curriculares Nacionais - Matemática. 10 ao 4o ciclo. 1998.

CUNHA, D. S. I. Investigações Geométricas: desde a formação do professor até a sala de aula de Matemática, Mestrado em Ensino de Matemática - UFRJ, Rio de Janeiro, 2009.

CEOLIN, T., MACHADO. A. R., NEHRING. C. M. O Ensino De Matemática E A Educação Inclusiva - uma possibilidade de trabalho com alunos deficientes visuais. In ljuí/RS: X Encontro Gaúcho de Educação Matemática, 2009.

D’AMBRÓSIO, B. S. Formação de Professores de Matemática para o Século XXI: O Grande Desafio. Proposições, vol.4, n.1, março, 1993.

MISKULIN, R.G.S. As potencialidades didáticos-pedagógicas de um laboratório em educação matemática mediado pelas TICs na formação de professores. In: LORENZATO, S. (Org). O Laboratório de Ensino de Matemática na Formação de Professores/- 2. Ed. - Campinas, SP: Autores Associados, 2009.

MORAN, J. M. Novas tecnologias e mediação pedagógica. Campina: editora Papirus, 2000.

OLIVEIRA, M. M. de. Como fazer projetos, relatórios, monografias, dissertações e teses. 4a ed. - Rio de Janeiro: Elsevier, 2008.

SCHEFFER, N. F. O LEM na discussão de conceitos de geometria a partir das mídias. In: LORENZATO, S. (Org). O Laboratório de Ensino de Matemática na Formação de Professores/- 2. Ed. - Campinas, SP: Autores Associados, 2009. 


\section{Capítulo 13}

\section{doi $10.37423 / 210604340$}

\section{CONTRIBUIÇÕES DO TEATRO DO OPRIMIDO NA EDUCAÇÃO DE JOVENS E ADULTOS - EJA: ABANDONO, RETOMADA E PERMANÊNCIA}

Edina Honorato Gonçalves

Robson Rosseto

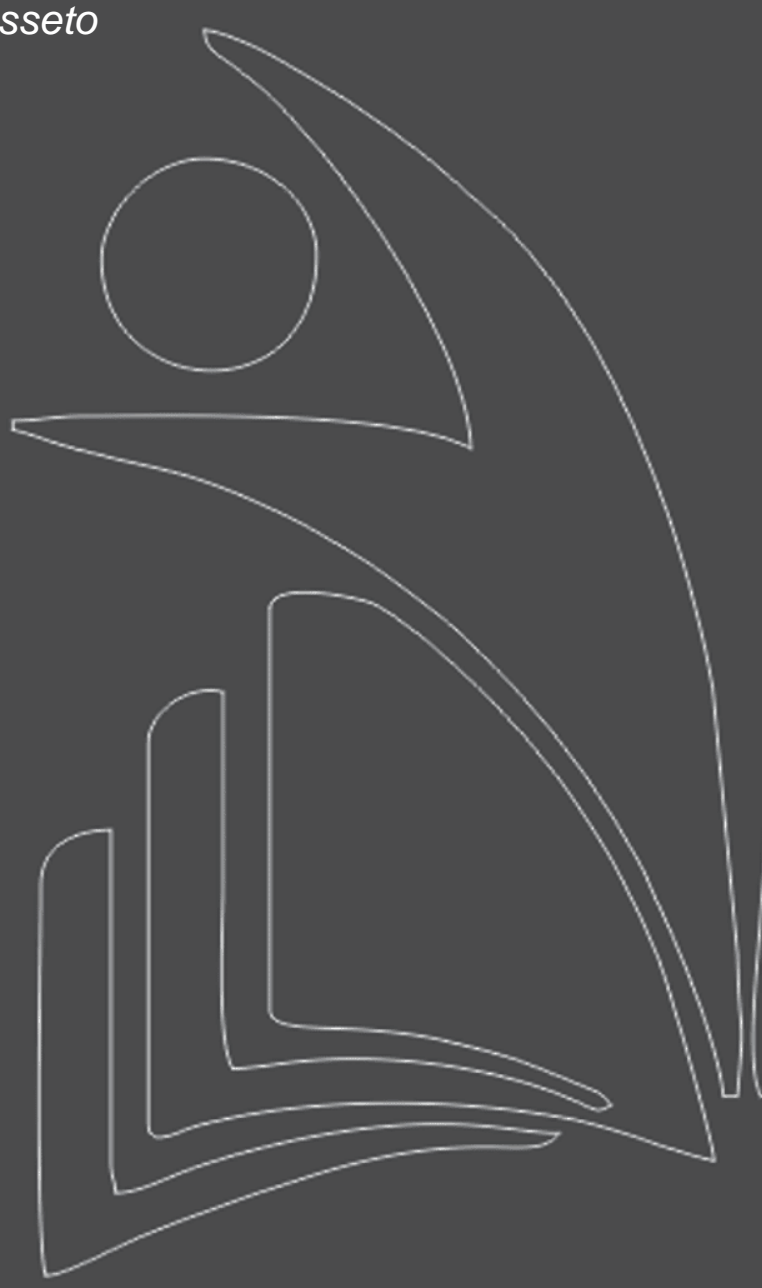

Universidade Estadual do Paraná - Unespar

Universidade Estadual do Paraná - Unespar 
O texto tem como objetivo identificar as questões que implicam no abandono e retorno dos estudantes inseridos na Educação de Jovens e Adultos - EJA, na modalidade de Ensino Médio, a partir de processos cênicos associados à história de vida dos participantes. Para tanto, esta investigação se fundamenta nos estudos teóricos pautados na Educação e na Pedagogia Teatral, cabendo destacar Augusto Boal e Viola Spolin. O intuito do trabalho realizado foi contribuir para a desestabilização do contexto social brasileiro marcado pela marginalização, exclusão e opressão de sujeitos que buscam concluir os seus estudos movidos pela perspectiva de inserção produtiva no mundo do trabalho.

O estudo buscou por meio da linguagem cênica, uma experiência que se possa afirmar efetiva, com vistas a contribuir para a aprendizagem dos estudantes. $O$ ensino da arte, como área do conhecimento e suas especificidades, agrega valores sociais, educacionais e culturais, portanto, acreditamos que a melhor forma de aprendizagem venha a concretizar-se através de processos pedagógicos.

A pesquisa de campo deste estudo envolveu no primeiro semestre do ano de 2021 uma turma composta por estudantes matriculados no Ensino Médio ofertado pelo Centro Estadual de Educação Básica de Jovens e Adultos - (CEEBJA) situado em um bairro periférico de Curitiba. O intuito foi orientar os participantes na disciplina Arte ofertada pela matriz curricular desta Escola, quando os mesmos foram estimulados à vivência e também ao debate sobre distintas situações geradoras de abandono e de retorno na modalidade escolar EJA. Para tanto, recorreu-se ao Teatro do Oprimido de Augusto Boal (2009), especialmente o Teatro Imagem, Teatro Jornal e o Teatro Fórum, assim como, a proposta teatral desenvolvia por Viola Spolin (2017). É considerável o alto índice de abandono escolar de jovens, adultos e idosos que, em função de condições adversas deixaram de frequentar os bancos escolares convencionais na idade apropriada. O teatro no contexto da EJA é de fundamental importância, na medida em que amplia o repertório artístico e cultural dos envolvidos possibilitando aos mesmos a vivência e o questionamento sobre distintas situações vivenciadas na cena.

Atualmente o ensino de teatro encontra espaço na escola, em instituições governamentais e organizações que versam sobre o desenvolvimento social do indivíduo em todas as faixas etárias e classes econômicas. Por tratar-se de uma arte que se justifica a si mesma, a importância do teatro já não deve ser mais questionada. Amplas pesquisas trazem grandes contribuições para o avanço da linguagem teatral e amplas reflexões acerca dos caminhos do teatro contemporâneo.

Incluso entre as normas do Plano Nacional de Educação no ano de 1934, a educação integral gratuita e de frequência obrigatória passa a atender a demanda de jovens e adultos, cuja responsabilidade é da União e está previsto na Constituição. Os Centros Estaduais de Educação Básica para Jovens e 
Adultos, "recebem estudantes com traços de vida, origens, idades, vivências profissionais, históricos escolares, ritmos de aprendizagem e estruturas de pensamento completamente variados" (BRASIL, 2006, p.7). Observa-se a tamanha distinção entre os estudantes e seus históricos de abandono, retorno e permanência nos estudos e isto depende da necessidade em que cada um se encontra e também depende de seus objetivos futuros. A heterogeneidade de idade dos estudantes apontam que são em sua maioria pessoas de baixa renda, que ficaram longos períodos afastados da escola e que estão em busca de melhores condições de vida, porém, há uma parcela destes estudantes, os quais recentemente passaram a fazer parte da demanda da EJA - a partir de 15 anos, que não ficaram muito tempo longe dos estudos, mas que seus objetivos diferem dos estudantes de idades mais avançadas.

Visando contribuir para fazer a diferença na educação destes estudantes que de alguma forma buscam recuperar o tempo perdido com relação aos estudos é que se faz necessário propor a linguagem teatral como conhecimento, ensino e aprendizagem. Segundo Flávio Desgranges:

O teatro vem sendo trabalhado, nas mais diversas instituições educacionais e culturais, preferencialmente, a partir da prática com jogos de improvisação, e isto porque se compreende que na investigação proposta por estes exercícios o prazer de jogar se aproxima do prazer de aprender a fazer e a ver teatro, estimulando os participantes (de qualquer idade) a organizar um discurso cênico apurado, que explore a utilização dos diferentes elementos que constituem a linguagem teatral, bem como a empreender leituras próprias acerca das cenas criadas pelos demais integrantes do grupo. (DESGRANGES, 2017, p. 87).

Para o autor, o ensino do teatro trabalhado em diversas instituições educacionais e culturais contribui para que os participantes sejam estimulados a construírem um discurso cênico mais elaborado se apropriando da linguagem teatral com base nas vivencias cênicas criadas e analisadas pelo grupo. $O$ ambiente escolar também é propício para trabalhar práticas artísticas durante as aulas de arte, destacando a importância da improvisação no ensino de teatro. Para Sandra Chacra:

A improvisação tem uma história longa, tão antiga como a do homem. Ela vem desde as épocas primitivas, perdurando como manifestação até o presente. Todas as formas de arte tiveram uma de suas origens na improvisação. $O$ canto, a dança e os rituais primitivos assumiram formas dramáticas num jogo em que um dos pólos é a atualidade improvisada. (CHACRA, 2005, p. 24)

Ao destacar a longevidade da improvisação a autora reforça sua importância nas artes e na própria história da humanidade, ultrapassando os limites do teatro para outras áreas do conhecimento. No entanto, este texto intenciona destacar a importância de proporcionar possibilidades do estudante da EJA vivenciar a linguagem teatral para enriquecer seus meios de expressão e desenvolvimento pessoal 
por meio da experiência com o Teatro do Oprimido e os Jogos Teatrais. Destaca-se também a relevância de uma ação pós-cena, ou seja, as experiências vivenciadas em cena discutidas, estimulando a reflexão dos estudantes acerca dos temas abordados, uma vez que,

nas avaliações das cenas, os participantes, seguindo as diretrizes do coordenador do processo, podem conversar tanto sobre questões relativas à vida social, presentes nas improvisações, problematizando as situações do diaa-dia, quanto sobre as resoluções artísticas apresentadas na oficina, com o intuito de aprimorar a capacidade do grupo de conceber um discurso cênico. (DESGRANGES, 2017, p. 88)

Desta maneira, o autor salienta que a experiência cênica pode oportunizar discussões em grupos para maior compreensão do que se vivenciou com a proposta apresentada. O momento da avaliação proporciona um diálogo com o texto, a interpretação de cada participante, as reações dos colegas que ora assistem, ora interpretam. É de grande relevância adquirir uma visão crítica sobre as ações desenvolvidas durante todo o processo de improvisação e experiência com a linguagem teatral.

A possibilidade de apresentar o universo do teatro aos estudantes da EJA através do Teatro do Oprimido e dos Jogos Teatrais vem de encontro com a investigação por meio de questionário específico com uma turma de estudantes matriculados no Centro Estadual de Educação Básica de Jovens e Adultos CEEBJA - CIC, na modalidade Ensino Médio, na cidade de Curitiba, com aproximadamente 15 a 20 estudantes. As práticas realizadas contabilizaram carga horária de 24 hora/aula no período noturno, sendo duas destas destinadas para a observação da turma, o que equivaleu a um bimestre. O questionário foi aplicado no 1 o semestre de 2021, antecedendo o início da regência. Para as práticas, os jogos teatrais foram embasados nas teorias de Viola Spolin e Augusto Boal. Com base na investigação realizada, foi possível articular as temáticas comuns entre os estudantes e pensar em roteiros que fossem significativos e simbólicos para cada um, tendo em vista a promoção da experiência com a linguagem teatral.

Aqui se faz urgente destacar que a educação necessitou se reinventar num período de tempo muito curto, pois diante de um contexto de pandemia mundial da COVID19 ${ }^{1}$, as escolas foram fechadas, mantendo professores e estudantes longe do habitual ambiente escolar. No Estado do Paraná, a Secretaria de Estado da Educação - SEED viabilizou salas virtuais para que os atendimentos aos estudantes pudessem continuar. Em 2020 houve um período de adaptação, momentos em que foi possível realizar encontros síncronos por videoconferência pelo Google Meet com os estudantes, porém, não era obrigatório o uso desta ferramenta. A SEED buscou entre os docentes da rede estadual aqueles que se disponibilizassem a gravar videoaulas que atendessem as demandas remotas para o 
Ensino Fundamental II e Ensino Médio. No entanto, em 2021 a SEED articulou para que se tornasse obrigatório o uso da ferramenta Google Meet, quando vinculou a presença do professor à realização da mesma. Diante deste cenário, a pesquisa de campo pensada de modo presencial, foi readequada e todas as atividades práticas foram adaptadas para ambiente remoto e síncrono.

Na abordagem com o Teatro do Oprimido - TO foi apresentado ${ }^{2}$ aos estudantes o teatrólogo Augusto Boal que objetiva em suas obras democratizar os meios de produção teatral, proporcionando às camadas sociais menos favorecidas a possibilidade de transformação da realidade por meio do diálogo. No livro Teatro do Oprimido e outras poéticas políticas (2009) publicado na Argentina e, posteriormente no Brasil, durante período de exilio, o autor aborda as ideias de jogos e exercícios que aparecem em seus demais livros. Para alcançar essa discussão junto aos estudantes da EJA se fez necessário desenvolver, mesmo que de modo remoto, as práticas teatrais do Teatro Imagem, Teatro Jornal (leitura simples, ação paralela e improvisação), e Teatro Fórum, cujas técnicas foram vinculadas à investigação realizada referente ao histórico de abandono dos estudantes. A princípio, uma videochamada foi realizada com o professor da turma para apresentar a ideia da pesquisa de campo. Num segundo momento foi realizada a observação da turma, ocasião em que tiveram três estudantes participando do encontro.

As aulas de arte no Centro Estadual de Educação Básica de Jovens e Adultos CEEBJA - CIC aconteceram nas quartas-feiras, no período noturno e totalizaram 3 horas/aulas semanais. Na semana subsequente não foi possível iniciar a pesquisa de campo por questões de troca de docente, logo não houve participações dos estudantes. Neste momento foi solicitado o acesso à lista dos matriculados na disciplina de arte para realizar uma busca ativa por meio de ligação telefônica e grupo no whatsapp. O questionário para investigar os motivos de abandono escolar e a relação de cada estudante com a linguagem teatral foi postado no ambiente virtual classroom, a partir do resultado da investigação foi iniciada a busca ativa dos estudantes, via telefone para fazer o processo de convencimento da importância da participação de cada um no modo síncrono. Muitos dos estudantes contatados relataram que não possuíam meios tecnológicos para acessar a plataforma de videoconferência, que no momento só era possível o acesso e realização das atividades postadas no classroom, outros relataram que os horários dos respectivos trabalhos não permitiam que participassem dos encontros virtuais. De todos os contatos realizados apenas 7 estudantes se dispuseram a participar de modo síncrono, a partir de então foi dado início às práticas teatrais embasadas no Teatro do Oprimido de Augusto Boal e Jogos Teatrais de Viola Spolin. Por coincidência, o tema gerador dos estudantes foram 
basicamente os mesmos, apenas mulheres participaram das aulas síncronas, sendo a gravidez precoce o motivo pelo qual abandonaram os estudos. Todas as práticas abordadas na pesquisa de campo giraram em torno do tema comum a todas as participantes.

Além do autor Augusto Boal e as técnicas do Teatro do Oprimido desenvolvidas por ele, também as técnicas dos Jogos Teatrais, e a improvisação sistematizada pela diretora teatral Viola Spolin (19061994) foram apresentados aos estudantes da EJA. As abordagens metodológicas dos jogos teatrais serviram de norte para os estudantes se conectarem com a linguagem. Os jogos teatrais são procedimentos com base na improvisação. Para Viola Spolin, improvisar significa:

Jogar um jogo; predispor-se a solucionar um problema sem qualquer preconceito quanto à maneira de solucioná-lo; permitir que tudo no ambiente (animado ou inanimado) trabalhe para você na solução do problema; não é a cena, é o caminho para a cena; uma função predominante do intuitivo; entrar no jogo traz para as pessoas de qualquer tipo a oportunidade de aprender teatro; é "tocar de ouvido"; é processo, em oposição a resultado; nada de invenção ou "originalidade" ou "idealização"; uma forma, quando entendida, possível para qualquer grupo de qualquer idade; colocar um objeto em movimento entre os jogadores como um jogo; solução de problemas em conjunto; a habilidade para permitir que o problema de atuação emerja da cena; um momento nas vidas das pessoas sem que seja necessário um enredo ou estória para a comunicação; uma forma de arte; transformação... Processo vivo. (SPOLIN, 2006, p. 341)

A autora discute o processo vivo que é o jogo teatral, desprovido de julgamento ou mesmo de enredo, onde a cena acontece e o que predomina é o intuitivo, lugar que os problemas surgem e são solucionados ali mesmo no ato de jogar. Neste processo vivo, o estudante da EJA teve a oportunidade de experimentar a improvisação livre e despreocupadamente. No entanto, para contribuir com o desempenho da improvisação, foram utilizadas as temáticas relacionadas aos motivos de abandono escolar, porém, sem deixar de solucionar os problemas que vão surgindo na cena de maneira natural e coletivamente, e assim se desenvolvendo social e intelectualmente. O processo do jogo, a relação do jogador e o ambiente, favoreceu a aprendizagem por meio das improvisações e possibilitou ampliar a aprendizagem por meio da linguagem teatral, pois no processo da educação, é necessário ter claros os objetivos específicos para o desenvolvimento da inteligência e este processo se relaciona com a linguagem e com o discurso, que estão presentes na linguagem teatral, em que os participantes da pesquisa de campo puderam vivenciar na prática.

O professor regente da turma me convidou para participar da sala virtual classroom, o que facilitou a comunicação com as estudantes. Neste ambiente foi possível postar o formulário com o questionário, textos para leituras complementares e o link que os direcionassem ao grupo do whatsapp. Nestes meios de comunicação eram postados um dia antes das aulas lembretes para os estudantes. Para dar 
início à pesquisa de campo foi realizado agendamento da videochamada e disponibilizado link no mural do Classroom e no grupo de whatsapp. O primeiro encontro iniciou com a apresentação entre professora e estudantes. Em seguida foi realizada uma breve apresentação da proposta da pesquisa, abordando os objetivos e os autores. Foi solicitado que cada estudante discorresse sobre a sua trajetória na escola e o seu contato com o teatro. Após a narrativa dos estudantes foi explanado sobre a proposta de improvisação com base no tema "gravidez", com o jogo teatral "só perguntas" que evidenciassem a seguinte estrutura dramática: ONDE? O QUÊ? QUEM? A turma foi dividida em duplas e no momento da realização do jogo, foi solicitado que os demais participantes desligassem áudios e câmeras para que visualizassem melhor o jogo entre a dupla. Seguindo as regras do jogo, na medida em que o jogo se desenvolvia, o jogador era substituído até que todos participassem. Nesta aula foi realizada duas rodadas do jogo, sucedido pelo momento de avaliação, em que foi incentivado que as estudantes discorressem sobre sua experiência com a prática executada. Nos relatos foi mencionada a dificuldade em pensar rápido sobre o tema e elaborar as perguntas e tomar o cuidado em não afirmar ao invés de só perguntar. De modo geral as participantes se interessaram pelo jogo e apreciaram a prática, demonstrando curiosidade em participar das próximas aulas, pois para a maioria delas a linguagem teatral foi novidade.

No encontro subsequente, antes de iniciar a proposta em si, foi realizado um aquecimento, sucedido por um alongamento dirigido, para em seguida iniciar a proposta prática com o exercício selecionado, cujo objetivo foi a desmecanização do corpo e a exploração de possibilidades dos movimentos corporais, ampliando a percepção dos participantes sobre o potencial de suas capacidades corporais e contribuindo na integração entre eles mesmos em ambiente virtual. O exercício "A menor superfície" ${ }^{3}$ de Augusto Boal foi conduzido, o qual foi explicado as regras da proposta. Na sequência a turma foi dividida em grupos, sendo 4 integrantes cada, para que executassem o jogo. Após alguns minutos, ao comando da professora, foi subdividido o grupo em duplas e solicitado que estendessem a mão como se estivesse tocando alguma parte do corpo do colega. A dupla se manteve com os microfones e as câmeras abertas para ficar em evidencia na tela. A orientação dada era para que a todo o momento se observassem, repetindo a ação de tocar o solo minimamente possível, movendose lentamente, descobrindo posições novas. Todos os participantes experimentaram a proposta sucedida pelo momento da avaliação, as quais estavam à vontade para narrar suas experiências, dentre elas cabe destacar as seguintes falas de determinados participantes: "foi difícil encostar algumas partes do corpo no chão, sou travada", "no dia a dia não costumo fazer movimentos além 
dos básicos", "esse tipo de exercício faz a gente lembrar que tem articulações no corpo que nem prestamos atenção".

As aulas seguintes ocorreram com a participação ativa dos envolvidos. Na execução do Teatro Imagem foi usado o recurso de captura de tela e, em seguida, compartilhado as telas das representações para que fizéssemos as análises das imagens, conforme as figuras abaixo.

Figura 1 - Experimentações com o Teatro Imagem
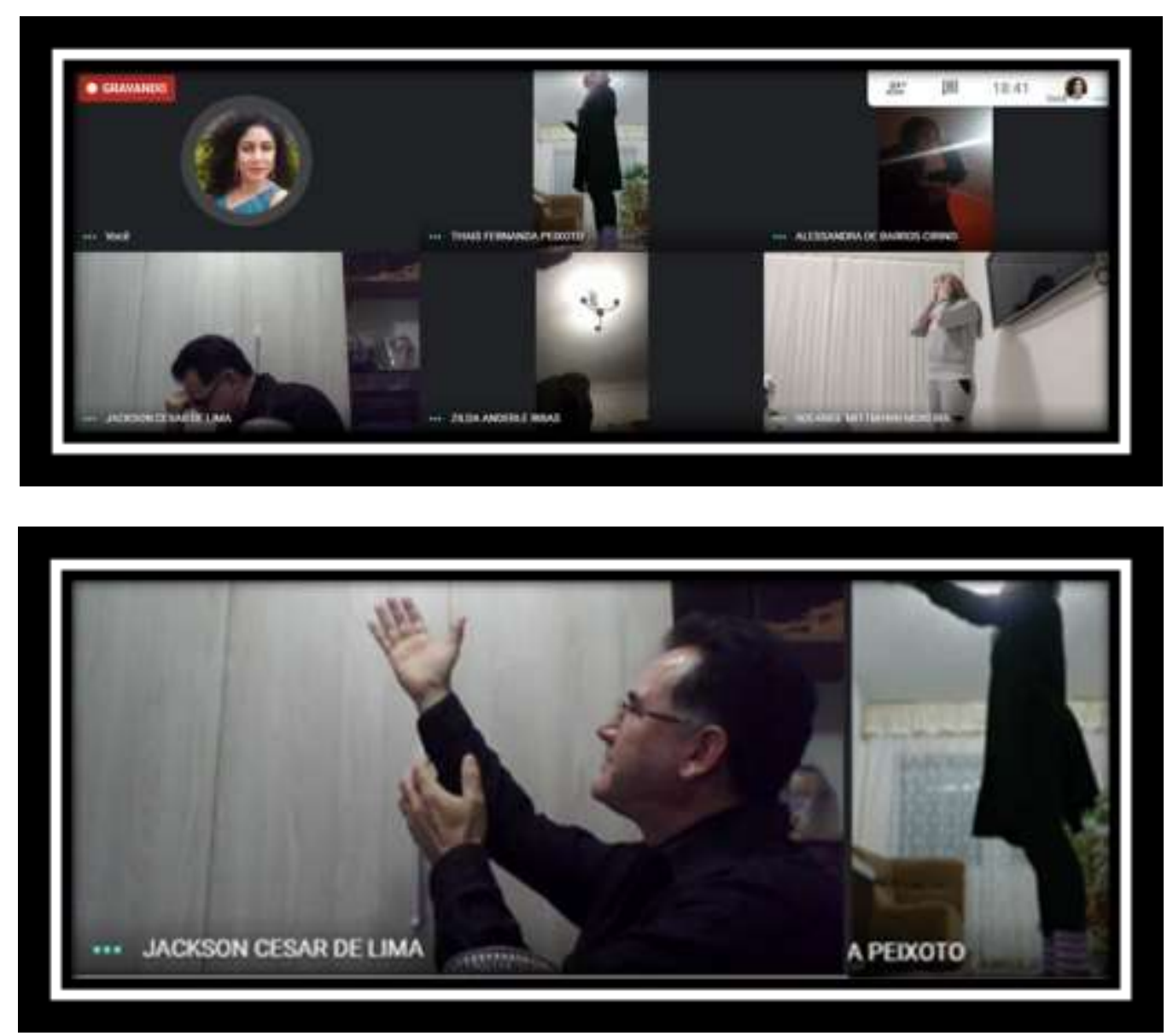

Fonte: Autoria própria, 2021

No Teatro Jornal (Figura 2) foi compartilhada uma notícia, a qual foi lida por uma participante (leitura simples), enquanto que os demais criavam imagens simultâneas (leitura paralela), seguido de improvisação. 
Figura 2 - Cena de experimentação com Teatro Jornal

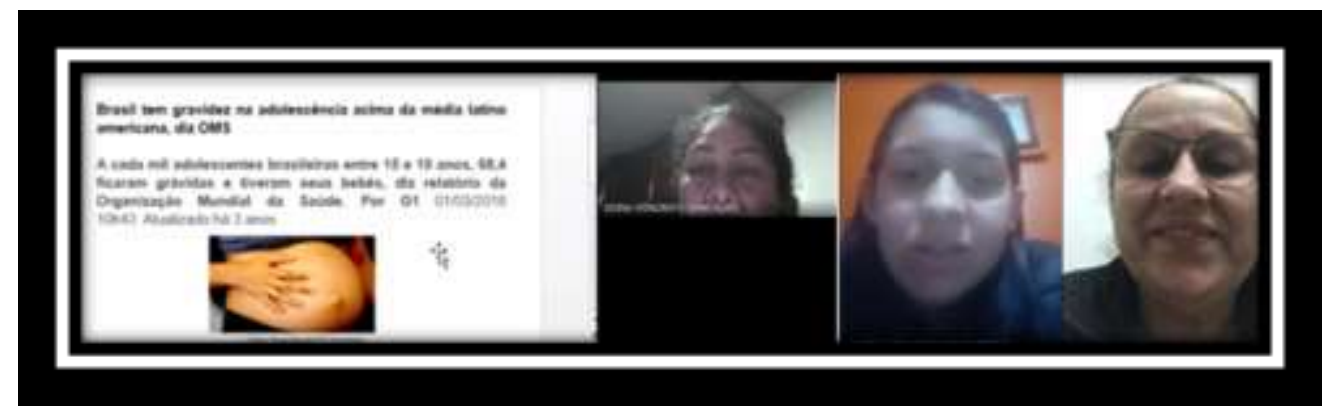

Fonte: Autoria própria, 2021

No Teatro Fórum cada participante recebeu um texto que correspondia ao motivo de abandono escolar de uma colega de turma, que durante a aula foi encenado até o momento da opressão, logo o fórum foi aberto para que fizessem intervenções na cena. (Figura 3)

Figura 3 - Cenas de experimentação com Teatro Fórum
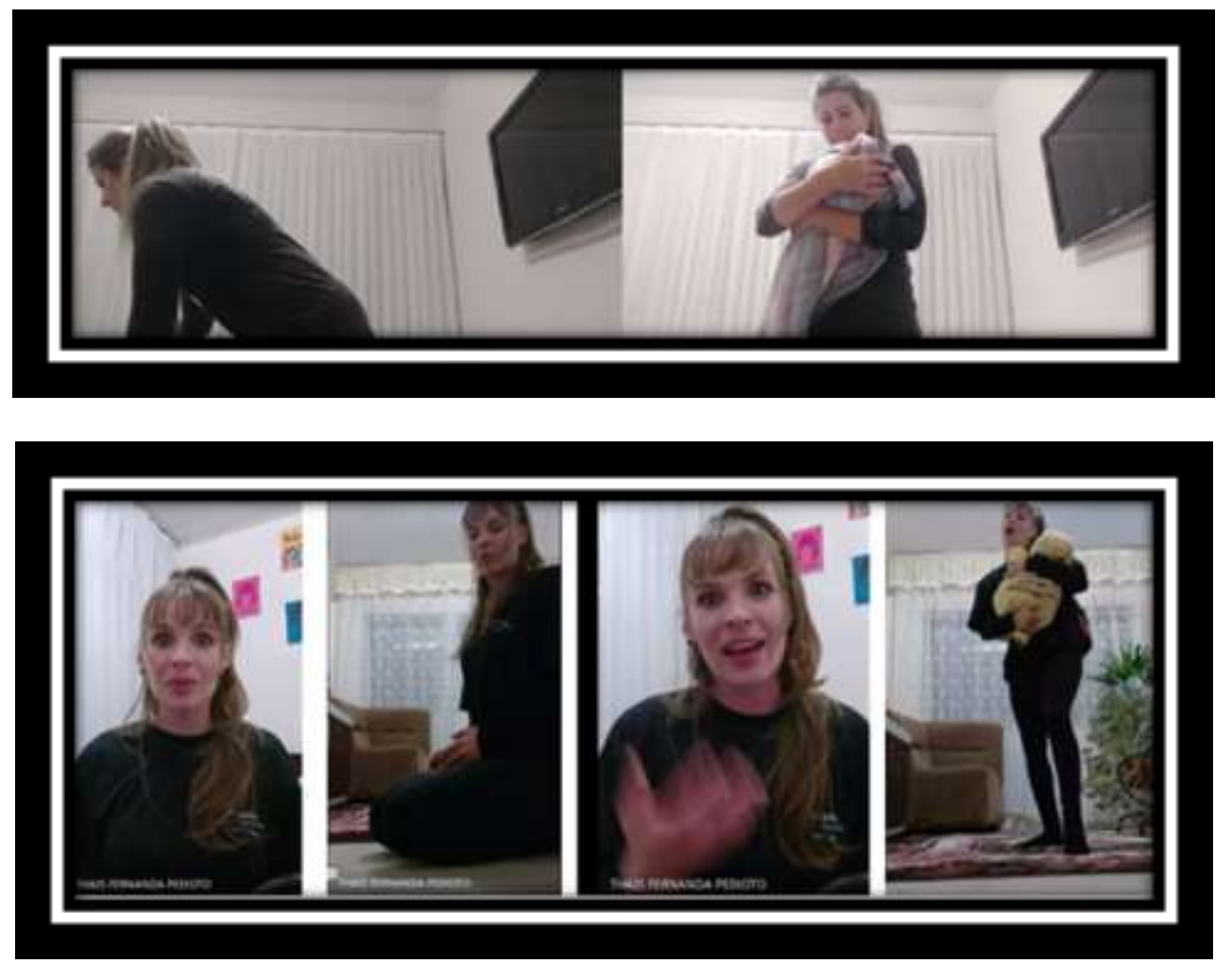

Fonte: Autoria própria, 2021.

Para os Jogos Teatrais foi enviando com antecedência textos para cada participante via whatsapp, os quais foram improvisados durante a aula, algumas participantes acrescentaram objetos para auxiliar na improvisação. O critério foi deixar evidente na cena as estruturas operacionais teatrais: Onde? 0 que? Quem? Todas as etapas vivenciadas foram sucedidas pelo momento de avaliação. A cada vivência 
foi percebido o envolvimento dos participantes e interação com o grupo, a criatividade foi aflorando dando vazão ao entendimento da proposta.

Figura 4 - Cena de experimentação com Jogos Teatrais

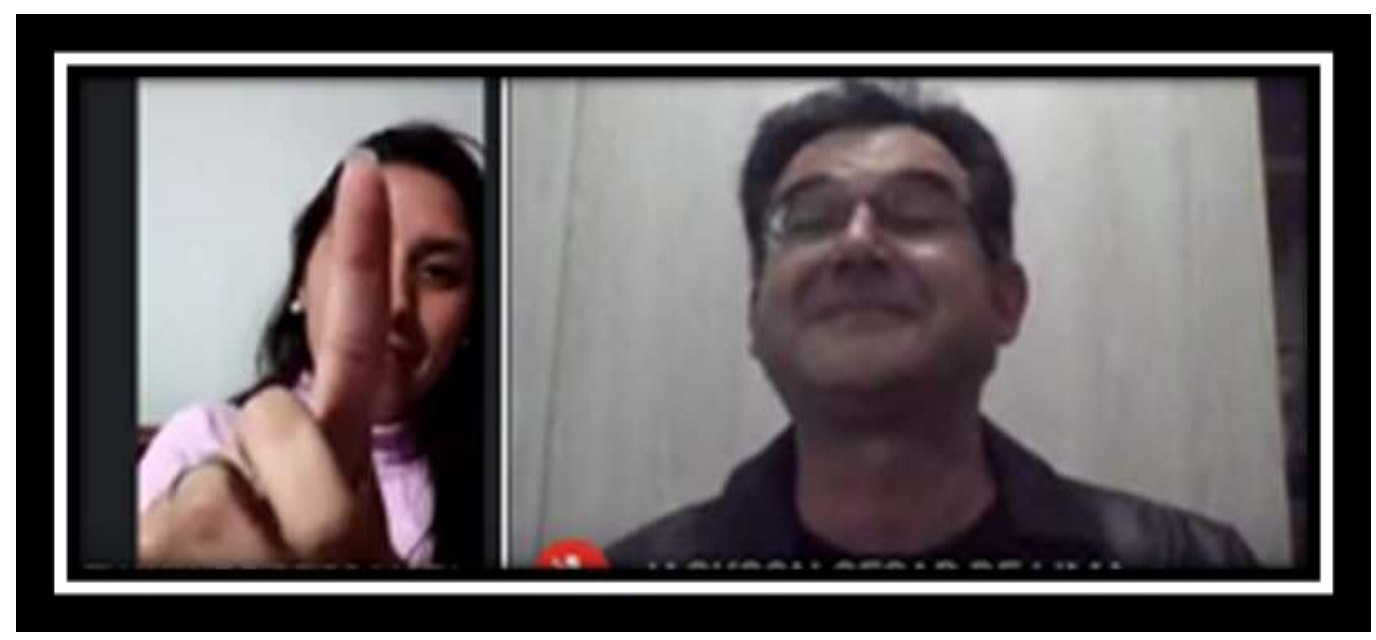

Fonte: Autoria própria, 2021.

Corroborando com as práticas vivenciadas em sala, Ingrid Koudela afirma que "A imaginação dramática está no centro da criatividade humana e, assim sendo, deve estar no centro de qualquer forma de educação" (2013, p. 27-28). A autora defende a imaginação dramática como indispensável para desenvolver o intelecto, certamente a capacidade de imaginação do ser humano se intensifica principalmente quando estimulada no ambiente escolar, tornando-se uma experiência efetiva, conforme afirma Jorge Larrosa Bondia:

A experiência é o que nos passa, o que nos acontece, o que nos toca. Não o que se passa, não o que acontece, ou o que toca. A cada dia se passam muitas coisas, porém, ao mesmo tempo, quase nada nos acontece. Dir-se-ia que tudo o que se passa está organizado para que nada nos aconteça. Walter Benjamin, em um texto célebre, já observava a pobreza de experiências que caracteriza o nosso mundo. Nunca se passaram tantas coisas, mas a experiência é cada vez mais rara. (BONDIA, 2019, p. 18)

Segundo exemplifica Bondia, a experiência é o que passa, acontece e toca o indivíduo, para então transforma-lo de alguma forma. $\mathrm{O}$ autor acrescenta que a experiência em si encontra-se cada vez mais rara, devido a excessos de informações que atravessa o ser humano, sem que o possa afetar. No que tange à experiência, percebe-se o diálogo com a linguagem teatral, pois o teatro é concebido e difundido como forma de conhecimento, necessária a todo sujeito da educação, capaz de criar ligações com os mecanismos inerentes aos processos cênicos, que neste caso se consolida através da experiência que vem a obter o jogador em cena. 
Após essas reflexões se faz necessário retornar a discussão do papel da educação na formação dos estudantes, formação esta que possa proporcionar experiências efetivas, capazes de transformações em suas histórias de vida. De acordo com Paulo Freire:

Quando vivemos a autenticidade exigida pela prática de ensinar-aprender participamos de uma experiência total, diretiva, política, ideológica, gnosiológica, pedagógica, estética, em que a boniteza deve achar-se de mãos dadas com a decência e com a serenidade. (FREIRE, 1997, p. 26)

Segundo o autor o papel do professor é fazer com que os estudantes tenham consciência do seu entorno, ou seja, através da dinâmica utilizada pelo professor é que o estudante vai fazer suas reflexões, vai aprender a exercer sua cidadania. Ainda ressalta que o professor também aprende com o estudante. Ele defende a experiência total, tanto do estudante, quanto do professor, pois o mesmo ensina e aprende simultaneamente e na sua prática docente proporciona reflexão, criticidade, instiga a curiosidade, inquietude, a persistência em aprender. E neste caso, a aprendizagem por meio do teatro ocorre quando o estudante passa pela experiência transformadora, como pode ser exemplificado a seguir:

A experiência, a possibilidade de que algo nos aconteça ou nos toque, requer um gesto de interrupção, um gesto que é quase impossível nos tempos que correm: requer parar para pensar, parar para olhar, parar para escutar, pensar mais devagar, olhar mais devagar, e escutar mais devagar; parar para sentir, sentir mais devagar, demorar-se nos detalhes, suspender a opinião, suspender o juízo, suspender a vontade, suspender o automatismo da ação, cultivar a atenção e a delicadeza, abrir os olhos e os ouvidos, falar sobre o que nos acontece, aprender a lentidão, escutar aos outros, cultivar a arte do encontro, calar muito, ter paciência e dar-se tempo e espaço. (BONDIA, 2019, p. 25)

O autor define experiência como algo arrebatador, que somente tocará o indivíduo mediante um gesto de interrupção, gesto este que possa desprender da "avalanche" de informações diárias que chegam às pessoas. Que o indivíduo detenha-se em algo significativo para sua vida, um "que" a mais que faça refletir, duvidar, querer saber mais sobre, que arrepie, que desperte a curiosidade, que transpasse por todo o corpo, que faça sentir o cheiro, o gosto, que afete de fato. Portanto, através da linguagem teatral os estudantes que vivenciaram corporalmente, cenicamente suas próprias histórias de vida através do Teatro do Oprimido e dos Jogos Teatrais, podem levar consigo uma base para analisar e refletir sobre seu entorno, discernindo com criticidade os acontecimentos políticos e sociais dentro e fora da escola, contribuindo para a construção da cultura e de uma identidade coletiva por meio da linguagem do teatro, garantindo efetivamente sua retomada e permanência nos estudos. 


\section{REFERÊNCIAS}

BOAL, Augusto. Teatro do Oprimido e outras poéticas políticas. Rio de Janeiro, Civilização Brasileira, 9a edição, 2009.

. Jogos para atores e não-atores. 12. ed. Rio de Janeiro: Civilização Brasileira, 2008.

BONDIA, Jorge Larrosa. Tremores: escritos sobre experiência. 1a edição; 4ạ reimp. - Belo Horizonte: Autêntica Editora, 2019.

BRASIL. Trabalhando com a educação de jovens e adultos: alunos e alunas da EJA: Caderno 1. Brasília, 2006. Disponível em: http://portal.mec.gov.br/secad/arquivos/pdf/eja_caderno1.pdf. Acesso em $10 / 07 / 20$.

CHACRA, Sandra. Natureza e sentido da improvisação teatral. São Paulo: Perspectiva, 2005.

DESGRANGES, Flávio. Pedagogia do Teatro: Provocação e dialogismo. São Paulo: Hucitec, 2017.

FREIRE, Paulo: Pedagogia da Autonomia - Saberes necessários à prática educativa. 6. ed. Rio de Janeiro: Paz e Terra, 1997.

KOUDELA, Ingrid Dormien. Jogos Teatrais. 7. Ed. - 2ª reimpressão. São Paulo: Perspectiva, 2013.

SPOLIN, Viola. Improvisação para o Teatro. 5. ed. Tradução: Ingrid Dormien Koudela e Eduardo José de Almeida Amos. São Paulo: Perspectiva, 2006.

. Jogos Teatrais na sala de aula - Um manual para o professor. 3. ed. Tradução: Ingrid Dormien Koudela. São Paulo: Perspectiva, 2017. 


\section{NOTAS}

Nota 1

A COVID-19 é uma doença infecciosa causada pelo novo Coronavírus (SARS-CoV-2) e tem como principais sintomas febre, cansaço e tosse seca.

Nota 2

O desenvolvimento prático da pesquisa foi realizado por um dos pesquisadores deste artigo, cuja investigação subsidiou a pesquisa de mestrado desenvolvida no Programa de Pós-Graduação Mestrado Profissional em Artes - PPGARTES, da Unespar.

\section{Nota 3}

"Cada ator estuda todas as posições que permitam ao seu corpo tocar o menos possível o chão, usando de todas as variações possíveis. [...] É necessário que, num momento ou noutro, toda a superfície do corpo toque o chão. A passagem de uma posição a outra deve ser feita muito lentamente, a fim de estimular todos os músculos que intervém na transição e permitir ao ator observar-se." (BOAL, 2008, p.93) 


\section{Capítulo 14}

\section{doi $10.37423 / 210604345$}

\section{ADAPTAÇÃO ESCOLAR NA PERSPECTIVA DAS CRIANÇAS DO PRE I}

Edlaine Rodrigues Pereira

Elenir Araújo Silva

Wandela Jheny Diniz Sinézio

Rafaela Correia dos Santos

Livânia Beltrão

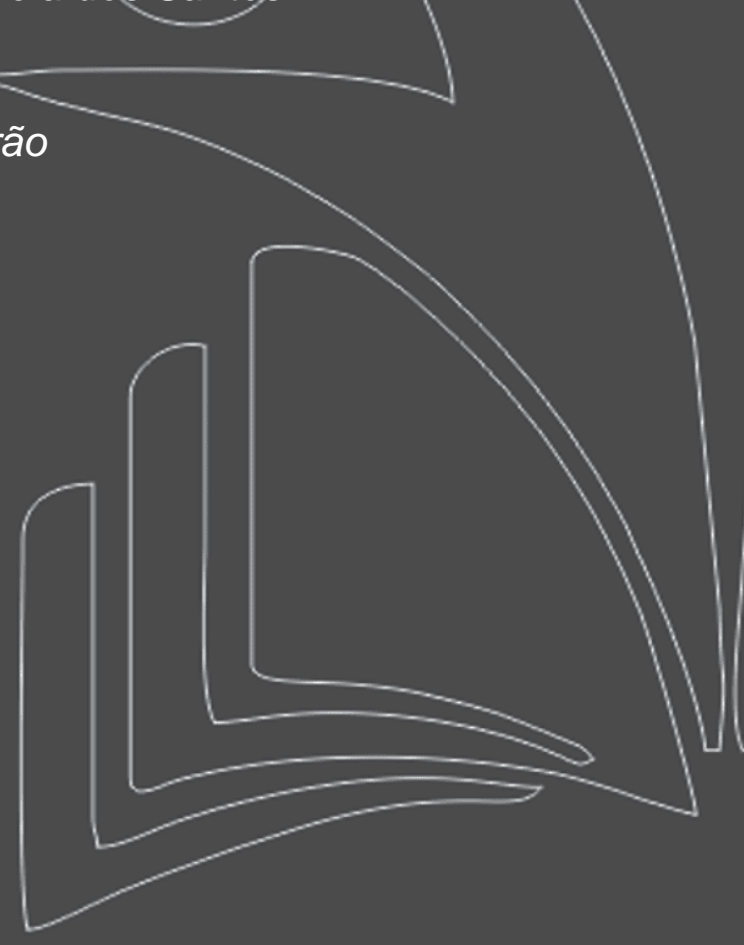

Universidade Estadual da Paraíba

Universidade Estadual da Paraíba

Universidade Estadual đa Paraíba

Universidade/Estadual da Paraíba

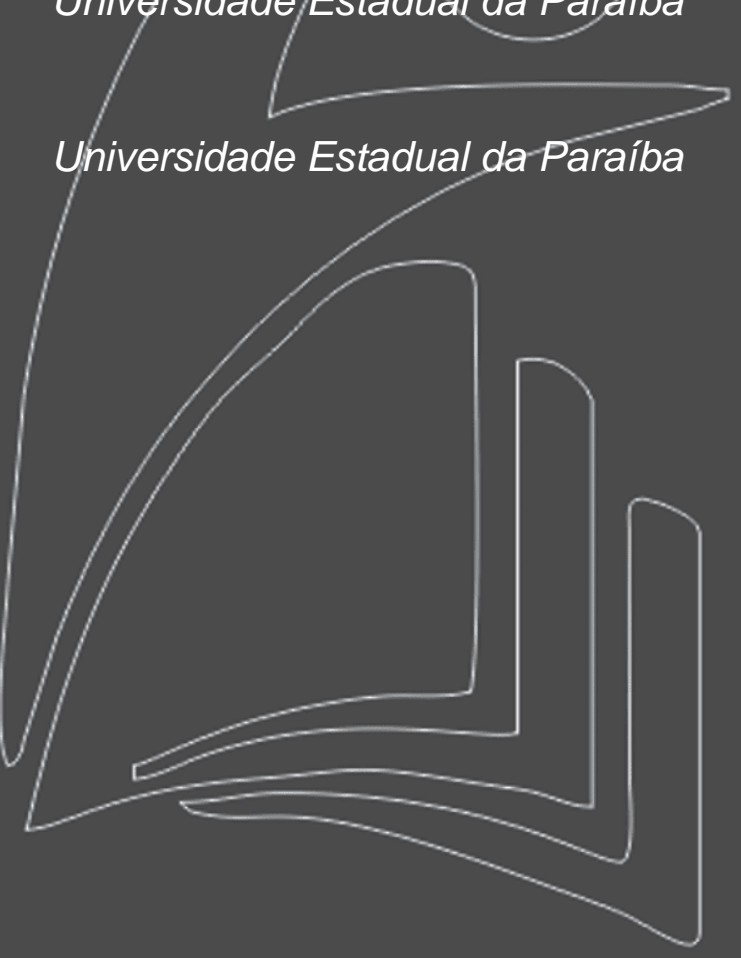




\section{Adaptação Escolar Na Perspectiva Das Crianças Do Pré I}

\section{INTRODUÇÃO}

Um dos problemas mais destacados na realidade escolar das crianças do Pré I é a dificuldade de adaptação destas à escola, principalmente quando na ocasião a criança vivencia sua primeira experiência com uma Instituição de Ensino. Nos primeiros dias de aula essas crianças tendem a chorar bastante e apresentar significativa relutância em permanecer na escola. Talvez esse fato se dê porque as crianças apresentam laços muito firmes com os pais e a casa onde vivem, tendo ainda atenção exclusiva para si e brinquedos disponíveis para brincar a qualquer hora, sem necessitar cumprir regras e horários.

Ao se depararem com um espaço onde existem muitas crianças com a mesma faixa etária, no qual é preciso dividir atenções, adaptar-se a regras básicas como, por exemplo, a hora certa de brincar ou lanchar, dividir os brinquedos com os coleguinhas e o mais importante, um ambiente conduzido por um adulto que não é o papai, a mamãe ou um membro da família, essas crianças na grande maioria das vezes sentem dificuldades de adaptação.

O fato é que toda criança precisa e deve ir à escola, faz-se necessário desta maneira, a busca por soluções plausíveis para que o ingresso na escola seja o mais positivo possível, evitando traumas que possam dificultar a vida escolar desses pequenos ao longo dos anos.

Essa temática da adaptação das crianças do Pré I na escola chamou-nos atenção por ser um aspecto observado em todas as Instituições de Educação Infantil no início do ano letivo. É notória nesses espaços de Educação Infantil a angústia de pais, professores e alunos no que se refere às dificuldades de adaptação das crianças. Essas observações nos motivaram a realizar a presente pesquisa.

Nesta perspectiva da adaptação escolar das crianças do Pré I, o objetivo geral deste trabalho foi analisar as dificuldades de adaptação das crianças do Pré I à escola. E os objetivos específicos foram: identificar fatores que possam auxiliar na adaptação das crianças na escola, e investigar até que ponto a relação da criança com o professor (a) pode influenciar neste processo.

O Referencial Curricular Nacional para a Educação Infantil (1998) afirma que entre a criança e as pessoas que interagem com ela estabelece-se uma relação de afetividade que envolve diversos sentimentos, essas pessoas são responsáveis pela mediação entre as crianças e seu contato com o mundo. Desta maneira, verificamos que as pessoas que vão interagir com as crianças na escola são muito importantes para em meio à confusão de sentimentos de medo e insegurança apresentados por elas, mediar sua adaptação naquele grupo escolar. 


\section{Adaptação Escolar Na Perspectiva Das Crianças Do Pré I}

\section{METODOLOGIA}

A presente pesquisa intitulada "Adaptação escolar na perspectiva das crianças do Pré I", utilizou o método do estudo de caso, que possibilitou o estudo intensivo de uma sala de aula do Pré I, composta por 32 alunos na faixa etária de 4 anos de idade, da Escola Municipal de Ensino Fundamental Manoel Pereira da Silva, na cidade de Esperança- PB. Essas crianças vivenciam em predominância sua primeira experiência com uma Instituição de Ensino, com exceção daqueles que advêm de creches e desta maneira, já são mais familiarizados com a escola e por isso, não serão analisados. As ações da pesquisa na Instituição foram realizadas no período de 07 de Fevereiro a 10 de Março de 2017.

Os instrumentos utilizados na pesquisa foram a observação de uma turma do Pré I e a conversa informal com os alunos no intuito de buscar atender os objetivos propostos pela pesquisa.

De início selecionamos a Escola e em seguida buscamos autorização da Secretaria de Educação de Esperança para podermos adentrar na Instituição e coletar os dados necessários para a pesquisa. Com a autorização em mãos, conversamos com a gestora da presente escola e expusemos as ações da pesquisa, que consistiria em observar uma turma do Pré I para analisar os aspectos de adaptação dos alunos à Instituição de Ensino. A gestora mostrou-se receptiva e nos deixou bastante confortáveis para coletar os dados da pesquisa.

A análise dos dados se deu com base em Mukhina (1995) tomando como parâmetro o desenvolvimento dos sentimentos das crianças, Balaban (1998) no que se refere ao início da vida escolar, os Referenciais Curriculares Nacionais para a Educação Infantil (RCNEl's) no que se diz do trabalho com a Educação Infantil, Silva e Navarro (2012) e Libâneo (2013) na relação professor/aluno e Macagnan (2015) na importância dos pais para adaptação dos filhos na escola.

\section{RESULTADOS E DISCUSSÃO}

As crianças do Pré I em sua maioria apresentam a idade de quatro anos e geralmente vivem sua primeira experiência com uma Instituição de Ensino. Como tudo que é novo, essa experiência pode causar estranhamento, nada mais natural do que a criança apresentar certa relutância em se adaptar à rotina escolar. Mukhina (1995) afirma que nessa fase os sentimentos da criança imperam em todos os aspectos, elas não sabem dominar suas paixões e se aprisionam nos sentimentos que os acometem.

Desta maneira, acreditamos que o fato do choro desesperado apresentado por algumas crianças nos primeiros dias de aula se dá pelo forte sentimento negativo causado pelo distanciamento destas com os pais e com a casa onde vivem. A criança esta saindo da sua zona de conforto. O ambiente é 


\section{Adaptação Escolar Na Perspectiva Das Crianças Do Pré I}

desconhecido, os coleguinhas também o são e, sobretudo, a professora ou o professor, que representa um adulto responsável por ela que não é a mamãe ou o papai.

É preciso ter a consciência de que para a criança é uma nova fase de sua vida, faz-se necessário levar em consideração que:

O início da vida escolar pode ser uma ocasião excitante ou também uma ocasião agradável. Junto com aqueles que realmente estão encantados por estarem iniciando sua vida escolar, existem freqüentemente outras crianças chorando ou pais tensos e nervosos (BALABAN, 1988, p. 24).

Na maioria das vezes as crianças criam bastante expectativa quanto ao primeiro dia de aula, vão felizes e entusiasmadas. Mas como podemos verificar na sala do Pré I observada, quando chegam ao ambiente escolar elas se deparam com outras crianças chorando e pais tensos e nervosos, que muitas vezes se questionam quanto a deixar a criança na escola ou não. Essas observações, que não passam despercebidas pelas crianças, acabam por nutrir nelas a insegurança, pois, se a escola é um lugar bom e seguro, como explicar a insegurança e o medo da mamãe ou do papai?

Observamos em uma determinada ocasião em que uma das criança foi levada à escola pelos pais, que a mesma chegou tranquilamente, escolheu uma mesinha para sentar e se despediu dos pais com naturalidade. Os pais visivelmente inseguros voltaram à sala de aula duas vezes para verificar se a criança estava chorando, na última vez a mãe entrou na sala e perguntou ao filho se ele ficaria bem. A insegurança da mãe foi tão notória que a criança imediatamente começou a chorar compulsivamente para não ficar na escola. Faz-se necessário desta maneira, que a família passe para a criança o sentimento de segurança pela Instituição de Ensino e pelas pessoas que a compõem.

Podemos constatar na observação da sala do Pré I, que os pais que chegam seguros na escola passam essa segurança para seus filhos, muitos dos pais que conversam com os filhos antes e explicam que eles estão na escola para estudar e aprender muitas coisas legais e que ao fim da tarde voltam para buscá-los, estes se adaptam mais rapidamente ao ambiente escolar. Diferentemente das crianças inseguras que geralmente sentem-se como se tivessem sido abandonadas na escola, sendo muito comum o questionamento "professora, mamãe vem me buscar?". É preciso que a mãe ou o responsável pela criança tenha clareza na conversação com a mesma e assim vá adaptando-a aos poucos, explicando-a que vai sair, mas que volta para busca-la.

Observamos na referente sala de aula do Pré I, a dificuldade de uma criança em se adaptar ao ambiente, esta chorava bastante e sempre repetia "mamãe foi embora, mamãe me deixou" e perguntava frequentemente "ela volta? Ela vem me buscar?". Com o passar dos dias, todas as crianças 


\section{Adaptação Escolar Na Perspectiva Das Crianças Do Pré I}

foram se adaptando e chegando calma na sala, mas a determinada criança continuava a apresentar o mesmo comportamento. Certo dia, em conversa com a criança, questionando-o o porquê daquele choro compulsivo, se ele já havia experienciado que a mãe todos os dias voltava para buscá-lo, descobrimos que ele é um dos filhos de outros quatro irmãos de pais separados, e que a mãe sempre que por algum motivo reclamava com eles, dizia: "qualquer dia vou embora e abandono todos vocês". Constatamos então, que esse era o medo que o acometia, que a mãe realmente fosse embora e o abandonasse na escola. Macagnan (2015) citando a psicoterapeuta Laila Pincelli, afirma que se a criança tem em mente que a mãe vai e volta como um acontecimento normal, ela fica tranquila. Acreditamos, portanto que, os pais são uma importante chave na adaptação da criança no ambiente escolar.

Segundo o Referencial Curricular Nacional para a Educação Infantil (1998, p. 17):

Entre o bebê e as pessoas que cuidam, interagem e brincam com eles se estabelece uma forte relação afetiva (a qual envolve sentimentos complexos e contraditórios como amor, carinho, encantamento, frustração, raiva, culpa etc.). Essas pessoas não apenas cuidam da criança, mas também medeiam seus contatos com o mundo, atuando com ela, organizando e interpretando para ela esse mundo. É nessas interações, em que ela é significada/interpretada como menino/menina, como chorão ou tranquilo, como inteligente ou não, que se constroem suas características. As pessoas com quem construíram vínculos afetivos estáveis são seus mediadores principais, sinalizando e criando condições para que as crianças adotem condutas, valores, atitudes e hábitos necessários à inserção naquele grupo ou cultura específica.

Percebemos desta maneira, a relevância da Educação Infantil na vida da criança, e a responsabilidade de fazer desta a experiência mais positiva possível, pois se a Educação Infantil se tornar um ambiente traumático para a criança, possivelmente isso acarretará em problemas por toda a sua vida escolar.

Outro aspecto importante para adaptação da criança é a afetividade entre os membros da Instituição com esta. Mukhina (1995, p. 210) afirma que:

A criança extrai suas vivências principalmente do contato com outras pessoas, adultos ou crianças. Se os que a rodeiam a tratam com carinho, reconhecem seus direitos e se mostram atenciosos, a criança experimenta um bem-estar emocional - um sentimento de segurança, de estar protegida.

As atitudes das pessoas que as rodeiam na escola é crucial para que as crianças se adaptem ao ambiente escolar. E nesta concepção, acreditamos que o professor também é de importância crucial para a adaptação do aluno. O professor será o primeiro adulto no qual a criança vai buscar segurança e geralmente é na figura do professor que esta busca o afeto que envolve sua vida familiar, pois, "todo relacionamento é arraigado de afeto, sendo este o principal componente nas relações humanas" 


\section{Adaptação Escolar Na Perspectiva Das Crianças Do Pré I}

(SILVA; NAVARRO, 2012, p. 95). E quando as crianças adentram na vida escolar, como é o caso da maioria da turma do Pré I observada, elas vão experienciar com mais frequência às relações humanas que as acompanharão a vida inteira, pois geralmente elas saem da zona de conforto da convivência na sua família, para conviver com muitas pessoas desconhecidas, desde a professora e os colegas da turma até os demais componentes da escola.

O professor será então, a primeira pessoa com a qual a criança cria laços afetivos, e esses laços fazem toda a diferença para que essa criança se adapte ao ambiente, pois, "as relações entre professores e alunos, as formas de comunicação, os aspectos afetivos e emocionais, a dinâmica das manifestações na sala de aula fazem parte das condições organizativas do trabalho docente [...]"(LIBÂNEO, 2013, p. 274).

As crianças são muito sensíveis a carinho e atenção, e um ambiente que lhes desperte estes sentimentos lhes dará segurança e consequentemente adaptação e carinho não somente pelos membros que compõem a escola, mas também pela própria escola. Essas relações afetivas lhes proporcionarão uma experiência positiva no ingresso à escola, o que acarretará positivamente em toda sua vida escolar, afinal, a Educação Infantil é a base de toda a educação vindoura, e, portanto, de suma relevância na vida da criança.

\section{CONSIDERAÇÕES FINAIS}

Pela observação dos aspectos analisados, concluímos que as crianças do Pré I que apresentam a idade de quatro anos, quando adentram na vida escolar estão saindo do conhecido da sua casa e da sua família para o desconhecido da escola e todas as pessoas que a compõem, e por isso a relutância muitas vezes na adaptação, medo do desconhecido. Como afirma Balaban (1988) é o início de uma nova fase na vida da criança, e como tudo que é novo, precisa passar pelo processo de adaptação.

No que se refere à adaptação das crianças na vida escolar, acreditamos ser de suma importância à participação dos pais no processo, passando para as crianças confiança no ambiente escolar e nas pessoas que passarão a fazer parte da rotina dos mais novos alunos. É necessário que os pais deixem claro para seus filhos que estão os deixando na escola e que voltam para buscá-los. Podemos observar que quanto mais segurança os pais passam para seus filhos, mais rapidamente eles se adaptam.

Outro aspecto muito importante na adaptação das crianças é afetividade entre os membros que compõem a escola e elas, Mukhina (1995) afirma que se as pessoas que rodeiam as crianças as tratam com carinho, elas passam a sentir confiança, e acreditamos que confiança é base de qualquer 


\section{Adaptação Escolar Na Perspectiva Das Crianças Do Pré I}

adaptação. Nesta concepção, constatamos ser de crucial importância a afetividade que envolve a relação professor/ aluno, pois o professor vai ser o primeiro adulto com o qual a criança vai adquirir confiança e, portanto, essa relação precisa repleta de afetividade, pois como afirma Libâneo (2013) a relação professor/aluno, as maneiras como se comunicam e os aspectos afetivos e emocionais fazem parte do trabalho docente. Acreditamos então, que quanto maior for a afetividade entre professor/aluno mais rapidamente este vai se adaptar ao ambiente escolar.

Por fim, concluímos que uma boa adaptação da criança com a escola é baseada em relações múltiplas que envolvem a confiança perceptível dos pais pela Instituição e pelas pessoas que a compõem, bem como, as relações afetivas que envolvem essas crianças dentro do espaço educativo. 


\section{Adaptação Escolar Na Perspectiva Das Crianças Do Pré I}

\section{REFERÊNCIAS}

BALABAN, Nancy. O início da vida escolar: da separação à independência. Porto Alegre: Artes Médicas, 1988

BRASIL. Referencial Curricular Nacional para a Educação Infantil. Ministério da Educação e do Desporto, Secretaria de Educação Fundamental. Brasília, MEC/SEF, 1998.

LIBÂNEO, José Carlos. Didática. 2 ed. São Paulo. Cortez, 2013.

MACAGNAN, MANUELA. Hora de voltar ao trabalho após o nascimento do bebê. Disponível em: http://bebe.abril.com.br/parto-e-pos-parto/hora-de-voltar-ao-trabalho-apos-o-nascimento-dobebe/. Acesso em: 12 jul. 2017.

MUKHINA, Valeria. Desenvolvimento dos sentimentos. In: Psicologia da idade pré-escolar: um manual completo para compreender e ensinar a criança desde o nascimento até os sete anos. São Paulo: Martins Fontes, 1996. p. 209- 217.

SILVA, Ormenzina Garcia da; NAVARRO, Elaine Cristina. A relação professor/aluno no processo ensinoaprendizagem. Revista Eletrônica Univar, v. 3, n. 8, p. 95-100, 2012. Disponível em:

http://www.univar.edu.br/revista/index.php/interdisciplinar/article/view/82. Acesso em: 10 jul. 2017 


\section{Capítulo 15}

\section{doi $10.37423 / 210604348$}

\section{REDES SOCIAIS COMO MEIOS DE SOCIABILIDADE DE PORTADORES DE ESCLEROSE LATERAL AMIOTRÓFICA - ELA}

Jassenildes Ditzel de Azevedo

Maria Rafaella Bech

Maria Marce Moliani

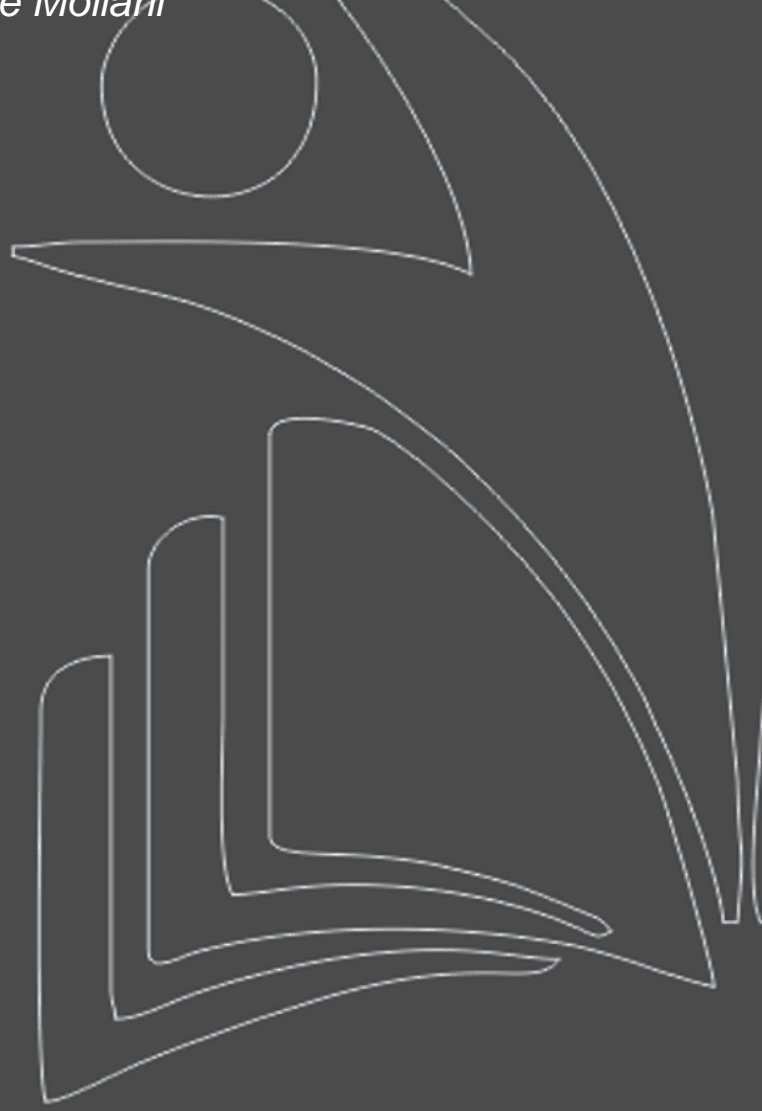

Universidade Estadual de Ponta Grossa

Universidade Estadual de Ponta Grossa

Universidade Estadual đe Ponta Grossa 


\section{INTRODUÇÃO}

O objetivo deste artigo é discutir o uso das redes digitais na produção de sociabilidade entre portadores, familiares e cuidadores de pessoas com ELA (Esclerose Lateral Amiotrófica). Uma vez que a ELA é uma doença considerada rara, as redes sociais virtuais se apresentam como um local adequado para a criação de comunidades de afetados pela doença onde esses podem trocar experiências, informarem-se, obterem apoio e acolhimento. É considerado como doença rara aquela que atinge até 65 pessoas a cada 100.000 habitantes.

Seguindo o exemplo dos grupos de auto ajuda $^{1}$, as comunidades digitais unem pessoas com problemas e interesses semelhantes e na qual a mutualidade das interações são fundamentais para o sentimento de pertencimento e acolhimento. A cordialidade é um requisito necessário para o pertencimento a qualquer grupo digital, sob pena de banimento caso as regras do grupo sejam desrespeitadas. Devido às suas características, a internet é um meio onde o indivíduo consegue se expressar com mais liberdade, sem temer julgamento de pessoas próximas, sem sentir o olhar de pena, o que permite sentir maior compreensão que muitas vezes não é encontrado no encontro face a face, uma vez que o controle de impressões é mais objetivo e também porque há encontro entre iguais,

Diante da realidade da doença, familiares e pacientes buscam entender seus efeitos, duração e medidas de cuidado e cura procurando, tanto no mundo real quanto no virtual, suporte para o seu enfrentamento. Assim, o objetivo desse artigo é compreender como a ELA atinge tanto o paciente quanto seus familiares. É importante colocar os familiares como afetados, uma vez que a doença implica em mudanças importantes na rotina familiar para a adaptação aos doentes e o avançar da moléstia coloca a necessidade de cuidados diuturnos ao doente, o que necessariamente vai abalar a dinâmica familiar e mudar a sociabilidade dos membros. Assim, as comunidades virtuais aparecem como meios adequados para a obtenção de informação sobre procedimentos e busca de tratamento, apoio emocional, orientação sobre a história natural da doença e principalmente, como local de escuta e acolhimento. Familiares, cuidadores e portadores de ELA, ao tomarem consciência de que essa moléstia demanda cuidados progressivamente integrais, vêem-se obrigados a prepararem-se para uma jornada de grandes dificuldades, pontuadas por medo, incerteza e cujo desenlace será a inevitável fatalidade.

A Ela é uma doença que por sua incidência ainda é considerada rara e incurável, o que dificulta aos acometidos obter informações e estabelecer estratégias para o seu enfrentamento. Sendo assim, a 
busca pelo apoio dentro das redes sociais torna-se cada vez mais recorrente, uma vez que essas permitem a construção de grupos de interesses comuns que promovem trocas de experiência, informações e apoio na no compartilhamento de vivências comuns.

A ELA (Esclerose Lateral Amiotrófica) se caracteriza como uma doença de caráter raro e degenerativo, que acarreta o agravo do sistema nervoso central comprometendo a função dos neurônios motores, gerando paralisia motora irreversível. (BERTAZZI, 2017). A ELA progride com a degeneração da parte motora em várias regiões, tais como região bulbar, cervical, torácica e lombar. A paralisia ocorre de forma gradual, e acaba por limitar a vida do portador à restrição do leito tornando-o dependente de múltiplos cuidados. Isso ocorre pois o desenvolvimento da doença faz com que seu portador vá perdendo capacidades básicas, tais como se movimentar, falar, deglutir e respirar. Até o presente momento não há na literatura um acordo sobre a existência de causalidades específicas da doença, mas estudos indicam que a ELA possui causa multifatorial, onde estão inseridos idade, fatores genéticos e ambientais. (BRASIL, 2019).

A ELA é uma das principais doenças neurodegenerativas ao lado de doenças como Alzheimer e Parkinson, dados epidemiológicos revelam que a incidência na população varia de 0,6 a 2,6 por 100.000 habitantes $^{2}$.

A incidência da doença é mais comum após os 50 anos, mas isso não significa que não possa afetar indivíduos mais jovens (BERTAZZI, 2017). Os sintomas se caracterizam por fraqueza e atrofia, fasciculações e cãibras musculares, espasticidade, disartria, disfagia, dispneia e labilidade emocional. A esclerose não afeta o sistema dos sentidos (visão, olfato, paladar, audição e tato), e quase raramente afeta funções fisiológicas, tais como função vesical, intestinal e raciocínio (Ministério da Saúde, 2019) O diagnóstico pode ser realizado por meio de exame de eletromiografia a partir do prognóstico clínico, no qual se pesquisa o quão acometido o neurônio motor inferior está, também pela ressonância nuclear magnética com espectroscopia e estimulação magnética do córtex que pesquisa o comprometimento do neurônio motor superior. (PALLOTA et al 2012).

\section{METODOLOGIA}

Trata-se de um estudo etnográfico. Elaboramos um banco de dados através da catalogação de comentários/postagens de duas páginas abertas de redes sociais no período de 2018 a 2019. Por motivos de privacidade e proteção dos envolvidos nesta pesquisa, os nomes dos grupos não serão nominados. 
O caráter etnográfico da pesquisa está ancorado no fato de que este método possibilita a compreensão dos grupos humanos, com o intuito de entender as trocas, as experiências, as relações entre si e como os indivíduos pertencentes aos grupos analisados se relacionam no ambiente que estão inseridos. A presença dos pesquisadores deu-se por meio de observação anônima, uma vez que trata-se de estudantes e pesquisadores na área de saúde e havia o receio desses serem eleitos interlocutores sobre a doença, com demandas sobre procedimentos, tratamentos, auxílios, entre outros.e que não pretendiam se colocar em posição de autoridade, criar constrangimentos em relação às crenças, esperanças e inseguranças dos membros e, especialmente, não se colocarem na posição de especialista do problema.

“A etnografia é uma metodologia propícia para descobrir a maneira de viver e as experiências das pessoas - a sua visão do mundo, os sentimentos, ritos, padrões, significados, atitudes, comportamentos e ações" (Lima, 1996).

Para MERCADO (2012) às informações presentes no ciberespaço são atemporais e isso dá ao pesquisador a possibilidade de encontrar as informações de sua comunidade alvo no tempo que estiver presente.

Dentro dos grupos a interação por parte dos membros acontece de maneira espontânea onde estes possuem liberdade para se fazerem presentes dentro da rede, porém seguindo normas estabelecidas pelos administradores das páginas.

Foram avaliados os dados coletados no período de janeiro de 2018 a agosto de 2019. Foram recolhidos tanto postagens quanto as respostas, com análise dos aspectos demográficos e caracterização dos comentários. A análise das postagens e discussões foi utilizada a fim de categorizar os comentários e caracterizar os grupos/páginas observados a fim de verificar a natureza dos mesmos: autoajuda? Luto? Informações? Foram excluídas postagens que continham vídeos, publicações de receitas, notícias, entre outros que não se caracterizem como comentário pessoal.

Os dados foram coletados em ambas páginas da rede social e após a separação de comentários e postagens, esses itens foram transcritos para um arquivo Microsoft Word ${ }^{\oplus}$, a fim de se obter melhor visualização, classificação das postagens e organização dos resultados. Posteriormente foi realizado o estudo demográfico das páginas a fim de se obter o perfil social de seus participantes.

Para preservar a identidade dos envolvidos na pesquisa etnográfica, os nomes foram substituídos por nomes de flores. Os comentários selecionados para a ilustração das análises foram transcritos e inseridos integralmente. 


\section{RESULTADOS E DISCUSSÃO}

Os resultados apresentados aqui, se referem a dois grupos do Facebook ${ }^{\circledR}$, que foram pesquisados no período de janeiro de 2018 a agosto de 2019. A página 1 é aberta e conta com 802 membros até o presente estudo. A página foi criada há cerca de 4 anos, em sua descrição apresenta-se que o grupo é destinado a portadores, famílias, profissionais de saúde e cuidadores, interessados em trocar experiências sobre a ELA. Já a página 2 é um grupo fechado e conta atualmente com 1.631 membros e foi criado há aproximadamente 7 anos. Em sua descrição possui o pedido de que pessoas relatem histórias como a do familiar da administradora do grupo e que se caso queiram, podem questionar sobre a patologia.

Foram coletados comentários, sendo eles de caráter pessoal e de forma indireta, como postagens e respostas. Com base nessas interações, conseguiu-se analisar que grande parte desses comentários eram feitos por mulheres, representando $84 \%$ da população pesquisada, enquanto os homens totalizam 16\%. No ano de 2018, 25 indivíduos comentaram na página 1, sendo 7 (28\%) homens e 18 (72\%) mulheres. Já no ano seguinte, na mesma página, foram 127 pessoas, sendo 15 (12\%) de homens e 112 (88\%) por mulheres, totalizando 157 comentários no período de estudo. A página 2 demonstrou um total de 97 indivíduos no espaço de tempo estabelecido, sendo no ano de 2018 cerca de 50 pessoas, com 09 (18\%) homens e 41 (82\%) mulheres no ano de 2018 e 09 homens e 38 (81\%) mulheres no ano de 2019 com um conjunto de 47 indivíduos (tabela 1).

$\begin{array}{cccc} & \text { Homens } & \text { mulheres } & \text { TOTAL } \\ 2018 & 7(28 \%) & 18(72 \%) & 25(16 \%) \\ 2019 & 15(12 \%) & 112(88 \%) & 127(84 \%) \\ & 22(14 \%) & 130(87 \%) & 152(100 \%) \\ \text { ELA } & & & \\ 2018 & \text { homens } & \text { mulheres } & \text { TOTAL } \\ 2019 & 09(18 \%)) & 41(82 \%) & 50(52 \%) \\ & 09(19 \%) & 38(81 \%)) & 47(48 \%) \\ & 18(19 \%) & 79(81 \%) & 97(100)\end{array}$

Legenda: Percentual demográfico em duas páginas de uma rede social de 2018 à 2019

Fonte: Os Autores, 2019.

Com a observação realizada em alguns perfis de indivíduos participantes das páginas nota-se uma baixa aderência de jovens e uma prevalência de pessoas com idade entre cerca de 30 a 50 anos. Notase que grande parte dos comentários são realizados por familiares que buscam ajuda, conforto e além de tudo, contam sua história para que mais pessoas possam se sentir acalentadas em um momento de dor. 
Os participantes acessarem a página/grupo agradecem pela acolhida e frequentemente demoram a realizar algum comentário relacionado à doença, o que pode ser explicado pela necessidade de compreender a forma como acontecem as interações nesse ambiente. Nesse sentido, percebemos que a entrada no ambiente virtual, os indivíduos observam a situação e depois manifestam-se, primeiro em busca de informação e em seguida através de colocações de problemas e vivências a fim de estreitar laços com os demais interlocutores.

Se lembrarmos o conceito de situação de Erving Goffman (2012), esse considera a análise da situação como ponto de partida para interações face a face, na qual o indivíduo analisa os elementos presentes na interação: os atores, os papéis, o cenário entre outros. No ambiente virtual, observamos similaridade na observância da situação, nas quais os elementos verificados seriam principalmente os participantes. Observa-se não apenas quem são os participantes doentes, familiares, cuidadores, amigos, mas também o tipo de linguagem utilizada, os tipos de manifestações aprovadas e desaprovadas e na qual o cenário seria o próprio ambiente virtual, o que se comunica e como se comunica: A experiência da doença, do cuidado, do sofrimento.

Em torno desses elementos que se constroem as significações do vivido por uns e outros. Isto adquire caráter simbólico porque na medida que estes conteúdos são compartilhados, podem orientar as pessoas em seu cotidiano e levam os indivíduos a buscarem a especificidade de sociabilidade aceita no ambiente. GOFFMAN (2002) mostra como o indivíduo vai atribuir um sentido às interações cotidianas a partir de sua experiência vivida. Esse processo também ocorre no universo virtual. Ou seja, para participar de uma comunidade virtual, a primeira atitude é observar as interações estabelecidas a fim de perceber quais as atitudes e posicionamentos são aceitáveis. $\mathrm{O}$ que ajuda a entender esta situação é o que Goffman considera enquadramento, ou seja, as pessoas compreendem a paisagem constituída pela doença como seu núcleo central e os demais elementos (familiares etc.) são parte dessa paisagem.

Existem relações de pertença entre os elementos de uma paisagem. Com esta metáfora Goffman nos ajuda a entender as interações entre os diversos elementos, aquilo que podemos chamar de relações de pertencimento. A partir disso se pode pensar nas formas que a sociabilidade assume nestes casos. Nesse sentido, não percebemos nas postagens posturas conflitantes ou atitudes que poderiam criar mal estar, repulsa ou antagonismos dos membros.

É possível pressupor que atitudes nesse sentido levariam ao banimento do participante, mas não foi encontrado durante o tempo da pesquisa qualquer posicionamento que demonstrasse raiva, desprezo 
ou desejo de abandono por parte dos cuidadores aos acometidos por ELA. A tristeza, o medo e a revolta, se voltam ao destino, nunca ao paciente, que é sempre visto como a grande vítima da fatalidade e isento de toda culpa.

Por outro lado, a maior parte dos membros da comunidade virtual tornam-se "participantes fantasmas", que tem acesso às discussões do grupo, mas que não interagem com os demais membros. Para MERCADO (2012) cada comunidade virtual funciona à sua maneira, de modo que, em cada comunidade existem sempre membros ativos que integram com o grupo e membros inativos que estão presentes mas não realizam interação. Inferimos que a explicação para a ausência de interação pode ser várias ordens: vergonha ou medo da exposição; desinteresse em criar vínculos; busca apenas de informação entre outras. A pesquisa, no entanto, foi realizada a partir dos relatos e comentários publicados, que após o levantamento e catalogação durante o período de levantamento foram classificados e analisados.

\section{AS CATEGORIAS DE ANÁLISE}

A análise do material catalogado levou à criação de 5 grandes categorias de postagens:

ESPERANÇA: nessa categoria observamos que o doente nem sempre acaba participando do processo de envolvimento com as redes sociais, mas quando o faz, se torna uma participação importante, pois mesmo sendo um portador de uma doença degenerativa ele demonstra otimismo.

CUIDADO: na qual observamos o familiar e o seu ato de cuidar. Esse ator social é o que mais participa da comunidade virtual e se apresenta como aquele que se questiona, que demanda ajuda, que solicita amparo ao mesmo tempo que se mostra altruísta. É o cuidador que atende e acompanha o doente até seus últimos suspiros.

O LUTO: a inevitável morte: a finitude da vida está sempre presente pois trata-se de uma doença incurável e aparece em grande parte dos comentários. É ao mesmo tempo um preparo à esse inevitável fim e a busca de consolo quando ele ocorre.

CONFORTO ATRAVÉS DA FÉ: A religiosidade faz parte da vida de muitos indivíduos e estes acabam relatando nos comentários, sendo revertidos como busca de apoio por meio da fé. E o quinto e último tema é 
O OUTRO COMO EU: é justamente o intuito do trabalho, entender como essas relações acontecem, como os indivíduos presentes nesse local interagem, trocam experiências e acabam vivenciando momentos juntos.

\section{ESPERANÇA}

Analisando os comentários feitos pelos próprios portadores de ELA ou de seus familiares que os relatos começam sempre com os depoimentos sobre a descoberta da doença. É possível perceber nessa participação a necessidade de relatar sua experiência, fazer-se compreender e preparar-se para a nova condição. A perplexidade que os acomete ao perceber a gravidade e inexorabilidade da ELA.

Entre os portadores é comum o desejo de alertar e ajudar outras pessoas a obterem um diagnóstico mais precoce da doença, ou seja, mesmo estando doente o paciente procura praticar a empatia. Abaixo alguns extratos que demonstram essas proposições, coletados das páginas e grupos de redes socias estudadas:

-"Eu demorei 18 meses para ser diagnosticada, comecei com dificuldades parar em pé e andar, voz tremida, tremedeira, dores musculares, engasgos"- Amarílis

- “(...) Aos 42 anos, especificamente em primeiro de maio de 2012, após uma caminhada, senti muita dor muscular na panturrilha (...) Após uns 45 dias, senti fraqueza no dedão direito, onde não conseguia firmar o chinelo no pé; após, isso veio as câimbras, as fasciculações musculares, e aumento da fraqueza. Primeiramente consultei médicos ortopedistas, fiz fisioterapia diversas, e nada de melhoria, fui por conta propria pesquisar, e em base aos sintomas que só aumentava, em 12/10/2012, já tinha a certeza de $90 \%$ que se tratava da "ELA", na época, totalmente desconhecia o que era ELA. (...) fiz mais três eletromiografias, e, em 05/05/2013, já tinha o laudo médico atestando a causa da fraqueza muscular, ou seja, tratava de fato de Esclarece Lateral Amiotrófica. (...)" - Cravo

Além dessa semelhança em relação à descoberta de portar a doença, outra semelhança observada nos doentes é o desconhecimento que eles têm sobre a doença, muitos não sabem como a doença age no corpo, quais são os sintomas, as gravidades e entre outras dúvidas relacionadas. Por esse motivo, mesmo que com alguns esclarecimentos médicos, o doente e até mesmo o cuidador, recorrem as redes sociais para esclarecer dúvidas e conhecer melhor a doença.

- "Boa noite, sou da cidade (...). E descobri a página hoje, pois hoje recebi a pior notícia, que meu pai está com essa doença chamada ELA. Meu chão se abriu, estou desesperada, já li sobre a doença e me desesperei mais ainda quando vi o que ira acontecer com ele, pelo amor de Deus, me ajudem, me dêem uma palavra sobre isso, o que eu faço, estou sem chão, e o médico disse que a dele está muito, não sei o que eu faço.."- Petúnia 
Mas mesmo com alguns depoimentos e comentários dos próprios portadores, é notável a menor participação deles nos grupos e páginas das redes sociais que foram analisadas, a grande maioria dos participantes são os familiares, que por sua vez, como citado anteriormente são majoritariamente os cuidadores desses doentes. Uma das razões para esta menor participação pode estar relacionada com as limitações físicas que a doença acomete o indivíduo, que dificultam e impedem que o mesmo realize movimentos básicos para manusear um smartphone ou utilizar um computador, por exemplo. Outro motivo que também pode estar relacionado, é o constrangimento e insegurança do doente em relatar suas dificuldades e vivências com a doença, pois conforme a doença avança o indivíduo se torna cada vez mais dependente de outra pessoa, algo que para muitas pessoas é constrangedor e de bastante difícil aceitação. O comentário abaixo é de um portador de ELA, que se mostra descontente ao se tornar dependente de alguém.

\footnotetext{
"Acabamos de receber o diagnóstico da minha mãe de ELA, alguém pode ajudar a entender e ao que correr atráz?"- Calêndula
}

No artigo de BANDEIRA, é avaliado a qualidade de vida de portadores de ELA em Brasília, em seus estudos ele comenta o fato de que o paciente vai percebendo a evolução da doença à medida que ela vai avançando e afetando diretamente seu cotidiano e suas atividades de vida diárias (AVD's), assim como também conclui que " (...) qualidade de vida dos portadores de ELA declina com a evolução da doença, que é rápida, e que estes se adaptam às suas limitações valorizando o que ainda Ihes é preservado." (BANDEIRA, 2010, P.133-138), mesmo com o avanço da doença e se tornando cada vez mais dependente do cuidador, o doente procura se manter confiante, tenta se adaptar e ver o lado bom das coisas, ter um cuidador familiar (CF) ao seu lado e receber o apoio de carinho das demais pessoas, o motiva cada vez mais a não desistir de lutar por sua vida. Abaixo segue alguns fragmentos de CF e de doentes, sobre esse apoio e motivação pela vida:

- “(...) E vida continua, mesmo com aumento das minhas limitações, toco a vida, com maior naturalidade possível, ao longo desses quase 7 anos, foram raros os momentos que fiquei desanimado ou triste. (...)Mesmo hoje vivendo sobre um leito, não mudei minha essência, de ser produtivo, de ajudar as pessoas!"Cravo

-“Muita paciência, amor, dedicação! Não é para sempre, passa muito rápido. Minha mãe ficou 1 ano na cadeira de rodas, cd dia mais sem forças, sem voz, mas a cabeça ótima. Passou muito rápido, por isso, dê todo amor q puder, passeie c ela, leva ela $p$ fazer o cabelo, as unhas, minha mãe gostava disso. Deus a abençoe e fortaleça" - Íris 


\section{CUIDADO}

Das páginas e grupos analisados nesse estudo, se observa que uma grande maioria dos cuidadores são os próprios familiares do doente, esse fato pode estar relacionado com várias questões, algumas envolvem dificuldades financeiras, por exemplo, nem todas as famílias que são afetadas direta ou indiretamente pela doença possuem recursos financeiros suficientes para contratar um cuidador e acabam não tendo outra opção, ser tornando assim o próprio cuidador do familiar acometido pela doença. Além disso, os custos com medicamentos e equipamentos necessários para o cuidado são bastantes altos, o que leva a muitas famílias a procurarem ajuda financeira por meio das redes sociais, onde acabam encontrando pessoas dispostas a realizar algum tipo de doação, ajuda psicológica e também a venda de medicamentos e equipamentos por preços mais acessíveis.

Ademais nos dados coletados, nota-se também a procura por medicações, indivíduos com dúvidas em relação a descoberta da doença, perfis que relatam notícias ou estudos sobre tratamentos experimentais que talvez possam ser a cura da doença, existindo assim uma variabilidade de informações e situações dentro das páginas. Os comentários abaixo são um dos exemplos desse compartilhamento de informações à respeito de possíveis tratamentos:

"Bom dia, alguém poderia me informar como estão usando o Jatobá pra tratamento da ELA" - Magnólia

"Alguma novidade sobre transplante de célula tronco ou tratamento da esclerose lateral" - Crisântemo

Outro fator que também leva ao familiar se tornar um cuidador está bastante relacionado com a teoria da dádiva, essa teoria nos diz muito sobre a importância que as relações interpessoais têm sobre o ato de cuidar, quando essas relações são bastantes consistentes, como as relações familiares por exemplo , a necessidade de doar-se ao outro através de atitudes se torna cada vez mais forte, ou seja, surge no CF a ideia de retribuir o cuidado e atenção que foram recebidos do familiar que agora se encontra doente.

Ao mesmo tempo que esse cuidado é feito, a esperança para uma cura e melhora são alimentadas todos os dias, mesmo que o CF e o próprio doente tenha consciência de que a cura para esta doença está muito longe de vir a surgir, alguns dos comentários coletados de grupos em uma rede social retrata bem essa questão de tentar manter a esperança e ao mesmo tempo ter consciência de que essa doença não traz boas perspectivas:

"Gostaria de ter esperança na cura ou até esperança num medicamento que estaguinasse a doença, mas minha experiência com essa doença terrível só me 
faz lembrar por tudo que vi minha mãe sofrer, lembro de dor, sofrimento e morte cruel sem chance de defesa."- Girassol

“Aproveitem $p$ dar muito amor às suas mãezinhas pq essa doença vem $p$ leválas mesmo, se estiver evoluindo rápido. O riluzol dá uma sobrevida melhor de 6 meses, depois disso a doença só evoluiu meio tomando ele."

Dália

A partir do momento em que a doença ELA começa a fazer parte da vida do CF sua vida muda completamente, suas preocupações maiores se voltam ao bem-estar e qualidade de vida do doente que ao longo do tempo se torna cada vez mais dependente do cuidador, conforme a evolução da doença acontece o cuidador se obriga, de certa forma, a mudar seu cotidiano para se dedicar totalmente ao doente. Essas mudanças drásticas e inesperadas, afetam bastante as relações sociais e familiares do cuidador assim como sua saúde mental, seus objetivos e perspectivas do futuro, consequência essa maior responsabilidade e dedicação com o cuidar do outro.

Dentre os vários comentários analisados, um se destacou por se tratar de um relato sobre toda essa mudança radical que a ELA causou na vida de uma cuidadora familiar, que no caso se trata da filha que passou a viver em função dos cuidados à sua mãe portadora da doença:

“(...). Eu tinha 12 anos de idade quando foi dado o diagnóstico, porém, não fazia ideia do que aconteceria na minha vida e nem na vida da minha mãe. No ano de 1995, minha mãe tinha 35 anos, foi quando começou a sentir fraqueza nas pernas, (...). Minha mãe realizou alguns exames. Até que 6 meses depois veio o diagnóstico de Esclerose Lateral Amiotrófica (...) Minha mãe ficou arrasada com toda informação, quanto a mim, não entendia muito bem o que estava acontecendo (...) Fiquei extremamente triste e chorei muito por não poder mais sair de casa. Fui me adaptando a situação, já não dormia mais, ficava atenta a todo momento, qualquer barulho que eu ouvia que poderia sinalizar algo ruim, me fazia levar correndo e ficar ao lado da minha mãe na cabeceira da cama. Foram 5 anos com a ELA, até que no dia 1 de novembro de 2000, minha mãe veio a falecer. Na época eu tinha acabado de completar 17 anos (...). Deus estava presente a todo momento, assim como é presente na minha vida. (...). “- Hortênsia

Apesar de todo o sofrimento e mudanças que acometem a vida do CF, este sempre procura transparecer otimismo e positividade ao doente, com o objetivo de proporcionar e manter a boa saúde mental do outro, tornando assim os dias do doente menos tristes e sofridos:

- "É um momento de choque muito difícil Mas não desanime essa doença para nós família assim como para o paciente é feita de fases vai passando uma de cada vez com coragem e dando coragem um sorriso de apoio para q o paciente não se sinta só força somos muitos nessa luta (...)"- Antúrio 


\section{O LUTO: UM FRAGMENTO SOBRE A MORTE}

A morte pode ser conceituada de várias formas, tanto no âmbito filósofo, religioso e biológico. 0 momento de determinação da morte biológica se dá quando nenhuma medida intervencional pode ser realizada para que ocorra a reversão e o indivíduo volte à vida. Para que exista a renovação dos seres humanos e assim o começo e fim de um ciclo a morte entra como atriz principal, sendo produto principal da vida (GONÇALVES, 2007).

BARROSO E MARTEL (2010) referem como a morte faz parte do processo de existência ao falarem sobre finitude da vida, vulnerabilidade corporal e mental e como estes são ligados ao destino final, do qual todos estão inseridos. SCHARAMM (2002) reflete também sobre como a morte é um processo inerente aos seres vivos, sendo parte do processo biológico e programado da vida. Sabemos que o deixar de existir é um processo intrínseco aos seres vivos e que todos tem um relógio biológico para que isso aconteça, porém, em algumas situações a morte é antecipada, sendo por um acidente, por uma doença incapacitante e degenerativa - no caso de estudo, a ELA - ou até mesmo a morte súbita.

A ELA se configura como uma doença incapacitante a longo prazo, entre a descoberta dos primeiros sintomas e o diagnóstico fidedigno são longos meses ou anos para que o portador receba a notícia de que está em com uma doença autoimune. Após a confirmação diagnóstica, o paciente entra em um corredor que só tem uma saída e uma direção, e é justamente esse caminho que o faz ter os sentimentos mais intensos de incerteza sobre o futuro.

A morte está presente nessa doença desde que foi designada, desde que foi concebida como doença incurável. O paciente que possui ELA está fadado a um destino, seu caminho se torna um tanto quanto árduo, visto as dificuldades que surgem durante todo o processo, como a degeneração do próprio corpo, a evolução de perde de autonomia, a falta de liberdade com si, entre outros. A ideia de morte e a consequência dela acabam se tornando parte da rotina de pacientes e cuidadores Porém, apesar de todos os empecilhos impostos por essa doença autoimune, pode-se notar que em alguns casos o paciente não desiste de continuar vivendo, assim como pode ser observado em um dos comentários, onde o paciente que possui ELA relata que não deixa de realizar suas atividades:

"E vida continua, mesmo com aumento das minhas limitações, toco a vida, com maior naturalidade possível, ao longo desses quase 7 anos, foram raros os momentos que fiquei desanimado ou triste [...] Mesmo hoje vivendo sobre um leito, não mudei minha essência, de ser produtivo, de ajudar as pessoas." Cravo 
Quem convive com a doença sabe que a perda é inevitável, que a patologia ainda sem cura, em algum momento levará o ente querido. De toda forma, a morte ainda assim consegue deixar marcas em quem fica, as dificuldades e os momentos permanecem na memória, como pode ser observado a seguir:

"Eu creio do fundo do meu coração. Só quem convive com um portador tem a
percepção do quão difícil é pra eles, pra família e pra todos a sua volta e pensar
que a exatos 4 anos atrás eu nem sabia que ELA existia. São verdadeiros
guerreiros" - Camélia É possível até notar como quem participou de todo o processo de adoecimento, diante de todo sofrimento e dificuldade consegue expressar um comentário de gratidão, como pode ser observado nesse comentário.

\footnotetext{
"Grata a Deus por ter vivenciado essa experiência, por passar por momentos extremamente difíceis mas com garra e coragem, por ser a pessoa que sou hoje" - Hortênsia
}

Para GENEZINI (2013) a "morte em vida" pode existir, quando o Familiar Cuidador toma decisões pelo seu doente, podendo representar a falta desse familiar, onde pode ser princípio para o "luto antecipatório". O luto antecipatório se designa como o sofrimento vivido antes da morte. O luto antecipatório, citado por NETO E LISBOA (2017) acontecimento este desenvolvido pelo psiquiatra alemão Erich Lindemann em 1944, refere que em seus estudos na II Guerra Mundial, as esposas de soldados recém retornados da batalha tinham dificuldades para aceitá-los novamente, visto que estas já anteriormente já tinham entrado em um processo de luto, pois a morte do ente já tinha sido aceita.

Em muitos casos, é o próprio familiar que se torna o cuidador, sendo assim, a ligação com a morte se torna ainda mais difícil, por muitas vezes é a filha, a mãe, o tio ou a prima que cuidam desse paciente. O sentimento de morte iminente também é um fator presente na vida de muitos familiares/cuidadores, como pode ser evidenciado a seguir:

"Sofrimento que dói na alma, minha mãe já está com todos esses sintomas, sinto cada momento que ela está perto de descansar dessa doença miserável, a cada falta de ar meu coração aperta mais forte" - Jasmin.

FLORIANI (2004) relata que a literatura tem mostrado como a morte afeta o ambiente em que os indivíduos estão inseridos, em virtude das atividades realizadas no local com o doente, que as memórias acabam se ligando ao recinto, assim, a continuidade da vida para os familiares que ficam se torna pesada e dificultosa.

O sofrimento dos familiares é vivenciado desde o início da descoberta, com a demora do diagnóstico, com o desconhecimento sobre a doença e a necessidade de aprender tudo sobre seus tratamentos e 
conseqüências. com as dificuldades nas atividades diárias, na readaptação de vida que todos os envolvidos com essa patologia tem que participar e a falta de perspectiva da doença, sabendo que esta não possui cura e que o único caminho é a morte. Dentre os comentários analisados, muitos deles relatam que a pessoa acometida pela ELA acabou falecendo e contam sobre como este (a) sofreu, como pode ser visto a seguir:

\footnotetext{
"Hoje mais uma pessoa foi vencida por essa doença terrível, minha cunhada depois de 1 ano e 3 meses diagnosticada com ELA, não resistiu, um sofrimento, só Deus sabe o quanto sofreu" - Margarida

"Minha era jovem e bonita. Gostava de viver, mas Deus a levou. O sofrimento foi grande, qdo morreu já não entendíamos quase nada do q falava e estava c muita dificuldade $p$ comer e não queria as intervenções, de jeito nenhum. Morreu com parada cardio respiratória, parecendo um passarinho, parando de respirar, mesmo c oxigênio" - Rosa
}

O profissional enfermeiro é o que mais tem contato com o doente, do primeiro ao último suspiro. Segundo GÓIS e DA SILVA ABRÃO (2015) é necessário que a discussão do processo de morrer e a questão da morte sejam abordados desde o início da graduação, para que esses futuros profissionais possam lidar de forma adequada para com seus pacientes, a fim de ofertar um cuidado humanizado, com o propósito de realizar uma assistência de qualidade, competência necessária para trazer ao doente que está em seus últimos dias de vida, conforto físico, alívio da dor e se possível suporte emocional.

\section{CONFORTO ATRAVÉS DA FÉ}

Sabe-se que a religiosidade no Brasil tem um cunho histórico, e que devido às transformações ocorridas ao longo desses 520 anos, atualmente o país possui uma pluralidade de crenças e valores (SOUZA, 2013).

Por religiosidade, compreende-se como sendo o experimento que o indivíduo realiza para alcançar fenômenos religiosos (DE FREITAS, 2014). Também pode ser referida como forma de se ligar ao sagrado, com modelo de crenças e valores (DO LAGO-RIZZARDI, TEIXEIRA e DE SIQUEIRA, 2010).

A doença traz consigo vários sentimentos, dentre eles, o sofrimento, que em grande parte das situações é o sentimento mais presente. Isso pode gerar uma dualidade em relação a religiosidade, pois pode trazer tanto descrença quanto força e otimismo na divindade (DO NASCIMENTO, 2007). A crença religiosa possui dois lados, de certa forma ela pode auxiliar o indivíduo acometido por uma doença, no sentido de trazer sentimentos positivos, tais como conforto, um afago, até mesmo 
esperança. Já do outro lado, pode trazer sentimentos negativos, tais como culpa e raiva. (STROPPA E MOREIRA-ALMEIDA, 2008).

Observa-se que em alguns comentários retirados das páginas das redes sociais, alguns trazem a religiosidade como fonte principal. DO LAGO-RIZZARDI, TEIXEIRA e DE SIQUEIRA (2010) ressaltam que estudos demonstram que a espiritualidade pode ter grande importância com o confronte de doenças crônicas.

\begin{abstract}
“Olá, não desanime, fique mais próxima da sua mãe, estou passando pela mesma fase que você. além do tratamento que estamos fazendo ela se apegou muito a religião. isso está fazendo muito bem psicologicamente pra ela. Não desanime, nada como um dia após o outro! Deus sabe de todas as coisas" - Flor de Cerejeira
\end{abstract}

"Querida se apegue a Deus, pois é nessas que precisamos segurar nas mãos de Deus. estarei orando por você"- Dente de Leão

Em sua grande maioria, os comentários vêm de familiares que convivem e/ou perderam seus entes queridos e de alguma forma precisam/querer receber/dar conforto a outros indivíduos. Estes, buscam na rede social, algum tipo de consolo ou alívio, por saber que mais pessoas passam pela mesma situação.

\footnotetext{
"Bom dia, venho Aki agradecer pela força e palavras de carinho, mas minha mãe veio a falecer $\square$, hoje faz 15 dias o vazio, a dor é imensa, ,mas de vê ela sofrendo daquele jeito tbm era doloroso, *a doença venceu mais uma vez, espero $q$ achem a cura pra essa doença, pra q pessoas não sofram como minha mãe sofreu $\square, . . *$ Deus está cuidando de minha mãezinha agora"- Gérbera
}

As falas evidenciam que a religião tem grande impacto na vida destes que sofrem com a doença autoimune, estudo do caso, e que estes buscam aliar-se uns aos outros em demonstração de apoio emocional, conforto e tentam de alguma forma prestar um bem-estar psicológico aqueles que recorrem à rede.

\title{
O OUTRO COMO EU
}

Alguns estudos abordam um pouco sobre essa questão de que a internet vem se tornando algo cada vez mais comum e positivo no processo de convivência com uma doença e outras pessoas, através de grupos de autoajuda, por exemplo.

Em um estudo realizado com familiares de pessoas com transtorno mental, mostra como os grupos de autoajuda são relevantes para troca de informações e interação com outras pessoas, "A necessidade de informações e orientações foi apontada como um dos fatores que tornam o grupo de autoajuda diferenciado para seus frequentadores" (BRISCHILIARI, 2014, p. 29-35). Dessa forma 
podemos observar que cada vez mais estes tipos de recursos vêm sendo usados com maior frequência e melhores aceitos pelas pessoas, "A concepção dos familiares participantes do estudo sobre a atuação dos grupos de autoajuda é positiva (...)" (BRISCHILIARI, 2014, p. 29-35).

A rede social, portanto, acaba se tornando uma "amiga" para essas pessoas, um recurso bastante útil, prático e rápido para essa troca de conhecimento e autoajuda, uma característica bastante comum nos grupos analisados neste trabalho. Como foi também observado e relatado nos resultados, além dessa característica outra que percebe-se ser muito comum nos grupos é a questão do apoio vindo de outros participantes dos grupos, através de palavras de conforto, mensagens positivas e muitas de carácter religioso. Esse apoio que é vindo de fora do ambiente familiar se torna valioso, pois muitas vezes é através desse apoio que os familiares e os próprios doentes conseguem se sentirem mais compreendidos, se sentirem mais confiantes para continuar lutando pela vida.

De todos os tipos de comentários coletados e observados, o depoimento de algum tipo de experiência com ELA, foi o tipo de comentário que mais apareceu. Quando um familiar muito próximo é diagnosticado com ELA a pessoa se desespera, sem saber o que fazer, o apoio da família nem sempre é presente e a questão financeira também acaba se tornando algo que dificulta toda a situação tanto do paciente como do familiar cuidador.

Nas redes socias essa pessoa pode encontrar outras pessoas que também estejam passando pela mesma situação, e assim estas se sentem acolhida para pedir algum tipo de ajudar, como nos diálogos abaixo que foram coletados de uma das páginas analisadas, onde um usuário esclarece um pouco a dúvida de outro:

\section{Diálogo 1:}

- "Como é o início dessa doença?"- Begônia

- "Depende de pessoa para pessoa, algumas começam com engasgos, que é a disfagia, outras com queda, perda de força nas mãos, e com o tempo vai evoluindo, chegando ao.uso de cadeira de rodas, a pessoa passa a ter mais dificuldade pra deglutir, sendo necessário o uso de sonda de gastrostomia, para se alimentar e traqueostomia." - Tulipa

\section{Diálogo 2:}

- "Boa noite! Gostaria da ajuda de alguém. Minha mãe tem ELA e já não consegue digitar no tablet para falar, como faço para comprar o Tobbi? Alguém que tenha pode me ajudar por favor? Desde já obrigada. प्पव०"- Orquídea

- "Entre em contato com o Instituto do Dr. Hemerson Casado Gama em Al. Tvz eles saibam de alguém que tenha $p /$ vender." - Hibisco 
As histórias que são relatadas também podem ser vistas como uma forma de ajudar e dar uma noção de como é a convivência com a doença, uma ideia do que é viver com ELA, para aqueles que estão começando a ter esse contato com a doença sendo eles portadores ou não, os comentários abaixo, retirados das páginas analisadas por esse estudo, são um exemplo de pessoas que contam um pouco a experiência com a doença de diferentes perspectivas:

- “Olá meus amigos! Essa é minha amiga Elaine, diagnosticada com ELA há seis anos. Mesmo com todas suas limitações e tristeza por conta da doença ela não dispensa alguns cuidados pessoais que a deixam mais feliz! Como uma excelente esteticista gosta dos cabelos pintados e a depilação feita com cera! Uma mulher que tenho um enorme carinho e admiração e quem tem me ensinado muito! $\square$ (...) Que Deus abençõe a todos nossos amigos acometidos dessa doença horrivel e seus familiares, e que a cura esteja cada dia mais próxima!ロuc口" - Violeta

- “Tenho esperança também, meu esposo está com ELA, desde janeiro de 2017. Está acamado, traqueistomizado, com alimentação enteral, tinha graças a Deus ajuda do Home Care, ele tem 68 anos, o amor da minha vida, não perco a esperança, o meu escudo é a fé em Deus na ciência, para descobrir a causa dessa doença tão cruel e devastadora que acaba com a dignidade da pessoa."Bromélia.

Marta Maia em seu trabalho publicado em 2017, mostra e discute um pouco sobre as experiências de pessoas com hepatite $C$, com os grupos de autoajuda da internet, as experiências relatadas mostram pontos positivos relacionado; “ (..) o facto de ler as histórias dos outros doentes, dos pares, permite ao indivíduo melhor situar-se e definir a sua própria história de vida." (MAIA, Marta, Forum Sociológico. Série II,2017). Isso acaba demonstrando o grande impacto positivo que as redes sociais proporcionam, pois além de oferecerem a troca de informações, as redes sociais também oferecem esse apoio social vindo de outros usuários, se tornando uma ferramenta de intervenção positiva na saúde mental dos familiares e portadores da doença, fator que em alguns casos pode-se não fazer presente no âmbito familiar e social dessas pessoas

\section{CONCLUSÃO}

Pode-se observar que, dos grupos analisados, a maioria dos comentários são realizados por mulheres que, por sua vez, são familiares do doente. Por uma questão social, a mulher é a que mais procura o serviço de saúde, podendo ser esta questão relacionada ao fato de que a maior quantidade de membros atuantes são mulheres e assim acabam se relacionando mais nesse ciberespaço. Observase que existe uma prevalência de participantes com idades de 30 a 50 anos, aproximadamente, pelo fato de que a doença acomete indivíduos com idade acima dos 30 anos, sendo assim, os participantes em sua maioria são pessoas que possuem relação com esse doente. 
A rede social, nesse contexto analisado pelo estudo, tem um papel bastante significativo no processo de interação, troca de informações e apoio entre os participantes. Através desse meio de comunicação tanto os doentes como os cuidadores, em sua maioria, se encontram mais acolhidos e motivados a continuar lutando contra a doença, pois nesse ambiente virtual eles possuem a possibilidade de compartilhar suas experiências, suas dores, dúvidas e seus momentos de alegria ao longo de toda a trajetória e vivência com a doença.

A morte assim como sabemos é inerente aos seres vivos sendo um processo biológico, mas nem por isso é um processo compreendido pelos indivíduos. Observa-se comentários de diversas faces relacionados ao processo de morte, ligados à questão da perda do doente, o sofrimento vivido durante o período da doença e o sofrimento residual pós morte. A questão religiosa torna-se de grande importância, a partir do momento em que tanto o familiar como o doente, a utilizam como um meio de suporte e apoio. Estudos relatam que a doença traz consigo pesares e com isso os indivíduos acabam recorrendo fortemente à religião, podendo se tornar algo positivo ou negativo no enfrentamento da doença. 


\section{REFERÊNCIAS}

1. Brasil. Ministério da Saúde. Portaria SAS/MS n¹151, de 11 de novembro de 2015. Protocolo Clínico e Diretrizes Terapêuticas da Esclerose Lateral Amiotrófica. Disponível em http://portalarquivos2.saude.gov.br/images/pdf/2015/novembro/13/Portaria-SAS-MS--1151--de-11-de-novembro-de-2015.pdf Acesso em 25 de maio de 2019.

2. BERTAZZI, Renan Nogueira et al. Esclerose lateral amiotrófica. Revista de Patologia do Tocantins,v. 4, n. 3, p. 54-65, 2017.

3. Ministério da Saúde. Esclerose Lateral Amiotrófica (ELA): o que é, causas, sintomas, tratamento, diagnóstico e prevenção. Disponível em < http://portalms.saude.gov.br/saude-de-az/esclerose-lateral-amiotrofica-ela> Acesso em 25 de maio de 2019.

4. PALLOTTA, Ronald; ANDRADE, Antonio; BISPO, Ohana Caroline Machado. A Esclerose Lateral Amiotrófica como Doença Autoimune. Revista Neurociências, v. 1, n. 20, p. 144-152, 2012.

5. LIMA, Cristina Maria Garcia de et al. Pesquisa etnográfica: iniciando sua compreensão. Rev. Latino-Am. Enfermagem, Ribeirão Preto, v. 4, n. 1, p. 21-30, Jan. 1996

6. MERCADO, Luis Paulo. Pesquisa qualitativa online utilizando a etnografia virtual. Revista Teias, v. , n. 30, p. 15, 2012.

7. BANDEIRA, Fabrício Marinho et al. Avaliação da qualidade de vida de pacientes portadores deEsclerose Lateral Amiotrófica (ELA) em Brasília. Revista Neurociencias, v. 18, n. 2, p. 133-138, 2010 .

8. GONÇALVES, Ferraz. Conceitos e critérios de morte. Nascer e Crescer, n. 16 (4), p. 245-248, 2007

9. BARROSO, Luís Roberto; MARTEL, Letícia de Campos Velho. A morte como ela é: dignidade e autonomia individual no final da vida. 2010.

10. Schramm FR 2002. Morte e finitude em nossa sociedade: implicações no ensino dos cuidados paliativos. Revista Brasileira de Cancerologia 48(1):17-20.

11. GENEZINI, DEBORA. Assistência ao luto. Manual de Cuidados Paliativos/Academia Nacional de Cuidados Paliativos. Rio de Janeiro: Diagraphic, p. 321-330, 2009.

12. NETO, Jorge Ondere; LISBOA, Carolina Saraiva de Macedo. Doenças associadas ao lutoantecipatório: uma revisão da literatura. Psicologia, Saúde \& Doenças, v. 18, n. 2, p. 308321, 2017.

13. FLORIANI, Ciro Augusto. Cuidador familiar: sobrecarga e proteção. Revista Brasileira de Cancerologia, v. 50, n. 4, p. 341-345, 2004.

14. GÓIS, Amanda Regina Silva; DA SILVA ABRÃO, Fátima Maria. O processo de cuidar do enfermeiro diante da morte. Revista de Enfermagem da UFSM, v. 5, n. 3, p. 415-425, 2015.

15. SOUSA, Rodrigo Franklin de. Religiosidade no Brasil. estudos avançados, v. 27, n. 79, p. 285-288, 2013. 
16. DE FREITAS, Marta Helena. Religiosidade e saúde: experiências dos pacientes e percepções dos profissionais. Revista Pistis Praxis, v. 6, n. 1, p. 89-105, 2014.

17. DO LAGO-RIZZARDI, Camilla Domingues; TEIXEIRA, Manoel Jacobsen; DE SIQUEIRA, Silvia Regina Dowgan Tesseroli. Espiritualidade e religiosidade no enfrentamento da dor. 2010.

18. DO NASCIMENTO, Mirian Noemia Ferreira. Religiosidade e saúde: etnografia de um grupo da RCC em diálogo com a perspectiva Junguiana. 2007.

19. STROPPA, André; MOREIRA-ALMEIDA, Alexander. Religiosidade e saúde. Saúde e espiritualidade: uma nova visão da medicina. Belo Horizonte: Inede, p. 427-443, 2008.

20. BRISCHILIARI, Adriano et al. Concepção de familiares de pessoas com transtorno mental sobre os grupos de autoajuda. Revista Gaúcha de Enfermagem, v. 35, n. 3, p. 29-35, 2014.

21. MAIA, Marta. Grupos de entreajuda de doentes com hepatite C no ciberespaço. In: ForumSociológico. Série II. CESNOVA, 2017

22. GOFFMAN, Erving. Os quadros da experiência social. Uma perspectiva de análise. Editora Vozes, Petrópolis, 2012.

23. A representação do eu na vida cotidiana. Editora Vozes, Petrópolis, 10a.Edição, 2002. 


\section{Capítulo 16}

doi $10.37423 / 210604353$

\section{A ANTROPOLOGIA BRASILEIRA E O MITO DA BRASILIDADE}

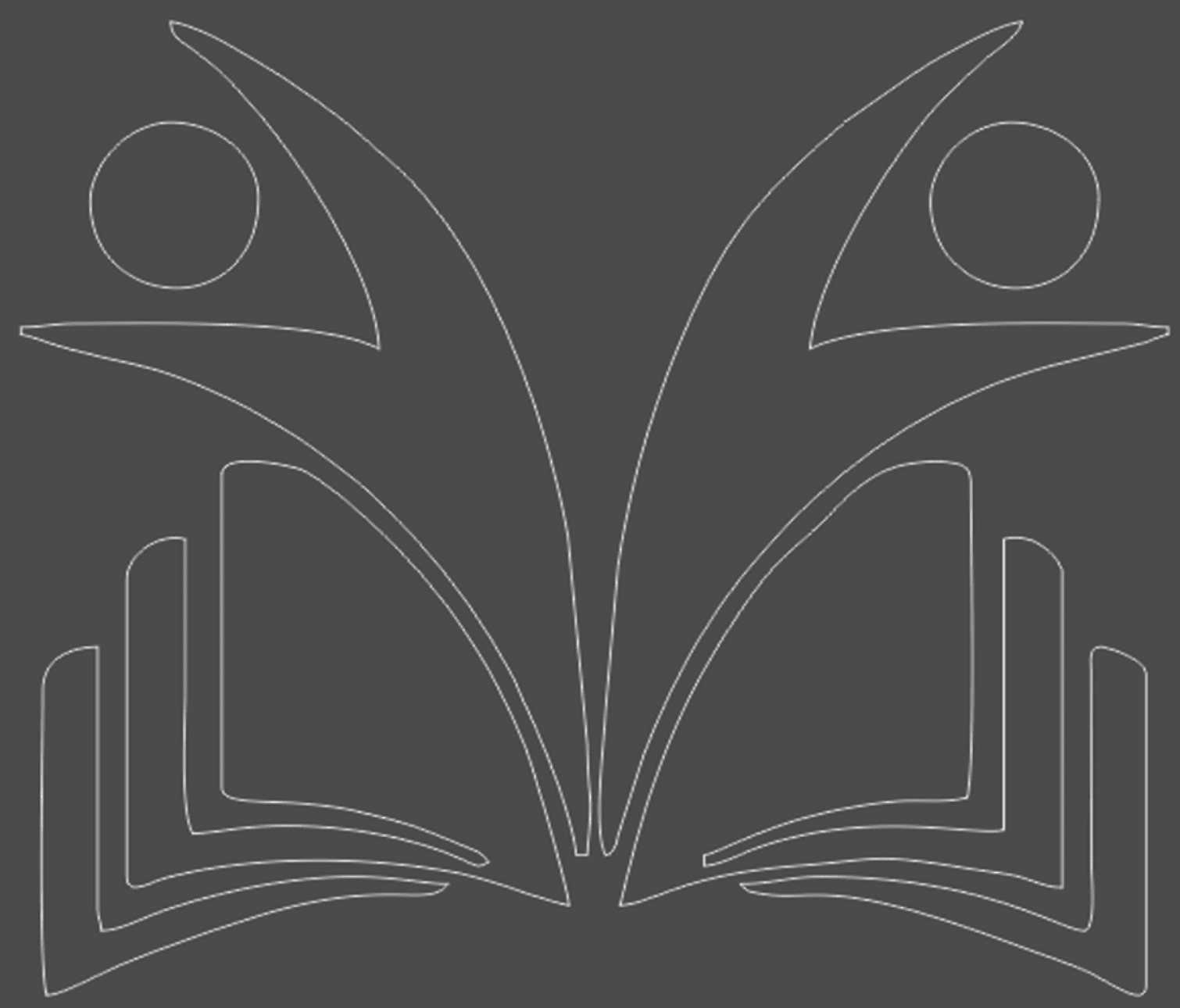




\section{A Antropologia Brasileira E O Mito Da Brasilidade ${ }^{1}$}

\section{INTRODUÇÃO}

Este artigo tem como objetivo repensar temas fundamentais da Identidade Brasileira, a partir da Antropologia brasileira. É importante chamar a atenção para a discussão de autores que se dedicaram ao tema da Identidade Nacional, ao papel do Índio, do Negro, da Religião, da mestiçagem, do sincretismo ao longo da história brasileira, com ênfase na discussão modernista, que, afinal, irá informar a própria antropologia brasileira.

No século XXI, o Governo Brasileiro, a partir do Encontro de Durban, em 2001, reconheceu o Brasil como um país racista. Tal reconhecimento, deu origem ao desenvolvimento uma série de políticas afirmativas de inclusão racial, voltadas para as populações negras e indígenas, amparadas pela Constituição de 1988. Essas políticas, em especial as chamadas cotas raciais, para ingresso nas Universidades públicas e no serviço público, têm tido consequências na vida cultural e na sociedade brasileira como um todo. Entre elas, podemos citar todo um debate sobre os tipos brasileiros, "as três raças', "a democracia racial", a mestiçagem e o Mestiço como o tipo Brasileiro por excelência. Com as críticas recorrentes do Movimento Negro Brasileiro sobre a mestiçagem e o seu papel no apagamento de possíveis identidades negras, ao longo da história recente do País, a necessidade de rever este tema se impõe, uma vez que tal tema original havia sido vivenciado e expresso de diversas formas, artísticas, culturais, educativas e políticas. Tentativas de alterar esse padrão identitário tem produzido um debate amplo, sobre a identidade cultural brasileira, os diversos grupos sociais que a formam e as relações entre eles. O que pede, de uma perspectiva antropológica, reflexões sobre as relações entre Identidade nacional, grupos étnicos e suas reinvindicações minoritárias. Afinal, existem "tipos brasileiros", por um lado e algum "brasileiro genérico", por outro?

\section{O MACUNAIIMA}

Se nos voltarmos para um personagem tipo da identidade brasileira já na nossa república, ao longo do século XX, deparamos com "Macunaíma", o herói sem nenhum caráter, personagem emblemático criado por Mário de Andrade, inspirado por lendas dos índios de Roraima. Macunaíma não teria nenhum "caráter nacional", daí a sua especificidade. Seu tipo é não ser um tipo, uma definição que não define, indefine. Além disso, sendo Índio, tendo nascido preto e virado branco, após um banho ritual, ele termina personificando não apenas o "mito das três raças", mas o projeto de Branqueamento da República brasileira. É importante revê-lo, em primeiro lugar, nesta discussão. 


\section{A Antropologia Brasileira E O Mito Da Brasilidade}

Uma antropóloga, celebre por sua crítica as cotas raciais no Brasil, Ivonne Maggie (2005) escreveu sobre esta relação. Ela chama a atenção para que, ao criticar a "mestiçagem brasileira" os programas de cotas estavam, de fato, criticando o ideal modernista. O que nos permite outra pergunta, até que ponto estes ideais foram realmente incorporados como uma identidade nacional e por quem? Ou será que não permaneceram mais como um discurso erudito? Várias questões podem ser colocadas a partir daqui. O que seria ser um "mestiço brasileiro"? Se alguém se define desta maneira, e em que circunstâncias tal identidade seria trazida à tona? Os ideais modernistas da Semana de 22, na sua tentativa de criar uma identidade nacional brasileira, positivando a mestiçagem, não precisam ser, realmente, revistos?

Se retomamos ao Manifesto Antropofágico de Oswald de Andrade, o que encontramos.? Em primeiro lugar, uma tentativa de criar uma versão brasileira de ideias europeus sobre Cultura, História e Civilização, tendo uma identidade nacional possível, para uma elite que tendia a se ver, dentro de certos limites, como europeus na América. Em segundo lugar, uma tentativa de criar uma "alma nativa", uma identificação com um tipo indígena ideal, uma origem mítica que estabelecesse relações entre a Terra, a História - ou a ausência dela - a Cultura e os seus habitantes. Uma origem mítica. Daí as evocações à devoração do Bispo Sardinha pelos índios Tupis, o ícone da Antropofagia, entre outros temas tomados para pensar um espirito "bricoleur" 2 do Brasil, como brasilidade. Por outro lado, se lemos o texto de Eduardo viveiros de Castro (1992), sobre o encontro dos tupis com os jesuítas, a impressão é de que o manifesto antropofágico, a antropofagia e o "herói sem nenhum caráter" atualizam exatamente o olhar jesuítico, europeu e católico sobre os índios do litoral e não uma visão deles mesmos sobre o que quer que seja.

Ou seja, temos uma questão bem presente, quem se identifica realmente com os ideais modernistas da Antropofagia, do Macunaíma, assim como os temas associados, "as três raças" e a "democracia racial"? Não há como negar que todos estes temas, que não são idênticos, se misturam e se confundem numa ideia genérica de Identidade brasileira, marcadas pela Mestiçagem e pelo sincretismo, mas, que tipo brasileiro emerge daí? Há mais questões em jogo Gustavo Lins Ribeiro (2000) tem um interessante capítulo sobre este tema. Originalmente uma história dos índios Taulipang, do Monte Roraima, foi aproveitada por Mario de Andrade, para propor uma identidade brasileira, inexistente até então. Originalmente, a ideia do Herói sem nenhum caráter, do ponto de vista do seu autor, seria a ausência de uma consciência tradicional, de uma civilização. No fim das contas, para Ribeiro, Mário de Andrade propôs uma identidade moderna, fragmentada, que quer ser, 


\section{A Antropologia Brasileira E O Mito Da Brasilidade ${ }^{1}$}

mas reconhece que não é. No Macunaíma, Mario de Andrade não procurou construir uma identidade brasileira bem definida, mas incompleta pelas limitações da Modernidade. Ele optou por construir uma identidade já moderna, reconhecendo a fragmentação e a ausência de definições duradouras, fazendo do Macunaíma dos Índios de Roraima um signo destas limitações modernas. Um Herói sem caráter nacional, que é não sendo.

A Ausência de "caráter" do Herói seria tanto uma imagem da ausência de tradições como da impossibilidade de construir alguma. Ribeiro chama a atenção de que, ao contrário de outras obras do modernismo brasileiro, não há, em Macunaíma, uma proposta de uma utopia tropical ou algum tipo de projeto de Nação ou País.

Há uma evidente tensão entre valores europeus e brasileiros, que a obra quer realçar, numa verdadeira colcha de retalhos, esta sim, identitária, ao que parece. A leitura de Ribeiro serve para pensar também o quanto alguma identidade brasileira é um tema de difícil abordagem e que, num certo sentido, a diversidade cultural e social presente no País se constitui num problema real para o que veio a ser conhecido como Pensamento Social Brasileiro. Diante de uma ideia de "civilização europeia" entendida como Homogênea e hegemônica, a diversidade cultural brasileira apareceria como problemática nas suas diferenças. De qualquer maneira a Antropofagia, como pensada pelos modernistas de 22 tornou-se um tema paradigmático para uma certa elite letrada no País, o que não significa que vivemos num país de "Macunaímas".

Neste século outras vozes surgem num novo debate sobre identidades e tipos no Brasil. Se tomarmos outro antropólogo contemporâneo, Kabenguele Munanga, originalmente congolês, e sua crítica a ideia da mestiçagem brasileira, encontramos uma crítica voltada para esse ponto, embora a partir de outro autor, o também antropólogo, Darcy Ribeiro.

Diz Munanga "Conta-nos o prof. Darcy Ribeiro que o mameluco, originado pelo cunhadismo e o mulato não eram nem europeus, nem índios e nem africanos. Eram ninguém. Tiveram que sair dessa "ninguedade" para procurar uma identidade, para inventar a sua própria identidade, que viria a ser brasileira. "Essa mestiçagem de gente, que não são europeus, nem africanos, nem nada" é o que Darcy chama de gênero humano novo, "uma civilização que vai se apresentar ao mundo como uma coisa melhor que o mundo ainda não viu. Essa coisa é uma coisa melhor, porque tem uma humanidade incorporada" (2008: 101)

Um verdadeiro resumo das considerações sobre a mestiçagem no Brasil, aqui enquanto projeto de Nação, e também sobre o Macunaíma como o modelo deste tipo nacional inexistente. A discussão de 


\section{A Antropologia Brasileira E O Mito Da Brasilidade}

Munanga é crítica, no sentido de chamar a atenção de que em nome desta construção de uma identidade mestiça, há toda uma negação do pluralismo real da sociedade e da cultura. Em nome do Macunaíma mestiço, ninguém pode ser mais nada, ou, pelo menos, os negros não devem se pretender negros, em particular, entre outros casos de identidades negadas ou desestimuladas. Macunaíma, Índio que nasceu negro e ficou branco reaparece, a partir destes novos olhares contemporâneos, como o próprio ícone do Branqueamento no Brasil e de sua mestiçagem.

Neste sentido Otávio Velho (2007) também tem uma discussão, onde apresenta, que, as atuais reivindicações identitárias de diversos segmentos da população brasileira, de fato buscam a construção de um novo pacto social, forçando uma revisão destes temas. Para ele, ninguém está querendo dividir o país, mas há uma revisão em curso, cujo resultado ainda não é visível. O que é lícito afirmar é que, numa sociedade sem identidade, diversos grupos sociais estão tentando criar as identidades que nunca tiveram. Afinal do Nada, nada irá sair. O que temos são os "zés ninguém", querendo ser, ser alguém, ser cidadão etc. Sendo assim, podemos afirmar que a construção de novas cidadanias e de um novo pacto social passa pela superação desse Macunaíma mestiço e de tudo associado a ele, e que o atual debate ainda não percebeu isso bem. Ele continua paradigmático da identidade brasileira republicana moderna enquanto a sua negação.

Noutro momento (2018) Otávio Velho retoma esta discussão chamando a atenção como a questão das cotas raciais - e da demarcação de terra indígenas - tornaram-se temas transversais aos consagrados debates entre Esquerda e Direita no cenário político brasileiro. Velho chama a atenção como a proteção ao Índios, e também um certo reconhecimento da importância dos negros para o Brasil, tivera origem, na república brasileira numa visão hierárquica da Sociedade, que reconheceria e protegeria, de alguma maneira, às suas raízes. Essa proteção hierárquica vai se esvanecendo, após a constituição de 1988, ao mesmo tempo que grupos indígenas, quilombolas, entre outros, vão se constituindo como novos agentes sociais com voz própria, reivindicando os seus direitos. O discurso étnico é uma realidade no Brasil contemporâneo, e é uma negação do discurso generalizante das "massas", do "povo", da "nação", tão caro à direita e à esquerda. Diante destas novas reivindicações, o discurso da Mestiçagem se desvenda como Ideologia desmobilizadora de fato.

Nesse novo contexto, é necessário reconhecer um novo lugar teórico a partir dos atuais movimentos sociais e dos sujeitos coletivos que se articulam em torno deles. Não apenas um novo objeto de interpretação, mas um novo guia (o termo é dele) para a reflexão antropológica. Já que estamos, o tempo todo, numa discussão antropológica. A importância dos antropólogos para a construção da 


\section{A Antropologia Brasileira E O Mito Da Brasilidade}

identidade brasileira é um tema antigo, este tema sempre foi alvo de uma antropologia do Brasil. Darcy Ribeiro, Roberto da Matta, Otavio Velho, Kabengele Munanga, são todos antropólogos de importância reconhecida, que, em algum momento de suas carreiras, pensaram o Brasil. Este projeto quer chamar a atenção de que é preciso retomar este tema neste momento da vida brasileira.

Roberto Da Matta (1983), formulou, há décadas atrás uma interessante reflexão sobre a importância das três raças no pensamento social brasileiro. Discordando das vozes que definiam este tema como um "Mito", preferiu falar apenas de uma fábula. Uma história mal contada, com autores e obras conhecidas e datadas, servindo para encobrir as evidentes desigualdades da sociedade brasileira. Estabelecendo uma mediação entre a ordem colonial hierárquica e aristocrática do Império e uma ordem igualitária e democrática instaurada pela república, que nunca se concretiza por causa da anterior, a Fabula das três raças permitiria pensar um passado igualitário para o país, quando as três raças se encontraram, distorcendo a história para justificar uma ordem política e econômica tremendamente injusta ${ }^{3}$.

O Dilema brasileiro, como ele chamou, continua sendo esse até hoje. A Ideia do Mito, entretanto, teve outras formulações. Renato Ortiz (1985), numa discussão também já clássica, elaborada nos anos 80, chamava a atenção de que haveria um mito em torno da nacionalidade, na medida em que permitia que cada cidadão se visse como fazendo parte do Brasil, a partir da sua experiência familiar, seu fenótipo, sua cultura local. Ortiz prefere falar em Mito porque este poderia ser perfeitamente situado na passagem da sociedade monárquica, ainda escravista, para a sociedade republicana, democrática, um momento de uma profunda mudança social. Mas ele percebe que não haveria uma ritualização deste mito, que não se realizaria completamente, através de algum cerimonial especifico. Seria linguagem, sem ser celebração. A ideia da fábula, ao invés de um mito, supera esse problema. Fabula é linguagem e não precisa ser celebração, à princípio.

Ortiz chama atenção para outra questão, envolvendo o movimento negro no Brasil. Para ele, como a ideia de Brasil mestiço impede uma melhor definição de fronteiras de cor, as manifestações e reinvindicações dos Negros passam a ser vistas como manifestações de Brasilidade, criando um continuo entre Negritude e Brasilidade, difícil de superar. Nesse sentido, minha experiência como professor e pesquisador do tema, aponta que os Negros estão muito mais presos a uma oposição sutil entre Negros e Mestiços do que entre Negros e Brancos. Essa tensão seria bem especifica do Brasil, como venho discutindo. ${ }^{4}$ 


\section{A Antropologia Brasileira E O Mito Da Brasilidade}

A partir de Ortiz seria interessante voltar a Roberto Da Matta e a sua proposta de estudar os carnavais, as paradas militares e as procissões religiosas, enquanto rituais da Nacionalidade brasileira. O estudo de Da Matta é bem conhecido e importante neste sentido, embora com uma série de problemas teóricos e etnográficos em torno da relação entre Rito, Mito, Sociedade e Estado Moderno.

Antes, todavia, é interessante recuperar os argumentos de Benedict Anderson, no seu "Nação e consciência Nacional". Anderson (1989) questiona as visões, de inspiração marxista de que as identidades nacionais seriam apenas ideologias para encobrir as desigualdades sócio econômicas que favorecem as classes dominantes. Não sendo apenas um fenômeno da Política e da Economia, as identidades nacionais deveriam ser vistas também, a partir da antropologia, como um fenômeno cultural comparável ao Parentesco e a Religião, dimensões da vida humana identitárias e ritualizadas. Identidades nacionais fazem parte do mundo moderno. Não são as mesmas e nem são equivalentes às de um mundo tradicional - seja lá o que se entenda por isso, mas atendem a necessidades sociais que fazem parte do mundo moderno, situam realmente as pessoas. Creio que o mais adequado é perceber que identidades nacionais gostariam de ser alguma coisa próximo a uma cosmologia tradicional, algo que poderia ser celebrado e constituiria parte importante das identidades pessoais do povo de um Estado Nação, mas não consegue chegar a tanto. Ficam no meio do caminho. Falta alguma coisa para ser uma totalidade, provavelmente em função da fragmentação das identidades modernas, que enfraquecem os sistemas simbólicos por ela gerados. Este tema também é clássico nas Ciências Sociais desde Durkheim, tendo sido discutido por diversos autores, como Giddens na Sociologia ou Mary Douglas na Antropologia.

De qualquer maneira, a proposta de Estudo de Da Matta, sobre a relação entre ritos e identidade brasileira merece ser retomada, a partir desta simples pergunta. Que relação existe entre a Identidade Brasileira e certos ritos e mitos presentes na sociedade, atualizados por diversos agentes? Rever os estudos de DaMatta e outros correlatos, realizados por seus orientandos, a luz das discussões atuais é um esforço interessante de ser retomado.

Maria Isaura Pereira de Queiroz (1988), numa coletânea organizada por Viola Sachs, estabelece um paralelo interessante entre o Modernismo de 22, com sua antropofagia e sua valorização do sincretismo, com a Umbanda, surgida no Rio de Janeiro no início do século XX. Culto sincrético por natureza, com influências kardecistas, de cultos bantos e da África Ocidental, além de evidentes influências ameríndias e católicas, celebra e ritualiza tipos nacionais em seu atendimento ao seu público. Maria Isaura procura enfatizar os pontos em comum, mas deixa de lado as diferenças. $\mathrm{O}$ 


\section{A Antropologia Brasileira E O Mito Da Brasilidade}

modernismo de 22 tornou-se a cultura de elite do Brasil, ou pelo menos de uma cultura de elite nativista. É certo que a Umbanda é conhecida e frequentada por pessoas de todas as classes sociais, mas em seus respectivos terreiros, com suas variações regionais. Mesmo assim, sempre foi alvo de preconceitos, que, a sua maneira, também falam de questões da identidade brasileira moderna na República.

O culto mesmo, atende a demandas pessoais por saúde, felicidade, casamento, trabalho, através de uma série de práticas mágicas, de aconselhamento e de pequenos rituais, tendo um caráter doméstico bem evidente. Me parece que para pensar a identidade brasileira a partir da Umbanda, pesquisar os debates em torno dela são o melhor caminho, pois a uma longa negociação simbólica, desde o início do Império, que informa suas práticas, crenças e tais questões e que se relacionam com a Identidade brasileira.

Estas discussões também sempre foram próximas da Antropologia. Aqui vale a pena lembrar uma reflexão sobre como a Antropologia Brasileira tanto constrói as imagens do Brasil, desde pelo menos Nina Rodrigues quanto tem tido uma certa obrigação de desconstrui-las depois, na tentativa de transformar a sociedade. É um duplo movimento ${ }^{5}$. As considerações de Da Matta e a tensão entre Fábula e Mito foram pensadas por outros autores e vale a pena nos determos em mais alguns pontos deste debate. A perspectiva de Maria Manoela da Cunha, em seu prefácio citado acima, foi desenvolvida por Lilia Schwarcz numa reflexão sobre Questão racial e Etnicidade (1999). Ela procura contrastar a imagem de Brasil e de sua democracia racial como desenvolvida por Gilberto Freire com a desconstrução produzida por Florestan Fernandes, entre outras leituras que compõem o debate sobre a questão racial no Brasil e chega à conclusão de que, em todas as suas versões a Democracia racial e as Três Raças aparecem como mito muito mais por resistirem às suas críticas como por permanecerem como tema, dentro e apesar delas. Talvez seja o caso de perceber a identidade Brasileira como o Mito que está sendo contado, através dessas narrativas acadêmicas, intelectuais e eruditas que o recontam e tornam a conta-lo. Ou seja, o pensamento social brasileiro tem que ser, reflexivamente objeto de sua própria analise.

Lilia Schwarcz considera, neste sentido as reflexões de Claude Lévi-Strauss sobre o estudo antropológico dos mitos ${ }^{6}$. Levi Strauss alerta que ao estudarmos mitos, estudamos suas versões e terminamos acrescentando novas versões as já existentes. Terminamos produzindo mais uma versão, erudita e acadêmica, dos mitos que pretendemos analisar. Macunaíma, como tema parece ser, 


\section{A Antropologia Brasileira E O Mito Da Brasilidade}

realmente um ícone não só da identidade brasileira republicana moderna, mas desse tipo de exercício circular que está sendo visto aqui.

Lorenzo Macagno (2014), em suas reflexões sobre o Brasil, afirma que, se na ideia da Fábula de DaMatta existe uma crítica da Democracia racial como ideologia, a ideia de Mito permite que seja possível lançar considerações sobre estas reflexões mais profundas, embora também reforce o caráter circular e perene desta mitologia Do Brasil e sobre o Brasil, enquanto tema da Antropologia brasileira por excelência. Talvez o mais indicado seja mergulhar na Fábula enquanto Mito explorando novas possibilidades de conta-lo.

Da Matta e seu "dilema" encontrou um grande crítico na figura do sociólogo Jessé Souza. Sem concordar inteiramente com os seus argumentos, gostaria de ressaltar que sua crítica desloca o tema da construção da Identidade Brasileira como Mito, que é o terminamos discutindo aqui, para o dilema que DaMatta apontou de uma sociedade dividida entre uma ordem burocrática estatal igualitária, típica de uma democracia moderna e uma ordem hierárquica colonial, herança da colônia e do império. Como se, para DaMatta, o Brasil estivesse divido entre uma Índia tradicional e hierárquica, segundo um modelo Dumontiano e um Estados Unidos completamente igualitário e democrático. E fosse preciso escolher o segundo para se tornar realmente moderno. Isto não é discussão teórica sobre Identidade Nacional e sim um projeto político de Nação, que também deveria ser melhor explicitado.

Olhando a partir de Jesse Souza, as considerações de DaMatta não resistem a uma boa crítica teórica e etnográfica, que, obviamente, não é o caso de se fazer neste momento, mas que necessitam de uma revisão, a partir de novas considerações teóricas e do estudo de novos materiais etnográficos.

Outro sociólogo importante para este debate é Antonio Sérgio Alfredo Guimarães, da Universidade de São Paulo. Com vasta obra sobre racismo e relações raciais no Brasil contemporâneo Guimarães (2012) demonstra que a "Democracia racial" torna-se um "mito", no sentido antropológico do termo, como resultado de um largo debate em torno das relações raciais no Brasil. Há um debate bastante tenso que dura décadas onde o tema aparece muito mais como um resultado do que como uma questão fundamental.

A discussão sobre a "democracia racial brasileira" nasce no Estado Novo e acompanha, de fato, uma discussão sobre a Democracia no Brasil e no Mundo, travada antes, durante e depois da segunda guerra mundial, envolvendo os temas consagrados: Mestiçagem, ausência de racismo, ascensão social dos mestiços, morenidade. Somente nos anos 60, após a Ditadura, a "democracia racial" torna-se o 


\section{A Antropologia Brasileira E O Mito Da Brasilidade}

mito a ser desmascarado, a fábula ideológica como quis DaMatta, através das críticas de Florestan Fernandes e Abdias do Nascimento. Essa crítica será primeiro cultural para se tornar realmente política somente com a redemocratização do País, na década de 80 .

Neste processo de politização, no qual os movimentos indígenas e negros surgem e ressurgem, respectivamente, com um vigor impressionante, conceitos fundamentais como Cultura, Raça, etnia, Nação, sociedade, comunidade são redefinidos, também por outros movimentos sociais, exigindo uma rediscussão acadêmica dos mesmos e dessa nova situação. A Leitura de Guimarães sugere que a tensão entre a Fábula e o Mito, no sentido levistraussiano e mais popular entre os antropólogos do que a discussão do próprio DaMatta, se impõe a partir deste movimento. Num movimento conceitual curioso, a Fábula de DaMatta agora passa a denunciar o racismo brasileiro como o faz o movimento negro, enquanto Mito - num sentido mais sociológico, de ideologia. A discussão não é mais sobre a racialidade na sociedade brasileira, mas sobre Racismo mesmo, situado na distância cada vez mais evidente entre o discurso e as práticas das relações raciais no Brasil. Mas o tema continua, como ícone de toda essa discussão tão fundamental.

. É possível adiantar que, quando vistas a partir de um contexto local e particular, as questões de inspiração DaMattiana apontam para outras perspectivas que não as que ele sugeriu. Existem elementos e dimensões específicas em torno de ritos religiosos, cívicos e das festas populares, que marcam o calendário social de qualquer cidade do Brasil. O trabalho de Matta, seja em "Carnavais, malandros e heróis", seja em "A Casa e a Rua", é por demais sincrônico em sua abordagem e questões históricas e contextuais precisam ser levados em conta para que as suas propostas analíticas realmente possam fazer sentido.

Esse exercício de revisão pode ser estendido ao Macunaíma, como um tipo brasileiro ideal. A importância de Macunaíma para a identidade brasileira continua sendo um tema atual, tendo sido alvo de estudos e experimentos nas Ciências Sociais, nas Artes, na Literatura, até na psicologia. $\mathrm{Na}$ verdade, trata-se de um tema mítico em plena reinterpretação no Brasil atual. A minha crítica básica vem a ser a ideia de uma "alma indígena" presente, primeiramente, na ideia da Antropofagia de Oswald de Andrade, e personificada também pelo Macunaíma de Mario de Andrade. No meu entender, tal "alma indígena" também é uma fabula, nos termos de Roberto da Matta, construída com objetivo de dotar de uma identidade nativa uma elite branca e branqueada profundamente europeizada e euro orientada, desejosa de ter uma identidade distinta diante destes mesmos europeus tão celebrados e admirados. Isso continua acontecendo até hoje. Sejam setores da elite 


\section{A Antropologia Brasileira E O Mito Da Brasilidade ${ }^{1}$}

culta, sejam migrantes bem-sucedidos, há uma demanda por uma identidade nativa dentro de um concerto de nações.

O ponto é que esta identidade nativa acaba encobrindo o fato histórico de que a construção da sociedade brasileira se fez às custas de uma incorporação muito violenta dos índios e seus territórios e dos africanos e de sua força de trabalho, relação que Da Matta também aponta. Há um certo travestir-se no outro, que encontra ecos na História, na política, na cultura e na Antropologia também, já que a teoria e o método se prestam para esse tipo de movimento. Me parece que vale a pena recuperar o conceito do "sistema interétnico" e ver no Modernismo, Na Umbanda e também na Antropologia situações de friç̧ão interétnica entre diversos grupos e interesses sociais, estes sim que formam a dinâmica sócio cultural brasileira, muito mais do que uma suposta "Antropofagia". Faz-se necessária uma crítica antropológica a ideia modernista de Antropofagia, a partir da discussão conceitual de Etnia, identidade étnica e Sistema interétnico.

. Com o avanço dos movimentos indígenas, negros e rurais, tal identidade é profundamente questionada por perspectivas indígenas e negras contemporâneas, que apresentam pontos de vista realmente nativos. Tais pontos de vista fazem eco como outras questões levantadas por autores nativos na América Latina, na África, e na Ásia, que forçam a um repensar das velhas identidades brasileiras e latino americanas do Século XX. Aqui também um outro estado da arte e um outro levantamento bibliográfico precisará ser realizado, para trazer elementos do debate intelectual contemporâneo para estas questões. 


\section{A Antropologia Brasileira E O Mito Da Brasilidade ${ }^{1}$}

\section{REFERENCIAS BIBLIOGRÁFICAS}

ANDERSON, Benedict. Nação e Consciência Nacional. São Paulo: Ática. 1989.

CASTRO, Eduardo Viveiros. "O mármore e a Murta: sobre a inconstância da alma selvagem." Revista de Antropologia. São Paulo: USP, v. 35, pgs 21-74. 1992

DAMATTA, Roberto. Carnavais malandros e Heróis. Rio de janeiro: Zahar. 1979.

Pgs 58-85. 1983. . Relativizando: Uma Introdução à Antropologia social. Petrópolis: Vozes, 3ạ Ed.

GUIMARÂES, Antonio Sérgio. Classes, raça e Democracia. Ed. 34, 2a ed. 2012.

MACAGNO, Lorenzo. O Dilema Multicultural. Curitiba, UFPR. 2014.

MAGGIE, Yvone. "MÁRIO DE ANDRADE AINDA VIVE? O ideário modernista em questão.". RBCS Vol. 20 nํ. 58, 2005.

MUNANGA, Kabengele. Rediscutindo a mestiçagem no Brasil: identidade nacional versus identidade negra. Belo Horizonte: Autêntica. 2008.

ORTIZ, Renato. Cultura brasileira e identidade nacional. São Paulo: Brasiliense. 1985.

QUEIROZ, Maria Isaura Pereira. "Identidade Nacional, religião, expressões culturais: a criação religiosa no Brasil." In SACHS, Viola. (org) Brasil \& EUA: Religião e Identidade nacional. Rio de Janeiro: Graal, 1988.

RIBEIRO, Gustavo. Cultura e política no mundo contemporâneo. Brasília: EDUNB. 2000.

- SCHWARCZ, Lilia Moritz. "Questão racial e etnicidade". In O que ler na Ciência Social Brasileira (1970-1995). São Paulo, SUMARÉ/ANPOCS/CAPES. 1999.

VELHO, Otávio. 2007. "A cata das cotas". Insight Inteligência, Rio de Janeiro, no 38.pgs 125-134. Republicado em Antinomias do Real, UFRJ, 2018. 


\section{A Antropologia Brasileira E O Mito Da Brasilidade ${ }^{1}$}

\section{NOTAS}

Nota 1

Apresentado inicialmente em XI Seminário Nacional Sociologia \& Política: Intermitências da Democracia e Desigualdades Sociais GT 06 - Pensamento Social. UFPR / Curitiba, 2020.

Nota 2

O termo consagrado por Claude Levi Strauss no seu célebre "O pensamento selvagem", cap. 1: “A ciência do Concreto". O pensamento artístico, como o pensamento mítico, trabalha rearticulando e reorganizando seus elementos dentro de uma estrutura prévia. No caso da identidade brasileira em questão, é possível afirmar que esta estrutura é criada e revelada neste esforço de organizar e articular uma ideia de "Brasil".

\section{Nota 3}

O tema aparece em vários momentos como: Relativizando: Uma Introdução à Antropologia social; Brasil \& EUA: Religião e Identidade nacional. ; Conta de mentiroso; Carnavais malandros e Heróis.

Nota 4

Silva da Silveira, Marcos. Algumas questões antropológicas a partir do programa de inclusão racial da UFPR. CAMPOS V.17 N.2 AGO.DEZ.2016. https://revistas.ufpr.br/campos/issue/view/2491

Nota 5

Essa reflexão é da Maria Manoela Carneiro da Cunha, no Prefácio de Antropologia do Brasil(1986).

Nota 6

Na Abertura das "MITOLÓGICAS - O cru e o Cozido". Publicado no Brasil em 1991 pela Editora Brasiliense. 


\section{Capítulo 17}

\section{doi $10.37423 / 210604355$}

\section{NEOLIBERALISMO E POLÍTICAS EDUCACIONAIS NO BRASIL: INFLUÊNCIAS SOBRE A BASE NACIONAL COMUM CURRICULAR}

Francisco Dened Lima Alves

Deusemar Cardoso do Nascimento

Rosana Siqueira Akes

\section{Elton Amaral de Araújo}

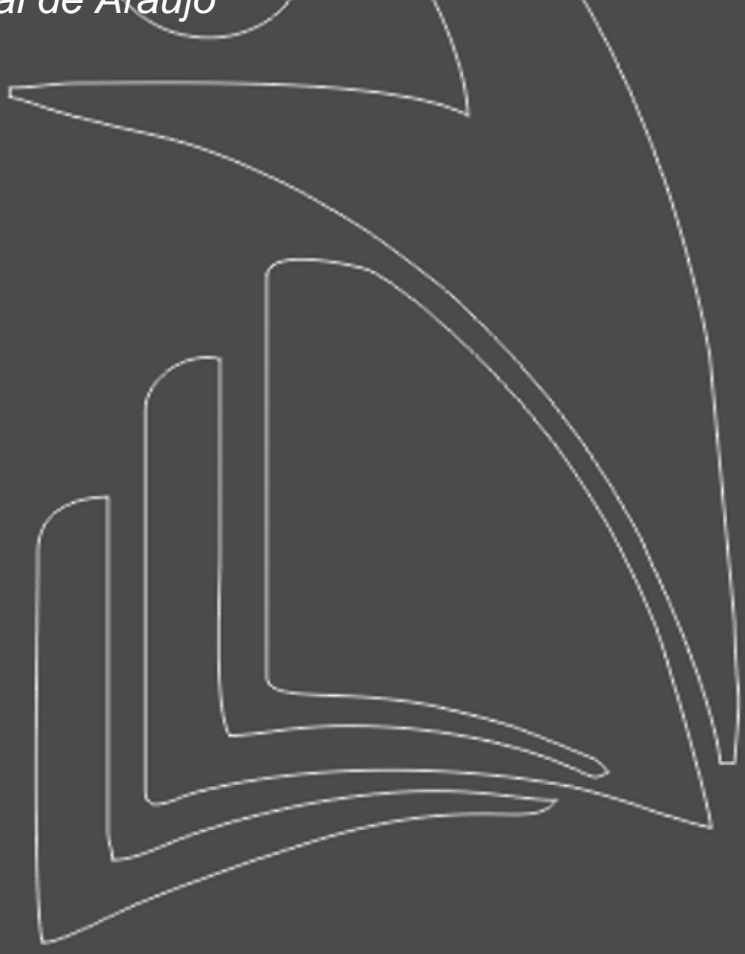

Universidade Estadual Vale do Acaraú - UVA

Universidade Federal do Mato Grosso do Sul, Campos Três Lagoas - UFMS/CPLT

Universidade Estadual Vale do Acaraú - UVA

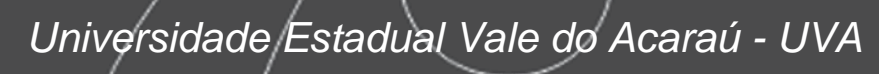


Resumo: O artigo apresentado, de cunho teórico bibliográfico, busca analisar e refletir sobre a como o neoliberalismo influenciou as políticas educacionais no Brasil. Assim como a presença do neoliberalismo nos países em desenvolvimento ou periféricos. Este trabalho acadêmico tem o intuito de mostrar a influências das grandes instituições financeiros em direcionar os rumos das políticas públicas voltadas à educação. Além de conceituar o neoliberalismo como corrente ideológica voltada ao capitalismo de mercado, em que a mesma desmonta o Estado, atuando principalmente em países periféricos. O neoliberalismo aliado as grandes instituições financeiras internacionais como Banco Mundial, ditam a regras econômicas e a política educacional, com o fortalecimento do Ensino Fundamental, e enfraquecimento do Ensino Superior. O Brasil aderiu a tal modelo econômico nas décadas de 1980-1990, e atualmente está mergulhado numa política neoliberal, que estagnou o país, e sobretudo o sistema educacional brasileiro, com o desmonte do projeto de educação dos governos anteriores. Dentre as ações neoliberais está a Base Nacional Comum Curricular (BNCC), como um instrumento para atender os interesses neoliberais, fomentando o discurso da qualidade da educação.

Palavras-chave: Neoliberalismo, Política Educacional, BNCC. 


\section{INTRODUÇÃO}

O neoliberalismo firma-se como um modelo econômico que domina os países em desenvolvimento a ponto de subjugá-los, tornando-os dependentes financeiramente. Os órgãos internacionais de financiamento passam a atuar nestes países e ditar as regras do mercado e as políticas públicas que devem ser desenvolvidas pelos governos. O processo de globalização impôs a países periféricos a presença do Banco Mundial e outras instituições financeiras internacionais que atuaram e atuam nas politicas de governo, com foco na educação básica, e enfraquecimento do ensino superior, pois tais instituições buscam o desmonte do Estado por meio da baixa qualificação profissional, por isso sugerem investir na educação básica, para que possam ter mão de obra barata para o mercado de trabalho.

O neoliberalismo foi implantado no Brasil no fim da década de 1980 e início da década de 1990, nos governos Collor e FHC. Com o desmonte do Estado a partir da intervenção no sistema educacional, com a descentralização da educação permitida pela Constituição Federal de 1988 (CF-88), em foi instituída a municipalização do Ensino Fundamental, criando-se a cultura da responsabilização. Na década de 90, a Lei de Diretrizes e Bases da Educação Nacional (LDB) - Lei no 9394/96, definiu os papéis dos entes federados em relação a educação. A descentralização do Ensino Fundamental foi uma manobra política neoliberal no setor educacional, firmada em nosso país com o Fundo de Desenvolvimento do Ensino Fundamental (FUNDEF), com a premissa do desenvolvimento do Ensino Fundamental, garantindo a qualidade do ensino, porém não garantiu o pleno atendimento da etapa de ensino citada. Com ele foram criados diversos conselhos regulatórios e o Sistema de avaliação da educação básica (Saeb), reforçando o domínio neoliberal nas ações do Estado.

Uma política educacional recente e com base na corrente neoliberal que tem como objetivo a qualidade da educação por meio do alinhamento do currículo nacional da educação básica. A Base Nacional Comum Curricular (BNCC), é um documento normativo que regula o currículo da educação básica. É tida por como uma política neoliberal, pelo fato de obedecer às regras das instituições internacionais que financiam as políticas de governo de países periféricos.

A partir dos pressupostos já citados há necessidade de refletir como as políticas públicas de educação são construídas e de que forma são influenciadas por instituições financeiras internacionais, assim como a contribuição de agentes multilaterais. Buscando construir o conhecimento sobre as políticas públicas e o neoliberalismo na educação de países periféricos. 
O artigo foi divido em quatro seções: a primeira seção aborda o neoliberalismo e suas origens, a segunda seção fala sobre o Banco Mundial como financiador de programas de governo nos países em desenvolvimento, assim como sua influência nas políticas educacionais. A terceira seção apresenta a influência do neoliberalismo no sistema educacional brasileiro, a quarta seção faz uma abordagem sobre a Base Nacional Comum Curricular (BNCC) como uma política neoliberal a serviço do mercado do capital.

\section{O NEOLIBERALISMO SUAS ORIGENS}

O termo neoliberalismo surgiu entre as décadas de 1930/1940, em meio a um contexto econômico de crise, com a queda da Bolsa de Nova York, em 1929, e da Segunda Guerra Mundial (1939-1945). Libâneo et al. (2012), conceituam o neoliberalismo:

Denominação de uma corrente doutrinária do liberalismo que opõe ao socialliberalismo e/ou novo liberalismo (modelo econômico keynesiano) e retoma algumas das posições do liberalismo clássico e do liberalismo conservador, preconizando a minimização do Estado, a economia com plena liberação das forças de mercado e a liberdade de iniciativa econômica (LIBÂNEO et al, 2012, p.110).

Segundo Libâneo et al (2012), o termo ressurgiu como programa de governo em meados da década de 1970, na Inglaterra (governo Thatcher), e no início da década de 1980, nos Estados Unidos (governo Reagan). O seu ressurgimento ocorreu devido à crise do modelo econômico keynesiano de Estado de bem-estar social ou estados de serviços. Tal modelo tornara-se hegemônico após a Segunda Guerra Mundial, o qual defendia a intervenção do Estado na economia com o intuito de promover a democracia, soberania, pleno emprego, justiça social, igualdade de oportunidades e a construção de uma ética comunitária solidária. “Desde os governos de Thatcher e Reagan, as ideias e as propostas do neoliberalismo de mercado passaram a influenciar a política econômica mundial, uma razão sobretudo de sua adoção e imposição pelos organismos financeiros internacionais, como FMl e o Bird" (LIBÂNEO, 2012, p.110).

A corrente doutrinária citada teve como pensadores: Ludwuig von Mises; Friedrich von Hayek e Milton Friedman. Libâneo (2012), ressalta algumas características do neoliberalismo:

A mesma faz uma crítica ferrenha ao paternalismo estatal e a crescente estatização e regulação social que atuam sobre as liberdades fundamentais do indivíduo por meio de interferências arbitrárias (governo ilimitado), pondo em risco a liberdade política, econômica e social (Hayek). A liberdade econômica é considerada condição para a existência das demais liberdades, como a política, a individual, a religiosa etc. Desse modo, o mercado é tido como princípio fundador, autounificador e autorregulador da sociedade. Defende a economia 
de mercado dinamizada pela empresa privada, ou melhor, a liberdade total do mercado, e ainda o governo limitado, o Estado mínimo e a sociedade aberta, concorrencial/competitiva. Opõe-se radicalmente às políticas estatais de universidade, igualdade e gratuidade dos serviços sociais, como saúde, seguridade social, educação (LIBÂNEO et al, 2012, p.110 -111).

As características apontadas pelo autor demonstram o poderio do neoliberalismo diante de países em desenvolvimento que apresentam um cenário propício aos financiadores de tal modelo econômico que algema e torna os mesmos reféns de uma situação forjada em nome do bem-estar alienado pelas instituições financeiras internacionais, em nome do alto lucro que podem ter com os países em desenvolvimento. Tais instituições ditam as regras de mercado e determinam as políticas de governo em todos os setores da sociedade.

Libâneo (2012), aponta os traços que evidenciam o projeto sociopolítico-econômico do neoliberalismo de mercado:

- desregulamentação estatal e privatização de bens e serviços;

- abertura externa;

- liberação de preços;

- prevalência da iniciativa privada;

- redução das despesas e do déficit públicos;

- flexibilização das relações trabalhistas e desformalização e informalização nos mercados de trabalho;

- corte dos gastos sociais, eliminando programas e reduzindo benefícios;

- $\quad$ supressão dos direitos sociais;

- programas de descentralização com inventivo aos processos de privatização;

- cobrança dos serviços públicos e remercantilização dos benefícios sociais;

- $\quad$ arrocho salarial/queda do salário real (LIBÂNEO et al., 2012, p.112).

Os traços apontados pelo autor trazem à tona a real situação de muitos países da América do Sul e América Latina que possuem acordos com o FMI, Bird, Banco Mundial e demais órgãos que controlam o sistema capitalista vigente, com destaque ao modelo neoliberal que domina os países em desenvolvimento. 


\section{BANCO MUNDIAL: O MINISTÉRIO DA EDUCAÇÃO DOS PAÍSES PERIFÉRICOS}

A presença do Banco Mundial em diversos países periféricos é marcante. Ele vem atuando em tais países com o intuito de garantir a governabilidade e a segurança dos mesmos. A entidade financeira vem atuando nesses territórios da periferia do capitalismo desde a década de 1980, influenciando os mais diversos setores da sociedade, com ênfase na educação. Essa atuação inicia com o processo de globalização que o mundo passou, e a periferia do capitalismo serviu como suporte ao crescimento dos financiadores do modelo econômico e a mesma se submeteu, da década de 1980 aos dias atuais. Leher (1999), enfatiza o pensamento do Banco Mundial frente a sua atuação em tais países,

[...] quanto no cerne da ideologia da globalização, conforme veiculada pelo Banco Mundial e pelos teóricos da sociedade do conhecimento. Ao considerar apenas a dimensão estritamente instrumental da educação (habilidades e qualificação requeridas) face à dinâmica do capital, o pensamento crítico não rompe os marcos do economicismo, contribuindo para a hipertrofia da crença no determinismo tecnológico, com significativas consequências desmobilizadoras (LEHER, 1999, p.19-20).

A ideologia da globalização e o aparato do Banco Mundial e outras instituições financeiras internacionais tem como base apoderar-se dos bens materiais e intelectuais, dos países em desenvolvimento, realizando adestramento da mão de obra necessária ao projeto econômico mundial. O foco do Banco Mundial como "o novo senhor da educação" (Leher, 1999), era promover políticas educacionais de ensino básico voltadas ao Ensino Fundamental, desvalorizando e desmontando o ensino universitário nos países que atuaria. Porém a mão de obra necessária deveria estar em consonância com a necessidades do mercado.

A partir de tal movimento imperativo do Banco Mundial ditando a regras do modelo de educação a ser desenvolvido nos países em desenvolvimento, não com o intuito de trazer benefícios e sim com o de dominar economicamente preparando sua população para tornar-se consumidores em potencial das transnacionais que passariam a atuar nos mesmos. Aumentando os bolsões de pobreza e interdependências dos países citados ao poderio financeiro do FMI, Banco Mundial e Bird. O desmonte do Estado é só uma consequência da nova forma de neocolonialismo que vivenciamos nas últimas décadas.

Libâneo (2012), aponta as orientações do Banco Mundial para o ensino básico e superior:

As orientações do Banco Mundial para o ensino básico e superior são extremamente representativas deste novo momento. Elas refletem a tendência da nova ordem econômica mundial, o avanço das tecnologias e da globalização, as quais requerem indivíduos com habilidades intelectuais mais diversificadas e flexíveis sobretudo quanto à adaptabilidade às funções que surgem 
constantemente. A solução consiste em desenvolver um ensino mais eficiente, de qualidade e capaz de oferecer uma formação geral mais sofisticada, em lugar de treinamento para o trabalho. No entanto, a instituição também estimula o aumento da competitividade, a descentralização e a privatização do ensino, eliminando a gratuidade (sobretudo nas universidades públicas), bem como a seleção pautada cada vez mais pelo desempenho (seleção natural das capacidades) (LIBÂNEO, 2012, p.116).

A real intenção do Banco Mundial, em relação as políticas educacionais dos países em desenvolvimento é a busca de um trabalhador capaz de adaptar-se as necessidades do mercado de trabalho e ao modelo de educação pensado por ele, pautado no futuro do consumo, independentemente da situação econômica do país. Ele age com o intuito de dominar a economia, negando os bens e serviços necessários a sociedade. O Estado está a serviço do capital especulativo, causando sofrimento social e desvalorização intelectual.

\section{A INFLUÊNCIA NEOLIBERAL NO SISTEMA EDUCACIONAL BRASILEIRO}

No tocante à educação, a orientação política do neoliberalismo de mercado evidencia, ideologicamente, um discurso de crise e de fracasso da escola pública, como decorrência da incapacidade administrativa financeira de o Estado gerir o bem comum (LIBÂNEO, 2012, p.114). O neoliberalismo faz o desmonte dos serviços essenciais à população, com o foco na educação. Para manter sua governabilidade mostra a sociedade que está promovendo, tal serviço, porém orientado por órgãos internacionais financeiros, diz ser incapaz de manter o mesmo funcionando, desresponsabilizando o Estado e responsabilizando o setor privado.

O neoliberalismo é implantado no Brasil, no fim da década de 1980 e início da década de 1990, nos governos Collor e Cardoso (Leher, 1999, p.24). O desmonte do Estado inicia com a intervenção no sistema educacional do Brasil. Em que a Constituição Federal de 1988, preconiza em seu texto a descentralização da educação por meio da lei. Como apontam Souza e Faria (2004):

Assim é somente quando na promulgação da CF de 1988, que a tese da descentralização da educação se torna efetivamente lei (Artigo no 211), através do qual se propugna, por ineditismo no Brasil, a organização dos sistemas de ensino entre a União, os Estados, o Distrito Federal e os Municípios pela via do chamado Regime de Colaboração, mais tarde reformulado pela Emenda Constitucional (EC) no 14, de 1996, que viabilizou, no ano seguinte, a implantação do Fundo de Manutenção e Desenvolvimento do Ensino Fundamental e de Valorização do Magistério (FUNDEF) ( SOUZA; FARIA, 2004, p. 926). 
Com a promulgação da CF houve a descentralização da educação, com a municipalização do ensino, os municípios passam a ser responsáveis pelo Ensino fundamental, com EC 14/96 eles tiveram aporte financeiro para seguir em frente com a municipalização. Em 1996 é instituída a Lei de Diretrizes e Bases da Educação (LDB) - Lei no 9.394/96, que define os papéis dos entes federados em relação a educação. As ações mobilizadas no período de 80 a 90 são caracterizadas por profundas reformas políticas e econômicas, que se estendem da redemocratização política à liberação e a privatização de sua economia (SOUZA e FARIA, 2004, p.926). As reformas educacionais que ocorreram na América Latina, foram acompanhadas por relatórios, diagnósticos e receituários, frutos da parceria com os órgãos multilaterais e financeiros, que ditaram as regras a serem seguidas pelos países em desenvolvimento dentre eles o Brasil. Podendo citar o Banco Mundial (BM), Banco Internacional para a Reconstrução e o Desenvolvimento (BIRD) e Banco Interamericano de Desenvolvimento (BID). Instituições voltadas para a cooperação técnica: Organização para a Cooperação e Desenvolvimento Econômico (OCDE), Programa das Nações Unidas para a Educação, Ciência e a Cultura (UNESCO), Fundo das Nações Unidas para a Infância (UNICEF), entre outras (SOUZA e FARIA, 2004, p.927).

O ensino nos anos 90 segue orientações dos diversos fóruns e conferências mundiais voltadas à educação, com destaque para a Conferência de Jomtien (em 1990, na Tailândia), patrocinada pelo UNICEF, PNUD e a UNESCO. A partir do mesmo surge o Plano Decenal de Educação para Todos (19932003). O Brasil neste período estava entre os 9 países que apresentavam maior taxa de analfabetismo do mundo. A partir do compromisso assumido com a Declaração de Jomtien, o Brasil teve que reorganizar seu sistema de ensino, priorizando uma política educacional para todos, a partir do plano decenal de educação, garantindo a gratuidade, equidade e qualidade do ensino. Com o estabelecimento de acordos e o plano decenal (1993-2003) educação para todos, a educação sofreu com corte de gastos públicos na década de 90, que fez com que o país tomasse emprestado capital financeiro internacional. Como aponta Sousa e Faria (2004):

[...] o uso instrumental do conceito de descentralização é, majoritariamente, aplicado como desconcentração, exprimindo a estratégia de retirada do Estado da prestação de serviços públicos essenciais da sociedade, com profundos impactos na área da educação entre outras (SOUSA e FARIA, 2004, p.929, apud, ABREU, 1999, SAVIANI, 1999, MARTINS, 2001).

A descentralização como manobra política neoliberal no setor da educação trouxe a municipalização, que é garantida com os recursos do FUNDEF, mas não garantiu o pleno atendimento e qualidade o ensino. Com a municipalização do ensino, são criados os Planos Municipais de Educação, Conselho 
Municipal de Educação e Conselhos de Acompanhamento e Controle Social, ambos são frutos da política de descentralização do poder por meio das práticas neoliberais.

No primeiro mandato de FHC, o presidente apresentou um programa denominado Acorda Brasil: Está na Hora da Escola, com destaque a cinco pontos como aponta Libâneo (2012),

a) distribuição de verbas diretamente para as escolas;

b) melhoria da qualidade dos livros didáticos;

c) formação dos professores por meio da educação a distância;

d) reforma curricular (estabelecimento de parâmetros curriculares nacionais - PCN - e diretrizes curriculares nacionais - DCN);

e) avaliação das escolas (LIBÂNEO, 2012, p. 186).

Os pontos em destaque na política educacional do governo FHC contemplaram os acordos com os órgãos internacionais e as orientações dos organismos multilaterais. Acreditava-se nesse período presidencial que a educação estava mudando. Porém, as avaliações em larga escala através do (Saeb), demonstrou a ineficiência do sistema educacional brasileiro, além de fatores negativos como a falta de vagas para milhares de crianças, o que gerou desconfiança. Tal política de avaliação perdurou nos anos seguintes e se faz presente na atualidade.

\section{A BASE NACIONAL COMUM CURRICULAR: UMA POLÍTICA NEOLIBERAL}

A política educacional voltada ao contexto a atual configura-se como, uma política voltada para os interesses neoliberais e capitalista, uma vez que esta surge como o interesse de órgãos financiadores da educação, obedecendo ao discurso de uma educação de qualidade. Segundo Triches e Aranda (2016), "destaca-se a Base Nacional Comum Curricular (BNCC) como ação da política de curricular brasileira". Política esta que foi discutida de 2015 a 2016, em dezembro de 2017 foi homologada, encontrando em processo de implementação pelos estados e municípios. Estes têm até 2021 para consolidar a implementação da BNCC adequando seus currículos.

\footnotetext{
"A Base Nacional Comum Curricular (BNCC), [...], apresenta direitos e objetivos de aprendizagem e desenvolvimento que devem orientar a elaboração de currículos da Educação Básica no país em conformidade com o que preceituam o Plano Nacional de Educação (PNE) e a Conferência Nacional de Educação (CONAE). Considerado pelo MEC como um instrumento de gestão pedagógica para auxiliar os professores, o documento que se configura como uma ação da política curricular brasileira, também tem o propósito de nortear a formação humana integral dos educandos e promover uma educação de qualidade social" (TRICHES; ARANDA, 2016, p. 83-84).
} 
Os autores apontam os direitos e objetivos de aprendizagem e desenvolvimento, sendo os norteadores para a implementação e adequação do currículo nas instituições de ensino do país. Mobilizando a adequação dos professores para as normas que são impostas pela BNCC.

A BNCC além deve ser estruturada para o mercado neoliberal, esta reformula o currículo das redes de ensino da educação básica no país. Unificando o currículo no território nacional. Lopes e Cáprio (2016), trazem a seguinte abordagem sobre o currículo:

O currículo não é um elemento inocente e neutro de transmissão desinteressada do conhecimento social. O currículo está implicado em relações de poder, transmite visões sociais particulares e interessadas, produz identidades individuais e sociais particulares. O currículo não é um elemento transcendente e atemporal - ele tem uma história, vinculada às formas específicas e contingentes de organização da sociedade e da educação (LOPES; CÁPRIO, 2016, p. 12).

O currículo como foi explicitado pelas autoras, vem carregado de intenções e estabelece relações de poder, faz parte do tempo presente, é real, revela suas particularidades individuais e sociais. Logo o currículo proposto pela BNCC, é engessado, por mais que seja justificado para que haja a redução de diferenças o mesmo só vem afirmar as desigualdades.

Ainda segundo Triches e Aranda (2016), a BNCC tem o propósito de

\begin{abstract}
"melhorar a qualidade da educação brasileira, através de políticas articuladas a segunda versão do documento especifica as políticas decorrem da BNCC: Política Nacional de Professores, Política Nacional de Materiais e Tecnologias Educacionais, Política Nacional de Avaliação da Educação Básica e Política Nacional de Infraestrutura Escolar" (TRICHES; ARANDA, 2016, p. 85).
\end{abstract}

As autoras apresentam as políticas públicas, designadas pela BNCC, estas são um instrumento regulador da formação, da elaboração de materiais, e da qualidade por meio dos resultados (avaliação externa). Na verdade, não há interesse na qualidade e sim apresentar resultados que agradem os órgãos internacionais como OCDE e UNESCO, que cobram os resultados dos países periféricos em relação a educação. O interesse do Estado enquanto financiador das políticas educacionais é ver a melhoria dos índices em instrumentos de aferição de resultados escolares como o Índice de Desenvolvimento da Educação Básica - IDEB.

A resolução CNE/CP 2/2017 em seu parágrafo 1ํ, do Art. 5ํ, determina:

§1ㅇ A BNCC deve fundamentar a concepção, formulação, implementação, avaliação e revisão dos currículos, e consequentemente das propostas pedagógicas das instituições escolares, contribuindo, desse modo, para a articulação de políticas públicas e ações educacionais desenvolvidas em âmbito federal, estadual, distrital e municipal, especialmente em relação à formação 
de professores, à avaliação da aprendizagem, à definição de recursos didáticos e aos critérios definidores de infraestrutura adequada para o pleno desenvolvimento de oferta de educação de qualidade (BRASIL, 2017, p. 5).

O parágrafo 1 을 do Artigo 5o da Resolução CNE/CP 02/2017, traz as atribuições ao Estado, mas da mesma forma que mostra tais atribuições, deixa o real interesse do governo, que é a qualidade da educação. Porém há muito o que se fazer para o alcance das políticas públicas propostas.

Segundo Macedo (2019), “o governo atribui à base, o papel de unificadora de políticas educacionais, de facilitadora da cooperação entre os regimes de governo e, por fim, de indicador de qualidade" (2019, p. 3). Como explicitado pela autora, a base tem diversas atribuições, mas na prática educacional, no chão da escola o desafio se contrapõe a tais atribuições, pois só haverá qualidade no ensino, se houver a ação real, capacitação e investimentos direcionados a implementação da BNCC.

Heleno (2017), nos diz que a BNCC em vez de facilitar os processos educativos e viabilizar o acesso dos estudantes a educação traz alguns entraves.

[...] a essência da BNCC coaduna com a manutenção do status quo quando dificulta o acesso da classe trabalhadora e de cor a um ensino de gestão pública, gratuito e de qualidade através da descentralização da educação básica, do repasse de verba pública para instituições privadas de educação, pela imposição de objetivos e o provável controle sobre a avaliação, por negar aos estudantes compreender a realidade concreta pela negação da ciência, da fragmentação da educação e pelo esvaziamento técnico da categoria cidadania. Proporcionando uma educação para o conformismo (HELENO, 2017, p. 391).

Como foi exposto pela autora, a BNCC em vez de viabilizar o acesso aos menos favorecidos no contexto sócio educacional, surge como uma proposta de tornar mais efetiva as diferenças sociais existentes. O pensamento dos governos neoliberais, os filhos da classe dominante devem ser favorecidos com as políticas de governo, e os filhos dos proletários devem se conformar com as políticas públicas que negam seus direitos.

\section{CONSIDERAÇÕES FINAIS}

O presente artigo teve como base o neoliberalismo como seu objeto de estudo, o mesmo com o intuito de analisar as estruturas do capitalismo ligada ao mesmo, o qual influenciou a educação brasileira por mais de duas décadas. Como abordado no trabalho acadêmico o neoliberalismo supervaloriza o capital financeiro e desvaloriza o capital humano. É a favor da desestatização, privatização, desresponsabilização do Estado, mostrando aos governos que o setor privado é capaz oferecer os serviços básicos à população, como saúde, educação e ação social. 
O neoliberalismo em nosso país foi efetivado no fim da década de 1980 com o governo Collor, e se perpetuou no governo Fernando Henrique Cardoso por dois mandatos, período que nosso país vive período de crise econômica em meio a globalização, sofrendo grande influência do FMI e Banco Mundial, os quais estabeleceram as diretrizes às políticas públicas. O foco principal foi a educação básica, com investimentos no Ensino Fundamental, regulando a gestão educacional, influenciando o currículo e promovendo a desvalorização do Ensino Superior.

A BNCC não é a solução viável à qualidade da educação, é apenas um documento normativo que regula os currículos da educação básica nacional. Com função de responsabilizar as escolas em relação aos resultados esperados pelo governo. A qualidade esperada são os resultados em avaliações externas nacionais e internacionais, pois os números para o Estado é um demonstrador de qualidade. Esta será mais uma política pública da educação que não terá alcance e nem conseguirá alcançar seus objetivos. Pois faltam os investimentos para formação de professores, recursos didáticos, materiais digitais e tecnologias educacionais, assim como a melhoria da infraestrutura escolar, não chegam a todos os espaços escolares do país.

Cabe reiterar que o grande desafio da educação nacional está em promover a equidade, de oportunidades aos cidadãos, para que tenhamos uma sociedade mais justa. Mas por via do neoliberalismo é impossível. 


\section{REFERÊNCIAS}

BRASIL, Ministério da Educação. Conselho Nacional de Educação. Conselho Pleno. Resolução CNE/CP no 2, de 22 de dezembro de 2017. Brasília, MEC, 2017.Disponível em:

<http://portal.mec.gov.br/maiseducacao/323secretarias112877938/orgaosvinculados82187207/530 31resolucoes-cp-2017>. Acesso em: 28 set. 2020.

HELENO, C. R. Contribuição à crítica da Base Nacional Comum Curricular - a máscara do conformismo na educação do Banco Mundial. Germinal: Marxismo e Educação em Debate, Salvador, v. 9, n. 3, p. 391, dez. 2017. ISSN 2175-5604. Disponível em:

<https://portalseer.ufba.br/index.php/revistagerminal/article/view/22459/15305>. Acesso em: 30 set. 2020. doi:http://dx.doi.org/10.9771/gmed.v9i3.22459.

LEHER, R. Um Novo Senhor da Educação? A Política educacional do Banco Mundial para a periferia do capitalismo. Revista Outubro, Ed. 03, 1999. Disponível em: <http://outubrorevista.com.br/um-novosenhor-da-educacao-a-politica-educacional-do-banco-mundial-para-a-periferia-do-capitalismo/> Acesso em: 29 set. 2020.

LIBÂNEO, J. C. et al. Educação Escolar: políticas, estrutura e organização. 10.ed. rev. e apl. São Paulo: Cortez, 2012.

LOPES, E. C. P. M.; CAPRIO, M. As influências do modelo neoliberal na educação. Revista on line de Política e Gestão Educacional, [S.I.], n. 5, dec. 2016. ISSN 1519-9029. Disponível em: <https://periodicos.fclar.unesp.br/rpge/article/view/9152>. Acesso em: 30 set. 2020. doi:https://doi.org/10.22633/rpge.v0i5.9152.

MACEDO, E. N. A BNCC como política educacional. Espaço Público, v. 3, p. 64 -76, mar. 2019. Disponível em: <https://periodicos.ufpe.br/revistas/politicaspublicas/article/view/239062> Acesso em 27 set. 2020.

SOUZA, D. B. de; FARIA, L. C. M. de. Reforma do Estado, Descentralização e Municipalização do Ensino no Brasil: A Gestão Política dos Sistemas Públicos de Ensino Pós-LDB 9394/96. Disponível em: http://www.scielo.br/scielo.php?pid=S010440362004000400002\&script=sci_abstract\&tlng=pt Acessado em: 14/08/2018.

TRICHES, E. F; ARANDA, M. A. M. A formulação da Base Nacional Comum Curricular (BNCC) como ação da política educacional: breve levantamento bibliográfico (2014- 2016). v. 3, no 05, Realização, 2016. Disponível em: http://ojs.ufgd.edu.br/index.php/realizacao/article/view/6362/3320. Acesso em: 17/06/2019. 


\section{Capítulo 18}

\section{doi $10.37423 / 210604357$}

\section{ANÁLISE DA PSICOPATIA SOB A ÓTICA DA PSICOLOGIA FORENSE}

ALLYNE EVELLYN FREITAS GOMES

Arthur Delmiro da Silva

Luiza Gabriela Martins Pinto Mendes

Márcia Adalgisa de Assis de Morais Barbosa

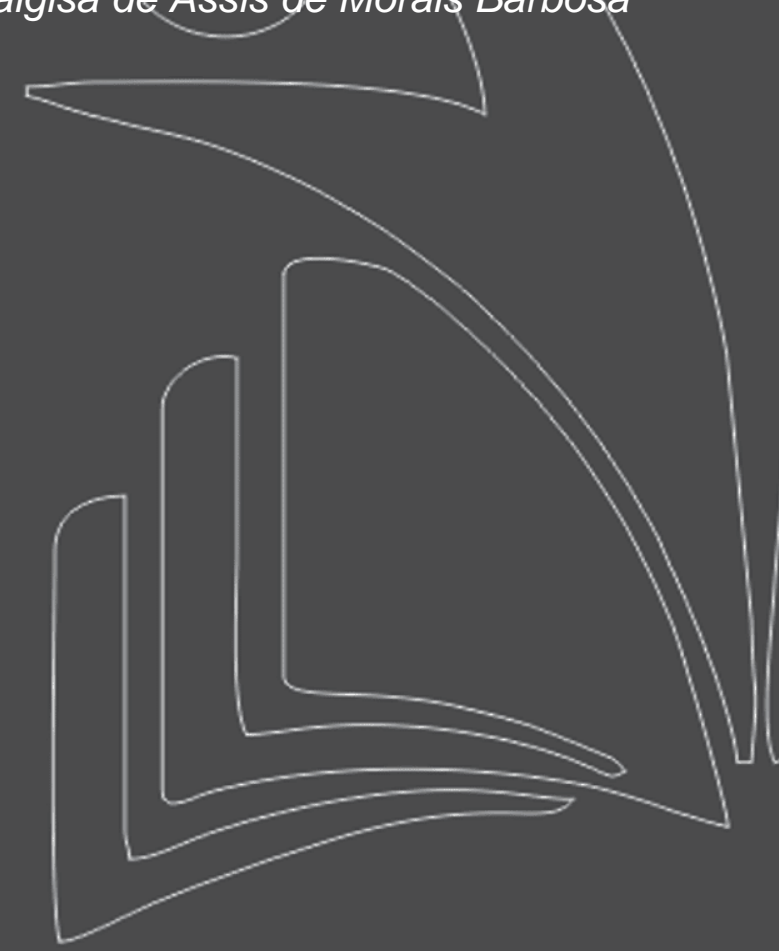

CENTRO UNIVERSITÁRIO MAURÍCIO DE NASSAU - UNINASSAU

CENTRO UNIVERSITÁRIO MAURÍCIO DE NASSAU - UNINASSAU

CENTRO UNIVERSITÁRIOMAURÍCIO DE NASSAU-UNINASSAU

CENTRO UNIVERSITÁRIO MAURÍCIO DE NASSAU - UNINASSAU

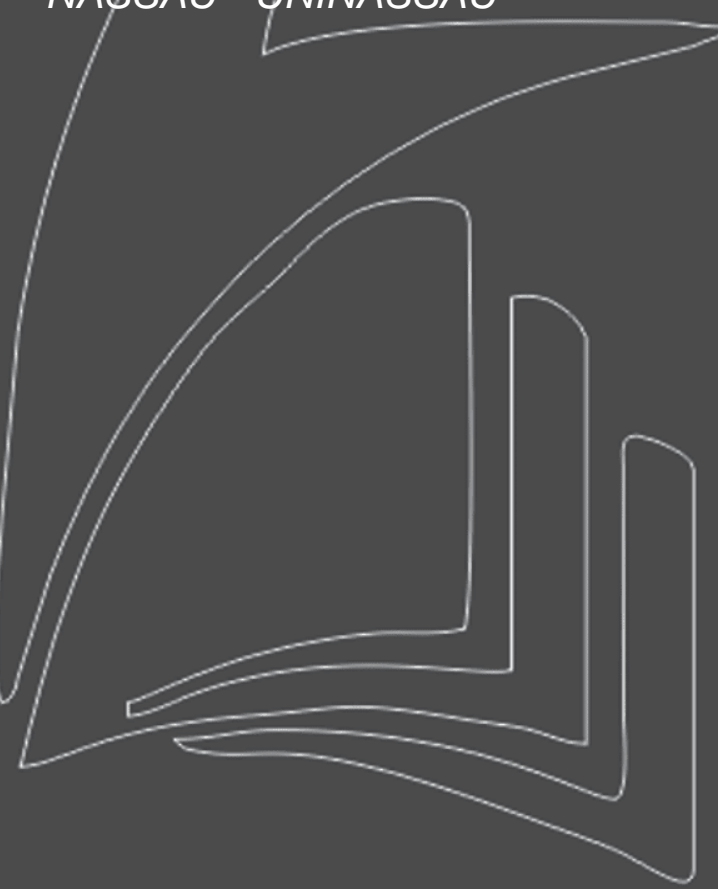




\section{Análise Da Psicopatia Sob A Ótica Da Psicologia Forense}

Resumo: A psicopatia é um transtorno que possui características marcantes, como a falta de empatia, impulsividade e ausência de culpa. Essas particularidades fazem com que exista a possibilidade desse indivíduo cometer crimes e trazer danos para a sociedade, já que o mesmo não possui os mesmos princípios de moralidade que pessoas sem o transtorno, porém nem todo psicopata irá cometer algum tipo de delito. Quando eles cometem crimes geralmente são graves e o fator diagnóstico acaba por atrair a atenção da população, mas que perde o foco da mesma quando avança para o âmbito carcerário. Este artigo propõe a discussão sobre esse transtorno e dos métodos utilizados pelos psicólogos ao realizar o acompanhamento e a intervenção psicológica nesses casos, além de entrevistar um psicólogo forense sobre a formação e a prática profissional na área e as políticas públicas relacionadas ao assunto.

Palavras-chaves: Psicopatia, Criminalidade, Psicologia Forense. 


\section{Análise Da Psicopatia Sob A Ótica Da Psicologia Forense}

\section{INTRODUÇÃO}

Os indivíduos com psicopatia apresentam características como: impulsividade, ausência de remorso, culpa e medo, além de um egocentrismo patológico, isso faz com que eles tenham uma deficiência moral comprometendo assim a compreensão de leis e regras. Sem deixar de lado o alto grau de manipulação e sedução que eles exercem sobre as pessoas em seu meio social. Porém devemos observar as crenças do senso comum onde se imagina esse indivíduo como o excluído da sociedade, pois eles podem não entender as emoções mas conseguem reproduzi-las a fim de manter sua máscara social e se adaptar ao meio que está inserido sem maiores problemas e sem levantar suspeitas.

A Psicopatia é definida no CID-10 (Classificação Internacional de Doença), como a F60.2:

Transtorno de personalidade caracterizado por um desprezo das obrigações sociais, falta de empatia para com os outros. Há um desvio considerável entre o comportamento e as normas sociais estabelecidas. O comportamento não é facilmente modificado pelas experiências adversas, inclusive pelas punições. Existe uma baixa tolerância à frustração e um baixo limiar de descarga da agressividade, inclusive da violência. Existe uma tendência a culpar os outros ou a fornecer racionalizações plausíveis para explicar um comportamento que leva o sujeito a entrar em conflito com a sociedade.

Entretanto, nem todo psicopata irá cometer crimes graves e/ou infligir regras sociais, pois é importante ressaltar que nem todo psicopata é criminoso, de forma que há níveis de psicopatia.

Sendo eles, a psicopatia leve onde a sua característica se dá pela probabilidade desses indivíduos não cometerem atos ilícitos ou que venham a quebrar as leis, usam de suas máscaras sociais para melhor se adaptarem na sociedade e manter uma vida considerada normal. Porém permanecem capazes de cometerem atos tidos como imorais, mas esses fatos não anulam a chance de se um dia cometer um crime.

O psicopata moderado é o sujeito que apresenta as características da psicopatia de forma mais intensa e acabam se envolvendo em crimes mais graves, deixando sua máscara social falhar assim exibindo a sua falta de moralidade de forma mais explícita, dificultando a sua capacidade de se camuflar no meio em que vive.

O psicopata grave é o que comete crimes hediondos e sem pudor, apresentando um certo sadismo ao demonstrar prazer em realizar o ato e cometendo crimes que apresentam um grau de crueldade elevado. Podemos observar isso nos casos dos assassinos em séries, quando se tratam de psicopatas. 


\section{Análise Da Psicopatia Sob A Ótica Da Psicologia Forense}

Dessa forma temos a definição de psicopatia dada por Robert Hare no livro Sem Consciência: O Mundo Perturbador dos Psicopatas que Vivem Entre Nós:

Os psicopatas não são pessoas desorientadas ou que perderam o contato com a realidade; não apresentam ilusões, alucinações ou a angústia subjetiva intensa que caracteriza a maioria dos transtornos mentais. Ao contrário dos psicóticos, os psicopatas são racionais, conscientes do que estão fazendo e do motivo por que agem assim.

O psicopata abrange dois lados da condenação, se enquadrando em alguns casos na sentença de imputabilidade ou semi-imputabilidade. A discussão existente sobre a semi-imputabilidade do psicopata no sistema penal é um assunto a ser debatido já que os mesmos são conscientes dos atos cometidos, mas não possuem empatia e nem respeito aos códigos morais e dessa forma a semiimputabilidade diminuiria o tempo de pena como visto no Art.26 do Código Penal Brasileiro:

Art. 26: É isento de pena o agente que, por doença mental ou desenvolvimento mental incompleto ou retardado, era, ao tempo da ação ou da omissão, inteiramente incapaz de entender o caráter ilícito do fato ou de determinar-se de acordo com esse entendimento. (Redação dada pela Lei no 7.209, de 11.7.1984).

Parágrafo único - A pena pode ser reduzida de um a dois terços, se o agente, em virtude de perturbação de saúde mental ou por desenvolvimento mental incompleto ou retardado não era inteiramente capaz de entender o caráter ilícito do fato ou de determinar-se de acordo com esse entendimento. (Redação dada pela Lei no 7.209, de

11.7.1984.

\section{JUSTIFICATIVA}

O Estado tem o dever de tratar todos os condenados de forma igualitária, independente dos crimes que foram cometidos. Sendo assim o princípio de individualização da pena acaba sendo perdido nessa situação, sendo cada vez mais comum o mesmo tipo de tratamento para pessoas com condutas e condições psicológicas distintas. A função social do cumprimento da pena é trabalhar na ressocialização desse criminoso, possibilitando assim que ao fim de sua pena ele possa reingressar na sociedade sem maiores problemas, em casos de criminosos psicopatas essa ressocialização não acontece, pois devido a sua deficiência moral o mesmo não enxerga seus atos como algo que precise de punição.

Uma visão psicológica para esse tema possibilitará a criação de melhorias na forma que esse acompanhamento deve ser feito, tendo em vista que a psicopatia não possui uma cura. Ao adentrarmos nessa área é necessário compreender o envolvimento nos âmbitos políticos, econômicos 


\section{Análise Da Psicopatia Sob A Ótica Da Psicologia Forense}

e sociais, pois, a partir do momento em que não ocorre uma atenção apropriada vai de contra os valores da sociedade e tudo o que nela se implica.

\section{HIPÓTESE}

A intervenção psicológica em psicopatas no âmbito penal pode influenciar positivamente na sociedade, a busca por formas de acompanhamento mais efetivas podem resultar na melhor adaptação e possível ressocialização desses indivíduos, sendo assim uma das principais questões e de forte importância é a tentativa de manter esse psicopata em controle com um acompanhamento feito por profissionais especializados que possam estabelecer a possibilidade de retorno ao convívio social, com um menor risco de reincidir a cometer atos criminosos e que venha a colocar a vida de terceiros em risco. Os benefícios gerados serão de imensa importância ao serem vistas de modo mais amplo para a sociedade, ao pensar em resultados a longo prazo.

\section{OBJETIVO GERAL}

Esclarecer o funcionamento do trabalho realizado pelo psicólogo forense ao lidar com pacientes com psicopatia.

\section{OBJETIVO ESPECÍFICO}

Buscar um processo terapêutico que seja efetivo no acompanhamento de criminosos com psicopatia.

\section{MÉTODOS}

Estabelecer contato por meio da entrevista inicial com um profissional da área a fim de compreender o funcionamento do acompanhamento psicológico voltado ao sistema carcerário e para a volta ao convívio em sociedade desses indivíduos

\subsection{PROCEDIMENTOS}

Foram feitas as seguintes perguntas ao profissional da área:Bloco 1 - Formação Acadêmica

1. Como você iniciou na área da psicologia forense?

2. Você como referência da área, quais são os caminhos de estudo para alunos e profissionais que querem se especializar na área? 
- Bloco 2 - Prática Profissional

3. Como funciona o trabalho de um psicólogo criminal?

4. Quais são as maiores dificuldades que você enfrenta nessa área?

5. Você já teve que lidar com algum caso em que estivesse envolvido um indivíduo psicopata?

6. Para você qual a definição de psicopatia e tem alguma diferença do Transtorno de Personalidade Antissocial?

7. Qual a sua opinião sobre a ressocialização de um criminoso psicopata?

8. Quais são os meios e instrumentos que temos para identificar um indivíduo com psicopatia?

9. Quais são as medidas que devem ser tomadas para o acompanhamento de um psicopata durante o período de reclusão e existe algum acompanhamento após sua soltura?

- Bloco 3- Políticas Públicas

10. O Estado contribui de alguma forma a respeito da atuação psicológica nessa área?

11. Quais são as medidas que o estado toma para a reabilitação do criminoso psicopata?

\section{ENTREVISTA}

Afim de complementar nosso artigo realizamos uma entrevista com o psicólogo forense e perito assistente técnico criminal Matheus de Oliveira que se formou em 2017 e se graduou em 2018, assim que se formou conseguiu um emprego na instituição de Ciências forenses de pós-graduação em perícias. Nessa instituição foi onde ele começou a ter um maior contato com a prática e teoria da Psicologia Jurídica. Fez sua pós-graduação e hoje está atuando como psicólogo forense realizando perícias psicológicas. 


\section{Análise Da Psicopatia Sob A Ótica Da Psicologia Forense}

O psicólogo forense criminal realiza perícias psicológicas, tanto como assistências técnicas por parte das partes que contratam, como também por perícia nomeada pelo juiz. Realiza perícias em penitenciárias, nos fóruns, no consultório, etc. O desconhecimento da área pelos profissionais pode ser uma das principais dificuldades da área, pois a faculdade não instruir o aluno sobre o assunto, faz com que ele tenha que procurar informações em outras fontes.

Matheus explica que ele já fez avaliações de pessoas com psicopatia e uma pesquisa onde identifica os psicopatas dentro dos ofensores sexuais. A psicopatia é um transtorno de personalidade que pode ser diagnosticado pela escala Hare e é diferente do transtorno de personalidade antissocial que vai abordar os aspectos comportamentais e antissociais do indivíduo, sendo assim o comportamento que foge do padrão do comum, desrespeitando leis e ferindo o outro. Já a psicopatia além dos aspectos comportamentais vai levar em conta os aspectos interpessoais e afetivos. Psicopatas não necessariamente são criminosos, hoje em dia se entende a psicopatia como um espectro onde uma pessoa pode estar dentro de vários níveis e vários graus, podem apresentar o transtorno em diferentes formas e o transtorno de personalidade antissocial estaria dentro desse espectro.

Sobre a ressocialização dos criminosos psicopatas, o entrevistado acha totalmente viável, não só dos psicopatas como de outros. Já que os criminosos diagnosticados com psicopatia são as minorias.

No Brasil a única escala validada para o diagnóstico da psicopatia é a escala Hare. Está sendo realizada uma pesquisa para a validação da escala Hare no diagnóstico de crianças e adolescentes, pois o quanto antes conseguir-se observar esses traços, evitaria que o transtorno se desenvolvesse não no sentido de rotular, e sim para prevenir em casos futuros. Também existem outros testes, mas apenas diagnosticar traços de psicopatia, como o teste de Rorschach, que diagnostica pessoas narcisistas, egocêntricas e compulsivas, mas não relaciona esses traços com a psicopatia.

O tipo de acompanhamento de um psicopata é o mesmo do acompanhamento que deveria ser dado a outro preso, ou seja, uma avaliação psicológica para diagnósticos assim que entrar na penitenciária, um acompanhamento terapêutico com medidas próprias de acordo com cada caso, um exame de prognóstico quando ele sair da penitenciária, para comparar a forma que ele entrou da que ele saiu e um acompanhamento psicológico quando ele saísse.

Já o estado não contribui de forma efetiva e eficaz, abrindo somente editais e vagas para psicólogos penitenciários. Todas as penitenciárias devem ter no mínimo um psicólogo, porém, apenas um não é suficiente por não dar conta de executar o trabalho que deveria ser feito por causa da alta demanda. 


\section{Análise Da Psicopatia Sob A Ótica Da Psicologia Forense}

Deveria haver uma instituição onde psicopatas que cometessem crime seriam presos ou internados e recebessem um tratamento adequado. 


\section{Análise Da Psicopatia Sob A Ótica Da Psicologia Forense}

\section{REFERÊNCIAS}

AGUIAR, Alexandre Magno Fernandes Moreira. A urgente necessidade de uma política criminal para os psicopatas. Jus Navigandi, Teresina, ano, v. 12.

AMBIEL, Rodolfo Augusto Matteo. Diagnóstico de psicopatia: a avaliação psicológica no âmbito judicial. 2006.

CHAVES, José Péricles; MARQUES, Leonor Matos. Psicopatas: como são tratados no sistema penal brasileiro.

MOUTA, Nidia. Análise da Psicopatia Homicida e sua punibilidade no atual Sistema Penal Brasileiro e seus efeitos na ressocialização. JusBrasil. 2015. disponível em:

https://nidiamouta.jusbrasil.com.br/artigos/250032965/analise-da-psicopatia-homicida-esuapunibilidade-no-atual-sistema-penal-brasileiro-e-seus-efeitos-na-ressocializacao\#. Acesso em 30 de set. de 2020.

OLIVEIRA, Gustavo Carvalho de et al. O exame de verificação de cessação de periculosidade: a importância da avaliação ampliada em um caso com conclusão contrária ao parecer da equipe assistente. Revista Latinoamericana de Psicopatologia Fundamental, v. 19, n. 2, p. 322-341, 2016...

ORGANIZAÇÃO MUNDIAL DA SAÚDE. CID-10: Classificação Estatística Internacional de Doenças com disquete Vol. 1. Edusp, 1994.

SZKLARZ, Eduardo. O psicopata na justiça brasileira. 2011. Super Abril. 25 de fev. 2011.

Disponível em: https://super.abril.com.br/comportamento/o-psicopata-na-justica-brasileira/. Acesso em 04 de out de 2020

VARGAS, Natã Sant'Ana; MADRID, Fernanda de Matos Lima. PSICOPATAS E A SANÇÃO PENAL NO BRASIL. ETIC-ENCONTRO DE INICIAÇÃO CIENTÍFICA-ISSN

21-76-8498, v. 15, n. 15, 2019. 


\section{Capítulo 19}

doi $10.37423 / 210604369$

A PSICOLOGIA ORGANIZACIONAL E DO TRABALHO COMO FERRAMENTA DE APOIO À GESTÃO DO CONHECIMENTO: UM ESTUDO NA MARINHA DO BRASIL

Lucilio Fontes Moura

Diego Lopes Pontes Duarte

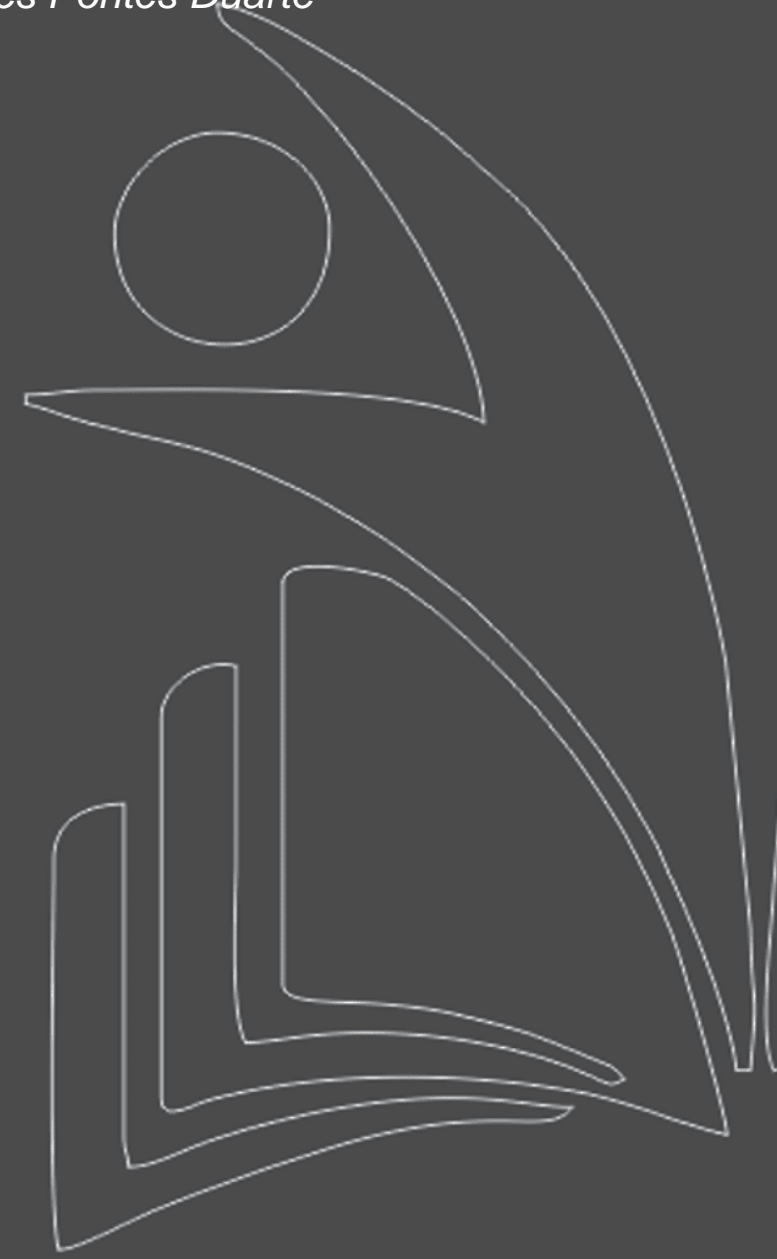

Marinha do Brasil

Marinha do Brasil

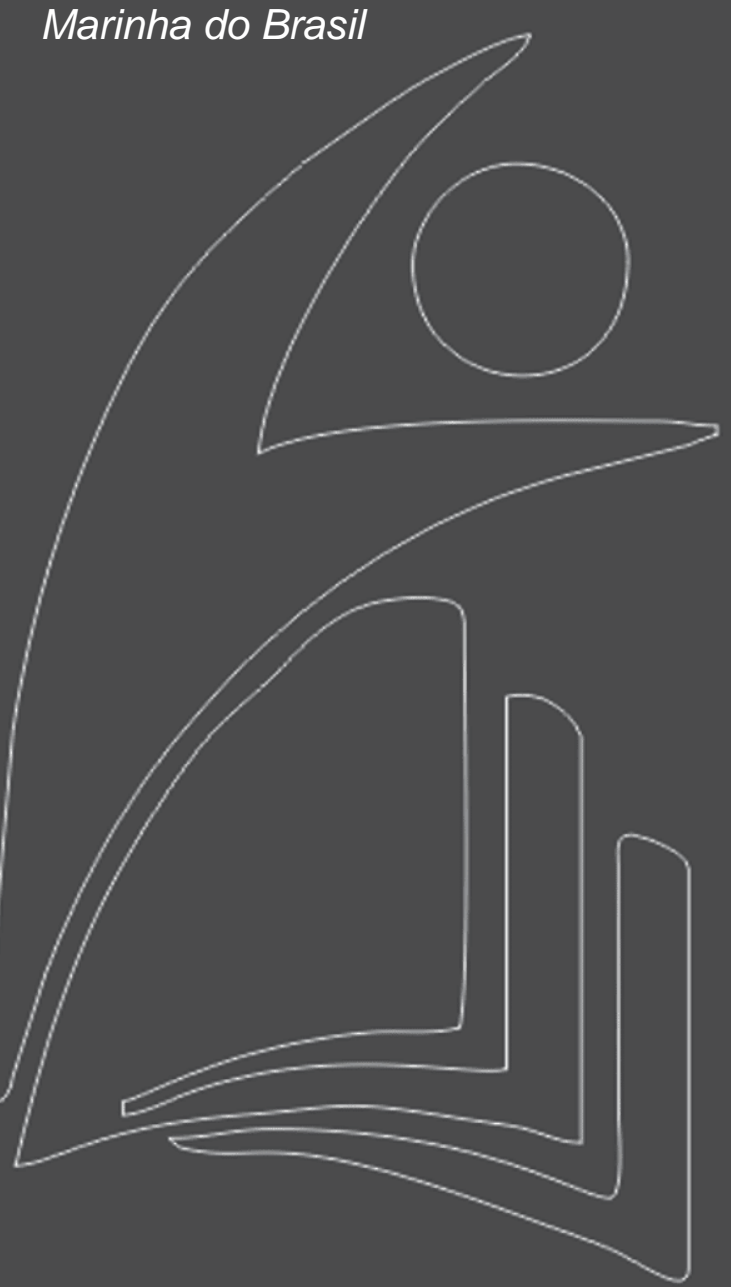


Resumo: A articulação da Psicologia com a Gestão do Conhecimento é de extrema importância como apoio à criação, ao acesso, à transferência e à conversão do ativo organizacional. O presente estudo visa identificar campos de atuação da Psicologia Organizacional e do Trabalho relacionados aos fatores críticos de sucesso em Gestão do Conhecimento sugeridos pelo Modelo de Excelência do Programa Netuno. Por meio de uma análise de conteúdo qualitativo de dados retirados do Modelo de Excelência do Programa Netuno, foi possível identificar oito campos de atuação.

Palavra-chave: Gestão do Conhecimento; Psicologia Organizacional e do Trabalho; Cultura Organizacional; Organizações Militares; Marinha do Brasil. 


\section{INTRODUÇÃO}

“O conhecimento e a informação são os recursos estratégicos para o desenvolvimento de qualquer país. Os portadores desses recursos são as pessoas", disse Peter Drucker, considerado o pai da administração moderna.

Um mundo cada vez mais automatizado e informatizado em ambientes organizacionais exige, igualmente, mais profissionais com conhecimentos relacionados a áreas tecnológicas. Sendo assim, é racional supor que áreas como Gestão do Conhecimento (GC) ganhem importância em um mundo onde os ativos intangíveis tornam-se relevantes no patrimônio das entidades, conforme inúmeros estudos demonstram (MAGRO et al., 2017).

De fato, o advento da sociedade do conhecimento (CAMPOS e BATISTA, 2008), que traz o trabalho com a informação como elemento fundamental no contexto dos negócios, torna a GC essencial às organizações com o fim de manterem-se competitivas e eficientes, além de garantirem a alta qualidade dos seus produtos e serviços (PARREIRA, 2013).

A presente pesquisa foi motivada pelo seguinte fato: pouco se analisa sobre o tema, embora a literatura explicite que a complexidade dos fatores humanos envolvidos no processo de GC seja um desafio muito maior do que a maioria dos projetos de gerenciamento de dados e informações (DAVENPORT, 1999).

O fato de a GC estar intimamente relacionada a fatores humanos sugere que é possível alcançar maior ou menor sucesso conforme se vale dos conhecimentos desenvolvidos pelas ciências humanas. Segundo Probst, Raub e Romhardt (2009), caso não observadas as regras básicas da Psicologia, tentativas da GC fracassarão.

A relevância dessa pesquisa se pauta no fato de que há uma ausência de estudos voltados aos fatores humanos relacionados à GC, embora se configurem em fatores que devem ser tratados prioritariamente.

A justificativa para o estudo traduz-se na identificação de um panorama geral de ações relacionadas à GC aplicada na Marinha do Brasil (MB), permitindo uma reflexão sobre o tema e lançando luz a possíveis oportunidades de melhorias.

Diante do exposto, o presente estudo avança na busca por respostas ao seguinte questionamento: a Psicologia Organizacional e do Trabalho (POT) pode contribuir como ferramenta de apoio nas práticas relativas à gestão do conhecimento na $\mathrm{MB}$ ? 
O objetivo geral da pesquisa é identificar campos de atuação da POT relacionados aos fatores críticos de sucesso em gestão do conhecimento sugeridos pelo Modelo de Excelência do Programa Netuno. Como objetivo específico, o presente estudo pretende levantar quais fatores críticos viabilizadores da GC são sugeridos como práticas pelo Modelo de excelência do Programa Netuno.

O artigo encontra-se dividido em 5 seções a partir desta introdução. Em seguida, são abordados, no referencial teórico, conceitos da Gestão do Conhecimento, Psicologia Organizacional e do Trabalho e um panorama geral do Programa Netuno na MB. Depois, apresentam-se os procedimentos metodológicos, contemplando coleta, análise dos dados e limitações do estudo. Na sequência, tem-se a apresentação e discussão dos resultados obtidos. E, por fim, são expostas as considerações finais.

\section{REFERENCIAL TEÓRICO}

\subsection{GESTÃO DO CONHECIMENTO}

O mundo dos negócios tem passado por grandes transformações devido às revoluções tecnológicas dos últimos anos. Fatores como recursos materiais, tamanho e estrutura organizacional estão sendo substituídos por informação, inovação, dinâmica operacional e flexibilidade devido ao ambiente de incerteza que as rápidas mudanças trazem (KOVALESKI, AZARIAS e CAMPOS JUNIOR, 2017).

Por conta dessas transformações o conhecimento recebeu um papel de destaque no mundo contemporâneo se tornando um recurso competitivo e fonte de poder de alta qualidade nas organizações (NONAKA e TAKEUCHI, 1997). Devido a esse fato, grandes esforços na busca por melhores processos de desenvolvimento desse capital intangível ocorreram.

Existem diferentes perspectivas e taxonomias na literatura para definir a natureza multifacetada do conhecimento. A definição adotada pelo estudo será a de Davenport e Prusak, que conceituam conhecimento como uma mistura fluída de informação contextual, experiências, valores e insights, que proporciona uma estrutura capacitada para avaliação e incorporação de novas experiências e informações (1998).

O conhecimento pode ser tácito ou explícito; pode estar em um indivíduo, grupo, repositórios físicos ou virtuais; pode estar relacionado a um objeto, capacidade ou estado cognitivo. Uma variedade de abordagens e de sistemas de gerenciamento do conhecimento são necessários para lidar com essa diversidade (ALAVI e LEIDNER, 2001). Além disso, as características intangíveis e componentes tácitos fazem do conhecimento um recurso de difícil imitação por parte das organizações (CHOO, 1998). Por 
esses motivos, a gestão do conhecimento torna-se fundamental para a manutenção de vantagens competitivas no mundo dos negócios (GONZALES e MARTINS, 2015).

O fato é que autores como Alvesson e Karreman (2001) afirmam que, por se tratar de uma evolução de dados e informação, o conhecimento possui um processo de gestão mais complexo. E mais, o conhecimento está intrinsecamente relacionado à ação humana, e por isso é dependente de indivíduos para adquirí-lo, compreendê-lo e desenvolvê-lo (SVEIBY, 1997). É um grande equívoco usar o gerenciamento de informação como ferramenta e conceito para planejamento da gestão de conhecimento (MCDERMOTT, 1999), no entanto, esse é um fenômeno muito comum de ocorrer.

A literatura apresenta uma série de barreiras e facilitadores para os processos da gestão de conhecimento, conforme apresentado nos Quadros 1 e 2.

Quadro 1: Aspectos facilitadores dos processos de gestão do conhecimento segundo a literatura

\begin{tabular}{|l|l|}
\hline \multicolumn{1}{|c|}{ Aspectos facilitadores } & \multicolumn{1}{c|}{ Autores } \\
\hline $\begin{array}{l}\text { Resolução de problemas e melhoria incremental; } \\
\text { cultura de aprendizagem e trabalho em equipe; } \\
\text { postura proativa e estrutura organizacional enxuta; } \\
\text { conhecimento primário e identidade compartilhados; } \\
\text { capacidade de absorção de conhecimento; mapeamento, } \\
\text { avaliação e desenvolvimento de competências; } \\
\text { estratégia inovativa e sistema de informação }\end{array}$ & Gonzalez e Martins, 2015 \\
\hline $\begin{array}{l}\text { Reconhecimento, desejo de colaborar, consciência } \\
\text { da utilidade do conhecimento, reciprocidade, } \\
\text { confiança, consciência de aprendizagem e relevância. }\end{array}$ & Alves, França e Magaldi, 2011 \\
\hline $\begin{array}{l}\text { A cultura organizacional, a motivação pessoal, a confiann } \\
\text { e a reciprocidade, o poder e o status, os mecanismos } \\
\text { de compartilhamento da informação e os sistemas } \\
\text { de recompensa. }\end{array}$ & Alves e Barbosa, 2010 \\
\hline Relações interpessoais e interações sociais. & Lin, 2008 \\
\hline
\end{tabular}

Fonte: Do autor

Quadro 2: Barreiras aos processos de gestão do conhecimento segundo a literatura

\begin{tabular}{|l|l|}
\hline \multicolumn{1}{|c|}{ Barreiras } & \multicolumn{1}{|c|}{ Autores } \\
\hline $\begin{array}{l}\text { Individualismo, medo de se expor, } \\
\begin{array}{l}\text { confidencialidade, competição NBR 6023 NBR 600 } \\
\text { interna, } \\
\text { seletividade, falta de tempo e perda de poder. }\end{array}\end{array}$ & Alves, França e Magaldi, 2011 \\
\hline $\begin{array}{l}\text { Desatenção com a infraestrutura cultural } \\
\text { das organizações e questões relativas a }\end{array}$ & $\begin{array}{l}\text { Paghaled, Shafiezadeh e Mohammadi, } \\
2011\end{array}$ \\
\hline
\end{tabular}




\begin{tabular}{|l|l|}
\hline confiança, poder e política. & \\
\hline Individuais: Resistência interna, falta de confiança & Hong, Suh e Koo, 2011 \\
e motivação e inabilidade. & \\
Organizacionais: linguagem usada, distanciamento \\
e excesso de burocracia.
\end{tabular}

Fonte: Do autor

Como é possível observar nos Quadros 1 e 2, a grande maioria dos facilitadores e barreiras estão associados a cultura organizacional e fatores humanos, e um número menor refere-se a infraestrutura de sistemas de informação e outros fatores externos.

O estudo bibliométrico de Kovaleski, Azarias e Campos Junior (2017) constatou que em que pese o tema da GC ser multidisciplinar, ele é mais fortemente relacionado a áreas de tecnologia da informação, o que está relacionado ao equívoco de que gestão do conhecimento é um mero gerenciamento de informações.

Poucos estudos voltados a fatores humanos foram identificados pelo estudo bibliométrico, o que revela um contrassenso, tendo em vista que uma cultura organizacional favorável é uma das condições mais importantes para o sucesso das iniciativas em Gestão de Conhecimento nas organizações (DAVENPORT e PRUSAK, 1998).

\subsection{A GESTÃO DO CONHECIMENTO NA MARINHA DO BRASIL}

Dentre diversos modelos de GC, sendo a grande maioria com maior enfoque ao setor privado, a Administração Pública conta com o Modelo de GC para a Administração Pública Brasileira (MGCAPB), formulado pelo Instituto de Pesquisa Econômica Aplicada (IPEA). Além desse modelo, a MB conta com orientações e boas práticas constantes no Manual de gestão administrativa da Marinha (EMA-134), o Manual de visitas, inspeções e reuniões funcionais da Marinha (EMA-130) e as Normas Gerais de Administração (SGM-107).

Ainda que as adaptações do modelo escolhido pela MB não tenham sido divulgadas até a conclusão do presente estudo, este foi utilizado como base teórica para o estudo. O modelo descreve a Gestão do Conhecimento através de seis componentes:

i)direcionadores estratégicos: visão, missão, objetivos estratégicos, estratégias e metas; ii) viabilizadores: liderança, tecnologia, pessoas e processos; iii) processo de GC: identificar, criar, armazenar, compartilhar e aplicar; iv) ciclo KDCA; v) resultados de GC; e vi) partes interessadas: cidadão-usuário e sociedade (BATISTA, 2012, p. 8). 
Desses componentes, os processos de GC são os responsáveis por mobilizar sistematicamente o conhecimento, enquanto os viabilizadores são os fatores críticos ao sucesso da gestão do conhecimento. Cabe aqui definir os quatro fatores críticos, segundo Batista (2012):

- Liderança: a alta administração desempenha papel importante nos esforços de implementação da GC. Compete a esse fator definir uma estrutura de governança, arranjos organizacionais, criação de equipes de GC, comunidades de práticas, definir uma política de proteção do conhecimento, estabelecer um sistema de reconhecimento e recompensa por aprendizado, criação do conhecimento e desempenho, e por fim, inspirar a prática de valores de compartilhamento do conhecimento e trabalhos colaborativos;

- Tecnologia: viabiliza a gestão do conhecimento através de ferramentas e sistemas como os mecanismos de busca, as redes, os repositórios de conhecimento, sistemas de workflow, gestão de conteúdo, gestão eletrônica de documentos, data warehouse e data mining;

- Pessoas: investimentos em capacitação e desenvolvimento, além da conscientização sobre as políticas de GC são fundamentais no envolvimento desse fator; e

- Processos: contribuem para o aumento da eficiência, efetividade social e melhoria da qualidade ao agregar valor na transformação. Dentre as práticas estão definidas o alinhamento estratégico, o mapeamento de competências, a modelagem dos sistemas de trabalho, a gestão de risco, o benchmarking, os sistemas de inteligência organizacional, os bancos de competências organizacionais e individuais e a gestão do capital intelectual.

Para a Administração Pública, é muito importante que o modelo de GC tenha uma relação com resultados organizacionais para que possa haver avaliação dos seus impactos nos processos, produtos e serviços (BATISTA, 2012). Na MB, inúmeras atividades relacionadas à GC passaram a ser realizadas graças à implantação do Programa Netuno, um programa da área de excelência em gestão pública implantado a partir de 2007 (BRASIL, 2015).

O Programa Netuno tem como finalidade contribuir para a melhoria contínua da organização administrativa e qualidade dos serviços prestados (BRASIL, 2011). A Diretoria de Administração da Marinha (DAdM) é a Organização Militar Orientadora Técnica (OMOT) do Programa Netuno e da área de Gestão do Conhecimento e possui a tarefa de orientar tecnicamente o pessoal, bem como normatizar, padronizar e atualizar procedimentos. 
Esse programa possui como base para identificar necessidades de melhorias nas OM a utilização de duas etapas, a autoavaliação e a validação, que em essência, consistem na identificação e análise das práticas de gestão das organizações. Essas etapas são realizadas com apoio do Modelo de excelência do Programa Netuno, materializados na lista P-10. Essa lista é dividida em critérios de avaliação, que por sua vez são divididos em itens no formato de perguntas, com finalidade de avaliação do sistema gerencial.

Cada item listado na P-10 possui uma pontuação específica, e os valores mudam conforme a resposta dada pela OM. Para facilitar o enquadramento dessas respostas, a lista P-10 é acompanhada do anexo "Tabela de distribuição de pontos", que apresenta uma série de respostas padrões com suas pontuações correspondentes.

\subsection{PSICOLOGIA APLICADA À GC}

A Gestão do Conhecimento costuma ser confundida com uma mera gestão da informação, baseandose em uma longa tradição ocidental que encarava as empresas como "máquinas que processam informação" (CARDOSO, 2007).

No entanto, a complexidade dos fatores humanos a serem gerenciadas nos processos de gestão do conhecimento são muito maiores do que para a maioria dos projetos de gerenciamento de informação (DAVENPORT, 1999). Os dados e informações são facilmente transferidos eletronicamente, mas o conhecimento parece ser melhor transferido através de uma rede humana (KOVALESKI, AZARIAS e CAMPOS JUNIOR, 2017).

O conhecimento é desenvolvido no cérebro humano e o clima organizacional é fator decisivo para persuadir as pessoas a criar, revelar, compartilhar e usá-lo. Por esses motivos, estudar os modos como os indivíduos se relacionam e se envolvem na utilização e compartilhamento de informações é essencial para as organizações nos dias atuais.

Citando Paula (2013), embora desenvolvida de maneira interdisciplinar com campos como o das ciências cognitivas, a ciência da informação se baseia em uma perspectiva mais do indivíduo do que de seu comportamento em um contexto social. Novos instrumentos são necessários para captar as múltiplas dimensões humanas, como linguística, subjetiva, social e emocional no processo de busca e compartilhamento de conhecimentos.

Em se tratando das dimensões humanas, a Psicologia é a ciência que se subdivide em ramos de conhecimento a fim de alcançar na totalidade os fenômenos humanos e sua realidade. Dentre essas 
subdivisões, a Psicologia Organizacional e do Trabalho busca especializar-se nos aspectos psicossociais relacionados às organizações e ao trabalho (BASTOS, 2003).

Uma revisão sistemática sobre a produção acadêmica do Brasil no período de 2010 a 2016, realizada por Oliveira, Silva e Sticca (2018) identificou dentro dos 180 artigos levantados, as seguintes categorias temáticas mais abordadas na subárea da Psicologia do trabalho: Saúde mental do trabalhador, condições e organização do trabalho e seus impactos; e orientação profissional e de carreira, englobando um total de 137 artigos.

A POT tem um papel fundamental no desenvolvimento de estratégias com vista a excelência organizacional. Sua articulação com a GC é fundamental como apoio à criação, ao acesso, à transferência e à conversão do ativo organizacional (SANTOS, 2012). Um trabalho psicológico pode auxiliar gestores a redefinir e sintetizar seus conhecimentos, deflagrando ações de eficiência, eficácia e efetividade.

Ainda de acordo com Santos (2012), a POT gera mecanismos e procedimentos que podem aprimorar as relações com os stakeholders, aumentar autonomia dos funcionários, atrair e reter os melhores colaboradores, facilitar e incentivar a aprendizagem, localizar e utilizar o potencial intelectual dos funcionários, explorar o conhecimento humano, as habilidades e o seu potencial, conceber e otimizar processos eficazes e alavancar melhores práticas.

Zanelli, Bastos e Rodrigues (2014) dividem a POT em três campos de atuação:

- Psicologia Organizacional - trabalha com variáveis de comportamento como satisfação, cultura organizacional, clima organizacional, comprometimento, relações interpessoais, motivação, produtividade, desenho (análise de cenários, planejamento estratégico, design organizacional) e consultoria organizacionais (diagnóstico, intervenção e mudanças organizacionais);

- Gestão de Pessoas - engloba atividades relacionadas à administração de pessoal como movimentação, desligamento e remuneração; análise de postos de trabalho, descrição de rotinas e fluxos de trabalho, recrutamento, seleção, treinamento e desenvolvimento; avaliação de desempenho e relações de trabalho; e

- Psicologia do Trabalho - com áreas de intervenção como ergonomia, saúde no trabalho, orientação profissional, aposentadoria, emprego, desemprego e empregabilidade.

- Cabe ressaltar que dentro dos campos de atuação da POT alguns temas estão fortemente relacionados aos aspectos facilitadores e barreiras dos processos de gestão do conhecimento 
mencionados anteriormente nos Quadros 1 e 2, são eles: cultura e clima organizacional, motivação, comprometimento, relações interpessoais, design organizacional, diagnóstico, intervenção e mudanças organizacionais, descrição de rotinas e fluxos de trabalho, seleção, treinamento e desenvolvimento.

Dentre as principais ferramentas que um psicólogo organizacional pode dispor em suas atividades estão os testes psicométricos; instrumentos de diagnósticos que podem avaliar o comportamento, clima, cultura, comprometimento organizacional entre outros; intervenções psicossociais e dinâmicas grupais.

\section{METODOLOGIA}

O presente estudo foi essencialmente qualitativo, de caráter descritivo, com modalidade na pesquisa bibliográfica e documental como ferramentas para alcançar o objetivo proposto.

A escolha pelo método qualitativo deveu-se: ao "caráter de interação dinâmica entre o pesquisador e o objeto de estudo" (GÜNTHER, 2006); e, também, à técnica de análise de dados adequada para se alcançar o objetivo de identificar se as práticas sugeridas pela MB, por meio da lista P-10, adotam os fatores críticos viabilizadores da GC promovidos pela POT.

Decorrem dessa escolha metodológica três características essenciais: visão holística, abordagem indutiva e investigação naturalística (ALVES-MAZZOTTI e GEWANDSZNAJDER, 2002). Isto é, foi considerada a soma das inter-relações presentes no contexto, para se compreender o significado do fenômeno estudado. A observação do objeto de estudo por parte do sujeito-pesquisador e a decorrente formulação de categorias de análise fez parte do processo de construção do conhecimento. E, por fim, houve a preocupação por minimizar ao máximo a intervenção do sujeitopesquisador sobre o processo de coleta de dados no campo da observação (CAMARGO e CORRER, 2011).

O caráter descritivo teve como foco estabelecer uma relação entre as variáveis propostas, cabendo ao autor realizar o estudo, a análise, o registro e a interpretação dos dados, minimizando a manipulação e influência do mesmo.

Um estudo bibliográfico foi realizado, inicialmente, com objetivo de levantar dados e informações que serviram de base para a investigação e para a delimitação da pesquisa, além de proporcionar o aprofundamento necessário sobre o tema. Nessa fase, pesquisas bibliométricas e revisões 
sistemáticas da produção acadêmica foram essenciais na identificação das tendências das áreas de GC e POT, bem como os autores mais citados.

Ainda nessa fase inicial, foi realizada uma entrevista semiestruturada com um militar identificado por atuar na área do Programa Netuno, com intuito de levantar informações sobre documentos, normas, manuais, modelos e procedimentos adotados pela MB relacionados à GC em suas organizações.

\subsection{COLETA DOS DADOS}

No que tange à fase de coleta de dados, Oliveira (2007) argumenta que a pesquisa bibliográfica tem como principal finalidade providenciar aos pesquisadores um contato direto com artigos, documentos e obras que tratem do tema estudado. Mais do que isso, essa modalidade de estudo permitiu a identificação das seguintes fontes de dados secundários: o EMA-130 a lista P-10 e seu anexo "Tabela de distribuição de pontos".

\subsection{ANÁLISE DOS DADOS}

O corpus de análise escolhido foram as respostas padrão encontradas no anexo da lista P-10, "Tabela de Distribuição de Pontos". A escolha por uma fonte secundária foi motivada em função de esse documento representar o padrão almejado pela MB para adoção pelas OM, portanto um norteador de implementações. Além disso, a existência de uma espécie de "gabarito" de resposta para um programa cujo sistema classifica as organizações por pontos, de certa forma influencia no processo de escolhas de práticas adotadas pelas OM.

Ao todo, 7 critérios compõem a lista P-10: Liderança e desempenho global; formulação e implementação das estratégias; imagem e relacionamento com outras $\mathrm{OM}$ e extra-MB; responsabilidade socioambiental, ética e controle social; gestão do conhecimento e informações comparativas; a tripulação, seu trabalho, sua capacitação e desenvolvimento; e processos orçamentários, financeiros, finalísticos e de apoio.

Os 7 critérios se subdividem em 53 itens e cada um desses possui 3 respostas padrão na "Tabela de distribuição de pontos", conforme exemplificado na Figura 1. Para a análise realizada, apenas as respostas com maior pontuação para cada item foram utilizadas, por se considerar que essas seriam as respostas mais completas. 
Embora a GC seja mais profundamente trabalhada através do critério "gestão do conhecimento e informações comparativas", todos os critérios foram analisados pela possibilidade de conterem práticas que indiretamente fomentem a GC.

Figura 1: Exemplo de resposta padrão

\begin{tabular}{|c|c|c|c|c|c|c|}
\hline \multirow{2}{*}{ Pontuaçào } & 0 & 4 & 8 & 10 & 12 & 15 \\
\hline & $\bullet$ & 0 & 0 & 0 & 0 & 0 \\
\hline 1.1 & & $\begin{array}{c}\text { A OM possui procedimentos (sem } \\
\text { Ol) para a tamada de decisấ. }\end{array}$ & & $\begin{array}{l}\text { A OQU possui padrío estabelecido (ainda } \\
\text { sem Ol) para a tomada de decisăo e sua } \\
\text { comunicacáo somente. }\end{array}$ & & $\begin{array}{l}\text { A OM possui Ol que prevé o tramite para } \\
\text { tomada de decisōes, sua comunicaçẫo } \\
\text { controle. }\end{array}$ \\
\hline
\end{tabular}

Fonte: "Tabela de Distribuição de Pontos" (Brasil, 2018).

O processo de análise de conteúdo qualitativo passou pelas fases: pré-exploratória, com a intenção de apreender e organizar de maneira não estruturada aspectos essenciais, contexto, impressões e orientações; seleção das unidades de análise, onde os recortes mais adequados foram escolhidos para a análise; e, finalmente, o processo de categorização e subcategorização destes recortes em elementos diferenciados para posterior agrupamento (CAMPOS, 2004).

A classificação de cada ação foi baseada em uma categorização apriorística, ou seja, as ações foram classificadas em categorias previamente definidas, quais sejam: categoria inicial - fatores críticos viabilizadores da GC - e os fatores críticos viabilizadores da GC em subcategorias - Liderança, Tecnologia, Pessoas e Processos. Por fim, com vistas a alcançar o objetivo geral da pesquisa, uma categoria final foi estabelecida, agrupando os fatores críticos por campo de atuação da POT.

A fim de maximizar a confiabilidade dos resultados, a fase de categorização do conteúdo qualitativo foi apreciada e debatida por outros pesquisadores, possibilitando, assim, a redução do viés do pesquisador.

\subsection{LIMITAÇÕES DO ESTUDO}

A falta de uma equipe de pesquisa foi sentida principalmente na fase de análise de conteúdo qualitativo, quando se percebeu a necessidade de discutir a classificação do conteúdo analisado, esse viés foi minimizado no debate de tais classificações com apoio dos orientadores.

Outra limitação percebida foi quanto aos recursos disponíveis à pesquisa, não foi possível realizar um levantamento representativo das práticas adotadas pelas OM em Gestão do Conhecimento, motivo pelo qual o autor se utilizou de um modelo de caráter orientativo proposto pela diretoria técnica responsável pela área. 


\section{APRESENTAÇÃO E DISCUSSÃO DOS RESULTADOS}

A fim de atender ao objetivo específico desta pesquisa, levantar quais fatores críticos viabilizadores da GC são sugeridos como práticas pelo Modelo de excelência do Programa Netuno, três etapas foram necessárias. A primeira listou todos os fatores críticos encontrados no modelo de GC do IPEA. Ao todo, foram identificados 25, distribuídos pelas subcategorias Liderança, Processos, Pessoas e Tecnologia.

A segunda etapa consistiu em separar todas as práticas sugeridas nas respostas padrão encontradas na "Tabela de Distribuição de Pontos". Ao todo, foram mapeadas 93 práticas. Por fim, foram identificadas e classificadas as práticas relacionadas aos fatores críticos. Ao todo, 60 práticas foram categorizadas com algum dos fatores críticos viabilizadores da GC. Os dados obtidos constam da Tabela 1.

Tabela 1: Número de práticas por fator crítico viabilizador da GC

Fator crítico viabilizador da GC

Capacitação e desenvolvimento

Gestão do capital intelectual

Mapeamento de competências

Política de proteção do conhecimento

Alinhamento estratégico

Conscientização sobre políticas de GC

Criação de equipes de GC

Modelagem dos sistemas de trabalho

Redes

Benchmarking

Inspira práticas de valores de compartilhamento e trabalho colaborativo

Estrutura de governança

Gestão de risco

Sistema de reconhecimento e recompensa

Arranjos organizacionais

\section{Número de práticas}

8

6

5

5

4

4

4

4

4

3

3

2

2

2 
Gestão de conteúdo

Gestão eletrônica de documentos

Sistema de inteligência organizacional
1

1

1

Total

60

Fonte: Do autor

As 60 práticas ficaram distribuídas entre 18 fatores críticos de um total de 25 levantados no modelo IPEA, sendo a categoria "Capacitação e desenvolvimento" a que se relacionou com um maior número de práticas, 8 no total, seguido de "Gestão do capital intelectual" com 6 práticas. Entre as categorias com menor frequência, encontradas em apenas uma prática, estão "Arranjos organizacionais", "Gestão de conteúdo", "Gestão eletrônica de documentos" e "Sistema de inteligência organizacional”.

A Tabela 2 elenca a frequência das práticas distribuídas pelas subcategorias Liderança, Processos, Pessoas e Tecnologia.

Tabela 2: Fatores críticos viabilizadores da GC consolidados por subcategoria

Fator crítico viabilizador da GC

Processos

Liderança

Pessoas

Tecnologia

Total
Quantidade de práticas relacionadas

$23(38,33 \%)$

$19(31,67 \%)$

$12(20 \%)$

$6(10 \%)$

$60(100 \%)$

\section{Fonte: Do autor}

Da análise da Tabela 2, tem-se que os fatores críticos relacionados à subcategoria "Processos" apresentam a maior frequência, com participação de $38,33 \%$ do total, enquanto os com menor frequência estão relacionados à subcategoria "Tecnologia", com 10\% do total. Esses dados denotam uma tendência do Modelo de excelência do Programa Netuno a fomentar práticas ligadas a fatores críticos viabilizadores da GC relacionadas a processos, em detrimento dos fatores críticos relacionados a tecnologia.

Não cabe ao presente estudo apurar a diferença de distribuição das práticas sugeridas pelo Modelo de excelência do Programa Netuno por subcategorias de fatores críticos ao sucesso da GC. 
Para alcançar o objetivo geral de identificar os campos de atuação da POT relacionados às práticas sugeridas pelo Modelo de Excelência do Programa Netuno ligadas a fatores críticos de sucesso em gestão do conhecimento, uma segunda categorização foi realizada. Os 19 fatores críticos identificados no Modelo de Excelência foram categorizados por campo de atuação da POT (Quadro 3).

Quadro 3: Campos de atuação da POT relacionados aos fatores críticos viabilizadores da GC

\begin{tabular}{|l|l|}
\hline \multicolumn{1}{|c|}{ Fatores críticos viabilizadores da GC } & \multicolumn{1}{c|}{ Campos de atuação da POT } \\
\hline Conscientização sobre políticas de GC & Cultura organizacional \\
\hline Inspirar prática de valores de compartilhamento & Cultura organizacional \\
\hline Arranjos organizacionais & Design organizacional \\
\hline Estrutura de governança & Design organizacional \\
\hline Benchmarking & Relações interpessoais \\
\hline Criação de equipes de GC & Relações interpessoais \\
\hline Sistema de reconhecimento e recompensa & Motivação \\
\hline Mapeamento de competências & Análise de postos de trabalho \\
\hline Modelagem dos sistemas de trabalho & Descrição de rotinas e fluxos de trabalho \\
\hline Gestão do capital intelectual & Gestão de pessoas \\
\hline Capacitação e desenvolvimento & Seleção, treinamento e desenvolvimento \\
\hline
\end{tabular}

Fonte: Do autor

Dos 18 fatores críticos identificados no Modelo de Excelência do Programa Netuno, 11 estão relacionados a campos de atuação da Psicologia organizacional e do trabalho. Somando o número de práticas quantificadas na Tabela 1 para cada um desses 11 fatores críticos tem-se um total de 42 práticas sugeridas pelas respostas padrão encontradas na "Tabela de Distribuição de Pontos". Ou seja, das 60 práticas relacionadas a fatores críticos de sucesso da GC sugeridas pelo Modelo de Excelência do Programa Netuno, 42 estão dentro do campo de atuação da POT, um número considerável em termos numéricos. 
Ao todo 8 campos de atuação da POT foram identificados, conforme o Quadro 3 apresenta: cultura organizacional, design organizacional, relações interpessoais, motivação, análise de postos de trabalho, descrição de rotinas e fluxos de trabalho, gestão de pessoas e seleção, treinamento e desenvolvimento.

\section{CONSIDERAÇÕES FINAIS}

Face ao exposto, o presente estudo atendeu seu objetivo geral de identificar os campos de atuação da POT relacionados às práticas sugeridas pelo Modelo de Excelência do Programa Netuno ligadas a fatores críticos de sucesso em Gestão do Conhecimento. Também cumpriu o objetivo específico de levantar quais fatores críticos viabilizadores da GC são sugeridos como práticas pelo Modelo de Excelência do Programa Netuno.

Como meio para alcançar esses objetivos, as respostas padrão encontradas no Modelo de Excelência do Programa Netuno foram analisadas por meio da técnica de análise de dados qualitativos com categorização apriorística. A categoria de fatores críticos viabilizadores da GC utilizada na análise foi baseada no Modelo de GC para a Administração Pública Brasileira do IPEA.

Ao todo, foram identificados 8 campos de atuação da Psicologia Organizacional e do Trabalho: cultura organizacional, design organizacional, relações interpessoais, motivação, análise de postos de trabalho, descrição de rotinas e fluxos de trabalho, gestão de pessoas e seleção, treinamento e desenvolvimento.

Um dado interessante identificado ao longo da análise dos dados é que dos 25 fatores críticos identificados no modelo de GC do IPEA, 7 não foram identificados em nenhuma prática propostas pelo sistema de avaliação do Programa Netuno, são eles: comunidades de práticas, bancos de competência organizacionais e individuais, mecanismos de busca, repositórios de conhecimento, sistemas de workflow, data warehouse e data mining. No entanto, desses 7 fatores críticos, apenas "comunidades práticas" estaria relacionado a um campo de atuação da POT, "relações interpessoais".

Vale ressaltar que dos demais campos de atuação da POT, os tópicos "clima organizacional", "comprometimento" e "diagnóstico, intervenção e mudanças organizacionais", não foram identificados nas práticas sugeridas embora a literatura considere essas áreas como facilitadores ou barreiras à GC. 
Por limitações dos recursos disponíveis à pesquisa não foi possível realizar um levantamento representativo das práticas adotadas pelas OM em Gestão do Conhecimento, motivo pelo qual o autor se utilizou de um modelo de caráter orientativo proposto pela diretoria técnica responsável pela área.

Sugere-se como estudos posteriores a análise das práticas realmente adotadas pelas organizações militares da MB. Uma outra sugestão de estudo seria identificar se as práticas adotadas pelas Organizações Militares da MB em GC são efetivas ou carecem de um apoio especializado como o da POT.

Aqui vale mencionar que ao longo da pesquisa foi identificado o Serviço de Seleção de Pessoal da Marinha (SSPM) como organização cuja missão está associada ao uso da Psicologia na MB, no entanto, dentre suas atuações, não foi identificado o uso da psicologia organizacional e do trabalho na gestão do conhecimento. 


\section{REFERÊNCIAS BIBLIOGRÁFICAS}

[1] ALAVI, M.; LEIDNER, D. E. Management and knowledge management systems: conceptual foundations and research issues. University of Minessota: MIS Quarterly, 25(1), 107-136, 2001.

[2] ALVES, A.; BARBOSA, R. R. Influências e barreiras ao compartilhamento da informação: uma perspectiva teórica. Brasília: Revista Ciência da Informação, v. 39 n. 2, maio/ago. p.115-128, 2010.

[3] ALVES, M.; FRANÇA, S. L. B.; MAGALDI, B. Identificação dos aspectos que influenciam o compartilhamento de conhecimento na organização: estudo de caso em uma empresa de consultoria. In: CONGRESSO NACIONAL DE EXCELÊNCIA EM GESTÃO, VII, 2011, Niterói, RJ: Anais, ago. 2011.

[4] ALVES-MAZZOTTI, A. J.; GEWANDSZNAJDER, F. O método nas ciências naturais e sociais: pesquisa quantitativa e qualitativa. São Paulo: Pioneira Thonson Learning, 2002.

[5] ALVESSON, M., KARREMAN, D. Odd Couple: Making Sense of the Curious Concept of Knowledge Management. Journal of Management Studies, 38(7), 995-1018, 2001.

[6] BASTOS, A. V. B. Psicologia organizacional e do trabalho: Que respostas estamos dando aos desafios contemporâneos da sociedade brasileira? In O. H. Yamamoto \& V. V. Gouveia (Eds.), Construindo a psicologia brasileira: Desafios da ciência e da prática psicológica (pp. 139-166).São Paulo, SP: Casa do Psicólogo, 2003.

[7] BATISTA, F. F. Modelo de gestão do conhecimento para a administração pública brasileira: como implementar a gestão do conhecimento para introduzir resultados em benefício ao cidadão. Brasília: IPEA, 2012.

[8] BRASIL. Marinha do Brasil. Estado-Maior da Armada. EMA-130. Manual de Visitas, Inspeções e Reuniões Funcionais da Marinha. Brasília, DF, 2018.

[9] _. Marinha do Brasil. Estado-Maior da Armada. EMA-134. Manual de Gestão Administrativa da Marinha. Brasília, DF, 2011.

[10] Marinha do Brasil. Secretaria-Geral da Marinha. SGM-107. Normas Gerais de Administração. Brasília, DF, 2015.

[11] CAMARGO, Mario Lázaro; CORRER, Rinaldo. A pesquisa em psicologia: ensaio sobre a psicologia enquanto ciência, a pesquisa qualitativa e o uso da entrevista como principal instrumento de coleta de dados. Bauru: Mimesis, v. 32, n. 2, p. 147-172, 2011.

[12] CAMPOS, C. J. G. Método de análise de conteúdo: ferramenta para a análise de dados qualitativos no campo da saúde. Brasília: RevBrasEnferm, 57(5), p. 611-4, 2004.

[13] CAMPOS, M. M.; BAPTISTA, S. G. Gestão do conhecimento organizacional na administração pública federal em Brasília: um estudo exploratório. Brasília: Revista Ibero-americana de Ciência da Informação, v.1 n.1, p.181-197, jan./jun, 2008.

[14] CARDOSO, L. Gestão do conhecimento e competitividade organizacional: Um modelo estrutural. Lisboa: Comport. Organ. Gest. v. 13, n. 2, p. 191-211, out. 2007. 
[15] CHOO, C. W. The knowingorganization: howorganizations use information for constructo meaning, create knowledge and make decisions. New York: Oxford Press, 1998.

[16] DAVENPORT, T. H. Knowledge Management andtheBroadFirm: Strategy, Advantageand Performance. Knowledge Management Handbook. Boca Raton: CRC Press, 1999.

[17] T. H.; PRUSAK, L. Conhecimento empresarial: comoas organizaçõesgerenciam o seu capital intelectual. Tradução Lenke Peres. Rio de Janeiro: Campus, p.6, 1998.

[18] GONZALEZ, R. V. D.; MARTINS, M. F. Gestão do conhecimento: uma análise baseada em fatores contextuais da organização. São Paulo: Prod, v. 25, n. 4, p. 834-850, dez. 2015.

[19] GÜNTHER, H. Pesquisa qualitativa versus pesquisa quantitativa: esta é a questão? Brasília: Psicologia: Teoria e Pesquisa, v. 22, n. 2, p. 201-210, maio/ago. 2006.

[20] HONG, D.; SUH, E.; KOO, C. Developing strategies for overcoming barrier stok nowledges haring based on conversational knowledge management: A case study of a financial company. Expert Systems with Applications n.38, 2011.

[21] KOVALESKI, A.; AZARIAS, J. G.;CAMPOS JUNIOR, F. C. Gestão do Conhecimento: uma Análise Bibliométrica sobre publicações de revisão. VII Congresso Brasileiro de Engenharia de Produção, Ponta Grossa - PR, 2017.

[22] MCDERMOTT, R. Why Information Technology Inspired but Cannot Deliver Knowledge Management. California Management Review, Vol 41, n. 4, pp. 103 - 117, jul. 1999.

[23] MAGRO, C.BD. et al. Relevância dos ativos intangíveis em empresas de alta e baixa tecnologia. Belo Horizonte: Nova econ., v. 27, n. 3, p. 609-640, Dec. 2017.

[24] NONAKA, I.; TAKEUCHI, H. Criação do Conhecimento na Empresa: como as empresas geram a dinâmica da inovação. Rio de Janeiro: Campus, 1997.

[25] OLIVEIRA, L. P.; SILVA, F. H. M.; STICCA, M. G. Revisão sistemática da produção acadêmica em Psicologia do Trabalho no Brasil. Brasília: Rev. Psicol. Organ. Trab., v. 18, n. 2, p. 354-363, jun. 2018.

[26] OLIVEIRA, M. M. Como fazer pesquisa qualitativa. Petrópolis: Vozes, 2007.

[27] PAGHALED, M.; SHAFIEZADEH, E.; MOHAMMADI, M. Information Technology and its Deficiencies in Sharing Organizational Knowledge. International Journal of Business and Social Science, v. 2, n. 8, p. 192-198, Maio. 2011.

[28] PARREIRA, T. J. A gestão do conhecimento no corpo de intendentes da Marinha do Brasil: desafios e oportunidades na busca pela excelência da aprendizagem organizacional. Dissertação (Mestrado em Administração) - Rio de Janeiro: Escola Brasileira de Administração Pública e de Empresas, Fundação Getúlio Vargas, 2013.

[29] PAULA, C. P. A. A investigação do comportamento de busca informacional e do processo de tomada de decisão dos líderes nas organizações: introduzindo a abordagem clínica da informação como proposta metodológica. João Pessoa: Perspectivas em Gestão \& Conhecimento, v. 3, Número Especial, p. 30-44, out. 2013. 
[30] PROBST, G.; RAUB, S.; ROMHARDT, K. Gestão do Conhecimento: os elementos constitutivos do sucesso. Porto Alegre: Bookman, 2009.

[31] SANTOS, A. M. S. A psicologia organizacional e do trabalho a serviço da gestão do conhecimento. Caçador, SC: Visão, v. 1, n. 1, jan./jun, 2012.

[32] SVEIBY, K. E. A nova riqueza das organizações: gerenciando e avaliando patrimônios de conhecimento. Rio de Janeiro: Campus, 1997.

[33] ZANELLI, J. C.; BASTOS, A. V. B.; RODRIGUES, A. C. de A. Campo profissional do psicólogo em organizações e no trabalho. In: Zanelli, J. C.; Borges-Andrade, J. E.; Bastos, A. V. B. (Orgs.), Psicologia, Organizações e Trabalho no Brasil. (pp.549-582). Porto Alegre: Artmed, 2014. 


\section{Capítulo 20}

doi $10.37423 / 210604371$

\section{ONDE SE INTEGRA AS(OS) PRETAS (OS) NA ORDEM COMPETITIVA DA REGIÃO METROPOLITANA DE SÃO PAULO?}

DANIEL VITOR NUNES DE MELO

UNIVERSIDADE FEDERAL DE MINAS GERAIS

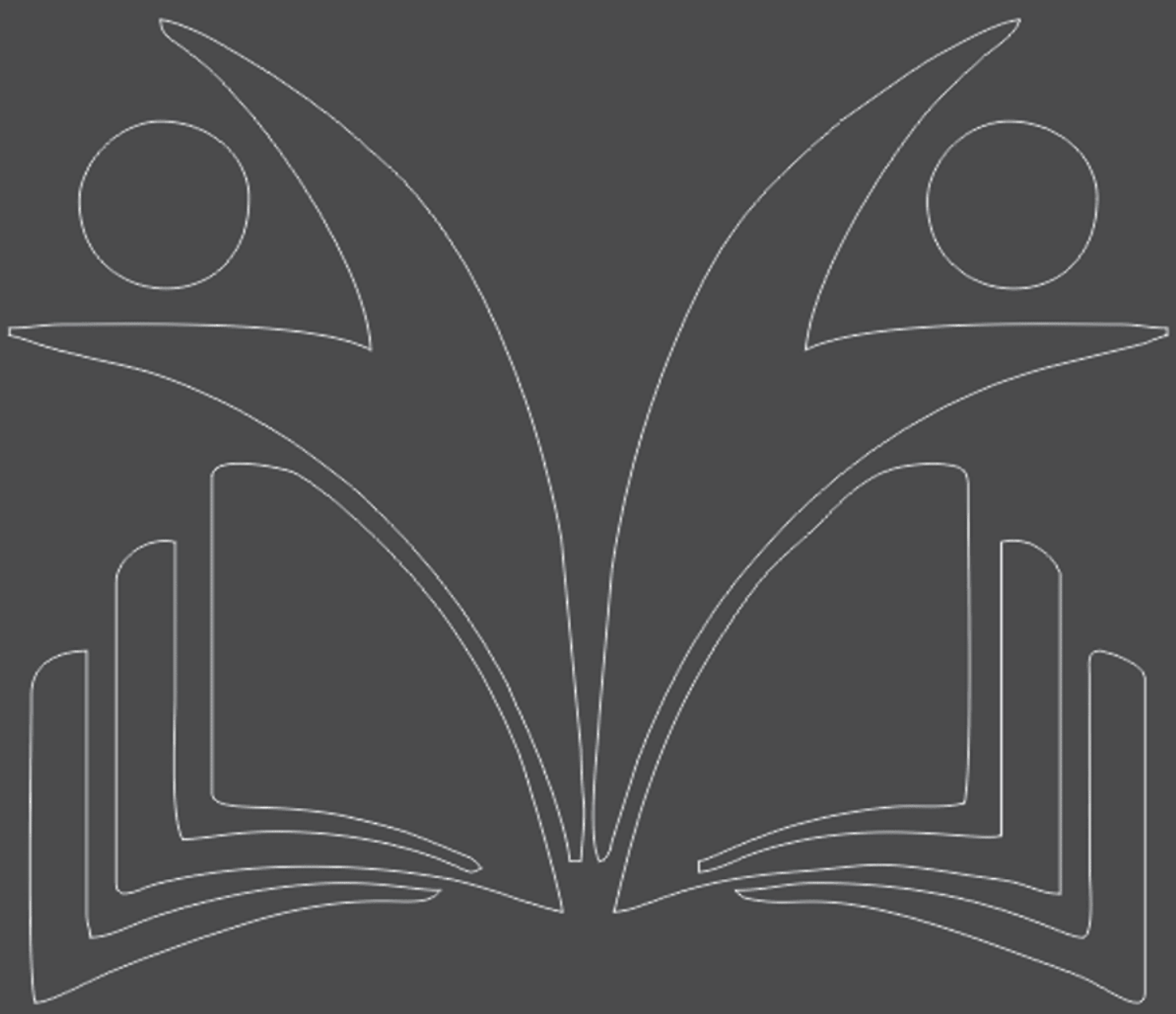


Resumo: A abolição da escravidão em 1988 foi um divisor de águas, de um lado foi um dos motivos para que o regime escravocrata viesse a ruínas, por outro vai ser base para a emergência da "república brasileira" e dos valores liberais que começavam a dominar o mundo. Entretanto, a pergunta que fica é: o que aconteceu com a população preta que ganhou a "liberdade" nesse movimento? Para a maioria dos autores que debatem o tal "problema do negro" na sociologia, antropologia e afins, afirmam que apesar da libertação do negro da posse dos senhores e pelo dito "fim" do sistema escravista, o estado - é muito menos os senhores e a Igreja - não auxiliou essa parcela da população á inserção na ordem competitiva que vinha se formando de forma muito acelerada, principalmente na cidade de São Paulo. Tendo a miserabilidade, vulnerabilidade e a marginalidade como destino, a população negra foi relegada aos postos mais subalternos da nova ordem socioeconômica que vinha se formando. Com a virada para o século XXI os problemas parecem ainda não terem resposta, em especial, na região metropolitana de São Paulo que abriga uma população enorme e no estado que em 2005 tinha 12.493.790 milhões de pessoas negras e pardas, dados divulgados pelo PNAD, com sua maior distribuição na região metropolitana, onde ainda se mantém traços de uma estrutura que parece não ser desmontada.

Palavras-chave: Sociedade de classes, Integração dos pretos(as), Mercado de trabalho. 


\section{INTRODUÇÃO}

O artigo a ser apresentado tem como intuito investigar a inserção da população afro brasileira na sociedade pós-abolicionista, utilizando-se da obra "A integração do negro na sociedade de classes Volume I" do autor Florestan Fernandes (2008) para entendimento desse período especificado e assim podendo fazer contraponto com outros artigos que debatem a questão racial no trabalho e com os dados e análises do sistema PED que analisou a incorporação de negros e não negros no mercado de trabalho no ano de 2017 e, além disso, buscou explicar os ocupados segundo os tipos de relações de trabalho tendo o 2 ㅇ semestre de 2014 e 1 ㅇ semestre de 2018 como períodos verificados. Desse modo buscarei entender quais as constâncias e inconstâncias desses fenômenos para a população preta na gigantesca região metropolitana da cidade de São Paulo. Esse trabalho tendo por justificativa á analise dos espaços que essa população esta inserida atualmente e como os mesmos podem ter ligação com que o autor da sociologia brasileira vai descrever em sua obra, ou seja, se atualmente ainda pode-se encontrar os resquícios de uma estrutura escravocrata, que para Florestan Fernandes teve certos aspectos transplantados para a sociedade de classes, nas relações sociais e indo mais a fundo na questão dos postos de trabalho - que se mostra um aspecto interessante para se entender essas questões - e se ligando ao debate da inserção do negro e sua marginalização.

Utilizando-se de um método histórico esse artigo vai buscar analisar os acontecimentos, processos e instituições do passado para entender sua intervenção atualmente, vinda desde a escravidão para entender sua relação com a ocupação e inserção de negros no mercado de trabalho da região metropolitana de São Paulo, esse método vai ser utilizado pelo fato de tendo como referência a emergência, desenvolvimento e consequentemente as alterações dessas instituições - como Estado, mercado de trabalho, entre outras - podendo assim comparar diferentes sociedades, "o método histórico preenche os vazios dos fatos e acontecimentos, apoiando-se em um tempo, mesmo que artificialmente reconstruído, que assegura a percepção da continuidade e do entrelaçamento dos fenômenos." (LAKATOS; MARCONI, 2007, p.107).

Em síntese, a investigação vai dar-se, especialmente, na região já exemplificada acima pelo fato do sociólogo paulista direcionar sua pesquisa a cidade de São Paulo e por entender que atualmente essa região engloba em uma grande conurbação - fenômeno no qual duas ou mais cidades se desenvolvem em proximidade se transformando em uma única - procurei por abranger essa pesquisa a esse determinado território onde poderei entender melhor a situação evidenciada por Florestan, o artigo vai se dividir em quatro partes, a primeira parte vai buscar explicar o processo de abolição e o que 
aconteceu com os povos recém libertos, seguindo por um debate diante da europeização e a imigração e como se travou essa "batalha" entre brancos e negros na sociedade competitiva que se formava, a terceira parte vai examinar o déficit preto que ocorreu durante a primeira metade do século XX e os efeitos da desorganização nessa parcela da população e por fim irei debater a introdução da população afro-descendente na sociedade de classes e seus locais assumidos nos postos de trabalhos.

\section{ABOLIÇAÕ DA ESCRAVATURA: O QUE ACONTECEU COM OS POVOS RECÉM LIBERTOS?}

O tal "final" do regime escravocrata no Brasil não ocorreu com uma ruptura dos antigos agentes de trabalho escravo de assistência, muito pelo contrário a maioria das estruturas desse regime foram ressignificadas na ordem competitiva que estava a se formar, além disso, a população que acabava de ser liberta foi deixada a mercê da sua própria sorte sem ter auxilio algum. Os senhores que traficaram e comercializaram essas pessoas procuraram por indenização, pois se sentiram lesados por perderem seu objeto de produção de riqueza, aceitando a abolição muito pelos movimentos de fuga que ocorreram na década de 1880 nas lavouras e pela pressão do movimento abolicionista que acabou sendo um processo histórico de condenação do antigo regime no que concerne aos interesses econômicos, valores sociais e ideais políticos da classe dominante, como atesta Florestan Fernandes (2008), que conseguiu com esse movimento levar essa "revolução" aos seus modos sem perder muito seus privilégios e poderio na sociedade, as(os) pretas (os) vão ser usadas(os) pelos brancos como um Aríele - maquina de guerra da antiguidade utilizada para quebrar portões - destruindo o "antigo regime", mas construindo outro sem muitas modificações estruturais. A igreja que de certa forma buscava "ajudar" os escravos pouco se importou com seu destino pós abolição, falar do papel do estado é ainda mais complicado, de quem se esperava realmente uma ação, acabou recebendo um "pacote" de omissão e repressão, o aparelho repressivo do estado atuou de forma a todo o momento em evitar o problema que acontecia a população negra, em nenhum momento se propôs uma reeducação do negro para o novo regime, diferentemente buscou-se reprimir, marginalizar e eternizar laços de servidão entre brancos e pretos.

A abolição teve duas "recepções" diferentes, quando falamos no estado de São Paulo, nas áreas onde o regime não obtinha mais prosperidade econômica, a abolição foi uma dádiva para a retirada de um fardo que eram as obrigações onerosas, que os prendiam aos remanescentes da escravidão. Aconteceu que assim o preto, "Perdendo sua importância privilegiada de mão-de-obra exclusiva, ele também perdeu todo o interesse que possuía para as camadas dominantes." (FERNANDES, 2008, p.32). Na região onde o café ainda dava "bons frutos" duas soluções foram propostas para esse 
"problema": onde apresentava a produção baixa e uma ordem tradicionalista mantida, os escravos voltavam ao sistema de produção trabalhando analogamente do mesmo modo que antes ou "se jogavam no mundo" e juntava-se a uma massa de desocupados em busca de novos postos de trabalho. Quando a produção era alta, que era reflexo de um crescimento econômico bem estruturado e uma organização do trabalho tinha por pretensão a formação de "reais" mercados de trabalho nesses locais, a arena do tal "embate" pretos x brancos, porém acabando por ser uma concorrência desleal e prejudicial aos pretos. Entretanto deixarei esse debate para a segunda parte do artigo onde aprofundarei sobre o tema.

\subsection{IMIGRAÇÃO E EUROPEIZAÇÃO: A LUTA PELA INTEGRAÇÃO NA ORDEM COMPETITIVA E NA SOCIEDADE DE CLASSES EM DISPUTA COM OS “NOVOS BRASILEIROS”.}

Até certo quartel do século XIX na cidade de São Paulo a população preta era maioria, mas chegando em 1886 já tínhamos $25 \%$ de imigrantes no total da população, passando o número de pretos na capital paulista. Do mesmo modo que a lavoura cafeeira impulsionou esse boom na cidade de São Paulo fazendo que diversos grupos buscassem suas oportunidades nessa metrópole que crescia inimaginavelmente rápido demais, ela também fez com que o preto procurasse voltar aos interiores, existem dois motivos que vou dar certa atenção, o primeiro é a difícil concorrência com o imigrante, que veio ao Brasil com outra mentalidade, já adequado de certa forma a ordem competitiva que estava se formando aqui e sem contar no projeto de embranquecimento que era implantado nessas terras, buscando a todo modo apagar essa "marca negra" que tentava ser escondida e limpa. O segundo motivo é a difícil adaptação da população preta a nova ordem de trabalho, essa parcela vinha de uma transição conflituosa e sem sequer um auxilio, fazendo que sua chegada a esse "outro mundo" fosse realmente truculenta, como diz Florestan (2008) o interior era um caminho mais fácil, até porque o preto buscava cada vez mais não disputar espaços com os "novos brasileiros" que tinham seus privilégios frente às instituições e eram tidos como peça essencial para a formação dessa nova sociedade.

Diferentemente de outros Estados - um exemplo interessante é a Bahia que absorveu os negros aos trabalhos artesanais urbanos - o negro não teve acesso a trabalhos como o artesanato urbano précapitalista ou no comércio de madurezas e de serviços, essas funções acabaram absorvidas pelos imigrantes que com esses acessos conseguiram se estabilizar e alguns tiveram até certa ascensão na ordem competitiva, o negro e o mulato nessa "briga" já começaram no chão, sem essas oportunidades o preto era confinado a tarefas e ocupações brutas, o chamado "serviço de preto", que eram mal 
remunerados e degradantes ao máximo, para se ter uma noção de como a disputa era tão desigual, o branco imigrante conseguia ter poder de competir com os brancos das camadas dominantes por locais de atuação. O ex-escravo era jogado para a marginalidade sendo um acessório de produção capitalista, o imigrante era um agente de trabalho livre e assalariado, tendo monopolizado as oportunidades reais de poder se classificar economicamente e de ascensão social.

Pensando mais ainda na questão do trabalho, e de analisar a questão da proletarização das classes, enquanto o "novo brasileiro" vinha de uma Europa onde ocorriam diversas revoluções e tendo pulsando em seu coração toda aquela filosofia socialista e anarquista, tendo sido assimilado nas fábricas e acabando por ser organizar e construir diversas greves e manifestações de cunho político, isto é, além de proletarizado o imigrante estava politizado e se organizando como classe autônoma. $A(0)$ negra(o) por outro lado, vinha de uma escravidão maltratante, opressiva e desconfigurante, estava apática é sua incorporação gradual não era nos postos de trabalho que ofereciam acessos, mas sim pela escoria do operariado urbano ou buscava-se o caminho da vadiagem e criminalidade, a proletarização dessa parcela da população não foi direcionada é o trabalho era um fim em si mesmo para provar aos outros sua dignidade e o exercimento da liberdade da pessoa humana, o branco tinha o trabalho como passagem para sair dessa condição que estava, era um degrau para a ascensão para uma vida mais estável e tranqüila.

A passagem para a ordem competitiva e a universalização do trabalho livre não foi um projeto que envolvia a reparação do escravo e seu direcionamento a nova ordem, a realidade é que como já foi dito a cima os movimentos abolicionistas foram fantoches para quebrar o antigo regime e romper as barreiras que impediam a chegada do branco imigrante, e retirar as amarras que reprimiam o trabalho livre e paralisavam a livre iniciativa. A imigração em massa pode-se dizer que teve seu alvo certo, e esse alvo era a exclusão do negro dessa nova sociedade, na verdade queria se construir uma nova sociedade apagando a trajetória dos próprios motores para a degradação do sistema de castas.

\subsection{DÉFICIT NEGRO E A DESORGANIZAÇÃO SOCIAL: QUEM ASSUME ESSE “PROBLEMA NEGRO”?}

A tal revolução burguesa ou revolução pelo alto - a nomenclatura vai depender de cada autor transformou as condições de organização de trabalho, como defende Florestan Fernandes (2008), porém como já foi explicitado o liberto (tal condição se ressignificou na sociedade e todos os preceitos que vinham com a condição de liberto viraram na condição agora de preto) acabava de vir de uma escravidão que deformava o seu agente de trabalho, o animalizando - fazendo um processo de 
atrofiamento da mente dos escravizados que viviam a todo o momento controlados, subjugados e principalmente violentados - de forma que era impedido de colher os frutos dessa universalização do trabalho livre. A escravidão jamais vai sair do que se propôs desde o inicio, ao escravo vai ser imposto um esforço físico descomunal com o "brinde" do constrangimento, não há educação para esse "trabalhador", não se pensa no futuro desses indivíduos amordaçados, como defende bem Caio Prado Jr (2011). Esses aspectos acabaram por influenciar numa desorganização ou desajustamento dessa "parcela de cor" da população e durante meados do século XX, vamos ter um fenômeno que é o déficit negro na cidade de São Paulo.

Como o estado de São Paulo vinha de um boom econômico pela expansão cafeeira que saiu do Vale do Paraíba e veio para o Oeste Paulista, as boas condições econômicas estavam de "mãos dadas" para o surgimento de uma ordem competitiva, como já explicitei o local onde toda essa riqueza se direcionou e começa-se a construir uma nova ordem econômica, social e política vai ser na Grande São Paulo. A parcela da "população de cor" vinha de um estado de anomia social- termo utilizado por Florestan Fernandes para exemplificar o distanciamento dos mesmos dessa ordem competitiva, do modo de vida que a população branca já se adequava, a um pensamento liberal que estava sendo assimilado por parcelas que não caiam ao pauperismo e desajustamentos - acabando por cair em uma cadeia de ferro, circulo vicioso, onde ficava presa (o) a miséria e a níveis de existência que iam se estreitando cada vez mais. O déficit da população negra vai ser causada aparentemente por questões econômicas e sociais, longe das teses que defendiam que todo esse desaparecimento da preta (o) na cidade de São Paulo por inferioridade psicobiologica ou demográfica, inclusive um dos fatores essenciais para se entender o tal déficit e a europeização que abarrotou a capital paulista com os "novos brasileiros", entre 1827 e 1930 era uma tendência de 2 italianos para 1 brasileiro nativo, um quadro que Florestan vai expor na sua obra a integração do negro na sociedade de classes - volume I - ,vai analisar o nascimento e óbitos dos negros, mulatos, brancos e amarelos, mostrando como é alarmante o déficit de nascimento dos pretos e mulatos, enquanto a população branca vinha crescendo gradualmente. O rápido aumento do estoque branco com essa imigração e mais a questão do cruzamento racial - formando os mestiços - vai fazer que os negros que nascessem mais claros se declarassem brancos, ainda mais em situações socioeconômicas favoráveis para essa identificação como branco, esse motivo para o autor é base para esse fenômeno, o branqueamento da população fez que o negro viesse a sumir nessa mestiçagem, sendo os seus sucessores mais "claros" serem por diversas vezes se declararem fora desse "mundo preto", buscando fugir dos estereótipos já autodeterminados para quem era preto (a) na sociedade de classes, a pobreza, vadiagem, subalternidade 
e a marginalização desses indivíduos era tida como destino, se afirmar como um "não negro" era uma busca por ascensão e quebra dessa "marca negra" que a maioria queria apagar de sua história. Além disso, a pauperização desses sujeitos acabou por não propiciar condições humanas para que existisse uma vida descente e ao menos que conseguissem uma sobrevivência, a mortalidade de pretas (os) e mulatas (os) era grande para a sua população total da cidade, em 1920-1928 nasciam 7.330 mulatos e morriam 7.105, os negros nasciam em media de 3.959 e morriam 7.050, enquanto a população branca tinha o índice de nascimento de 199.162 e um total de 100.947 óbitos, as condições de desajustamento que explicitarei mais a frente foram um golpe forte para as populações que viviam a mercê da própria sorte, tendo o estado como um inimigo, jamais como um braço para se levantar da situação que estavam, fica exposto então que

O essencial, portanto, não está nas proporções nem no teor aparentemente
catastrófico do "déficit negro", mas no que ele representa como índice
demográfico de um desajustamento de caráter estrutural e persistente. A
situação econômica, social e cultural aparece, assim como regulador inexorável
do crescimento vegetativo da "população negra". As características
demográficas que poderiam contar vantajosamente, na competição biótica do
negro e do mulato com o branco de origem nativa e estrangeira, acabaram
sendo abatidas ou parcialmente anuladas, sempre em consequências das
mesmas razões fundamentais" (FERNANDES, 2008, p.136) O déficit da população negra e mulata não modificou apenas a questão demográfica como disse 0 sociólogo paulista acima, teve o desajustamento estrutural como alicerce da "degradação preta", mas o que quer dizer Fernandes quando fala sobre desajustamento? Para se entender esse fenômeno, deve-se primeiro atentar a conclusões que o autor chega, sendo que para o mesmo as compensações individuais ou coletivas que a cidade oferecia, não modificava em nada a posição que se encontrava pretos e mestiços no sistema de relações sociais e econômicas já estruturado na sociedade paulistana. Sabe-se que o pós primeira guerra (1914-1918) vai mudar o jogo econômico deixando o campo de lado e fazendo a cidade ganhar valor ainda mais - fazendeiro passa a ser o capitalista típico - fazendo que o operário ganhe caminhos para subir de posição na ordem competitiva, entretanto o negro não estava encaixado nessa proletarização, o branco imigrante tinha prioridade para a entrada nas fábricas, o negro era tido como desqualificado, fora de jogo pela busca de posições altas e intermediarias, esperava-se uma segunda abolição para que conseguisse assim seus "dias de glória". Isso tudo desanimava a parcela da "população de cor" que ia mais e mais ao fundo poço - fazendo um contraponto Guerreiro Ramos (1954) vai ir contra a idéia de que a(o) preta (o) se entregou a essa desanimo e vai evidenciar que os autores desse "problema do negro" acabavam por construir um ideal de brancura, esquecendo das revoltas e da luta dos negros pela sobrevivência nesse regime - e ainda 
mais pelo fato dessa saída da escravidão sem um auxilio, fizesse que partilhassem do ócio disfarçado ou da vagabundagem como uma auto-afirmação, isto é, queriam resguardar aquilo que tinham ganhado a liberdade e a dignidade da pessoa humana, aspecto que foi retirado desses indivíduos durante todo o processo de escravidão mercantil no Brasil.

A tese de Florestan vai ser voltada a defender que a impossibilidade do negro de se inserir nesse modo de "ganhar a vida", fez com que os ex-escravizados(as) não conseguissem participar economicamente, socialmente e culturalmente daquela sociedade, assim o desajustamento estrutural vai ser um peso para a entrada no mercado de trabalho que vinha se construindo, o alcoolismo, a dificuldade em formar um família tradicional, a vagabundagem, promiscuidade dos cortiços, o suicídio, o parasitismo do negro e do mulato em cima das mulheres negras e mulatas, tudo isso tendo como fator dinâmico as condições engendradas e mantidas pela pauperização, esse aspecto acabou por combinar, influenciar e fortalecer a anomia e a miséria, a exclusão dos acessos para ocupações conspícuas condenavam o preto a vegetar socialmente. Os postos de trabalhos direcionados a essa parcela da população era os "serviços de pretos", os homens acabavam por serem "jogados" aos postos mais subservientes nas fábricas, fazendo os trabalhos que nem os italianos queriam fazer, eram ocupações que degradavam não apenas fisicamente, mas psicologicamente também, as mulheres continuavam a herança colonial trabalhando nos serviços domésticos nas famílias tradicionais brasileiras, continuavase a relação senhor e escravo. Poucas (os) pretas e mulatas (os) conseguiam ocupações que davam de certa forma uma esperança de modificação social e econômica de sua situação, existia-se uma "nata" da população negra que estavam nos serviços públicos ou tinham cargos de confiança com os brancos, fazendo que dentro mesmo da "sociedade negra" existisse uma distinção entre essa elite e os "rale". A realidade da maioria dessa população "desajustada" era de ocupações sem garantia de permanência, fazendo que pulassem de um emprego a outro a todo o momento, quem se sujeitava ao subjugo dos brancos ficava nos tais serviços de negro" como já explicitei acima, o crime e o parasitismo eram uma forma mais fácil de poder sair daquela situação e até de ser respeitado dentro das periferias negras, para muitos "vagabundos", "ladrões", quem se sujeitava a ser capacho dos brancos eram os "otários", a prostituição ( em maioria para as mulheres, existindo também entre os homens) e o crime junto ao ideal de procura por um parasitismo fazia que as ocupações da ordem competitivas não ficassem tão atrativas aos mesmos, a vida ilegal além de trazer uma tal segurança econômica, dava a esses indivíduos respeito de uma parcela dessa população - mesmo atestando que o conservadorismo na população negra era gigante, muito pelo apego as raízes do sistema escravocrata, que tinham sido abandonadas pelos brancos que aderiram aos valores liberais, enquanto o negro ficava "parado" 
nesses preceitos - . Entre 1900-1930 a "população de cor" estava em um ciclo vicioso, onde a rondava a herança sócio cultural (escravidão) e a exclusão do negro e mulato das "formas de ganhar a vida".

Para finalizar essa parte queria ressaltar o desemprego que era cotidianamente algo rotineiro para a população negra, sendo que a estabilidade no trabalho para essa parcela era algo inimaginável, o que imperava nesses meios era o emprego parcial e as vezes total, de baixíssima remuneração, levando muitas vezes a repulsa do negro e mulato pelo trabalho na ordem competitiva por essas humilhações morais e físicas de se submeter a trabalhos degradantes, a pauperização aumentou ainda mais a situação desumana que vivia essa população, a mulher negra e mulata por ter essa continuidade da relação senhor x escravo acabou por ter um "beneficio" a mais de poder conseguir sustentar a casa sem ter tanta instabilidade, deve-se exaltar a importância da mulher negra e mulata para a salvação real de grande parte dessa população, segurando nas costas a responsabilidade de não deixar chegar a degradação total da população negra, mesmo tendo que segurar a "barra" de um parasitismo do homem negro que por diversos motivos acabou por utilizar a mulher negra como seu alicerce, a prejudicando de diversas formas, além disso não se deve esquecer que apesar de toda a dificuldade dos pretos e mulatos (as) havia uma rede de ajuda entre eles, mesmo que essa rede por muitas vezes prejudicava e acaba piorando a situação de diversas famílias, certamente o acolhimento de idosos, necessitados e pessoas acamadas foi algo que existiu nas periferias onde foram deixados a mercê uma população que saia de uma situação de desumanização.

\subsection{COMO A INSERÇÃO DO NEGRO NA ORDEM COMPETITIVA TEM SIDO ATUALMENTE: AS NEGRAS(OS) NO MERCADO DE TRABALHO DA REGIÃO METROPOLITANA DE SÃO PAULO.}

O século XX marcou a história mundial por diversos aspectos, para os afro-brasileiros que viviam na região da Grande São Paulo essa época queria ser esquecida, a subalternidade, falta de auxilio, pauperismo e nenhuma perspectiva para a sua real libertação, foram alguns das questões que marcaram a trajetória negra. Os postos de trabalho mal remunerados, degradantes, que evidenciavam a continuidade das relações escravistas numa sociedade que discursava valores liberais de igualdade, racionalização e justiça, diziam muito de qual sociedade ainda vivíamos no Brasil em meados do século passado.

O debate sobre a questão racial no mercado de trabalho e algo bem recente, o racismo vai se tornar crime inafiançável e imprescritível, sujeito a pena de reclusão, de acordo com Art. 5ㅇ Inciso XLIV em 5 de Outubro de 1988 (Brasil,1988), sendo em 1998 que vai ser levado a questão racial até a sede da 
Organização Internacional do Trabalho (OIT) em Brasília, onde se realizou uma reunião para introduzir dois quesitos de cor em dois formulários que são ligados ao mercado de trabalho no Brasil: esses dois formulários sendo o RAIS - Relação anual de informações sociais que busca por coleta de dados no setor do trabalho e para assim suprimir as necessidades de controle de atividade trabalhista no pais, provimento de dados para a elaboração de estatísticas do trabalho e disponibilizar informações do mercado de trabalho as entidades governamentais - e o CAGED que é o cadastro geral de empregados e desempregados do país.Sendo que 1991 o IBGE foi "coletar a cor" pela primeira vez, como relata Roland (2000), divulgando apenas dados que continham valores absolutos de cada sub população, atualmente o Instituto Brasileiro de Geografia e Estatística utiliza da auto-classificação, como você se identifica racialmente? Essa é a base para a pergunta classificatória.

Analisando agora diferentes estudos sobre a questão da (o) negra (o) no mercado de trabalho, começamos pelo período da década de 1990 onde se começa a incluir o quesito de cor nas pesquisas empíricas sobre o trabalho, como já foi dito anteriormente, na década onde o Brasil estava vindo de uma redemocratização após um longo tempo governado por uma ditadura civil-militar, o país tinha crescimento insignificante do PIB, altas taxas de desemprego, precarização das condições de trabalho, terceirizações, subcontratações e o mercado informal crescendo mais e mais, em 1999 vamos ter uma pesquisa realizada pelo PED - Programa estratégico de desenvolvimento - onde a população negra era $41,3 \%$ da população em idade ativa (PIA), tendo sua maior presença no sudeste, muito pelo processo histórico de formação econômica e social, isso tudo evidenciado por Tomé (2006), chegando ao ano de 2001 o DIEESE - Departamento Intersindical de Estatística e Estudos Socioeconômicos - vai "soltar" um estudo descrevendo a condição do mercado de trabalho no Brasil, aprofundando sobre a questão da população negra, dando um salto quando se fala sobre o "debate negro", a conclusão aparente do DIESSE e que o mercado de trabalho é uma das esferas em que se mais se explicita os mecanismos de discriminação, mostrando até suas nuances mais sutis, sendo que vemos isso até materializados na cinematografia onde o documentário de Joel Zito (1997), "a exceção e a regra" mostra de forma real como a preta e o preto sofrem sendo ridicularizados e sofrendo o racismo nos pequenos detalhes. Como Tomé (1997) mesmo relata na sua pesquisa, o passado e mantido, o negro sempre mais tempo sem emprego, sujeitos a todo tempo ao desemprego, e quando conseguem se firmam em alguma ocupação, são as mais bravas ocupações.

A parcela negra da população vai se firmar no mercado de trabalho na idade entre 10 e 40 anos, sendo menos presente entre 25-39 anos, considerada a faixa de idade mais produtiva - essa faixa de idade 
sendo ocupada majoritariamente pelos "não negros"-, os dados que Tomé(2006) trás evidenciam que na "idade produtiva" os "não-negros" em Recife, Salvador e São Paulo ultrapassam os negros na participação do mercado de trabalho. O que tudo isso pode apresentar como análise?

Pode-se confirmar com estes dados que quanto mais cedo o trabalhador se insere no mercado, menos tempo existe para o investimento em uma educação de qualidade, o que contribui de forma negativa para que este permaneça em ocupações precárias por muito mais tempo. Auferindo rendimentos abaixo do mínimo necessário a uma existência digna, é preciso permanecer trabalhando na velhice e requisitar o auxilio dos mais novos para aumentar a renda. Esse círculo vicioso. (TOMÉ, 2006, p.p 4-5)

Esse círculo vicioso que a autora descreve, aparentemente vem sendo construído historicamente e estruturalmente, em consonância com Florestan, descreve-se uma ferramenta usada pela população negra desde o inicio da sua inserção na sociedade de classes, os mais novos tinham que procurar emprego desde novo para aumentar a renda de casa, sem esse aumento da renda pelo trabalho infantil, muitas famílias teriam morrido de fome ou se desajustado ainda mais.

Caminhando alguns anos à frente, apresenta-se uma pesquisa do sistema PED, publicada em novembro de 2018, debatendo "os negros no mercado de trabalho da região metropolitana de São Paulo", entrando a fundo na questão dos diferenciais de inserção dos negros e "não-negros" no mercado de trabalho de 2017 e os ocupados segundo os tipos de relação de trabalho (2ㅇs semestre de 2014 - 1은 semestre de 2018). Com a crise econômica que assolou o pais em 2014, os índices de desemprego subiram muito na Região Metropolitana de São Paulo, chegando a 20,8\% na população afro-brasileira, dentro da questão do desemprego o PED tem duas definições, o desemprego aberto e oculto, o aberto abrange pessoas que procuraram algum tipo de emprego de efetivamente no último mês anterior a entrevista e também não poderiam ter tido atividade remunerada nos últimos 7 dias. 0 desemprego oculto são aqueles indivíduos que tiveram realização de algum trabalho remunerado por autoocupação, mas não tendo nenhuma projeção de continuar obtendo renda, que também realizaram trabalhos voluntario para parentes e amigos ou mudaram de emprego no mês que havia passado. Entretanto, vamos entender quais as ocupações que essa população tem realizado atualmente, analisamos acima que em meados do século $X X$, existia uma continuidade pela manutenção dos empregos análogos ao regime escravocrata, com as mulheres direcionadas aos serviços domésticos e os homens realizando serviços braçais e degradantes, ambos geralmente sem remuneração adequada e longe de termos na época uma legislação trabalhista - que vai ser implantada no Governo Vargas -. A crise econômica vai ser sentida no mercado de trabalho mais fortemente nos anos de 2015/2016, o trabalho de carteira assinada vai diminuir para as negras (os) e vai se aumentar o trabalho autônomo, 
diminuição de 55,3 \% de assalariados em 2016 para 53,5\% em 2017 e os autônomos vão aumentar em 2017 de 16,2\% para 18,2\%, como vai ser relatado pelo Sistema PED (Novembro de 2018). Isso mostra que o desemprego afeta drasticamente a população negra nos tempos de crise, sendo essa parcela o bode expiatório para pagar problemas de um sistema econômico- social.

Estruturalmente, continuamos a mesma trajetória descrita minuciosamente desde a pós-abolição, as pretas (os) são maioria nos serviços domésticos e menos representativas no setor publico e agregado, como: empregadores, profissionais universitários autônomos, donos de negocio familiar. Posições desde o começo direcionadas a elite branca já estabelecida aqui desde a colonização e para os "novos brasileiros" que vieram construir o Brasil a pedido dos "donos do local". O sistema PED (Novembro de 2018) levanta outros diversos dados que são interessantes para entender as ocupações dos negros em relação aos brancos, ano de 2017 negros continuam com maioria no setor da construção civil: 8,3\% contra 5,5\% dos "não-negros", na indústria o branco continua como maioria 15,2\% e os negros com 14,1\%, e o comércio - setor que paga os menores salários médios - continua uma tendência a maioria negra com $18,0 \%$ e $17,9 \%$ de brancos. Observa-se que a uma continuidade pelos trabalhos ditos mais subalternos direcionados a "população de cor", sendo o setor de serviços o mais forte entre a população de cor, inclusive com essa mesma população tendo rendimentos do trabalho por hora equivalente a 69,3\% dos "não negros", apesar de que em 2017 tenha existido uma retração desta diferença tendo o negro aumentado seu rendimento em 1,5\%, recebendo $R \$ 9,52$ hora e os brancos apresentando redução de $0,7 \%$, recebendo $R \$ 13,88$ hora.

O que ficou evidenciando com a Pesquisa do PED (Novembro de 2018) é que durante a crise (período do segundo semestre de 2014 e segundo semestre de 2017) o negro vai buscar a autonomia no trabalho, muito pelo desemprego afetar a contratação, então existe um aumento do número de pretas (os) que criaram seus negócios familiares e que trabalharam independentes, o fim da crise (segundo semestre de 2017- primeiro semestre de 2018) e a recuperação econômica trouxe a população negra novamente a ocupar os postos de trabalho de carteira assinada, e mesmo com esse fenômeno continua-se um caminho para o trabalho não formalizado e independente, mas mesmo com esse crescimento a estrutural ocupacional não se move, até porque a população negra por questões histórico estruturais não retém para si a grande parcela do capital cultural, escolar e econômico, que são interligados, a falta de um pode afetar o outro conseqüentemente e a disputa com outras classes que detém todos esses capitais não se torna fácil, como relata bem Bourdieu (2007). 
Afinal, os pretos (as) mesmo em locais onde são superiores numericamente, sofrem com o desemprego sempre de forma mais pesada, inclusive quando sua escolaridade é "alta", a preferência pelo branco para os cargos mais importantes é nítida. Observando diversas pesquisas e analises existe uma consonância em mulheres e homens "de cor" ocuparem os postos mais vulneráveis de trabalho, sendo a região metropolitana de São Paulo um exemplo, deixando ainda mais explicito que as mulheres pretas são as mais prejudicadas nesse aspecto, desde sempre sendo a base da sociedade de classes as mesmas tem as ocupações mais precárias (domestica, assalariada sem carteira, autônomas que trabalham com o público) e mesmo assim conseguiram em 131 resistir a busca das elites brancas pela destruição da população afro-brasileira.

\section{CONSIDERAÇÕES FINAIS}

Em síntese, esse artigo tentou explicitar após uma análise da historiografia da inserção do negro na sociedade de classes pelo viés, principalmente de Florestan Fernandes, e também pela análise de estudos de diversos órgãos públicos e privados para entendimento da situação da população negra no momento atual. O que ficou evidente é a estrutura de desigualdades que se mantém após 131 anos da abolição da escravidão nas terras brasileiras, fazendo que a população afro-brasileira se encontre até hoje na base dessa pirâmide estrutural e sendo sempre a parcela mais afetada por causa das crises do sistema econômico que o mundo se encontra inserido.

Embora possa se observar que na década de 1980 inicia-se de um período de conquistas de direitos para a população negra, o que vemos atualmente não são "dias" tão maravilhosos para esse povo, que mesmo conseguindo sua tal "liberdade" teve sua trajetória nas mãos de uma elite branca que pouco se importou com os destinos e problemas enfrentados por uma gigantesca massa de indivíduos que acabavam de sair de um sistema econômico-social massacrante e dilacerante, que não deixava marcas apenas físicas, mas marcas ainda mais pesadas na questão psicossocial.

Como foi explicitada durante todo o artigo a dificuldade que as (os) pretas (os) tiveram para se adentrar a nova ordem competitiva que vinha se formando foram diversas, levando a um desajuste estrutural dentro da "sociedade negra", causando problemas como: alcoolismo, sexualização precoce, crimes, prostituição, dificuldade em formar famílias, parasitismo dos homens negros diante das mulheres negras, desemprego e um déficit da "população de cor" na cidade de São Paulo. Todos esses motivos foram influenciados por um espectro que rondava as periferias a todo o momento, que é a miséria, esse fator fazia que sempre se vivesse em uma linha tênue, qualquer problema que ocorre em certo grupo poderia levá-lo da pobreza a miséria em pouco tempo. Com a falta de auxilio mais a 
subalternidade que se encontravam no mercado de trabalho a possibilidade de melhorar de vida era quase que impossível, o destino dos filhos era uma das possibilidades mais certas de se conseguir algo, fora a criminalidade que era um caminho que trazia além de estabilidade econômica, fazia bem para o ego.

O reflexo disso se vê atualmente, mesmo com a população negra sendo maioria no mercado de trabalho, analisando o caso da região metropolitana de São Paulo, continua-se um direcionamento dos negros (as) para empregos domésticos, subalternos e com pior remuneração, recebendo 69,3\% do rendimento da parcela "não negra", evidenciando ainda mais que o não auxilio a inserção dos afrobrasileiros se configurou em uma perpetua "sombra" que atrapalha os negros (as) a emergir na pirâmide social do capitalismo. Mesmo com um avanço significativo da população negra nos postos de trabalho ditos independentes - sem ligação com carteira assinada - e na criação de negócios próprios, ainda assim a distância para a população branca - que domina as posições fora do serviço formal - e muito grande.

Nessa situação fica o questionamento: a situação das (os) negras (os) continua a mesma da pósabolição? É uma resposta complexa que se procura e aparentemente há muito a se aprofundar em um debate que por muito tempo foi escondido e que ganhando espaço precisa ser debatido, visibilizado e principalmente tido como realidade de uma sociedade que ainda não aprendeu a dar lugar aos povos que construíram esse país deixando seu sangue e suor. 


\section{REFERÊNCIAS BIBLIOGRÁFICAS}

ANDREWS, G. R.(1997). Democracia racial brasileira 1900 - 1990: um contraponto americano. Estudos Avançados, 11 (30), p. 96-115.

Atividade Legislativa. Disponível em

<https://www.senado.leg.br/atividade/const/con1988/con1988_15.12.2016/art_5_.asp> Acesso em: 26 nov. 2019

BASTOS, E. R. . Um debate sobre o negro no Brasil. São Paulo em Perspectiva, São Paulo, v. 1, n.5, p. 20-26, 1988.

FERCOMÉRCIO RS/SENAC. Manual para elaboração de artigos: conforme a NBR 6022:2003. Porto Alegre: 2014.

FERNANDES, Florestan. A integração do negro na sociedade de classes. São Paulo: Globo, 2008.

GUIMARÃES, A. S. A. . Preconceito de cor e racismo no Brasil. Revista de Antropologia (São Paulo) , São Paulo, v. 47, n.1, p. 9-44, 2004.

GUIMARÃES, A. S. A. . Racismo e Anti-Racismo No Brasil. NOVOS ESTUDOS CEBRAP, n.43, p. 26-44, 1995.

HASENBALG, Carlos. Discriminação e desigualdades raciais no Brasil. Belo Horizonte: UFMG, 2005.

MARTINS, T. C. S. . O negro no contexto das novas estratégias do capital: desemprego,precarização e informalidade. Serviço Social \& Sociedade , v. 111, p. 450-467, 2012.

Negros e não negros no mercado de trabalho em 2017. Novembro de 2018. Disponível em > https://www.dieese.org.br/analiseped/2018/2018pednegrossao.html < Acesso em: 24 nov.19

NORMA BRASILEIRA. ABNT NBR 6024: Informação e documentação - numeração progressiva das seções de um documento - apresentação. Brasília. 2012

PERFIL DOS MUNICÍPIOS PAULISTAS. Disponível em < http://www.perfil.seade.gov.br/\# > Acesso em: 24 nov. 2019

QUEIROZ, F. A. . MANUAL METODOLÓGICO: Dicas de como se fazer resenhas, artigos, seminários... 2016. (Desenvolvimento de material didático ou instrucional - Material Didático).

RAMOS, A.G. . O problema do Negro na Sociologia Brasileira. Transcrito de Cadernos de Nosso Tempo, 2 (2): 189-220, jan./jun. 1954. Republicado em Simon

ROLAND, E. M. S. . Discriminação Racial no mercado de trabalho e o quesito cor. Mercado de Trabalho - conjuntura e análise, Rio de Janeiro/Brasília, v. 13, p. 9-12, 2000.

SABINO, G.F.T. . Racismo: o negro e as condições de sua inserção no mercado de trabalho brasileiro no final da década de 90. Revista Urutágua (Online) , v. 1, p. 06, 2006. 
SANTOS, E. F. ; Scopinho, R. . Fora do jogo? jovens negros no mercado de trabalho. Arquivos Brasileiros de Psicologia (Online) , v. 63, p. 26-37, 2011.

Schwartzman, editor, O Pensamento Nacionalista e os "Cadernos de Nosso Tempo". Brasília, Câmara dos Deputados e Biblioteca do Pensamento Brasileiro, 1981, pp. 39-69

SILVA, R. M. da C. História dos trabalhadores negros no Brasil e desigualdade racial. In: Universitas JUS, v. 24, n. 3, p. 93-107, 2013.

SISTEMA PED. Inserção da população negra nos mercados de trabalho metropolitanos. Novembro de 2017. Disponível em > https://www.dieese.org.br/analiseped/2017/2017apresentacaoNegros.htmk< Acesso em: 26 nov.19

SISTEMA PED. MERCADO DE TRABALHO REGIÃO METROPOLITANA DE SÃO PAULO. Fevereiro de 2019 - no 411. Disponível em > https://www.dieese.org.br/analiseped/2019/201902pedsao.html< Acesso em:26 nov.19

SISTEMA PED. OS NEGROS NO MERCADO DE TRABALHO DA REGIÃO METROPOLITANA DE SÃO PAULO: Diferenciais de inserção entre

SOARES, S. S. D. . O Perfil da Discriminação no Mercado de Trabalho ? Homens Negros, Mulheres Brancas e Mulheres Negras. Brasília: IPEA, 2000). 


\section{Capítulo 21}

\section{doi $10.37423 / 210604372$}

\section{A MORALIDADE SECULAR: ACESSO E DISTRIBUIÇÃO DE RECURSOS NA ASSISTÊNCIA À SAÚDE POR H. T. ENGELHARDT JR.}

Isabel Cristina Correia

Monique de Alencar Lucena

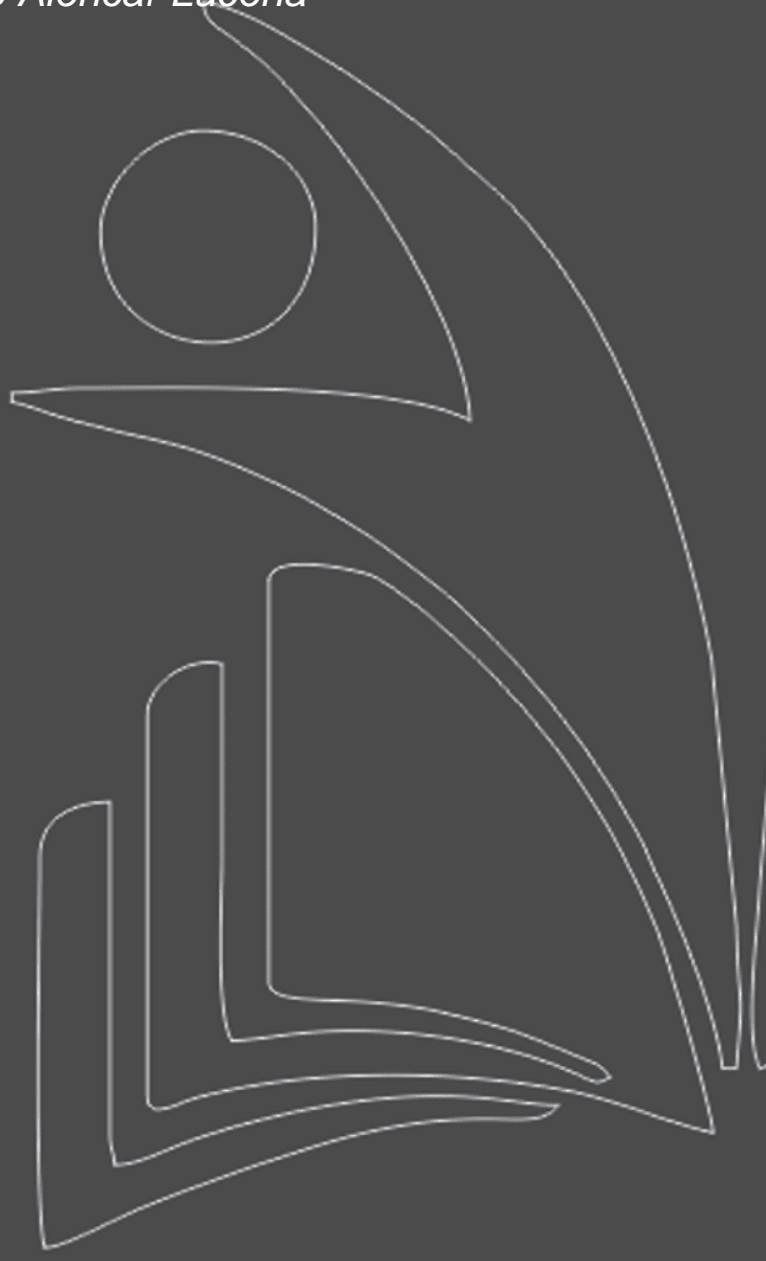

Cátedra da Unesco de Bioética -

Universidade de Brasília

Cátedra da Unesco de Bioética -

Universidade de Brasilia

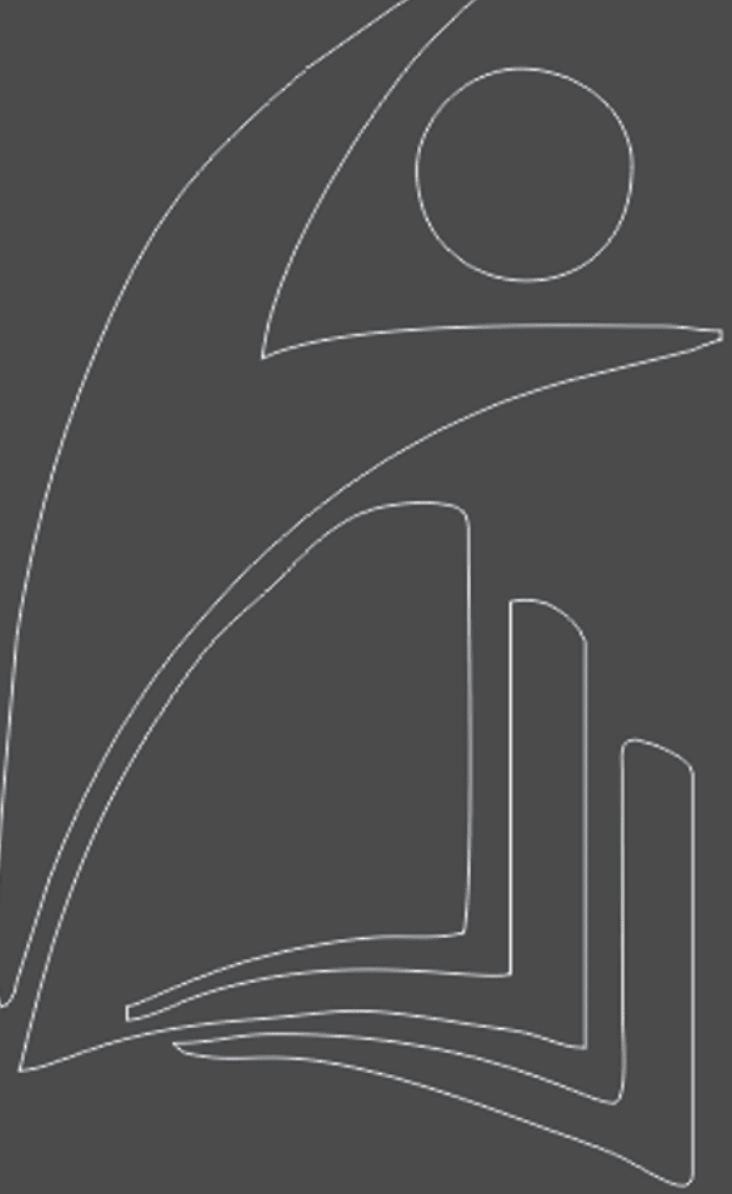


Resumo: O artigo trata-se de uma pesquisa teórica, cujo objetivo é analisar criticamente os pressupostos da bioética secular, do estadunidense H. T. Engelhardt Jr, com um enfoque no campo da saúde pública, principalmente no que diz respeito ao acesso e distribuição de recursos em saúde. Fezse um levantamento bibliográfico nas bases de dados científicas (PubMed, Scielo, Bireme), e uma leitura aprofundada da obra clássica do autor intitulada "Fundamentos da Bioética" - utilizado na 2a edição da tradução brasileira de 1998. O trabalho traz, ainda, uma breve contextualização da trajetória de vida do autor expondo suas principais ideias e atividades desenvolvidas no campo da bioética, que, para muitos, apresentam-se como incômodas, polêmicas, porém, atuais. A bioética secular de Engelhardt pressupõe uma moralidade sem essência, que reconhece as limitações da autoridade do Estado em prover a saúde, uma vez que, em termos seculares, apenas o indivíduo é dotado de autoridade, desde que este não a tenha transferido para outro por livre consentimento, revelando um caráter ultraliberal do autor. Para Engelhardt, os conflitos não podem ser solucionados diante do pluralismo existente, aponta que apenas o reconhecimento de uma moralidade secular possibilita o pluralismo pacífico em Bioética quando os "estranhos morais" se encontram.

Descritores: Bioética. Secularismo. Acesso a cuidados de saúde. Liberalismo. Pluralismo moral. 


\section{INTRODUÇÃO}

Após o que considera "malogro modernista do projeto filosófico", que pretendia justificar através da razão uma moralidade canônica fundamental a todos, preocupado com a ameaça do niilismo e do relativismo da pós-modernidade, o bioeticista estadunidense Hugo Tristram Engelhardt Júnior (19412018), propõe uma ética secular pautada numa moralidade sem essência, ajustada na defesa extrema da autonomia, liberdade e propriedade individual.

A moralidade secular, trazida nas obras de Engelhardt, denota idéias que são atuais, visionárias e polêmicas, algumas podendo até provocar um sentimento de repulsa à primeira vista, dadas as expectativas da razão em busca de um bem-estar comum. Contudo, o conceito ético secular não é formulado para viver a vida, ao contrário, traduz uma moralidade capaz de vincular pessoas que têm visões morais diferentes, para que vivam pacificamente.

Para Engelhardt, a moralidade secular não apresenta solução para os conflitos, mas, proporciona uma explicação da moralidade que deveria orientar os indivíduos quando se encontram como estranhos morais. Reconhece que há comunidades onde os homens e as mulheres podem viver vidas morais coerentes e perseguir suas próprias virtudes. O autor defende, ainda, que a única solução do conflito é a manutenção da diferença por meio da tolerância diante do exercício da liberdade, seguindo o princípio do consentimento.

Através de uma admirável contextualização dos fatos, é nítido o aspecto ultraliberal com que Engelhardt conduz as ações e práticas em saúde. Admitindo-se uma ética secular, é totalmente permissível considerarmos moralmente aceitas algumas práxis que até hoje não se têm um consenso, observando o direito indelével de liberdade dos indivíduos, em consonância ao princípio do consentimento que está regrado na permissão e na tolerância que une os estranhos morais, tenta oportunizar a pacífica convivência entre os indivíduos diante de questões morais que envolvem aborto, eutanásia, comercialização de órgãos, compra e venda de assistência à saúde, entre outros aspectos que dividem opiniões de valores distintos.

Nos conflitos relativos à moral o que está em jogo não são apenas os fatos, mas as avaliações dos fatos. Assim, a bioética secularista traz um modelo que reconhece a variedade e o caráter conflitante dos recursos morais e exige uma sensibilidade apropriada a todos os recursos. 
O objetivo deste trabalho é fazer uma análise crítica da obra de H.T. Engelhardt, em suas considerações bioéticas, concatenando suas ideias centrais ao campo da saúde pública, percorrendo desde a biografia e trajetória acadêmica do autor até o mister bioético que deixou como legado.

\section{BIOGRAFIA E TRAJETÓRIA DO AUTOR}

Hugo Tristram Engelhardt Júnior, além de professor, médico e filósofo, foi uma personalidade de referência na ciência e na bioética anglo-saxônica e no mundo. Nasceu em 27 de abril de 1941 no Texas - Estados Unidos (EUA), e morreu aos 77 anos, no dia 21 de junho de 2018, em Houston, Texas. Texano que defendia acima de tudo a secularidade nos diálogos bioéticos sendo, ele próprio, ortodoxo praticante, carregando, portanto, ideias "conservadoras" e perturbadoras sobre temas como aborto e a manipulação de embriões, por exemplo, considerados "manifestações altamente maléficas".

Formado em medicina na Universidade de Tulane, tornou-se um filósofo americano, com doutorado em filosofia da Universidade do Texas, em Austin. Foi professor de filosofia na Rice University, em Houston, Texas, especializado em história e filosofia da medicina, particularmente do ponto de vista da filosofia continental. Ele também foi professor emérito do Baylor College of Medicine de Ética Médica e Política de Saúde. Toda sua vida foi marcada por uma ação acadêmica profundamente coerente com os princípios que ele abraçou ao longo da sua existência. Na Universidade, se caracterizou por ser um filósofo crítico, provocativo, tentando - através do discurso pragmático especialmente compreender e propor soluções para as inaceitáveis disparidades sociais constatadas no mundo contemporâneo.

Por algum tempo foi editor-chefe do Medical and Philosophy Jornal e Christian Bioethics. Editou a série de livros "Filosofia e Medicina". Era membro do Hasting Center, um instituto independente de pesquisa em bioética. Escritor de obras, como a consagrada The Foundations of Bioethics - traduzido para dezenas de idiomas, como chinês, italiano, japonês, português e espanhol - e Bioethics and Secular Humanism: The Search for a Common Morality. Seu livro seminal de 1986, Fundamentos da Bioética, levou praticamente duas décadas de trabalho e teve apoio e sugestões dos colegas do Institute of Ethics, na Universidade de Georgetown, e do Center for Ethics, Medicine and Public Issue, em Houston.

Antes de o termo Bioética ser apresentado por Van H. Potter, em 1970, o professor Engelhardt já escrevia a respeito dessa ética de forma natural, por causa do engajamento tanto em medicina quanto em filosofia. 
Engelhardt foi reconhecido como um dos pioneiros do campo da bioética, escrevendo mais de 300 livros, capítulos e artigos que examinaram personalidade e identidade, bioética, genética, humanismo secular, a desprofissionalização da medicina, teologia cristã e ética, direitos dos animais, política de saúde e muito mais. Foi uma figura imponente na bioética acadêmica.

Considerado com um homem doce e simpático, sua imagem que, por vezes, contrastava com a austeridade de seus textos: as botas, gravata em forma de laço e barba estilo "Tio Sam" não refletiam a profundidade de conceitos citados por dezenas de autores, como o dos "Estranhos Morais" que, em suma, aponta à possibilidade de pluralismo pacífico em Bioética.

Envolvente escritor, de alto nível intelectual, ao mesmo tempo que era considerado polêmico e denso, seus escritos apesar de provocativos, não eram ofensivos, mantinha uma linguagem atual e bem estruturada.

\section{IDEIAS CENTRAIS DA OBRA DE H.T. ENGELHARDT JR}

O ponto de partida do pressuposto bioético de Engelhardt funda-se no que ele considera o "fracasso do iluminismo", cuja aspiração era descobrir, pelo uso da razão, uma solução concreta para resolver os conflitos morais apoiando-se num ideário de moralidade essencial universal que garantiria a paz permanente.

O uso da razão procurava compreender o caráter de vida boa e os princípios gerais da moral fora de qualquer narrativa moral particular. Contudo, essa expectativa tornou-se improcedente, pois em vez de a filosofia ser capaz de ocupar o vazio deixado pela fragmentação da hegemonia do pensamento cristão no Ocidente, apresentou-se como várias filosofias e éticas filosóficas concorrentes.

Com a fragmentação da perspectiva moral universal, a bioética contemporânea enfrentou um considerável ceticismo, politeísmo, pluralidade de sentidos morais e crescente desafio das políticas públicas.

Diante de um pluralismo moral, Engelhardt, sugere que a esperança filosófica para unir os povos, seria um comunalismo geral de pessoas, que deveria unir membros de comunidades morais diversas. Assim, defende a adoção de uma moralidade secular, livre de valores religiosos, sociais, culturais, ou ideologias particulares, mas que permita tolerância às ideias distintas.

A moralidade secular não pode proporcionar uma visão normativa do bem ou uma explicação canônica essencial sobre a ação apropriada. Quando um problema não é resolvido pelo arrazoamento moral, 
ou seja, quando não há clareza moral dos fatos ou os próprios princípios parecem ser insuficientes para solucionar problemas, e mais ainda quando os argumentos de ambas as partes são convincentes e lógicos, os conflitos morais não encontrarão resolução por sadios argumentos racionais ou invocando uma autoridade moral trivialmente conhecida. ${ }^{3}$

A classificação das pessoas em comunidades de "estranhos morais" e "amigos morais" conferem originalidade à proposta bioética de Engelhardt. Estranhos morais são pessoas que não compartilham as mesmas filosofias morais de evidência e inferência necessárias à resolução de conflitos morais, ou que não têm compromisso comum com os indivíduos ou instituições dotadas autoridade para resolvêlos. Os amigos morais são aqueles que compartilham uma moralidade comum, assim, são capazes de resolver os conflitos morais por meio de uma arguição moral sadia valendo-se de uma autoridade presumidamente reconhecida. ${ }^{4}$

Em termos morais seculares, o bioeticista entende, que a vida de um ser humano não é estritamente a vida de uma pessoa. Um ser humano é apenas um produto biológico, torna-se pessoa se, e somente se, chegar a desenvolver a capacidade mental de racionalizar. As pessoas são a base para o estudo da moralidade, somente elas têm problemas e obrigações morais, ou seja, o início da vida biológica humana não é o início da vida de uma pessoa como agente moral que poderia participar na moralidade que une estranhos morais. Para o autor, só há vida quando há cérebro, cita que "um corpo humano que só pode funcionar biologicamente, sem uma vida mental interior, não sustenta um agente moral" (Engelhardt, p. 293).

Engelhardt classifica a bioética em dois modos: 1) a bioética que fundamentar-se em uma moralidade essencial, que confere vultosa orientação sobre o que é certo ou errado, bom ou mau, além da limitada exigência de que não se utilizem de pessoas sem sua autorização; 2) a bioética de compromisso, pautada numa moralidade estritamente continuísta, onde os indivíduos lançam aos esforços comuns a autoridade moral de seu consentimento.

O princípio do consentimento é a fonte fundamental de autoridade moral secular. Na impossibilidade de constituir uma moralidade canônica e diante das dificuldades conceituais, do malogro em estabelecer uma acepção concreta da vida boa, a única forma de unir os estranhos morais é através do respeito mútuo, que necessariamente implica em restrição, através da permissão, da liberdade ou visão de valores do outro.

O Livre e Informado Consentimento é uma prática heterogênea, justificada pelo respeito à liberdade dos indivíduos com vistas a atender seus melhores interesses, compreende obter permissão não 
apenas dos indivíduos que devem ser tratados, mas também dos responsáveis por indivíduos incapazes de consentirem por si mesmos. Paradoxalmente, a ética secular assevera que o direito de consentir é diferente do direito de ser informado, logo, o princípio do consentimento não exige que o indivíduo seja informado, mas, que apenas tenha oportunidade de informar-se. Com isso, em uma moralidade secular, admite-se a ausência de maiores explicações sobre os benefícios e riscos.

A liberdade de escolher compreende 3 tipos de liberdade: 1) ser capaz de escolher, 2) estar desimpedido de compromissos anteriores ou autoridade justificada e 3) estar livre de coação. A decisão é uma escolha competente porque nasce de um agente responsável. Os juízos são feitos em liberdade, o agente aceita conscientemente a responsabilidade, mesmo que a predileção de alguns indivíduos possam ser problemáticas, estranhas e trágicas para outros não significa que se pode usar da força contra eles.

A capacidade de os pacientes escolherem com efetiva liberdade dependerá de quanto sabem sobre os prováveis benefícios e riscos do tratamento ou benesse que estão considerando, e suas alternativas. Evidências científicas demonstram que revelações que prejudicam gravemente o paciente na verdade podem ser consideradas como má prática médica. ${ }^{6}$

Há indivíduos que colaboram e participam totalmente do seu tratamento e até o controlam, já outros depositam sua confiança em um profissional que confiam e consideram como responsabilidade do profissional suportar os temores, anseios e hesitações que fazem parte da tomada de decisão em circunstâncias de incerteza.

O princípio do consentimento dá às pessoas o direito de agirem de maneira beneficente para chegarem a um comum acordo nas relações que envolvem a assistência à saúde, reconhecendo as particularidades morais de cada indivíduo, e que estes são livres e diferem quanto a dimensão de suas necessidades, inexistindo a comparação ou avaliação essencial entre necessidades e desejos em assistência à saúde. Com isso, as comunidades pluralistas podem desenvolver seus sistemas autônomos de assistência à saúde, de maneira que não precisam envolver-se em serviços de assistência à saúde a elas imorais.

As iniquidades podem ser explicadas pela teoria da "loteria natural" e "loteria social". As loterias natural e social, juntamente com as livres decisões das pessoas, determinam a distribuição de recursos naturais e sociais. 
A loteria natural é a expressão usada para identificar mudanças na sorte resultantes de forças naturais, e não diretamente da ação de pessoas. A loteria social é a sentença empregada para identificar mudanças na sorte decorrente de ações de pessoas, decorre da complexa e imprevisível interação das decisões das pessoas e do imprevisível caráter dos resultados que dependem de forças sociais e não das decisões imediatas.

A loteria natural cria desigualdades e coloca os indivíduos em extremos opostos, os dela privilegiados não precisarão de assistência à saúde durante a maior parte da vida, enquanto os que dela são desfavorecidos, carecem de assistência à saúde para ao menos minorar seus sofrimentos. Contudo, ninguém pode ser responsável pelos trágicos acontecimentos da natureza, assim, ninguém pode ser responsabilizado, ninguém pode ficar encarregado da responsabilidade de tornar sadios aqueles que perdem na loteria natural, com base na responsabilização pelos danos.

A restituição por um dano é obrigação daquele que causou o dano e não da sociedade ou dos outros inocentes. Com isso, assume que a compra de assistência à saúde compensa a perda de quem perde na loteria natural e ganha na loteria social, assim, uma pessoa que nasceu com uma doença grave, mas que tem recursos, pode minorar seu sofrimento por poder investir em melhorias à sua saúde.

As incapacidades, doenças e ferimentos devidos à ações não-consentidas de outros são injustas, enquanto que as mazelas decorrentes da natureza são infelicidade e, o fato de algumas pessoas terem a felicidade de dispor de mais recursos não é mais nem menos arbitrário ou injusto do que o fato de alguns dispuserem de melhor saúde, melhor aparência ou maiores talentos.

\section{ACESSO E DISTRIBUIÇÃO DE RECURSOS NA ASSISTÊNCIA À SAÚDE}

O acesso e a distribuição de recursos na assistência à saúde não é, na visão de Engelhardt, um direito humano fundamental, revelando um ponto de vista extremamente liberal, onde todo e qualquer incentivo será permitido em moralidade secular (desde oferta de prêmios, dinheiro, satisfação sexual e outros prazeres da carne) contanto que a oferta ou a manobra não torne impossível a escolha racional e livre. Para ele, os direitos à saúde carecem de ser criados.

O Estado é a estrutura que abriga as mais diversas moralidades, assim, reconhecer que as pessoas não comungam de uma mesma moralidade limita a autoridade coercitiva do Estado em detrimento do respeito à autonomia, liberdade e propriedade individual. ${ }^{2}$

O autor impele que um conceito de sistema de saúde universal promovido gratuitamente pelo Estado é moralmente injustificado, como ele mesmo afirma "um ato de imoralidade secular, posto que seria 
um ato coercitivo de zelo ideológico totalitarista, que menospreza as diversidades morais que combinam os interesses de assistência à saúde, os limites morais seculares da autoridade do Estado e a autoridade dos indivíduos sobre si" (Engelhardt, p. 447).

Engelhardt salvaguarda os princípios de justiça social como sendo aqueles da justa aquisição, justa transferência e retribuição por injustiças passadas, indo de encontro aos pressupostos da Teoria da Justiça de John Rawls, onde defende que ao Estado cabe a responsabilidade pela assistência à saúde como forma de justiça distributiva ( Rawls, p. 304).

Se alguém tem propriedade da justa aquisição ou justa transferência, então sua posse sobre aquela propriedade não poderá ser prejudicada pelas tragédias e necessidades dos outros. A transferência de bens particulares a outros não depende de o outro ser necessitado ou se o indivíduo detentor da posse vai sofrer ou não com a transferência dos recursos, mas de consentir a transferência, exceto se o bem for de propriedade comum de grupos.

Os princípios da moralidade secular têm na liberdade não apenas um valor entre tantos, mas a fonte de autoridade moral expressa na decisão ou permissão. Desse modo, as alocações dos recursos de assistência à saúde, devem ocorrer segundo a restrição de respeitar as livres decisões das pessoas, inclusive o exercício a seus direitos de propriedade, podendo, inclusive, comprar a assistência à saúde, bem como fornecer assistência à saúde a outros que desejam, ou vendê-la.

Os interesses pela justiça como beneficência são motivados em parte pelas desigualdades, em partes pelas necessidades. Uma sociedade precisa ter legitimamente adquirido recursos para poder estabelecer um sistema de saúde comunal e não taxar os recursos privados em detrimento de preservar e salvar a vida de indigentes.

O maior inconveniente na alocação de recursos é que não existe um conceito canônico de necessidades, sendo impossível, em termos morais seculares, determinar se investir em educação é mais vantajoso que investir em saúde ou na construção de uma área de lazer para determinadas comunidades. É imperioso definir o que de fato é considerado necessidade e o que representa meros desejos.

Um sistema de assistência à saúde que reconhece as limitações morais e financeiras do fornecimento de assistência à saúde teria que, primeiramente, aceitar a desigualdade no acesso à assistência à saúde como moralmente inevitável, tendo por limitação os recursos privados e a liberdade humana, segundamente, aceitar o estabelecimento de um preço para salvar a vida humana, a fim de garantir 
um sistema economicamente eficiente. Fora essa ideologia, que o autor considera óbvia, a ideia de um sistema de assistência à saúde universal, justo e beneficente é uma ilusão coletiva.

É inviável, em termos seculares, proporcionar a melhor assistência à saúde para todos e conter gastos, não se pode garantir assistência à saúde para todas e respeitar a liberdade de os indivíduos perseguirem pacificamente com outros a suas próprias visões de assistência à saúde (ex: vender órgãos, praticar o aborto, eutanásia). Não é possível oferecer uma assistência à saúde igual, que seja ao mesmo tempo a melhor possível, por causa da finitude dos recursos.

Os sistemas públicos de saúde são tentativas comunais de dar garantias contra as perdas nas loterias naturais e sociais, por meio da beneficência humana planejada, com vistas a minimizar as tragédias naturais, bem como as decisões maldosas e egoístas das pessoas que não reagem com solidariedade diante dos necessitados.

Uma fronteira deve ser estabelecida entre as perdas que serão sanadas com o uso de fundos públicos e as que não o serão. É impossível, em termos morais seculares gerais, traduzir todas as necessidades individuais em direitos e em reivindicação sobre os recursos dos outros. $O$ fato de alguns indivíduos não disporem de fundos para pagar pela assistência à saúde e terem necessidades extremas não cria, por si mesmo, uma obrigação da sociedade no sentido de fazer qualquer reparação. Deste modo, estar disposto a ajudar os necessitados não é equivalente a comprometer-se a usar da força do estado para obrigar os não-crentes a serem caridosos.

O autor defende, à luz dos princípios da permissão, da beneficência e dos direitos à propriedade, um sistema de assistência à saúde de várias camadas, que refletem a coexistência de propriedades privadas e comunais, reconhecendo que nem toda propriedade é privada tampouco pública. Com isso, as nações e outras organizações sociais poderiam investir seus recursos comuns na proteção de seus membros contra as perdas nas loterias naturais e sociais ao tempo que permitiriam a livre negociação da assistência à saúde em busca de serviços adicionais ou melhores.

Poderíamos imaginar vários grupos criando suas próprias medidas de assistência à saúde, integradas a um pacote político básico. Poderiam ser dados descontos para a assinatura de acordos limitando o tratamento ou impedindo a eutanásia. Como vantagem moral, estaria o fato de que o indivíduo não precisaria envolver-se no fornecimento de assistência à saúde que considere imoral. 
Os pressupostos bioéticos trazidos por Engelhardt, a priori, causam profunda estranheza, e às vezes, até um certo incômodo, mas à medida que nos aventuramos em uma leitura aprofundada de sua obra, percebemos uma coerência entre as ideias, que concordemos com elas ou não, são de extrema importância para a bioética contemporânea. A escrita do autor é bastante estruturada, a leitura é densa, mas de fácil entendimento.

O primeiro aspecto bioético a considerar, na obra de Engelhardt, é que não há pretensão de se propor uma solução universal aos conflitos morais. Ao contrário, reconhece que não há uma única moralidade, mas que há moralidades. Faz, inclusive, uma crítica à ideia de moralidade comum, advogando que o iluminismo falhou em provar a existência de uma essência canônica que pudesse solucionar os conflitos.

Assim, a premissa bioética de Engelhardt, adota uma moralidade secular, livre e que respeita o pluralismo. Seria, na própria definição do autor, uma moralidade sem essência, que visa unir as pessoas de forma pacífica tendo em vista o respeito mútuo através do consentimento livre de coerção ou qualquer forma de violência.

Compreender o âmago da moralidade secular, requer, antes de tudo, entender que para ter essência moral é preciso endossar premissas ou regras morais particulares de evidência moral como ponto de partida, ou seja, já ter feito uma escolha prévia, com respeito ao caráter apropriado da racionalidade moral, assim, produzir um padrão de resultados em vez de outro. Dessarte, a escolha de uma noção de racionalidade moral precisa incluir uma visão particular em relação a correr riscos e sobre a maneira pela qual as igualdades têm importância.

Quando nos encontramos como estranhos morais, precisamos nos entender para decidir com imparcialidade o que vamos fazer juntos, quando esse comum acordo não é possível, precisamos concordar em seguir nossos respectivos caminhos e somente por meio da tolerância chegaremos a um respeito mútuo, no entanto, isso não significa ser conivente com valores contrários, mas, reconhecer na bioética secular uma chance de convivência estável e tranquila. Assim, a bioética secular não deve se relacionar à moralidade, mas, permitir convivência pacífica e tolerante com a pluralidade.

Outro ponto a ser mencionado, para melhor lucidez dos argumentos de Engelhardt, principalmente quando na discussão de temas polêmicos como aborto, suicídio, pesquisa em saúde, acesso à saúde, venda de órgão humanos, entre outros, é admitir a diferença entre o que é ser humano e o que é pessoa. ${ }^{2} \mathrm{Na}$ concepção do autor, o ser humano é tido apenas como produto biológico e não têm valor 
próprio algum, enquanto que a pessoa humana é dotada de vida mental superior. Às pessoas podem recair culpa ou não das ações, ou seja, elas atuam como agentes morais e são dotadas de moralidade e responsabilidade.

Com essa diferenciação, Engelhardt esclarece que, diante de uma moralidade secular, seria legítimo aceitar o aborto, pois um embrião ou mesmo um recém-nascido, não pode ser considerado uma pessoa, porque não possui clareza mental para ser considerado agente moral. Afirma que uma criança é considerada apenas uma potencial pessoa, mas até que esteja mentalmente madura, não faz jus a essa definição, sendo propriedade dos seus progenitores. Essa lógica recai também para as pessoas com deficiência ou incapacidades mentais, bem como para idosos senis.

Afirma que o indivíduo é a fonte de autoridade secular, devendo ser respeitado seu direito à liberdade, autonomia e propriedade. É neste contexto, que o autor nega a eficácia de uma autoridade plena do Estado em decidir sobre a saúde das pessoas, pois uma universalização da saúde feriria diretamente a autonomia e a liberdade dos indivíduos, por não conseguir abarcar todas as necessidades e, nem mesmo definir o que seria necessidade real para os indivíduos, pois fora de uma visão moral particular, não existe meios canônicos para distinguir entre os desejos e as necessidades, tampouco determinar o que seria a vida boa.

As opções filosóficas e políticas do autor são notadamente obsoletas e destoantes das recomendações em saúde arroladas nas teorias de justiça que são defendidas internacionalmente, inclusive, constitucionalizada no Brasil pela Carta Magna de 1988, que garante saúde como direito de todos e dever do Estado e pela bioética de intervenção, defendida por Garrafa e Manchola-Castillo (2017), onde pontuam a discussão sobre a equidade como o indicador justo para guiar o tema de alocação de recursos para os programas públicos.

O bioeticista nega a ideia de que a saúde é um direito humano essencial. Para ele, um sistema de saúde igualitário seria imoral e incoerente, pois deixaria de reconhecer a pluralidade moral e a autoridade individual. Reconhece a limitada autoridade moral secular do Estado para obrigar coercitivamente a caridade com vistas à uma justiça social.

Engelhardt aponta a justiça apenas como um reflexo da autonomia individual, por isso, defende que a saúde deveria ser compreendida como outras áreas tais como educação, habitação e segurança pública, onde os indivíduos têm permissão para procurar serviços privados de melhor qualidade. 
Discordamos do autor quando este sugere que não se pode raciocinar custos investindo em programas de saúde coletiva, pois, temos a exemplo do Brasil, com o Sistema Único de Saúde (SUS), uma perfeita prova de que saúde se constrói com o fortalecimento das bases (saúde primária), pois investir em promoção e prevenção em saúde é comprovadamente mais vantajoso tanto do ponto de vista econômico, quanto técnico e, mais eficiente que investir exclusivamente em saúde secundária e/ou terciária, não que isso não seja necessário.

Consideramos que maioria dos artigos que fazem referência à obra de Engelhardt, discutem especialmente a questão da distribuição dos recursos em saúde, talvez, por ser um tema majoritariamente político-econômico, que gera conflitos que há muito flagelam a maior parte da sociedade, havendo reconhecimento que os recursos são finitos e que a distribuição de renda entre os indivíduos e/ou nações não é equânime do ponto de vista histórico-geográfico-cultural.

Assevera que o campo da assistência à saúde é sustentado pela confiança. Na política secular de assistência à saúde, as decisões só podem obter sua autoridade na permissão dos envolvidos. A moralidade secular é fundamentada nos limites da razão e da autoridade.

Cada pessoa depende de acordos mútuos para participar dos complexos empreendimentos de assistência à saúde, as pessoas deveriam ter liberdade de criar oportunidades para conduzir sua saúde de acordo com sua moralidade, as associações e instituições deveriam ser capazes de criar sua própria política de assistência à saúde, refletindo suas próprias visões morais.

Impele que se nas várias comunidades encontramos visões morais diferentes, aliadas a diferentes interpretações do que deveria ser considerado como mínimo decente de assistência à saúde, ou um padrão de serviços, esta diversidade deveria ser uma motivação para que os grupos particulares ofereçam pacotes particulares de assistência à saúde apropriada.

Assim, propõe um sistema de assistência à saúde que reconheça as desigualdades do acesso à saúde como inevitáveis, por causa da liberdade humana e dos recursos privados, uma vez que todos os indivíduos estão expostos às vicissitudes da natureza, devendo aceitar também o estabelecimento de um preço para salvar a vida humana.

Notamos um estilo ultraliberal nas proposições desse bioeticista, com tendência mercantilista da saúde e desconstrução do papel do Estado em prover assistência à saúde. 


\section{CONSIDERAÇÕES FINAIS}

Diante de um pluralismo moral, Engelhardt defende a adoção de uma moralidade secular, livre de valores, doutrinas ou ideologias particulares, mas que permita tolerância às ideias distintas. Para ele, o conflito surge quando as diferenças são confrontadas, quando há intolerância diante das dessemelhanças e do exercício de liberdade e, não é solucionável quando os estranhos morais se encontram.

Sob uma concepção marcadamente ultraliberal, e majoritariamente contrária aos esforços internacionais que discutem questões em saúde, o autor nega a existência de um dever moral do Estado em assumir qualquer papel no provimento de assistência à saúde, reconhecendo a limitação da autoridade do Estado perante o respeito à autonomia, a liberdade e a propriedade individual, ignorando totalmente as desigualdades que condicionam a saúde dos indivíduos, relacionando-as ao infortúnio da "loteria natural".

Apesar das polêmicas e ideias intrigantes, Engelhardt não pretende conduzir os fatos ao caos, tampouco propõe uma ética que possa ditar a melhor forma de viver, ao contrário, assevera uma bioética secular capaz de unir indivíduos com moralidades diferentes para que estes possam conviver pacificamente por meio da tolerância e da liberdade através do consentimento livre de ameaças. 


\section{REFERÊNCIAS}

1. Engelhardt Jr HT. Fundamentos da bioética. Tradução de José A. Ceschin. São Paulo: Edições Loyola; 2004.

2. Cescon E. O conceito funcional de pessoa na bioética secular. Veritas, v. 58, n. 1, jan./abr. 2013, p. 190-203.

3. Cândido AM, Alcantara R, Garrafa V. Secularismo, pós-modernidade e justiça distributiva na assistência à saúde em H.T. Engelhardt Jr.

4. Madrid R. La bioética de Tristram Engelhardt: entre la contradicción y la postmodernidad. Rev.Bioética. 2014; 22(3): 441-447.

5. Rawls J. Uma teoria da justiça ( Trad. Almiro Pisetta e Lenita Esteves). São Paulo: Martins Fontes, 2000, p. 303-313.

6. Garrafa V, Manchola-Castillo C. Releitura crítica (social e política) do princípio da justiça em bioética. R.Dir. Gar. Fund., Vitória, v. 18, n. 3, p. 11-30, set./dez. 2017 


\section{Capítulo 22}

doi $10.37423 / 210604373$

\section{QUANDO ADOLESCENTES SE MATAM: O COMPORTAMENTO SUICIDA EM ADOLESCENTES NO CONTEXTO DAS IGREJAS EVANGÉLICAS}

Isabel Cristina Correia

Nilton Eliseu Herbes

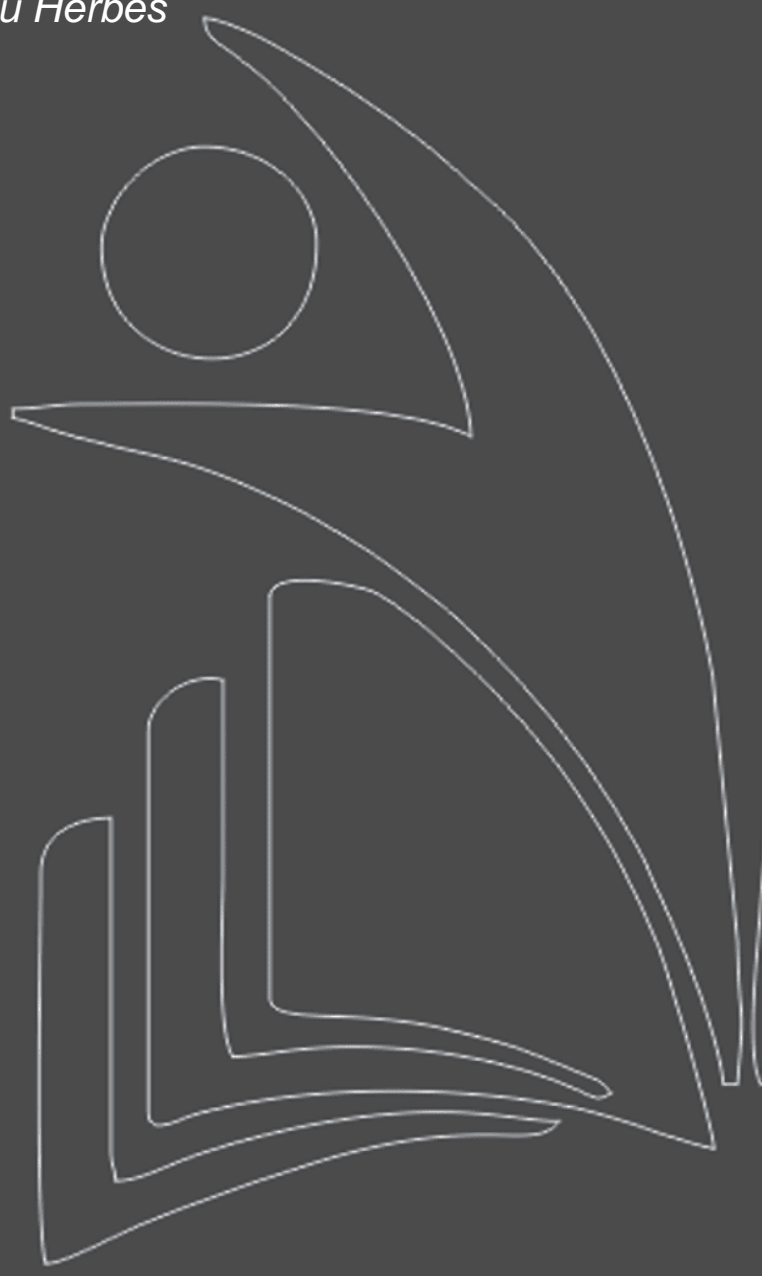

Programa de Pós-Graduação em Teologia da Faculdades EST

Programa de Pós-Graduação em Teologia da Faculdades EST

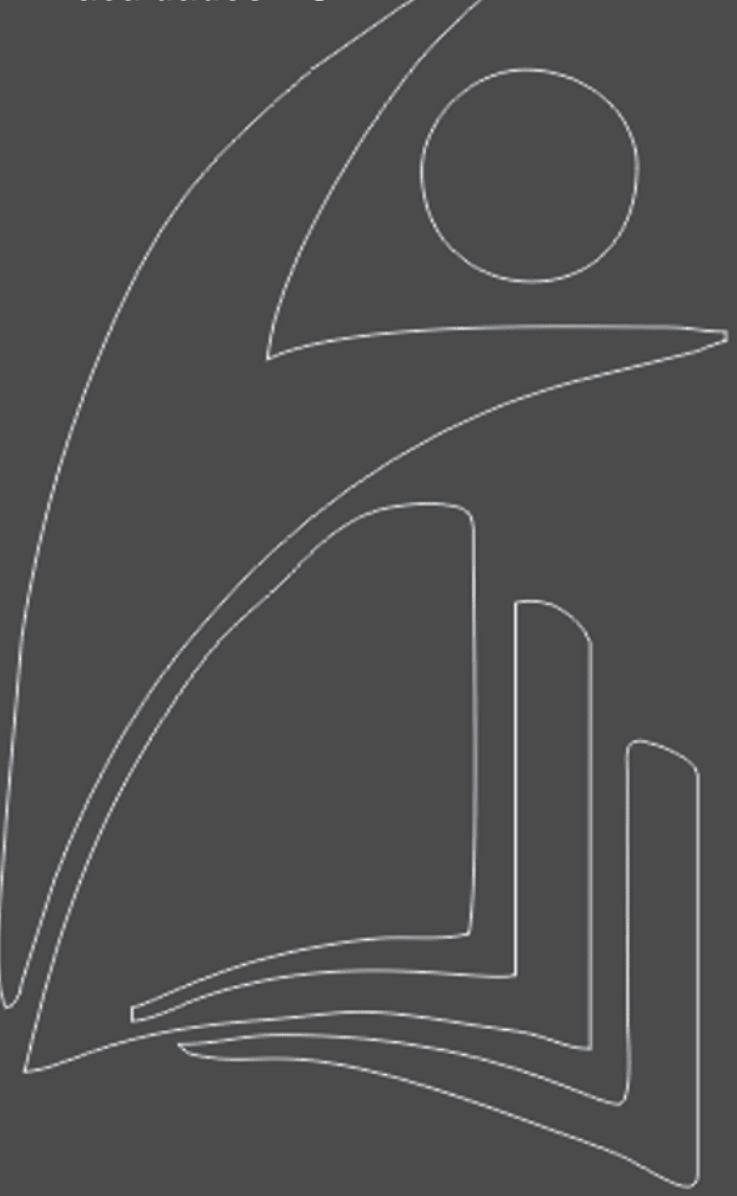


Resumo: Buscou-se com esta investigação a compreensão do comportamento suicida nos adolescentes e jovens, com singular atenção para a ideação suicida em jovens cristãos, principalmente os que estão em igreja de teologia protestante. Essas elucubrações foram embasadas em bibliografias sobre o assunto. A ideação suicida e o próprio ato de autoextermínio, em índices numéricos crescentes no mundo, são uma realidade no Brasil. Brasília reflete essa estimativa alarmante, fato que tem aguçado o interesse e as várias linhas de ações e medida de emergência na área da saúde, da educação e da sociedade em forma geral, até mesmo da espiritualidade, quem tem papel de auxiliar, confortar e amparar os seres humanos em seus sofrimentos, dores e anseios. Vários fatores serão analisados, como as motivações, o contexto histórico e o filosófico da ideação de infringir a morte em si mesmo. O presente estudo objetiva destacar os comportamentos suicidas presentes no âmbito infanto-juvenil nas igrejas cristãs de confissão protestante, e avaliar as possibilidades de atuação das instituições religiosas na prevenção do suicídio, somando esforços com o Estado, no trabalho de prevenir autoquirias e conscientizar a comunidade sobre as necessidades desses jovens.

Palavras-chave: Comportamento suicida. Suicídio. Adolescente. Cristianismo. 


\section{INTRODUÇÃO}

Aflição, angústia, dor, desespero, depressão, morte, suicídio são vocábulos fortes que nem sempre são capazes de expressar o real sofrimento dos parentes, amigos e autores do autocídio. Numa realidade assustadora e crescente de casos nos quais a faixa etária, mais afetada, está entre 10 e 19 anos, segundo publicação feita no Jornal A folha de São Paulo, do dia 24 de abril de 2018, numa reportagem com título de "Suicídio de adolescentes avança, e casos recentes mobilizam escolas em São Paulo"1 ${ }^{1}$. Reportagens como essas são, cada vez mais, comuns quebrando o sigilo que era vergonhosamente imposto nos casos de suicídio, quando o silêncio imperava nos meios de comunicação e nas famílias enlutadas.

Neste efetivo, através da pesquisa, procuramos ter uma clara percepção da ideação suicida dos adolescentes principalmente os de formação cristã protestante, e a ideação deles, no que se referem ao suicídio. Nessa direção, a pesquisa se ocupou com as situações em que a depressão pode ser exacerbada por crises próprias da vida do jovem, que por vezes levam os adolescentes aos mais diversos pensamentos, até mesmo de morte.

Podemos dizer que existe ideação suicida nos adolescentes que frequentam as igrejas evangélicas? Quais são as causas que levam os adolescentes a esse comportamento? As igrejas evangélicas têm abordado o tema "suicídio" em seus discursos e sermões aos jovens adolescentes? Como a comunidade científica tem estudado esse comportamento dentro das igrejas? Todas essas questões se condensam no seguinte problema de pesquisa: o que se tem escrito sobre a ideação suicida em adolescentes evangélicos em pesquisas científicas? É uma preocupação levantar dados sobre o comportamento suicida em adolescentes que estão inseridos em uma religião cristã?

Diante dessa situação, partiu-se da suposição que adolescentes com comportamento de risco estão sujeitos às ideações suicidas, mesmo estando dentro do contexto de uma comunidade de fé, posto que as igrejas estão inseridas num contexto social maior - sociedade - na qual a depressão e a ansiedade tem sido cada dia mais presentes. Suspeitou-se que o grande desencadeador da ideação suicida entre os adolescentes tenha sido a desesperança e a busca pelo sentido de viver. As igrejas abordam o tema "suicídio" pensando, a priori, nos adolescentes que não possuem contato com elas pressupondo que esses jovens são mais suscetíveis aos processos depressivos e de desarranjos psicossociais. 
Estudar os fatos da construção mental que podem levar os jovens ao suicídio é um desafio por um lado, mas por outro lado, pode tornar-se uma maneira de diminuir os casos de autocídio, pois compreendendo os processos envolvidos, tornar-se-ia mais fácil criar uma política de prevenção e combate a essa mazela social que afeta a juventude do mundo.

Essas políticas de prevenção, aliadas à espiritualidade cristã protestante/evangélica, podem abrir um campo novo para discussão, amparo e apoio, levando ao jovem, com essas características de ideação suicida, um cuidado espiritual necessário via aconselhamento pastoral.

À vista disso, o aconselhamento pastoral tem grande potencial de contribuir na detecção precoce desses pensamentos, por via de acompanhamento ao jovem em situação de risco, trazendo benefícios de prevenção e tratamento calcado em preceitos cristãos e, desse modo, o resgate do ser humano como ser integral. Sendo assim, essa pesquisa teve como objetivo reunir a literatura científica encontrada sobre o tema em publicações mais recentes. Percebeu-se que um número muito alto de suicídio entre adolescentes tem sido divulgado nas redes sociais e de comunicação aberta.

Um jornal de grande circulação do Distrito Federal destacou em uma matéria que a cada 40 segundos uma pessoa tira a própria vida em alguma parte do planeta. A cada 24 horas, 30 desistem de continuar vivendo no Brasil. A cada mês, dez se matam no Distrito Federal. Os problemas, muitas vezes reticentes nestas pessoas, foram trazidos à tona, foram conhecidos apenas após o evento da morte, embora a Organização Mundial da Saúde estima que nove em cada dez casos pudessem ser prevenidos $^{2}$. Em todo o mundo, o suicídio é uma das principais causas de morte na adolescência.

No Brasil, estatísticas mostraram que os índices de suicídio aumentaram entre 2011 e 2015, sendo a quarta maior causa de morte de jovens entre 15 e 29 anos. Em média, cerca de 30 pessoas tiraram sua vida por dia. Os homens foram os que apresentaram maiores taxas de mortalidade, $79 \%$ do total, enquanto entre as mulheres o percentual é $21 \%$. Viúvos, solteiros e divorciados também foram os que mais morreram por suicídio $(60,4 \%)$. Os dados mostraram que os indígenas são os que mais cometem suicídio (15,2\%), se comparados com brancos $(5,9 \%)$ e negros $(4,7 \%)$. As mulheres tiveram maior índice de tentativas de suicídio, que permaneceram até a idade adulta. Porém os homens, pela agressividade do ato, possuíram maior estatística de suicídio consumado ${ }^{3}$.

Em relação à ideação suicida, estudos apontaram que "a ideação suicida pode ser considerada um fator de risco para o suicídio efetivo, junto com a depressão e a desesperança. ${ }^{4 \prime}$ A cidade distrital de Águas Claras foi considerada, no Distrito Federal, a segunda cidade com maior índice de suicídio nos últimos anos ${ }^{5}$. Isso despertou o interesse em compreender melhor o assunto por meio dos jovens e 
adolescentes e sua percepção desse tema tão denso e lamentável. Surge então uma pergunta: como as igrejas têm se relacionado com esses fatos e o que pode ainda ser feito?

Nesse pressuposto, entendeu-se que é preciso ter conhecimento atualizado e sistematizado da ideação suicida nos infanto-juvenis como forma de prevenção e de maior conhecimento dos processos e características, na detecção de doenças associadas e comportamentos de risco para que esta pesquisa possa contribuir para o aperfeiçoamento da vivência do aconselhamento pastoral.

\section{BREVE INCURSÃO NAS DIFERENTES VISÕES DE SUICÍDIO}

O fenômeno do suicídio no decorrer da história foi entendido de diversas maneiras, adaptando-se às culturas, e às características socioeconômicas de cada povo. A concepção de autoquíria em diferentes fontes é muito variável, e vai desde uma transgressão normal a um ato heroico, ou apaixonado.

O suicídio na Grécia, desde a Era Clássica, vem sendo discutido e várias linhas de pensamento surgiram. Os pensamentos que mais prevaleceram foram ligados à aceitação para os casos de autoextermínio motivada por: patriotismo, remorso, fidelidade, amor, castidade, fuga da senectude da velhice, dentre outros, mas seguia um sério protocolo de que fossem avisadas as autoridades (estado) militares ou religiosas ${ }^{6}$. Quem cometia suicídio sem prévia autorização do Estado, tinha "geralmente o corpo violado e arrastado em vias públicas, não se fazia o funeral, e era enterrada em lugar não apropriado e isolado sem lápide ou epitáfio uma forma de não ser lembrado"7.

Em análise desta realidade da cultura grega, observamos as narrativas que favoreceram nossa visão desses pensamentos a respeito dos suicídios na vida dos deuses, deusas, heroínas, heróis e dos seres humanos comuns, como a de Jocasta mãe de Édipo, sua filha a jovem Antígona, também filha de Édipo, Febra esposa de Teseu, Ajax, filho do Rei Telemos, Narciso filho do Deus do rio Céfiso e da ninfa Liríope, e muitos outros também cometeram o autoextermínio ${ }^{8}$.

Na Roma antiga não foi muito diferente por defluência do estoicismo, movimento filosófico que preza a fidelidade ao conhecimento, desprezando todos os tipos de sentimentos externos, no qual o suicídio ganhou conotação política "como ato de resistência perante o poder político opressor, vide como exemplo a morte de Sêneca perante Nero e a de Catão diante da soberania de César ${ }^{9} . "$

\subsection{A VISÃO JUDAICO-CRISTÃ HISTÓRICA}

Na visão judaica, prevalecente até hoje, o suicídio é visto como um ato pecaminoso contra o criador, que é o autor e dono da vida, a pessoa suicida deve ser enterrada em uma área especial do cemitério 
e o shivá ${ }^{10}$, não deve ser observado pelos familiares, e nem sua a roupa deve ser rasgada ao final do luto. ${ }^{11}$

Em casos extremos, os judeus aceitam e compreendem o autoextermínio, pois partem do pressuposto de que o indivíduo estava impedido de utilizar a capacidade mental plena de sua consciência, isso em caso de adoecimentos psiquiátricos, dores emocionais extremas e até mesmo em doenças terminais, que culminou com a decisão de terminar com a própria vida. Essa ideia, de que o suicídio é pecado, vem sendo mantida desde a formação mosaica da tora, e mesmo a tora não deixou de relatar casos de suicídios, como: Abimelec em Juízes 9,35; o rei Saul e seu escudeiro em 1 Samuel 31, 4-6; Aitofel em 2 Samuel 17,23; Zimri no livro de 1 Reis 16,18 e o mais famoso, já nos evangelhos, é Judas que tem seu suicídio narrado em Mateus 27, $5^{12}$.

No estoicismo, que também teve grande atuação no cristianismo, em sua origem, muitos cristãos se "entregavam à morte voluntariamente, se matavam, visando o alívio dos sofrimentos terrenos e buscando o cessar da dor, para estar junto a Deus. ${ }^{13 \prime \prime}$

Só no ano de 453 o "Concílio de Arles decidiu condenar o suicídio como um crime canônico. Após esse evento a Igreja Católica voltou a discutir o suicídio algumas outras vezes, das quais mencionamos: no Concílio de Orleans em 533 definiu-se a proibição de funeral religioso, e oração proferida pelo sacerdote para os suicidas, no ano 561 no Concílio de Braga, baniu todos os ritos funerários até os dirigidos por leigos, sobre pena de pecar contra o autor da vida além da proibição do enterro em cemitérios comuns. Em 693 no Concílio de Toledo, foi votada a excomunhão de suicida arrependido o do suicida mal sucedido. Na Idade Média, no Sínodo de Nimes, em 1284, foi feito o reforço das restrições nos funerais de suicidas, e dos enterros em cemitério comuns. No século XX, em 1918, o Papa Bento XV restaurou os ritos funerários dos suicidas, com claro sintoma de loucura e demências, ou dos que se declaram arrependidos em suas mensagens de despedida que deveriam ser analisadas pelos bispos das dioceses ${ }^{14}$.

Para os reformadores, tanto Martim Lutero como João Calvino, havia concordância que a ideia de suicídio era a mesma com maior ou menor grau de intensidades quanto aos motivos, mas concordava com o resultado, que o suicida seria indubitavelmente condenado ao inferno, essa era a mesma posição que a Igreja Católica da época possuía ${ }^{15}$.

Calvino afirmou que "um cristão nunca chega a cometer suicídio, porque Deus impediria." Diferente de outros teólogos protestantes, como Jacob Arminius, que em relação ao autoextermínio, afirmava 
que um fiel cristão pode cometer suicídio, mas perderá sua salvação ${ }^{16}$, e do século XVI até a atualidade essas ideias pouco mudaram.

Recentemente, o teólogo presbiteriano Augustus Nicodemus ${ }^{17}$ afirmou em uma conferência, juntamente com também teólogo Franklin Ferreira, que em se tratando da "graça divina e do suicídio" um cristão pode sim cometer suicídio, mas por graça de Deus, não necessariamente perderia a salvação, embora o seu ato seja pecado. A transcrição abaixo mostra bem a ideia dele.

Eu acho que todos nós temos que concordar que o suicídio nunca deveria ser a saída. É um dos pecados proibidos no mandamento 'Não matarás'. Interpretado pela comissão de fé de Westminster, ele diz que esse pecado não só proíbe que a gente tire a vida dos outros, mas que tire a nossa própria. Então, o suicídio é pecado... Todavia ele não é um pecado sem perdão. O único pecado sem perdão, que tem na Bíblia é a blasfêmia contra o Espírito Santo... Então podem acontecer com todos esses fatores, como pressões externas, problemas psicológicos, problemas existenciais que um crente em um momento de fraqueza ele ceda e ele então veja o tirar a sua própria vida como a única forma de escapar da angústia, da depressão e das trevas em que ele está passando naquele momento. E ele vai cometer esse ato... É pecaminoso? De fato é, mas, não será isso que irá separá-lo da graça de Deus e do perdão que é dado em Cristo Jesus. Se a nossa salvação vai depender de na hora da nossa morte a gente ter colocado em dia todos os nossos pecados, então pouca gente vai escapar, não é? Então, a pessoa que cometeu o suicídio e atentou contra a própria vida, de fato pecou contra o mandamento 'Não matarás', mas isso não a impedirá de entrar no gozo da vida eterna, porque a salvação é dada pela graça de Deus e nada pode nos separar disso." ${ }^{18}$

Abduz-se basicamente destas afirmações uma mudança na forma de entender a ação humana e a forma de submetê-la a visão de Deus, manifesto em amor na cruz de Cristo.

Desde a época da Reforma até a atualidade, a teologia protestante pouco mudou acerca do assunto da autoquíria. Só muito recentemente constata-se uma mudança gradativa e tímida acerca desse assunto. O que se preservou foi a unânime condenação ao ato e não sua condenação eterna. Não há apoio ao autocídio, pois se sabe, que existem redes de apoio e prevenção ao suicídio, ferramentas de amparos, que podem ser utilizadas bem como as psiquiátricas, as farmacológicas, as psicológicas e as espirituais, com o aconselhamento pastoral que provê amparo e acompanhamento pessoal e bíblico.

Quanto à teologia condenatória, quem não consegue ajuda anterior e conclui com o ato do autoextermínio, nota-se a transição, com a valorização da doutrina da salvação, soteriologia, com estudos profundo e mudança de entendimento, que depreende que o pecado do suicídio é de pleno conhecimento de Deus e por Ele entendido como qualquer outro pecado, isso não fere a Integridade Divina, e sua ação salvífica em Cristo, apenas manifesta maior perdão a "um coração sem fé 
momentânea que é diferente de fé que salva, o ser sem perspectiva de uma ação de Deus se entregando a negação da vida e ao desligamento da dor pela morte autoprovocada." ${ }^{19}$

\subsection{VISÃO FILOSÓFICA E PSICANALÍTICA A RESPEITO DO SUICÍDIO}

A filosofia conceitua suicídio como "atitude de matar-se é um ato que consiste em pôr fim intencionalmente à própria vida"20, o que causa um elevado grau de sofrimento ao autor e postumamente a seus círculos sociais, familiares, de amizade e coleguismo (principalmente em caso de adolescentes e jovens).

O suicídio está entre as três principais causas de morte entre os jovens na atualidade, segundo a Organização Mundial da Saúde (OMS), perdendo só para violência urbana e no trânsito com $56 \%$ e nesta soma estão inclusos os conflitos territoriais no mundo e a morte no contexto do tráfico de drogas. O suicídio desponta neste ranking ${ }^{21}$, Em segundo lugar, com 32,5\% entre 9 e 25 anos de idade, e 11,5\% outros tipos de morte nas quais estão as doenças e a fome. A média de suicídios aumentou $60 \%$ nos últimos 50 anos, a cada 40 segundos acontece um autocídio no mundo, e cerca de $22 \%$ deles acontecem no Brasil ${ }^{22}$.

Como entender isso através da filosofia? O problema central para o filósofo "se a vida não nos pertence, se não escolhemos o momento de nascer, o que nos autorizaria então a deixá-la quando assim deliberássemos? ${ }^{23 "}$ De acordo com o pensamento da lei natural, "Deus nos concedeu a vida e não podemos tirá-la por nós mesmos. ${ }^{24 \prime \prime}$ Mas nos deparamos com o livre-arbítrio e a decisão não natural de cometer o suicídio, pois entende-se que se está contrariando a Lei de Deus no autoextermínio, por ser oposto à natureza. O ser humano existe como ser vivo e se apega à vida, e o comum é lutar para preservá-la não a extinguir. $O$ ato de tirar a própria vida traz consigo inúmeras dimensões: os motivos (causas internas), as influências (causas externas e sugestões) e os revezes, que poderiam ser evitados, entre outros.

A psicanálise entende o ato de tirar a própria vida, em parte, como um evento em que a "pulsão de morte prevalece em relação à pulsão de vida" 25 , existindo no subconsciente humano uma constante luta entre a vida e a morte, luta essa em que a última é sempre a vencedora. Já Freud ${ }^{26}$ afirma que o equilíbrio se faz necessário no âmbito das duas pulsões, e a pulsão de morte (predominantemente vencedora) permaneceria a serviço da vida, unida na constante disputa, gerando anseios, desejos de vida, atuando em um movimento paralelo e constante. 
Ainda na psicanálise, a morte é compreendida como um "parto ao contrário", no qual se deseja o reencontro em simbiose com a mãe, em uma espécie de útero. Ele busca uma figura protetora, visando basicamente o princípio de prazer." Em se falando do suicídio, a psicanálise vê como um "acting-out ${ }^{27}$ ou atuação, como é chamado pela psicanálise, ou seja, a expressão brutal, crua, sem mediação de verbalização, dos conteúdos psíquicos através de atos. ${ }^{28 \prime \prime}$

Assim sendo, o suicida entra num ciclo de "incompletude, e fracassa nessa busca do desejo e do

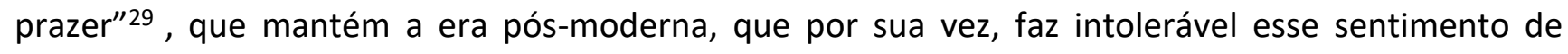
fracasso, de dor e perdas, e assim conduz o sujeito para dentro de si mesmo, e, em si mesmo, remói a dor e a perda até exaurir a pulsão de vida, isso também é chamado de "crise de despersonificação", na qual o indivíduo se perde em reconhecer-se e acaba introjetando agressor (ego), que o vence e deixa como uma última ação o ato de auto morte $\mathrm{e}^{30}$.

A partir dessas perspectivas nos deparamos com a realidade da mortandade autoprovocada em jovens e adolescentes, veracidade assustadora no nosso país, fato este que também vem afetando a igreja cristã, nossas comunidades de fé, na qual o amparo muitas vezes tem falhado, na prevenção dos suicídios.

\section{SUICÍDIO NA JUVENTUDE: UMA REALIDADE QUE PREOCUPA}

Os comportamentos suicidas podem ser classificados como: ideação suicida, tentativa de suicídio e suicídio consumado. O risco de comportamento suicida aumenta durante a adolescência e no início da idade adulta. A ideação suicida refere-se a pensamentos acerca de autodestruição, que incluem a ideia de que a vida não vale a pena ser vivida, bem como planos específicos para Ihe pôr um fim. É tida como um indicador fundamental para o risco de suicídio sendo um componente básico na classificação de comportamentos suicidas ${ }^{31}$.

A presença de ideação suicida é habitualmente um sinal de sofrimento emocional grave e aparece como um dos principais sintomas na tentativa de suicídio e suicídio consumado. A maioria das tentativas de suicídio, planejadas ou não, ocorrem no primeiro ano após o início da ideação suicida ${ }^{32}$. Vários estudos apontam para a presença de ideação suicida nos adolescentes, variando as estimativas de prevalência em função dos estudos e das populações, provavelmente pelas diferentes definições de ideação suicida e pelas diferenças nas populações estudadas.

A literatura aponta ainda para diferenças de gênero associadas à prevalência da ideação suicida. As adolescentes do sexo feminino revelam duas a três vezes mais probabilidade de desenvolverem uma 
perturbação do humor e da ansiedade do que os rapazes, padrão este que se mantém na idade adulta $^{33}$.

Também a autoquíria é um fenômeno multifacetado, uma vez que sua estrutura acaba sendo uma grande e intrincada rede de fatos, dissabores, motivos e causas. Trata-se de um fenômeno que ultrapassa os limites de um único campo do conhecimento, implicando desde fatores sociais (credos religiosos, família, política, grupos sociais, disposições organo-psíquicas, características do ambiente físico), culminando em processos cognitivos de imitação, sendo o último fator de grande preocupação na faixa etária adolescente, pela sua importante prevalência como fator associado ${ }^{34}$.

Isso vem gerando grande preocupação mundial, a Organização Mundial de Saúde (OMS), informou que de 2002 a 2014, a taxa de suicídio da população entre 15 e 29 anos aumentou quase 10\% no Brasil, o que é considerado alta. O número equivale a 5,6 casos a cada 100 mil habitantes. Divulgou também pesquisa feita pelo Ministério da Saúde em 2017, que mostra que o suicídio cresceu e já é a quarta maior causa de morte entre jovens de 15 a 29 ano $^{35}$.

Diante dessa realidade, a igreja necessita assumir um papel ativo junto, com a escola, a sociedade e a família, na prevenção, cuidado e apoio a jovens em situação de risco, lutando contra os instigadores hoje presentes nas mídias sociais e outros canais de comunicação.

\subsection{FATORES DESENCADEANTES}

As crianças e adolescentes, cada dia mais tem facilidade de acesso, por vezes ilimitado à internet, por meios dos computadores e smartphones, por exemplo, estando susceptíveis a todo tipo de informação. Nota-se que muitas dessas tecnologias vêm sendo usada para induzir jovens ao autoextermínio, e podem ser desencadeantes e fomentadores de suicídio jovem.

Já tivemos fenômenos de grande repercussão em meio virtual, como o aliciador virtual "Baleia Azul". Esse jogo virtual consiste em uma série de 50 desafios diários, enviados à vítima por um 'curador'. "Há desde tarefas simples como desenhar uma baleia azul numa folha até outras muito mais mórbidas, como cortar os lábios ou furar a palma da mão." ${ }^{36}$ A matéria "Suicídio de adolescentes avança: casos recentes mobilizam as escolas de São Paulo" do dia 25 de abril de 2018, do jornal Folha de São Paulo, mostrou essas novas abordagens, no que se refere ao mal social que se tornou o suicídio na atualidade ${ }^{37}$. 
Faz-se necessário o uso dos dados para melhor avaliarmos o grau de complexidade do suicídio em meio a jovens e adolescentes, e assim delimitarmos a ação para se traçar uma linha de prevenção e apoio aos familiares.

O Ministério da Saúde, em 2006, apresentou a Estratégia Nacional para Prevenção do Suicídio, visando a diminuição do autoextermínio e das tentativas causados, com impactos irreversíveis a muitas famílias. Também em 2006 foi lançado o Manual de Prevenção do Suicídio para Profissionais das Equipes de Saúde Mental, este último com o objetivo de detectar em tempo hábil, os sinais do suicídio para tratá-lo e evitá-lo, diminuindo este fenômeno social assustador por meio da prevenção 38 .

Os meios de comunicação escritos, físicos ou virtuais, no rádio, e na televisão, por questões éticas não divulgavam os suicídios, para respeitar o luto das famílias e para não ser um incentivo indireto a esta prática. Diante de um crescimento numérico de casos, principalmente em meio aos jovens e adolescentes, a prática jornalística começou a mudar e a entender a importância de divulgar os fatores desencadeantes do suicídio, como forma de chamar a atenção da população para o fato.

\subsection{FATORES DESENCADEANTES: BULLYING}

Na atualidade, os casos de bullying ${ }^{39}$ vêm gerando uma ascensão vertiginosa no número de suicídios entre as vítimas deste tipo de assédio segundo a $\mathrm{OMS}^{40}$.

O bullying é definido pelo uso de força ou coerção para afetar negativamente aos demais, envolvendo um desequilíbrio do poder social, físico e/ou emocional, e atos danosos voluntários e repetitivos. Pode ser persistentemente dirigido a um alvo baseado na raça, cor, peso, origem, grupo étnico, religião, crença, deficiência, orientação sexual, gênero, aparência física, sexo, ou outras características que distingam o eleito no grupo.

Assume várias formas: verbal, física, relacional/social e eletrônica, sendo o último mais conhecido como cyberbullying ${ }^{41}$.

A maioria das vítimas desse fenômeno encontra-se em estado de pressão psicológica. É a partir dessa pressão sofrida que o adolescente se vê sem saída e a única maneira de poder aliviar este sofrimento seria tirando sua própria vida ou matando o causador de tudo isso. Para ser considerado bullying, a vítima tem que ter sofrido entre dois ou mais episódios consecutivos. A sequência desses episódios pode levar o indivíduo que sofre desse fenômeno a se estressar e não suportar mais tal pressão sofrida. 
O tema está sendo muito discutido em nosso país e no mundo todo, não só nas escolas, mas em vários outros lugares como nas academias, nas universidades, nas redes sociais. Suas consequências são grandes e temos que estar atentos e ter conhecimento profundo do que seja o bullying e todos os fenômenos que o rodeiam. Pode-se relacionar ao suicídio, a baixa autoestima que afeta muito os adolescentes e, com isso, os deixa mais suscetíveis ao fato ${ }^{42}$.

O alto número de casos comprovados de suicídios motivados por bullying, requer uma política séria de combate dentro das escolas, com ações mais efetiva e de prevenção ao suicídio ${ }^{43}$. É preciso saber reconhecer os sinais emitidos pelos adolescentes e jovens, o estresse constante psicossocial, a depressão, a perda de autoestima, e identificar os possivelmente afetados dessas mazelas sociais modernas. Ele acontece na maioria das vezes de forma silenciosa e cabe a nós termos informações sobre o mesmo, estarmos preparados e prevenidos, pois ocorre constantemente e está em quase todos os lugares com diferentes formas de manifestações.

\section{A IGREJA COMO FATOR DE PREVENÇÃO AO SUICÍDIO}

Muitas comunidades cultivam um discurso triunfalista que busca afastar vestígio de sofrimento e fragilidade, discurso que não condiz com o que realmente vivemos em nossa jornada de discipulado, intimidade com Deus e transformação contínua, tantas vezes permeada pela dor em nossa realidade cotidiana.

Outros tantos atribuem cruelmente as fragilidades à falta de fé, tornando mais grave o quadro emocional. O estigma, a vergonha, a impotência, a dificuldade em se compreender os fenômenos em saúde mental ${ }^{44}$, as distorções teológicas que não abrem espaço para o diálogo dificultam o estudo do fenômeno suicídio em ambiente religioso. Como seres humanos, pessoas cristãs não estão imunes aos sofrimentos psíquicos e angústias da alma e suas mazelas mesmo que sejam praticantes de sua fé, e tenham uma espiritualidade ativa.

Nessa busca de apoio aos jovens em risco de suicídio, a OMS, lançou em 2006, uma apostila intitulada. "Prevenção do Suicídio Um Recurso Para Conselheiros" que reafirma que a sociedade deve tentar socorrer esses adolescentes e jovens, e a igreja cristã deve reassumir sua posição de cuidado, valorização e reconstrução, psicológica e espiritual.

Depois da hospitalização, a criança ou adolescente necessita de cuidados de seguimento por profissionais de saúde adequadamente treinados, incluindo conselheiros. $O$ aconselhamento durante este período deve focar-se em reduzir fantasias mórbidas acerca da morte, rejeição, alienação, perda e castigo, assim 


$$
\begin{aligned}
& \text { como em estabilizar a situação e considerar uma avaliação } \\
& \text { psicofarmacológica. }{ }^{45}
\end{aligned}
$$

Existe dificuldade em abordar questões emocionais, da subjetividade, que por tantas vezes nos parecem inacessíveis e inomináveis. Os sofrimentos de ordem psíquica mostram-se multifatoriais, sejam desequilíbrios químicos, aspectos biológicos, socioculturais e até mesmo "religiosos" 46.

A comunidade cristã sofre de maneira geral com a dificuldade de integração entre temas da saúde mental e espiritualidade cristã, tão necessária e urgente atualmente. É necessário incentivar o diálogo para auxiliar na prevenção desta questão do suicídio, por exemplo, bem como de tantas outras que assolam a saúde emocional.

Ainda que não se possa afirmar exaustivamente que a participação religiosa possa ser um fator que impeça o suicídio, não se pode negar que o envolvimento com a religião (frequência a atividades religiosas, prática de oração, meditação) seja um fator que inibe o comportamento suicida. Percebese que a prevenção do suicídio pode ser feita mediante reforço de fatores protetores, que por sua vez irão enfraquecer os fatores apontados como sendo de risco tanto no nível pessoal como social. Um estudo realizado no centro de saúde mental para crianças e adolescente no Camboja, em 2016, mostra a importância da formação de programas de prevenção de suicídio para jovens em situação de risco, considerando o quadro de suicídio existente no país ${ }^{47}$. Entre os fatores que geram proteção podem ser mencionados os bons vínculos afetivos, sensação de estar integrada a um grupo ou comunidade, religiosidade, estar casado ou casada ou em uma relação fixa e ter filhos e filhas menores.

É fato notório que a religião de um modo geral oportuniza uma forte rede social de apoio, visto que: estabelece crenças na vida após a morte, apresenta um Deus amoroso, fornece modelos de enfrentamento de crises, possui, em muitos casos, uma resposta e significado às dificuldades da vida, possui uma hierarquia social e desaprova sistematicamente a prática do suicídio por considerar a vida como dom recebido ${ }^{48}$.

Toda religião possui uma ordem de vida estabelecida com a qual organiza a vida de seus fiéis proporcionando-Ihes momentos de oração e auxiliando pessoas com problemas mais sérios. Tais iniciativas reduzem a solidão, a sensação de isolamento, torna a pessoa útil, importante, contribuindo para que o indivíduo não fique obsessivamente ruminando seus problemas.

Também é muito comum observar que o envolvimento religioso parece capacitar indivíduos com doenças graves a lidar melhor com esta experiência e a vivenciar um crescimento psicológico a partir destas experiências de saúde precária. O estudo de 2012, na Universidade de Colorado (EUA) mostra 
que o comportamento suicida diminui com a inserção das atividades religiosas no adolescente. ${ }^{49} \mathrm{E}$ com isso sugere que a prevenção, identificação e avaliação longitudinal precisam ter um cuidado especial para reduzir o agravo da ideação suicida.

\section{CONSIDERAÇÕES FINAIS}

A literatura aponta que a ideação suicida e o suicídio em si continuam sendo um grande problema de saúde pública em todos os países, sendo que os jovens do sexo masculino e de baixo nível socioeconômicos são os mais expostos à mortalidade por autoextermínio. É de consenso na literatura a conclusão de que a religião foi colocada como um importante fator de proteção contra a ideação suicida nos adolescentes, como apoio e tendo a função de auxílio no sofrimento, seja de cunho fisiológico ou emocional. Sendo assim, compreendemos a importância deste tema, uma vez que a ideação suicida em adolescentes pode ser detectável e é passível de prevenção ${ }^{50}$.

Observou-se com a pesquisa, que o levantamento bibliográfico obtido não respondeu à questão principal, sobre publicações que esclarecessem a compreensão sobre ideação suicida nos adolescentes que estão inseridos nas igrejas evangélicas, o que pode sugerir desde um silenciamento sobre o tema, como, quem sabe, um pressuposto de que isso não ocorreria nessa população jovem de igrejas protestantes ou evangélicas. A literatura trouxe, por outro lado, que elementos disponíveis no contexto das igrejas, tais como rede de apoio, escuta qualificada das necessidades dos jovens, orientações e acompanhamentos diversos por meio do aconselhamento pastoral funcionam como boas práticas em prevenção. Em suma, o contexto das comunidades das igrejas tem as condições de prover ações de acolhimento, de socialização, de escuta, de cuidado humano, encarando a questão, e não silenciando, e não negando, não considerando que seja um fenômeno que existe apenas "lá fora", e que as igrejas estão sim - e quanto antes assumirem isso, melhor - inseridas no contexto social, atual, sujeitas a influências de todas as ordens, com a diferença crucial de poder ser um espaço diferenciado de vida, de positividade, de ação efetiva, de espiritualidade no meio a essa triste realidade.

Assim, não podemos afirmar em que grau as igrejas estão isentas dos atos suicidas, mesmo sendo consideradas um importante fator protetor a tais comportamentos. Os adolescentes protestantesevangélicos estão inseridos na sociedade geral, sujeitos aos mesmos fatores desencadeantes, e, portanto, expostos aos mesmos riscos como qualquer outro jovem. Por isso sugerimos que novos estudos venham complementar, e até especificar o conhecimento sobre o evento, principalmente em 
Brasília, cidade em que as estatísticas ganham destaque, devido às altas taxas de mortalidade por causas de comportamento suicida. Assim, esperamos que as pesquisas venham colaborar com gestores a desenvolverem estratégias e ações prioritárias, a fim de contemplar a prevenção dessas causas. 


\section{REFERÊNCIAS}

ALVAREZ, Alfred. O Deus Selvagem: um estudo do suicídio. São Paulo: Companhia das Letras, 1999.

ALVES, Ernani Simas. Medicina legal e Deontologia. Ed. Santa Cruz. Curitiba, 1967.

ANTUNES, Jessica. (12 de março de 2016). A cada mês, dez pessoas tiram a própria vida no Distrito Federal. Jornal de BRASÍLIA.

ARIÈS, Phelippe. História da morte no ocidente: da idade média aos nossos dias. Rio de Janeiro, RJ: Ediouro. 2003.

BÍBLIA Online. Bíblia Online. Disponível em: <https://www.bibliaonline.com.br/acf>. Acesso em: 01 de Dezembro 2017.

BORGES, Vivian Roxo; WERLANG, Blanca Susana Guevara; COPATTI, Mônica. Ideação suicida em adolescentes de 13 a 17 anos. Barbarói, n. 28, p. 109, 2008.

BOTEGA, Neury José. Suicídio e Tentativa de Suicídio. In: Lafer, B. et al. Depressão no Ciclo da Vida. Porto Alegre: Artes Médicas, 2000.

BRASIL. Ministério da Saúde (2006). Prevenção do suicídio: manual dirigido a profissionais das equipes de saúde mental. Organização Pan-Americana da saúde. Universidade Estadual de Campinas. Recuperado: 11 nov. 2012. Disponível: http:// portal.saude.gov.br/portal/arquivos/pdf/manual prevencao suicidio saúde mental.pdf.

BROMBERG, Maria Helena P.F; KOVÁCS, Maria Julia; CARVALHO, Maria Margarida M.J; CARVALHO, Vicente Augusto de. Vida e Morte: Laços da Existência. Ed. Casa do Psicólogo; São Paulo, 1996.

CAEIRO, Vânia Sofia Rosa. (2011). Morte Voluntária - Sui Caedes. Tese de Mestrado em Medicina Legal. Instituto de Ciências Biomédicas Abel Salazar ICBAS. Universidade do Porto. Porto. PT. 2011.

CALDAS. Ana Lucia. É Preciso Falar sobre Bullying, Depressão e Suicídio: Alerta aos Especialistas. Agência Brasil. Repórter Jornalismo, 29 de abril de 2017. Brasília. DF: acesso: http://agenciabrasil.ebc.com.br/geral/noticia/2017-04/e-preciso-falar-sobre-bullying-depressao-esuicidio-alertam-especialistas.

CARVALHO, Ilona Szabó. (25 de abril de 2018). Suicídio de adolescentes avança: e casos recentes mobiliza as escolas de São Paulo. Folha de São Paulo, p. Cotidiano B5.

CASSORLA, Roosevelt. M.S. Do suicídio: estudos brasileiros. Campinas: Papirus, 1991.

CASSORLA, Roosevelt.M.S. O que é suicídio. São Paulo: Abril Cultural - Brasiliense, 1985.

CRABB, Larry. Atravessando Problemas Encontrando Deus. São Paulo - SP: Sepal, 1977.

DA COSTA ARAÚJO, Luciene; VIEIRA, Kay Francis Leal; DE LIMA COUTINHO, Maria da Penha. Ideação suicida na adolescência: um enfoque psicossociológico no contexto do ensino médio. Psico-USF, v. 15, n. 1, p. 47-57, 2010. 
DE ALMEIDA, Alexander Moreira; NETO, Francisco Lotufo. Religião e Comportamento Suicida. In: Meleiro, A.M.A.S.; Teng, C.T; Wang, Y.P. (Eds.) Suicídio: Estudos Fundamentais. São Paulo, Segmento Farma, 2004. pp.: 53-60.

DIAS, Maria Luiza. O suicida e as mensagens de adeus. In: Cassorla, R.M.S. Do suicídio: estudos brasileiros. Campinas: Papirus, 1991.

DIAS, Paulo, GONÇALVES, Marianne. (1999). Avaliação da ansiedade e da depressão em crianças e adolescentes (STAI-C2, CMAS-R, FSSC-R e CDI): estudo normativo para a população portuguesa. Avaliação Psicológica: formas e contextos, 4, p. 553-564.

DURKHEIM, Emile. O suicídio. Rio de Janeiro: Zahar, 1982.

FEIJÓ, Marcelo. Suicídio: entre a razão e a loucura. São Paulo: Lemos Editorial, 1998.

As Pulsões e suas vicissitudes (1915) in Obras Completas, Rio de Janeiro: Imago, 1969.

FREUD, Sigmund. A Psicopatologia da Vida Cotidiana (1901) in Obras Completas, Rio de Janeiro: Imago, 1968.

GAARDER, Jostein et al. O livro das religiões. São Paulo: Companhia das Letras, 2005.

HILDEBRANDT, Leila Mariza; ZART, Franciele; LEITE, Marinês Tambara. A tentativa de suicídio na percepção de adolescentes: um estudo descritivo. Revista Eletrônica de Enfermagem, v. 13, n. 2, p. 219-226, 2011.

JORNAL DE BRASÍLIA. A cada mês, dez pessoas tiram a própria vida http://www.jornaldebrasilia.com.br/cidades/a-cada- mes-dez- pessoas-tiram- a-própria-vida-nodistrito-federal/). Distrito Federal. Matéria publicada no dia 05 de setembro de 2016. Disponível em

KUCZYNSKI, Evelyn. Suicídio na infância e adolescência. Psicologia USP, v. 25, n. 3, 2014.

LACHAUD, Denise. Dicionário de Psicanálise: Freud \& Lacan. Salvador: Ágalma, 1994.

LINDBERG, Carter. Uma Breve História do Cristianismo. São Paulo: Loyola, 2008.

MONTAIGNE, Michel. Ensaios. São Paulo: Abril Cultural, 1972 (Os Pensadores, XI).

MORE, Thomas. A Utopia. São Paulo: Abril Cultural, 1972 (Os Pensadores X).

MOREIRA, Lenice Carrilho de Oliveira; BASTOS, Paulo Roberto Haidamus de Oliveira. Prevalência e fatores associados à ideação suicida na adolescência: revisão de literatura. Psicologia Escolar e Educacional, v. 19, n. 3, p. 445-453, 2015.

NICODEMUS, Augustus., \& FERREIRA, Franklin (21 de 07 de 2017). O Suicídio da perspectiva cristã. https://www.youtube.com/watch?v=p8w21qExr9l.

O GLOBO. (20 de abril de 2017). O que se sabe até agora sobre o jogo da "Baleia Azul". O GLOBO. https://oglobo.globo.com/sociedade/o-que-se-sabe-ate-agora-sobre-jogo-da-baleia-azul-21236180. 
OLSON, Roger E. (2001). História da teologia cristã: 2000 anos de tradição e reformas. São Paulo: Editora Vida. 18a edição, 2010.

OMS. Organização Mundial de Saúde (2000). Departamento de Saúde Mental. Transtornos Mentais e Comportamentais. Prevenção do suicídio: Manual para professores e educadores. Recuperado: 27 nov.2012.

Disponível:

http://<http://apps.who.int/iris/bitstream/10665/66801/5/WHO_MNH_MBD_00.3_por.pdf>apps.w ho.int/iris/bitstream/10665/66801/5/WHO_MNH_MBD_00.3_por.pdf<http://apps.who.int/iris/bitst ream/10665/66801/5/WHO_MNH_MBD_00.3_por.pdf>.

OMSBR (07 de 08 de 2016). OMS: suicídio é responsável por uma morte a cada 40 segundos no mundo. OMS: suicídio é responsável por uma morte a cada 40 segundos no mundo.

PUENTE, Fernando Rey (Org.). Os Filósofos e o Suicídio. Belo Horizonte: Editora UFMG, 2008.

RUESCH, Hans. No país das sombras longas. Rio de Janeiro: Editora Record,1974.

SILVA, Viviane Franco da; et al. Fatores associados à ideação suicida na comunidade: um estudo de caso-controle. Cadernos de Saúde Pública, v. 22, n. 9, p. 1835-1843, 2006.

SOUZA, Ana Claudia Gondin; BARBOSA, Guilherme Correa; MORENO, Vânia. Suicídio na adolescência: revisão de literatura. Revista Uningá, [S.I.], v. 43, n. 1, mar. 2015. ISSN 2318-0579. Disponível em: <http://revista.uninga.br/index.php/uninga/article/view/1202>

SPRAT, Laércio. Aspectos culturais do suicídio. Revista da Associação Portuguesa. Psicologia - Morte e Suicídio. Vol. V, no 2. Lisboa: 1987.

STROPPA, André; MOREIRA-ALMEIDA, Alexander. Religiosidade e saúde. Saúde e espiritualidade: uma nova visão da medicina. Belo Horizonte: Inede, p. 427-443, 2008.

VAINSENCHER, Semira Adler. Enterro judeu. Pesquisa Escolar Online, Fundação Joaquim Nabuco, Recife. Disponível em:

http://basilio.fundaj.gov.br/pesquisaescolar/index.php?option=com_content\&view=article\&id=255: enterro-judeu-\&catid=40:letra-e . Acesso em: dia 28 de abril de 2018.

VENEU, Marcos Guedes. Ou Não Ser. Brasília: Editora UnB, 1994. 


\section{Capítulo 23}

doi $10.37423 / 210604374$

\section{A AUTONOMIA, O CONSENTIMENTO E OS INDIVÍDUOS SEM A CAPACIDADE PARA CONSENTIR: UMA REFLEXÃO.}

Isabel Cristina Correia

Débora R. O. Eleutério de Azevedo

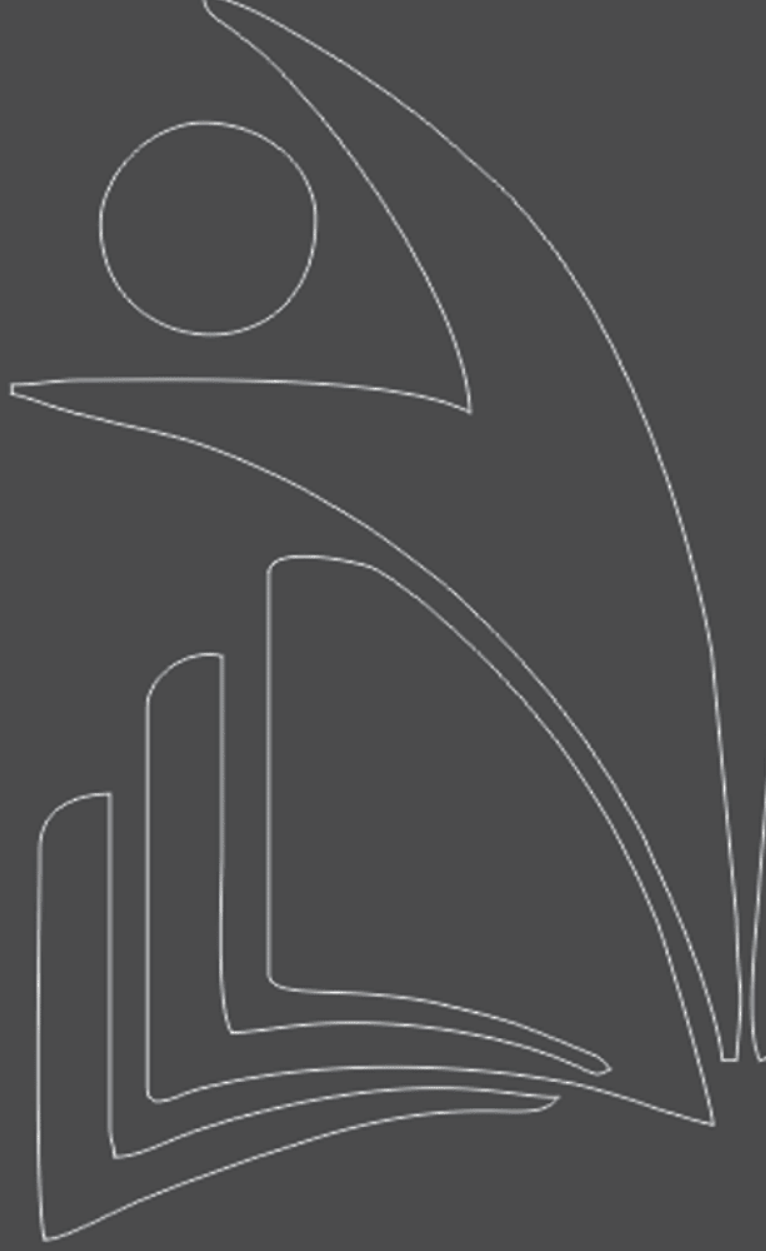

Cátedra da Unesco de Bioética -

Universidade de Brasília

Cátedra da Unesco de Bioética -

Universidade de Brasilia

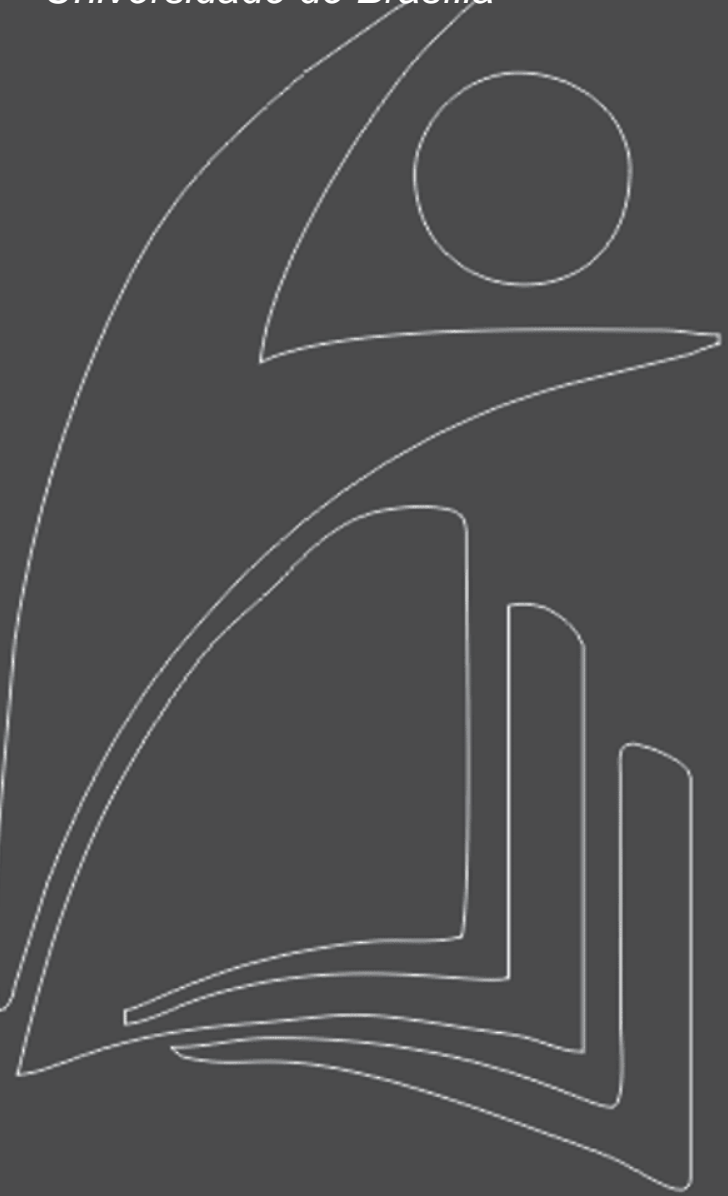


Resumo: A Declaração Universal sobre Bioética e Direitos Humanos (2005) versa sobre a autonomia em três dos seus artigos: autonomia e responsabilidade individual (5ㅇartigo), o consentimento (6으 artigo) e os indivíduos sem a capacidade para consentir (7ํartigo). A compreensão clara do significado de autonomia pode auxiliar na interpretação correta das diferentes situações de tomada de decisão com relação à vida. Para tanto, é necessário que o profissional de saúde esclareça adequadamente o paciente a respeito da situação, para que assim se configure, de fato, como um agente ativo neste processo. Entra em cena, então, a questão do consentimento do paciente. Porém, alguns grupos têm a sua autonomia reduzida ou são considerados incapazes de consentir e, nesses casos, a responsabilidade é transferida para um tutor ou responsável legal, que deve fazer a escolha, tendo por objetivo o melhor para o indivíduo afetado. Frente à complexidade do assunto, o presente artigo busca trazer uma discussão teórica acerca dos conceitos, da aplicabilidade dos princípios presentes na Declaração e da sua relação prática com os usos do termo de consentimento informado.

Palavras-chaves: Autonomia. Consentimento. Capacidade. Responsabilidade. DUBDH 


\section{INTRODUÇÃO}

A discussão e a criação de mecanismos internacionais de proteção aos Direitos Humanos trouxeram consigo princípios que passaram a nortear a prática biomédica, de forma que os conceitos propostos por Beauchamp e Childress fossem reconhecidos como alicerces na área da Bioética. São eles: o respeito à autonomia, a beneficência, a não-maleficência e a justiça. ${ }^{1}$

Com o desenvolvimento da Bioética, porém, percebeu-se que esses princípios estão moralmente aquém das discussões éticas que extrapolam o campo biomédico. A partir da homologação da Declaração Universal sobre Bioética e Direitos Humanos (DUBDH) pela Organização das Nações Unidas para a Educação, a Ciência e a Cultura (UNESCO), a autonomia teve sua participação modificada no contexto acadêmico internacional, uma vez que um princípio deu origem a três artigos: autonomia e responsabilidade individual (artigo 5ㅇ), consentimento (artigo 6ㅇ) e indivíduos sem capacidade de consentir (artigo 7으). ${ }^{2}$

Nesse sentido, a compreensão clara do significado de autonomia pode auxiliar na interpretação correta das diferentes situações de tomada de decisão com relação à vida. Autonomia tem origem nas expressões gregas autos, que se traduz por "mesmo", e nomos, que é "lei", "regra", "governo", indicando a noção de "autogoverno". No entanto, para que seja respeitado o princípio da autonomia são essenciais duas condições: liberdade e qualidade do indivíduo. Atende-se à primeira quando não há influências controladoras, nem forças coercitivas; à segunda através do amplo entendimento da situação sobre a qual se deve decidir. ${ }^{3}$

Em outras palavras, respeitar a autonomia de alguém é considerar seus valores, opções e posições, garantindo sua liberdade de ação, além de proporcionar todas as informações necessárias para que se elabore juízo próprio. ${ }^{1}$ Dessa forma, a autonomia pode estar reduzida em alguns grupos, como, as pessoas institucionalizadas ou com transtornos mentais. Ou podem ser considerados incapazes de consentir, como: crianças, pessoas inconscientes e animais. Nesses grupos, a responsabilidade é transferida para um tutor ou responsável legal, que deve fazer a escolha tendo como objetivo o melhor para o indivíduo afetado. ${ }^{2}$

A DUBDH estabelece em seu quinto artigo:

"Deve ser respeitada a autonomia dos indivíduos para tomar decisões, quando possam ser responsáveis por essas decisões e respeitem a autonomia dos demais. Devem ser tomadas medidas especiais para proteger direitos $e$ interesses dos indivíduos não capazes de exercer autonomia." (UNESCO, 2005, p. 06) 
A partir desse artigo, a tomada de decisão sobre submeter-se, ou o tutelado, a um procedimento médico passa pelo consentimento. Este, segundo a DUBDH, deve ser prévio, livre e esclarecido, o que implica ao profissional de saúde a transmissão adequada da informação para que o empoderamento do indivíduo seja bastante à melhor decisão para si, ou para seu tutelado. ${ }^{4}$

O presente artigo busca trazer reflexões sobre autonomia e responsabilidade, consentimento e autonomia de pessoas sem capacidade para consentir, com um breve enfoque para a conceituação e análise das questões bioéticas relacionadas.

\title{
AUTONOMIA E RESPONSABILIDADE INDIVIDUAL
}

\section{Artigo 5 - Autonomia e Responsabilidade Individual}

\begin{abstract}
"Deve ser respeitada a autonomia dos indivíduos para tomar decisões, quando possam ser responsáveis por essas decisões e respeitem a autonomia dos demais. Devem ser tomadas medidas especiais para proteger direitos $e$ interesses dos indivíduos não capazes de exercer autonomia." 2
\end{abstract}

A pessoa autônoma é aquela que tem liberdade de pensamento, é livre de coações internas ou externas para escolher entre as alternativas que lhe são apresentadas. ${ }^{3}$

Embora a aplicação mais antiga do termo autonomia remonte à Antiguidade Grega, numa referência à noção de autogoverno (auto = mesmo; nomos = lei, regra, governo) das poleis (cidades-estados), foi a partir do lluminismo Renascentista, principalmente com René Descartes (1596-1650), que essa expressão passou a ter uma relação mais clara com o indivíduo e suas escolhas. ${ }^{5}$

A partir de um questionamento radical sobre toda e qualquer forma de conhecimento, Descartes chega à célebre conclusão "Penso, logo existo" (DESCARTES, 2001, p. 38). O sujeito cartesiano, então, surge como cognoscente, cuja prerrogativa fundamental consiste no uso do intelecto que, enquanto faculdade da alma (res cogitans), se impõe como única via de acesso à verdade. De posse desse atributo superior, o humano torna-se capaz de compreender a constituição de seu corpo (res extensa) e aprender a realidade do mundo. ${ }^{6,8}$ No entanto, para solucionar a possibilidade de única crença solipsista, foi necessário recorrer a Deus ${ }^{5,8}$ e, nesta relação entre res cogita-Deus-res extensa, foi preservado o espaço da liberdade, na medida em que o filósofo reconhece que "a principal perfeição do homem é ter livre-arbítrio"5 (DESCARTES, 1997, p. 40).

No entanto, foi Immanuel Kant quem aprimorou essa relação, ao colocar a autonomia da vontade como princípio supremo da moralidade: 


\begin{abstract}
"A moralidade é, pois, a relação das ações com a autonomia da vontade, isto é, com a legislação universal possivel por meio das suas máximas. A ação que possa concordar com a autonomia da vontade é permitida; a que com ela não concorde é proibida. A vontade, cujas máximas concordem necessariamente com as leis da autonomia, é uma vontade santa, absolutamente boa." (KANT, 2007, p. 84).
\end{abstract}

Em outras palavras, ele afirmou que, respeitada a autonomia de um indivíduo em suas escolhas, a decisão é tomada com boa vontade. Consagra-se a moralidade, então, na medida em que, pelo seu ponto de vista, ela é a única condição para que o humano, ser racional, seja "um fim em si mesmo" (KANT, 2007, p. 77) e possa agir segundo um "dever", uma necessidade de cumprir uma ação por respeito à lei, uma vez que esta é universal, inequívoca ${ }^{5}$. Como diz o pensador: "Age segundo a máxima que possa simultaneamente fazer-se a si mesma lei universal" (KANT, 2007, p.80). É preciso salientar que a concordância em agir por "dever" à lei universal é, em última análise, uma ação constante da boa vontade: "E absolutamente boa a vontade que não pode ser má, portanto quando a sua máxima, ao transformar-se em lei universal, se não pode nunca contradizer" (KANT, 2007, p. 80).

O universalismo categórico da filosofia moral kantiana permaneceu até o final do século XIX, momento no qual as intensas censuras de Schopenhauer, Nietzsche e Freud e, posteriormente, já no século XX, a transformação da moral em ética aplicada, colocam sua formulação original em xeque. ${ }^{5}$ Todavia, a autonomia foi mantida como um norteador da construção do conceito de cidadania, no século passado, ${ }^{5}$ tendo-se em vista que o respeito a esse princípio representa o empoderamento do indivíduo em relação a si e aos outros. ${ }^{4}$

Com o advento da Bioética, inicialmente com um aspecto anglo-saxônico e deontológico, o respeito à autonomia passou a ser um dos quatro princípios que guiavam a prática biomédica: autonomia, beneficência, não-maleficência e justiça. ${ }^{1}$ Contudo, o caráter individualista aplicado aos princípios da Bioética, que até aquele momento estava ancorada nesta visão principialista, fez com que a ideia de respeito à autonomia individual se aproximasse, perigosamente, do egoísmo e elevasse esse princípio à uma categoria superior à dos demais. ${ }^{11}$

Diante da pluralidade cultural do mundo dos séculos $X X$ e $X X I$, os pensadores e pesquisadores da disciplina se viram questionados e foram obrigados a rever a aplicação e a aplicabilidade dos quatro princípios. Esse movimento culminou com a redação e a homologação, em 2005, da Declaração Universal sobre Bioética e Direitos Humanos (DUBDH) pela Organização das Nações Unidas para Educação, Ciência e Cultura (UNESCO). Como resultado, dentre outros, o respeito à autonomia 
individual foi ampliado para três artigos: autonomia e responsabilidade individual ( $5^{\circ}$ artigo), consentimento ( $6^{\circ}$ artigo) e indivíduos sem capacidade de consentir ( $7^{\circ}$ artigo). ${ }^{2}$

A partir do momento em que a DUBDH postula a autonomia, capacidade do humano para escolher o Ihe parece melhor dentro das opções disponíveis, como um elemento a ser respeitado nas tomadas de decisão que interferem em sua vida, vem à tona a questão das relações médico-paciente. Historicamente, há uma dualidade de visões que vem desde a Grécia Antiga e que pode ser percebida através do Juramento de Hipócrates. Embora se trate de uma obra primorosa do saber humano e aponte a conduta tradicional do médico com relação ao paciente, como pessoa que busca o bem-estar do outro, às vezes em detrimento do seu próprio, há uma lacuna nela no que se refere ao livre-arbítrio do paciente. ${ }^{3}$

Como o Juramento espelha a visão da época em que foi concebido, na qual o exercício da Medicina tinha algo de sacerdotal e o conhecimento só devesse ser revelado aos iniciados, os profissionais tinham o dever de não o revelar ao "profano". Por outro lado, no mesmo período surgia uma medicinaciência, que, dentre outras características, buscava esclarecer seus pacientes no que tangia à enfermidade que lhe acometia e a sua origem, apoiando-se no que se pensava sobre a natureza de todos os corpos. No entanto, a conduta costumava variar, segundo Platão, de acordo com o tipo de profissional: o de cidadãos livres ou o de escravos. O primeiro, em geral, era esse que expõe ao paciente detalhes concernentes à doença; o segundo atendia seus pacientes sem prestar explicação alguma. $^{3}$

Como herança das antigas práticas de cura não esclarecidas, ainda se vê a ocorrência do paternalismo, situação na qual o médico toma as decisões, buscando oferecer ao paciente o tratamento que lhe parece mais adequado, considerando seus saberes, ponto de vista e responsabilidade, mas ignorando o que enfermo pensa da abordagem e a sua autonomia. $O$ faz, portanto, sem autorização do paciente ou mediante coerção e desacatando o princípio do respeito à autonomia. ${ }^{4}$

Então, se faz necessário lembrar que, para que seja possível o exercício da autonomia, devem ser atendidas duas condições: liberdade e capacidade do indivíduo. A primeira faz alusão tanto às possibilidades de escolha, quanto às de ação e se cumpre quando há diversidade de opções, porque, se só existe um caminho a ser seguido, não acontece escolha, e na ausência de forças coercitivas, o que possibilita que se proceda de acordo o que foi eleito ${ }^{3}$. A segunda traz a capacidade de deliberar sobre questões pessoais e atuar de forma consciente. Ou seja, o indivíduo se torna capacitado para conduzir suas predileções a partir do momento em que detém conhecimento pleno das possibilidades 
disponíveis e suas repercussões, podendo, assim, elaborar um juízo próprio ${ }^{4}$ e arcar com as consequências da escolha feita. Diante do exposto, pode-se dizer que o consentimento dado subsequentemente ao cumprimento das exigências acima é autônomo e implica a obrigação do profissional/pesquisador de saúde em informar o paciente/sujeito de estudo de maneira adequada e o entendimento por parte do deste. No entanto, alguns grupos não conseguem cumprir os referidos pré-requisitos, seja pela redução de sua autonomia, como acontece em indivíduos institucionalizados e portadores de transtorno mental, seja por serem incapazes de consentir, que seriam pessoas inconscientes, crianças e, extrapolando o conceito para pessoas não-humanas, animais. ${ }^{12}$ Nesses casos, transfere-se a responsabilidade para um tutor ou responsável legal que materializa sua concordância em submeter a si ou a seu tutelado (humano ou não-humano) quando firma o termo de livre consentimento. ${ }^{4}$

\section{RESPONSABILIDADE INDIVIDUAL DO PACIENTE}

No Artigo 5 da DUBDH, o termo responsabilidade não é empregado em seu sentido jurídico, mas sim bioético, ou seja, são obrigações morais do paciente, que podem, em determinadas situações, traduzir-se em seu cunho legal.

O princípio da responsabilidade do paciente assenta que este deve compartilhar informações determinadas com os profissionais de saúde, visando auxiliá-los na condução de seus cuidados. Assim, se apresenta uma lista de informações importantes que são de posse do paciente ou de seus familiares: "a) sua experiência de vida e de adoecimento, b) circunstâncias sociais e econômicas, c) hábitos passados e presentes, d) comportamentos e atitudes de risco, e) valores, preferências, incluindo as culturais e religiosas" (Albuquerque, 2016, p.22).

Ao partilhar essas informações o paciente reparte a responsabilidade pelo tratamento escolhido. A natureza colaborativa de cuidados em saúde demanda que paciente e seus familiares participem de seu cuidado. A eficácia do atendimento e a satisfação do paciente, dependem em parte, no cumprimento de determinadas responsabilidades do paciente.

Porém, Albuquerque questiona até que ponto as pessoas são responsáveis por suas próprias condições de saúde, pois os determinantes sociais da saúde têm sua importância e fogem muitas vezes da governabilidade dos pacientes. ${ }^{13}$ 


\section{CONSENTIMENTO}

\section{Artigo 6-Consentimento}

“a) Qualquer intervenção médica preventiva, diagnóstica e terapêutica só deve ser realizada com o consentimento prévio, livre e esclarecido do indivíduo envolvido, baseado em informação adequada. O consentimento deve, quando apropriado, ser manifesto e pode ser retirado pelo indivíduo envolvido a qualquer momento e por qualquer razão, sem acarretar desvantagem ou preconceito.

b) A pesquisa científica só deve ser realizada com o prévio, livre, expresso e esclarecido consentimento do indivíduo envolvido. A informação deve ser adequada, fornecida de uma forma compreensivel e incluir os procedimentos para a retirada do consentimento. O consentimento pode ser retirado pelo indivíduo envolvido a qualquer hora e por qualquer razão, sem acarretar qualquer desvantagem ou preconceito. Exceções a este princípio somente devem ocorrer quando em conformidade com os padrões éticos $e$ legais adotados pelos Estados, consistentes com as provisões da presente Declaração, particularmente com o Artigo 27 e com os direitos humanos.

c) Em casos específicos de pesquisas desenvolvidas em um grupo de indivíduos ou comunidade, um consentimento adicional dos representantes legais do grupo ou comunidade envolvida pode ser buscado. Em nenhum caso, o consentimento coletivo da comunidade ou o consentimento de um líder da comunidade ou outra autoridade deve substituir o consentimento informado individual." 2

A necessidade de autorização da própria pessoa para que seu corpo pudesse ser tocado, violado ou manipulado está presente na tradição anglo-saxã desde a promulgação, em 15 de julho de 1215, da Carta Magnum Libertatum. Um dos primeiros casos de que se tem conhecimento sobre uma demanda judicial entre médico e paciente data de 1767, na Inglaterra, e se referia ao caso no qual o paciente foi a júri contra os médicos que realizaram procedimento cirúrgico sem lhe consultar, alegando a falta de informação das possíveis consequências daquele tratamento e a corte inglesa condenou os médicos. ${ }^{14}$ Em 1914 o juiz Benjamin Cardozo, no caso Schloendorff vs. Society of New York Hospital, proferiu a sentença sobre o direito de autodeterminação acerca do destino do próprio corpo por parte de um adulto consciente. Considerado o embrião da doutrina do Consentimento Informado, em 1957 o termo "informed consent" foi utilizado numa decisão proferida pelo tribunal da Califórnia. ${ }^{15}$ Como 
exposto acima, a utilização da expressão "consentimento informado" (Cl) foi utilizada ao final do século XX, existindo poucas informações antes dos anos $1960 .^{15}$

Na Segunda Guerra Mundial eclodiu a preocupação da ética em pesquisa com seres humanos, quando crimes e torturas contra a humanidade foram praticados em nome das pesquisas. Esse fato teve importância nas questões relacionadas tanto à ética em pesquisa, como aos direitos humanos, e vislumbrou a normatização para a prática em saúde. No artigo de Kottow ${ }^{15}$ sobre a história da ética em pesquisa foi observado que desde antes da Guerra havia uma circular emitida em 1931, pelo Ministério da Saúde da Alemanha, que regulamentavam as pesquisas.

A noção de consentimento informado é um princípio fundamental da ética médica e se embasa no conceito de autonomia da pessoa. Seus fundamentos foram inicialmente descritos no Código de Nuremberg (1947), que trouxe a necessidade do consentimento informado em pesquisas. Foi distribuído em 10 artigos norteadores para as pesquisas com seres humanos. ${ }^{16}$

Desde então, na prática biomédica, o princípio do respeito à autonomia individual é expresso mediante o consentimento informado, cujas informações transmitidas pelo profissional/pesquisador, referentes ao efeito esperado pela ação que ele irá realizar, com a consequente liberdade do indivíduo para decidir sobre seu consentimento ou sua discordância. ${ }^{17,18}$

Os termos de consentimento informado ( $\mathrm{TCl})$, conhecidos também como termo de consentimento livre e esclarecido (TCLE), foram incorporados como obrigatórios tanto na prática clínica como nos protocolos de pesquisas clínicas internacionais, englobando as pessoas como se todas fossem autônomas e igualmente capazes, sem levar em conta as vulnerabilidades. ${ }^{21}$ Por conta disso, alguns critérios são observados em relação ao consentimento e a forma como ele é dado.

O consentimento deve ser dado livremente, de forma consciente, sem coação física, psíquica ou moral ou quaisquer outras formas de manipulação impeditivas da livre manifestação da vontade pessoal. De preferência em local tranquilo, onde o indivíduo possa refletir e estar livre de restrições internas, causadas por distúrbios psicológicos, e livre de coerções externas, por pressão de familiares, amigos e principalmente dos profissionais de saúde. Para Hewlett (1996), o consentimento só é moralmente aceitável quando está fundamentado em quatro elementos: informação, competência, entendimento e voluntariedade. ${ }^{19}$

A comunicação é de fundamental importância para o estabelecimento do consentimento informado. Estudos apontam falha na comunicação e revelam que usar somente linguagem técnica dificulta e 
prejudica o processo. ${ }^{19}$ É necessário que o esclarecimento seja adaptado às circunstâncias socioculturais e psicológicas do paciente. As informações devem ser simples, aproximativas, inteligíveis e fornecidas dentro de padrões acessíveis aos níveis intelectual e cultural do paciente. Tampouco há necessidade de utilizar-se linguajar técnico-científico.

Um dos dilemas morais enfrentados na comunicação entre profissionais e pacientes, é a definição de quais seriam as informações relevantes a serem dadas, que logicamente variam para cada situação clínica e para cada paciente. Ele tem o direito moral de ser esclarecido sobre a natureza e os objetivos dos procedimentos diagnósticos, preventivos ou terapêuticos; ser informado da duração dos tratamentos, dos benefícios, prováveis desconfortos, dados estatísticos, alternativas terapêuticas existentes e possíveis riscos físicos, psíquicos, econômicos e sociais que possa ter. ${ }^{18,19}$

A utilização de formulários padronizados sobre os procedimentos a serem realizados e pesquisas segue frequentemente este padrão de informações. Entretanto, informações por escrito consistem em mero rito legal e administrativo, por isso não devem ser fontes exclusivas de esclarecimento da pessoa assistida. Segundo Garrafa, o uso massivo, horizontal, obrigatório e indiscriminado dos "termos de consentimento informado" (TCl) sem levar em consideração os fatores culturais específicos e do nível socioeconômico da população atendida, propicia a distorção de seu objetivo histórico, que seria a proteção e defesa dos indivíduos, especialmente os mais vulneráveis, nos atendimentos médicohospitalares e nas pesquisas com seres humanos. ${ }^{20}$

Quaisquer atos médicos devem ser autorizados pelo paciente, tendo o consentimento informado. Indivíduos com autonomia reduzida (como pessoas institucionalizadas e portadores de transtorno mental), ou incapazes de consentir (pessoas inconscientes e crianças e animais), a responsabilidade é transferida para um tutor ou responsável legal. A elas garante-se proteção especial, de modo que se conceda autorização para pesquisa e prática de saúde no melhor interesse do indivíduo afetado, devendo, sempre que possível, o participante decidir sobre o consentimento e/ou retirada, quando for o caso.

Contudo, discute-se a autonomia dessas pessoas já tendo instrumentos para auxiliar essas populações, mais vulneráveis, na tomada de decisão (instrumentos psicológicos, especialmente) - sempre na visão dos melhores interesses.

Nesse contexto, a DUBDH traz, no artigo 7, os indivíduos sem a capacidade para consentir, que será discutido a seguir. 


\section{INDIVÍDUOS SEM A CAPACIDADE PARA CONSENTIR}

\section{Artigo 7-Indivíduos sem a Capacidade para Consentir}

"Em conformidade com a legislação, proteção especial deve ser dada a indivíduos sem a capacidade para fornecer consentimento:

a) a autorização para pesquisa e prática médica deve ser obtida no melhor interesse do indivíduo envolvido e de acordo com a legislação nacional. Não obstante, o indivíduo afetado deve ser envolvido, na medida do possível, tanto no processo de decisão sobre consentimento assim como sua retirada;

b) a pesquisa só deve ser realizada para o benefício direto à saúde do indivíduo envolvido, estando sujeita à autorização e às condições de proteção prescritas pela legislação e caso não haja nenhuma alternativa de pesquisa de eficácia comparável que possa incluir sujeitos de pesquisa com capacidade para fornecer consentimento. Pesquisas sem potencial benefício direto à saúde só devem ser realizadas excepcionalmente, com a maior restrição, expondo o indivíduo apenas a risco e desconforto mínimos e quando se espera que a pesquisa contribua com o benefício à saúde de outros indivíduos na mesma categoria, sendo sujeitas às condições prescritas por lei e compatíveis com a proteção dos direitos humanos do indivíduo. A recusa de tais indivíduos em participar de pesquisas deve ser respeitada." 2

O direito de exercer a autonomia está sujeito a limites. No entanto, eles são restritos e, geralmente, estão consagrados na lei. Significativamente, o direito só pode ser revogado em raras circunstâncias, cada uma das quais envolve a proteção da autonomia dos outros. A liberdade de tomar decisões autênticas depende da capacidade de fazê-lo. Sob uma ótica jurídica, capacidade de fato significa a faculdade de o indivíduo praticar pessoalmente os atos da vida civil. ${ }^{13}$

As pessoas que não possuem essa capacidade são frequentemente chamadas de incompetentes. Vários grupos de pessoas têm sido tradicionalmente rotulados dessa maneira. Incluem pessoas com dificuldades de aprendizagem, doentes mentais, crianças, pacientes em estado de choque, idosos confusos e pessoas inconscientes. Os critérios utilizados para identificar esses grupos incluem: a capacidade de compreender as questões envolvidas nas decisões em questão; a capacidade de avaliação racional; um resultado razoável da decisão; e evidência da decisão tomada. ${ }^{13}$ 
Há uma série de casos em que a autonomia dos tomadores de decisão é aparentemente comprometida por sua condição e necessitam ser descritas com cuidado. Por exemplo, as crianças, por sua própria natureza, são incompetentes porque não conseguem pensar como adultos. Isso é certamente verdade em crianças muito pequenas, mas, na medida em que as crianças se desenvolvem, elas podem mostrar diferenças marcantes entre si. Conforme se desenvolvem, o grau de sua maturidade também desenvolve, ao ponto de serem considerados plenamente competentes e capazes de decisões autônomas. Da mesma forma, pessoas com doenças mentais podem ser capazes de tomar decisões autônomas em alguns momentos ou em certas fases de sua doença ou sobre alguns assuntos. ${ }^{22}$

As pessoas sem a capacidade de consentir evidentemente têm necessidades de saúde, assim como outras. Uma questão importante, muito debatida nas últimas décadas, para este assunto é a do paternalismo, que, não raro, acontece de forma indiscriminada no âmbito dos indivíduos com ou sem a capacidade de consentir. Isso se baseia no pressuposto de que a pessoa que decide, ou seja, o tutor, deve saber melhor do que o paciente o que é melhor para ele. ${ }^{22}$

\section{CONSIDERAÇÕES FINAIS}

O esclarecimento do indivíduo por meio da melhor informação pode propiciar a autonomia, assim como o poder de consentimento de acordo com suas convicções, tornando-o mais livre. Ainda assim, a obtenção de consentimento para decisões a serem tomadas sobre cuidados de saúde ou pesquisa envolvendo pessoas sem a capacidade de consentir é uma tarefa particularmente delicada.

Nesse sentido, o termo de consentimento livre e informado pode ser usado de forma superficial: ignorando as características sócio-culturais da população atendida, trazendo apenas informações escritas, sem o acompanhamento das explicações que facilitariam o entendimento do texto e com uma redação repleta de jargões. Como, em muitos casos, a situação do paciente é de desamparo, a assinatura do termo se converte em um mero rito burocrático para ter acesso ao atendimento de saúde, sem que ele compreenda, de fato, o significado e o peso de sua assinatura naquele documento. Assim, o que deveria ser uma ferramenta de proteção do paciente, transforma-se num escudo para o profissional de saúde alegar que o enfermo concordou com os procedimentos propostos.

Contudo, se o profissional de saúde age de maneira ética, ele busca esclarecer o mais amplo e claramente possível aquele que o procurou em busca de cuidados. Deve apresentar-lhe todas as características das opções de diagnóstico, prevenção e tratamento disponíveis. Após o cumprimento 
dessas etapas e a plena compreensão pelo paciente daquilo a que se submeterá, ele assina o termo de consentimento, materializando a sua real concordância.

Nesta condição, o profissional caminha na direção apontada pelos referenciais bioéticos, nos quais o consentimento do paciente é visto como um processo continuado na relação médico-paciente, com informações e esclarecimentos que visam primordialmente proteger e estimular a autodeterminação do paciente no sentido mais amplo do respeito à dignidade da pessoa, seja ela humana ou não. 


\section{REFERÊNCIAS}

1. Beauchamp T.L., Childress J. F. Principles of biomedical ethics. 7a ed., Nova York: Oxford University Press, 2013;

2. Organização das Nações Unidas para a Educação, a Ciência e a Cultura. Declaração Universal sobre Bioética e Direitos Humanos. [Internet]. Paris: Unesco; 2005 [acesso em: 24 de agosto de 2019]. Disponível em: http://bvsms.saude.gov.br/bvs/publicacoes/declaracao_univ_bioetica_dir_hum.pdf;

3. Garrafa V. Iniciação à Bioética, Curitiba, CFM, 1998;

4. Albuquerque R., Garrafa V. Autonomia e indivíduos sem a capacidade para consentir: o caso dos menores de idade, Revista Bioética, 2016, v 24 (3): p 452-458;

5. Siqueira-Batista R, Schramm FR. A eutanásia e os paradoxos da autonomia, Ciência e Saúde Coletiva, v13 (1): p. 95-102, 2008;

6. Pequeno M. Capítulo 5: Sujeito, autonomia e moral, p. 187-207. Educação em Direitos Humanos: fundamentos teóricos-metodológicos, Editora Universitária, 2007;

7. Descartes R. Discurso do Método. Tradução: Maria Ermantina Galvão. São Paulo, Martins Fontes, 2001;

8. Descartes R. Meditações Metafísicas. EDIPRO, 1a edição, 2016;

9. Descartes R. Princípios de Filosofia. Tradução: João Gama, Lisboa, Edições 70, 1997;

10. Kant I. Fundamentação da Metafísica dos Costumes. Tradução: Paulo Quintela. 1a edição, Lisboa, Edições 70, 2007;

11. Garrafa V. Capítulo 24: Bioética, p. 739-757. Políticas e Sistema de Saúde no Brasil, 2a edição, Editora FIOCRUZ, 2012;

12. Singer P. Ética Prática. São Paulo, Martins Fontes, 2002;

13. Albuquerque A. Direitos Humanos dos Pacientes: Teorias e Princípios. p. 18-23, Curitiba, Ed.Juruá. 2016;

14. Goldim JR. Consentimento informado além da autonomia. In: Souza RT, editor. Ciência e ética: os grandes desafios. Porto Alegre: EDIPUCRS; 2006.p.45-64.

15. Kottow M. História da ética em pesquisa com seres humanos. RECIIS: revista eletrônica de comunicação, informação \& inovação em saúde. 2(supl.1):7-18, 2008;

16. Código de Nuremberg. Tribunal Internacional de Nuremberg - 1947. Trials of war crimi- nal before the Nuremberg Military Courts. Control Council Law [Internet] 1949; 10(2):181-182.[citado em 2016 out 10]. Disponível em: http://www.ufrgs.br/bioetica/nuremcod.htm;

17. Engelhardt HTJ. Fundamentos da Bioética. 2a Ed, SP, Edições Loyola, 2004; 
18. Bazzaco AA, Valelongo PO, Miziara ID, Barbosa CP. Entendimento do consentimento livremente esclarecido na reprodução assistida. Rev. bioét. (Impr.). 22(1):134-44, 2014;

19. Hewlett S. Consent to clinical research: adequately voluntary or substantially influenced? J Med Ethics, 22:232-7, 1996;

20. Garrafa V. Da bioética de princípios a uma bioética interventiva. Rev. Bioét.,13(1):125 34. 2005;

21. Garrafa V. Ampliação e politização do conceito internacional de bioética. Rev bioét (Impr.), 20 (1): 9-20, 2012;

22. Ten Have H, Jean M. The UNESCO Universal Declaration on Bioethics and Human Rights. UNESCO, 2009; 


\section{Capítulo 24}

\section{doi $10.37423 / 210604375$}

\section{BIODIVERSIDADE E SEGURANÇA ALIMENTAR}

Isabel Cristina Correia

Bárbara Braga Cavalcante

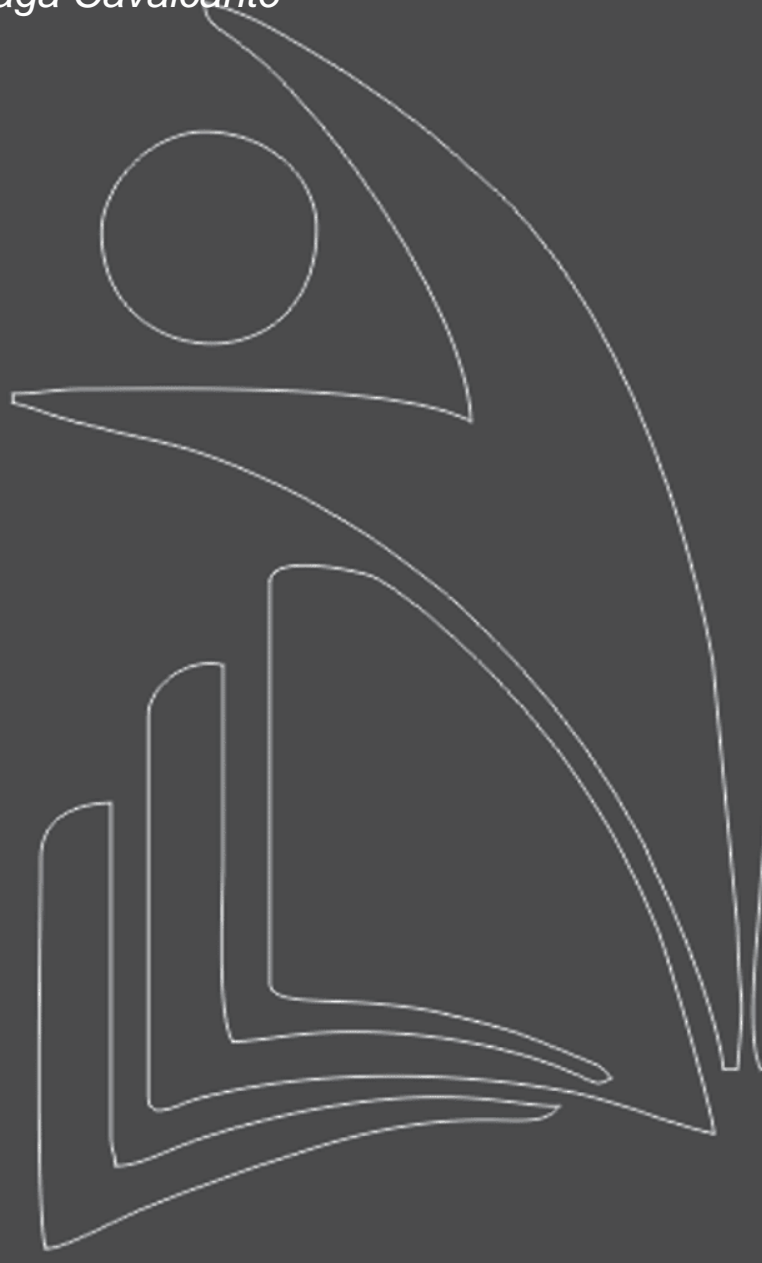

Cátedra da Unesco de Bioética -

Universidade de Brasília

Cátedra da Unesco de Bioética -

Universidade de Brasilia

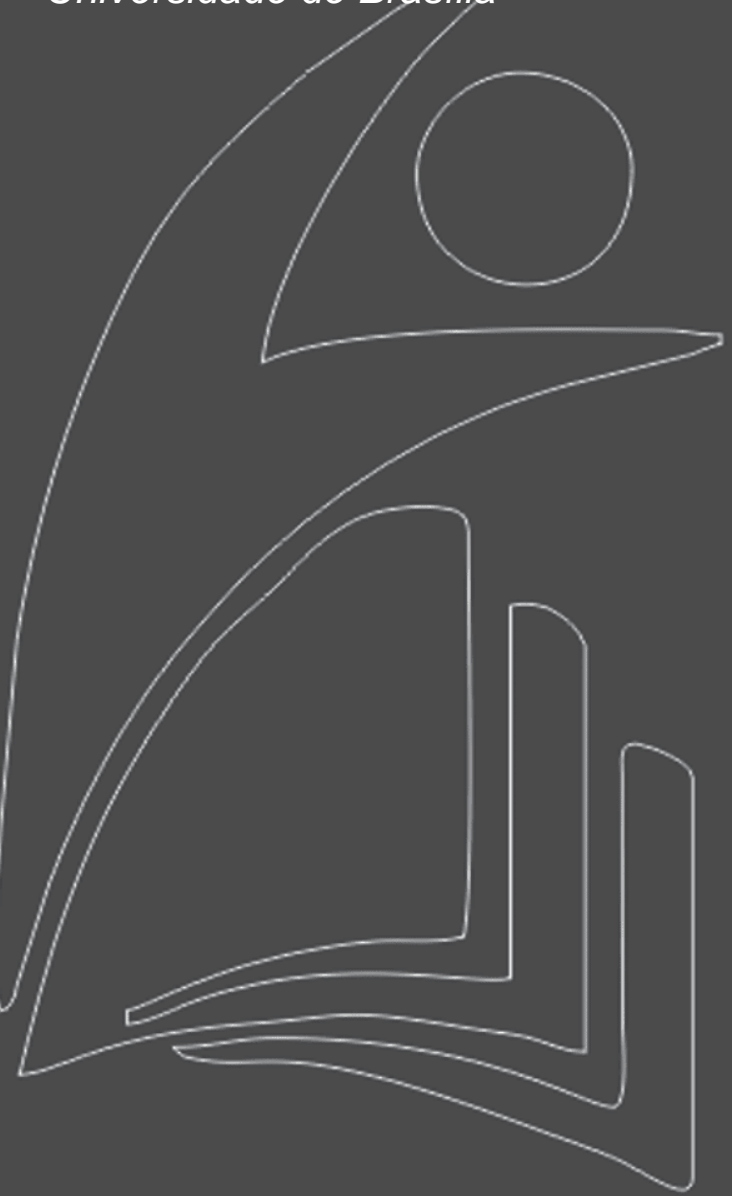




\section{"Biodiversidade e Segurança Alimentar"}

Resumo:O presente texto apresenta a quinta conferência do ano de 2019 do XI Ciclo Anual de Conferências de Bioética da UnB, promovida pelo Programa de Pós-Graduação em Bioética da Universidade de Brasília (PPG Bioética - UnB). Esta conferência tratou do tema "Biodiversidade e Segurança Alimentar". As discussões sobre os aspectos éticos, sociais e políticos que envolvem a biodiversidade e segurança alimentar são extremamente necessárias e muito ricas em seus desdobramentos. Assim, valendo-se das reflexões fomentadas pela bioética, o presente trabalho busca contextualizar brevemente o tema no cenário mundial e nacional. Tendo como objetivo incorporar essas discussões na Cátedra, no sentido de que possam ser problematizadas e estudadas, contribuindo, assim, para a produção científica do PPG Bioética - UnB. 


\section{INTRODUÇÃO}

O palestrante trata a temática "Biodiversidade e Segurança Alimentar" no contexto atual, em que a degradação do meio ambiente e dos ecossistemas, assim como as mudanças climáticas, dentre outros, tem contribuído para a insegurança alimentar no mundo. Dentre os recursos naturais, destaca-se o solo como o mais atingido pelas ações antrópicas e ainda pouco conhecido pela sociedade (BERTOL et al, 2012).

Para Lepsch (2011) o solo é importante do ponto de vista ecológico, econômico e social. Portanto, sua conservação é garantia da própria estabilidade do país e deve ser preocupação e responsabilidade de toda sua população. Tanto que em 2015 a Organização das Nações Unidas (ONU) declarou como Ano Internacional do Solo, alertando a população mundial sobre o fato de que mais de $40 \%$ dos solos do planeta encontram-se em situação de degradação. Isso implica em "plantar uma saca de milho e não conseguir colher outra". Entre as principais formas de degradação estão a erosão, a salinização, a compactação e a desertificação (ONU,2016).

A diversidade biológica ou biodiversidade refere-se à variedade dos organismos no mundo e às relações complexas entre os seres vivos e entre estes e o ambiente. $O$ termo diversidade biológica foi utilizado pela primeira vez pelo cientista e conservacionista de vida selvagem Raymond F. Dasmann em 1968. Já em 1988 o entomologista E.O.Wilson utilizou o termo em uma publicação científica como título de um manuscrito.

A biodiversidade abrange a diversidade genética, de espécies e do ecossistema, bem como a variedade dos diferentes ecossistemas em cada uma das diversidades especificadas. Segundo a Organização das Nações Unidas para a Alimentação e a Agricultura (FAO), é a biodiversidade que contribui para a agricultura e produção de alimentos, já que possui um valor essencial na produção e provisão de inúmeros serviços ambientais essenciais que contribuem para o bem estar da humanidade.

Dentre esses podemos citar: funcionamento do ecossistema, alimentos, decomposição de resíduos, regulação do clima, despoluição ambiental, fertilização do solo, polinização, controle de pragas e doenças, manutenção de recursos genéticos para a agropecuária, fármacos, benefícios estéticos e culturais.

Por longo período existiu a crença de que os bens ambientais eram inesgotáveis. Os problemas ecológicos, tais como mudanças climáticas, contaminação do solo, água, e atmosfera por poluentes, aumento gradativo da população humana, perda e fragmentação dos habitats, exploração excessiva 


\section{"Biodiversidade e Segurança Alimentar"}

de plantas e animais, desertificação de imensas regiões, uso de híbridos e monoculturas na agroindústria e nos programas de reflorestamento, são apontados como causa da perda da biodiversidade, trazendo como consequência a perda da funcionalidade do ecossistema e a degradação das propriedades do solo, do ar e da água. Tais consequências clamam por uma solução ética, com mudança de paradigma na vida pessoal, na convivência social, na produção de bens de consumo e, principalmente, na relação com a natureza (JUNGES, 2010).

Para tanto, foram apresentadas soluções, divididas em dois tipos de estratégias, a saber: TécnicoBiofísica, abordagem dominada pelas ciências naturais e a Político-Social, dominada pelas ciências sociais. Esse trabalho terá como foco a segunda estratégia, ou seja, a Político-Social, pois essa defende o desenvolvimento sócio ecológico, e enfatiza as relações sociais e governança, sustentabilidade e bem-estar da humanidade (GLADMAN et al, 2017).

\section{SEGURANÇA ALIMENTAR E A BIOÉTICA}

Segurança alimentar, é entendida como uma situação quando todas as pessoas, em todos os momentos, têm acesso físico, social e econômico a recursos alimentares suficientes, seguros e nutritivos que atendam às suas necessidades e preferências alimentares para uma vida ativa e saudável. Os pilares da segurança alimentar são - disponibilidade, estabilidade, condições de utilização e acesso (FAO, 2011).

Considerar a insegurança alimentar como um problema de bioética exige, em primeiro lugar, compreender que o próprio campo da bioética é mais amplo do que aquele estritamente voltado aos conflitos das áreas biomédicas e biotecnológicas. Esta compreensão mais abrangente da bioética surge com Van Rensselaer Potter no final da década de 80, e é reforçada constantemente pelas diversas produções da chamada perspectiva crítica da bioética latino-americana, ou ainda a interface entre a bioética e os direitos humanos, tal como exposta na Declaração Universal sobre Bioética e Direitos Humanos, DUBDH (SGANZERLA, RAULI E RENK, 2018, p.270).

Em segundo lugar, exige reconhecer que, globalmente, há um conflito de natureza moral na questão alimentar, caracterizado pelas injustiças sociais evidenciadas em dados publicados pela FAO e da Organização Mundial de Saúde (OMS).

Existem aproximadamente de 880 milhões a 1,3 bilhão de pessoas vivendo cronicamente em insegurança alimentar no mundo. No ano de 2011, por exemplo, 10 milhões de pessoas morreram de 


\section{"Biodiversidade e Segurança Alimentar"}

fome no mundo, dentre estas, três milhões eram crianças (FAO, 2011). Isso quer dizer, que a fome matou mais pessoas do que a AIDS, a malária e a tuberculose juntas. (OMS, 2011).

Esses números são o reflexo da sociedade moderna, em que o lucro é privilegiado em detrimento do respeito à vida humana. Morrer de fome, é uma forma inaceitável de violação da dignidade humana, entretanto, nem mesmo a estatística é capaz de sensibilizar a grande maioria dos tomadores de decisão, o que reforça a natureza moral da insegurança alimentar.

Considera-se, portanto, determinante que o campo da bioética seja incorporado nos processos de definição das políticas públicas, objetivando sua melhoria considerando, sobretudo, os mais excluídos e necessitados na garantia dos direitos humanos, dentre os quais aqui se destaca o da alimentação, debate ético de uma situação persistente resultante da exclusão social (CARVALHO E ROCHA, 2013).

Dentre as propostas latino-americanas, a bioética de intervenção merece destaque, pois esta se ocupa dessas situações ditas persistentes, e a insegurança alimentar é uma delas, já que é um problema que continua acontecendo e que não deveria mais acontecer em pleno século XXI (GARRAFA E PORTO, 2002). O atual contexto brasileiro, por exemplo, torna necessário e imprescindível adotar ações estruturantes no campo da proteção e promoção dos direitos humanos, dentre eles o direito fundamental de alimentar-se adequadamente. Portanto, a bioética, enquanto disciplina politizada e social, possui um enfoque direcionado ao papel do Estado na proteção dos vulneráveis e excluídos, e na intervenção do Estado e da sociedade na construção de políticas públicas voltadas a assegurar tais direitos.

A Declaração Universal sobre Bioética e Direitos Humanos é o resultado prático do esforço acadêmico e militante de estudiosos brasileiros e da América Latina na ampliação do texto para os campos sanitário, social e ambiental. Nessa perspectiva, a Declaração consolida-se como marco histórico da bioética, voltando-se à supressão das iniquidades no acesso aos direitos humanos por meio da ética e da justiça social (DUBDH, 2005).

Dentre os artigos contidos na Declaração, o princípio 14, intitulado "Responsabilidade Social e Saúde" trata do acesso à nutrição adequada como um direito fundamental de todo ser humano (DUBDH, 2005). Garrafa (2005) ao apresentar o documento afirma que a ampliação conceitual da bioética promovida pela homologação do documento, não só democratizou a agenda da bioética, como também a tornou aplicada e comprometida com as populações vulneráveis. Seu conteúdo é um instrumento à disposição da democracia, no sentido do aperfeiçoamento da cidadania e da aplicação dos direitos humanos universais. 


\section{"Biodiversidade e Segurança Alimentar"}

O direito humano à alimentação deverá ser assegurado por intermédio de políticas de segurança alimentar e nutricional que, por sua vez, são de responsabilidade do Estado e da sociedade sobre a qual pesam obrigações frente a normas legais universais (MALUF, 2007). Nesse sentido, ao longo do tempo, o marco da política para a garantia da segurança alimentar e nutricional no país e as políticas e programas a ele correlacionados obtiveram consideráveis avanços, tanto do governo quanto da sociedade (CARVALHO E ROCHA, 2013).

O Programa Fome Zero, lançado em 2003, é apresentado pela FAO como uma referência para outros países do mundo. Tal iniciativa visava combater a fome e as suas causas estruturais, que geram a exclusão social e para garantir a segurança alimentar dos brasileiros em três frentes: um conjunto de políticas públicas; a construção participativa de uma Política Nacional de Segurança Alimentar e Nutricional; e um grande mutirão contra a fome, envolvendo as três esferas de governo (federal, estadual e municipal) e todos os ministérios. Como resultado obtido, o índice de pessoas em situação de insegurança alimentar no Brasil passou de 10,6\% no início dos anos 2000, o que representaria 19 milhões de pessoas, para 2,5\%, entre 2008 e 2010. A FAO atribui essa redução a políticas sociais contra a extrema pobreza e ao combate à seca no Nordeste.

O Programa destinava-se a ser o segmento do aparelho do Estado responsável pela promoção de políticas sociais ditas "emergenciais", visando ações estratégicas eficientes de combate à fome e à miséria para a redução das disparidades regionais e sociais. Sua base teórico-legal foi, em grande parte, inspirada no projeto de reforma institucional e cultural que propunha a criação de instituições normativas e organizacionais que viabilizassem uma reforma para a gestão da coisa pública, tendo em vista dois critérios: democracia e eficiência (PERES, 2005).

Dentre os benefícios que o programa proporcionou à população brasileira, vale destacar as várias iniciativas promovendo a produção, distribuição de alimentos de qualidade e a inclusão social de pessoas em estado de vulnerabilidade alimentar, assim como a inserção de um novo modelo agroecológico de produção, elevando a conservação da biodiversidade. Não podendo deixar de destacar os programas de assentamento rural e de agricultura familiar que trouxeram uma visão participativa e no pressuposto da população se autogerir.

Políticas públicas para a promoção da segurança alimentar são legítimas e necessárias em uma sociedade que ainda convive com desigualdades inaceitáveis. Este quadro torna necessário e imprescindível adotar ações estruturantes no campo da proteção e da promoção dos direitos 


\section{"Biodiversidade e Segurança Alimentar"}

humanos, contribuindo para que pessoas e famílias tenham assegurada a plenitude de seus direitos, dentre eles o direito fundamental de alimentar-se adequadamente (CARVALHO E ROCHA, 2013).

Entretanto, o atual cenário político brasileiro é crítico, já que nem mesmo o presidente acredita que exista fome no Brasil, um problema que afeta cerca de cinco milhões de pessoas no país. Para José Graziano da Silva, ex-diretor-geral da FAO e um dos criadores do Fome Zero, "o Brasil tem negligenciado a fome e as políticas sociais". Um exemplo disso, é a extinção do Conselho Nacional de Segurança Alimentar e Nutricional (CONSEA) pelo atual governo.

Segundo a FAO (2011), aproximadamente 880 milhões a 1,3 bilhão de pessoas estão cronicamente em insegurança alimentar no mundo. Cerca de 2 bilhões de pessoas continuam subnutridas. $O$ grande desafio então seria: Como alimentar 9.6 bilhões de pessoas no ano 2050? Sabe-se que há uma real necessidade de aumentar em 70 - 100\% a produção de alimentos e $75 \%$ das pessoas em estado de vulnerabilidade alimentar estão no meio rural. Várias regiões do mundo com altos índices de insegurança alimentar são regiões de elevada biodiversidade; Estima-se que cerca de $3 / 4$ da diversidade genética das culturas agrícolas foram perdidas no último Século (FAO, 2011). Elevado uso de defensivos, a poluição e o aumento das emissões de CO2 são agravantes da insegurança alimentar (SUNDERLAND, 2011).

Um bilhão de pessoas dependem de produtos florestais para a nutrição e como fonte de renda; $\mathrm{O}$ desmatamento compromete a caça de animais que, por sua vez contribuem com $30-50 \%$ das necessidades de proteínas das comunidades rurais; assim como a exploração excessiva da pesca. Estima que $77 \%$ das espécies de peixes de valor comercial se encontram em estado de sobrepesca (FAO, 2011). Um agravante é a sobrepesca por grandes empresas pesqueiras, comprometendo a pesca por pescadores que tem a pesca como meio de sobrevivência; Poluição de rios, lagos e ambientes marinhos - afetam a biodiversidade e suprimento de alimentos, principalmente a provocada por vazamento de combustível fóssil e outras substâncias tóxicas (SUNDERLAND, 2011).

A aplicação da ecologia na agricultura como movimento social leva em consideração os aspectos ecológicos, equidade, fortalecimento, soberania alimentar, desenvolvimento rural e sistemas de comércio local. Apresenta foco em pequenos produtores, principalmente nos países periféricos. Há uma importante reflexão a respeito da manutenção da saúde do solo. Para tanto, situações emergenciais de proteção são acionadas, como a adubação verde, o consórcio de culturas, coberturas orgânicas do solo, plantio direto (FRANCO, 2013). 
Nesse contexto, o governo brasileiro buscou iniciativas para a biodiversidade em alimentos e nutrição, na busca do enfrentamento da fome e da miséria do país, criando programas como o, citado anteriormente, Fome Zero.

\section{CONSIDERAÇÕES FINAIS}

Diante da extrema dependência do ser humano dos serviços ambientais prestados pela biodiversidade torna-se imperativo entendimento de sua complexidade para nortear as decisões quanto ao seu uso e preservação. Como direito fundamental do ser humano, assegurado na Declaração Universal de Direitos Humanos e na Constituição Brasileira, o acesso à alimentação de qualidade especialmente aos que vivem em condições de vulnerabilidade alimentar é de responsabilidade dos governantes e da sociedade civil organizada.

Tendo em vista o desafio de produzir alimentos para alimentar a crescente população humana e de preservar a biodiversidade, as discussões devem ser pautadas nos conhecimentos gerados pela ciência e as decisões tomadas levando em conta o contexto de cada realidade, sempre no sentido de maximizar tanto a produção quanto a conservação da biodiversidade.

Portanto, a educação e a transferência de conhecimentos às comunidades são imprescindíveis para o uso e preservação dos recursos naturais. Não há como dissociar os temas da segurança alimentar e a biodiversidade, visto que a primeira é dependente da segunda.

A bioética alcança questões públicas e busca a garantia dos direitos humanos, dentre os quais aqui se destaca o da alimentação, debate ético de uma situação persistente resultante da exclusão social. Assim, pode ser adequado instrumento para discutir essa diversidade de problemas de saúde global a partir dos princípios de justiça, equidade e solidariedade, visando reduzir injustiças e promover uma comunidade global responsável com as gerações atuais e futuras. 


\section{REFERÊNCIAS BIBLIOGRÁFICAS}

1. BERTOL, I; MAFRA, A.L.; COGO, N.P.; BARBOSA, F. T.; MIQUELLUTI, D.J.; OLIVEIRA, L. C.; RECH, T.D.; MOREIRA, M. A. Manejo e conservação do Solo e da Água: Retrospectiva, Constatação e Projeção. Boletim Técnico do CAV - UDESC. 2012.

2. CARVALHO, L.R.T.; ROCHA, D.G. Programa de Aquisição de Alimentos: a lente bioética na segurança alimentar. Rev. bioét. (Impr.). 2013; 21 (2): 278-90. 2013.

3. FAO - Organização das Nações Unidas para a Alimentação e a Agricultura. Disponível em: <http://www.fao.org/brasil/pt/>. Acesso em: 01 dez.2019.

4. FAO. Os Desafios para um Mundo sem Fome. 2011. Disponível em: http://www.fao.org/ Acesso em: 01 dez.2019.

5. FRANCO, J. L. D. A. The concept of biodiversity and the history of conservation biology: from wilderness preservation to biodiversity conservation. História (São Paulo), 32(2), 21-48. 2013.

6. GARRAFA,V. Inclusão Social no Contexto Político da Bioética. Revista Brasileira de Bioética, v. 1, n. 2, p. 122-132, 11. 2005.

7. GARRAFA, V., PORTO, D. Bioética, poder e injustiça: por uma bioética de intervenção. São Paulo: Loyola/Centro Universitário São Camilo/SBB, 35-44. 2002.

8. GLAMANN, J.; HANSPACH, J.; ABSON, D.J.; COLLIER, N.; FISHER, J. The intersection of food security and biodiversity conservation: a review. Regional Environmental Change, 17(5), 13031313. 2017.

9. JUNGES, J.R. (Bio) Ética Ambiental. São Leopoldo: Unisinos, 2010.

10. LEPSCH, I. 19 lições de pedologia. São Paulo: Oficina de Textos, 2011. 456p

11. MALUF, R.S.J. Segurança Alimentar e Nutricional. Petrópolis. VOZES, 2007.

12. OMS. Estatísticas Mundiais de Saúde. 2011. Disponível em: http://nacoesunidas.org/>. Acesso em: 01 dez.2019.

13. ONU BR. Ano Internacional dos Solos: ONU destaca práticas sustentáveis para diminuir degradação de terras. Disponível em: https://nacoesunidas.org/ano-internacional-dos-solosonu-destaca-praticas-sustentaveis-para-diminuir-degradacao-de-terras/ Acesso em: 03 dez.2019.

14. PERES, T.H.D.A. Comunidade Solidária A proposta de um outro modelo para as políticas sociais. Civitas-Revista de Ciências Sociais, 5(1), 109-126. 2005.

15. SGANZERLA A.; RAULI, P.M.F.; RENK, V. E, ORGANIZADORES. Bioética Ambiental. Curitiba: PUCPRESS, 2018. 319p.

16. SUNDERLAND, T.C.H. Food security: why is biodiversity important?. International Forestry Review, 13(3), 265-274. 2011.

17. UNESCO. Declaração Universal sobre Bioética e Direitos Humanos. 2005. Disponível em: http://bvsms.saude.gov.br/bvs/publicacoes/declaracao_univ_bioetica_dir_hum.pdf. Acesso em: 05 dez. 2019. 


\section{Capítulo 25}

\section{doi $10.37423 / 210604397$}

\section{A CLASSE ESPECIAL NA CONJUNTURA DA EDUCAÇÃO ESPECIALINCLUSIVA: UMA POSSIBILIDADE DE ESCOLARIZAÇÃO?}

Maria José Calado Souza

Glória Maria Alves Machado

Maria José de Souza Marcelino

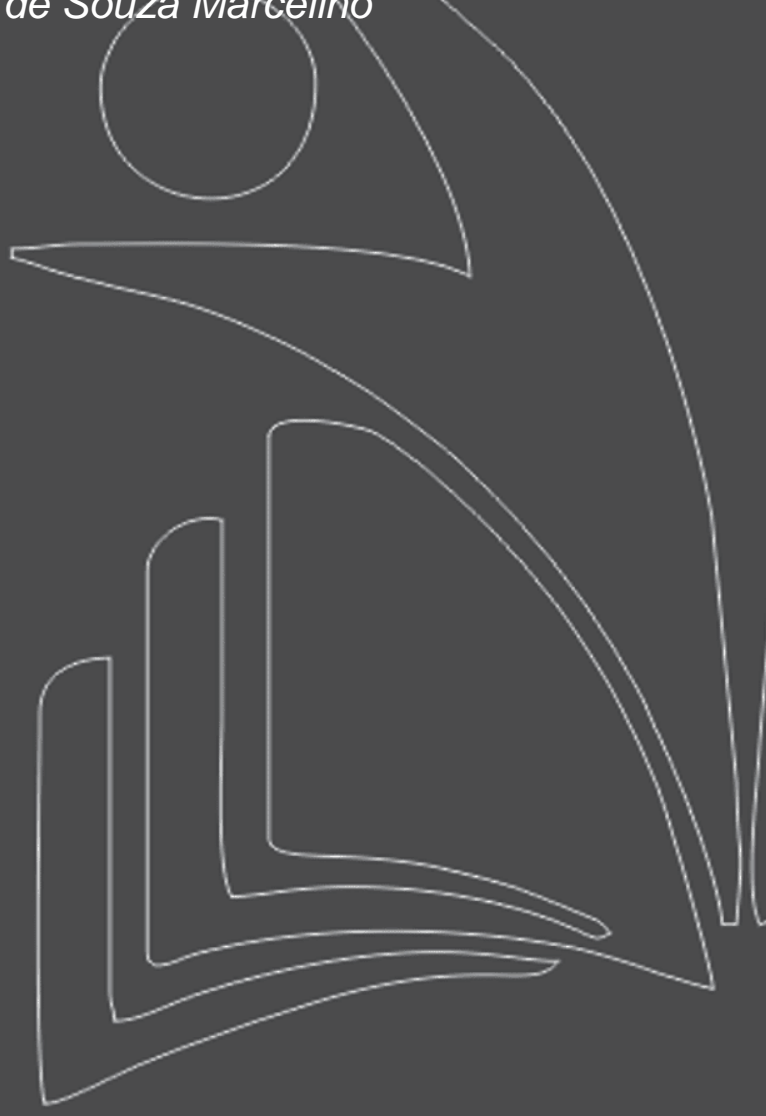

Secretaria de Educação do Estado de

Pernambuco

Secretaria de Educação do Estado de

Pernambuco

Prefeitura da Cidade do Paulista e Araçoiaba 
Resumo: Na atual conjuntura da educação especial inclusiva, identifica-se na Rede Estadual de Ensino de Pernambuco a classe especial para estudantes considerados público alvo da educação especial. Classe especial, que na sua gênese, funcionava como lugar de guarda e assistência, pautada num modelo de educação segregador e excludente que não visava a escolarização do estudante e, nesta, o direito à aprendizagem escolar. E hoje quando se discute, no mundo, a inclusão escolar e busca-se através da definição e implantação de políticas públicas educacionais alternativas para se garantir o direito inalienável a educação escolar de todos os estudantes, questiona-se qual o foco da classe especial. Neste aspecto, este artigo traz o resultado de uma pesquisa que buscou responder ao seguinte problema: a classe especial na conjuntura da educação especial inclusiva vem se constituindo em possibilidade de escolarização? Nesta perspectiva, a pesquisa teve como objetivo investigar se a classe especial na conjuntura da educação especial inclusiva vem se constituindo em possibilidade de escolarização. Para tanto, utilizou-se um questionário para coletar os dados. Os sujeitos foram professoras de classe especial que participavam de uma formação, promovida por uma Gerência Regional de Educação do Estado de Pernambuco. A análise e discussão dos dados, pautada numa abordagem de cunho qualitativo, confirmou o pressuposto inicial que foi na direção de distanciamento da classe especial da escolarização dos estudantes. A análise e discussão, também evidenciou que o foco da classe especial, no âmbito investigado, é a socialização dos estudantes. Quanto a contribuição pauta-se na premissa que a escolarização é um direito do estudante e que todas as oportunidades devem ser garantidas independentes do espaço educacional em que ele se encontrem.

Palavras-chave: Educação Especial Inclusiva, Classe Especial, Escolarização. 


\section{INTRODUÇÃO}

O pensamento acerca da concepção da Educação Escolar Inclusiva, que traz em seu cerne a garantia da participação dos estudantes no mesmo espaço pedagógico, com condições que proporcionem o desenvolvimento da aprendizagem, assim contemplando a diversidade, possibilitou a reflexão sobre o foco da classe especial, a qual vem se mantendo no cenário educacional, mesmo com as mudanças trazidas pela atual Política de Educação Especial que vão na contramão dos princípios dessa classe. A resistência de permanência das classes especiais permite conjecturar sobre as possibilidades de aprendizagens que são oferecidas, de modo a garantir a escolarização dos estudantes público alvo da Educação Especial.

A partir dessas reflexões e de experiências pedagógicas junto a professores de classes especiais, entre estas, a experiência em formação continuada, buscou-se responder a seguinte indagação: A classe especial na conjuntura da educação especial inclusiva vem se constituindo em possibilidade de escolarização? Nessa perspectiva, definiu-se como objetivo geral investigar se a classe especial na conjuntura da educação especial inclusiva vem se constituindo em possibilidade de escolarização. Seguindo nessa direção, definiuse como objetivos específicos: Identificar o foco das atividades que são realizadas na classe especial; Apontar os recursos que costumam ser utilizados pelos professores nas atividades realizadas na classe especial; Verificar que atividades o professor costuma realizar com vista à escolarização na classe especial e Averiguar avanços percebidos na escolarização de estudantes na classe especial.

Nesta direção, as discussões teóricas aqui apresentadas estão de acordo com as categorias temáticas e foram referendadas em autores que discutem o tema em tela. Para a análise e discussão dos dados optouse por uma abordagem de cunho qualitativo. A pesquisa teve como sujeitos 10 (dez) professoras de classe especial de uma Gerência Regional de Educação do Estado de Pernambuco. As discussões e os resultados apontam para a confirmação do pressuposto levantado inicialmente. A contribuição pauta-se na premissa de que a escolarização é um direito do estudante e que todas as oportunidades devem ser garantidas, independentes do espaço educacional em que eles se encontrem.

\section{EDUCAÇÃO ESPECIAL INCLUSIVA}

A Lei de Diretrizes e Bases da Educação Nacional, Lei 9.394/96 define em seu Art. 58, a Educação Especial como "[...]a modalidade de educação escolar oferecida preferencialmente na rede regular de ensino, para educandos com deficiência, transtornos globais do desenvolvimento e altas habilidades ou superdotação." Assim, compreende-se que esta modalidade de ensino, faz parte da Educação Geral e que os estudantes público alvo, estão inclusos no ensino regular. 
Todavia, em meio a compreensão de inclusão, observa-se o termo "preferencialmente", o que leva a diferentes entendimentos, e pode permitir ações de exclusão dos estudantes, considerando que o despreparo dos sistemas de ensino "[...] para acolher todos, acabam realmente excluindo os casos que, por sua complexidade, não têm no momento condições de atender [...] (RIBEIRO, 2003, p.47). Isso posto, a princípio, pode-se destacar na conjuntura atual dos sistemas de ensino, a educação especial, na qual, ainda se faz presente a classe especial, organizada, à primeira vista, de maneira pouco ou nada inclusiva, se comparada a sua organização inicial, quando pensada num modelo segregador, excluía seus estudantes do direito à aprendizagem.

Contudo, a despeito desse entendimento, mas não descartando essa realidade, considera-se pertinente uma reflexão acerca da possibilidade de uma nova organização da classe especial, (enquanto sua permanência nos sistemas de ensino), mesmo com ciência de que seus objetivos, se contrapõem aos da inclusão, tendo em vista que ainda é prática na educação do Estado de Pernambuco. No entanto, se faz necessário pensar nessa organização com o olhar direcionado a contribuição da educação especial inclusiva, com seus princípios para escolarização de seus estudantes.

Nesse sentido, é pertinente refletir que ações inclusivas são aquelas que favorecem a permanência com qualidade, sucesso e desenvolvimento da aprendizagem dos estudantes no espaço escolar, dentre as quais, aquelas observadas não apenas em sala de recursos multifuncional, com o atendimento Educacional Especializado, o qual tem a função de complementar ou suplementar a formação do aluno por meio da disponibilização de serviços, recursos de acessibilidade e estratégias [...] (BRASIL, 2008) mas, em todos os espaços da escola, desde que haja, dentre outros aspectos, sensibilidade, compromisso e conhecimento dos sujeitos envolvidos, entre os quais, o professor, que estando ele, na sala de aula regular ou na classe especial, sua prática pode fazer a diferença mesmo em meio a diferentes entendimentos, considerando as nuances da importância de um sistema educacional inclusivo, onde a todos os estudantes são garantidos os direitos à aprendizagem.

\section{CLASSE ESPECIAL}

A inclusão na educação, pelo menos em tese, é realidade. Todavia, se observa que caminhos ainda estão sendo percorridos objetivando sua concretude, ainda há a necessidade de pensar questões atinentes ao processo, tendo em vista que não é um processo exclusivo da educação especial, porque encontra-se condicionado a garantia do direito de todos independentes das diferenças que possam apresentar.

Em meio a educação escolar, ainda perdura algumas classes especiais, que tiveram suas raízes amarradas à concepção de integração que visa preparar diferentes, com valores e saberes diferentes" (p.87). Neste 
sentido, a escolarização aqui entendida como um processo de ação/reação que envolve o ensino e a aprendizagem, perpassa por diferentes modificações e ajustes em todo o contexto da o estudante para o ingresso no ensino regular, partindo da premissa que "a integração ao sistema de ensino regular é um processo individual. Em que cada caso, deverá ser estabelecido o momento oportuno para que o educando comece a frequentar a classe comum" (BRASIL, 1995, p. 29). Esses espaços pedagógicos, considerados pertencentes a educação paralela a educação comum denominada de ensino regular, surgem, "[...] pautados na necessidade científica da separação dos alunos 'normais' e 'anormais' na pretensão da organização de salas de aula homogêneas, [...]" (KASSAR,2009, p.24).

Assim, pode-se questionar qual o propósito da classe especial no contexto atual e se ela está na via da escolarização dos estudantes. Possivelmente a resposta é não, pois neste espaço pedagógico, de acordo com a literatura, se define o momento para o estudante ingressar na sala regular, justificando-se que os estudantes, público alvo dessa classe, necessitam ser preparados para tal fim, como se a 'preparação' só acontecesse em situação de segregação. Esse entendimento, vai na contramão da educação especial inclusiva, tendo em vista que imposições não podem ser realizadas. É preciso reconhecer ganhos ocorridos em espaços pedagógicos, comum a todos. E, neste sentido, a sala regular de ensino oportuniza, entre outros ganhos, a convivência com os pares, a aprendizagem compartilhada, a ajuda mútua, e, sobretudo, o respeito as diferenças. Dessa forma, reconhecer-se fazendo parte disso, é condição que favorece a efetivação da escolarização e consequentemente da aprendizagem.

Observa-se que o termo "favorecer" é diferente do termo "condição", para efetivação da escolarização e da escolarização. Assim, compreende-se que a classe especial pode ou não ser reconhecida como um espaço que (des)favorece o processo de escolarização e, consequentemente, da aprendizagem. Além do que, esta não se encontra desvinculada da legislação educacional, portanto está posta como mais um espaço pedagógico para estudantes público alvo da educação especial.

\section{ESCOLARIZAÇÃO}

A escola traz em seu cerne uma proposta de organização que visa favorecer não apenas a socialização, mas o ensino-aprendizagem. Portanto, como diz Goulart (2007) “, a escola é, então, lugar de encontro de muitas pessoas; lugar de partilha de conhecimentos, ideias, crenças, sentimentos, lugar de conflitos, portanto, uma vez que acolhe pessoas aprendizagem para realização do trabalho pedagógico.

Escola, considerando a diferença como elemento que norteia as ações educativas, dessa forma, contribuindo para garantir o direito de aprender de todos os estudantes. 
A escola, como lugar de partilha de conhecimento, lugar de ação/reação, em relação ao processo de escolarização dos estudantes público alvo da educação especial, tem demonstrado ser uma instituição que apresenta em suas ações, grandes desafios, tendo em vista as particularidades dos estudantes, muitas vezes atribuídas em função da deficiência.

A escola, muitas vezes, não dar conta da escolarização desses estudantes, deixando de cumprir o que lhe é cabível, diante das diferentes matizes e dificuldades existentes no fazer inclusivo. Todavia, isto não a exime da responsabilidade, de forma a buscar meios para atender as necessidades educativas desses estudantes. É preciso ultrapassar os possíveis entraves que levam muitos professores de classe especial a ficarem imobilizados, possibilitando-os a manter-se na busca da escola ideal, pois, como destacam Vasques e Baptista "apesar dos ideais inclusivos, os esforços almejam ainda a adaptação e a normalização, havendo uma certeza em relação a quem são os sujeitos da educação especial e quais são as suas (im)possibilidades educacionais." (2013, p. 281). Para ultrapassar uma visão excludente e discriminatória é preciso compreender que:

A experiência de escolarização envolve uma construção compartilhada a partir dos nossos pressupostos a respeito de escola, aluno, educação, [...] Tais antecipações ganham significados a partir do contexto, da historicidade e da interpretação dos sujeitos e instituições envolvidas (Idem).

Nesse sentido, é preciso apoderar-se dos princípios inclusivos afastando-se de concepções que reforçam a crença na impossibilidade dos sujeitos público alvo da educação especial escolarizar-se e obterem conhecimentos, apriori, veiculados na escola pelos professores.

As formas de organização e funcionamento do trabalho pedagógico são, muitas vezes, determinantes para o processo de escolarização dos estudantes, pois o reconhecimento da responsabilidade de todos, constitui-se como fator indispensável em meio aos desafios existentes. Quase sempre são escassas as expectativas de aprendizagem em relação aos estudantes púbico alvo da educação em tela, o que deixa resumida a proposição de atitudes inerentes a escolarização. Nessa direção, como diz Carvalho (2013), perde-se oportunidade de discutir alternativas de aprendizagem para esses estudantes, isto é, indicar possibilidades de

\section{METODOLOGIA}

Toda pesquisa científica pressupõe uma abordagem teórico-metodológica para subsidiar o levantamento e a interpretação dos dados, a qual expressa a opção do(s) pesquisador(es) para 'olhar' o objeto de estudo, uma vez que existem diferentes enfoques epistemológicos que explicam, de formas distintas, a relação sujeito-objeto na apreensão da realidade que está sob investigação, ou seja, "o referencial teórico de um 
pesquisador é um filtro pelo qual ele enxerga a realidade, sugerindo perguntas e indicando possibilidades" (LUNA, 2002, p. 32).

A opção aqui, para enxergar a realidade sob investigação, foi na direção da abordagem teóricometodológica de cunho qualitativo que pressupõe objeto situado e histórico que não se desvela na essência, que não é passível de medição e quantificação, mas é passível de ser apreendido - de forma aproximada - no processo de pesquisa, uma vez que "o processo de abstração e reprodução da realidade numa linguagem compreensível certamente apresentará deformidades, posto que o mundo real jamais apresentará a sua essência quando representado simbolicamente" (SEABRA, 2001, p. 13).

Nesse sentido, o olhar do pesquisador é predominantemente indutivo, pois as inferências a que se chega decorrem de "[...] abstrações [que] são construídas à medida que os dados particulares que foram recolhidos vão se agrupando" (BOGDAN e BIKLEN, 1994, p.50), pois "não se trata de montar um quebracabeça cuja forma final conhecemos de antemão. Está-se a construir um quadro que vai ganhando forma à medida que se recolhem e examinam as partes" (Idem).

A opção segue a direção do que vem sendo revelado pela ciência atual, ou seja, o caráter dinâmico do conhecimento que está sempre se metamorfoseando. Esta, como diz Minayo (2000) “[...] é uma construção que se faz a partir de outros conhecimentos sobre os quais se exercita a apreensão, a crítica, e a dúvida" (p.89).

Foi no entendimento de pesquisa como aproximação do objeto, que não se permite apreender na totalidade em decorrência do seu caráter dinâmico, temporário e modificável, que se priorizou a abordagem qualitativa, haja vista que o 'olhar' qualitativo atende melhor às análises dos fenômenos sociais.

Este estudo teve sua gênese em uma experiência de formação continuada com professores de classes especiais de uma Gerência Regional de Educação do Estado de Pernambuco. A formação objetivava discutir sobre o lugar da classe especial para a escolarização de estudantes com deficiência. Nessa direção, a formação teve início com um levantamento, junto as professoras, do cotidiano da classe especial.

Para tanto, aplicou-se um questionário com questões abertas, com vistas a problematização do tema da formação. Dentre as questões propostas para o levantamento, priorizou-se 04 (quatro), na perspectiva de responder à questão que deu origem ao estudo: a classe especial na conjuntura da educação especial inclusiva vem se constituindo em possibilidade de escolarização? Para responder a questão inicial, definiuse como objetivo investigar se a classe especial na conjuntura da educação especial inclusiva vem se constituindo em possibilidade de escolarização. 
Partiu-se do pressuposto que a classe especial na conjuntura da educação especial inclusiva não vem se constituindo em possibilidade de escolarização, continua arraigada a crenças e valores oriundos do contexto em que emergiu.

\section{RESULTADOS E DISCUSSÃO}

O estudo em foco foi realizado com 10 (dez) professoras de classe especial de uma Gerência Regional de Educação do Estado de Pernambuco, conforme quadro a seguir.

\begin{tabular}{|l|l|c|c|}
\hline Sujeitos & Sexo & $\begin{array}{c}\text { Tempo de exercício em } \\
\text { classe especial }\end{array}$ & Formação acadêmica \\
\hline Professora 1 & Feminino & 20 & Pedagogia \\
\hline Professora 2 & Feminino & 22 & Pedagogia \\
\hline Professora 3 & Feminino & 15 & Pedagogia \\
\hline Professora 4 & Feminino & 20 & Pedagogia \\
\hline Professora 5 & Feminino & 17 & Pedagogia \\
\hline Professora 6 & Feminino & 20 & Pedagogia \\
\hline Professora 7 & Feminino & 20 & Pedagogia \\
\hline Professora 8 & Feminino & 22 & Pedagogia \\
\hline Professora 9 & Feminino & 21 & Pedagogia \\
\hline Professora10 & Feminino & 23 & Pedagogia \\
\hline
\end{tabular}

Quadro I - Caracterização dos sujeitos.

Fonte: Próprios autores

A leitura dos dados evidencia que os sujeitos da pesquisa são todos do sexo feminino, com formação em pedagogia e com tempo de exercício em classe especial variando entre 17 e 23 anos. Portanto, considerando o tempo de atuação dos sujeitos em classe especial, pode-se dizer que a prática das professoras em tela teve sua gênese numa concepção de classe especial como lugar de guarda e assistência, sem foco na escolarização um dos princípios da educação especial inclusiva justificada na atual política de educação especial. 
Questão 1. Qual o foco das atividades que você realiza na classe especial?

\begin{tabular}{|l|l|}
\hline \multicolumn{1}{|c|}{ Sujeitos } & \multicolumn{1}{c|}{ Respostas } \\
\hline Professora 1 & $\begin{array}{l}\text { A partir de um planejamento anual dividido por unidade, dando ênfase aos eventos como } \\
\text { carnaval, páscoa, festas juninas, entre outros. }\end{array}$ \\
\hline Professora 2 & De acordo com o nível de cada um. \\
\hline Professora 3 & $\begin{array}{l}\text { Com atividades diversificadas, respeitando as diferenças e o tempo do desenvolvimento } \\
\text { cognitivo de cada estudante. }\end{array}$ \\
\hline Professora 4 & $\begin{array}{l}\text { Com práticas diversificadas e, em habilidades cognitivas diferentes, valorizando o } \\
\text { desenvolvimento individual. }\end{array}$ \\
\hline Professora 5 & $\begin{array}{l}\text { Utilizando o concreto (tocar, visualizar) pra depois partir para a leitura, escrita, pintura e } \\
\text { colagem. }\end{array}$ \\
\hline Professora 6 & Com perseverança. Todos os dias são novas descobertas. \\
\hline Professora 7 & Com base em um planejamento, buscando adequar as necessidades de cada um. \\
\hline Professora 8 & A Partir da necessidade e dificuldade de cada um. \\
\hline Professora 9 & De acordo com o nível de dificuldade de cada um aluno, considerando sua especificidade. \\
\hline Professora10 & Com atividades diversificadas, valorizando o desenvolvimento individual. \\
\hline
\end{tabular}

Quadro 2 - Foco das atividades.

Fonte: Próprios autores

Ao se indagar os sujeitos da pesquisa sobre o foco das atividades que realiza na classe especial, as respostas dadas evidenciam foco no planejamento, em datas comemorativas, no reconhecimento do nível de desenvolvimento, no uso de atividades diversificadas, nas necessidades e dificuldades dos estudantes, na ênfase no concreto, na pintura e colagem.

Como o olhar aqui é sobre a escolarização em classe especial, a análise dos dados permite inferir que o fazer das professoras, distancia-se das proposições da educação especial inclusiva que tem como premissa o acesso e a permanência, com qualidade do estudante com deficiência em classe regular.

Essa inferência justifica-se no fato da leitura e a escrita aparecer apenas uma vez. A Professora 5 ao mencionar a leitura e a escrita em sua resposta não dá ênfase a esses aspectos da escolarização, haja vista que coloca no mesmo grau de importância o concreto, a pintura e a colagem. As respostas das professoras dão a entender que a classe especial não está para a escolarização dos estudantes com deficiências.

Questão 2. Que recursos você costuma utilizar nas atividades realizadas na classe especial?

\begin{tabular}{|l|l|}
\hline \multicolumn{1}{|c|}{ Sujeitos } & \multicolumn{1}{c|}{ Respostas } \\
\hline Professora 1 & $\begin{array}{l}\text { Computadores, vídeos, televisão, folhas em geral, xerox, quadro, data show, entre } \\
\text { outros. }\end{array}$ \\
\hline Professora 2 & O que a escola disponibiliza e sucata. \\
\hline Professora 3 & $\begin{array}{l}\text { Aparelho de som, DVD, TV, jogos diferenciados, jornais, revistas, livros, tesoura, } \\
\text { cola, lápis grafite e coloridos, materiais reutilizáveis, fotografias, etc. }\end{array}$ \\
\hline Professora 4 & Televisão, jogos, filme, história sem escrita, colagem, com objetos didáticos. \\
\hline Professora 5 & $\begin{array}{l}\text { Quadro, piloto, jogos diferenciados, jornais, figura, revistas, músicas, livros, tesoura, } \\
\text { cola, lápis grafite e coloridos, materiais reutilizáveis, caderno, pincel, e outros. }\end{array}$ \\
\hline
\end{tabular}




\begin{tabular}{|l|l|}
\hline Professora 6 & Livros didáticos, jornais e revistas, gibis, etc. \\
\hline Professora 7 & $\begin{array}{l}\text { Pesquisa na internet, computador, livro didático, jogos educativos e livros } \\
\text { paradidáticos. }\end{array}$ \\
\hline Professora 8 & Materiais concretos, jogos e brincadeiras, livros paradidáticos. \\
\hline Professora 9 & $\begin{array}{l}\text { Quadro, música, contação de história, colagem, pintura, desenhos, TV, materiais } \\
\text { pedagógicos como quebra cabeças e jogos de encaixe. }\end{array}$ \\
\hline Professora10 & DVD, jogos, filmes, cartazes com objetos. \\
\hline
\end{tabular}

Quadro 3-Recursos utilizados nas atividades.

Fonte: Próprios autores

Quanto aos recursos utilizados pelas professoras na classe especial, pode-se inferir que escolas de uma Gerência Regional de Educação do Estado de Pernambuco estão equipadas com recursos diversos e necessários ao desenvolvimento de atividades em sala de aula, com vista a escolarização do estudante. Tudo vai depender de como o professor concebe a classe especial, reconhecendo nesta as singularidades dos estudantes e respeitando seu ritmo e tempo. Esse entendimento não responsabiliza o professor pela escolarização do estudante, mas parte-se da premissa que a concepção que se tem de uma realidade, direciona o agir dos indivíduos na respectiva realidade. Nesse sentido, a concepção do professor em relação a classe especial, direciona o seu fazer.

Questão 3. Que atividades você costuma realizar com vista à escolarização na classe especial?

\begin{tabular}{|l|l|}
\hline \multicolumn{1}{|c|}{ Sujeitos } & \multicolumn{1}{c|}{ Respostas } \\
\hline Professora 1 & Gincanas, dramatização, eventos culturais, etc. \\
\hline Professora 2 & A socialização dos estudantes. \\
\hline Professora 3 & Atividades intelectuais inserida no contexto atual. \\
\hline Professora 4 & Priorizando e valorizando as atividades intelectuais dos estudantes. \\
\hline Professora 5 & Festividades, eventos, projetos, etc. \\
\hline Professora 6 & $\begin{array}{l}\text { Atividades envolvendo o cotidiano escolar. Tudo é vivenciado de forma prática, } \\
\text { buscando transforma a teoria em prática. }\end{array}$ \\
\hline Professora 7 & Busca-se envolver a comunidade escolar. \\
\hline Professora 8 & Atividades com foco no social do estudante. \\
\hline Professora 9 & Atividades que proporcionem a Participação através da integração social. \\
\hline Professora10 & Envolvendo a família e valorizando as necessidades intelectuais dos estudantes. \\
\hline
\end{tabular}

Quadro 4 - Atividade realizadas com vista a escolarização.

Fonte: próprios autores

As respostas dadas, quando se indaga a respeito das atividades realizadas com vista à escolarização dos estudantes vai reafirmando o pressuposto levantado inicialmente. A medida que se recolhem e as examinam, vai se rematando o distanciamento da escolarização.

Os dados recolhidos junto as Professoras 1, 2, 5, 6, 7, 8 e 9 quando examinados, negam a escolarização e reconhecem a classe especial como espaço promovedor de socialização. A ênfase é dada a situações 
que colocam os estudantes da classe especial em contato com estudantes de classes regulares. de uma Gerência Regional de Educação do Estado de Pernambuco, do processo de escolarização do estudante com deficiência.

As Professoras 3, 4 e 10 se referem às atividades intelectuais, sem contudo, deixar claro se elas tem como foco a escolarização. A intelectualidade do indivíduo é inerente a situações cotidianas e a situações acadêmicas, pois o indivíduo é por natureza um ser biopsicossocial e, nesse sentido, a intelectualidade se faz presente tanto em situações promovedoras de socialização, quanto em situações com foco na escolarização.

Questão 4. Que avanços você percebe na escolarização de estudantes na classe especial?

\begin{tabular}{|l|l|}
\hline Sujeitos & Questão 1. \\
\hline Professora 1 & O principal é a socialização dos estudantes. \\
\hline Professora 2 & A socialização e o querer desenvolver as atividades propostas. \\
\hline Professora 3 & Respeito, autonomia, segurança, amizade e disciplina. \\
\hline Professora 4 & Oralidade, respeito, amizade, disciplina \\
\hline Professora 5 & Dons diferenciados, um estudante toca bateria, outros gostam de trabalhos manuais. \\
\hline Professora 6 & Os avanços são lentos. \\
\hline Professora 7 & A socialização, na minha opinião é o fundamental. \\
\hline Professora 8 & Ao grande desenvolvimento no nível intelectual de aprendizagem \\
\hline Professora 9 & Participação e socialização. \\
\hline Professora10 & Respeito, amizade, amor, família, disciplina. \\
\hline
\end{tabular}

Quadro 5- Avanços percebidos na escolarização.

Fonte: próprios autores

Quando questionadas sobre avanços referentes a escolarização dos estudantes, as Professoras 1, 2, 7 e 9 deram ênfase a socialização, conforme a transcrição a seguir: "O principal é a socialização dos estudantes" (1); "A socialização e o querer desenvolver as atividades propostas" (2); "A socialização, na minha opinião é o fundamental" (7); "Participação e socialização" (9).

Já as Professoras 3, 4 e 10 deram ênfase a condutas e comportamentos que não exclusivos de serem trabalhados na escola, tais como: "Respeito, autonomia, segurança, amizade e disciplina" (3); "Oralidade, respeito, amizade, disciplina" (4); "Respeito, amizade, amor, família, disciplina" (10).

A Professora 5 considerou como avanço na escolarização competências não acadêmicas "Dons diferenciados, um estudante toca bateria, outros gostam de trabalhos manuais". A Professora 6 não mencionou nenhum avanço limitou-se a dizer que "os avanços são lentos". Apenas a Professora 8 respondeu de forma aproximada ao perguntado "ao grande desenvolvimento no nível intelectual de aprendizagem", sem, contudo ter especificado qualquer avanço. 
Frente ao exposto, mais uma vez reafirma-se o distanciamento das classes especiais, de uma Gerência Regional de Educação do Estado de Pernambuco, do processo de escolarização do estudante com deficiência.

\section{CONCLUSÃO}

O referencial teórico, reconhecido por Luna (2002) como filtro para desvelar a realidade, possibilita ao pesquisador dialogar com o objeto de estudo. O diálogo que se institui com o recolhimento e exame das partes, possibilita a construção de inferências acerca do objeto sob investigação, como afirmam Bogdan e Biklen (1994).

Foi com esse entendimento, analisando as partes que se reconheceu a confirmação do pressuposto acerca do problema que originou o estudo. Dizendo de outra forma, que a classe especial na conjuntura da educação especial inclusiva não vem se constituindo em possibilidade de escolarização para os estudantes com deficiência, continua arraigada à crença e valores oriundos do contexto em que emergiu.

A análise dos dados evidencia um distanciamento da escolarização dos estudantes em classe especial. Resume-se a escolaridade a socialização do estudante, dando a entender que para os estudantes com deficiência a escola tem objetivos distintos dos propostos nas Matrizes Curriculares Nacionais para a Educação Básica.

Evidencia também um fazer na classe especial, com vista ao desenvolvimento de condutas e comportamentos que não são exclusivos da escola, ou seja, é a família que cabe a maior responsabilidade em desenvolvê-los.

Esse entendimento dos sujeitos da pesquisa pode ter sua gênese no desconhecimento acerca da escolarização, como direito para o estudante em tela, ou na concepção que tem sobre a classe especial.

A questão que se deixa para reflexão não estar voltada para a extinção de classes especiais, haja vista que esta deve ter ou tem o seu valor pedagógico no que concerne a escolarização do estudante com deficiência, caso contrário não estaria resistindo ao tempo.

A reflexão que se deixa vai à direção de instituí-la como lugar de aprendizagem escolar, para alguns que reconheçam na classe especial, um lugar com possibilidades de atender as suas necessidades educativas, com vista a escolarização. 
O estar e compartilhar do mesmo espaço pedagógico, classe regular, não dever ser uma imposição, mas um direito. As singularidades e necessidades educacionais do público alvo da educação especial são muitas e diferenciadas. Ao estudante e a família deve ser dado o direito de escolha: frequentar a classe especial ou a classe regular. Contudo, qualquer que seja o espaço pedagógico oferecido e escolhido deve se ter como premissa o que é direito de todos e a escolarização é um deles. O limite no desenvolvimento de competências escolares será informado pelo estudante e não prédeterminado pelos responsáveis pela escolarização. Todavia todas as condições e oportunidades para que a escolarização seja efetivada, devem ser garantidas. 


\section{REFERÊNCIAS}

BOGDAN, R. BIKLEN, S. Investigação Qualitativa em educação: uma introdução à teoria e aos métodos. Porto: Porte d.1994. BRASIL. LEI № 9.394. de 20 de dezembro de 1996. Disponível em http://www.planalto.gov.br.

BRASIL, Ministério da Educação. Política Nacional De Educação Especial Na Perspectiva Da Educação Inclusiva, Brasília, 2008.

CARVALHO, Maria de Fátima. O aluno com deficiência intelectual na escola: ensino, aprendizagem e desenvolvimento humano. In MILETTI, Silvia Marcia Ferreira. KASSAR, Mônica de Carvalho Magalhaes. (Org.) - A Escolarização de alunos com deficiências. Campinas, SP: Marcado de Letras, 2013.

GOULART, Cecília. A organização do trabalho pedagógico: alfabetização e letramento como eixos orientadores. In Ensino Fundamental de nove anos: orientação para inclusão de da criança de seis anos de idade. Organização. BEAUCHAMP, Joanete. PAGEL, Sandra Denise. NASCIMENTO, Celia Ribeiro do. Brasília: Ministério da Educação, Secretaria de Educação Básica, 2007.

LUNA, S. V. de. O falso conflito entre tendências metodológicas. In: FAZENDA, Ivani. Metodologia da pesquisa cientifica. São Paulo: Cores. 2002.

MINAYO, M. C. de S. O Desafio do Conhecimento: pesquisa qualitativa em saúde, 7 ed. São Paulo: Hucitec; Rio de Janeiro: Abrasco, 2000.

VALQUES, Carla Karnoppi. BAPTISTA, Claudio Roberto. Os desafios da escolarização de sujeitos com transtornos Globais do desenvolvimento. In MILETTI, Silvia Marcia Ferreira. KASSAR, Mônica de Carvalho Magalhaes. (Org.) - A Escolarização de alunos com deficiências. Campinas, SP: Marcado de Letras, 2013.

SEABRA, G. de F. Pesquisa Cientifica: o método em questão. Brasília: UNB, 2001.

RIBEIRO, Maria Luisa Sprovieri. Perspectivas da Escola Inclusiva: Algumas reflexões. In RIBEIRO, Maria Luisa Sprovieri; BAUMEL, Roseli Cecília Rocha de Carvalho. ( org).

Educação Especial: do querer ao fazer. São Paulo: Avercamp,2003. 


\section{Capítulo 26}

\section{doi $10.37423 / 210604404$}

\section{MEMÓRIA E PATRIMÔNIO:O PRIMEIRO RESGATE DO COMPLEXO INDUSTRIAL TÊXTIL ALAGOANO, FERNÃO VELHO}

Mônica Peixoto Vianna

Débora do Nascimento Oliveira

Joyce Caroline Cavalcante Pantaleão

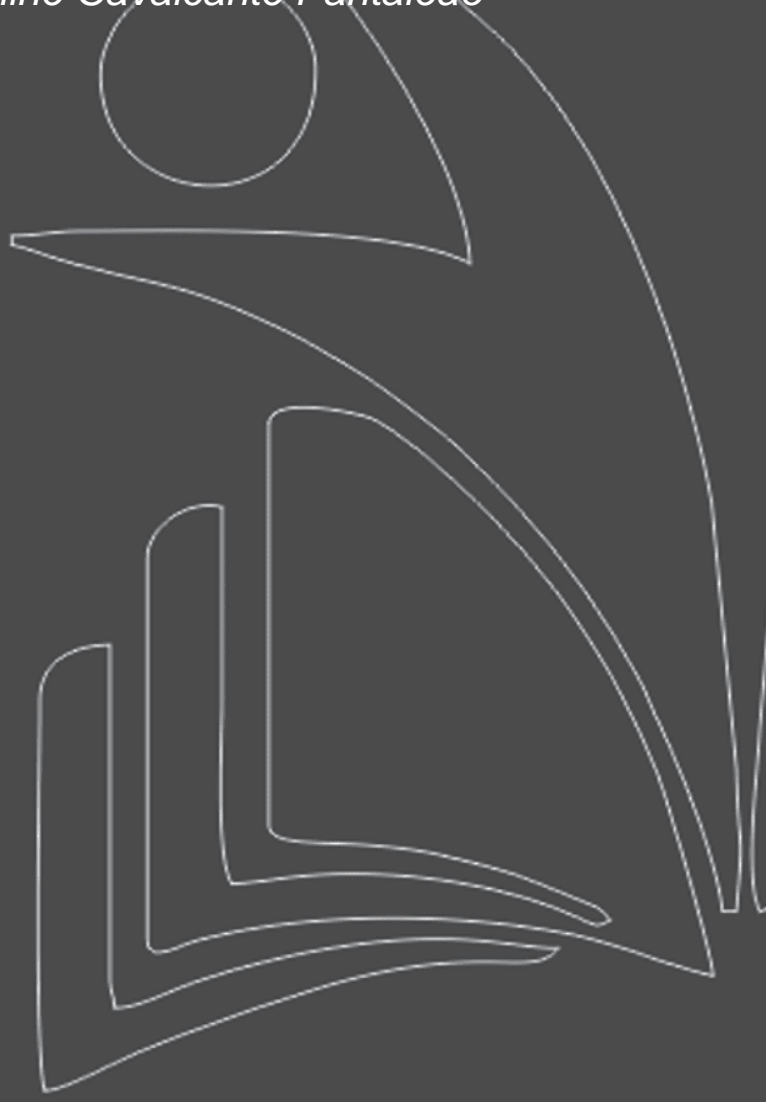

Centro Universitário Tiradentes - UNIT

Centro Universitário Tiradentes - UNIT

Centro Universitário Tiradentes - UNIT

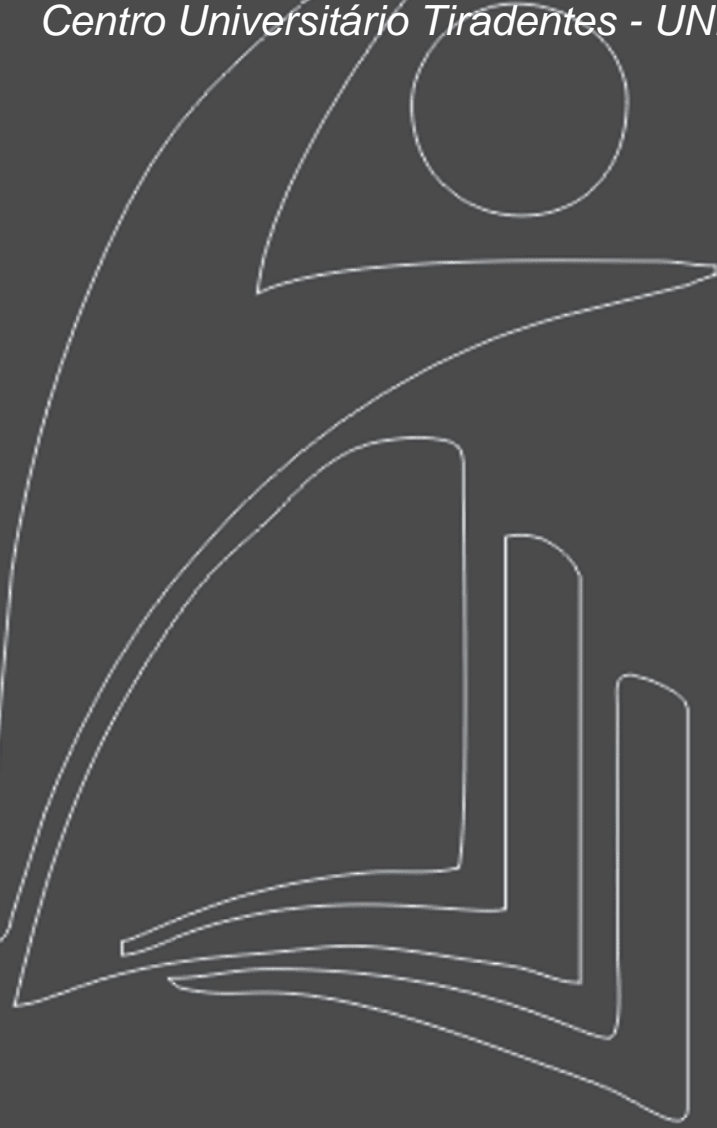


Resumo: O artigo faz um levantamento e estudo da memória coletiva do primeiro complexo industrial têxtil alagoano, Fernão Velho, e daquela que ficou conhecida como "Fábrica Carmen", analisando todos os vestígios da cultura industrial que possuam valor histórico, tecnológico, social, arquitetônico ou científico e que ajudem no enquadramento do antigo núcleo operário como patrimônio industrial alagoano. Dessa forma, o artigo mostra a criação da antiga "Companhia União Mercantil" (atual "Fábrica Carmen") e do núcleo residencial operário de Fernão Velho; discorre sobre os conceitos de história e de memória, sobretudo coletiva, e como ele se aplica ao atual bairro de Fernão Velho, para finalmente entender os conceitos de patrimônio material e imaterial e os elementos que caracterizam o chamado "patrimônio industrial têxtil". Finalmente, o trabalho mostra a importância do resgate dessa memória coletiva, através de exemplares desse patrimônio industrial têxtil existentes atualmente no bairro, para a população local.

Palavras-chave: Patrimônio industrial; Memória coletiva; Fernão Velho. 


\section{INTRODUÇÃO}

O primeiro complexo industrial têxtil da região Nordeste do Brasil foi a atual Fábrica Carmen que originalmente chamava-se "Companhia União Mercantil". Implantada em 1857 por José Antonio de Mendonça, época em que se deu um processo de várias turbulências econômicas no Brasil, que ainda possuía a maior parte de sua mão-de-obra concentrada no trabalho escravo. Esse fato fez com que a antiga "Companhia União Mercantil" se tornasse uma indústria de destaque e pioneirismo, tanto por conta de sua relação trabalhista e de organização social quanto pela sua grande produção de bens econômicos (MARINGONI, 2011).

A região em que foi implantada, localiza-se a noroeste da capital de Alagoas, às margens da Lagoa Mundaú, no atual bairro de Fernão Velho. Sua urbanização se deu quando Dom Pedro II concedeu uma sesmaria a Fernão Dias Velho, sendo os seus primeiros habitantes compostos basicamente por pescadores e coletores de mariscos (TICIANELI, 2016). Quando José Antônio de Mendonça - Barão de Jaraguá - comprou as terras após a morte do fundador do distrito, foi dado ao distrito industrial o nome de seu primeiro dono, forma encontrada para que ele pudesse ser homenageado.

A localização estratégica do bairro de Fernão Velho favoreceu muito todo o processo de desenvolvimento da fábrica e de sua vila operária. Afastada dos bairros já estabelecidos de Maceió, a vila operária que possuía características muito similares às vilas europeias, encontrou espaço adequado para ser instalada ao lado da fábrica, de forma que os trabalhadores pudessem ir ao trabalho sem precisar fazer grandes deslocamentos.

Além da praticidade, isso permitia um maior controle dos patrões com relação aos horários de trabalho e até mesmo a realização das atividades externas nos momentos de folga. De fato a Fábrica foi responsável por trazer desenvolvimento para a região, mas não só econômico, também ofereceu suporte para expansão da cultura e tradição do povo, através da produção de eventos públicos para celebração de datas importantes ou apenas para o lazer da comunidade, um exemplo era a festa de natal que era realizada tradicionalmente todos os anos e reunia todos os moradores do bairro. A maioria das festividades acontecia no prédio do Recreio Operário, que foi construído quando o bairro já estava em domínio do grupo Othon. Hoje, o espaço ainda existe, porém, diferente do que acontecia antigamente os bailes e apresentações artísticas acontecem com muito menos frequência e são organizados pela associação e pelos próprios moradores que se engajam em rememorar e trazer para as novas gerações um pouco do que acontecia ali. 
Além do que já foi mencionado, outro ponto de relevância em Fernão Velho foi a construção da linha ferroviária, que era uma grande necessidade por conta da distribuição de tecidos que acontecia nacional e internacionalmente. Ainda hoje o percurso do trem é feito para a região litorânea da Lagoa Mundaú, sendo o seu destino final o histórico bairro Jaraguá, vale frisar que assim como Fernão Velho o bairro do Jaraguá também apresentava uma significativa relação comercial no seu passado.

Alguns anos depois do falecimento do primeiro proprietário da Fábrica, Barão de Jaraguá, a Companhia União Mercantil foi vendida. O novo patrão, José Teixeira de Machado esteve à frente da Fábrica por duas décadas, tempo em que implantou mudanças significativas, como a criação de novas instalações para acompanhar o processo de aumento da produção dos tecidos, o que acarretou novas contratações e consequentemente veio ampliar a vila operária para abrigar os novos funcionários. Esse momento foi de grande produtividade para toda a atividade têxtil do estado e projetou mundialmente o que era produzido em Alagoas. Segundo Paiva Filho (2013), naquela época, acontecia a exposição do tecido em feiras internacionais, como a exposição de Turim na Itália e isso ajudou a mercadoria da região a ganhar mais respeito e competitividade no Brasil, o que era positivo não somente para Fernão Velho, mas também para outras companhias, como por exemplo a "Companhia Alagoana de Fiação e Tecidos".

Depois de José Teixeira Machado, Doutor Antônio de Melo Machado e Doutor Arthur de Melo Machado, sucederam o pai até o ano de 1938, mantendo de maneira satisfatória as atividades da fábrica e todo o funcionamento do bairro. De acordo com Farias (2012), foi durante o ciclo mencionado anteriormente que o número de teares, por exemplo, se multiplicou significativamente de 80 para 1000, o que deixava claro o momento de excelência que vivia a indústria no início do século XX. Embora esse crescimento fosse extremamente positivo nem tudo se desenrolou bem para a companhia, já que começaram a existir divergências nas decisões dos proprietários. Essas situações conflitantes somadas ao fato de que a indústria têxtil brasileira estava vivenciando uma crise afetou diretamente Fernão Velho, fazendo com que a fábrica viesse a ser vendida em 1938 para a família Leão (FARIAS, 2012, p. 31).

Os novos donos ampliaram a Fábrica com novos maquinários e começaram a oferecer ainda mais suporte e assistência social aos operários. Criaram por exemplo uma quadra de jogos, onde os operários poderiam realizar eventos esportivos (FARIAS, 2012, p. 32). Isso gerou diversas oportunidades para participar de competições e complementar as formas de lazer. Além dos esportes, dos bailes e festas tradicionais que aconteciam, existia também o Cine Teatro São José onde passavam 
filmes clássicos e aconteciam apresentações com atores famosos da época, logo, percebe-se que o bairro era um local bastante animado e com boas opções de lazer.

Porém, em 1943, a família Leão vendeu a fábrica para o Grupo Othon. Uma das primeiras ações que o grupo tomou foi modificar o nome para Fábrica Carmen. O complexo fabril agora pertencente à nova família passou por importantes mudanças na infraestrutura, "como drenagem e calçamento do povoado" e a construção do Recreio Operário em 1948 (SILVA; PALMEIRA, 2010, p. 08). Othon Lynch Bezerra de Mello e seu grupo, foi o proprietário que passou mais tempo na direção dos trabalhos têxteis, vivenciando diversos momentos de positividade econômica, até o período sua decadência que acabou levando ao fechamento da Fábrica.

Alguns moradores relatam que o fechamento da Fábrica aconteceu principalmente pela falta de um maior investimento na modernização o que acabou por não permitir o acompanhamento do ritmo das outras fábricas brasileiras, mas isso divide opiniões.

Após o fechamento da Fábrica diversas pessoas do bairro ficaram sem trabalho, depois de passar grande parte da vida se dedicando ao trabalho fabril. Segundo Farias (2012), o Governo não deu nenhum suporte para os operários desempregados e, apesar da dificuldade para conseguir novas atividades, os homens ainda conseguiam com maior facilidade arrumar empregos temporários ou no ramo da construção civil, mas as mulheres em sua maioria não foram aceitas no mercado e ficaram sem grandes expectativas.

Atualmente, o bairro ainda sofre com o abandono do poder público em várias situações, como é o caso da coleta de lixo e limpeza geral do bairro, mas existem moradores que se dedicam muito em prol da realização de melhoramentos e preservação da memória do bairro. Algumas casas na vila operária ainda possuem características estéticas preservadas, outras foram modificadas e adequada para as necessidades dos moradores. A maior parte dos moradores do bairro estão lá desde que trabalhavam na Fábrica, mas já existem novas gerações e novos estilos de vida se formando. A atividade econômica está principalmente concentrada em pequenos estabelecimentos comerciais no bairro, já que a pesca e coleta de mariscos foi muito afetada pela poluição da lagoa. Existe também na região um criatório de jacarés Mister Cayman, que tem exportado couro para o exterior e possui bastante potencial para expansão, prometendo futuramente empregar alguns moradores do bairro e movimentar a economia local. 


\section{FERNÃO VELHO COMO “PATRIMÔNIO INDUSTRIAL TÊXTIL” DE ALAGOAS}

De acordo com a Constituição Federal de 1988, Artigo 216, patrimônio cultural são bens "de natureza material e imaterial, tomados individualmente ou em conjunto, portadores de referência à identidade, à ação, à memória dos diferentes grupos formadores da sociedade brasileira". O conceito de patrimônio no Brasil, inicialmente estabelecido pela Constituição de 1937, não reconhecia os bens de caráter imaterial como patrimônio, e tinha sua definição limitada a apenas bens históricos e artísticos, porém, com a mudança na Constituição de 1988, o conceito de patrimônio foi ampliado, incorporando os bens de caráter material e imaterial e estabelecendo outros meios de preservação, como o Registro e o Inventário, além do Tombamento que já era vigente. A mudança na Constituição foi essencial para garantir as gerações futuras conhecer o seu passado, através de bens materiais e imateriais que representam a história, cultura, as tradições e identidade do seu povo.

Patrimônio é tudo o que criamos, valorizamos e queremos preservar: são os monumentos e obras de arte, e também as festas, músicas e danças, os folguedos e as comidas, os saberes, fazeres e falares. Tudo enfim que produzimos com as mãos, as ideias e a fantasia (LONDRES, 2001).

De acordo com o Decreto-Lei no 25/1937, os bens de natureza material são bens palpáveis, podendo ser móveis ou imóveis, cuja preservação seja de interesse público, como edificações, cidades históricas, sítios arqueológicos e paisagísticos, acervos, documentos, entre outros. Já o patrimônio imaterial, é passado de geração em geração e está relacionado aos saberes, técnicas, práticas, habilidades, manifestações culturais, festas e rituais que fazem parte da vivência de um lugar ou até mesmo locais como mercados e feiras que abrigam práticas culturais coletivas.

O patrimônio cultural é a herança que os moradores possuem de um lugar, e a sua preservação contribui para a permanência dos bens em bom estado e consequentemente asseguram para as gerações futuras o contato com a identidade do local que elas estão inseridas. A preservação desses bens não é somente responsabilidade do IPHAN, mas também requer zelo e cuidado de todas as pessoas, que são responsáveis também por transmitirem esse patrimônio e deixar um legado para as gerações que virão.

Patrimônio industrial é um conceito mais recente, comparado aos outros grupos de patrimônio existente. Ele surgiu em meados dos anos de 1950 após alguns importantes exemplares de arquitetura industrial mundiais serem demolidos. Com a Revolução Industrial muitas cidades passaram por mudanças arquitetônicas, econômicas, trabalhistas, que marcaram gerações, com isso foi constatado 
a importância de se preservar alguns exemplos de bens industriais, como parte de uma identidade populacional.

Essa ampliação do bem cultural, englobando os aspectos industriais, se deu de forma tardia no Brasil e até os dias atuais ainda é pouco disseminada, possuindo poucos esforços para tornar esses vestígios de cultura industrial, de fato, patrimônio. De acordo com a Carta de Niezhny Tagil (2003) os edifícios, fábricas, moinhos, máquinas a vapor, as formas de produção, meios de transportes, estrutura e infraestrutura e os lugares aonde foram desenvolvidas essas atividades, como as habitações fazem parte dos vestígios industriais que possuem valor histórico, tecnológico, social, arquitetônico ou científico.

A arqueologia industrial é um instrumento que busca investigar os vestígios, materiais e imateriais, de cultura industrial afim de entender como se deu o desenvolvimento das indústrias e a transformação das cidades em consequência desse processo e a importância da sua preservação para a identidade do povo, conservando e preservando a cultura e história do local.

A “Fábrica Carmem" foi implantada no bairro de Fernão Velho em 1857, como Companhia União Mercantil. Na época em que foi inserida se destacou pelo seu maquinário moderno, qualidade de produção e pela relação com os trabalhadores, modificando um cenário escravo para assalariado. Trouxe modernidade e urbanização para o bairro, por causa da sua relevância política e econômica, oferecendo emprego para os moradores, moradia, acesso a saúde, festividades e eventos proporcionados pelo dono da Fábrica.

Devido às inúmeras benfeitorias que a Fábrica trouxe para o bairro e para as famílias ali inseridas, além da forma de vida que foi modificada e as novas tradições adquiridas com a implantação da fábrica, a maioria deles a tem como parte da história e da identidade local. A Fábrica Carmem teve grande importância para o desenvolvimento de Fernão velho e Alagoas, trazendo crescimento e evolução ao bairro na época em que foi inserida.

Como já foi citado anteriormente, os vestígios industriais são considerados patrimônio quando possuem valor histórico, tecnológico, social ou arquitetônico. Com base nessa definição foram analisados os elementos e a importância da Fábrica Carmem para os moradores de Fernão Velho, o que levou a concluir a importância dela para a história do bairro.

De acordo com a Carta de Nizhny Tagil (2003), um dos valores do patrimônio industrial é o valor social como parte do registro da vida das pessoas, gerando um sentimento de identidade e apropriação pelo 
lugar. Além disso, a preservação do patrimônio industrial representa o testemunho das atividades e técnicas históricas que eram utilizadas. E por ser uma fábrica pioneira no Nordeste, ela deve ser cuidadosamente avaliada e protegida.

Ainda de acordo com a Carta, ela fala sobre a importância de identificar e proteger os vestígios industriais para que as gerações futuras possam ter contato com a história local e fala também sobre a importância de se preservar a memória da população que trabalhou na fábrica ou que teve alguma relação com ela, arquivando em inventários, com fotografias e desenhos.

Depois das análises feitas e de tomar conhecimento das definições de patrimônio industrial, pode-se concluir que a Fábrica Carmem se enquadra como patrimônio industrial têxtil devido a sua relevância na geografia em que está inserida e da sua importância para a história, cultura e identidade do bairro.

\section{HISTÓRIA X MEMÓRIA INDIVIDUAL X MEMÓRIA COLETIVA}

Seria impossível falar sobre memória e mais especificamente sobre a memória coletiva, sem mencionar a história e a relação dos indivíduos com ela. Desde o passado, no nascimento das sociedades ocidentais, segundo Le Goff (1996), a ciência histórica se definia em relação à realidade, porém essa realidade é observada de forma totalmente diferente quando vista através de outras ciências. No caso da história se observa através do relato de determinados indivíduos, que viram e sentiram tais acontecimentos, os testemunhos que comprovam a história. Porém, essa forma de comprovação pode ser considerada muito menos objetiva e precisa, já que existem diversos pontos de vista e sentimentos distintos sobre o mesmo fato. Contudo, os relatos desde a antiguidade são registrados em escritos documentados, vale ressaltar que para Le Goff (1996) o documento é monumento e sobretudo questionável e proveniente de análise crítica. O mesmo, afirma que a forma de reunir testemunhos diminuiu as limitações que aconteciam por meio da transmissão oral e desde que as bibliotecas começaram a existir e abrigar tudo que foi documentando, criou-se a possibilidade da disponibilidade de consultas, tornando mais concreto os materiais da ciência histórica.

O afastamento da história vivida da história natural, acabou permitindo o surgimento da filosofia da história. Para ele, desde o início do século passado vem se desenvolvendo a ciência histórica, que estuda a história da história. Dessa forma, diversos historiadores e filósofos desde a Antiguidade e seus primeiros registros, se esforçam para recolher fatos, definir leis e de fato fazer dela uma ciência. Com essas inúmeras tentativas é que vieram as mais diversas teorias, que trouxeram a possibilidade de reflexão e comparação das sociedades e estruturas, causando o que chamou de "alargamento da 
história do mundo" e que permite que a história não seja novamente vista como apenas um relato sem comprovação (LE GOFF,1996).

A história e o tempo são impossíveis de serem dissociados, afinal a cronologia é fundamental para a construção histórica, seja ela de uma experiência individual ou coletiva. É o tempo que alimenta a história através dos acontecimentos gerados e vividos por indivíduos e suas memórias. Quando se analisa os dados da filosofia histórica se observa a duração do fato e seu tempo de forma subjetiva ou simbólica. Ou seja, é fato que o tempo histórico encontra o tempo da memória e assim é alimentado (LE GOFF, 1996).

É seguindo isso que fica possível se falar sobre história e memória social, se aproximando mais diretamente da relação dos indivíduos que constroem a história. O estudo da memória social é fundamental para abordar as problemáticas do tempo e da história, onde a memória sempre está de alguma forma relacionada a isso, mesmo que sutilmente (LE GOFF, 1996). Vale ressaltar também que a memória social está atrelada e até fundamentada na memória coletiva.

Para Halbwachs (1990), a memória coletiva se relaciona com a memória histórica, com o tempo, o espaço e principalmente com a sociedade. Ele afirma que ninguém se recorda de nada sozinho, é a sociedade que tem esse papel de lembrar e de fazer viva a memória. "Um homem que se lembra sozinho daquilo que os outros não se lembram assemelha-se a alguém que vê o que os outros não vêem" (HALBWACHS, 1990 p.228).

A consciência social orientou o pensamento de Halbwachs (1990), ele afirmou que as pessoas são seres sociais que de alguma forma sempre estão confinados a sociedade (HALBWACHS, 2006). Isso pode ser visto como um ciclo natural e involuntário, recebe-se pensamentos e memórias de outras pessoas e enxerga-se muito a partir de referências que foram recebidas, é como se não existisse de fato um pensamento individual único e exclusivo, mas correntes de pensamentos que foram desenvolvidas a partir do pensamento de outras pessoas.

Segundo Halbwachs (1990) é também assim que acontece com a memória, quando se lembra determinada coisa essa memória já surge como um ponto de vista cheio de referências de um determinado grupo do qual se faz parte. Partindo desse princípio, memórias são também influenciadas por grupos, o que levanta o questionamento de que a memória individual é quase inexistente. Halbwachs (1990) chamou de "intuição sensível”o que seria a memória individual genuína, sem influência coletiva o que é quase impossível, mas para o autor não deve ser descartado. Seguindo isso, deve-se levar em consideração que desde sempre o indivíduo é influenciado, como por exemplo nas 
memórias da infância, essas já chegam através do ponto de vista do grupo familiar, da sensação e da lembrança de várias pessoas que estavam no momento ou que se recordam do ocorrido. Se um único indivíduo narra um fato onde apenas ele vivenciou o momento, após um tempo vários pensamentos serão questionados se foram de fato como se recorda, já que não existia na ocasião uma outra pessoa para fundamentar e tornar viva a memória do acontecimento, o mesmo não acontece com uma memória coletiva onde se apresentam várias visões sobre o mesmo fato e detalhes do contexto, permitindo que a memória seja sustentada e muito mais detalhada.

Então, pode-se dizer que cada memória individual é um ponto de vista sobre uma memória coletiva (HALBWACHS, 2006). Quando se tenta explicar essas diferenças de ponto de vista volta-se a questão da influência dos tantos pensamentos da sociedade. Um estado que parece pessoal e revela complexo e cheio de fragmentos. O autor afirma que essa nossa sensação de unidade aparente é natural. Segundo ele, muitos filósofos mostram que o sentimento de liberdade poderia se explicar através do que ele chama de "séries causais" que se combinam para formar uma ação.

A partir disso fica evidente que não pode ser considerada memória coletiva a memória vinda de uma única pessoa, pois são necessários diferentes relatos e pontos de vista distintos sobre o mesmo acontecimento para que com essa junção de memórias individuais se forme uma nova e mais complexa memória, capaz de sustentar a história e tradição de um determinado povo. São os aglomerados de memórias registradas que fazem com que se tenha acesso a acontecimentos e situações que seriam impossíveis de serem conhecidos caso não existissem registros. É totalmente insuficiente ouvir uma única classe social, ou apenas um grupo de pessoas para entender e coletar fatos de uma cultura que em sua estrutura é formada por vários grupos, com infinitas especificidades e experiências diferentes, ouvindo apenas uma classe ou um determinado grupo de indivíduos muito seria perdido.

Cada memória é relevante, já que cada indivíduo possui seu ponto de vista, sua identidade, suas recordações e vivencias distintas. Segundo Le Goff (1996), deve-se tratar a memória para que ela sirva de libertação e não para a servidão dos homens. Por isso, a memória não deve ser manipulada por um governo, todos os lados precisam ser avaliados criticamente e posteriormente disponibilizados para consulta, mostrando comprovações e embasamento sempre que possível e assim possibilitando maior veracidade e opiniões coletivas. 
Porém, ainda que existam os registros, a memória precisa ser rememorada e não apenas registrada, é preciso que, além de preservada, seja veemente mencionada, mostrada as novas gerações ao passar dos anos para que nada se perca.

Para Halbwachs (2006), a memória existe na medida em que se forma um senso de pertencimento em um grupo, criado pelos laços afetivos que foram desenvolvidos por eles. Já Pollak (1989), acredita que o sentido social da memória e o senso de pertencimento dos grupos favorece a criação de uma identidade, que também está liga aos espaços e objetos que estão presentes nas memórias. Dentro desse ponto de vista, a identidade se liga à história vivida e diretamente à memória de um determinado grupo social.

\section{A MEMÓRIA COLETIVA DO PRIMEIRO BAIRRO FABRIL DE ALAGOAS}

Fernão Velho pode ser considerado um lugar de memória, seguindo a perspectiva de Nora (1981), que cita "lugares de memória" como espaços que devem ser construídos para guardar as tradições, vivências e costumes para assim os proteger do esquecimento.Partindo disso e, trazendo as reflexões e conceitos mencionados anteriormente para a realidade do bairro de Fernão Velho, é imprescindível começar pela história do bairro segundo a memória coletiva dos grupos sociais de diversas gerações que lá se encontram.

A memória coletiva de Fernão Velho está viva e presente no bairro, embora muito se tenha perdido desde o fechamento da Fábrica Carmen. A memória e algumas das muitas tradições não foram perdidas. É perceptível na maioria dos relatos sobre os tempos de funcionamento da Fábrica que os trabalhadores lembram com muito carinho e saudosismo daquela época. Embora existam discordâncias com relação a estabilidade econômica em que os trabalhadores viviam, nenhum discorda sobre as histórias felizes vividas.

No local ainda existem diversos moradores que continuam rememorando os acontecimentos e tradições. São detalhes, como as cores e elementos das fachadas das construções, sons como o que as máquinas faziam e segundo moradores antigos davam para serem ouvidos em todo o bairro, o clássico toque da Fábrica, que segundo relatos era o apito que tocava sempre que deveriam acontecer as trocas de grupos de trabalho, apito esse que pontualmente acabava orientando os moradores das horas do dia, o cheiros característicos do lugar, o costume de conversar nas portas das residências e se encontrar na praça no final do expediente, etc. Esses e muitos outros detalhes ainda mais sutis estão presentes carinhosamente na memória dos moradores. 
FIGURA 01: Operários saindo da Fábrica após expediente.

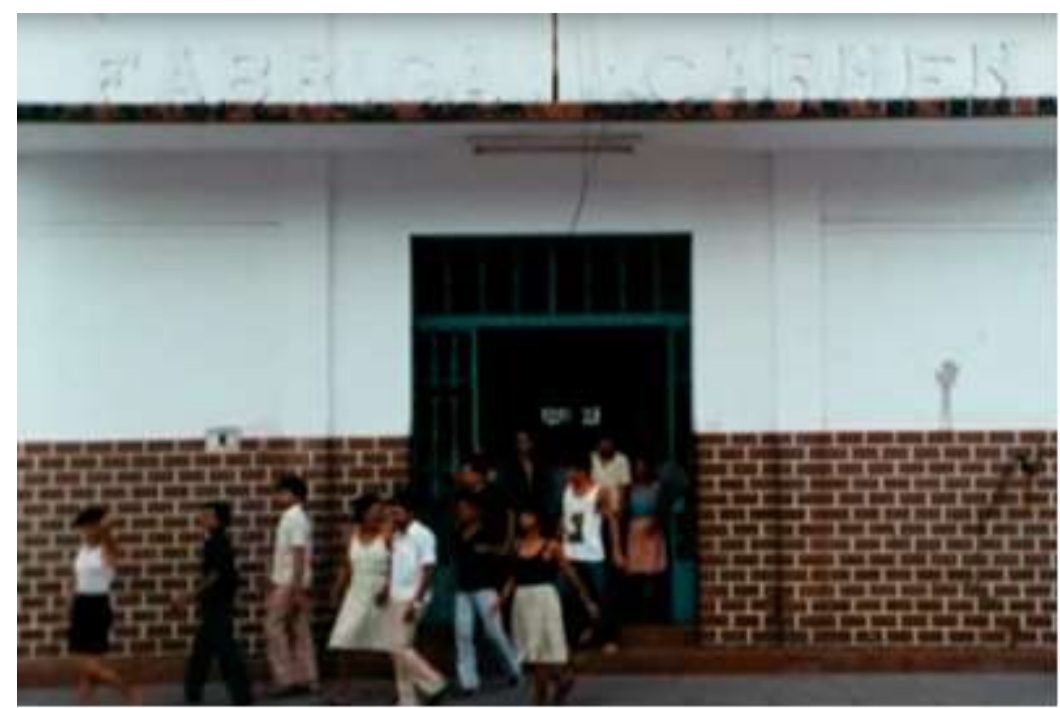

Fonte: Documentário Memória da Vida e do Trabalho.Publicado em: 6 de Nov de 2012.

Na imagem apresentada anteriormente é relevante mencionar a diferença entre olhar as imagens antes e depois de ouvir os relatos dos moradores. É interessante que após os relatos, ao observar as imagens, automaticamente se cria a vontade de estar presente naquele momento e ouvir os ruídos e sensações que agora são possíveis de serem imaginados.

Fica comprovada a incrível capacidade que a memória coletiva tem de fazer com que de alguma forma até quem não viveu determinado momento consiga se aproximar de sentimentos e situações vividas anteriormente. É como se fosse possível vivenciá-los tamanha a proximidade que o compartilhamento das memórias possibilita.

É relevante frisar que até mesmo as mudanças que parecem pequenas modificaram completamente a vida dos trabalhadores e moradores. Os mais antigos dizem sentir tanta falta do toque da Fábrica que até hoje os dias da semana e as horas não parecem mudar. O ritmo de vida também foi consideravelmente alterado, embora o bairro sempre tenha sido calmo, as atividades da Fábrica traziam uma rotina bastante ativa, considerada por alguns muito corrida e árdua, e por outros tão prazerosa que nem parecia tão cansativa quanto era.

Embora as horas de trabalho fossem intensas e as condições nem sempre favoráveis, muitos dos que trabalharam por anos tecendo, engomando ou desenvolvendo alguma das etapas na produção ou funcionamento da Fábrica também narram com muito orgulho as atividades que executavam e demonstram enorme satisfação pela contribuição que davam para os resultados.Olhando de certo ângulo e seguindo o que foi relatado no documentário "História de Fernão Velho" era como se os 
indivíduos vivessem de fato em função da Fábrica, porém, para alguns isso era considerado bom e para outros apesar dos pontos positivos se enxergava uma situação de domínio.No documentário alguns demonstram sua insatisfação por conta da relação de dependência que os donos da Fábrica criavam nos trabalhadores, relação que a primeira vista parecia uma ajuda e até mesmo incentivo, como os vales que eram fornecidos quando os trabalhadores necessitavam de algum dinheiro, e descontados do salário posteriormente, além disso, era de certa forma cobrada uma exclusividade na prestação de serviço, porém, para complementar a renda muitos depois da carga horária que cumpriam na Fábrica ainda trabalhavam no roçado ou pesca para conseguir sustentar suas famílias.

O fato é que o trabalho fabril em Fernão Velho é impossível de ser dissociado da memória coletiva, pois os trabalhadores passaram boa parte dos seus dias seguindo aquela rotina e criando várias de suas histórias e memórias ali. Mas, além do serviço os donos da Fábrica ofereciam diversas opções de lazer e cultura para os trabalhadores e suas famílias. As memórias atreladas a esses acontecimentos são comentadas por todos com muita satisfação.

Segundo os moradores de diversas gerações que acompanharam o funcionamento da Fábrica na década de 1940, uma de suas épocas mais positivas, eram produzidos tradicionalmente todos os festejos e datas comemorativas, como a grande festa de Natal, Carnaval, festejos juninos e até comemorações mais típicas da cultura local, como apresentações de Pastoris locais, danças folclóricas como Caboclinhos, Cheganças, apresentações de baianas e muitas outras atrações que também eram trazidas de outros locais para enriquecer ainda mais as festividades e possibilitar a troca de culturas.

FIGURA 02: Festejos tradicionais do bairro de Fernão Velho, na época em que a Fábrica ainda estava em funcionamento.

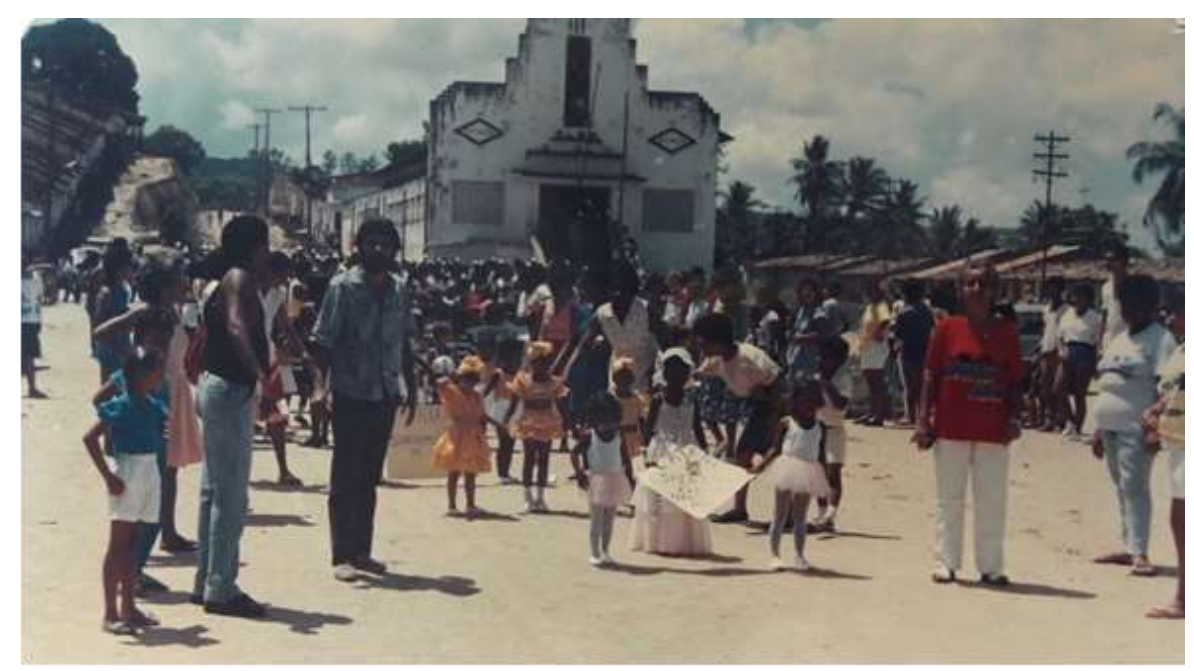

Fonte: Acervo do morador Plínio Claudenes Alves da Rocha (s.d.). 
FIGURA 03: Vila Operaria antigamente.

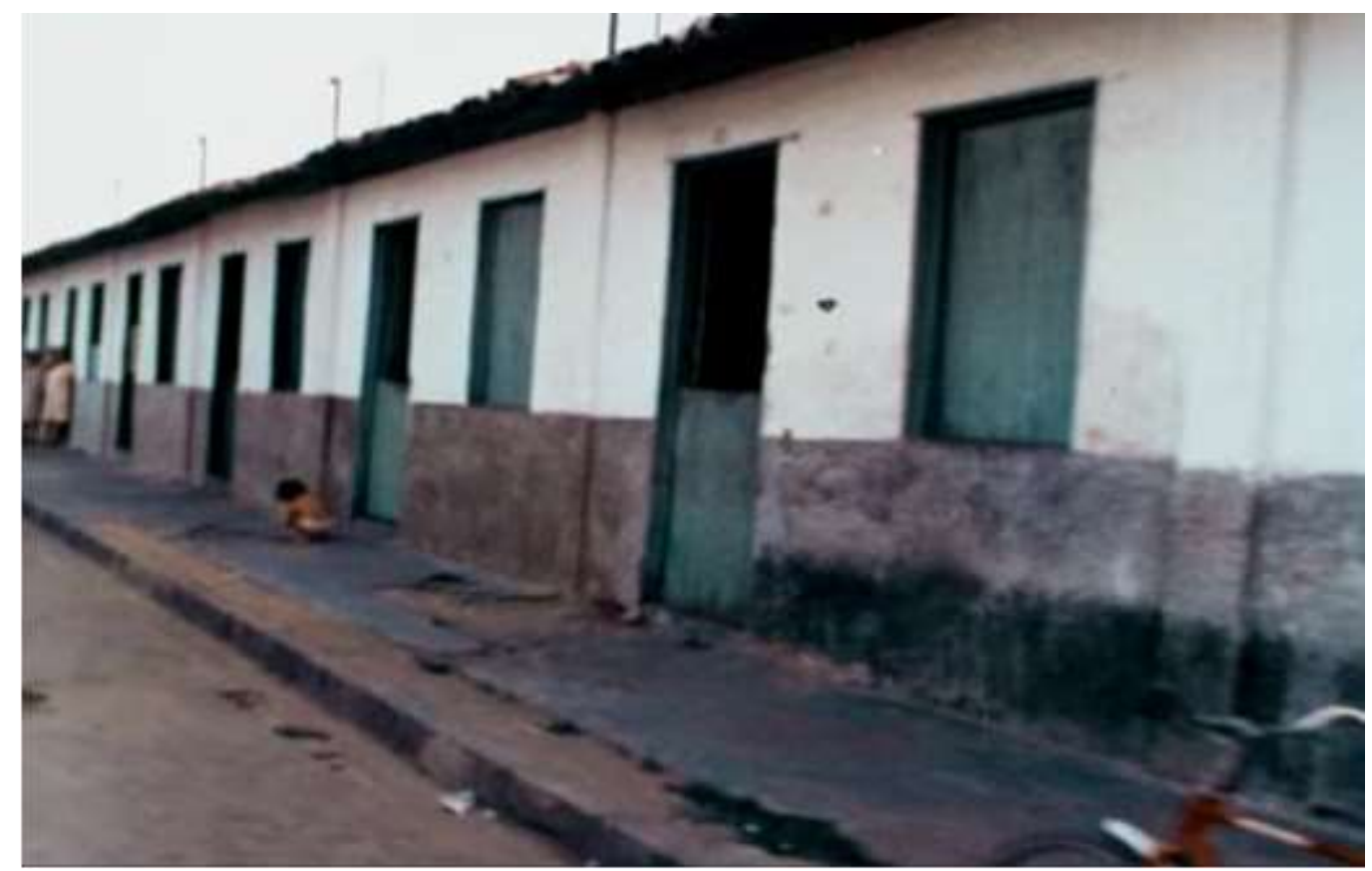

Fonte: Documentário Memória da Vida e do Trabalho. Publicado em 6 de Nov de 2012.

FIGURA 04: Vila Operaria atualmente.

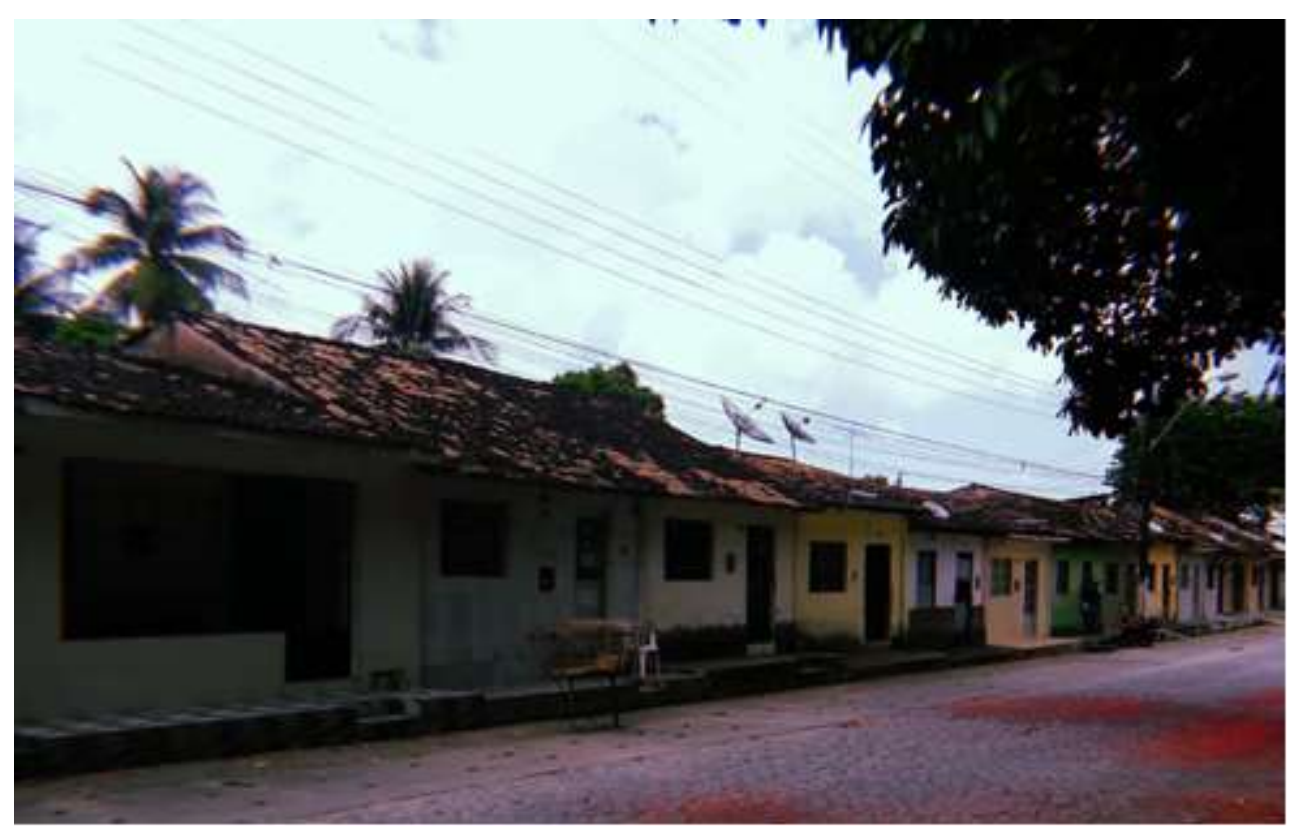

Fonte: acervo pessoal.

Comparando as duas fotos anteriores (Fig. 03 e 04), pode-se notar a diferença estética na fachada das casas da Vila Operária. Embora continuem miscigenadas, os elementos da fachada foram modificados pela maioria dos moradores, adequando as suas necessidades e preferências, diferente do acontecia antigamente, quando as casas recebiam o mesmo tratamento e seguiam uma mesma linguagem 
estética de cores e elementos das fachadas. No restante do bairro algumas outras construções tiveram sua estética preservada pelos donos, alguns modificaram apenas as cores, outros optaram por manter todos os elementos da fachada na tentativa de realmente deixar viva a memória do local e eternizar os elementos que também são significativos e contam a história do lugar.

Embora muito tenha se perdido nos últimos anos, alguns moradores ainda lutam incansavelmente pela preservação da memória do local e de tudo que ainda resta. São muitos os que reconhecem a importância da história e se empenham para continuar compartilhando com as novas gerações, buscando desenvolver também nos mais novos um senso de pertencimento pelo local, suas tradições e toda a memória coletiva. Pensando nisso a associação dos moradores e os próprios moradores estão sempre tentando conseguir apoio dos órgãos públicos para realizar ações no bairro.

Através das visitas feitas, foi possível relatar que Fernão Velho continua sendo o palco para alguns eventos. Em 2019 sediou a abertura do São João de Maceió, recebendo atrações e shows que movimentaram o bairro, somente o tradicional "Trem do Forró" que acontece através de uma parceria da prefeitura com a CBTU foi cancelado nesse ano, mas as outras atrações foram mantidas. Além do festejo junino, nos dias 1, 2 e 3 de agosto de 2019, aconteceu a primeira FLIFEV - Festa Literária de Fernão Velho, o evento transformou toda a Praça São José em um espaço de incentivo à cultura, educação e preservação histórica. Acontecimentos como esse são extremamente importantes e tornam cada vez mais possível o desenvolvimento do bairro e sua preservação. Muitos artesãos locais também participaram da Festa Literária, mostrando como a cultura no bairro é relevante e merece ser valorizada. Segundo relatos dos próprios moradores existem planos para futuras exposições em Fernão Velho, onde serão expostos os trabalhos de artistas locais, buscando assim trazer mais gente para vivenciar o bairro e dar visibilidade e incentivo aos artistas. Vale ressaltar também, que além desses eventos, por conta própria os moradores realizam atividades culturais, como por exemplo, a exibição de documentários sobre a história do bairro e apresentação de fotos e de todo o acervo que alguns moradores preservam. Iniciativas como essa fortalecem a memória coletiva e permitem uma eterna rememoração, já que através disso as novas gerações entram em contato com todos os acontecimentos e tradições passadas.

\section{CONSIDERAÇÕES FINAIS}

Após quase um ano de pesquisa dedicada ao patrimônio e memória coletiva do bairro de Fernão Velho, foi possível compreender melhor sobre toda história desde que o bairro era o antigo núcleo 
operário da pioneira "Companhia União Mercantil" (atual "Fábrica Carmen") até o fechamento da Fábrica e como isso interferiu diretamente na vida dos moradores e no funcionamento do bairro. Foi possível também entender os elementos da cultural industrial e comprovar que se pode de fato caracterizar o bairro como patrimônio industrial têxtil de Alagoas.

Através da aproximação da história, vivência no local e dos relatos informais de seus moradores ficou evidente a força e importância da memória presente no bairro de Fernão Velho e como muitos de seus moradores tentam preservar e relembrar as memórias, tradições e cultura riquíssima do local. Esse contato permitiu aplicar os conceitos de memória, principalmente coletiva, que foram levantados através da bibliografia, iconografia e áudio visual e fazer uma análise totalmente fundamentada no que foi visto no bairro, relacionando com a realidade local. Foi possível também identificar os problemas e potenciais do bairro, levando sempre em consideração o sentimento dos moradores diante das mudanças e adequações que tiveram que fazer para viver a nova realidade.

Percebeu-se que, embora todos relatem a insatisfação por conta do futuro indefinido do prédio da Fábrica, e que mencionem alguns pontos negativos como o abandono por parte das políticas públicas que acaba dificultando o bom funcionamento do bairro, a maioria dos moradores relata gostar bastante de morar no local, principalmente pela tranquilidade e por todas as histórias de diversas gerações que continuam de alguma forma presentes. É visível que apesar das inúmeras mudanças que aconteceram com o fechamento da Fábrica, tanto na dinâmica do bairro quanto da vida dos moradores, por parte de muitos ainda se preserva o mesmo sentimento que se tinha nos melhores anos de funcionamento da Fábrica.

\section{SOBRE O TRABALHO}

Esse artigo é fruto de uma pesquisa realizada entre 2018-2019 como Iniciação Científica de duas alunas do curso de arquitetura e urbanismo do Centro Universitário Tiradentes (UNIT), sob orientação da profa. Dra. Mônica Peixoto Vianna (e-mail: monica_vianna@yahoo.com) e que teve o apoio do programa PROVIC para a sua realização. 


\section{REFERÊNCIAS BIBLIOGRÁFICAS}

BRASIL. DECRETO-LEI № 25, DE 30 DE NOVEMBRO DE 1937. Disponível em:

http://www.planalto.gov.br/ccivil_03/Decreto-Lei/Del0025.htm. Acesso em: 10 de junho de 2019.

CARTA DE NIZHNY TAGIL SOBRE O PATRIMÔNIO INDUSTRIAL - TICCIH, 2013. Disponível em: www.ticcih.org. Acesso em: janeiro de 2019.

CONSTITUIÇÃO FEDERAL DE 1988. Artigo 216. Disponível em:

https://www.senado.leg.br/atividade/const/con1988/CON1988_05.10.1988/art_216_.as. Acesso em: 10 junho 2019.

DOCUMENTÁRIO MEMÓRIA DA VIDA E DO TRABALHO - PARTE 1. Estrela do Norte. Publicado em 6 de Nov de 2012.Disponível em: https://www.youtube.com/watch?v=y8JT_SWJiOI\&t=93s. Acesso em: 20 de julho de 2019.

DOCUMENTÁRIO MEMÓRIA DA VIDA E DO TRABALHO - PARTE 2. Estrela do Norte. Publicado em 12 de Nov de 2012. Disponível em: https://www.youtube.com/watch?v=Q1nWXTRrVJs\&t=187s. Acesso em: 20 de julho de 2019.

FARIAS, Ivo dos Santos. Dominação e resistência operária no núcleo fabril de Fernão Velho/AL (19531962). 2012. 115 f. Dissertação (Mestrado em Sociologia) - Instituto de Ciências Sociais, Universidade Federal de Alagoas, Maceió, 2012.

HALBWACHS, Maurice. A memória coletiva. Tradução: Beatriz Sidou. São Paulo: Centauro, 2006.

HALBWACHS, Maurice. A memória coletiva. Tradução: Laurent Léon Schaffter. São Paulo: Vértice, 1990 IPHAN. Instituto do Patrimônio Histórico e Artístico Nacional. Disponível em:

<http://portal.iphan.gov.br/>. Acesso em: 26, out., 2018.

LE GOFF, Jacques. Memória. In: . História e Memória. 2 ed. Campinas: Editora da Unicamp, 1996

LONDRES, Cecília (org.). Revista Tempo Brasileiro n. 147: Patrimônio Imaterial. Rio de Janeiro, out./dez., 2001.

MARINGONI, Gilberto. História - Império de crises. Disponível em:

http://desafios.ipea.gov.br/index.php?option=com_content\&view=article\&id=2572: catid=28\&ltemid =23. Acesso em: 17 de fev. 2018.

NORA, Pierre. Entre a memória e a história: a problemática dos lugares. Tradução: Yara AunKhoury. Projeto História. São Paulo: PUC, 1981.

PAIVA FILHO, Arnaldo. Rio Largo: cidade operária. Maceió: SENAI/AL, 2013.

POLLAK, Michael. Memória, esquecimento, silêncio. Tradução: Dora Rocha Flaksman. Estudos Históricos. Rio de Janeiro, v. 2, n. 3, 1989. 
SILVA, J. D. do N.; PALMEIRA, Maria Verônica L. Heranças e Transformações de um Bairro Industrial: o caso de Fernão Velho, Maceió-AL. In Segundo Seminário de Patrimônio Agroindustrial - Lugares de Memória, 2010. Anais... São Carlos, 2010. p.1-16.

TICIANELI, Edberto. O Natal de Félix Lima Júnior em Bebedouro. Disponível em: <https://www.historiadealagoas.com.br/o-natal-de-felix-lima-junior-em-bebedouro.html> Acesso: 10 de janeiro de 2019. 


\section{Capítulo 27}

doi $10.37423 / 210604406$

\section{REFLEXÕES SOBRE A TRAJETÓRIA DA MULHER NO CAMPO ESPORTIVO}

Ester Gomes Bernabé

Raquel Quirino

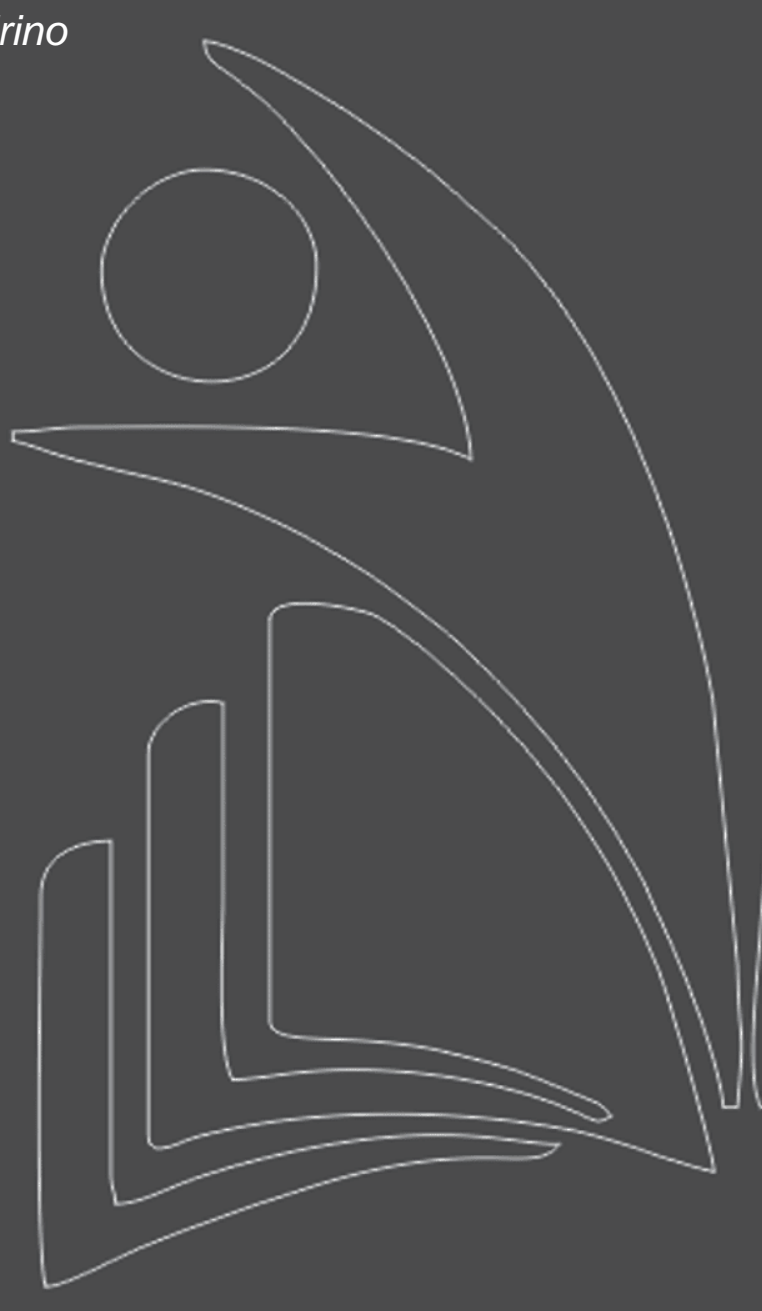

CEFET MG

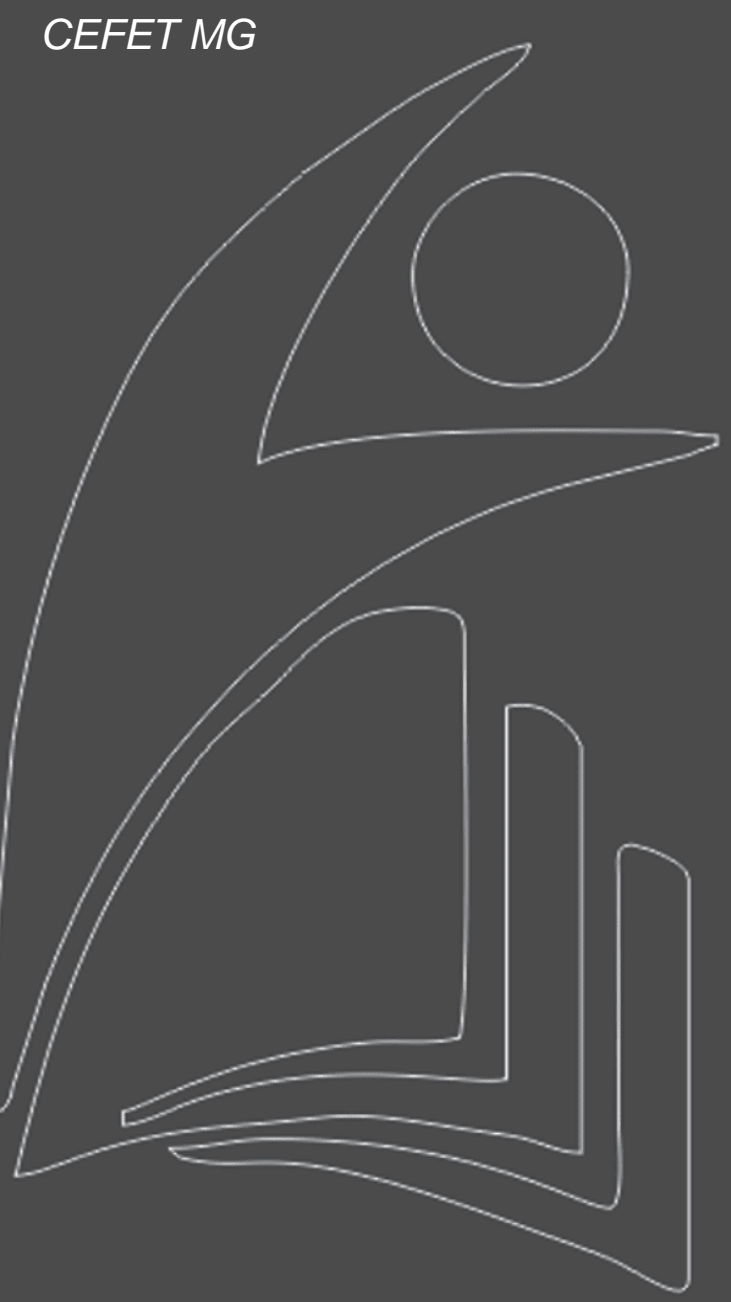




\section{Reflexões Sobre A Trajetória Da Mulher No Campo Esportivo}

Resumo: Quando refletimos sobre a inserção da mulher no esporte na atualidade, faz-se necessário resgatar o contexto histórico de como esse fato ocorreu. Isso porque o papel desempenhado pela mulher no esporte confunde-se e mescla-se com seu papel social na história, perspectiva esta escrita e interpretada sob um ponto de vista masculino, amparado pelo patriarcado que se perpetua até os dias de hoje. Neste artigo buscamos demonstrar por meio de uma revisão bibliográfica, que apesar da tentativa de ocultá-la, a mulher esteve presente no mundo do esporte desde a antiguidade, e que a sua presença nesses círculos foi conquistada através de enfrentamento e resistência de mulheres destemidas dispostas a mudar o "status quo".

Palavras-chave: Esportes, Gênero, História, Mulher. 


\section{INTRODUÇÃO}

Atualmente as atividades esportivas são consideradas um dos maiores fenômenos sociais vigentes, tem estabelecido como um campo privilegiado de estudos e intervenções seja pelas performances de seus praticantes ou do ponto de vista educativo, para Silva e Rubio (2003) o esporte é uma forma elementar de socialização, compondo o imaginário popular com valores como força e superação de limites, um reflexo do modelo social contemporâneo. Além de promover a inclusão social em âmbito geral, o esporte também tende a contribuir com as relações sociais de gênero, quando proporciona a ambos os sexos alguma equidade de condições para praticá-lo.

Nas sociedades ocidentais, especialmente durante a segunda metade do século $X X$, as relações sociais de gênero passaram por grandes transformações, provocadas, sobretudo, pelo crescimento do Movimento Feminista. Entretanto, muitas representações consolidadas por séculos de opressão histórica permanecem presentes, embasando, discursos e ações do senso comum, no meio esportivo não é diferente é o que afirmam Rúbio e Simões (1999), quando comparam o esporte á uma tela que reflete os valores culturais de cada sociedade na qual ele é praticado, reproduzindo seus sistemas hierárquicos e também suas peculiaridades sociais.

As construções sociais de gênero também influenciam na segmentação do esporte, pois acabam por dividir o campo entre práticas "masculinas" e práticas "femininas", contribuindo para a perpetuação de ideias preconcebidas a cerca do envolvimento da mulher com o esporte. A pesquisadora Fátima Cecchetto (2004), durante o estudo intitulado "Violência e estilos de masculinidades" (2004) se deparou com diversos relatos que demonstravam uma concepção tradicional da masculinidade, em que a agressividade e a superioridade da força concretizam ideias do caráter distintivo das características de macho. Mais que uma "área masculina", o esporte é o lugar da ausência feminina. Ainda de acordo com Cecchetto (2004) o senso comum tende a naturalizar que "o uso conspícuo da força física é uma decorrência natural do fato de se ter nascido com hormônios e órgãos sexuais masculinos e, portanto, faria parte da essência (e da natureza) do homem" (CECCHETTO, 2004, p.37).

Quando verificado os números nota-se uma diferença significativa entre a presença feminina e masculina nos esportes: uma pesquisa realizada pelo IBGE sobre a prática de esporte e de atividades físicas de 2015 aponta que, dos praticantes de esporte, 63,2\% eram homens, e 36,8\% mulheres. Em quase todas as Grandes Regiões, mais de $60 \%$ dos praticantes eram homens, excetuando-se apenas a Centro-Oeste, onde a distribuição registrou $59,2 \%$ de homens e $40,8 \%$ de mulheres. 


\section{Reflexões Sobre A Trajetória Da Mulher No Campo Esportivo}

No quesito modalidade de predominância masculina o IBGE (2015) constatou que o futebol se destaca, os homens correspondem a $94,5 \%$ dos praticantes dessa modalidade. Para os homens, vale destacar a superioridade em participação nas seguintes modalidades: ciclismo $(75,2 \%)$; lutas e artes marciais (70,0\%); e atletismo (64,5\%). Por outro lado, os quatro esportes predominantemente praticados pelas mulheres, foram: dança e ballet (85,0\%); Ginástica rítmica e artística $(80,5 \%)$; caminhada $(65,5 \%)$; e fitness $(64,4 \%)$.

Diante do exposto o presente artigo tem por objetivo apontar através de uma revisão bibliográfica como se deu a inserção das mulheres no meio esportivo, a fim de historicizar os avanços femininos obtidos no esporte e dar visibilidade às conquistas construídas pelas mulheres esportistas. Para tanto foram descritas cronologicamente as principais marcas históricas femininas no esporte, sendo que a primeira parte é dedicada aos feitos femininos internacionais e a segunda parte às conquistas das mulheres brasileiras.

Para realizar a revisão da bibliografia utilizou-se como referências teses e dissertações no banco de dados da Capes, artigos e periódicos na base de dados do Scielo, além de livros conceituados que versam da temática. Durante o período pesquisado foram usados os descritores como: "mulheres", "gênero", "esporte", "história”. As principais referências pesquisadas foram as autoras Ana Miragaya (2002), Ludmila Mourão (2000, 2002), Katia Rúbio (1999, 2003), Silvana Vilodre Goellner (2005), acadêmicas reconhecidas no estudo de gênero no campo da educação física.

\section{A INSERÇÃO DA MULHER NOS ESPORTES}

A história de inclusão das mulheres no esporte é identificada como um exemplo de poder e dominação masculina, como também uma trajetória de desigualdade onde as mulheres desempenhavam papéis de submissão, sem poder buscar respeito e igualdade conforme afirma Miragaya (2002). Para analisar a participação da mulher no esporte é necessário resgatar-se o contexto histórico onde esse fato se iniciou.

Os primeiros registros encontrados são dos Jogos Olímpicos da Antiguidade datam de 776 a.C. a 393 d.C, as chamadas Panatéias, segundo Miragaya (2002) estes eram considerados o evento esportivo mais importante do planeta, era visto como festa religiosa, onde competidores se reuniam a cada quatro anos, em comemorações aos Deuses marcadas por jogos de variadas modalidades, onde somente os homens podiam competir, e às mulheres jovens e solteiras a procura de um marido era 


\section{Reflexões Sobre A Trajetória Da Mulher No Campo Esportivo}

concedida permissão para assistir os Jogos Olímpicos. As mulheres chegaram a ser prêmios para vencedores das corridas de biga e charrete (MIRAGAYA, 2002).

Uma das poucas formas de mulheres participarem das Olimpíadas da antiguidade era indiretamente, foi o que fez a princesa espartana Kyniska a primeira a ganhar uma medalha de ouro nos Jogos e ter seu nome incluído entre os 'heróis' através de estátua e homenagem, ela era a criadora dos cavalos de raça que foram vencedores nos Jogos de 396 a.C. e de 392 a.C. (MIRAGAYA, 2002).

Os Jogos Olímpicos da Antiguidade duraram 12 séculos (até 393 d.C), e foram abolidos após a conquista da Grécia pelo imperador romano Teodósio II, por causa do mau relacionamento entre gregos e romanos, da brutalidade e corrupção que ocorria durante os jogos e por considerar as práticas esportivas como festas pagãs (MIRAGAYA, 2002).

Durante a Idade Média os espetáculos públicos tornaram-se assunto privado, conforme explica Rúbio e Simões (1999), mas, ainda assim mulheres tanto quanto homens envolviam-se numa ampla variedade de jogos com bola. A partir do século XII feudalismo e cruzadas marcam um período onde a mulher passou a desenvolver vários papéis, esperava-se que a nobre fosse educada e o sentido dessa educação ia além de ler e escrever. Por educação entendia-se a arte da caça com falcões, jogo de xadrez, contar estórias, responder questões com sagacidade, cantar e tocar vários instrumentos musicais e dançar.

Essa condição feminina de partícipe da vida pública vem sofrer alterações significativas a partir do século XVII, época em que o poder era centralizado e exercido pela Igreja, foi um período de grande perseguição à mulher, denominado "A Caça às Bruxas" (Muraro, 2002), quando a mulher perde completamente seus direitos individuais e passa a ser subjugada pelo marido ou, quando solteira, pelos parentes homens. O reflexo desse quadro é que a mulher é absolutamente excluída das atividades esportivas e de lazer, como afirma Rúbio e Simões (1999).

A partir do final do século XVIII e início do XIX, em meio ao início do protestantismo, à revolução industrial e posteriormente a revolução francesa a mulher passou a participar mais ativamente da vida pública conforme explica Muraro (2002). No esporte não é diferente, os cavalheiros ingleses passaram a levar suas esposas a competições de box e remo, corridas de cavalos e alguns outros eventos. Um dos esportes mais populares da época, o boliche, ainda que uma prática masculina, contou com grande participação feminina principalmente na Inglaterra, o que veio acontecer com outras modalidades como o cricket, o bilhar, o arco e flecha, formas rudimentares do que viria a ser o futebol e algumas 


\section{Reflexões Sobre A Trajetória Da Mulher No Campo Esportivo}

atividades praticadas na neve, estendendo-se a países continentais como Alemanha e França (RUBIO e SIMÕES, 1999).

Apesar da aparente aproximação feminina das práticas esportivas, mesmo sem ter a competição como objetivo principal, a restauração dos Jogos Olímpicos da Era Moderna, em 1896 não refletiu essa realidade. O barão Pierre de Coubertin, pedagogo e historiador francês fundador dos Jogos Olímpicos da Era Moderna, manteve a antiga tradição grega e excluiu as atletas dos Jogos. Coubertin era completamente contra a prática de esportes e atividade física pelas mulheres, (OLIVEIRA, CHEREM e TUBINO, 2008) apontam que, de acordo com Coubertin, as mulheres tinham a função de procriação, sua glória viria através do número e da qualidade dos filhos que produzisse. No que se refere ao esporte, ele acreditava que o papel da mulher é de encorajar seus filhos a vencer, não cabendo a ela bater recordes.

Entretanto nas Olimpíadas de Paris de 1900 lacunas na organização e a falta de coesão do Conselho Olímpico Internacional - COI, no controle do programa dos jogos, permitiu que duas modalidades fossem destinadas às mulheres, culminando com a inclusão do golfe e tênis femininos, onde não havia contato físico e eram considerados esteticamente belos como aponta Devide (2002). Este acontecimento consagrou à britânica Charlotte Cooper o título de primeira campeã Olímpica, conquistado no tênis feminino.

Nos Jogos de 1912, em Estocolmo, depois de uma batalha que durou vários anos permitiu-se a participação feminina em provas de natação, entretanto as atletas norte-americanas foram impedidas de competir, pois o Comitê Olímpico Americano (COA) não permitia que elas participassem de modalidades que não usassem saias longas, em protesto as tenistas também se recusaram a competir no evento (DEVIDE, 2002).

Em 1916 os Jogos Olímpicos não foram disputados, em decorrência da primeira guerra mundial. Em 1917 a francesa Alice Milliat reivindicou ao COI o direito das mulheres terem o mesmo programa olímpico que os homens, em face da negativa Milliat fundou em 1921 a Federação Esportiva Feminina Internacional (FEFI). No ano de 1922 em Paris, foi organizada a primeira edição dos Jogos Olímpicos Femininos com exclusiva participação das mulheres, que reuniu cerca de 300 atletas, em onze provas e mais de vinte mil espectadores (OLIVEIRA, CHEREM e TUBINO, 2008).

Após a primeira edição, a FEFI reeditou o evento com o nome de Jogos Femininos Mundiais (The Women's World Games) a cada quatro anos, até 1934, com um programa de provas maior que a realizada nos Jogos Olímpicos e incluía modalidades por eles proibidas, como as provas de salto e 


\section{Reflexões Sobre A Trajetória Da Mulher No Campo Esportivo}

longas distâncias do atletismo. A perseverança de Alice Milliat, em conjunto com outras mulheres, idealizadores e protagonistas da participação feminina nos Jogos Olímpicos, aos poucos levou o COI a inserir as modalidades do atletismo no programa olímpico para as mulheres. (MIRAGAYA, 2002).

Em 1928 eram cinco modalidades femininas nas Olimpíadas, uma delas o Atletismo, incluído pela primeira vez nos jogos em caráter de exibição, restrito a cinco provas. Segundo Fernandes (2014) o esporte esteve entre as modalidades proibidas, pois, acreditava-se que os saltos e as corridas de meio fundo e fundo acarretariam danos a seus órgãos reprodutores femininos. A inclusão do Atletismo nos Jogos de 1928 foi considerado uma vitória, mas um fato colocou em risco este avanço: ao final da prova dos 800 metros rasos, algumas atletas desfaleceram na pista oferecendo argumentos àqueles que defendiam a exclusão feminina baseados na sua incapacidade física para provas de resistência, mesmo depois de técnicos argumentarem que as atletas não tivessem sido preparadas adequada e especificamente para aquela prova (SOARES, 1988).

Os Jogos de 1932 (Los Angeles) e 1936 (Berlim) foram marcados por um aumento considerável de mulheres, chegando a representar $10 \%$ do total de participantes. De lá para cá esses números têm sofrido transformações tanto no que se refere ao aumento de modalidades como à quantidade de participantes, na última Olimpíada ocorrida no Brasil em 2016, as mulheres representavam cerca de 45\% dos participantes em 28 modalidades diferentes (COI, 2016). Essa transformação, porém, não ocorre no que tange a participação nos órgãos decisórios, onde o predomínio masculino de mantém ao longo de mais de 100 anos é o que afirma Rubio e Simões (1999).

\section{A MULHER BRASILEIRA E O ESPORTE}

A inserção das mulheres brasileiras no mundo esportivo data de meados do século XIX. No entanto, é a partir das primeiras décadas do século XX que a participação se amplia adquirindo, portanto, maior visibilidade. Vale lembrar que nos primeiros anos do século $X X$, o Brasil está imerso em grades transformações, tais como: o desenvolvimento industrial, as novas tecnologias, a urbanização das cidades, o fortalecimento do Estado, as manifestações operárias, entre outros fatores, formando o tecido das novas demandas sociais, no qual circulam valores conservadores e revolucionários que tanto promovem a legitimação do já instituído, quanto procuravam a experimentação de novas possibilidades culturais, conforme aponta Goellner (2005). 


\section{Reflexões Sobre A Trajetória Da Mulher No Campo Esportivo}

O processo de ocupação do espaço esportivo pela mulher brasileira é qualitativamente diferente do processo de ocupação de outros espaços, em que a tensão da relação entre os gêneros é maior, é o que afirma Mourão (2000):

[...] a mulher brasileira não demandou um confronto com o homem, numa redistribuição do território esportivo. Antes, passou a aparecer, tornou-se visível, no turfe, na natação, no tênis, e assim sucessivamente, sem representar perigo à hegemonia masculina. Foi - e é - um processo de infiltração lenta e progressiva, na prática, sem o discurso de contestação por parte das mulheres, com as vicissitudes próprias de um movimento desse tipo; e hoje, quando se mapeia o território esportivo brasileiro, verifica-se que a mulher está presente na prática de quase todas as modalidades esportivas; e, simultaneamente, assistimos a uma transformação visível das representações sociais face à sua infiltração nessa prática (MOURÃO, 2000, pag.7).

A expansão do fenômeno esportivo pode ser identificada como um dos motivos pelos quais foi possível o Brasil participar dos Jogos Olímpicos de 1924, Goellner (2005) afirma que foi o improviso de uns cidadãos e o entusiasmo de outros que garantiram a presença do país nos Jogos. Na Olimpíada de 1928 o espírito entusiasta não se manteve, o Brasil não participou por falta de verbas. Na Olimpíada de 1932, sediada em de Los Angeles, o Brasil registrou a participação da sua primeira atleta: a nadadora paulista Maria Lenk, então, com 17 anos de idade (OLIVEIRA, CHEREM e TUBINO, 2008).

O contexto internacional de mudança e inovações que aconteciam na Europa chega também ao Brasil, os ecos das lutas femininas projetam novas perspectivas para as mulheres brasileiras. $\mathrm{O}$ desejo de ampliar a participação feminina em espaços esportivos predominantemente masculinos, fez com que a sociedade brasileira se mobilizasse, o que culminou na organização em alguns centros urbanos de competições para a participação exclusivamente feminina, cuja primeira edição aconteceu, respectivamente, em 1935, os Jogos Femininos do Estado de São Paulo; em 1949, os Jogos da Primavera no Rio de Janeiro; e em 1954, os Jogos Abertos Femininos em Porto Alegre (GOELLNER, 2005).

Segundo Mourão (2000) os "Jogos da Primavera", se constituíram numa grande festa esportiva e estética, e ajudou a popularizar o esporte entre as mulheres:

Analisando os "Jogos da Primavera", verifica-se que o esporte feminino passou por uma mudança substancial na medida em que a mulher esportista teve espaço na mídia, ganhou força junto à opinião pública; logo, os Jogos possibilitaram e favoreceram a transformação das representações restritivas à prática do esporte pela mulher. Como se pôde confirmar, os Jogos se constituíam em um evento de grande participação de moças e de público (MOURÃO, 2000, pag.16). 


\section{Reflexões Sobre A Trajetória Da Mulher No Campo Esportivo}

Nesta época no Brasil, entre meados do século XIX até o Estado Novo, o esporte desconhece a interferência do governo. Embora existisse uma esfera esportiva integrada à vida cotidiana, como modalidades, campeonatos e clubes regimentados, essas estruturas provinham de entidades organizadas pela sociedade civil, conforme afirma Pimentel e Mezzadri (2007).

Entretanto com o advento do Estado Novo caracterizado pela forte centralização estatal e pelo empenho na construção de uma identidade nacional através de intervenção em esferas da vida cotidiana, como saúde, trabalho, educação e, inclusive, no esporte (PIMENTEL; MEZZADRI, 2007). A partir daí o Estado pensa o esporte como um instrumento de projeção internacional, e o Conselho Nacional de Desportes (CND), com o objetivo de controlar e fiscalizar todas as questões relacionadas às atividades físicas.

Em 1941, o General Newton Cavalcanti apresenta, ao CND, subsídios para a oficialização da interdição de mulheres em algumas modalidades esportivas, através do artigo 54 do Decreto Lei n. 3.199, as mulheres ficam impedidas de praticar esportes considerados incompatíveis com a sua "natureza", como lutas, ou modalidades que exigiam maior contato corporal e extravasasse agressividade (LARDIES, 1951).

Mais tarde em 1965 durante a ditadura militar o Estado proibiu a participação da mulher em alguns esportes específicos por meio da Deliberação no 7/65, que estipulou: “Não é permitida a prática feminina de lutas de qualquer natureza, futebol, futebol de salão, futebol de praia, polo, halterofilismo e beisebol". (MOURÃO, 2002, p.833).

Somente a partir da segunda metade da década de 1970, após profundas transformações sociais, culturais e políticas, a distensão da ditadura civil-militar e com o desenvolvimento do movimento feminista, o Brasil abriu espaço para a discussão acerca da posição da mulher na sociedade, inclusive no âmbito legislativo.

As transformações políticas, influenciadas pela pressão da sociedade civil, levaram à revogação da Deliberação no 7/1965 através da Deliberação no10 de 1979, que permitiu a possibilidade das mulheres praticarem e competirem em quaisquer atividades esportivas. Apesar do avanço, a legislação ainda era restritiva, pois estava condicionada à exigência da entidade internacional da modalidade realizar campeonatos e torneios oficiais com mulheres ou mistos. Caso contrário, deveria ser solicitada uma autorização ao CND para a modalidade ser praticada (BRASIL, 1984), apenas após a promulgação da Constituição Federal de 1988, que garante em seu artigo $5^{\circ}$ que todos são iguais 


\section{Reflexões Sobre A Trajetória Da Mulher No Campo Esportivo}

perante a lei, sem distinção de qualquer natureza, foi que as mulheres tiveram a garantia de igualdade legal em todos os âmbitos sociais, inclusive no esporte (BRASIL, 1988).

No final dos anos 50 e no início dos 60, o Brasil viu despontar um ícone do esporte nacional, a tenista Maria Esther Bueno, que conquistou espaço no cenário esportivo internacional ao vencer o Campeonato de Wimbledon nos anos 1959, 1960 e 1965, na categoria individual, e em 1958, 1960, 1963, 1965 e 1966, na categoria de duplas (GOELLNER, 2005).

Em 1964, a atleta Aída dos Santos, foi a única mulher da delegação brasileira a ir aos Jogos Olímpicos de Tóquio e que bravamente conquista o 4ㅇ lugar no salto em altura, conforme destaca Goellner (2005) Aída dos Santos obteve a melhor participação brasileira nas Olimpíadas, sem que tivesse técnico, ou mesmo as sapatilhas adequadas para a competição.

Em 1979, Joaquim Mamede de Carvalho e Silva, presidente da Confederação Brasileira de Judô, inscreve mulheres, utilizando nomes masculinos, no campeonato Sul-americano de judô, na cidade de Montevidéu, no Uruguai. Este artifício foi criado porque era proibida a participação feminina em esportes de lutas e artes marciais, pelo Decreto nㅇ 7/65. Das quatro judocas que participaram do Sulamericano, duas levaram medalha de ouro e uma medalha de bronze, após ser descoberto e ser chamado para prestar esclarecimentos no CND, Mamede levou as atletas de quimono com as suas medalhas no peito (SOUZA, 2006).

A participação das atletas brasileiras nos Jogos Olímpicos cresceu significativamente a partir dos anos 70, sendo que a primeira premiação com o ouro olímpico aconteceu em Atlanta, em 1996, no vôlei de praia para a dupla Jacqueline Silva e Sandra Pires. A ascensão na participação e premiação das atletas brasileiras permaneceu nas edições posteriores dos Jogos Olímpicos, tanto que na última Olimpíada ocorrida em 2016, ocorrida no Brasil, a delegação brasileira contou com participação de 209 mulheres, um recorde de participação feminina, com destaque para Rafaela Silva que conquistou medalha de ouro no Judô e para a dupla Martine Grael e Kahena Kunze que também levaram o primeiro lugar na disputa de Vela (COB, 2016).

A mulher brasileira alcançou um espaço considerável no campo desportivo, entretanto Mourão (2000) afirma que, não houve, na história da emancipação esportiva da mulher brasileira, confrontos ou lutas por espaço, mas sim um processo lento de infiltração, que se consolida na prática e no exercício da interação, frequentemente com apoio velado ou aberto dos homens mais esclarecidos da sociedade, mas com foi mantido um controle normativo que insere a mulher no esporte sem possibilitar-lhe uma emancipação para a prática esportiva. 


\section{Reflexões Sobre A Trajetória Da Mulher No Campo Esportivo}

Mourão (2000) acrescenta ainda que, não haver, no esporte brasileiro, um movimento feminino ou feminista, em prol da equalização de gênero, conforme se pode verificar pela ausência de movimento contestador das esportistas brasileiras, num contexto em que era e ainda é o homem, em sua maioria absoluta, que ocupa as esferas de poder, no comando as federações, confederações, clubes e ligas como dirigente, técnico e árbitro.

\section{CONSIDERAÇÕES FINAIS}

Apesar da crescente presença feminina na vida esportiva do país e no mundo, a situação atual das mulheres deve ser avaliada com cautela. Mesmo que a participação delas como atletas seja significativa, ainda é consideravelmente menor que a dos homens, principalmente em modalidades que tradicionalmente são ditas "masculinas". Além dos dados numéricos, esta diferença pode ser identificada nas mais diversas instâncias em que se praticam as atividades corporais e esportivas, nas ausências da mulher nos cargos de poder e nas posições de maior prestígio.

Este estudo relatou os avanços obtidos, os obstáculos enfrentados e procurou destacar as grandes protagonistas que participaram do processo de inserção da mulher no esporte, em âmbito nacional e internacional. Deixa claro ainda, que como em outros campos sociais, o esporte tem muito que evoluir para garantir a equidade de gênero, que existem muitas lacunas a serem preenchidas e barreiras a serem derrubadas para que homens e mulheres possam desenvolver a excelência esportiva, independente do gênero.

Inicialmente segregada a atividades esportivas específicas, atualmente parte integrante de quase todos esportes, a mulher brasileira, conseguiu ocupar várias esferas do meio esportivo. Acreditamos que a crescente democratização da participação da mulher no esporte vislumbra a possibilidade de um mundo mais justo, na medida em que diminui os abismos entre homens e mulheres independentemente de suas características étnicas e biológicas. 


\section{REFERÊNCIAS}

BRASIL. Câmara dos Deputados. Decreto-lei n. 3.199, de 14 de abril de 1941: Estabelece as bases de organização dos desportos em todo o país. Disponível em: <http://www2.camara.leg.br >. Acesso em: 13 de Abril de 2018.

. Constituição (1988). Constituição da República Federativa do Brasil. Brasília, DF: Senado Federal: Centro Gráfico, 1988. 292 p.

. Ministério Da Justiça. CND baixa instruções às Entidades Desportivas do país, para a prática de desportos pelas mulheres. In: Legislação Sobre Esportes: coleção de textos legais - 16. Brasília: Departamento de Imprensa Nacional, 1984, p. 313-314.

CECCHETTO, F. R. Violência e estilos de masculinidade. Rio de Janeiro: FGV, 2004.

COB. Comitê Olímpico Brasileiro. Cartilha Mundo Olímpico. 2016. Disponível em: <https://www.cob.org.br/pt/cob/documentos> Acesso em: 08 de julho de 2018.

COI. Comitê Olímpico Internacional. Women In The Olympic Movement. jan/2016. Disponível em: <https://stillmed.olympic.org/Documents/Reference_documents_Factsheets/Women_in_Olympic_ Movement.pdf> Acesso em: 08 de julho de 2018.

DEVIDE, F. P. História das mulheres nos jogos olímpicos modernos. In: Da Costa LP, Turini M. Coletânea de testos em estudos olímpicos. Rio de Janeiro (RJ): Gama Filho; 2002. v.1.

FERNANDES, V. L. F. P. Mulheres de Ouro: Trajetória e representações de atletas de lutas. 2014. Dissertação (Mestrado em Educação Física) - Faculdade de Educação Física e Desportos, Universidade Federal de Juiz de Fora, Juiz de Fora. 2014.

GOELLNER, S. V. Mulher e esporte no Brasil: entre incentivos e interdições elas fazem histórias. Pensar a Prática, Goiás, v. 8, n.1, p. 85-100, jan./jun. 2005.

IBGE - Instituto Brasileiro de Geografia e estatística. Pesquisa nacional por amostras de domicílios. Práticas de esporte e atividade física, 2015. Disponível em: <https://biblioteca.ibge.gov.br>. Acesso em: 13 de Abril de 2018.

LARDIES, M. Coletânea de leis e regulamentos dos desportos. Porto Alegre: Oficinas Gráficas da Imprensa Oficial, 1951.

MIRAGAYA, A. A mulher olímpica: tradição versus inovação na busca pela inclusão. In: Da Costa LP, Turini M. Coletânea de testos em estudos olímpicos. Rio de Janeiro: Gama Filho; 2002. v.1.

MOURÃO, L. Representação social da mulher brasileira nas atividades físicodesportivas: da segregação à democratização. Revista Movimento, Porto Alegre, v.6, n. 13, p. 5-18, 2000.

. Vozes femininas e o esporte olímpico no Brasil. In: TURINO, M.; DA COSTA, L. (Orgs.). Coletânea de textos em estudos olímpicos, v. 1. Rio de Janeiro: Editora Gama Filho, p. 831-849, 2002.

MURARO, R. M. (2002). A mulher no terceiro milênio: uma história da mulher através dos tempos e suas perspectivas para o futuro. 8a edição. Rio de Janeiro: Record, Rosa dos Tempos. 


\section{Reflexões Sobre A Trajetória Da Mulher No Campo Esportivo}

PIMENTEL, E. S; MEZZADRI, F. M. O Estado Novo e a concepção de esporte no Decreto Lei 3.199 de 1941. In:. XVIV Simpósio Nacional de História. Anais. São Leopoldo: UNISINOS, 2007.

OLIVEIRA, G.; CHEREM, E. H. L.; TUBINO, M. J. G. A inserção histórica da mulher no esporte. Revista Brasileira de Ciência e Movimento, v.16, n.2, p. 117-125, 2008.

RUBIO, K.; SIMÕES, A. C. De espectadoras a protagonistas: a conquista do espaço esportivo pelas mulheres. Revista Movimento, Porto Alegre, v. 5, n.11, p. 50-56, 1999.

SILVA, M. L.; RUBIO, K. Superação no esporte: limites individuais ou sociais? Revista Portuguesa de Ciências do Desporto, Porto, v. 3, n. 3, p.69-76, 2003.

SOARES, G. A. D. A mulher nas Olimpíadas. Ciência Hoje. v.43, n.8, 1988.

SOUZA, G. C. Narrativas do judô feminino brasileiro: construção da historiografia de 1979 a 1992. In: XII Encontro Regional de História. Rio de Janeiro, 2006.

SOUZA, G. C.; MOURÃO, L. Mulheres no Tatame: o judô feminino no Brasil. Rio de Janeiro: MAUAD X: FAPERJ, 2011. 


\section{Capítulo 28}

\section{doi $10.37423 / 210704435$}

\section{MINERAÇÃO DE DADOS: UM ESTUDO PARA IDENTIFICAÇÃO DO PERFIL DOCENTE DAS IES COM CONCEITO 3 OU SUPERIOR NO IGC AVALIADO EM 2016 NO ESTADO DO ES}

Denilton Macário de Paula

André Bessa da Silva

Geórgia Regina Rodrigues Gomes

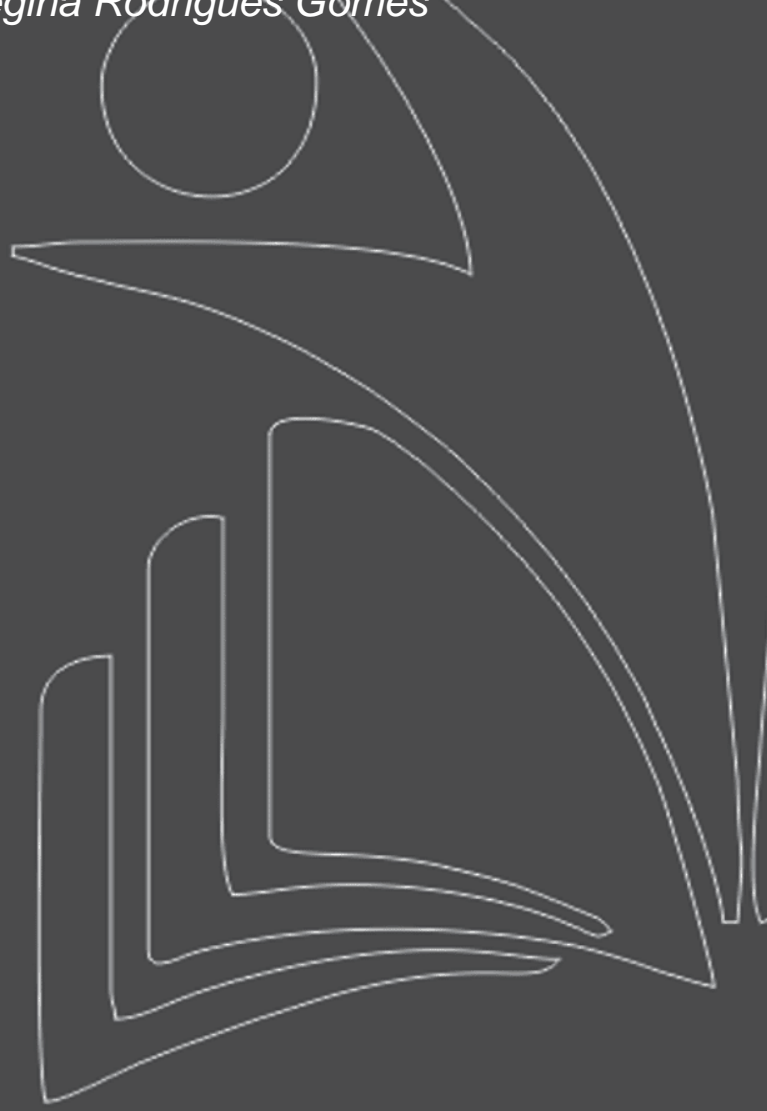

Instituto Federal do Espírito Santo - Campus

Viana

Faculdade Multivix Cachoeiro de Itapemirim Campus 1

Universidade Federal Fluminense INFES/UFF

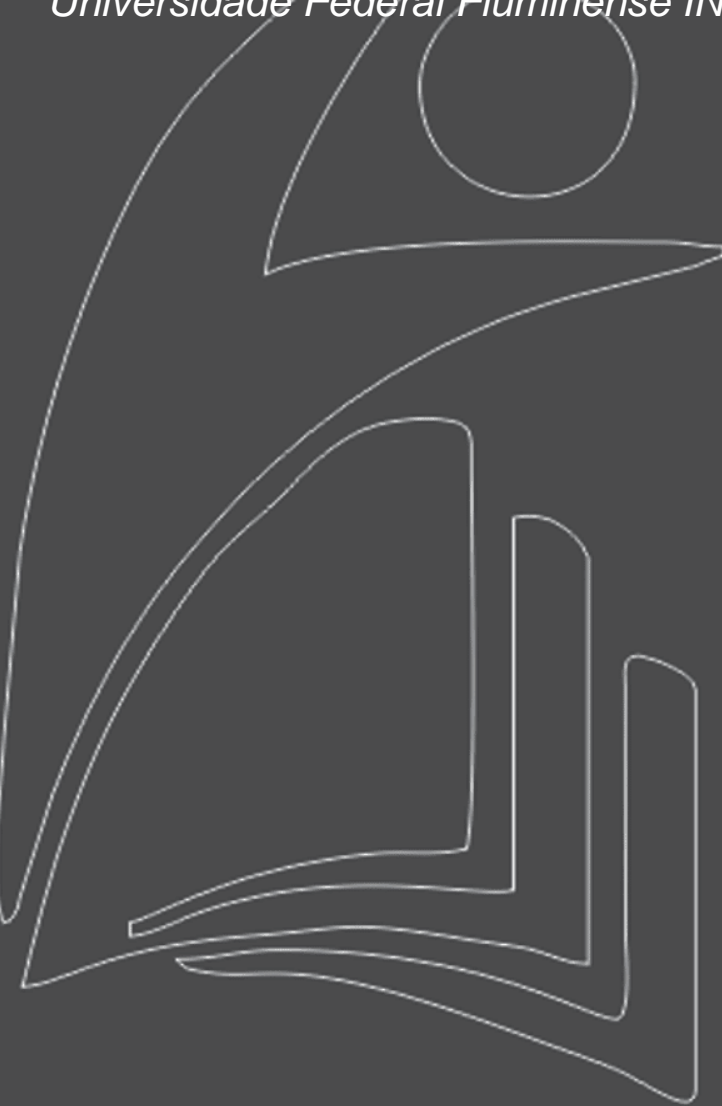


Resumo: Neste trabalho de pesquisa o objetivo é aplicar técnicas de mineração de dados para extrair informações relevantes da base de dados do censo superior de 2016, disponibilizados pelo INEP, sendo utilizada como metodologia uma pesquisa de revisão bibliográfica para conceituação de termos e algoritmos de mineração dados a serem utilizados na pesquisa, bem como discernimento dos processos e indicadores que o MEC leva em consideração para avaliar uma instituição de ensino superior no Brasil. Além disso, também é aplicado o tratamento dos dados anterior a fase de mineração e aplicação do processo do KDD. A pesquisa resulta na criação de clusters de informações, que agrupam os dados da mineração em 7 grandes grupos, além de detalhar algumas ramificações contidas na árvore de decisão criada com base no algoritmo J48. Com este trabalho, podemos concluir que a mineração de dados se apresenta como uma ferramenta poderosa para extração de conhecimento, que nos possibilitou traçar perfis dos docentes capixabas das instituições com IGC 3 ou superior.

Palavra-chave: Algoritmos, Clusters, Ensino Superior Mineração de dados, KDD, J48. 


\section{INTRODUÇÃO}

Este artigo tem por objetivo apresentar uma análise do perfil dos docentes em instituições de ensino superior no estado do Espírito Santo, levando em consideração o índice geral de cursos (IGC) com índice satisfatório ou superior, este índice hoje se constitui de uma métrica que afere qualidade do curso superior em instituições públicas e privadas. Para a confecção do estudo foram analisados os Microdados do Censo 2016, que está disponível para consulta pública no site do INEP, e nesta base de dados foram aplicados técnicas de mineração de dados usando o software Weka 3.8.3.

O Ministério da Educação (MEC) possui hoje uma série de instrumentos que ele utiliza para a avaliação do Ensino Superior no Brasil, hoje grande parte das diretrizes de avaliação são reguladas pelo SINAES, sistema nacional de avaliação do Ensino Superior, que congrega um conjunto de conceitos, dentre os quais destacamos o Índice Geral de Cursos (IGC), que hoje assume grande importância para as instituições de Ensino Superior de modo geral, mas em especial as faculdades, centros universitários e universidades privadas.

Os conceitos gerados pelas avaliações do MEC e de institutos abarcados pelo ministério para avaliar o ensino superior, podem fazer uma diferença significativa na opção de escolhas de cursos a serem cursados nestas instituições, além de ser um importante chamariz para o marketing intra e extra institucional, por permitir a criação de rankings que indicam o grau de qualidade dos cursos de determinada instituição (Ristoff e Giolo, 2006).

Como Cunha et. Al (2003) expõe no cenário atual das políticas de avaliação do ensino superior, o índice alcançado, assume um papel importante para conferir ou associar um alto grau de qualidade, nos casos de conceitos positivos, este passa a ser um grande trunfo para as campanhas de marketing da instituição e do curso, e quando mal avaliado é um agente impulsionador dentro da instituição para buscar melhorias para boas conceituações futuras.

\section{ENSINO SUPERIOR NO BRASIL}

No Brasil o ensino superior é ofertado por instituições que se classificam administrativamente como universidades, centros universitários, faculdades, institutos federais e a regulação e avaliação são incumbências do Instituto Nacional de Estudos e Pesquisas Educacionais Anísio Teixeira (INEP) e pelo Ministério da Educação (MEC). 
Por meio de avaliações como o ENADE o MEC avalia e acompanha o processo de ensino e aprendizagem e o desempenho dos discentes em relação ao curso e disciplinas cursadas nas mais diversas graduações.

O Exame Nacional de Desempenho dos Estudantes (Enade) é um dos pilares da avaliação do Sistema Nacional de Avaliação da Educação Superior (Sinaes), criado pela Lei no10.861, de 14 de abril de 2004. O Sinaes é composto, ainda, pelos processos de Avaliação de Cursos de Graduação e de Avaliação Institucional que, junto com o Enade, formam um 'tripé' avaliativo que permite conhecer em profundidade o modo de funcionamento e a qualidade dos cursos e instituições de educação superior (IES) de todo o Brasil. (INEP, 2016).

Como consta no SINAES vol. 5 do INEP (2015), o IGC é um indicativo da qualidade dos cursos oferecidos pelas instituições de ensino superior levando em consideração a conceituação obtida pela instituição no ENADE. O IGC considera além dos aspectos sociais e desempenho discente, também a formação docente e infraestrutura da instituição de ensino superior.

Como apontado na Figura 1, os resultados do IGC 2016, mostram que grande parte das instituições brasileiras encontram-se na faixa C (nota 3), que é um índice satisfatório, mas qual o perfil dos docentes das instituições D e E? Este estudo utiliza esta indagação para o escopo do estado do Espírito Santo, para ajudar a traçar o perfil destes docentes.

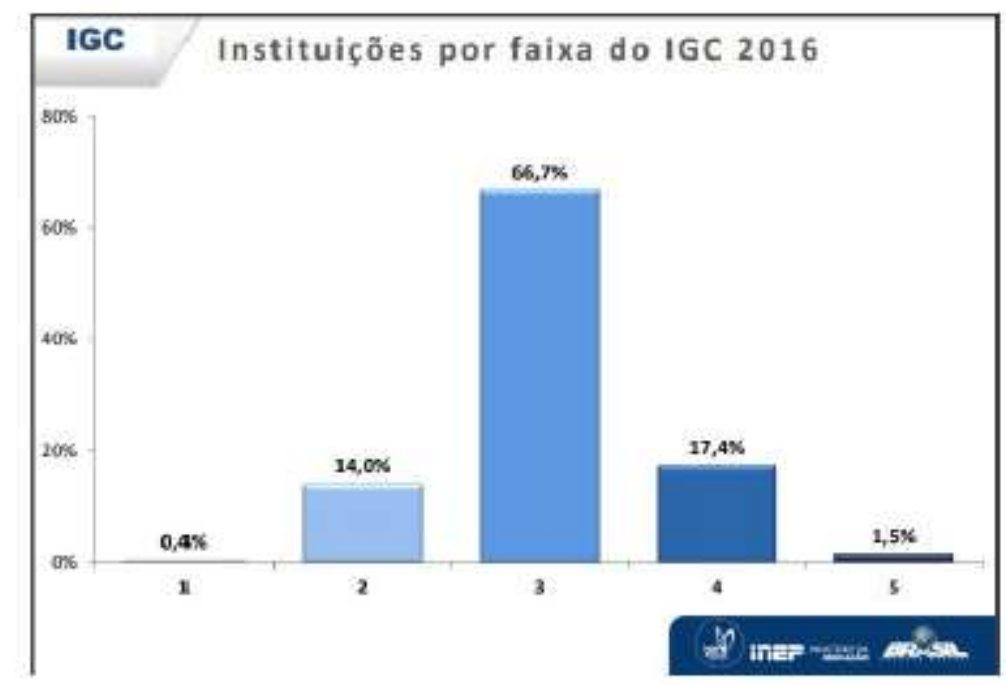

Figura 1 - Resultado do IGC 2016. Fonte: INEP. Disponível em < http://download.inep.gov.br/educacao_superior/igc_cpc/2016/apresentacao_resultados_CPC_e_IG C_20 16.pdf>

\section{MINERAÇÃO DE DADOS}

A coleta de informação de caráter relevante, hoje assume grande importância independente da área de estudo ou conhecimento e se mostra cada vez mais necessária para empresas e organizações para 
ações estratégicas e como suporte a tomada de decisão. Portanto se faz necessário o conhecimento de técnicas e ferramentas que a isso propicie.

Soma-se a isso o grande volume de informação produzido, sobretudo nas últimas décadas no que se refere a implementação de enormes bases de dados transacionais, inteligência computacional e das redes de telecomunicações, neste cenário a mineração de dados pode ser usada como uma excelente ferramenta para busca de informações úteis nesta gigantesca massa de dados, possibilitando aos tomadores de decisão, a melhor ação a ser tomada em condições de certeza limitada (SOCZEK e ORLOVSKI, 2014).

De acordo com Cardoso e Machado (2008), dentro da área de banco de dados, a Mineração de dados, é uma disciplina que vai propor e apresentar técnicas e algoritmos com a finalidade de extrair informações relevantes de base de dados densamente povoadas. Ainda segundo os autores, na mineração de dados, pode-se de maneira automatizada encontrar informações que estão "escondidas" nos dados, isso permite uma ação rápida pelo tomador de decisão com base nos dados encontrados.

Importante destacar que a mineração de dados é vista como parte de um processo maior de descoberta de conhecimento em bases de dados denominada Knowledge Discovery In Databases ou simplesmente KDD, há na literatura quem considere Data Mining e KDD sinônimos (FAYYAD et. al., 1996).

Tradicionalmente, ainda se faz uso de técnicas manuais para a coleta de dados, para a partir deste ponto, iniciar o processamento das informações por especialistas que decodificarão os dados e informação em uma série de relatórios a serem entregues aos tomadores de decisão, mas devido aos avanços em tecnologias, que hoje, geram um grande volume de dados, a coleta e análise manual, torna-se impraticável, e é neste momento que a mineração de dados torna-se um interessante ferramenta na busca e análise de dados. (CAMILO e CARLOS, 2009).

Remontando aos objetivos deste artigo, será realizada a mineração de dados em uma base de dados do INEP (Instituto Nacional de Estudos e Pesquisas Educacionais Anísio Teixeira) do ano de 2016 com as informações dos docentes, colocando o foco da mineração na identificação do perfil docente das instituições de ensino superior no estado do Espírito Santo para instituições com IGC satisfatório ou superior, apresentando o processo de seleção e transformação dos dados usando o KDD (Knowledge Discovery In Databases). 


\section{KDD (KNOWLEDGE DISCOVERY IN DATABASES)}

No processo de mineração de dados o KDD é o processo que visa encontrar os padrões dentro das volumosas bases de dados que temos, sendo caracterizada como o núcleo do processo de mineração que envolve seus algoritmos de exploração de dados e modelagem de padrões até então desconhecidos na base de dados (MAIMON, 2009).

De acordo com Vianna (2010), o KDD é o conjunto de tarefas que permite a busca de conhecimento em enormes bancos de dados, neste processo de investigação se dará através do levantamento, seleção dos dados, o pré-processamento e pôr fim a mineração, que permitirá a transformação dos dados extraídos em conhecimento útil à tomada de decisão. Na Figura 2 é apresentado o processo do KDD.

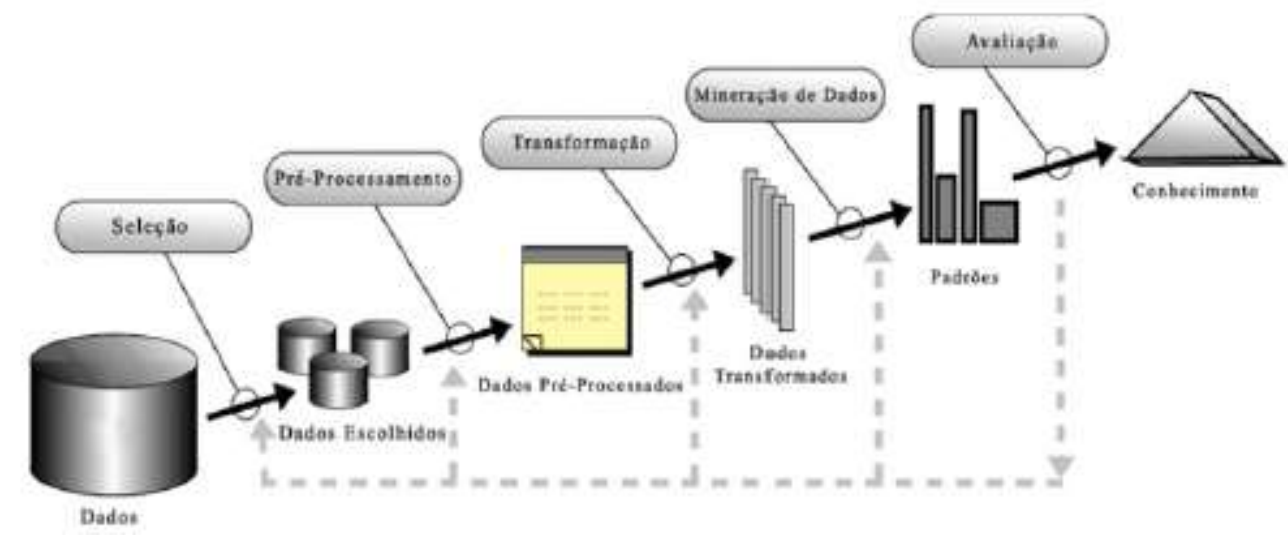

Figura 2 - Processo de Mineração de Dados com base no KDD

FONTE: CAMILO E CARLOS (2009).

FONTE: CAMILO E CARLOS (2009).

\section{METODOLOGIA}

Como metodologia para desenvolvimento deste trabalho de pesquisa foram aplicados os processos de seleção, pré-processamento e transformação dos dados presentes no KDD, Figura 2, como forma de preparar a base de dados para a mineração. Para a seleção dos dados desta pesquisa foi realizada usando os Microdados do Censo 2016, que estão disponíveis no site do INEP. Para Cardoso e Machado (2008), o KDD se destaca como a parte mais importante neste processo de busca de conhecimento através da mineração de dados.

Neste trabalho, foi realizada também uma revisão bibliográfica baseada na consulta de artigos científicos, sites especializados, capítulos de livros e dissertações com o intuito de sustentar conceitos 
importantes referentes à mineração de dados e as informações sobre o processo de avaliação do Ensino Superior no Brasil. A pesquisa bibliográfica como aponta Gil (2002) permite ao pesquisador uma ampliação do conhecimento sobre um determinado assunto.

Na Figura 3 é apresentado um recorte da base de dados com as informações dos docentes dos cursos superiores.

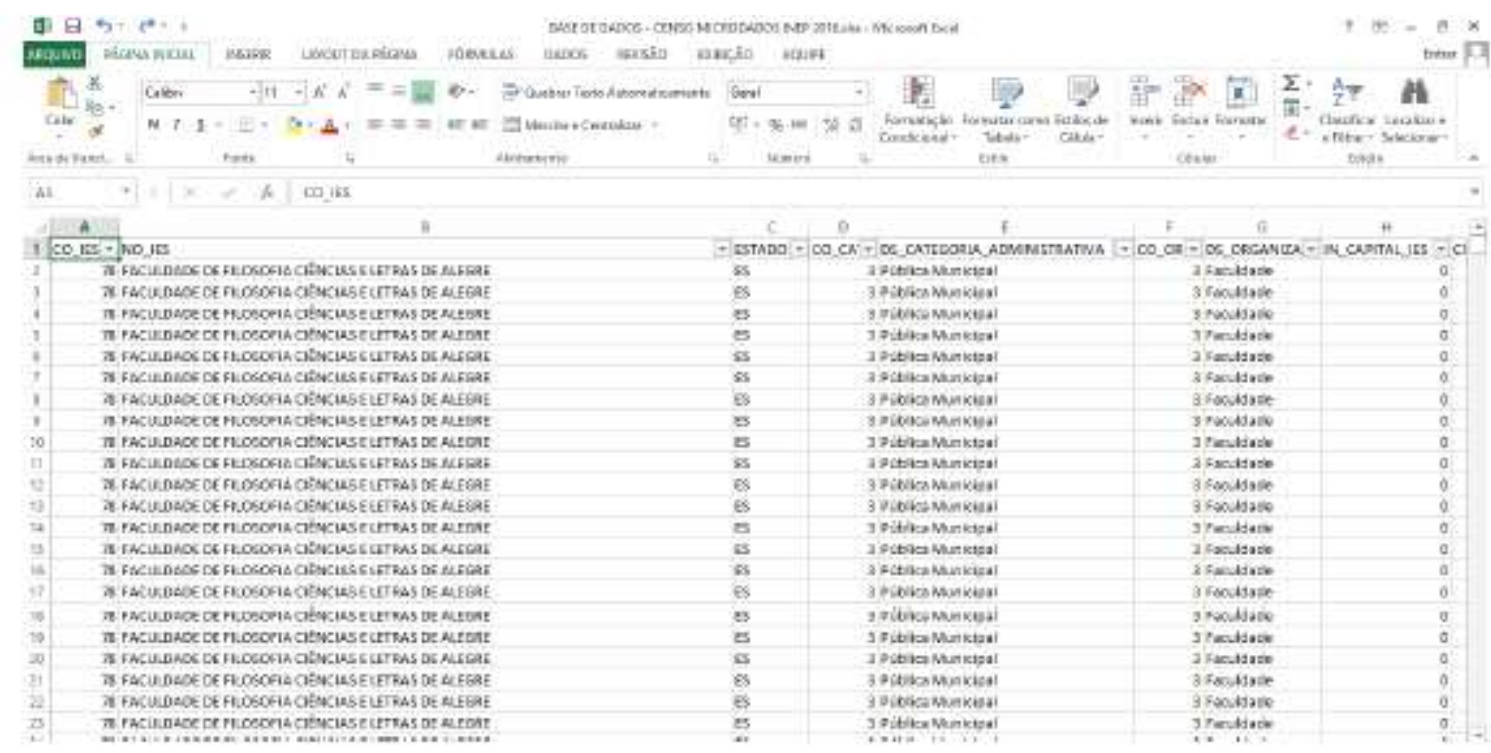

Figura 3 - Recorte parcial da base de dados com informações de docentes da IES com IGC satisfatório do estado do Espírito Santo, advindas dos microdados do Censo 2016. Portal INEP.

\section{PRÉ-PROCESSAMENTO DE DADOS}

Nos arquivos dos Microdados do Censo da Educação Superior 2016 de informações disponibilizados pelo INEP contavam com 397.612 registros sobre dados dos docentes das instituições de ensino superior de todo o Brasil.

Utilizando-se da ferramenta Microsoft Excel, foi realizado um processo inicial de adequação da base de dados disponibilizada no formato ".TXT" (texto), neste processo foram removidos os caracteres pipe (|) por ponto e vírgula (;) e a remoção dos caracteres cedilha (ç) e acentos. Nas figuras 4 e 5 são apresentados o estado do arquivo ".TXT" aberto dentro do Excel e como a ferramenta ajuda na adequação do formato dos dados respectivamente. 


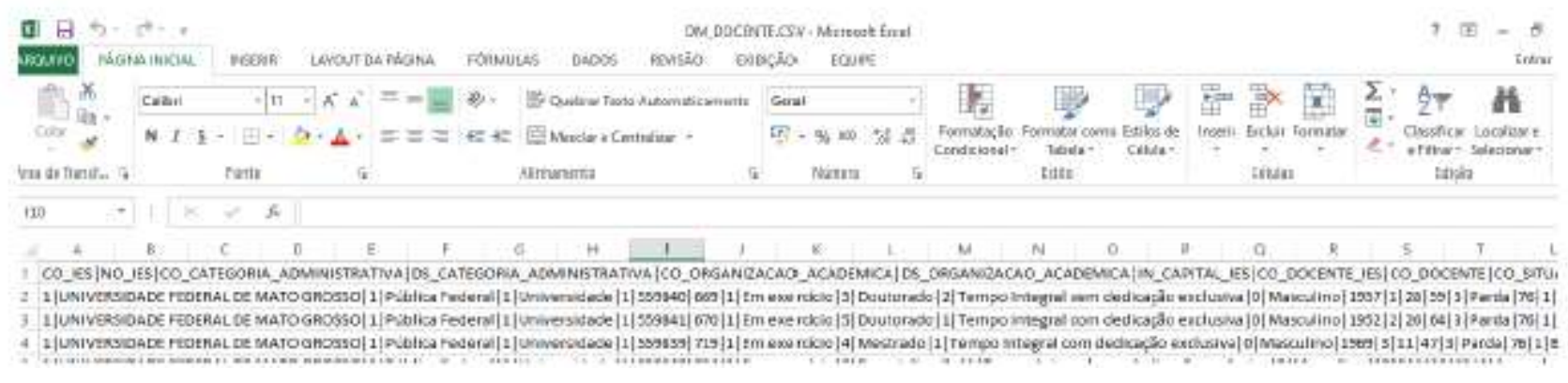

Figura 4 - Recorte parcial da base de dados com informações do docente da IES antes do processo de tratamento da base.

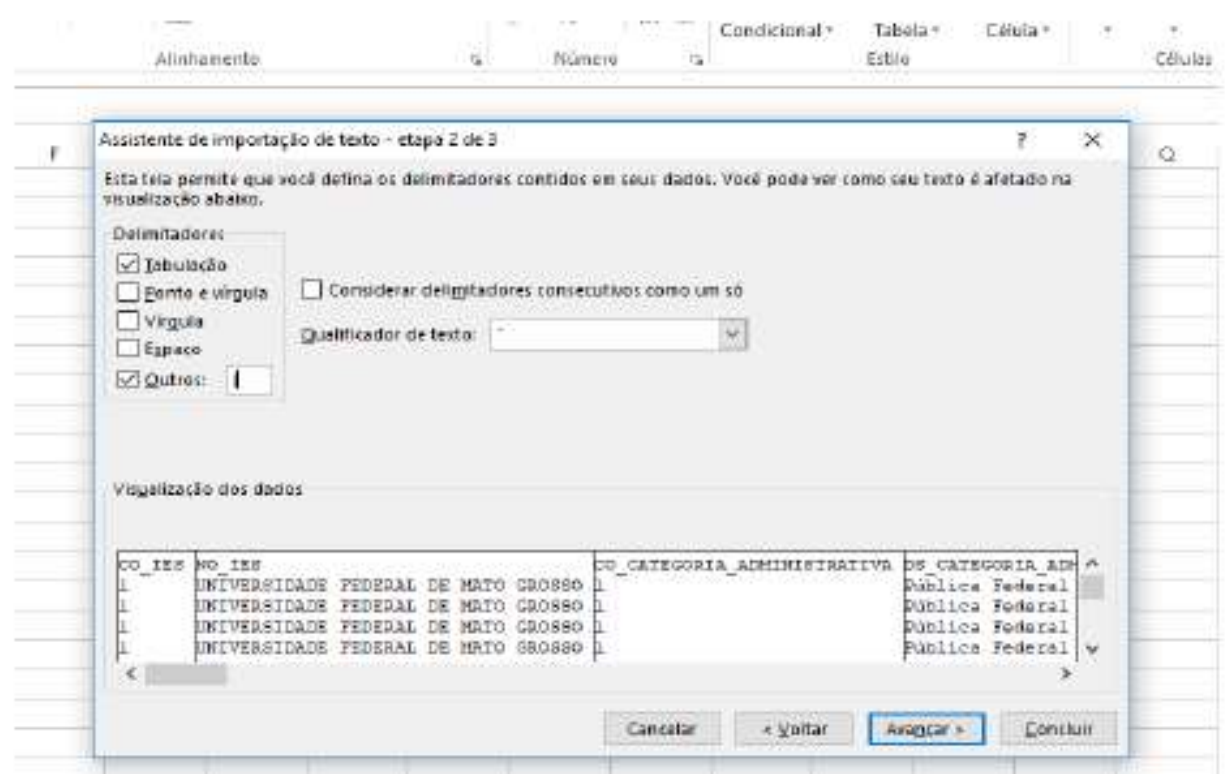

Figura 5 - Ferramenta Microsoft Excel para abertura do arquivo de microdados do senso 2016.

Nesta base foi realizado um processo de extração dos dados de instituição e docentes do Ensino Superior do estado do Espírito Santo, formando uma base de dados 7234 registros. Vale ressaltar que foi realizada uma limpeza e tratativa nos dados a fim de eliminar registros com informações incompletas, ou com valores nulos, pois sem isso aplicar o processo de mineração poderia causar inconsistências de informações geradas neste estudo.

Um detalhe importante sobre os dados do censo 2016, é que o mesmo não informa os conceitos do IGC das instituições de Ensino Superior, sendo necessária a inclusão desta informação em uma coluna em nossa base de dados, como apresentada na Figura 6. 


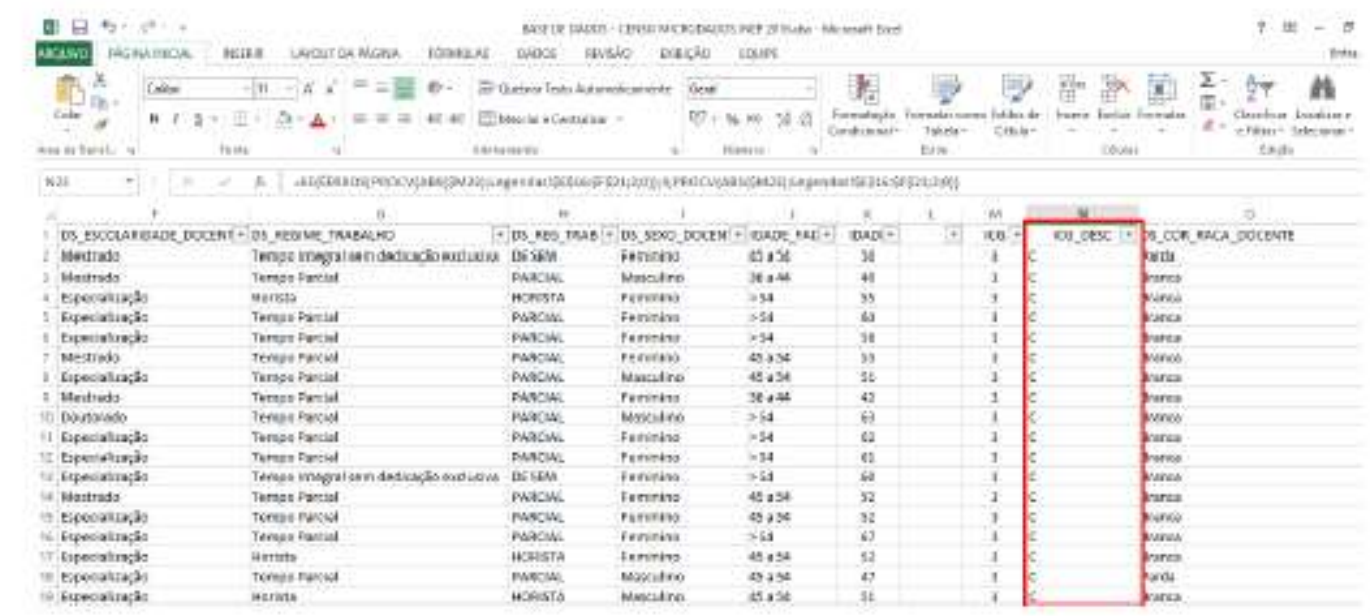

Figura 6 - Recorte parcial da base de dados com a adição da coluna que conceitua a instituição com o IGC.

Após a tratativa da base de dados para aplicarmos a mineração de dados utilizando os dados do censo 2016 para identificação dos perfis docentes das instituições IGC 3 ou superior no estado do Espirito Santo foram destacados 9 atributos chaves, conforme a quadro 1, tomando como referência o trabalho Batista et Al (2015). 
Quadro 1: Atributos da base de dados a ser minerada.

\begin{tabular}{|c|c|c|}
\hline ATRIBUTO & DESCRICYÃO & VALOR \\
\hline \multirow{6}{*}{ DS_CATEGORIA_ADMINISTRATIVA } & \multirow{6}{*}{$\begin{array}{c}\text { Categoria } \\
\text { Administrativa }\end{array}$} & PUBLICA FEDERAL \\
\hline & & PUBLICA ESTADUAL \\
\hline & & $\begin{array}{l}\text { PUBLICA } \\
\text { MUNICIPAL }\end{array}$ \\
\hline & & PRIVADA \\
\hline & & PRIVADA \\
\hline & & ESPECIAL \\
\hline \multirow{5}{*}{ DS_ORGANIZACAO_ACADEMICA } & \multirow{5}{*}{$\begin{array}{c}\text { Organização } \\
\text { acadêmica }\end{array}$} & UNIVERSIDADE \\
\hline & & CENTRO \\
\hline & & UNIVERSITARIO \\
\hline & & FACULDADE \\
\hline & & $\begin{array}{l}\text { INSTITUTO } \\
\text { FEDERAL }\end{array}$ \\
\hline \multirow{2}{*}{ LOCALIZACAO } & \multirow{2}{*}{$\begin{array}{l}\text { Localização da } \\
\text { IES }\end{array}$} & CAPITAL \\
\hline & & INTERIOR \\
\hline \multirow{4}{*}{ DS_ESCOLARIDADE_DOCENTE } & \multirow{4}{*}{$\begin{array}{l}\text { Titulação } \\
\text { Acadêmica }\end{array}$} & GRADUAÇÃO \\
\hline & & ESPECIALIZACCÃO \\
\hline & & MESTRADO \\
\hline & & DOUTORADO \\
\hline \multirow{4}{*}{ DS_REG_TRAB } & \multirow{4}{*}{$\begin{array}{l}\text { Regime de } \\
\text { Trabalho }\end{array}$} & $\begin{array}{l}\text { DE SEM (Integral sem } \\
\text { dedicação exclusiva) }\end{array}$ \\
\hline & & PARCIAL \\
\hline & & HORISTA \\
\hline & & \begin{tabular}{|l|} 
DE (Integral com \\
Dedicação exclusiva)
\end{tabular} \\
\hline \multirow{2}{*}{ DS_SEXO_DOCENTE } & \multirow{2}{*}{ Sexo Docente } & MASCULINO \\
\hline & & FEMININO \\
\hline IDADE & Faixa Etária & $20 \dot{A}+64$ \\
\hline \multirow{3}{*}{ IGC_DESC } & \multirow{3}{*}{$\begin{array}{c}\text { Conceito do IGC } \\
\text { do MEC }\end{array}$} & $\mathrm{C}=3$ \\
\hline & & $\mathrm{D}=4$ \\
\hline & & $E=5$ \\
\hline \multirow{6}{*}{ DS_COR_RACA_DOCENTE } & \multirow{6}{*}{ Raça declarada } & $\begin{array}{l}\text { Docente não quis } \\
\text { declarar cor/raça }\end{array}$ \\
\hline & & Parda \\
\hline & & Branca \\
\hline & & Preta \\
\hline & & Índio \\
\hline & & Amarela \\
\hline
\end{tabular}

Para realizarmos a mineração nos dados do senso docente 2016, dentre os diversos algoritmos disponíveis na ferramenta Weka 3.8.3 foi utilizado para este estudo à classificação dos dados com a Clusterização e a análise de árvore s de decisão usando o algoritmo J48.

\section{PROCESSAMENTO}

No desenvolvimento deste trabalho, optou-se por usar a ferramenta de mineração de dados Weka 3.8.3 desenvolvida em linguagem Java pela Universidade Waikato em Hamilton, na Nova Zelândia, Figura 7. Nesta ferramenta são agrupados algoritmos e técnicas de mineração de dados como J48, Apriori, Clusterização além de contar com uma série de processo que auxiliam no pré-processamento 
da base de dados, que pode ser oriunda de um arquivos texto ou separado por vírgulas (.csv) ou ainda pode-se conectar diretamente em bases de dados do tipo relacional como um banco Oracle, Mysql ou PostgresSQL.

\section{TAREFA DE CLUSTERIZAÇÃO}

Para a aplicação da mineração nos dados do INEP para o censo docente de 2016, os dados foram devidamente tratados anteriormente, um dos algoritmos usados foi o de Clusterização presente na ferramenta Weka 3.8.3.

De acordo com Jain et. al, (1999), a Clusterização é um tipo de classificação de dados não supervisionados, onde se formam os denominados Cluster ou simplesmente grupamentos. Sendo assim, podemos definir de uma maneira simples que a Clusterização é um algoritmo de agrupamento de dados multivariados que utiliza métodos numéricos, objetivando agrupar de maneira automática uma série de dados $\mathrm{n}$ em uns grupos ou clusters $\mathrm{k}$ de acordo com sua similaridade.

Portanto a idéia central do algoritmo é agrupar em mesmo cluster elementos com alto grau de similaridade (mesmo padrão), mas que devem ser diferentes de elementos de outros clusters, ou seja, dissimilares (CASSIANO, 2014).

Para Cassiano (2014) a grande vantagem de se usar a Clusterização é que ao agruparmos dados que sejam similares podemos descrever de forma mais clara e eficiente características de cada grupo de dados identificado. Fornecendo assim uma maior compreensão dos dados originais além de permitir criarmos esquemas de classificação e descobrir relações realmente interessantes entre os atributos dos dados de uma forma que se possam extrair informações, pelas quais usando as técnicas tradicionais não conseguiríamos alcançar.

Na confecção deste trabalho, para utilizarmos a Clusterização foi parametrizada a ferramenta para criação de 7 clusters de dados usando a técnica do "Simple K-means", usando como função de distância um método Euclidiano. 


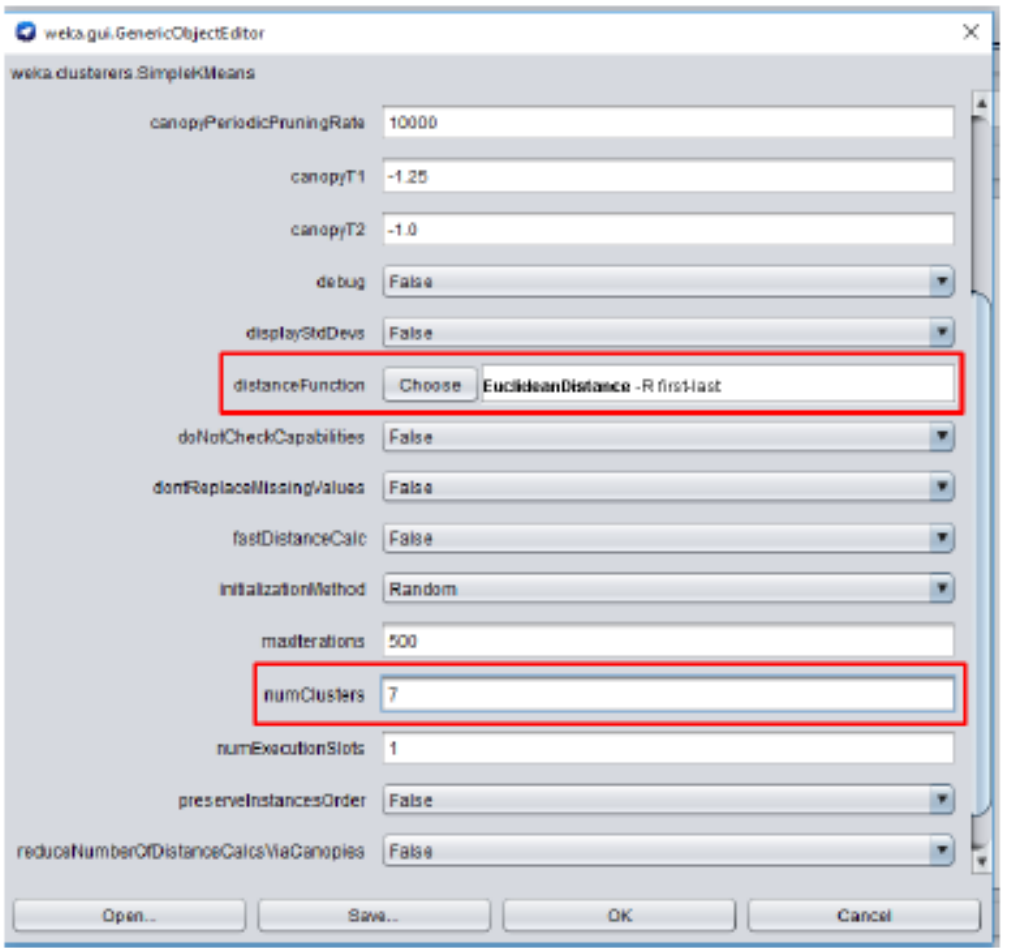

Figura 7 - Parametrização do cluster no Weka 3.8.3.

Monteiro e Silva et. Al (2001), afirmam que o K-means ou K-médias consiste em um método no qual um conjunto de valores iniciais n são agrupados como estimativas iniciais temporária das médias dos k clusters, onde k é o número de clusters a ser definido pelo usuário. A partir desde ponto os dados são agrupados de maneira a juntar os mais similares e depois comparados com os mais "distantes" e com os outros Clusters formados.

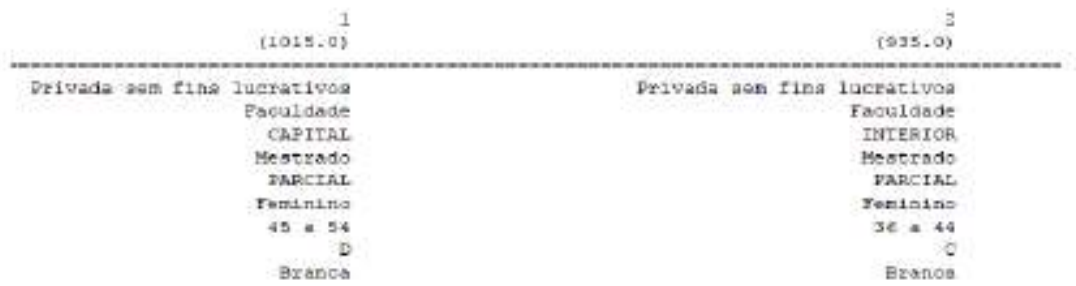

Figura 8 - Recorte do resultado da execução da Clusterização utilizando o Weka 3.8.3, apresentação de 2 dos 7 clusters criados.

\section{TAREFA DE CLASSIFICAÇÃO}

O Algoritmo J48 possibilita a criação de modelos de árvore de decisão, nesta técnica o algoritmo gera árvores decisórias onde cada nó avalia a significância de cada atributo da base de dados. O J48 é uma 
reescrita em linguagem de programação JAVA do algoritmo C45 escrito inicialmente em linguagem C (QUINLAN, 1993).

Na computação árvore s são estruturas de dados formadas por um conjunto de nós, que armazenam informações. Na hierarquia, toda árvore possui um nó raiz, que representa o mais alto nível da árvore, que é também seu ponto de partida para ligações entre os demais elementos da árvore s, sendo que um nó que não possui desmembramento ou filhos é chamado de nó folha (CAMPOS, 2017).

Como explica Campos (2017), que em uma árvore de decisão, toda decisão tomada, parte ou se encaminha do nó raiz até os nós folhas da árvore gerada.

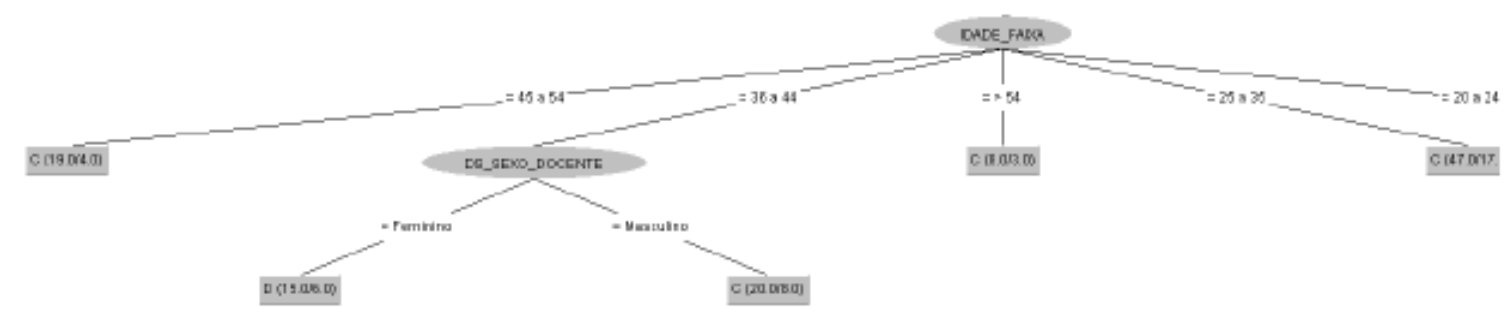

Figura 9- Exemplo de um nó folha em uma árvore. Imagem retirada da análise no Weka 3.8.3

Diante do exposto sobre árvore $s$ de decisão, para utilização da mesma no Weka 3.8 .3 foi parametrizado um fator de confiança de 0,25. Executado tendo como o nó folha o atributo IGC_DESC como pode ser analisado nas Figuras 10 respectivamente.

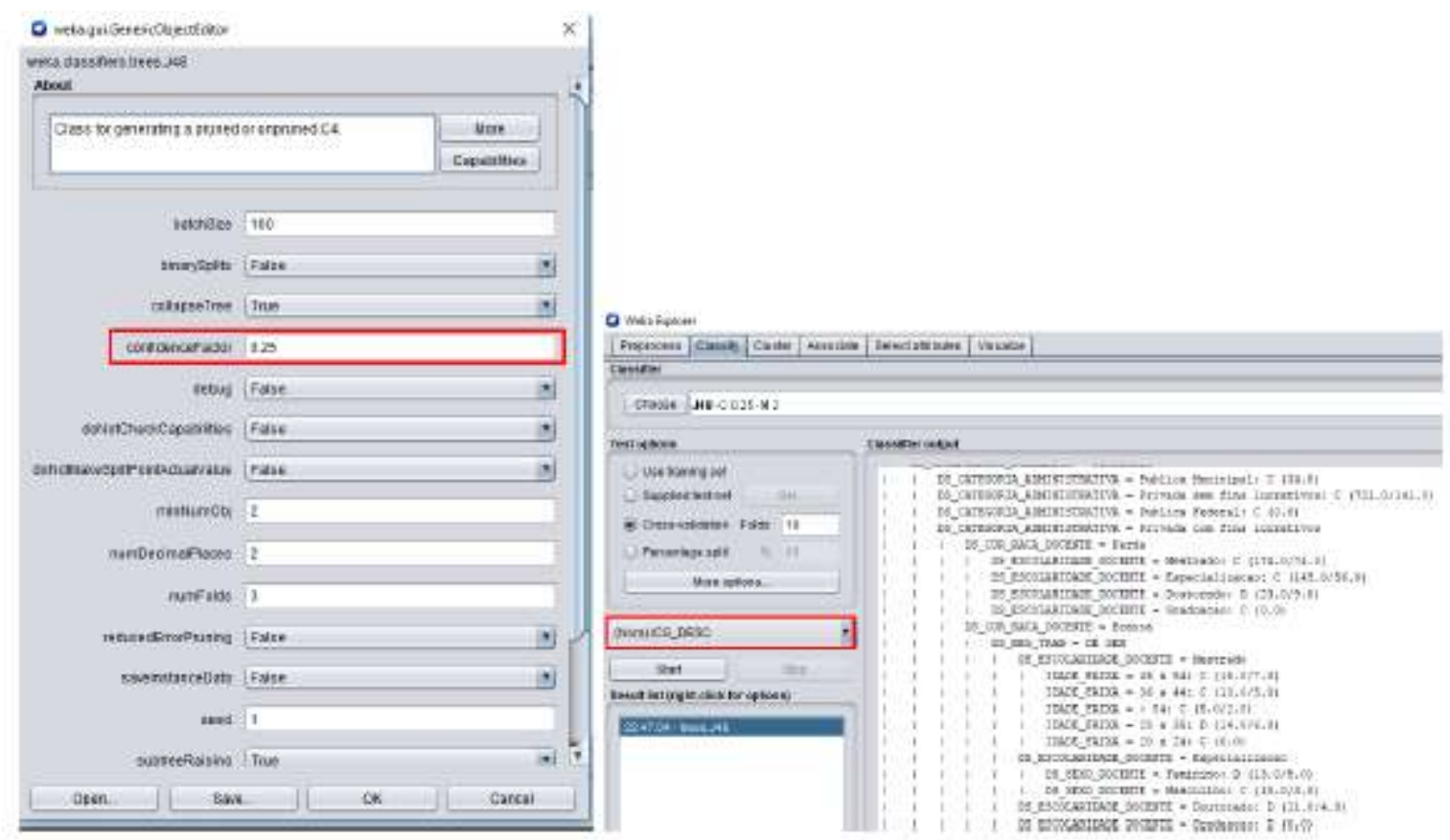

Figura 10 - Recorte da parametrização e resultado da execução do algoritmo J48 no Weka 3.8.3. 


\section{RESULTADOS E DISCUSSÕES}

Utilizando como ferramenta o software Weka 3.8.3, foi carregado para o aplicativo uma base de dados no formato arquivo de texto separado por vírgula (.csv), base está que passou por um préprocessamento dos dados no software Microsoft Excel. Nesta base foram aplicados dois algoritmos de mineração a Clusterização para agrupamento de dados e o J48 para criação de uma árvore de decisão para análise dos ramos mais interessantes gerados, tendo como nó folha a informação do IGC da instituição vinculado ao docente.

Neste processo de mineração de dados foram gerados como resultados 7 clusters com os atributos definidos na tabela de atributos conforme explicitado na seção PRÉ- PROCESSAMENTO DE DADOS. Com 7 clusters agrupamos os dados de maneira simplificado e já podemos inferir conhecimento sobre a base de dados.

Na Figura 11 ficam ilustrados alguns dos clusters gerados no processo de mineração de dados dentro do Weka 3.8.3.

\begin{tabular}{|c|c|c|c|}
\hline$(1666.0\rangle$ & $\begin{array}{r}4 \\
(698.0)^{4}\end{array}$ & $\begin{array}{r}5 \\
{[359.0\}^{2}}\end{array}$ & $\begin{array}{r}6 \\
{[404.0)^{6}}\end{array}$ \\
\hline Fublica Fedeza] & Fublice Eederal & Exiveds ous fing luckativos & Fublios Eederal \\
\hline Daiversidade & E Institurto Federal de Educaces Cienolo e Tecrologie & Foculasde & On1vezsidade \\
\hline CAFITAL & Captial & caFtraL & CAPITAL \\
\hline Doutored: & Hestrado & Mesteado & Mestzado \\
\hline se & DE & BCEISTR & DE SEM \\
\hline Fesinine & Masculino & Eeninino & Masculino \\
\hline $86 \mathrm{a} 44$ & $25 \div 35$ & $86 \pm 44$ & $25 \div 36$ \\
\hline t & D & D & D \\
\hline Brande & Brenot & Brence & Benase \\
\hline
\end{tabular}

Figura 11 - Recorte parcial dos clusters gerados no weka 3.8.3. Clusters de 3 a 6.

No primeiro cluster gerado, número 0, foi identificado uns grupos de docentes que atuam em instituições PRIVADAS COM FINS LUCRATIVOS, classificada como FACULDADE no INTERIOR do Espírito Santo em sua maioria com título de ESPECIALIZAÇÂO são do sexo MASCULINO entre 25 a 35 anos e com regime de trabalho PARCIAL, se autodeclaram BRANCOS e a instituição é IGC C.

No cluster número 1 outro grande agrupamento evidencia que instituições PRIVADAS SEM FINS LUCRATIVOS classificados como FACULDADE e localizados na CAPITAL, os docentes em sua maioria tem a titulação de MESTRADO, dedicação PARCIAL são do sexo FEMININO de 45 a 54 anos, são BRANCAS e a instituição é IGC D.

O terceiro cluster, número 2, agrupa as instituições FACULDADES PRIVADAS SEM FINS LUCRATIVA no INTERIOR do estado, os docentes têm MESTRADO como titulação e um regime PARCIAL de trabalho, são do sexo FEMININO com idades de 35 a 45 anos, brancas a instituição é IGC C. 
Analisando o quarto cluster, número 3, é possível identificar um agrupamento onde instituições PUBLICA FEDERAL, denominadas como UNIVERSIDADE que se encontram na CAPITAL, a titulação dos docentes é DOUTORADO que possuem dedicação exclusiva (DE), do sexo FEMININO de 36 a 44 anos, BRANCAS as instituições são IGC D.

$\mathrm{Na}$ análise do quinto cluster, número 4, as instituições PUBLICA FEDERAL, classificadas como INSTITUTO FEDERAL na CAPITAL tem docentes com MESTRADO com dedicação exclusiva (DE), do sexo MASCULINO com idades de 25 a 35 BRANCOS e o IGC do instituto é D.

No Sexto cluster o agrupamento reuniu instituições FACULDADES COM FINS LUCRATIVOS localizadas na CAPITAL, possuem docentes HORISTAS com titulação de MESTRADO são do sexo FEMININO com idades de 36 a 44 anos BRANCAS com IGC da instituição sendo D.

No último cluster criado, número 6, nas instituições PUBLICA FEDERAL classificadas como UNIVERSIDADES na CAPITAL os docentes com MESTRADO sem dedicação exclusiva (DE SEM) são do sexo MASCULINO, declaram-se BRANCOS com idades de 25 a 35 anos e a instituição é IGC D.

Na execução do algoritmo de árvore de decisão J48, foi gerada uma série de ramos que possibilitam a análise de um recorte interessante de dados para a análise na figura 12 e 13 ilustramos partes dos ramos da árvore gerada. 


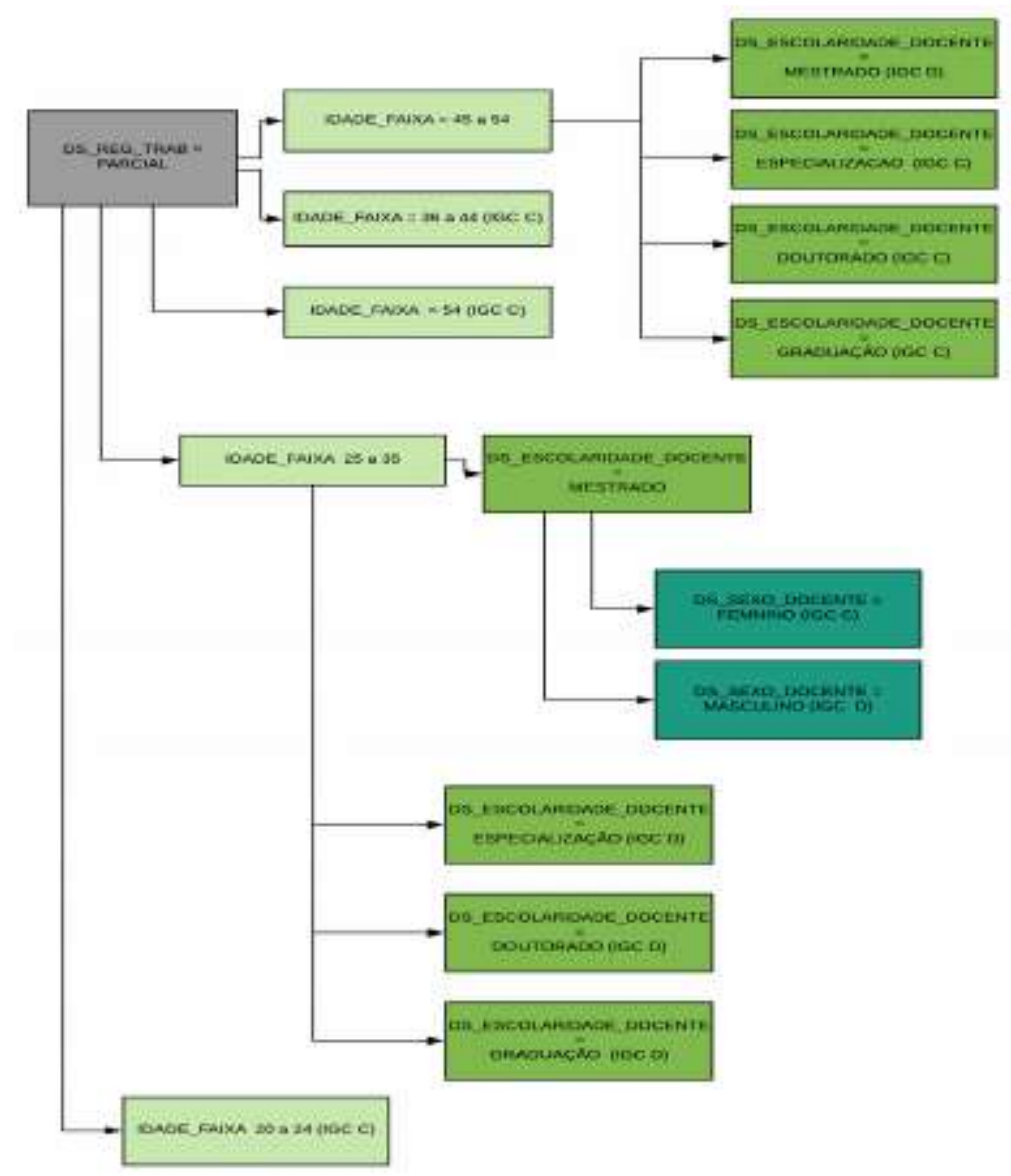

Figura 12 - Recorte parcial da árvore J48 com o atributo DS_REG_TRAB com o valor PARCIAL.

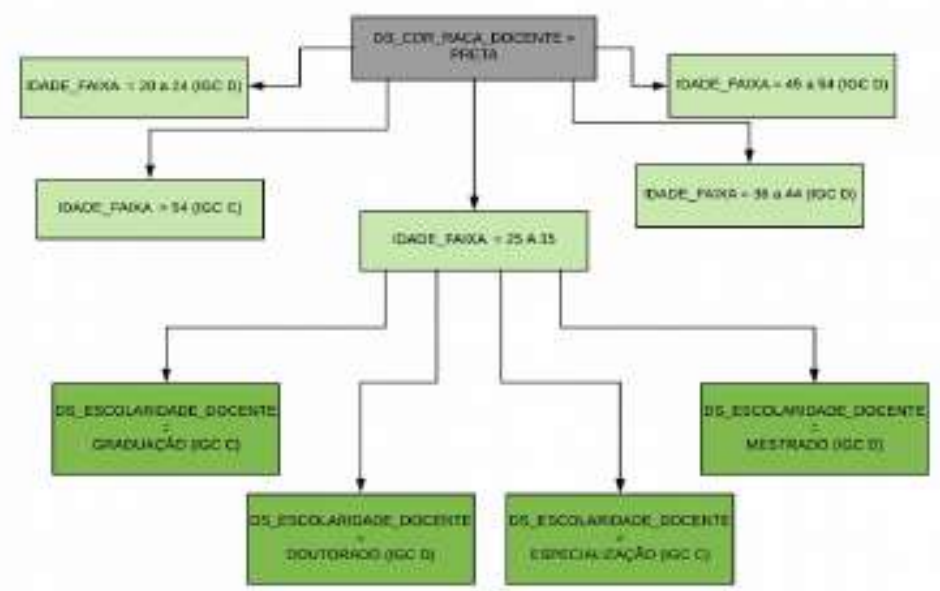

Figura 13 - Recorte parcial da árvore J48 com o atributo DS_COR_RACA_DOCENTE com o valor PRETO.

Na criação da árvore de decisão na ferramenta Weka, podemos analisar o corte da figura 16, onde a partir do nó DS_REG_TRAB = PARCIAL são criados ramos para os valores das faixas etárias 
(IDADE_FAIXA) onde para a faixa de 45 a 54 anos existem dados sobre a titulação docente e a classificação da instituição, onde: Mestrado (IGC D), Doutorado (IGC C), Especialização (IGC C) e Graduação (IGC C).

Para um novo corte na árvore de decisão J48, analisamos o Nó DS_COR_RACA_DOCENTE = PRETA, na qual é possível ramificar a IDADE_FAIXA de 25 a 35 com a titulação docente e a classificação da instituição, sendo: Mestrado (IGC D), Doutorado (IGC D), Especialização (IGC C) e Graduação (IGC C).

Abaixo na Figura 14e 15 é apresentado o Log da árvore decisão J48 após a execução do algoritmo na ferramenta Weka 3.8.3.

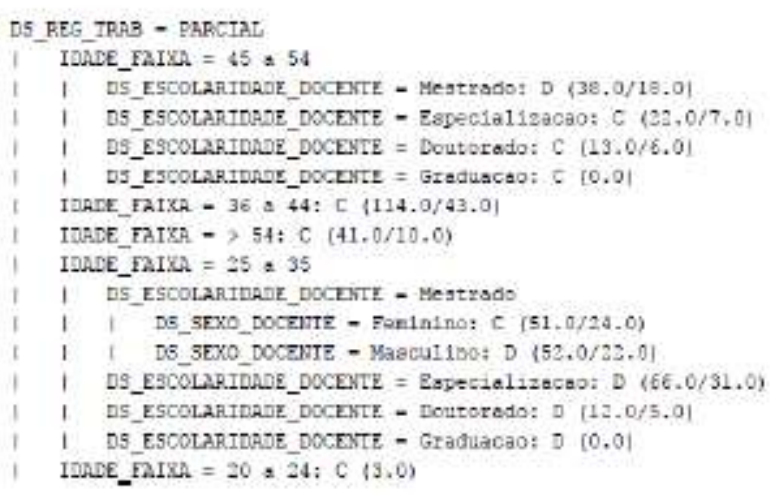

Figura 14 - Recorte parcial da árvore J48 com o atributo DS_REG_TRAB com o valor PARCIAL Imagem de Log da ferramenta Weka 3.8.3.

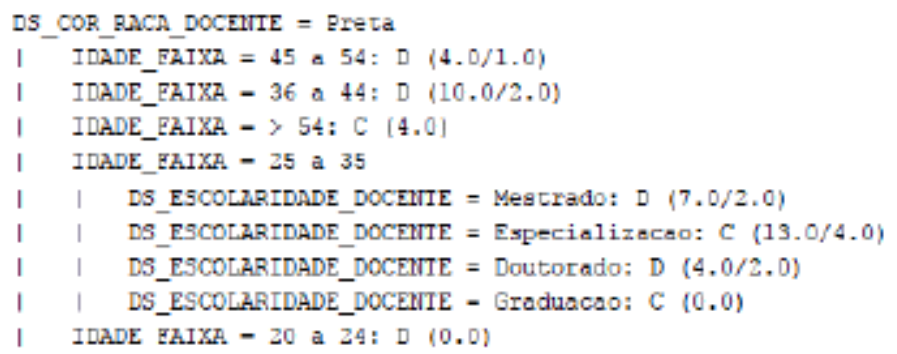

Figura 15 - Recorte parcial da árvore J48 com o atributo DS_COR_RACA_DOCENTE com o valor PRETA. Imagem de LOG na ferramenta Weka 3.8.3

\section{RESULTADOS E DISCUSSÕES}

Utilizar o processo de mineração de dados nos dados do censo 2016 do ensino superior para traçarmos o perfil do docente capixaba com índice satisfatório no IGC com o auxílio de rotinas inclusas do KDD e com os algoritmos de mineração presentes no software Weka na sua versão 3.8 .3 se mostrou muito eficiente. Conseguindo criar Cluster com dados relevantes para uma visão macro das informações da 
base e em uma visão mais detalhada explorar as informações por intermédio da árvore de decisão do J48.

Neste trabalho foi possível identificar de maneira clara o perfil do docente em instituições de ensino superior com índice de satisfatório a ótimo (3 a 5) no estado do Espírito Santo para os dados do censo 2016 do INEP.

Na análise de dados é possível afirmar com base nos resultados obtidos que as instituições classificadas como Universidades Públicas Federais, que em sua maioria localiza-se na capital do estado enquadram-se no perfil de IGC nota D nota próxima da máxima aferida pelo censo INEP 2016, explicitando o caminho de excelência do ensino superior público do estado do Espírito Santo. O estudo apresenta também bons índices nas instituições particulares do estado, que buscam o reconhecimento e a busca de excelência.

Dos perfis identificados com base na Clusterização e Árvore de decisão:

1. Docentes que atuam nas universidades federais do estado o Espírito Santo são doutores com dedicação exclusiva, localizada na capital, com predominância do sexo feminino com uma faixa etária de 36 a 44 anos em média, de raça declarada branca são IGC D.

2. Instituições privadas com fins lucrativos que se encontram no interior do estado, em sua maioria se enquadram como faculdade, seus docentes são na maioria especialistas, com dedicação parcial, homens brancos, com faixa etária de 25 a 35 anos, são IGC C.

3. No Interior, os docentes que se auto declaram negros estão na faixa 25 a 35 anos com mestrado e doutorado são IGC D, já os com especialização são IGC C.

4. No interior os docentes com titulação de mestre com faixa etária de 36 a 54 anos, estão como IGC C.

5. Os Centros Universitários do Espírito Santo são IGC C.

Com este estudo chega-se à conclusão que a titulação do docente ainda tem um grande peso na classificação do IGC, sobretudo nas instituições privadas e que se encontram fora da capital do estado, pois em sua maioria o perfil encontrado foi o $C$, e que há um predomínio do sexo feminino nas instituições com IGC satisfatório ou superior na capital do estado. Destacamos também a baixa frequência de Negros e Índios com titulação de mestres.

As informações obtidas com este estudo podem ser de grande valia para políticas de inclusão ou equidade para os órgãos competentes, além de ajudar as instituições a planejar melhor, suas ações rumo a excelência nas avaliações, uma vez conhecido o perfil docente com os melhores índices de IGC do estado do Espirito Santo, fica mais fácil traçar estratégias para alavancar os índices e chegar a pontuação 4 ou 5. 


\section{REFERÊNCIAS BIBLIOGRÁFICAS}

BATISTA, Fábio Barbosa; BARRETO, Willian de Sousa; GOMES, Geórgia Regina Rodrigues. Utilização de Mineração de Dados para descrição do perfil dos docentes das IES com conceito satisfatório no IGC em 2011 do estado do Rio de Janeiro. Revista de Ciência \& Tecnologia. Junho de 2015. Universidade de Iguaçu (UNIG)- RJ.

CARDOSO, Olinda Nogueira Paes; MACHADO, Rosa Teresa Moreira. Knowledge management using data mining: a case study of the Federal University of Lavras. Revista de Administração Pública, v. 42, n. 3, p. 495-528, Jun 2008.

CAMPOS, Raphael; Árvores de Decisão. <Https://medium.com/machine-learning-beyond- deeplearning/\%C3\%A1rvores-de-decis\%C3\%A3o-3f52f6420b69>.Acessado em :10-12-

2018.

CAMILO, Cássio Oliveira; CARLOS, João. Mineração de Dados: Conceitos, Tarefas, Métodos e Ferramentas. RT-INF_001-09. p. 29, 2009. Instituto de Informática. Universidade Federal de Goiás. Goiás-GO.

CASSIANO, Keila Mara. Análise de Séries Temporais Usando Análise Espectral Singular (SSA) e Clusterização de Suas Componentes Baseada em Densidade. Teste (Doutorado em Engenharia Elétrica) - PUC. Rio de Janeiro. 2014.

CUNHA, M.I.; FERNANDES, C, M.; FORSTER, M. M. Avaliação externa e os Cursos de Graduação: implicações políticas na prática pedagógica e na docência. Perspectiva para o ensino e à docência universitária frente ao impacto das políticas de avaliação externa no Brasil. In: DIAS SOBRINHO, J, RISTOFF, D.(Orgs.) Avaliação e compromisso público. A educação superior em debate. Florianópolis: Insular, 2003.p. 97-112.

FAYYAD, Usama; PIATETSKY-SHAPIRO, Gregory; SMYTH, Padhraic. From Data Mining to Knowledge Discovery in Databases. p. 18, 1996. Al Magazine.

GIL, Antônio Carlos. Como elaborar projetos de pesquisa. 4. ed. São Paulo: Atlas S.a, 2002. 176 p.

INEP, Manual do Enade, 2016 - Brasília: Inep, 2016. Disponível em:

< http://download.inep.gov.br/educacao_superior/enade/manuais/manual_do_enade_28092016

.pdf>. Acessado em: 13-12-2018.

INEP, SINAES2015 - volume 5, 2015- Brasília: Inep, 2015. Disponível em

<http://portal.inep.gov.br/documents/186968/484109/SINAES++Sistema+Nacional+de+Avalia\%C3\% A7\%C3\%A3o+da+Educa\%C3\%A7\%C3\%A3o+Superior+Vol+5/ee07ce50-a60f-4614-9aac01bfe168df5f? version=1.2>. Acesso em: 12-12-2018.

JAIN, A.K., MURTY, M.N. \& FLYNN, P.J. “Data Clustering: A Review”, ACM Computing Surveys, vol. 31, no. 3, pp. 264-323,1999. 
MAIMON, Oded. Introduction To Knowledge Discovery In Databases. Israel, 2009. Disponível em: <http://www.ise.bgu.ac.il/faculty/liorr/hbchap1.pdf>. Acesso em: 03/12/2018.

MONTEIRO E SILVA, A. B., PORTUGAL, M. S., CECHIN, A. L. (2001). Redes Neurais

Artificiais e Análise de Sensibilidade: Uma Aplicação à Demanda de Importações Brasileira. Revecap vol. 5 n. 4.

QUINLAN, J.R. C4.5: programs for machine learning. Sydney, Austrália: Morgan Kaufmann Publishers, 1993. $302 \mathrm{p}$.

RISTOFF, Dilvo; GIOLO, Jaime. O Sinaes como Sistema. RBPG, Brasília, v. 3, n. 6, p. 193- 265, dez. 2006.

SOCZEK, Felipe Cebulski; ORLOVSKI, Regiane. Mineração de Dados: Conceitos e aplicação de algoritmos em uma Base de Dados na área da saúde p. 25, 2014. Semana Acadêmica - Revista Científica. 